\section{Pacific Northwest}

National Laboratory

Operated by Battelle for the

U.S. Department of Energy

\title{
Uranium Contamination in the Subsurface Beneath the 300 Area, Hanford Site, Washington
}

\author{
RE Peterson \\ ML Rockhold \\ RJ Serne \\ PD Thorne \\ MD Williams
}

February 2008

Prepared for the U.S. Department of Energy under Contract DE-AC05-76RL01830

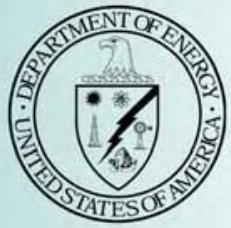




\title{
DISCLAIMER
}

This report was prepared as an account of work sponsored by an agency of the United States Government. Neither the United States Government nor any agency thereof, nor Battelle Memorial Institute, nor any of their employees, makes any warranty, express or implied, or assumes any legal liability or responsibility for the accuracy, completeness, or usefulness of any information, apparatus, product, or process disclosed, or represents that its use would not infringe privately owned rights. Reference herein to any specific commercial product, process, or service by trade name, trademark, manufacturer, or otherwise does not necessarily constitute or imply its endorsement, recommendation, or favoring by the United States Government or any agency thereof, or Battelle Memorial Institute. The views and opinions of authors expressed herein do not necessarily state or reflect those of the United States Government or any agency thereof.

\author{
PACIFIC NORTHWEST NATIONAL LABORATORY \\ operated by \\ BATTELLE \\ for the \\ UNITED STATES DEPARTMENT OF ENERGY \\ under Contract DE-AC05-76RL01830
}

Printed in the United States of America
Available to DOE and DOE contractors from the Office of Scientific and Technical Information,
P.O. Box 62, Oak Ridge, TN 37831-0062;
ph: (865) 576-8401
fax: $(865) 576-5728$
email: reports@adonis.osti.gov

\begin{abstract}
Available to the public from the National Technical Information Service, U.S. Department of Commerce, 5285 Port Royal Rd., Springfield, VA 22161 ph: (800) 553-6847 fax: (703) $605-6900$ email: orders@ntis.fedworld.gov online ordering: http://www.ntis.gov/ordering.htm
\end{abstract}


PNNL-17034

\section{Uranium Contamination in the Subsurface Beneath the 300 Area, Hanford Site, Washington}

R. E. Peterson, Editor

Contributors:

R. E. Peterson

M. L. Rockhold

R. J. Serne

P. D. Thorne

M. D. Williams

February 2008

Prepared for

the U.S. Department of Energy

under Contract DE-AC05-76RL01830

Pacific Northwest National Laboratory

Richland, Washington 99352 



\section{Acknowledgments}

The following persons were responsible for the content and authorship of the principal sections of this report: R. E. Peterson (introduction, background information, and current conditions), P. D. Thorne (hydrogeologic framework), M. D. Williams and M. L. Rockhold (groundwater flow), and R. J. Serne (geochemistry). Key contributors to various sections include B. N. Bjornstad (stratigraphy), R. Mackley (riverbed interface), J. M. Zachara, J. P. McKinley, W. Um, C. F. Brown, and C. Liu (geochemistry), and S. B. Yabusaki (uranium transport). R. E. Peterson (editor) was responsible for the scope and presentation format of this report.

Numerous discussions with J. L. Lindberg, R. M. Smith, and M. J. Nimmons have provided new ideas and concepts regarding the 300 Area uranium plume, and their contributions are appreciated. The authors would like to acknowledge the helpful support of Chris Newbill and JoAnne Rieger for graphics and data compilations, respectively. Text editing and word processing were accomplished by Wayne Cosby, Andy Fish, and Mike Parker under the capable direction of Hope Matthews. 



\section{Executive Summary}

The persistence of uranium in 300 Area groundwater at concentrations that exceed the drinking water standard is a departure from predictions made in the early 1990s during the initial remedial investigation of the 300-FF-5 Operable Unit. Subsequent review of the remedial action decision made in 1996 prompted the U.S. Department of Energy to initiate further investigation into an explanation for this persistence, and also to re-evaluate potential technologies that could be applied to reduce uranium concentrations in groundwater to meet regulatory standards. A work plan was developed during 2004 and 2005 under the Hanford Federal Facility Agreement and Consent Order (Tri-Party Agreement) Milestone M-016-68. Proposed activities will culminate in a report describing the results of a feasibility study and a draft proposed plan to modify the interim action being conducted under the existing record of decision.

Approximately $650,000 \mathrm{~m}^{3}$ of groundwater beneath the 300 Area are impacted by uranium at concentrations that exceed the drinking water standard of $30 \mu \mathrm{g} / \mathrm{L}$. The mass of uranium in that groundwater volume is estimated to vary within the approximate range of 45 to $77 \mathrm{~kg}$. The uranium plume is primarily contained within saturated sediment of the Hanford gravels formation, a highly permeable hydrologic unit. The level of contamination has remained relatively constant in recent years, in spite of surface waste site source removal actions, groundwater plume discharge to the Columbia River, and withdrawal of groundwater at a water supply well. Concentrations of uranium in the groundwater plume vary seasonally, in terms of maximum observed values as well as distribution pattern. Concentrations typically range from natural background levels (less than $10 \mu \mathrm{g} / \mathrm{L}$ ) up to $200 \mu \mathrm{g} / \mathrm{L}$.

Discharge of the groundwater plume to the Columbia River occurs primarily via upwelling through the riverbed, with an estimated areal extent of $\sim 0.17 \mathrm{~km}^{2}$. More limited discharge also occurs via several riverbank springs, where concentrations are similar to those observed at near-river wells. Estimates for uranium flux to the river via groundwater discharge indicate a rate of several hundred $\mathrm{kg} / \mathrm{yr}$. However, uranium concentrations in nearshore river water in areas adjacent to plume discharge (water depths $\sim 1 \mathrm{~m}$ or less) during recent years fall in the range of 0.5 to $1.7 \mu \mathrm{g} / \mathrm{L}$, thus revealing the mitigating process of contaminant dilution in the free-flowing stream.

The mobility characteristics of uranium vary within the multiple subsurface zones that contain residual contaminant uranium. Principal subsurface zones include 1) the vadose zone, 2) a zone through which the water table rises and falls, 3) the aquifer, and 4) a zone where groundwater and river water interact beneath the river shoreline. Principal controls on mobilization include the form of the residual uranium (e.g., crystalline minerals, amorphous precipitates/coatings, sorbed onto sediment), the transporting medium (e.g., water infiltration from the land surface, groundwater), and the rate of exchange between the form and transporting medium. The bicarbonate content of aqueous media strongly influences the rate of exchange, with relatively higher content enhancing mobility. Groundwater has a higher bicarbonate content than river water or other freshwater sources, such as utility and potable water systems.

The inventory of contaminant uranium that continues to supply the groundwater plume may be stored in numerous potential subsurface "compartments" defined for the various zones listed above. Of the 10 compartments evaluated, the largest inventory is for the vadose zone beneath former liquid-waste disposal sites, while the second largest compartment is in the zone beneath waste sites through which the water 
table rises and falls. The former compartment is a less likely current contributor to groundwater contamination because of the relatively more-resistant form of the uranium and the low moisture flux in that compartment. The latter zone is a more likely current contributor because of periodic saturation by groundwater and a possibly less retentive form of uranium being present in the intermittently wetted sediment. The inventory of uranium in the aquifer, as dissolved and sorbed forms, is estimated to represent $\sim 5 \%$ of the total inventory calculated for the 10 compartments. A summary of the inventory analysis by compartment is shown in Figure ES-1.

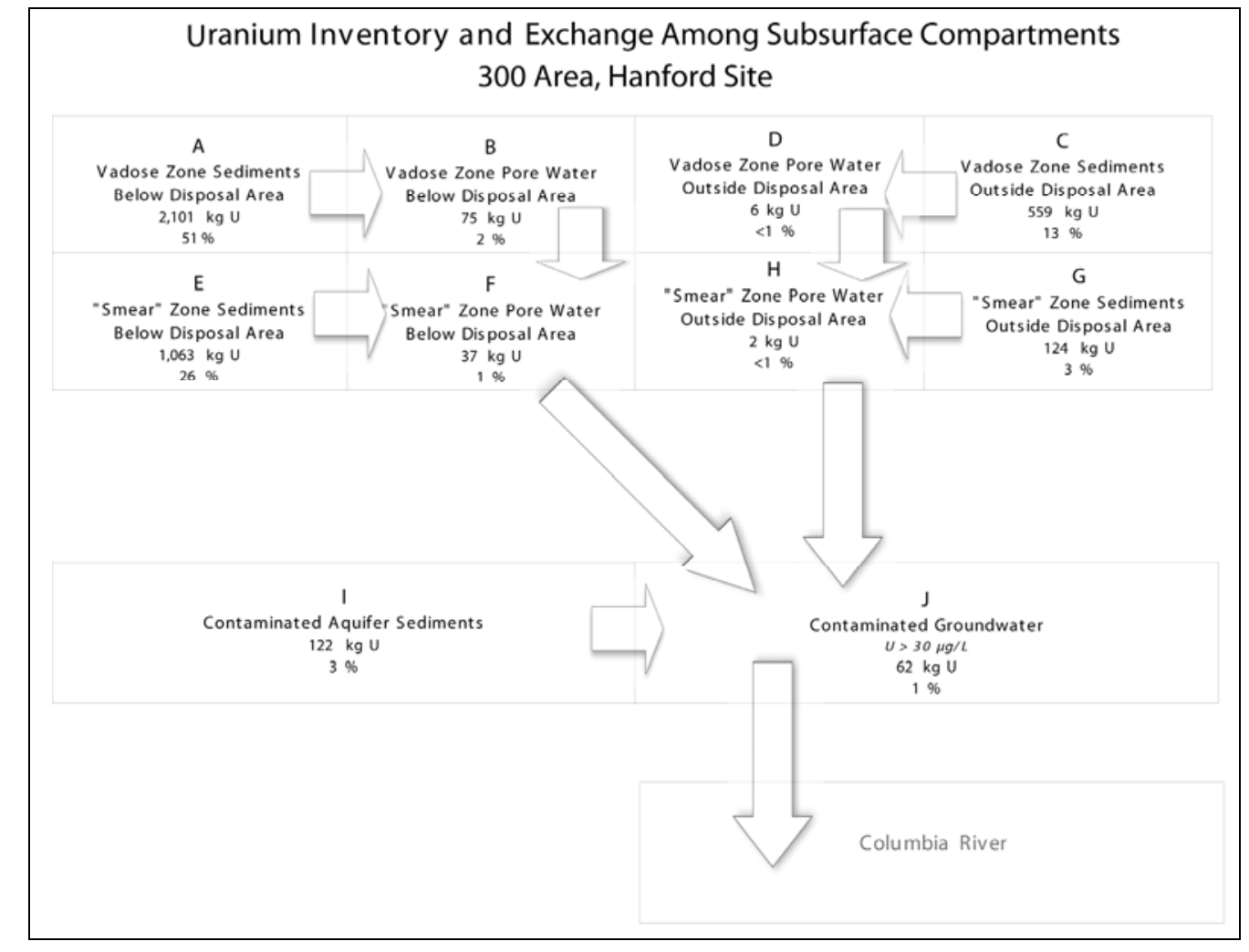

Figure ES-1. Uranium Inventory in Various Compartments in the 300 Area Subsurface

The variety of processes affecting the mobility of uranium in the subsurface, along with the numerous potential compartments where residual contamination may be located, presents challenges for predicting uranium movement through environmental pathways. The processes responsible for the persistence of the plume may involve cycling of uranium between the aquifer and overlying zone through which the water table fluctuates. Contaminated groundwater is moved upward into the lower vadose zone, and when the water table subsequently falls, contaminated moisture is left behind. Some of the uranium in groundwater may become sorbed to sediment in that zone, to subsequently slowly release. Also, near the Columbia River in the zone of groundwater/river water interaction, where the bicarbonate content is lowered because of infiltrating river water, the tendency for uranium to adsorb onto sediment is enhanced, thus slowing dissipation via the groundwater pathway. Fluctuations in the Columbia River stage are the driving mechanism for the rise and fall of the water table beneath the 300 Area, and also for creating the dynamic hydraulic and geochemical environment found in the zone of interaction beneath the shoreline. 
The current conceptual model for uranium contamination in the subsurface at the 300 Area has significant implications regarding the selection and implementation of a remedial action technology. A working assumption is that remediation of contamination held in the water table excursion zone directly beneath former liquid-waste disposal facilities would contribute to reducing persistent, elevated concentrations of uranium in groundwater. A technology involving injecting polyphosphate solution into the aquifer is currently being tested in the vicinity of a former 300 Area waste disposal facility, with an interpretation of initial test results expected by September 2008. 



\section{Acronyms and Abbreviations}

\begin{tabular}{|c|c|}
\hline$\mu \mathrm{EXAFS}$ & microprobe $\mathrm{x}$-ray absorption fine structure \\
\hline$\mu \mathrm{XANES}$ & microprobe x-ray absorption near-edge structure \\
\hline$\mu \mathrm{XAS}$ & microprobe x-ray spectroscopy \\
\hline$\mu \mathrm{XRF}$ & microprobe x-ray fluorescence \\
\hline BWTF & Buried Waste Test Facility \\
\hline CERCLA & Comprehensive Environmental Response, Compensation, and Liability Act \\
\hline CSM & conceptual site model \\
\hline DOE & U.S. Department of Energy \\
\hline DOE-RL & U.S. Department of Energy, Richland Operations Office \\
\hline DRM & distributed rate model \\
\hline EPA & U.S. Environmental Protection Agency \\
\hline ERDF & Environmental Restoration Disposal Facility \\
\hline GEA & gamma energy analysis \\
\hline HEIS & Hanford Environmental Information System \\
\hline HRM & Hanford River Marker \\
\hline ICP-MS & inductively coupled plasma mass spectrometry \\
\hline LFI & limited field investigation \\
\hline MCL & maximum contaminant level \\
\hline NPL & National Priorities List \\
\hline RACS & Remediation and Closure Science Project \\
\hline RCRA & Resource Conservation and Recovery Act \\
\hline SCM & surface complexation adsorption model \\
\hline WMA & waste management area \\
\hline WIDS & Waste Information Data System \\
\hline XRF & $\mathrm{x}$-ray fluorescence \\
\hline
\end{tabular}





\section{Contents}

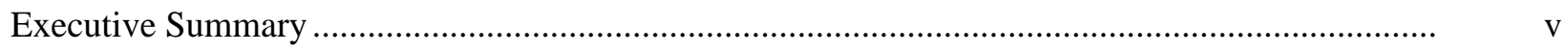

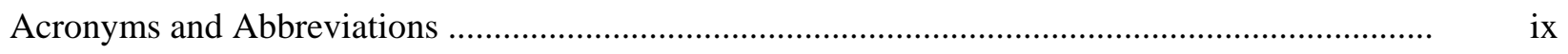

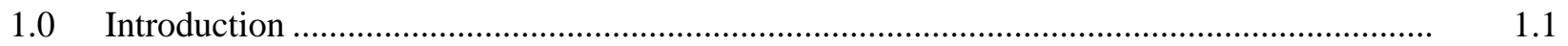

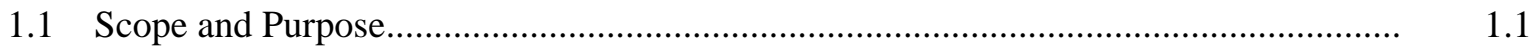

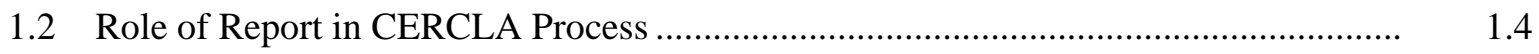

1.3 Recent Advances in Understanding the 300 Area Uranium Plume............................. 1.4

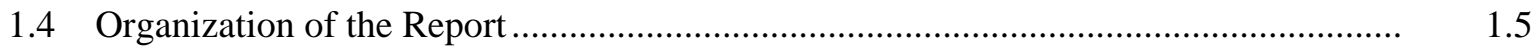

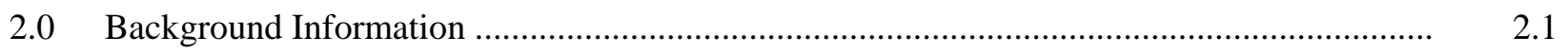

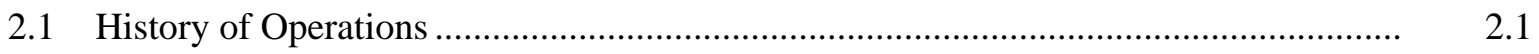

2.2 Historical Development of a Conceptual Model for the 300 Area Uranium Plume ..... $\quad 2.5$

2.3 Role of CSM in Remedial Action Decisions.............................................................. 2.9

2.4 Current Concepts ............................................................................................ 2.10

2.4.1 Historical Emplacement of Contaminant Uranium .......................................... 2.11

2.4.2 Release of Uranium Since Waste Disposal Operations Ended........................... 2.14

2.4.3 Persistence of the Uranium Plume Under Current Conditions............................ 2.15

2.4.4 Summary of Problem Statement....................................................................... 2.16

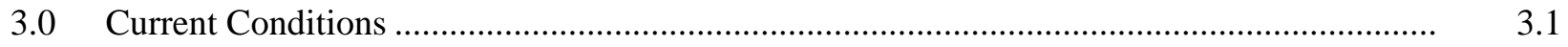

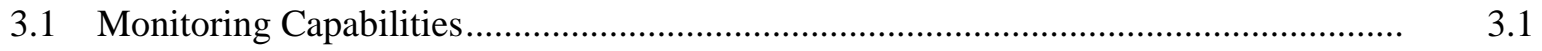

3.2 Extent of Uranium Plume Beneath the 300 Area ........................................................

3.3 Seasonal Variability in the Uranium Plume ...............................................................

3.3.1 Evidence for Remobilization from Lower Vadose Zone.................................... 3.10

3.3.2 Uranium Concentrations and Mixing with River Water .................................... 3.12

3.3.3 Summary of Seasonal Variability of the Uranium Plume .................................. 3.15

3.4 Trends in Plume Parameters .................................................................................

3.5 Discharge of Plume into the Columbia River............................................................ 3.23

3.6 Uranium in Surface Water at the 300 Area Shoreline ................................................ 3.27

3.7 Uncertainties in Plume Characteristics................................................................... 3.29

4.0 Hydrogeologic Framework ......................................................................................

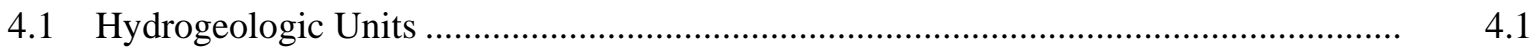

4.1.1 Ringold Formation .................................................................................... 4.2

4.1.2 Hanford Formation ......................................................................................... 4.5

4.1.3 Recent Eolian Deposits and Backfill .............................................................. 4.6

4.2 Revision of Hanford/Ringold Contact Surface........................................................

4.3 Vadose Zone................................................................................................. 4.15

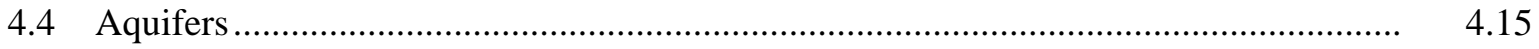


4.5 Aquifer Interface with Columbia River Channel ...................................................

4.6 Spatial Data Management (EarthVision ${ }^{\mathrm{TM}}$ database) ................................................ 4.22

4.7 Uncertainties in Defining the Hydrogeologic Framework …....................................... 4.22

5.0 Groundwater Flow and Transport..................................................................................... 5.1

5.1 General Flow Patterns and Velocities .................................................................. 5.1

5.1.1 Early 1990s Water-Level Monitoring Network ................................................ 5.2

5.1.2 Current (2004 and Later) Water-Level Monitoring Network............................. 5.4

5.1.3 Movement Rates Revealed by Historical Plume Events .................................. 5.17

5.1.4 Polyphosphate Treatability Test Flow Rates and Directions............................. 5.18

5.2 Computer Simulations of Groundwater Flow and Transport ...................................... 5.20

5.2.1 Previous Modeling Studies.............................................................................. 5.22

5.2.2 Large Domain 300 Area Groundwater Flow and Transport Model ................... 5.24

5.2.3 Smaller-Domain 300 Area Flow and Transport Modeling................................ 5.30

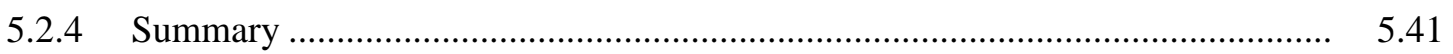

6.0 Geochemical Characteristics of Contaminant Uranium .....................................................

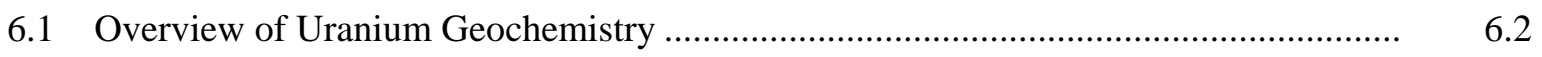

6.1.1 Chemical Species ...................................................................................... 6.3

6.1.2 Computerized Aqueous Speciation Calculations ............................................. 6.3

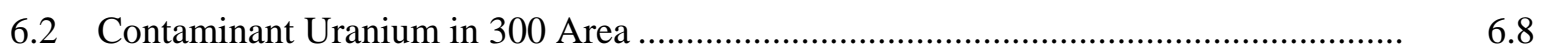

6.2.1 Background Uranium Concentrations in Hanford Media .................................. 6.8

6.2.2 Mineral Form of Background Uranium........................................................... 6.10

6.2.3 Waste-Effluent Characteristics................................................................. 6.12

6.3 Conceptual Geochemical Model (Based on Box Model Inventories) ........................... 6.15

6.3.1 Compartments A and B (Sediment and Pore Water Within Facility

Footprints) and E and F (Smear Zone Directly Below Facility Footprints)....... 6.16

6.3.2 Uranium in Compartments C and D and G and H (Sediments and Pore Waters Outside Facility Footprints, Including the Smear Zone Compartments)

6.3.3 Uranium in Compartments I and J (Aquifer Sediments and Groundwater Within the $30 \mu \mathrm{g} / \mathrm{L}$ Uranium Isopleth) ............................................................. 6.36

6.3.4 Observations on the Uranium Inventory in Box-Model Compartments ............ 6.37

6.4 Controls on Uranium Mobility (Residual Uranium Still in the 300 Area) .................... 6.38

6.4.1 Previous Uranium Mobility Investigations Using Residual 300 Area

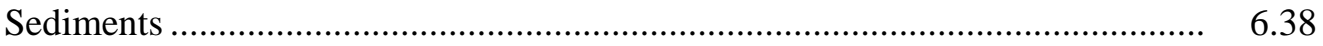

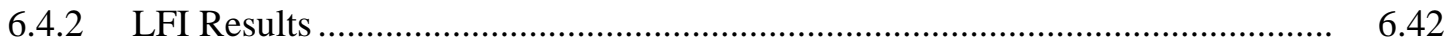

6.4.3 Dissolved vs. Particulate Uranium .............................................................. 6.45

6.5 Controls on Uranium Mobility: Processes Contributing to Mass Transfer from Solid to Solution and Vice Versa. 
6.5.1 Solid-Phase Characterization of 300 Area Process Pond Sediments ................. 6.46

6.5.2 Adsorption-Based Models Used in the Current 300 Area Mass Transport Code .................................................................................................... 6.49

6.5.3 Variably Saturated Flow-and-Transport Predictive Modeling of 300 Area Vadose Zone and Groundwater Uranium Plumes ........................................... 6.51

6.5.4 Key Geochemical Variables Controlling the Transfer of Uranium Between Sediment and Solution.................................................................................. 6.59

6.6 Uncertainties Related to Uranium Geochemistry, Available Data for Uranium Distribution in the 300 Area Subsurface, and Future Mass Transport Simulations ....... $\quad 6.62$

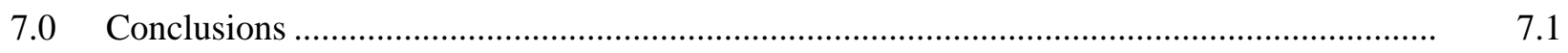

7.1 Uranium Plume Characteristics ...........................................................................

7.2 Potential Repositories for Contaminant Uranium ...................................................

7.3 Ramifications for Remedial Action............................................................................

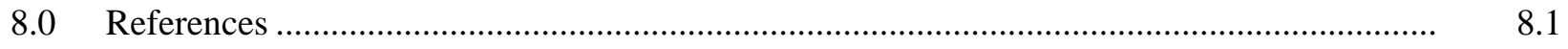




\section{Figures}

1.1 Index Map for the Hanford Site, South-Central Washington............................................... 1.2

1.2 Index Map for the 300-FF-5 Operable Unit, 300 Area National Priorities List Site .............. 1.3

2.1 Aerial Photo Showing the Locations of Principal Waste Disposal Sites ............................... 2.2

2.2 Historical Uranium and Water Table Elevation Trends near the North and South Process Ponds.

2.3 Schematic Showing Principal Subsurface Zones Involved with Uranium Contamination...... 2.12

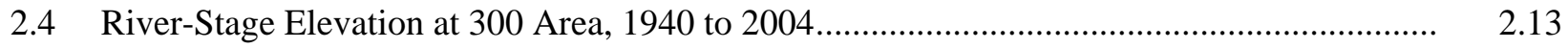

2.5 Uranium Concentrations near and Downgradient of the 300 Area Process Trenches ............ $\quad 2.14$

3.1 Location Map for Monitoring Wells and Shoreline Sampling Sites at the 300 Area ............. 3.2

3.2 Schematic Showing Positions of Monitoring Well Screens Relative to Hydrostratigraphic Units

3.3 Cross Section Along the 300 Area Shoreline Showing Positions of Screens for near-River Monitoring Wells and Aquifer Tubes

3.4 Outflow from Priest Rapids Dam, Which Approximates Flow Through the Hanford Reach of the Columbia River....

3.5 Uranium Plume in Groundwater Beneath 300 Area During June 2006......

3.6 Uranium Plume in Groundwater Beneath 300 Area During December 2006.

3.7 Uranium Plume in Groundwater Beneath 300 Area During June 2007.

3.8 Uranium Concentration Trends at Various Depths in the Unconfined Aquifer.

3.9 Relationship Between Uranium Concentrations and Water Levels and Specific Conductance at Well 399-1-17A.

3.10 Uranium Concentrations and Water Levels at Well 399-1-17A

3.11 Wells Showing Increased Uranium Concentrations When Water Level is Raised.

3.12 Wells Showing Decreased Uranium Concentrations When Water Level in Well is Raised....

3.13 Map Illustrating Areas Where Uranium Concentrations Vary in Response to Raised Water Levels at the Well

3.14 Trends in 300 Area Uranium Plume in Groundwater: Volume, Mass, and Area of Plume.....

3.15 Map Showing Maximum Uranium Concentrations Observed at Aquifer Tube Sites

3.16 Uranium Concentrations for December 2006 Through January 2007 at 300 Area Aquifer Tubes and Wells near the River.

3.17 Uranium Concentrations in Water from Two Prominent Springs Along the 300 Area Shoreline

4.1 Hydrogeologic Stratigraphic Column for the 300 Area

4.2 Photos of Core Samples from the 2006 Characterization Borehole 399-3-18.

4.3 Ringold Mud Clasts Found Within the Hanford Formation Gravel and Sand at a Pit Excavated in the South Process Pond 
4.4 Contour Map of Contact Elevation Between the Ringold and Overlying Hanford Formations

4.5 Map Showing Locations of Cross Sections .

4.6 Cross Section A-A' Showing Hydrogeologic Units and Seasonal Water Table Elevations at the 300 Area

4.7 Cross Section B-B' Showing Hydrogeologic Units and Seasonal Water Table Elevations at the 300 Area

4.8 Cross Section C-C' Showing Hydrogeologic Units and Seasonal Water Table Elevations at the 300 Area

4.9 Cross Section D-D’ Showing Hydrogeologic Units and Seasonal Water Table Elevations at the 300 Area

4.10 Cross Section E-E' Showing Hydrogeologic Units and Seasonal Water Table Elevations at the 300 Area

4.11 Three-Dimensional View of the Top of the Ringold Formation Showing Boreholes Defining the Fine-Grained Subunit.

4.12 Locations for Pumping Tests and Hydraulic Conductivity Values for Results Considered Most Reliable

4.13 Locations of the Drive-Point Penetrations and the "Depth of Refusal” Results

4.14 Transects for Example Acoustic Profiles of the Riverbed Shown in Figure 4.15

4.15 Example Acoustic Profiles of the Riverbed Along the Transects Shown in Figure 4.14

4.16 Locations of Sediment Samples Collected from the Riverbed and Photos of the Sediments ..

4.17 Area Where Saturated Hanford Formation Sediment is in Contact with the River Channel Based on the Current Hydrogeologic Model

5.1 Columbia River Stage at the 300 Area SWS-1 Gauging Station, January 2006 to August 2007

5.2 Wells Where Hourly Water-Level Data Have Been Obtained

5.3 Columbia River Stage at the 300 Area SWS-1 Gauging Station, January 1992 to March 1993.

5.4 Wells in the Early 1990s Water-Level Monitoring Network with Low-River Stage Example

5.5 300 Area Water-Level Monitoring Network-Initial High-River Stage Example

5.6 300 Area Water-Level Monitoring Network—Sustained High-River Stage Example.....

5.7 300 Area Water-Level Monitoring Network—-Initial Lower River Stage Following High-River Stage Example

5.8 300 Area Water-Level Monitoring Network—Sustained Low River Stage-Inflow Example

5.9 300 Area Water-Level Monitoring Network—Sustained Low River Stage-Outflow Example

5.10 300 Area Water-Level Monitoring Network - Hydraulic Gradient Rose Diagrams for MidOctober, 2006 Through July 26, 2007 
5.11 300 Area Water-Level Monitoring Network—Hydraulic Gradient Rose Diagrams for July 26, 2006 Through July 26, 2007.

5.12300 Area Water-Level Monitoring Network—Hydraulic Gradient Rose Diagrams for July 26, 2006 Through July 26, 2007.

5.13 Hydraulic Gradient Directions for August 2006 Through January 2007 Calculated from 300 Area Automated Water-Level Network for Well Cluster 399-1-16A, 399-2-2, and 399-1-7.

5.14 Hydraulic Gradient Directions for February 2007 Through July 2007 Calculated from 300 Area Automated Water-Level Network for Well Cluster 399-1-16A, 399-2-2, and 399-1-7

5.15 Temperature Measurements at Wells in the RACS 300 Area Monitoring Network for 2006.

5.16 Electrical Conductivity Measurements at Wells in the RACS 300 Area Monitoring Network for 2006.

5.17 Monitoring Well Network for the Polyphosphate Treatability Test

5.18 Boundaries for Three-Dimensional Models in the 300 Area

5.19 Plan View of STOMP Model Grid R5B with Selected Wells

5.20 Three-Dimensional View of STOMP Model Grid R5B with the Top of the Model Domain in the Vadose Zone at an Elevation of $109 \mathrm{~m}$

5.21 Simulated Instantaneous Water Fluxes Calculated for Model Boundaries

5.22 Simulated Cumulative Water Fluxes Calculated for Model Boundaries

5.23 Simulated Annual Cumulative Water Flux for Period from February 1, 1992 to February 1, 1993, Along 3,019 m of 300 Area Shoreline

5.24 Plan View of STOMP Model Grid with Selected Wells.

5.25 Hydraulic Property Zonation at $\mathrm{Z}=103$-m Elevation for Small-Scale 300 Area Model ........

5.26 Hydraulic Property Zonation at Z = 102-m Elevation for Small-Scale 300 Area Model ........

5.27 Simulated Instantaneous Water Fluxes Calculated for Model Boundaries ..............................

5.28 Simulated Cumulative Water Fluxes Calculated for Model Boundaries .................................

5.29 Simulated Annual Cumulative Water Flux for 2006

5.30 Timing for Tracer Pulses and Drift for Simulation Results Shown in Figures 5.31 to 5.33 ....

5.31 Simulated Conservative Tracer Pulse for Case r1b2-lowrk During Initial Seasonal River Stage Increase in 2007

5.32 Simulated Conservative Tracer Pulse for Case r1b2-lowrk During High River Stage Period in June 2006 Followed by Lower Stage in July ....

5.33 Simulated Velocities from Calculated Center of Mass Positions of Tracer Pulses for Case r1b2-lowrk.

6.1 Aqueous U(VI) Speciation as a Function of $\mathrm{pH}$ and Total Aqueous U(VI) and Carbonate Concentrations in Hanford Sediment Pore Water.

6.2 Aqueous U(VI) Speciation in the Presence of $\mathrm{Ca}$, Ca and $\mathrm{Mg}$, and $\mathrm{Ca}$ and $\mathrm{PO}_{4}$ in Hanford Sediment Pore Water 
6.3 Crystal Structure of Betafite C, Based on Previous XRD Measurements.

6.4 Schematic of Uranium Inventories in Compartments and Uranium Flow Between Compartments

6.5 Sample Locations for Investigations by Serne et al. and Zachara et al.

6.6 Aerial Photo of North Process Pond Open Excavation.

6.7 Photograph Montage of Samples from South Process Pond \#2 Site.

6.8 Estimated Vadose Zone Location with Elevated Water-Leachable Uranium at 399-1-23 ......

6.9 Estimated Vadose Zone Location with Elevated Water-Leachable Uranium at 399-3-18 ......

6.10 Schematic Representation of the Paragenesis of Important Uranyl Mineral Groups...............

6.11 Simulated Sorbed Uranium Migration at 0, 1, 1.5, and 2.5 Years from the Emplacement Zone $280 \mathrm{~m}$ from the River for the Constant $\mathrm{K}_{\mathrm{d}}$ Model and Distributed Rate Mass-Transfer Adsorption Model

6.12 Simulated Aqueous Uranium Migration at 0, 1, 1.5, and 2.5 Years from the Emplacement Zone $280 \mathrm{~m}$ from the River for the Constant $\mathrm{K}_{\mathrm{d}}$ Model and Distributed Rate Mass-Transfer Adsorption Model

6.13 Simulated Migration of Sorbed Uranium at 0, 0.3, 1, 3, and 10 Years from the Emplacement Zone $30 \mathrm{~m}$ from the River for the Constant $\mathrm{K}_{\mathrm{d}}$ Model, Distributed Rate Mass-Transfer Model, and Multi-Component Surface Complexation Adsorption Model ......

6.14 Simulated Migration of Aqueous Uranium at 0, 0.3, 1, 3, and 10 Years from the Emplacement Zone $30 \mathrm{~m}$ from the River for the Constant $\mathrm{K}_{\mathrm{d}}$ Model, Distributed Rate Mass-Transfer Model, and Multi-Component Surface Complexation Adsorption Model ......

6.15 U(VI) Sorption Dependence on the Alkalinity of Artificial Groundwater Solutions of Varying Composition.

\section{Tables}

2.1 Operating Periods for Key Liquid Waste Disposal Facilities

2.2 Summary of Remedial Actions at Major Liquid-Waste Disposal Sites

3.1 Proportion of Groundwater in Samples from 300 Area Aquifer Tubes.

3.2 Maximum Observed Uranium Concentrations at 300 Area Wells and Aquifer Tubes.

3.3 Attributes of 300 Area Uranium Plume in Groundwater

4.1 Elevation Picks for Top of Ringold and Fine-Grained Subunit.

5.1 Wells Where Hourly and Sub-Hourly Temperature and Electrical Conductivity Measurements are Available from the RACS 300 Area Monitoring Network

5.2 Hydraulic Properties Used in Case: coral:/files1/r5b-flow-lowrk..

5.3 Hydraulic Properties Used in Case: clam:/files0/r1b2-lowrk

6.1 U(VI) Aqueous Speciation Reactions 
6.3 Background Uranium Concentrations in Hanford Site Groundwater .................................... 6.9

6.4 Uranium Disposed to Facilities at the Hanford Site............................................................. 6.13

6.5 Uranium Inventory in Compartments of the Box Model for 300 Area................................. 6.17

6.6 Uranium in Residual Sediment at the South Process Pond After Excavation.......................... $\quad 6.20$

6.7 Uranium in Residual Sediment at the North Process Pond After Excavation......................... 6.21

6.8 Locations and Uranium Concentrations in near-Surface Sediments Studied by Serne et al.... $\quad 6.21$

6.9 Locations and Uranium Concentrations in Process Ponds Sediment Samples Studied by

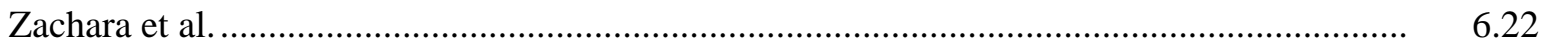

6.10 Uranium in Residual 300 Area Process Trenches Sediment After Excavation ...................... $\quad 6.26$

6.11 Uranium in Residual 307 Process Trenches Sediment in 1992, Following Remediation in

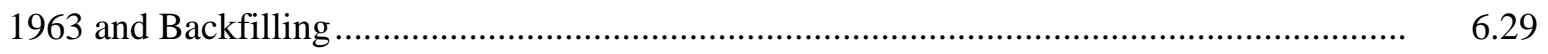

6.12 Total Uranium Concentration and Lithology of LFI Borehole Sediments with Hanford

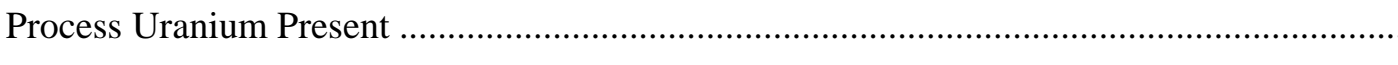

6.13 Total Uranium Concentration and Lithology of LFI Borehole Sediments with No Signs of

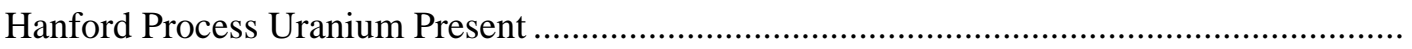

7.1 Summary of Uranium Inventory Estimates for Various Subsurface Repositories in the 300 Area 


\title{
1.0 Introduction
}

\author{
(R.E. Peterson)
}

This report updates earlier published information describing the features and processes associated with uranium contamination in the subsurface beneath the 300 Area of the Hanford Site (Figure 1.1). It contributes to the conceptual site model (CSM) for the 300 Area, as defined by the U.S. Environmental Protection Agency for remedial investigations. ${ }^{1}$ The CSM is useful for planning projects, developing computer simulations, interpreting monitoring results, and communicating progress, both within the project and with the general public (USACE 2003, p. 2-1). The primary role of a CSM is "to describe what is known or can be inferred about a site for the purpose of making a decision" (Shaw 2006). CSMs evolve and become more focused as the remedial investigation and feasibility study for a contaminated site progresses under the Comprehensive Environmental Response, Compensation, and Liability Act (CERCLA) process. Consequently, subsequent versions of CSMs for an operable unit may be referred to as "limited CSMs," in that their scope may not cover all contaminants of potential concern, all pathways for dispersal, or risks associated with potential receptors.

\subsection{Scope and Purpose}

The scope described in this report reflects the iterative nature of the remedial investigation process and is limited to the following:

- The contaminant is uranium.

- The geographic area is the 300 Area subregion of the 300-FF-5 Operable Unit, and includes the underlying vadose zone and uppermost aquifer (Figure 1.2).

- The media include sediment and water (moisture) in the vadose zone, the uppermost aquifer, and the interface between the aquifer and the Columbia River systems.

The decisions to be supported by information presented in this report are associated with the 300-FF-5 Phase III Feasibility Study, which is currently in progress. As stated in the work plan for that study (DOE-RL 2005b, p. 1), the objectives for re-evaluating the remedy for uranium in the 300 Area are to "identify, develop, and select remedial actions that have the potential to (1) restore, to the extent possible, the 300-FF-5 groundwater aquifer to its highest and best beneficial use, and (2) reduce risk to human health and the environment.” Fundamental information needs associated with these decisions are addressed in this report:

- The extent and amount of contaminant uranium in the vadose zone and aquifer.

- The geochemical characteristics of contaminant uranium in the vadose zone and aquifer.

- The source for the continuing replenishment of contaminant uranium in groundwater.

- The patterns and rates by which groundwater flows through the uppermost aquifer.

\footnotetext{
${ }^{1}$ The U.S. Environmental Protection Agency (EPA) guidance for conducting remedial investigations (EPA 1988, p. 2-7) indicates that a "conceptual site model should include known and suspected sources of contamination, types of contaminants and affected media, known and potential routes of migration, and known or potential human and environmental receptors." The stated purpose in the guidance for developing and maintaining a conceptual site model is "...to evaluate potential risks to human health and the environment...” and to “...assist in the identification of potential remedial technologies.”
} 


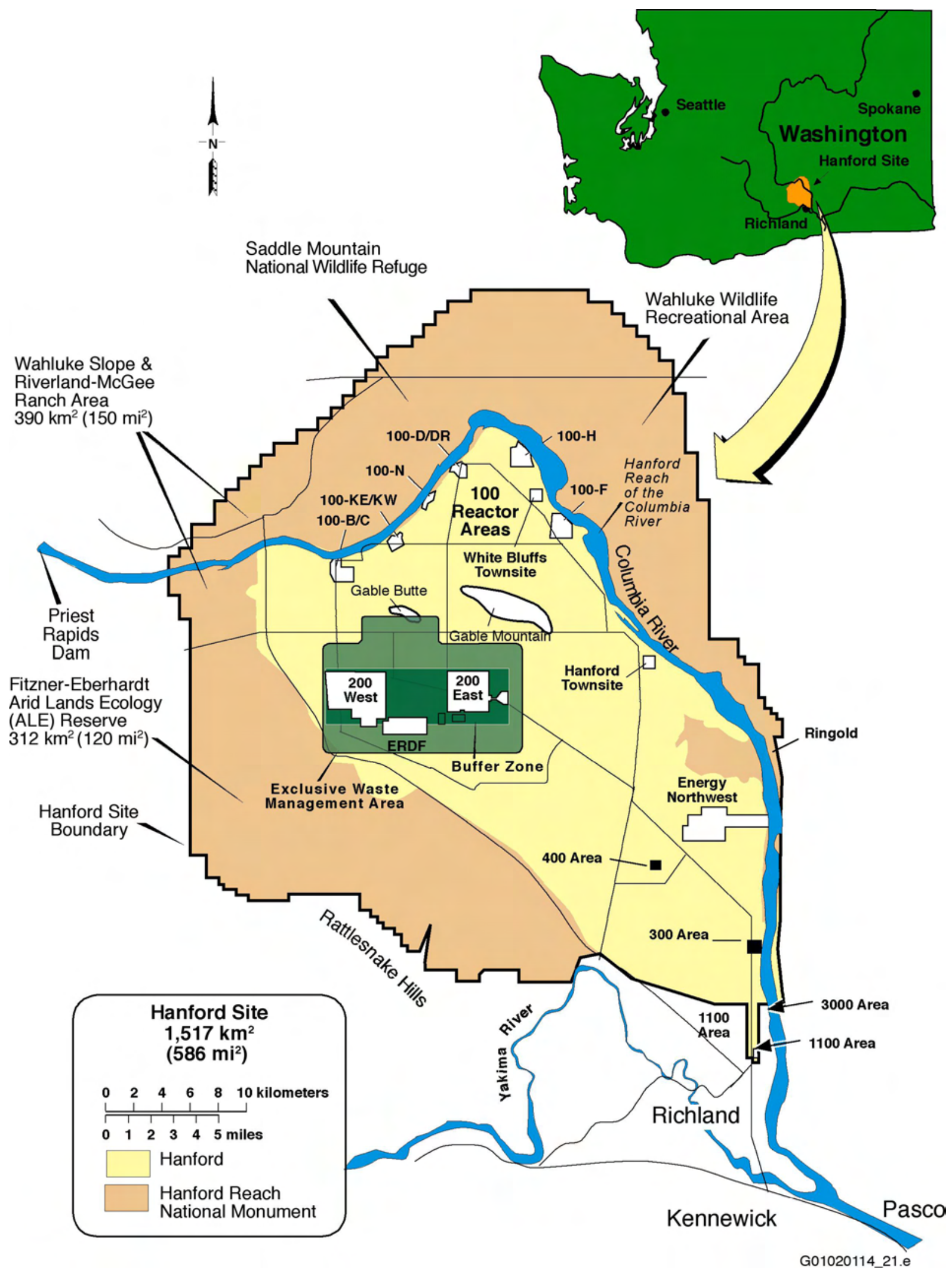

Figure 1.1. Index Map for the Hanford Site, South-Central Washington 


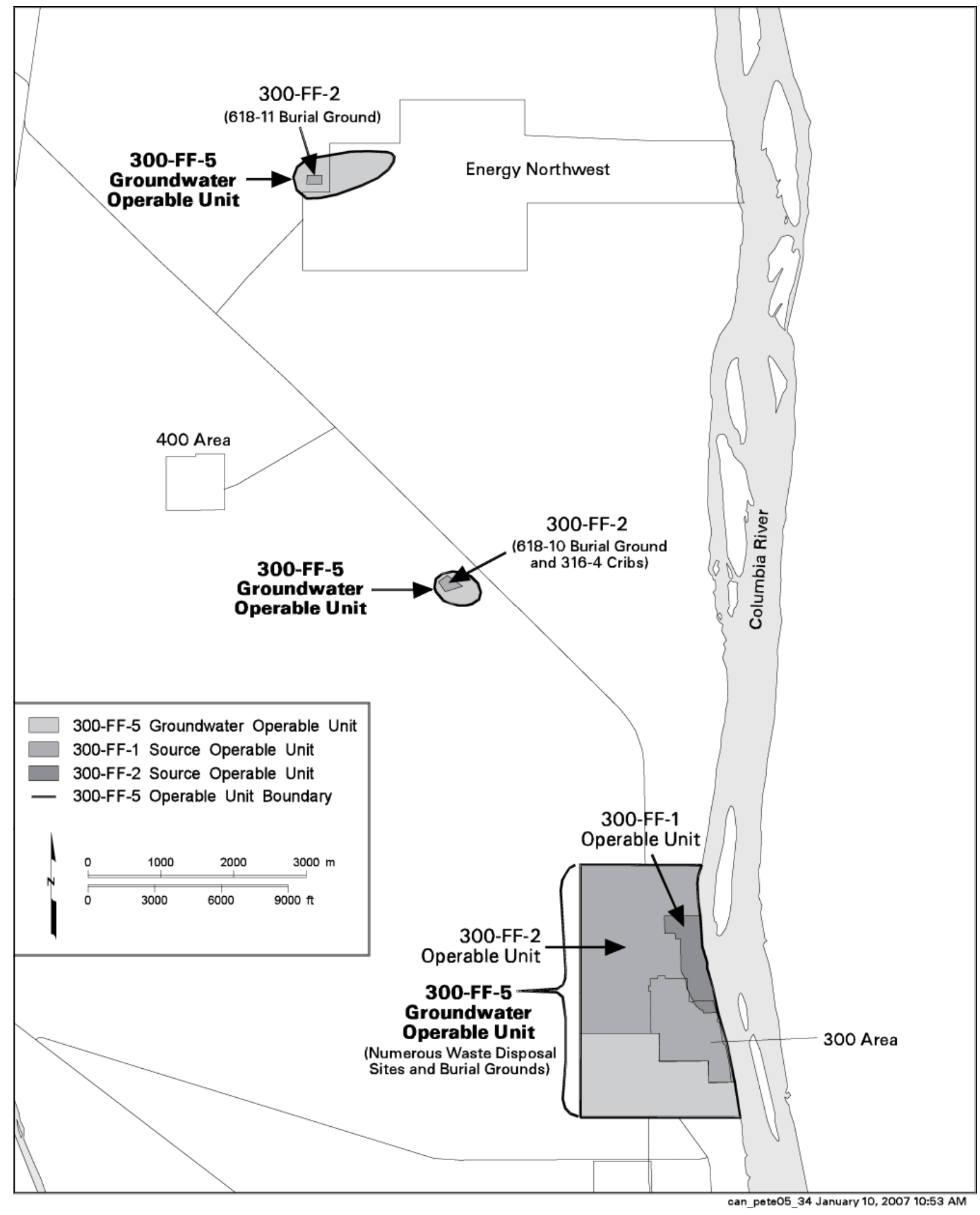

Figure 1.2. Index Map for the 300-FF-5 Operable Unit, 300 Area National Priorities List Site 


\subsection{Role of Report in CERCLA Process}

This report provides updated information on certain aspects of the CSM for the 300-FF-5 Operable Unit. The new information is the result of interim action monitoring and characterization activities being conducted under the current record of decision (EPA 1996b). The report also incorporates new information from a limited field investigation (LFI) involving uranium in the 300 Area subsurface environment and from various investigations conducted outside of the CERCLA program. The report describes features and processes associated with contaminant uranium that are relevant to planning and implementing treatability tests, screening remedial action technologies, and developing remedial action alternatives. As such, the report will serve as a source of technical information for subsequent program documents and various decisions associated with remedial action decisions.

Key CERCLA program documents that will follow this report include the Phase III Feasibility Study report and a proposed plan for interim remedial action involving uranium in the 300 Area. These documents are currently scheduled to be completed during 2008. A change to the existing record of decision will be prepared and the selected remedy implemented after receiving public input on the proposed plan. Additional reports that contribute, or will contribute in the near-term, to the CSM are associated with the results of 1) computer simulation of groundwater flow and transport in the 300 Area (Williams et al. 2008), 2) a compendium of information on all uranium investigations for the Hanford Site (Zachara et al. 2007a), and 3) the polyphosphate treatability test that is currently underway in the 300 Area (Vermeul et al. 2007). Additional conceptual models will be prepared in the future for other contaminants of potential concern, and for the outlying burial ground subregions of the 300-FF-5 Operable Unit, as part of providing a basis for decisions associated with final remedial actions for the 300 National Priorities List site.

\subsection{Recent Advances in Understanding the 300 Area Uranium Plume}

A significant amount of new information on the characteristics of this contamination has been acquired since the most recent comprehensive description of the plume was published in 2005 (Peterson et al. 2005, Chapter 3). The LFI conducted during 2006 involved drilling at four representative locations (Williams et al. 2007). Sediment and water samples were collected at various depth intervals, and the samples were examined with a comprehensive suite of analyses. An intensive geologic description of the core recovered during drilling produced new, detailed information on the stratigraphy of the unconfined aquifer, which in turn led to re-interpreting features and stratigraphic contacts recorded on drill logs for existing wells. This permitted an extensive update to the hydrogeologic framework within which the contamination resides. Major findings from the LFI include the following:

- The three-dimensional spatial framework within which uranium contamination is contained has been refined.

- It has been confirmed that uranium contamination in the aquifer is restricted to the saturated Hanford gravels hydrologic unit within the unconfined aquifer.

- Levels of uranium contamination in the vadose zone were lower than expected, and evidence was lacking for significantly elevated levels of uranium in the zone through which the water table rises and falls. 
- Analytical results for extracts from vadose zone sediment indicate that relatively high concentrations of dissolved uranium in vadose zone moisture are possible.

- The levels of contaminant uranium remaining in the vadose zone at the four borehole locations are too low to be quantified by high-resolution spectral gamma geophysical logging.

- No evidence was found for sequestration of uranium on aquifer solids at levels significantly higher than background levels for total uranium in a sediment sample. However, investigations using water and bicarbonate leach solutions are being used to differentiate potentially more mobile contaminant uranium from background uranium in those sediments.

The LFI drilling and characterization activities also revealed new information on elevated concentrations of volatile organic compounds at depths in the unconfined aquifer not normally monitored. The compounds of concern are trichloroethene and tetrachloroethene, along with their degradation product cis-1,2-dichloroethene. These compounds appear to be restricted to an undesignated fine-grained unit of well-sorted sand within the Ringold Formation Unit E. Additional investigation of this discovery continued during 2007 with the drilling of four characterization boreholes, each of which was completed as a monitoring well (Kooiker et al. 2007).

\subsection{Organization of the Report}

The description of features and processes associated with uranium contamination in the 300 Area's subsurface environment begins with an overview of selected key aspects of the CSM, along with background information on how information on the uranium plume has evolved with time. The background information is followed by the following: current conditions and trends, hydrogeologic framework, groundwater flow, and geochemistry. 



\title{
2.0 Background Information
}

\author{
(R.E. Peterson)
}

This section briefly describes historical 300 Area operations that have influenced uranium contamination in the subsurface environment. Some of the material is taken from an earlier report that describes contaminants of potential concern for the 300-FF-5 Operable Unit and a limited conceptual model for uranium (Peterson et al. 2005, Section 3). This is followed by a discussion of the chronological development of information on 300 Area hydrogeology and uranium contamination. The section concludes with an overview of current concepts associated with uranium contamination in the subsurface at the 300 Area.

\subsection{History of Operations}

Historical operations involving fuel fabrication and research activities at the 300 Area have contaminated engineered liquid-waste disposal facilities, the underlying vadose zone, and the uppermost aquifer with uranium. The principal reports describing historical operations for the purpose of supporting remedial action decisions are Young et al. (1990), Young and Fruchter (1991), Gerber (1992), and DeFord et al. (1994). The greatest impact to groundwater from disposal of waste containing uranium probably occurred during the period of Hanford's peak plutonium production, i.e., the 1950s through the mid-1960s. During this period, effluent was directed to the South and North Process Ponds and a lesser amount to the 307 Process Trenches. Contaminated process wastes continued to be generated during the 1970s and 1980s, with disposal shifting to the 300 Area Process Trenches in the mid-1970s. Figure 2.1 provides a location map for these waste-receiving facilities. Additional contamination of the 300 Area subsurface occurred because of leakage from the process sewer system (Waste Information Data System [WIDS] Code 300-15), which delivered fuel fabrication and other process/research waste effluents to the various disposal sites (Lindberg and Bond 1979).

Before the construction of McNary and Priest Rapids Dams (1956 and 1961, respectively), the seasonal discharge of the Columbia River through the Hanford Reach varied in the approximate range of 60,000 to $450,000 \mathrm{ft}^{3} / \mathrm{s}$. The greatest discharge and the highest-stage elevations typically occurred during May and June. River-stage conditions at the 300 Area are influenced by the release from Priest Rapids Dam (upstream), as well as by the pool elevation for McNary Dam (downstream). The seasonal high conditions resulted in an elevated water table beneath the 300 Area. Because of this occurrence, contaminant uranium in groundwater may have been moved upward into the lower vadose zone throughout the area occupied by the plume. As the water table elevation returned to more normal levels later in the summer, uranium may have been left behind in the lower vadose zone, having been sorbed onto sediment and/or remaining in residual amounts of groundwater. Figure 2.2 illustrates the historical ranges in elevation of the water table, and in uranium concentrations in groundwater at wells near the south and north process ponds. The limited monitoring data available for the 1950s and 1960s suggest that the water-table elevation during that time extended 2 to $3 \mathrm{~m}$ above the typical maximum water-table elevations today. Uranium concentrations in groundwater appear to have been in the 600 to 1,200 $\mu \mathrm{g} / \mathrm{L}$ range.

Table 2.1 lists the the operating chronology for each of the major liquid-waste disposal sites. Remedial actions were undertaken at each of these sites during the 1990s (DOE-RL 2005a). These actions included the removal of contaminated soil, which was then transported to the Environmental Restoration Disposal Facility (ERDF) in the Central Plateau region. Table 2.2 shows selected information for cleanup at each of these sites. 


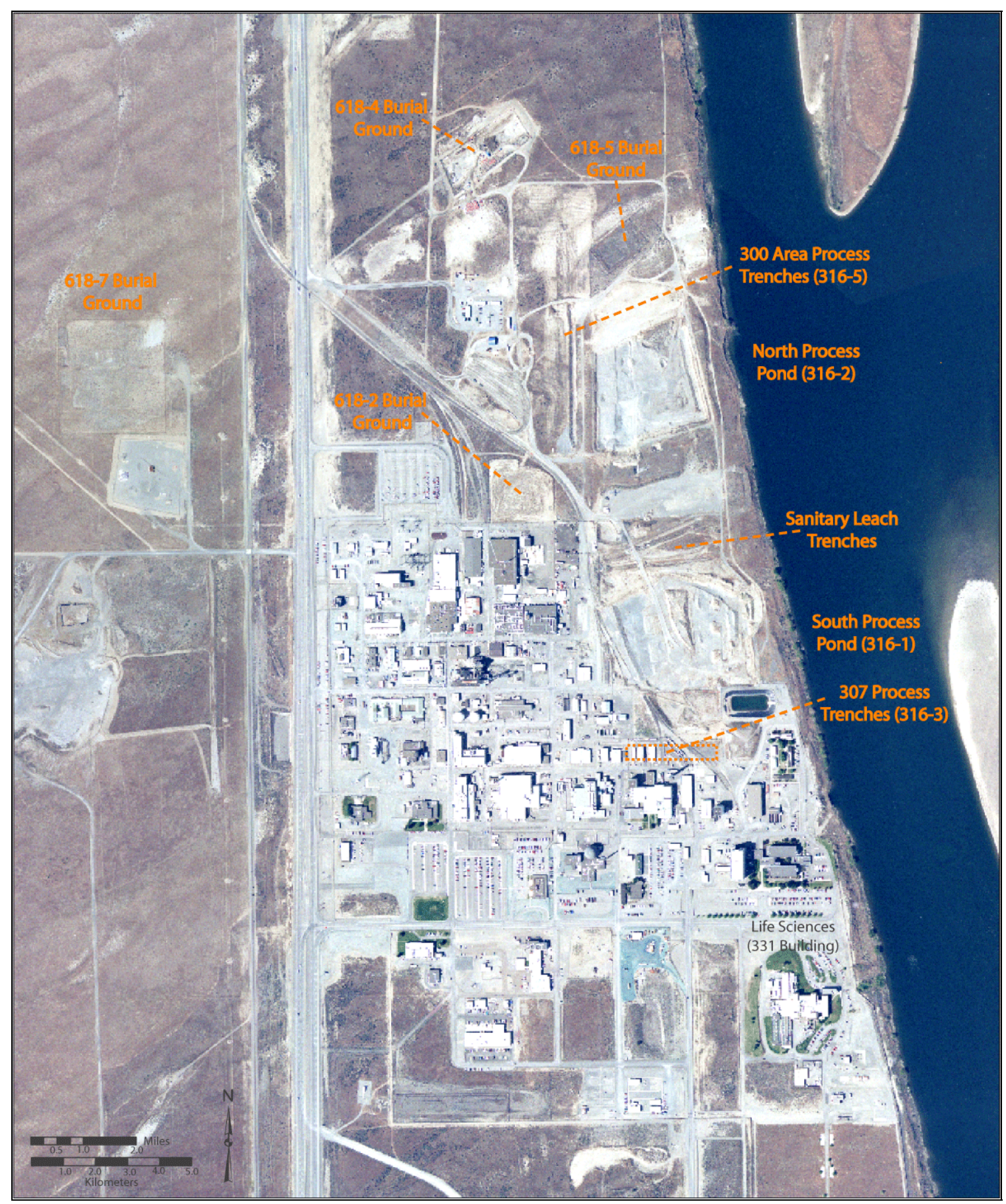

Figure 2.1. Aerial Photo (2002) Showing the Locations of Principal Waste Disposal Sites

A groundwater plume has likely been present beneath the 300 Area since disposal operations started in 1948. Its persistence today indicates some level of re-supply via mechanisms not yet clearly defined, because the rate of groundwater movement appears to be sufficient to have moved the plume away from the area in the absence of a continuing source. Also, a significant amount of uranium is removed from the aquifer via water supply well 399-4-12 at the Life Sciences Facility (331 Building). This well has provided water for aquarium operations since 1982. 
(a) Well 399-1-1, Near North Process Pond

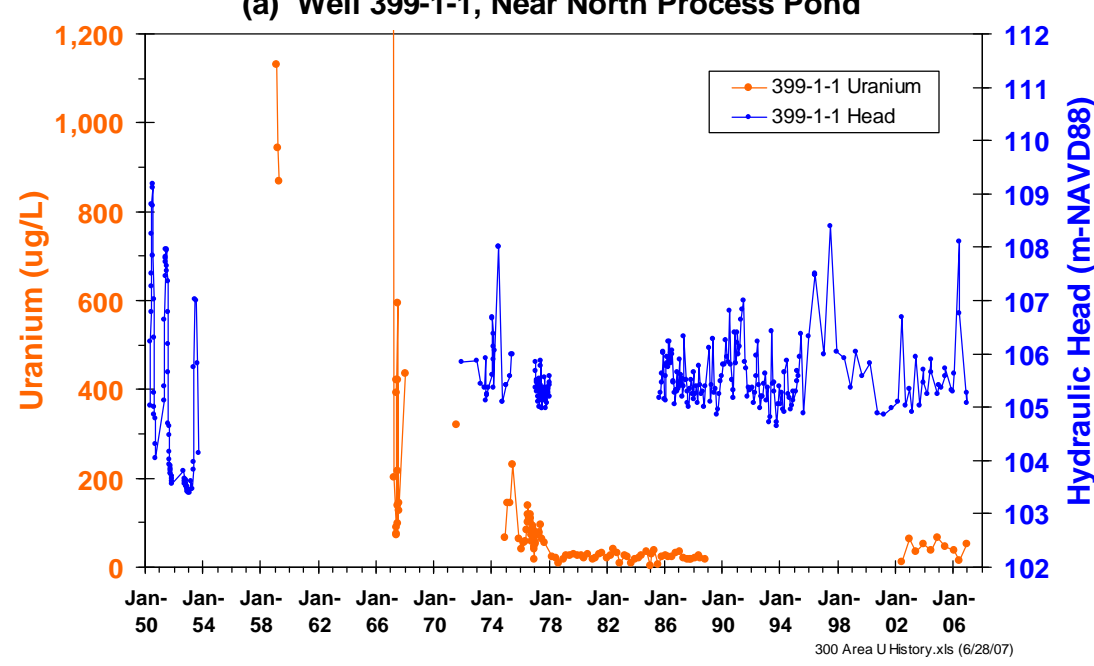

(c) Well 399-2-1, Near South Process Pond (b) Well 399-1-2, Near North Process Pond

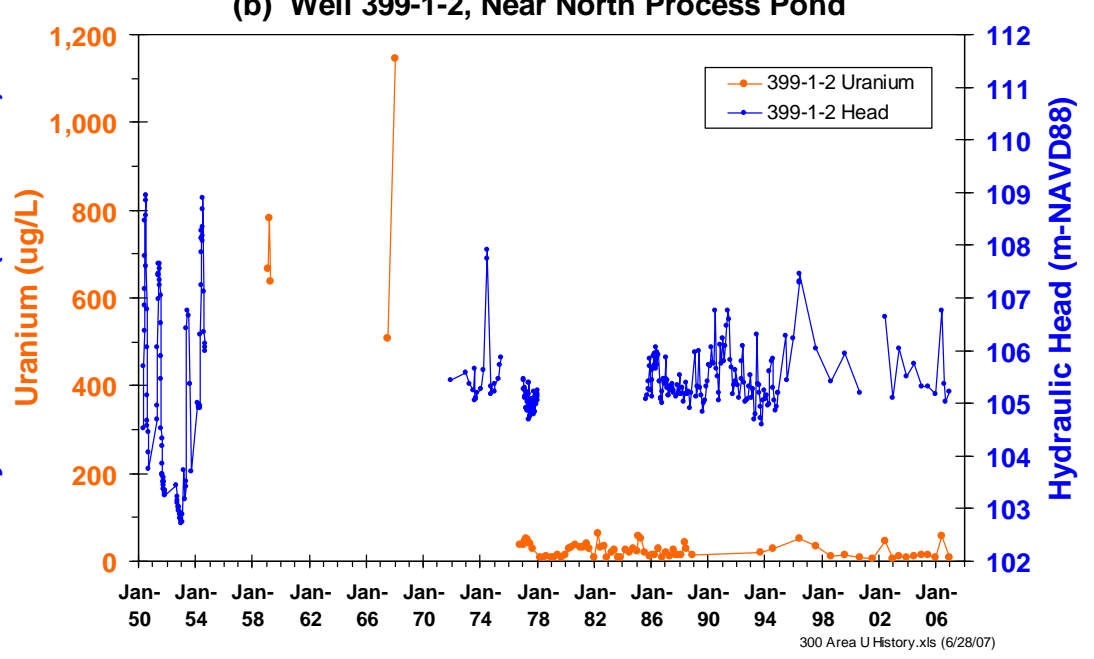

(d) Well 399-3-1, Near South Process Pond

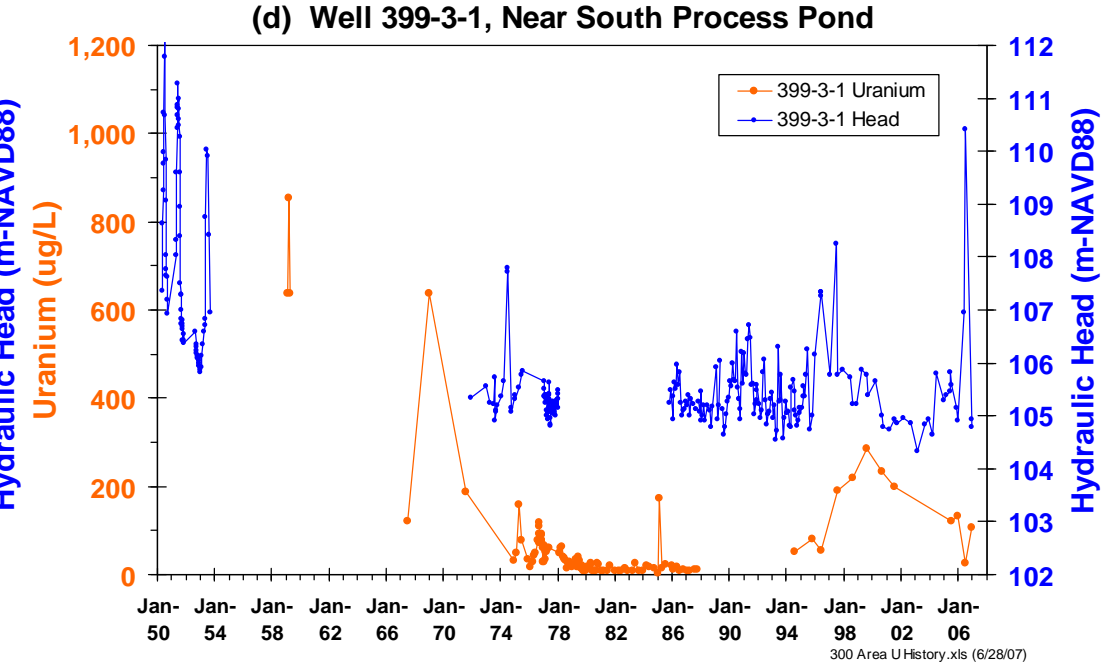

Figure 2.2. Historical Uranium and Water Table Elevation Trends near the North and South Process Ponds 
Table 2.1. Operating Periods for Key Liquid Waste Disposal Facilities

\begin{tabular}{|c|c|c|c|}
\hline Disposal Facility & $\begin{array}{l}\text { WIDS }^{(\mathrm{a})} \\
\text { Code } \\
\end{array}$ & $\begin{array}{l}\text { Period of Use } \\
\text { for Effluent } \\
\end{array}$ & Comments \\
\hline 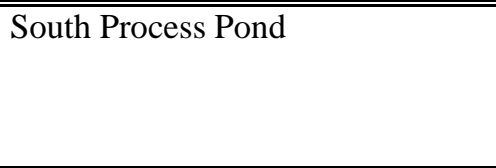 & $316-1$ & 1943 to 1975 & $\begin{array}{l}\text { Estimates for uranium disposed to south and north } \\
\text { process ponds range from } 34,000 \mathrm{~kg}^{(\mathrm{b})} \text { to } \\
45,500 \mathrm{~kg}^{(\mathrm{c})} \text {. Removal of contaminated soil } \\
\text { completed in 2000; excavation backfilled in } 2004 .\end{array}$ \\
\hline North Process Pond & $316-2$ & 1948 to 1974 & $\begin{array}{l}\text { Removal of contaminated soil completed in 1999; } \\
\text { excavation backfilled in } 2004 \text {. }\end{array}$ \\
\hline 307 Process Trenches & $316-3$ & 1953 to 1963 & $\begin{array}{l}\text { Taken out of service in } 1965^{(\mathrm{b})} \text {; backfilled; } \\
\text { buildings and pavement constructed over } \\
\text { footprint; remedial action not yet undertaken. }\end{array}$ \\
\hline 300 Area Process Trenches & $316-5$ & $\begin{array}{l}1975 \text { to } 1985 \\
1985 \text { to } 1994\end{array}$ & $\begin{array}{l}\text { Received non-hazardous liquid effluent after } 1985 \\
\text { through December } 1994 \text {. Expedited Response } \\
\text { Action in } 1991 \text { to remove contaminated soil. }\end{array}$ \\
\hline Treated Effluent Disposal Facility & & 1994 to present & $\begin{array}{l}\text { Receives } 300 \text { Area effluents via the process sewer } \\
\text { system. }\end{array}$ \\
\hline \multicolumn{4}{|c|}{$\begin{array}{l}\text { (a) Waste Information Data System } \\
\text { (b) Young and Fruchter (1991) } \\
\text { (c) Simpson et al. (2006) } \\
\text { Source: 300-FF-1 Operable Unit Remedial Action Report (DOE-RL 2005a) }\end{array}$} \\
\hline
\end{tabular}

Table 2.2. Summary of Remedial Actions at Major Liquid-Waste Disposal Sites

\begin{tabular}{|c|c|c|c|c|}
\hline Disposal Facility & $\begin{array}{l}\text { Excavation } \\
\text { Dates }\end{array}$ & $\begin{array}{l}\text { Backfill } \\
\text { Date }\end{array}$ & $\begin{array}{c}\text { Cleanup } \\
\text { Verification Report }\end{array}$ & Comments \\
\hline $\begin{array}{l}300 \text { Area Process } \\
\text { Trenches }\end{array}$ & 1991 & $\begin{array}{l}\text { (Remained } \\
\text { open) }\end{array}$ & $\begin{array}{l}\text { DOE/RL-91-11 } \\
\text { (DOE-RL 1992) }\end{array}$ & $\begin{array}{l}\text { Scraped bottom of trenches and } \\
\text { moved sediment to north end }\end{array}$ \\
\hline $\begin{array}{l}300 \text { Area Process } \\
\text { Trenches }\end{array}$ & $\begin{array}{c}\text { Jul } 1997 \text { to Feb } \\
1998\end{array}$ & 2004 & $\begin{array}{l}\text { BHI-01164 } \\
\text { (BHI 1998) }\end{array}$ & $\begin{array}{l}\text { Additional excavation of sides } \\
\text { and bottoms of trenches }\end{array}$ \\
\hline North Process Pond & $\begin{array}{l}\text { May } 1998 \text { to } \\
\text { Jun } 1999\end{array}$ & 2004 & $\begin{array}{l}\text { BHI-01298 } \\
\text { (Lerch 1999) }\end{array}$ & $\begin{array}{l}\text { Removed } \sim 30,000 \mathrm{~kg} \text { of } \\
\text { uranium }^{(a)}\end{array}$ \\
\hline South Process Pond & $\begin{array}{c}\text { Jun } 1997 \text { to Jun } \\
2000\end{array}$ & 2004 & $\begin{array}{l}\text { CVP-2003-00002 } \\
\text { (BHI-2003) }\end{array}$ & $\begin{array}{l}\text { Removed } \sim 40,000 \mathrm{~kg} \text { of } \\
\text { uranium }^{(\mathrm{b})}\end{array}$ \\
\hline $\begin{array}{l}307 \text { Process } \\
\text { Trenches }\end{array}$ & 1965 & 1965 & $\begin{array}{l}\text { (Remedial action under } \\
\text { CERCLA not yet } \\
\text { undertaken) }\end{array}$ & $\begin{array}{l}\text { Backfilled with scrapings from } \\
\text { South Pond and fly ash }{ }^{(\mathrm{c})}\end{array}$ \\
\hline \multicolumn{5}{|c|}{$\begin{array}{l}\text { (a) WIDS report for 316-2 } \\
\text { (b) WIDS report for 316-1 } \\
\text { (c) Young and Fruchter (1991) } \\
\text { Note: A comprehensive description of these remedial actions is presented in the 300-FF-1 Operable Unit Remedial } \\
\text { Action Report (DOE-RL 2005a). }\end{array}$} \\
\hline
\end{tabular}

Some uranium is known to remain in the underlying vadose zone after the most contaminated waste-disposal sites and adjacent soil were excavated from 1995 to 2004 . Evidence supporting this conclusion comes from the cleanup verification sampling that was done at each excavation before backfilling (see reports listed in Table 2.2) and from samples collected at two locations each in the south and north process ponds (Zachara et al. 2005). The latter effort consisted of using a backhoe to collect samples comprising vertical profiles that extended down to the water table. Uranium in groundwater is currently transported to the Columbia River under natural hydrologic flow conditions where it discharges into the river system and is dispersed via additional transport pathways (e.g., the free-flowing stream, biota and food chain, and sediment). 


\subsection{Historical Development of a Conceptual Model for the 300 Area Uranium Plume}

Several comprehensive investigations have been conducted in the past that contribute to the current understanding of uranium contamination in 300 Area groundwater. However, very little information regarding the distribution of uranium in the vadose zone has been published, with the most significant new information being supplied by research conducted under DOE's various science and technology initiatives (Zachara et al. 2005) and the recently completed LFI under the CERCLA program (Williams et al. 2007).

Principal groundwater investigations and their key contributions to a conceptual model for uranium are summarized below in chronological order:

Geohydrology and Ground-Water Quality Beneath the 300 Area, Hanford Site, Washington (Lindberg and Bond 1979)

- Comprehensive groundwater sampling (monthly) and water-level measurements (weekly) in 27 wells during 1977 were provided, resulting in detailed maps for contaminants and water-table elevation.

- Principal hydrostratigraphic units associated with the unconfined aquifer were described, including the two common facies of Ringold Formation Unit E (primarily sand and gravel; some silt and clay) and the overlying "Pasco gravels," which are now referred to as Hanford gravels or Hanford formation.

- The presence of a major north-south trending paleochannel of highly transmissive sediment within the aquifer was acknowledged. The channel is an erosional feature incised into the Ringold Formation. This paleochannel merges with the current Columbia River channel in places to the north and south of the 300 Area. The paleochannel influences the distribution of contaminant uranium in groundwater.

- The paleolevee that separates the current river channel from the paleochannel is breached in the area between the north and south process ponds, allowing rapid exchange between groundwater and river water and promoting a riverbank spring (currently named "S3-DR42-2” or “Spring 9”).

- The displacement of the uranium plume to the west as far as Steven's Drive was described. This is a consequence of high river conditions and reversed water-table gradient.

- The importance of uranium discharge to the unlined process ponds, leakage from the process sewer lines, highly variable groundwater movement patterns, and transmissive aquifer sediment in creating a widespread uranium plume was acknowledged.

- Groundwater flow modeling indicated flow rates from the 300 Area Processes Trenches at up to $\sim 10 \mathrm{~m} / \mathrm{d}$.

Interim Characterization Report for the 300 Area Process Trenches (Schalla et al. 1988)

- Hydrogeology of the 300 Area was extensively investigated as part of a groundwater monitoring compliance program regulated under the Resource Conservation and Recovery Act (RCRA) for hazardous chemicals.

- Eighteen new monitoring wells were installed during 1986 and 1987, and they covered multiple horizons in the unconfined aquifer and the uppermost confined aquifer. 
- It was acknowledged that Columbia River fluctuations are the primary natural influence on groundwater flow directions and that discharge to the 300 Area Process Trenches is the most important artificial influence. This was based on monthly and hourly monitoring of water tables.

- It was determined that the hydraulic head in the uppermost confined aquifer was roughly 20 to $35 \mathrm{ft}$ (6.1 to $10.7 \mathrm{~m}$ ) higher than in the overlying unconfined aquifer, thus indicating the low probability for downward migration of contaminants from the unconfined to the confined aquifer.

- It was suggested that there is a plume migration rate of $\sim 35 \mathrm{ft} / \mathrm{d}(10.7 \mathrm{~m} / \mathrm{d})$ from the Process Trenches to the Columbia River via the shallow portion of the unconfined aquifer.

Phase I Hydrogeologic Summary of the 300-FF-5 Operable Unit, 300 Area (Swanson et al. 1992)

- Nineteen new groundwater monitoring wells were installed within and near the 300 Area in 1991, with screened intervals at multiple depth horizons.

- The project resulted in new stratigraphic information, new data on hydraulic parameters for the region immediately west of the 300 Area, and radionuclide logging for some of the new wells.

Phase I Remedial Investigation Report for the 300-FF-5 Operable Unit (DOE-RL 1994b)

- This report presents the first comprehensive description of contamination in the 300 Area surface and subsurface environment and the risks associated with that contamination.

- Data collection: Water, sediment, and biota

- Description of physical characteristics

- Nature and extent of contamination

- Contaminant transport analysis

- Baseline risk assessment

- Summary: Description of CSM

- Conclusions and Recommendations.

- The purpose for the remedial investigation was “...to gather and develop the necessary information to understand risks to human health and the environment from these groundwater impacts, and to support the development and evaluation of remedial alternatives during the feasibility study."

- The results of the remedial investigation “...will be used by the Tri-Parties to make a riskmanagement-based selection of remedies for contamination...in the groundwater aquifer and shoreline saturated sediment..."

- Phase I collected and evaluated groundwater data from four rounds of sampling that were conducted from December 1991 to December 1992. One comprehensive sampling event along the 300 Area shoreline (water and sediment) was conducted during August 1992.

- Results of groundwater flow and transport modeling were presented, which led to predictions for future maximum uranium concentrations in groundwater in 2018, the first year during which institutional controls might be relaxed by DOE for the 300 Area.

- Uncertainty in simulating uranium transport in the aquifer was discussed because of 1) unknowns regarding partitioning between dissolved and solid phases, 2) kinetic vs. equilibrium solubility constraints, and 3) possible migration of uranium from waste sites as colloids/flocs. It was also assumed that the vadose zone no longer acted as a source for uranium input to the aquifer. 
- No human health or environmental risks were identified that would warrant an expedited response action for groundwater. A recommendation was made to obtain additional data regarding contaminant concentrations in river water near the 300 Area shoreline and at "other appropriate points” in the remedial response process.

- Additional investigations were recommended, including a focus on the transport and fate of uranium in the unconfined aquifer, particularly with respect to the possible role of colloids/flocs, and the mobility of uranium solutes.

Remedial Investigation/Feasibility Study Report for the 300-FF-5 Operable Unit (DOE-RL 1995b)

- All the work conducted during the initial remedial investigation for the operable unit was summarized. This consisted of the 300 Area and its immediate surroundings at the time. The Phase I Remedial Investigation report was complemented by including the results of additional rounds of groundwater sampling and Columbia River environmental sampling. Investigations looked at groundwater and the surface water and sediment associated with the 300 Area river shore.

- Three major uncertainties were identified that were associated with predicting future uranium contamination in groundwater ${ }^{2}$ :

- Solubility-controlled release mechanism or sorption-controlled release mechanism—which is dominant?

- Value(s) for uranium distribution coefficient $\left(\mathrm{K}_{\mathrm{d}}\right)$.

- Average linear velocity of groundwater.

- Testing was conducted to determine whether filtering a groundwater sample influenced the total uranium measured in the sample. Results indicated no significant difference in total uranium measured for filtered and unfiltered samples. It was concluded that this is the result of either low suspended solids in groundwater and/or low sorption of uranium to any solids present.

- Reduction in uranium concentrations at wells in the northern portion of the plume was interpreted to be a consequence of removing contaminated sediment from the 300 Area Process Trenches. This interpretation has subsequently been shown to be incorrect.

- It was suggested that uranium is being released from sediment in the zone immediately above the average water table. This is based on observed increases in concentrations at some wells during periods of elevated water table conditions

- It was concluded that uranium migration appears to be controlled by a sorption-controlled release mechanism.

- A "best" estimate of the time required for uranium concentrations in the plume to fall below the proposed maximum contaminant level of $20 \mu \mathrm{g} / \mathrm{L}$ was presented. The estimate was 3 to 10 years from late 1993. An earlier estimate presented in the initial remedial investigation report (DOE-RL 1994b) suggested that uranium levels may still exceed $20 \mu \mathrm{g} / \mathrm{L}$ as far into the future as 2018.

\footnotetext{
2 At the time of the remedial investigation, it was assumed that institutional controls would be relaxed no earlier than 2018, the target date set by the Tri-Parties for the completion of remedial actions for all operable units on the Hanford Site.
} 
Operation and Maintenance Plan for the 300-FF-5 Operable Unit (DOE-RL 2002a)

- Working assumptions were presented regarding the characteristics of the 300 Area uranium plume, as part of the CSM for the 300-FF-5 Operable Unit.

- The dilution of the plume near the 300 Area Process Trenches during 1991 through 1994 was acknowledged, with a subsequent rise in concentrations following the cessation of clean water discharges to the trenches.

- The seasonal cycle in uranium distribution patterns caused by periodic raising of the water table into contaminated sediment was acknowledged.

- Precipitation, adsorption, dilution, and dispersion were identified as the primary processes associated with natural attenuation of the plume.

Contaminants of Potential Concern in the 300-FF-5 Operable Unit (Peterson et al. 2005)

- Included in this expanded groundwater report for fiscal year 2004 was a section describing the conceptual model for uranium contamination in the 300 Area. The report provided new information on trends in several characteristics of the groundwater plume (e.g., maximum annual concentrations since 1992; estimates for volume of plume and mass of dissolved uranium for multiple time periods). Uranium concentration trend charts for 300 Area wells are included as an appendix. The results from research involving the geochemistry of uranium in 300 Area sediment and efforts to simulate uranium transport were summarized.

- Four potential causes for variability in uranium plume distribution patterns since the early 1990s were identified: 1) removal of contaminated sediment from the 300 Area Process Trenches, 2) cessation of liquid-waste disposal to the ground, 3) large-scale excavation activities at the North and South Process Ponds, and 4) unusually high water-table conditions during 1996 and 1997.

- It was suggested that some degree of balance has been established in recent years between the influx of clean groundwater to the 300 Area, re-supply of dissolved uranium to the plume via release from the vadose zone and/or from aquifer solids, and loss of uranium via river discharge and withdrawal at a water supply well (399-4-12 at the 331 building).

- Earlier concepts were reiterated that uranium sources in the vadose zone may include two categories: uranium widely distributed in the zone through which the water table rises and falls, and residual contamination in the vadose zone beneath the footprints of remediated waste sites.

- It was acknowledged that the dilution of contamination that occurs in wells near the river and the possibility that the change in geochemistry in the zone of groundwater/river mixing (i.e., reduction in bicarbonate content) may promote the sorption of uranium onto aquifer solids.

- The following uncertainties with respect to evaluating remedial action technologies were included in this recent update to the CSM for uranium:

- Groundwater and uranium mass balance for the aquifer beneath the 300 Area and rate of pore volume exchanged.

- Inventory and mobility of uranium associated with 1) the vadose zone beneath waste sites, 2) the zone within which the elevation of the water table rises and falls, and 3) aquifer solids.

- Rates and mechanisms by which the inventory of contaminant uranium, wherever sequestered, is re-supplying the observed plume. 
To address these uncertainties, additional work was recommended, including a computer simulation of groundwater flow and uranium transport, a field investigation involving drilling to further define the vertical and lateral extent of uranium contamination, and continued research into the geochemical controls on uranium mobility. The updated conceptual model for uranium described in the following sections presents the new information that has become available to reduce these uncertainties.

\subsection{Role of CSM in Remedial Action Decisions}

The initial CSM for the 300-FF-5 Operable Unit was included in an early remedial investigation report (DOE-RL 1994b), although the phrase “conceptual site model” was not actually used. However, descriptions for the various features, processes, and risks associated with contaminants of potential concern in the operable unit do provide information necessary for remedial-action decision making. Because of large uncertainties associated with some aspects of the initial remedial investigation, additional work was conducted during the early 1990s, including:

- conducting additional sampling along the 300 Area shoreline to better understand risks associated with the surface water pathway,

- continuing the monitoring of volatile organic compounds to better understand trends, and

- refining the understanding of the fate and transport of uranium in groundwater.

With respect to uranium contamination, the additional work focused on reducing the uncertainty in the predictions of future conditions that were presented in the early remedial investigation report. ${ }^{3}$ Those predictions suggested that concentrations of uranium in groundwater may still exceed the proposed drinking water standard of $20 \mu \mathrm{g} / \mathrm{L}$ in 2018, the first year during which institutional controls might be relaxed in the 300 Area. The additional work involved conducting uranium analyses on filtered and unfiltered groundwater samples, determining whether a solid phase uranium precipitate serves as a source for continuing to supply groundwater, and refining estimates for the uranium distribution coefficient $\left(\mathrm{K}_{\mathrm{d}}\right)$. This, and work on other contaminants of potential concern, was completed, and the results were described in a subsequent remedial investigation report (DOE-RL 1995b).

The refined predictions for future conditions indicated that concentrations of dissolved uranium in the unconfined aquifer would reach remediation goals (i.e., the proposed drinking water standard of $20 \mu \mathrm{g} / \mathrm{L}$ ) in 3 to 10 years from late 1993. The conceptual model at the time of modeling the uranium plume made a key assumption: uranium contributions to groundwater from source operable units would be negligible. This was considered reasonable in light of the rapidly evolving source removal activities and experience with removing contaminated soil from the 300 Area Process Trenches in 1991 (DOE-RL 1992). Implicit in this assumption, though not directly stated, was that there would also be no continuing supply of uranium from the vadose zone beneath these waste sites. Also implicit was that the most recent waste site source for supplying uranium to groundwater was the 300 Area Process Trenches.

Based on the refined description of the uranium plume presented in the second remedial investigation report (DOE-RL 1995b), a record of decision (EPA 1996b) was developed that included the following interim remedies:

\footnotetext{
${ }^{3}$ Uncertainties listed for uranium include 1) whether uranium migration is dominated by a solubility-controlled release mechanism or a sorption-controlled mechanism, 2) the value for a uranium distribution coefficient (Kd), and 3) groundwater flow velocity (DOE-RL 1995b, p. ES-2).
} 
- "Continued monitoring of groundwater that is contaminated above health-based levels to ensure that concentrations continue to decrease.”

- "Institutional controls to ensure that groundwater use is restricted to prevent unacceptable exposures to groundwater contamination.”

"Continued groundwater monitoring” was considered necessary to verify modeled predictions of contaminant attenuation and to evaluate the need for active remedial measures (EPA 1996b, p. 62). The term "ensure" was used in the record of decision in the sense of verifying predicted conditions.

Because predictions of future uranium concentrations in groundwater did not evolve as expected during subsequent monitoring, DOE initiated new activities to refine the conceptual for uranium and to investigate candidate technologies for remedial action. ${ }^{4}$ These new initiatives are described in Federal Facility Agreement and Consent Order M-016-04-05, August 9, 2004. The relevant Tri-Party Agreement Milestone is M-016-68, which had a due date of March 31, 2005. The primary deliverables prepared to satisfy that milestone are 1) a Work Plan for a Phase III Feasibility Study of uranium in the 300 Area (DOE-RL 2005b) and 2) an expanded groundwater report for fiscal year 2004 that included a description of the conceptual model for uranium in the 300 Area (Peterson et al. 2005).

In summary, the role of the conceptual model for uranium in the 300 Area has been to provide relevant information on the characteristics of uranium contamination in groundwater to remedial action engineers, human and ecological health risk assessors, DOE management, regulatory agencies, and the general public. The remainder of this report provides the most recent observations concerning uranium contamination in the subsurface environment and interpretations as to how and why the plume is evolving as it is with time.

\subsection{Current Concepts}

The uranium plume in groundwater beneath the 300 Area has not evolved as predicted by the results of modeling during the initial remedial investigation in the 1990s. Most notably, concentrations of uranium have not decreased to meet the drinking water standard during the 3 to 10 years following the 1993 prediction. Also, other plume parameters, such as areal extent, volume of contaminated groundwater, and mass of dissolved uranium, have not shown a distinct decreasing trend in recent years, as might be expected if there were no continuing re-supply of uranium to the plume (Peterson et al. 2005). Consequently, investigators and decision-makers are left with a central question: What causes the persistence of the 300 Area uranium plume?

The initial remedial investigation prediction that uranium concentrations would decrease to a proposed drinking water standard of $20 \mu \mathrm{g} / \mathrm{L}$ in 3 to 10 years from 1993 made several key assumptions: 1) no future increases in groundwater concentrations and 2) negligible re-supply of uranium to the groundwater plume. Had there been no re-supply of the plume since the early 1990s, concentrations would likely have fallen to less than the concentration standard because of uranium mass removal by discharge of contaminated groundwater into the river and by withdrawal of contaminated groundwater at water supply well 399-4-12. Work conducted since the initial remedial investigation suggests that these assumptions are not completely valid and that uranium is being re-supplied to groundwater from several

\footnotetext{
${ }^{4}$ The objective for remedial action of groundwater beneath the 300 Area was to reduce the concentrations of dissolved uranium to meet the EPA drinking water standard (30 $\mu \mathrm{g} / \mathrm{L}$ for an unfiltered water sample).
} 
potential inventory zones and by several potential processes. Portions of the following text were first presented in the second 5-year review report for the CERCLA record of decision (DOE-RL 2006b). The discussion in the review was prepared to answer the question: Is the remedy functioning as intended by the decision documents? Additional ideas and concepts are summarized from the historical reports described in Section 2.2 above, as well as from very recent information developed as a consequence of the LFI (Williams et al. 2007).

\subsubsection{Historical Emplacement of Contaminant Uranium}

Figure 2.3 shows a schematic diagram that is used to illustrate the various inventory zones where contaminant uranium may be sequestered and also to identify some of the processes that act to mobilize and distribute uranium in the subsurface. The vadose zone beneath the primary sites for disposing of liquid wastes (i.e., South and North Process Ponds; 300 Area Process Trenches) was a transport pathway to groundwater during waste-disposal operations. Some uranium became sequestered within the vadose zone by multiple potential processes, such as precipitation and adsorption (see Section 6.0, Geochemical Characteristics of Contaminant Uranium). The most mobile fraction reached the groundwater pathway as a dissolved constituent and migrated as a contaminant plume, with ultimate discharge into the freeflowing stream of the Columbia River through the riverbed, and to a lesser extent, via riverbank springs.

Movement of the plume beneath the 300 Area was complicated by the rise and fall of the river stage, especially during the period of seasonal high-river discharge in the spring and early summer months. During the early operations period (1940s, 1950s, and 1960s), high-river-stage conditions created a hydraulic gradient that caused groundwater plumes to move inland from their normal positions under more typical gradients and river stages. Depending on the length of time that the hydraulic gradient was reversed, groundwater plumes may have been pushed inland as far as the north-south highway that borders the 300 Area on the west (see Figure 2.1).

Before McNary Dam and Priest Rapids Dams were constructed, seasonal ranges in Columbia River discharge and stage elevation were much greater than when the dams were completed (Figure 2.4). Also, periodic floods in pre-dam years, such as the 1948 flood, significantly impacted groundwater conditions near the river. The water table beneath the 300 Area would be elevated well above typical current levels during these high-river conditions, thus pushing contaminated groundwater upward into the lower vadose zone. As the water table receded to a lower elevation later in the summer months, some contamination likely remained behind in the lower vadose zone throughout an area much broader than the area directly beneath waste sites (contamination "smear" zone).

Also, during the 1940s and early 1950s, the seasonal low river stage was considerably lower than in post-dam years, creating a steep hydraulic gradient toward the river, and thus promoting strong groundwater flow and an increased flux of contaminant uranium into the river channel. These wide swings in water table elevation and river stages would have enhanced the movement of contaminants through the aquifer and into the Columbia River.

The South and North Process Ponds were in use during these years of wide swings in water table elevation. It is possible a considerable inventory of uranium was moved into the lower vadose zone over a wide area as a consequence of seasonal high-water table conditions from 1943 to the early 1970s. Some of the uranium dissolved in groundwater would have sorbed onto vadose zone sediment. Desorption of that uranium may be continuing today and is considered a potential source for re-supplying the current plume. 


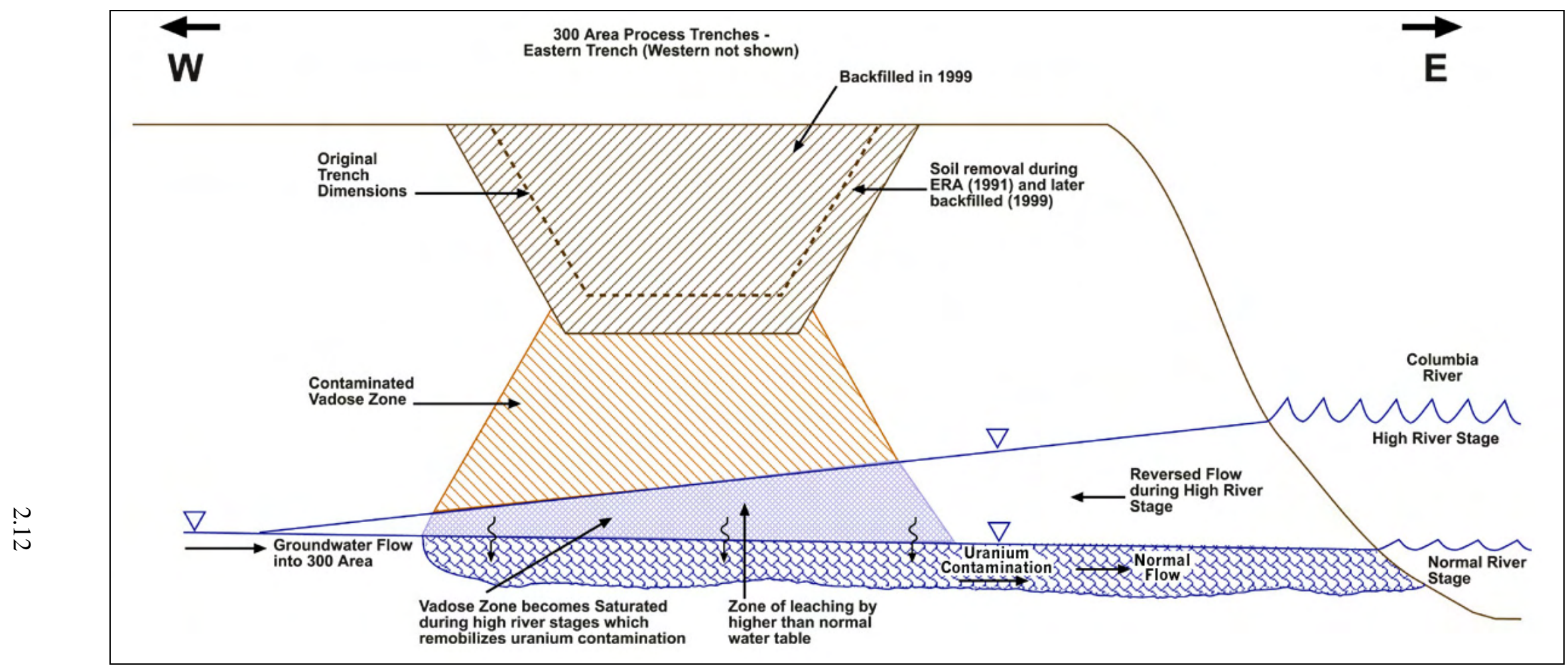

Figure 2.3. Schematic Showing Principal Subsurface Zones Involved with Uranium Contamination (Lindberg and Chou 2001) 


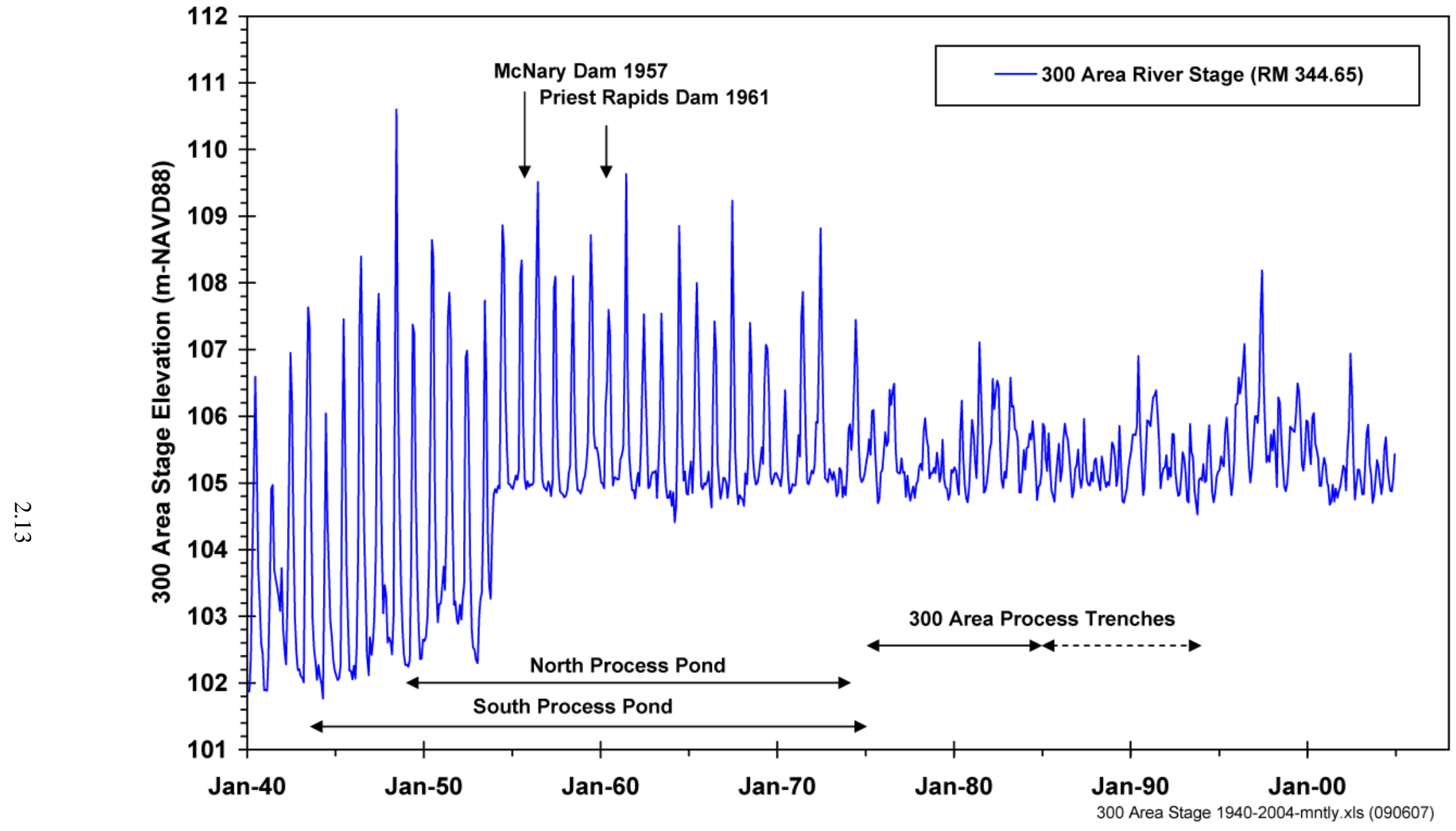

Figure 2.4. River-Stage Elevation at 300 Area, 1940 to 2004 (data from Waichler et al. 2005) 


\subsubsection{Release of Uranium Since Waste Disposal Operations Ended}

The last liquid effluent containing uranium was disposed to the ground in the 300 Area at the 300 Area Process Trenches in 1985. Only nonhazardous effluent was disposed to that facility from 1985 until December 1994. Also, contaminated sediment was removed from the bottom and sides of each of the two trenches in 1991 during an expedited response action (DOE-RL 1992). Infiltration of subsequent discharges to the trenches was enhanced by this removal action such that infiltration occurred primarily at the southern ends of the trenches, thus concentrating the loading of the vadose zone with liquid effluent in that area. The groundwater at a well located near the south end of the trenches showed the effect of this discharge, which had a composition more similar to river water than to natural groundwater.

Figure 2.5 shows the impact of these discharges on groundwater at well 399-1-17A, which was installed in 1987 near the south end of the trenches (see Figure 2.1 for an index map). Following the cessation of hazardous waste discharge in 1985, uranium concentrations at the well were the highest of any 300 Area monitoring well. Uranium at the well reflected discharges to the trenches that occurred between 1975 and 1985. These discharges had a low specific conductance and low alkalinity (low bicarbonate content) compared to 300 Area groundwater. This promoted adsorption of uranium onto sediment in the portion of the aquifer impacted by the discharge. Following the expedited response action, clean water with low alkalinity continued to be discharged, which also promoted the retention of uranium on aquifer solids.

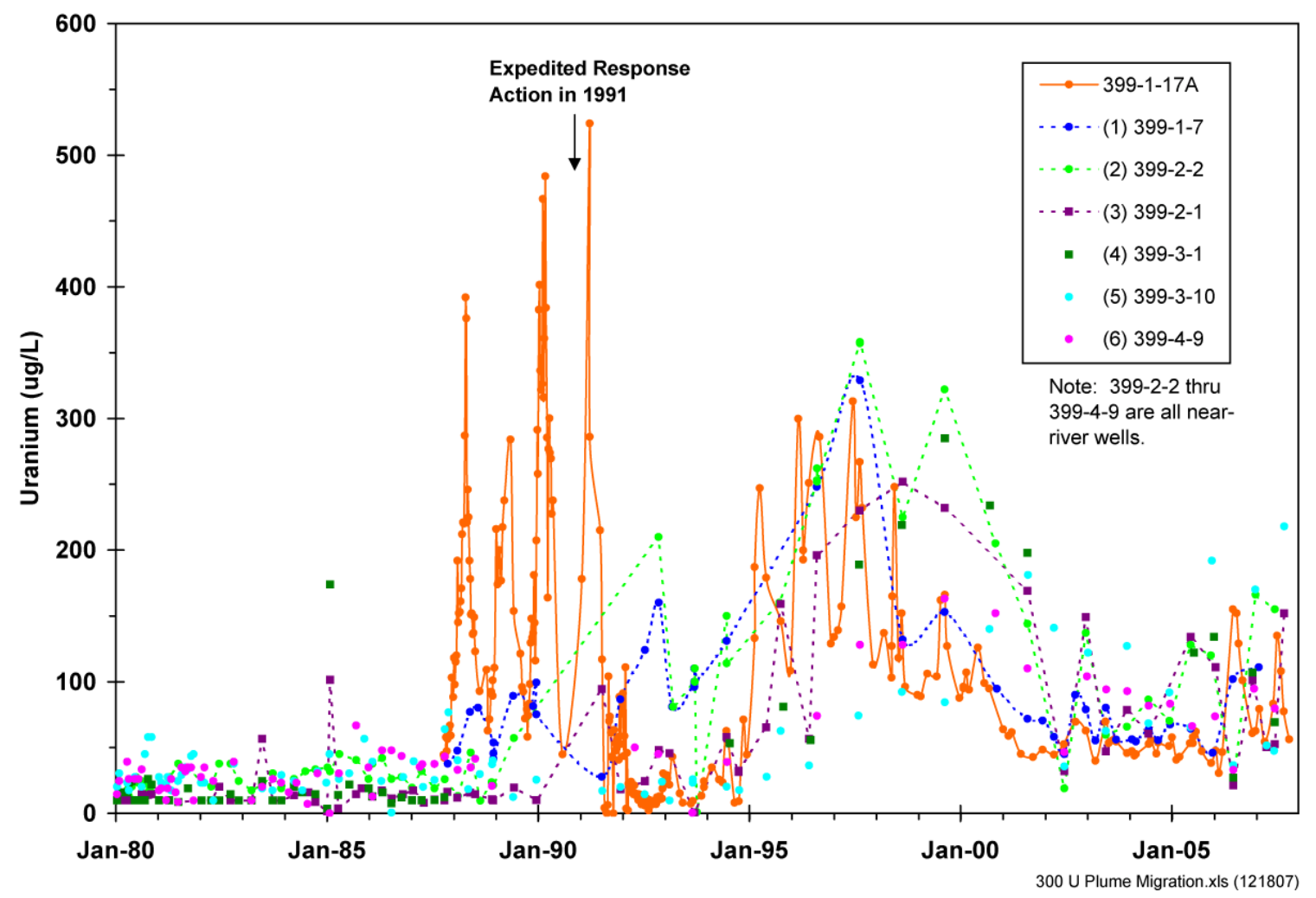

Figure 2.5. Uranium Concentrations near and Downgradient of the 300 Area Process Trenches 
Once discharge of the clean water ended in December 1994, the impacted aquifer sediment was exposed to fresh groundwater that migrated into the area from the north and west, thus creating more favorable conditions for desorption (i.e., the higher ionic strength of groundwater promotes mobility of uranium). By early 1995, uranium concentrations rose dramatically back to pre-expedited response action levels because of this change in the geochemical environment. Since that time, concentrations have gradually decreased as the plume disperses and the amount available to re-supply the plume becomes less and less with each seasonal cycle of the water table.

Figure 2.5 also shows the concentration trends at wells located downgradient along the flow path from the south end of the 300 Area Process Trenches (Section 5.0 provides more information on groundwater flow paths and rates). Note that concentrations at these wells were significantly lower than at 399-1-17A in the late 1980s. This suggests that the influence on groundwater of past disposal to the South and North Process Ponds during the late 1980s is less than the influence of disposal at the 300 Area Process Trenches, and perhaps even negligible compared to earlier years. The "pulse" of increased concentrations can be tracked along the downgradient flow path as it migrates from well to well to the southeast toward the river (Note: wells are listed in the legend in order of increasing distance downgradient from 399-1-17A).

\subsubsection{Persistence of the Uranium Plume Under Current Conditions}

Several zones and release mechanisms have been postulated (Peterson et al. 2005; DOE-RL 2006b) to explain the persistence of the uranium plume under the conditions that have existed since the wastedisposal years. First, there is evidence to suggest continued release of uranium from the lower vadose zone beneath some past-practices disposal sites, i.e., at depths in the vadose zone greater than the remedial-action excavation depths. Because of the interaction between liquid wastes containing uranium and vadose zone sediment, some uranium remains bound to the sediment and is available for subsequent remobilization by infiltrating moisture and/or unusually high water-table conditions. Evidence supporting this inventory zone and mobilization mechanism includes the higher groundwater concentrations observed near these former waste sites during certain times of the year (described in Section 3.0, Current Conditions).

Second, aquifer sediment beneath the 300 Area is heterogeneous with respect to particle characteristics and the capacity to transmit water. Lenses of low-permeability sediment may have been saturated with the relatively more contaminated groundwater that existed during the operations period, and those lenses are today slowly releasing that contamination back into the relatively less-contaminated groundwater in the surrounding high-permeability sediment. The limited number of aquifer sediment samples from lowpermeability lenses has not shown strong evidence for this, but it remains a possible contributing source. Contaminant material adsorbed to aquifer sediment under earlier, more contaminated conditions may also be desorbing under current conditions (see discussion of geochemistry in Section 6.0).

Finally, excavations at liquid-waste disposal sites during the 1990s removed some protective surface cover and shortened the distance between the exposed surface and the water table, thus somewhat enhancing conditions necessary for vadose zone uranium to migrate downward, potentially reaching groundwater. It was necessary to apply water during the excavation operations to protect workers from contaminated airborne dust. The increased infiltration of moisture beyond the amount from natural precipitation may have remobilized uranium and carried it down to the aquifer. Coincidentally, the years 1996 and 1997 experienced significantly higher water-table conditions than normal, thus increasing the 
likelihood of remobilizing uranium from the lower vadose zone. Also, the discharge of clean water to the 300 Area Process Trenches, which had been diluting the plume that existed during the early 1990s, ceased in December 1994, and contaminant concentrations rose back to pre-diluted levels in the region impacted by discharges to the trenches.

\subsubsection{Summary of Problem Statement}

Current concepts related to the persistence of the uranium plume can be summarized as answers to three questions:

1. Where is the inventory of uranium that feeds the current plume?

a. Vadose zone beneath former liquid waste disposal facilities.

b. More widespread zone through which the water table rises and falls.

c. Solid materials in the aquifer.

2. How is the inventory of uranium mobilized to re-supply the plume?

a. Mobility is dependent on the form of the stored inventory.

b. The inventory has existed under the current hydrologic conditions for many years.

c. Potential drivers include the infiltration of moisture from the surface, a fluctuating water table, and groundwater flow.

3. How long can the inventory continue to supply uranium to the plume?

a. The answer involves rates of release to the transporting medium, rate of movement of the transporting medium, and the amount of uranium stored in each of the various candidate source zones.

The following sections of this report describe current conditions in greater detail, the hydrogeologic framework within which uranium contamination resides, groundwater flow and transport, and the geochemical characteristics that control inventory and mobility. 


\subsection{Current Conditions}

(R.E. Peterson)

The driver for characterization of uranium-plume features and processes in the 300 Area is the record of decision for interim action (EPA 1996b). The remedy selected for interim action included institutional controls on the use of groundwater and continued monitoring of the plume to track changes in concentrations with time. Expectations were that uranium concentrations would continue to decline at a predictable rate. Subsequent 5-year reviews of the 1996 record of decision have concluded that the interim remedy remained appropriate, but that additional work should be conducted to refine the description of uranium contamination and to investigate the feasibility of reducing uranium concentrations in the plume using active technology ${ }^{5}$ (EPA 2001; DOE-RL 2006b).

During late 2004/early 2005, a comprehensive description of the uranium plume in 300 Area groundwater was prepared as part of an expanded annual report for groundwater conditions in the 300-FF-5 Operable Unit (Peterson et al. 2005). The following paragraphs provide an update to that description, based on several years of additional monitoring results, results from a LFI (Williams et al. 2007), and improved methods to characterize trends. Key features included in the description are geographic extent of contamination, seasonal variability in the plume, long-term trends in plume parameters, and conditions at shoreline monitoring sites. The discussion starts with a description of monitoring capabilities, which play a large role in the degree of uncertainty associated with the description.

\subsection{Monitoring Capabilities}

Requirements for groundwater monitoring and characterization of plumes are contained in an Operations and Maintenance Plan for the 300-FF-5 Operable Unit (DOE-RL 2002a). The groundwater and river shoreline sampling requirements and schedules are contained in a Sampling and Analysis Plan (DOE-RL 2006a), which implements the environmental monitoring requirements of the Operations and Maintenance Plan.

Figure 3.1 is a map showing the locations of monitoring wells, aquifer tubes at the Columbia River shoreline, and riverbank springs - nearly all of which are used to monitor groundwater quality under the CERCLA program. Figure 3.2 is a diagrammatic cross-section that illustrates the various depths and hydrologic units monitored by traditional wells (more detailed information is presented in Section 4.0). Names for "shallow" wells typically have no suffix or an "A"; they monitor the upper portion of the unconfined aquifer, which includes the water table. Names for "intermediate" wells have a "B" suffix; they monitor the lower portion of the unconfined aquifer. Names for "deep" wells have a "C" suffix; they monitor the first confined hydrologic unit beneath the unconfined aquifer. Figure 3.3 is a cross section oriented along the Columbia River shoreline that shows the positions of screens for wells near the river, and screens for aquifer tubes. The vertical scale is elevation, and the horizontal scale is a relative position along the shore, referred to as the Hanford River Marker system (HRM). The distance from HRM 42 to HRM 43 is approximately $1.9 \mathrm{~km}(1.2 \mathrm{mi})$.

\footnotetext{
${ }^{5}$ Action Item 19-1 of second 5-year review (DOE-RL 2006b): “Complete focused feasibility study for 300-FF-5 Operable Unit to provide better characterization of the uranium contamination, develop a conceptual model, validate ecological consequences, and evaluate treatment alternatives. Concurrently test injection of polyphosphate into the aquifer to immobilize the uranium and reduce the concentration of dissolved uranium. These activities support a CERCLA proposed plan.” Due date for completion of this action item is September 2008.
} 


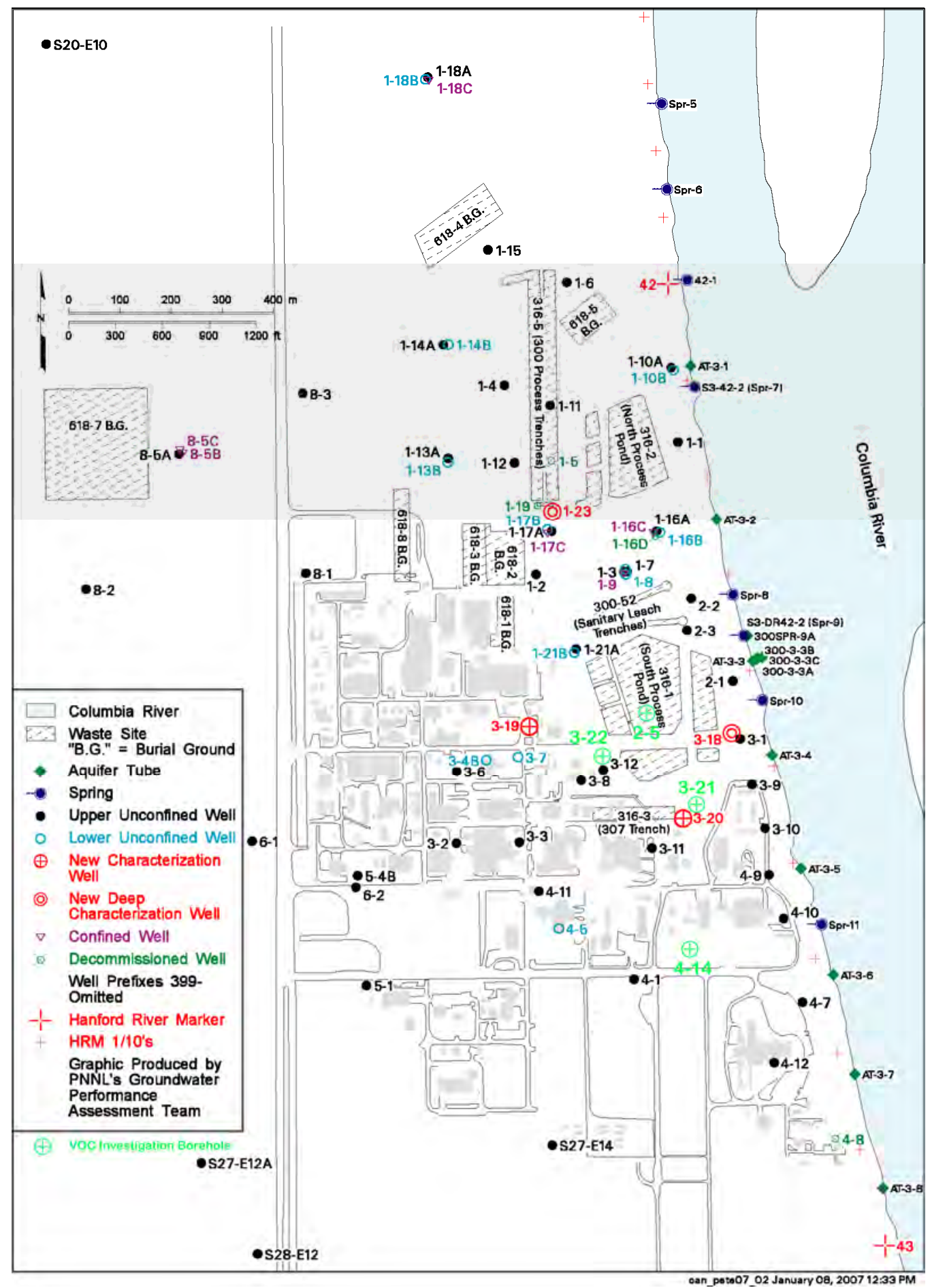

Figure 3.1. Location Map for Monitoring Wells and Shoreline Sampling Sites at the 300 Area 


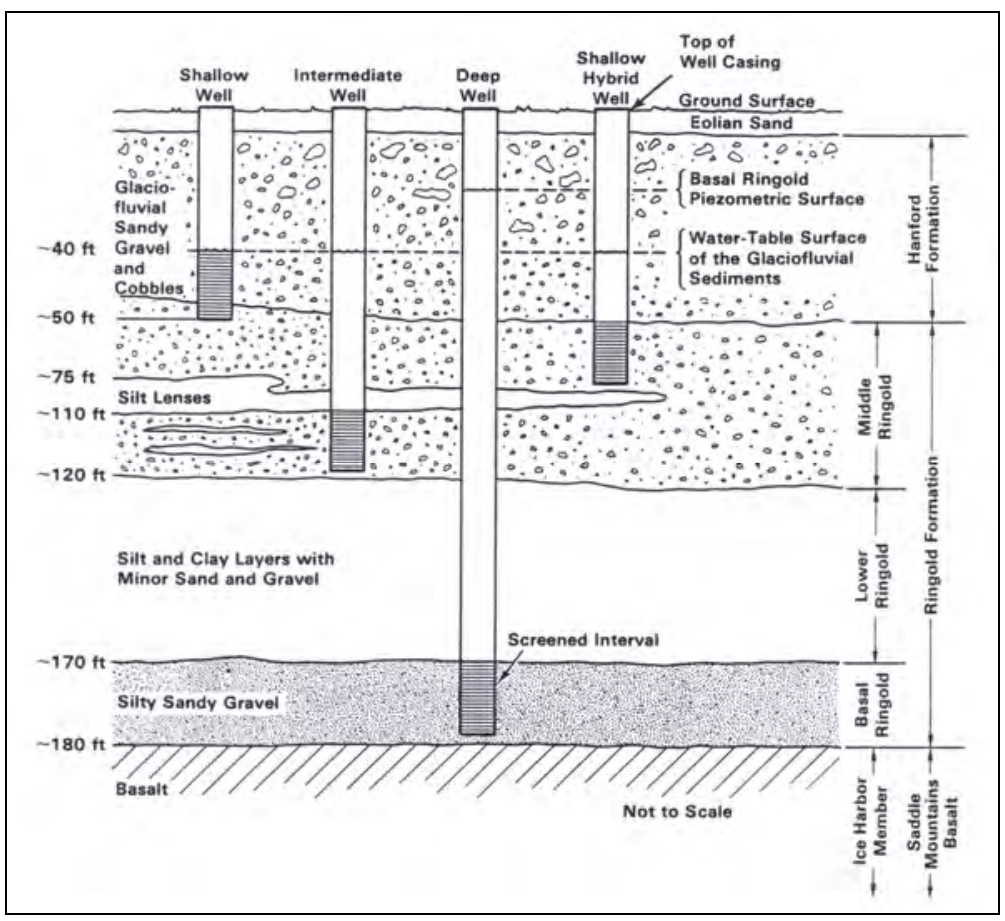

Figure 3.2. Schematic Showing Positions of Monitoring Well Screens Relative to Hydrostratigraphic Units (Schalla et al. 1988)

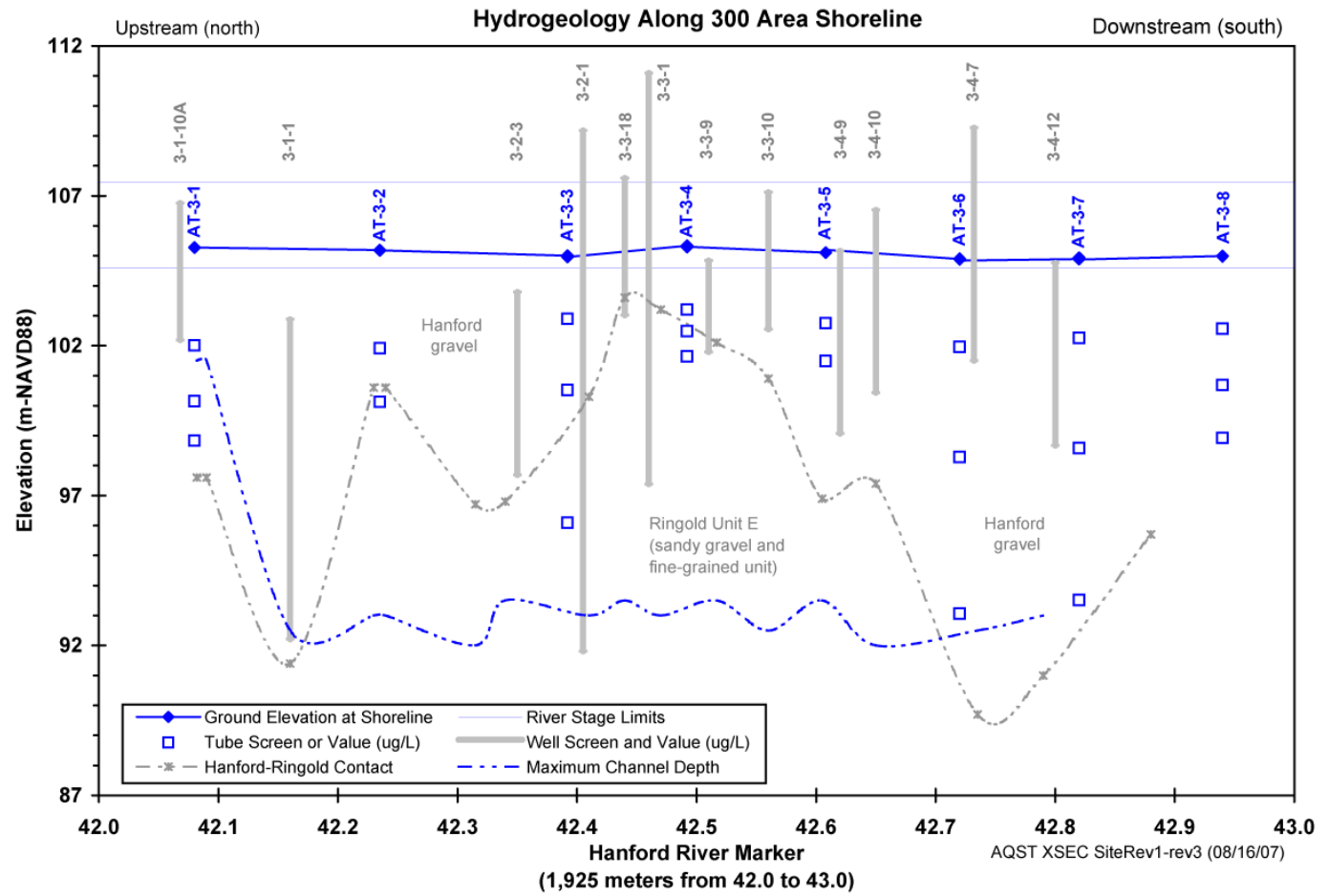

Figure 3.3. Cross Section Along the 300 Area Shoreline Showing Positions of Screens for near-River Monitoring Wells and Aquifer Tubes 
Monitoring is conducted under the DOE's Groundwater Remediation Project per schedules presented in the Sampling and Analysis Plan (DOE-RL 2002b). Schedules are reviewed annually, and significant changes are made with the concurrence of the Tri-Parties via the National Priorities List Agreement/ Change Control process. Minor modifications may also be made to accommodate changing field access conditions, well maintenance issues, and needs for special investigations. The detailed schedule for the current fiscal year is maintained in the Groundwater Remediation Project’s scheduling database.

Briefly, all wells used to monitor the uranium plume under the CERCLA program are sampled semiannually, with events in June and December. The June event is intended to capture conditions when the highest uranium concentrations have been observed in the past. The December event is intended to capture long-term average characteristics for the plume. Concentration changes are related to seasonality in the elevation of the water table beneath the 300 Area, which is driven by changes in the stage of the adjacent Columbia River. Figure 3.4 shows recent trends in discharge from Priest Rapids Dam, which illustrates the seasonality in discharge through the Hanford Reach (the June and December sampling events are indicated by the horizontal arrows). Aquifer tubes at the shoreline are sampled twice a year, although the schedule is less predictable because it is dependent on river-stage conditions. Tubes are typically sampled during the fall months and again in late winter before the spring runoff.

Additional monitoring is conducted near the former 300 Area Process Trenches under the RCRA program for post-closure monitoring (Lindberg et al. 1995). This monitoring consists of sampling at three downgradient well locations and one upgradient location monthly for four consecutive months, twice a year. Constituents of interest are volatile organic compounds and uranium. The first months of each sequence are June and December, and the sampling is coordinated with the CERCLA sampling events. The RCRA requirements for monitoring are part of the Sitewide Permit (Ecology 2007).

In addition to the use of riverbank springs and aquifer tubes under the CERCLA program, the river environment is also monitored under DOE’s Public Safety and Resource Protection Program (DOE-RL 2000). Among the multiple objectives for projects within this program is the requirement to monitor the migration of contamination from Hanford Site sources to offsite locations and pathways. The schedule for collecting samples from a variety of media under this program is published annually (e.g., Bisping 2007). Along the 300 Area, samples are collected annually from riverbank springs, nearshore river flow, and mainstream river flow. Sediment samples are also collected at the locations of riverbank springs. Co-sampling with this program by the Washington State Department of Health is conducted as part of the Department's oversight role at the Hanford Site.

\subsection{Extent of Uranium Plume Beneath the 300 Area}

Plume maps showing uranium concentrations in groundwater beneath the 300 Area during June and December 2006, and June 2007, are shown in Figures 3.5, 3.6, and 3.7, respectively. The uranium contours shown on these maps were prepared using data from the Hanford Environmental Information System (HEIS) and are the same contours shown in the annual groundwater project reports (e.g., Peterson et al. 2007a, Section 2.12). The outermost contour (10 $\mathrm{g} / \mathrm{L})$ approximates the maximum extent of contaminant uranium. Natural uranium in unconfined aquifer sediment near the 300 Area is assumed to be in the 3 to $8 \mu \mathrm{g} / \mathrm{L}$ range, based on measurements from locations believed to be beyond the influence of waste-disposal operations in the 300 Area. For example, the historical trend at 399-1-18A remained in the range of 3.3 to $7.5 \mu \mathrm{g} / \mathrm{L}$ from 1987 to 2007. At the scale of the entire Hanford Site, samples collected from various locations to characterize natural background revealed uranium concentrations in the range of 0.5 to $12.8 \mu \mathrm{g} / \mathrm{L}$ (DOE-RL 1997b). 


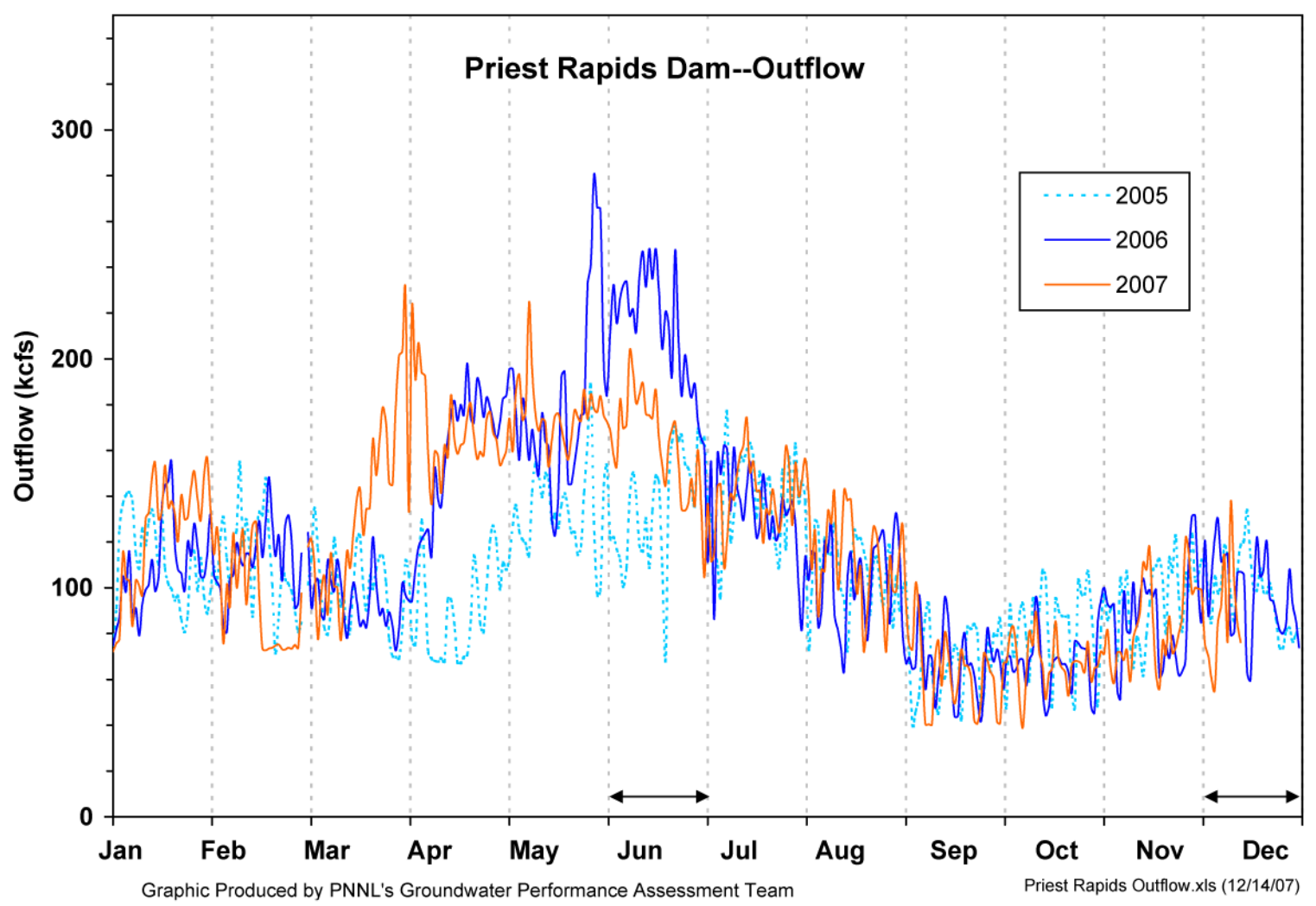

Figure 3.4. Outflow from Priest Rapids Dam, Which Approximates Flow Through the Hanford Reach of the Columbia River

The water table contours shown in Figures 3.5 and 3.7, from which direction of flow can be inferred, are as measured during the seasonal period of high-water-table conditions in June. Contours shown on the December 2006 map (Figure 3.6) illustrate long-term average elevations for months other than the June high-water period. This convention was selected to illustrate the relatively brief period during the seasonal high (6 to 8 weeks) when direction of flow is more southerly than during the remaining months of the year when the direction is predominantly toward the southeast. Seasonal variability in flow direction is discussed in more detail in Section 5.

The vertical distribution of uranium in the aquifer is less clearly defined than the lateral distribution. Most monitoring wells have their screened intervals in the upper portion of the unconfined aquifer and typically in saturated Hanford sediment. Monitoring wells with screens in the lower portion of the unconfined aquifer do not show significant levels of uranium contamination, compared to levels in the upper portion. Historical trends at wells 399-1-17A,B,C and 399-1-16A,B,C (Figure 3.8a and b, respectively; see Figure 3.2 for the relative positions of screened intervals for shallow [-A], intermediate [-B], and deep [-C] well completions) illustrate this. Very little work has been done with regard to defining vertical profiles of concentrations within the screened intervals of existing wells. Information available to date regarding the vertical distribution of uranium contamination does suggest that the bulk of dissolved uranium is in groundwater associated with the Hanford gravels hydrologic unit. Supporting this conclusion are the monitoring results from the shallow and deep unconfined aquifer well screens, results from aquifer tubes at various depths in the aquifer near the Columbia River (see Section 3.5), and results from the four boreholes that were part of the recent LFI (Williams et al. 2007). 


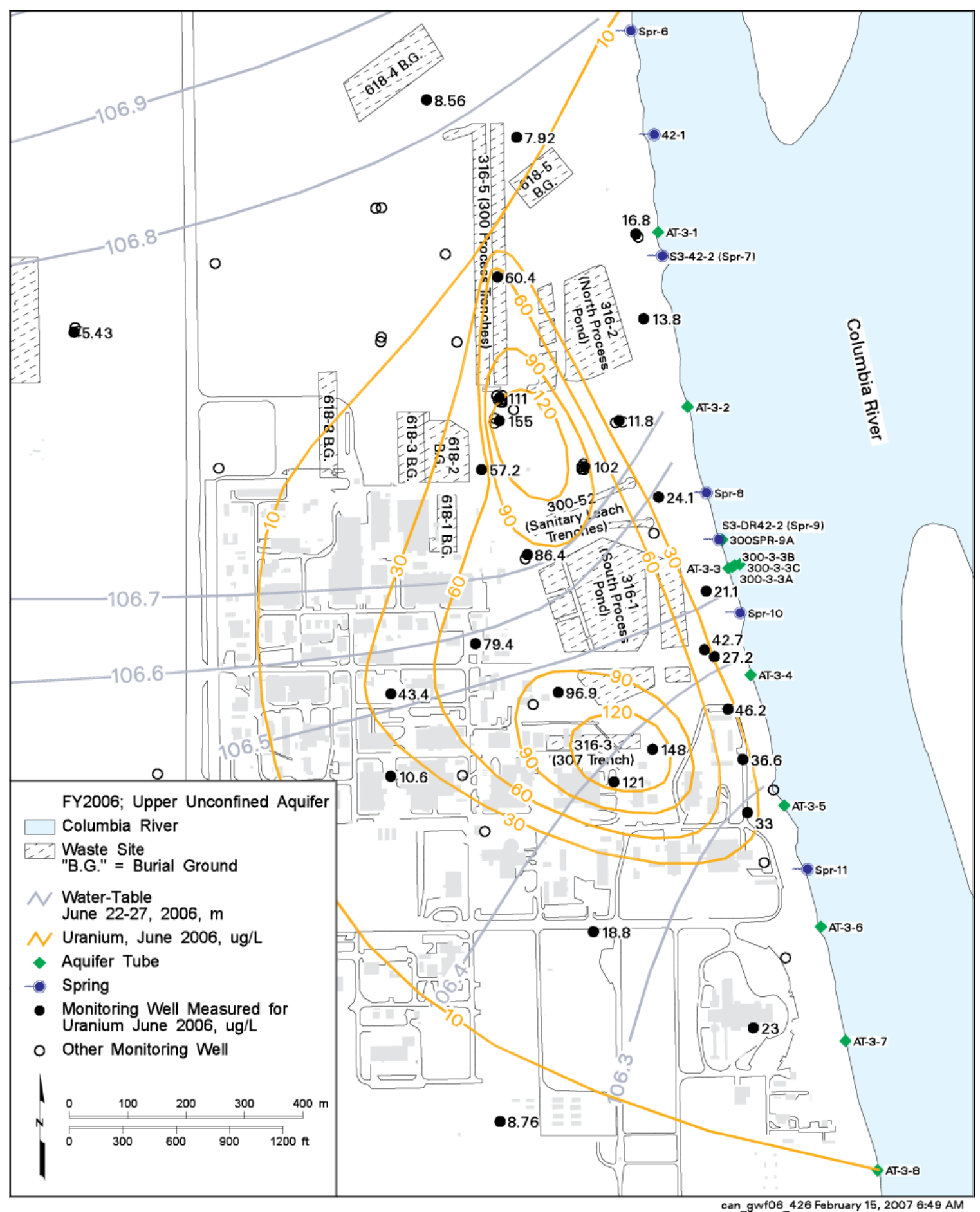

Figure 3.5. Uranium Plume in Groundwater Beneath 300 Area During June 2006 


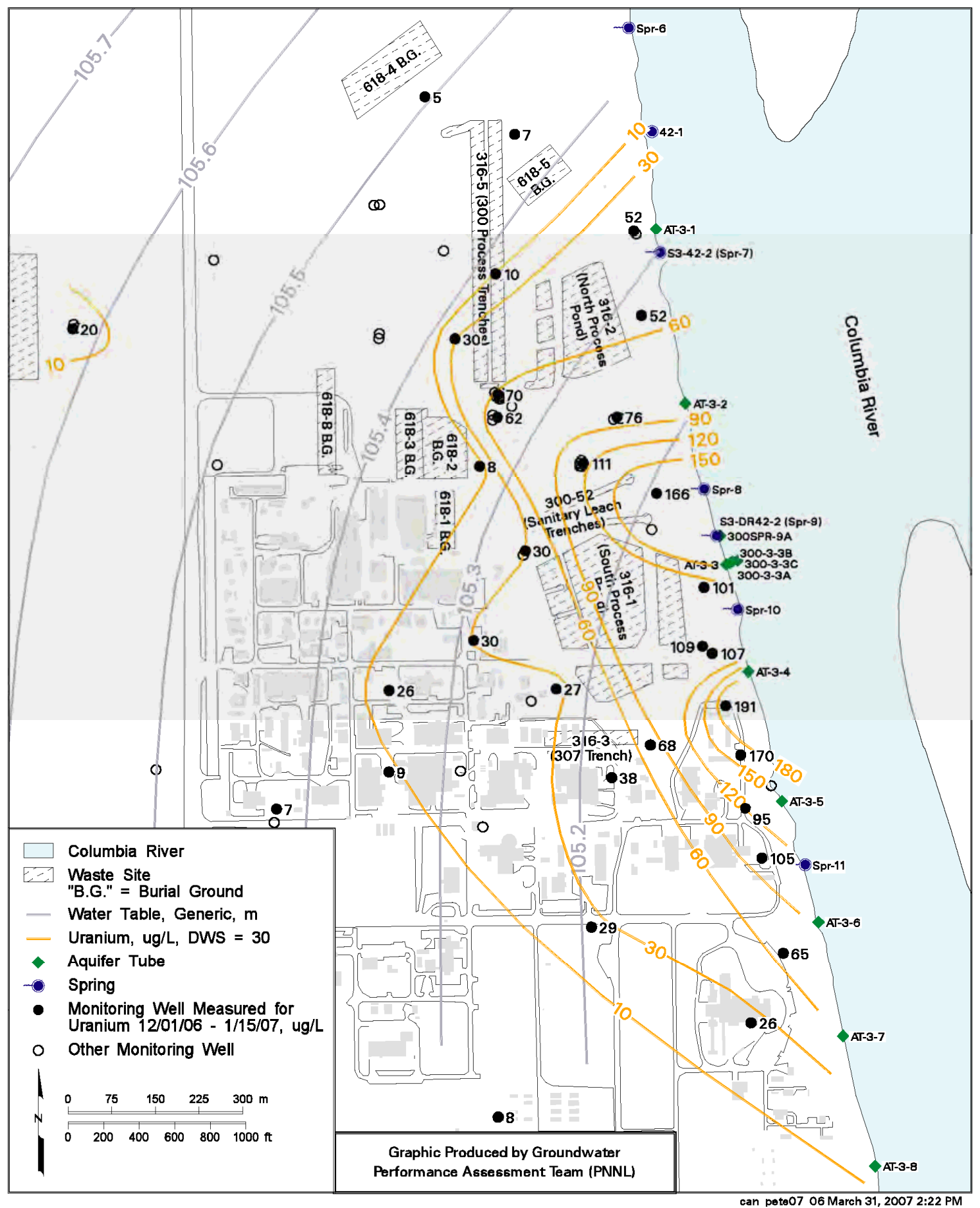

Figure 3.6. Uranium Plume in Groundwater Beneath 300 Area During December 2006 


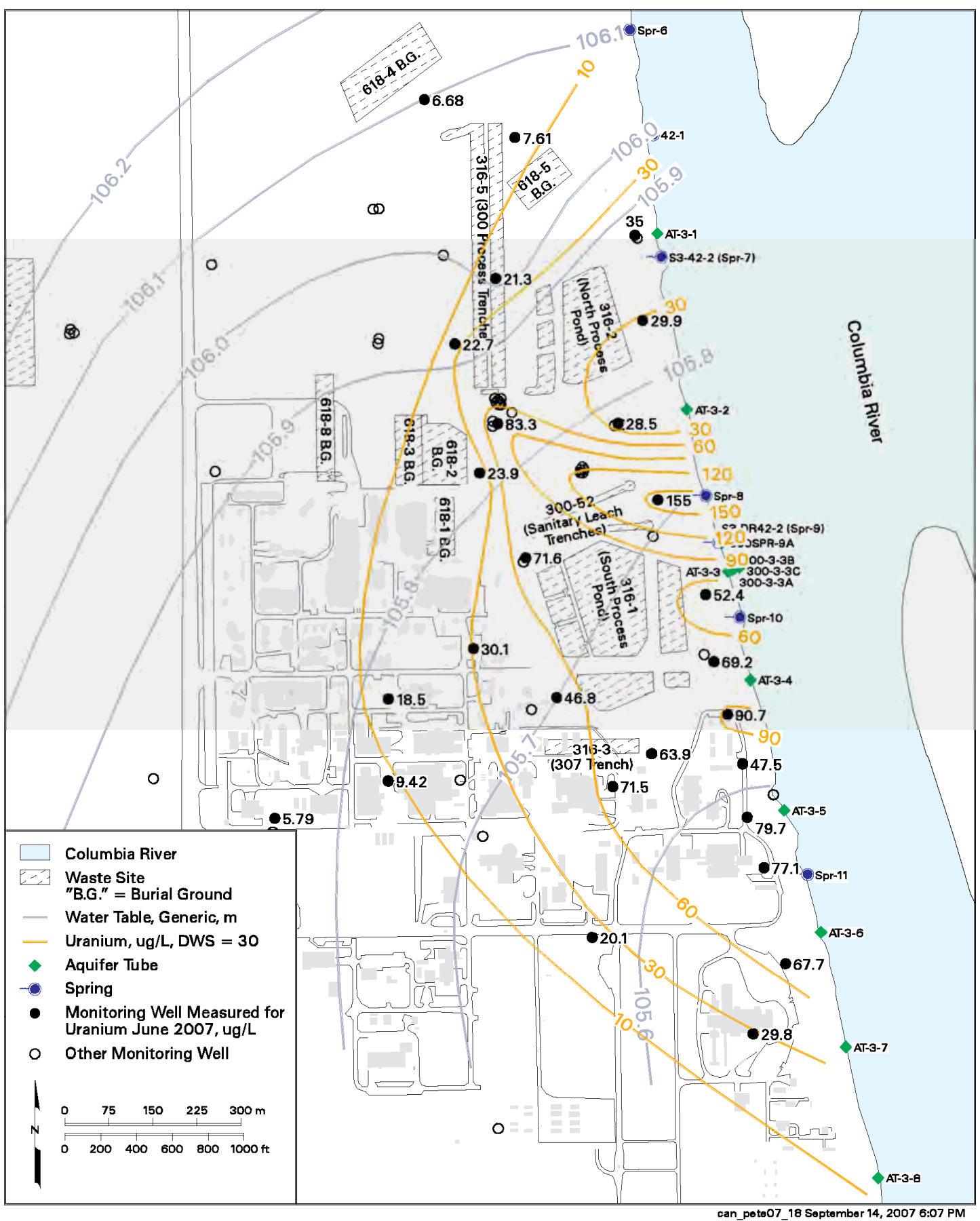

Figure 3.7. Uranium Plume in Groundwater Beneath 300 Area During June 2007 

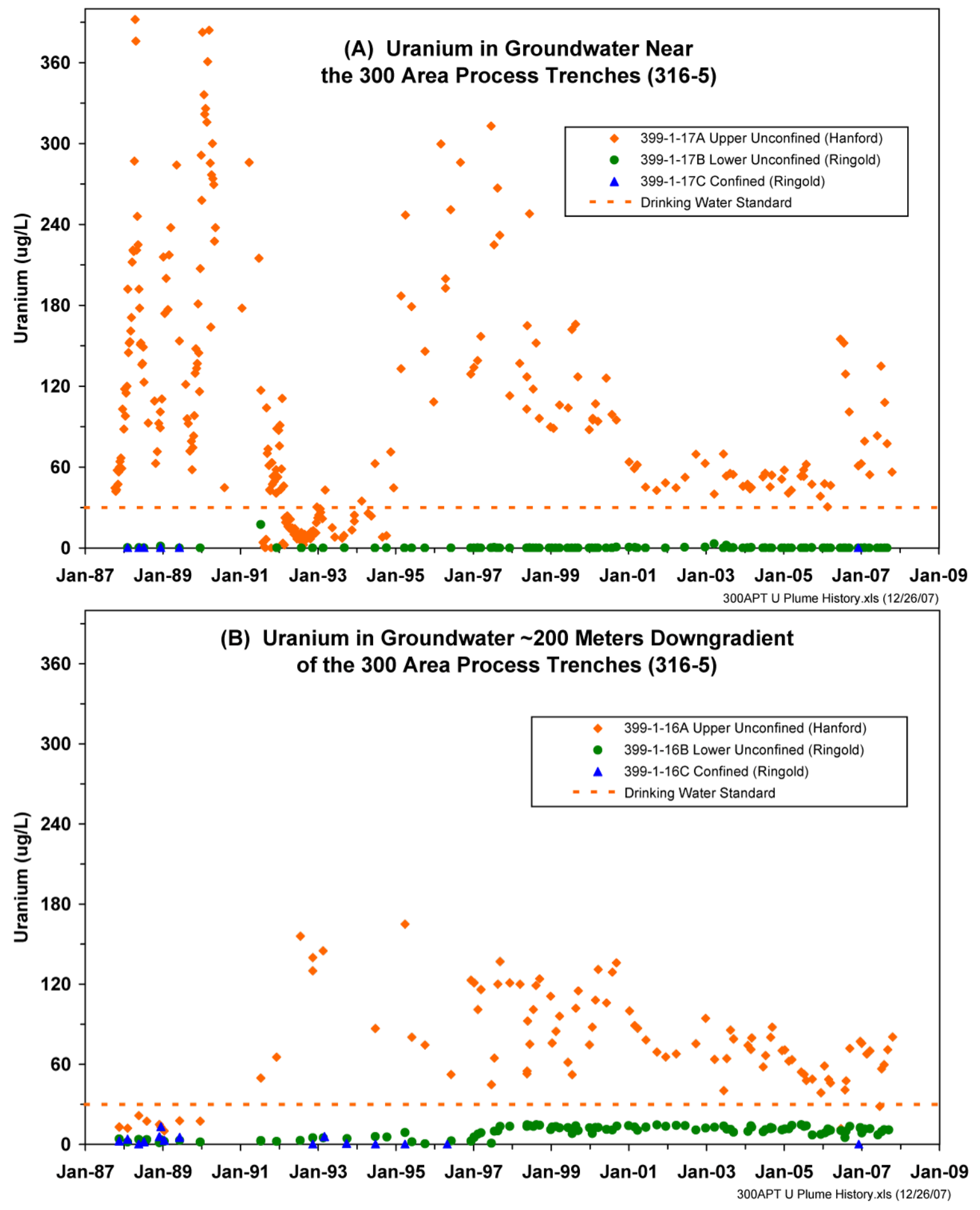

Figure 3.8. Uranium Concentration Trends at Various Depths in the Unconfined Aquifer

\subsection{Seasonal Variability in the Uranium Plume}

The seasonal variability in concentrations and distribution patterns for the uranium plume has been frequently described in annual groundwater monitoring reports (e.g., Peterson et al. 2007a, Section 2.12) 
and other investigation reports (e.g., DOE-RL 2002a; Peterson et al. 2005, Section 2.0). Figures 3.5 through 3.7 are maps that provide examples of the changes in concentration patterns that occur during an annual cycle. Seasonal variability is also illustrated in the long-term trends at well 399-1-17A, which is located near the southern end of the former 300 Area Process Trenches. Since all discharges to the process trenches ended in December 1994, there has been a general decline in uranium concentrations at the well, but with episodic increases when the water table is elevated during the May/June seasonal high.

Figure 3.9 shows the relationships between uranium concentrations, water level, and specific conductance at well 399-1-17A. In the years following the 1991 Expedited Response Action to remove contaminated sediment from the Trenches (DOE-RL 1992), a strong correlation is apparent between elevated water levels in the well and relatively high uranium concentrations (Figure 3.9a). Also, when water levels are high in the well (reflecting the seasonal high river stage), the specific conductance of some samples from the well are relatively lower (Figure 3.9b), suggesting that river water has infiltrated inland as far as this well, which is approximately $325 \mathrm{~m}$ from the shoreline.

Two phenomena are typically called upon to explain the seasonal differences in the uranium plume: 1) remobilization of uranium present in the lower vadose zone at some locations caused by the elevated water table during May/June and 2) dilution of uranium concentrations in wells near the river because of the influx of river water during the seasonal high-discharge conditions. Because of the rapid movement of groundwater beneath the 300 Area, concentration patterns may change rapidly, i.e., on a frequency scale of weeks to several months.

\subsubsection{Evidence for Remobilization from Lower Vadose Zone}

During the May/June seasonal high-water table, groundwater moves upward into the lower vadose zone, perhaps by as much as several meters. Uranium appears to be mobilized by the change from unsaturated to saturated conditions in the lower vadose zone regions where contaminant uranium still resides. The relatively high concentration zones shown on the June maps (see Figures 3.5 and 3.7) are situated near former liquid-waste disposal sites where contamination in the lower vadose zone is most likely to remain. The remobilization phenomenon is also illustrated in Figure 3.9a, which shows elevated uranium concentrations during the 1996/1997 period of unusually high-water-table conditions. (Note: Elevated uranium concentrations at well 399-1-17A after December 1994 were also influenced by cessation of clean-water discharges to the 300 Area Process Trenches. This discharge had diluted groundwater beneath the waste site, artificially lowering uranium concentrations.)

Figure 3.9a shows trends suggesting that the concentration increases occur frequently, but not always, when the water table is elevated. The explanation for this may be related to timing; i.e., the water table became elevated at some time before the sampling event, but the frequency of monitoring has not been sufficient to reveal the details of changes in uranium concentrations. Figure 3.10 shows recent sampling at 399-1-17A along with a hydrograph for the 300 Area river stage, which is monitored more frequently than at the wells. Evidence to support the hypothesis that uranium is remobilized from the lower vadose zone when the water table rises above long-term levels is readily apparent for conditions during summer 2006, and again in summer 2007. What is harder to explain is why the same thing did not occur during summer 2002 when water table conditions were very similar. The explanation for the different behavior may have to do with the timing of the sampling event, and/or with variability in the rates for release/movement of uranium in the vadose zone. 

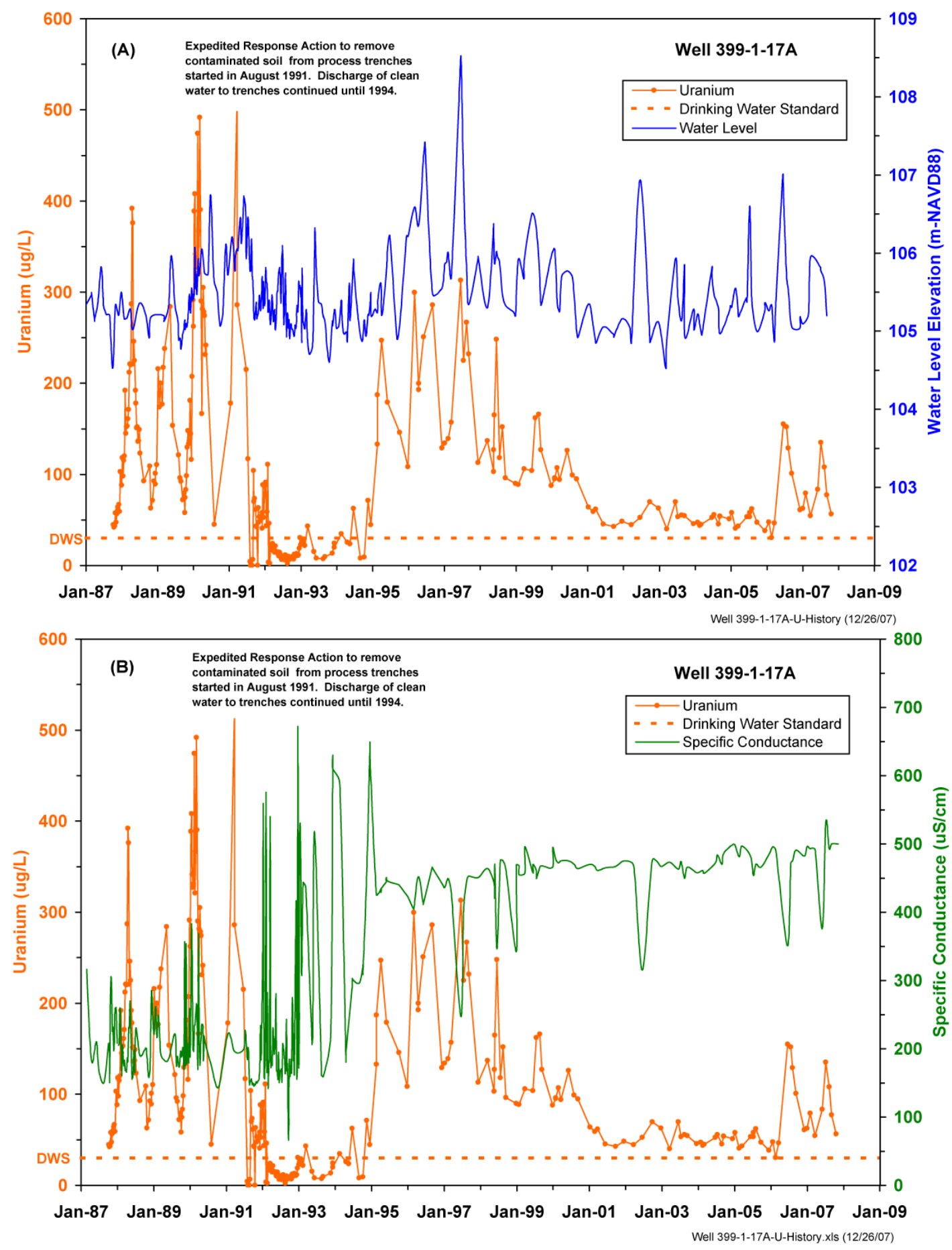

Figure 3.9. Relationship Between Uranium Concentrations and Water Levels (A) and Specific Conductance (B) at Well 399-1-17A 


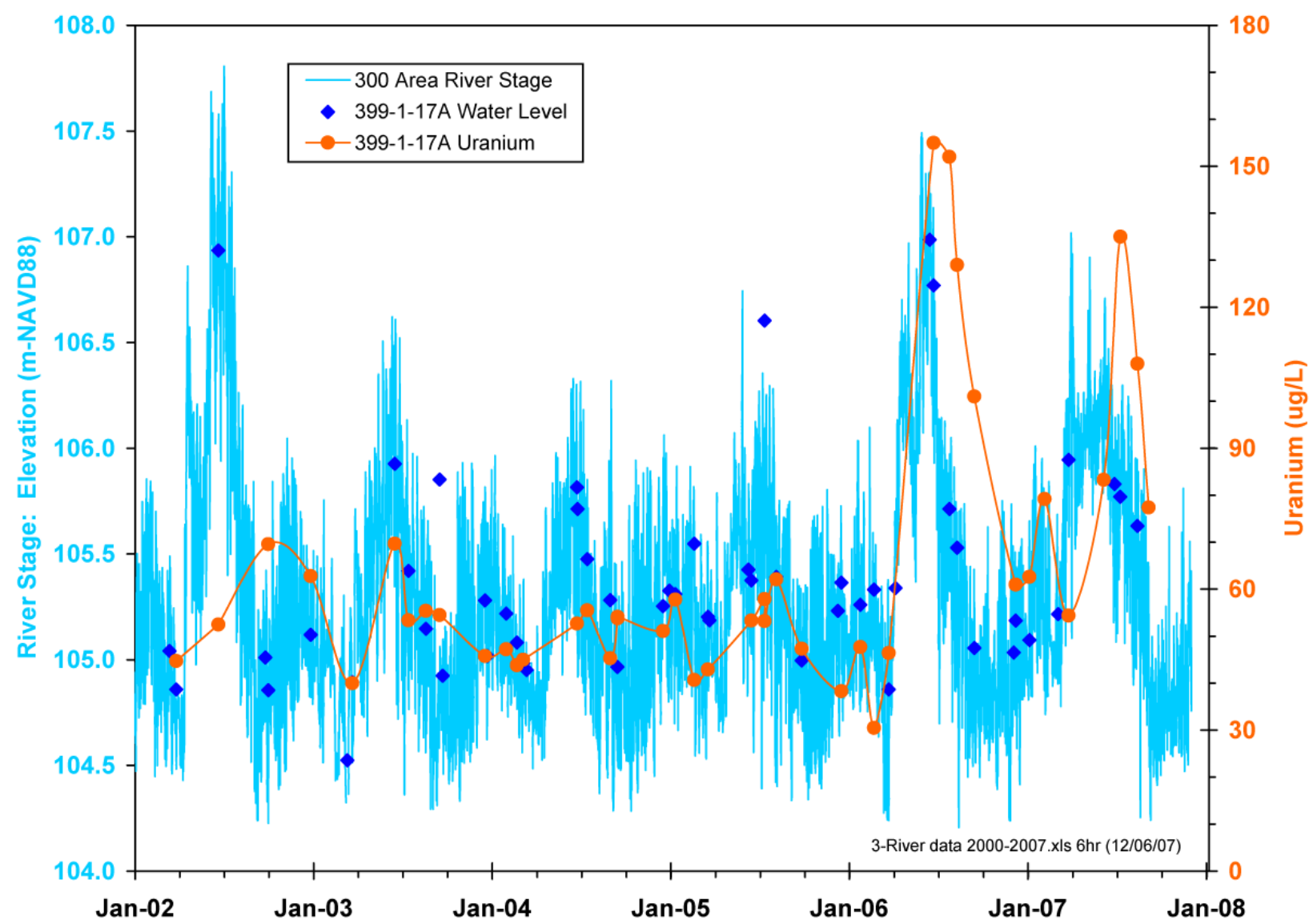

Figure 3.10. Uranium Concentrations and Water Levels at Well 399-1-17A

There is also evidence to suggest that water-level-induced mobilization of uranium held in the lower vadose zone occurs over an area larger than beneath the footprints of former liquid-waste disposal sites. Samples from wells located at some distance away from those waste sites also showed an increase in uranium concentrations during the high-water-table conditions of 1996/1997 (e.g., 399-3-6, 399-3-12, 399-4-1, 399-4-11, and 399-8-1). Figure 3.11 illustrates trends at wells located in areas where vadose zone contamination from surface-waste disposal activities is not expected to be present. One explanation is that the uranium plume during the early years of 300 Area operations (late 1940s and 1950s) was pushed inland and upward into the lower vadose zone by higher river-stage conditions (Lindberg and Bond 1979). As the water table fell to more normal levels, some contaminated groundwater remained behind in the lower vadose zone, perhaps allowing uranium to be adsorbed to vadose zone sediment and later released to groundwater when the plume was at lower concentrations (DOE-RL 1995b).

\subsubsection{Uranium Concentrations and Mixing with River Water}

The seasonal differences in concentration patterns for the uranium plume, as shown in Figures 3.5 through 3.7, are the result of variability in input of uranium from the lower vadose zone and also their proximity to the Columbia River. During high-river-discharge conditions in the spring, bank storage 

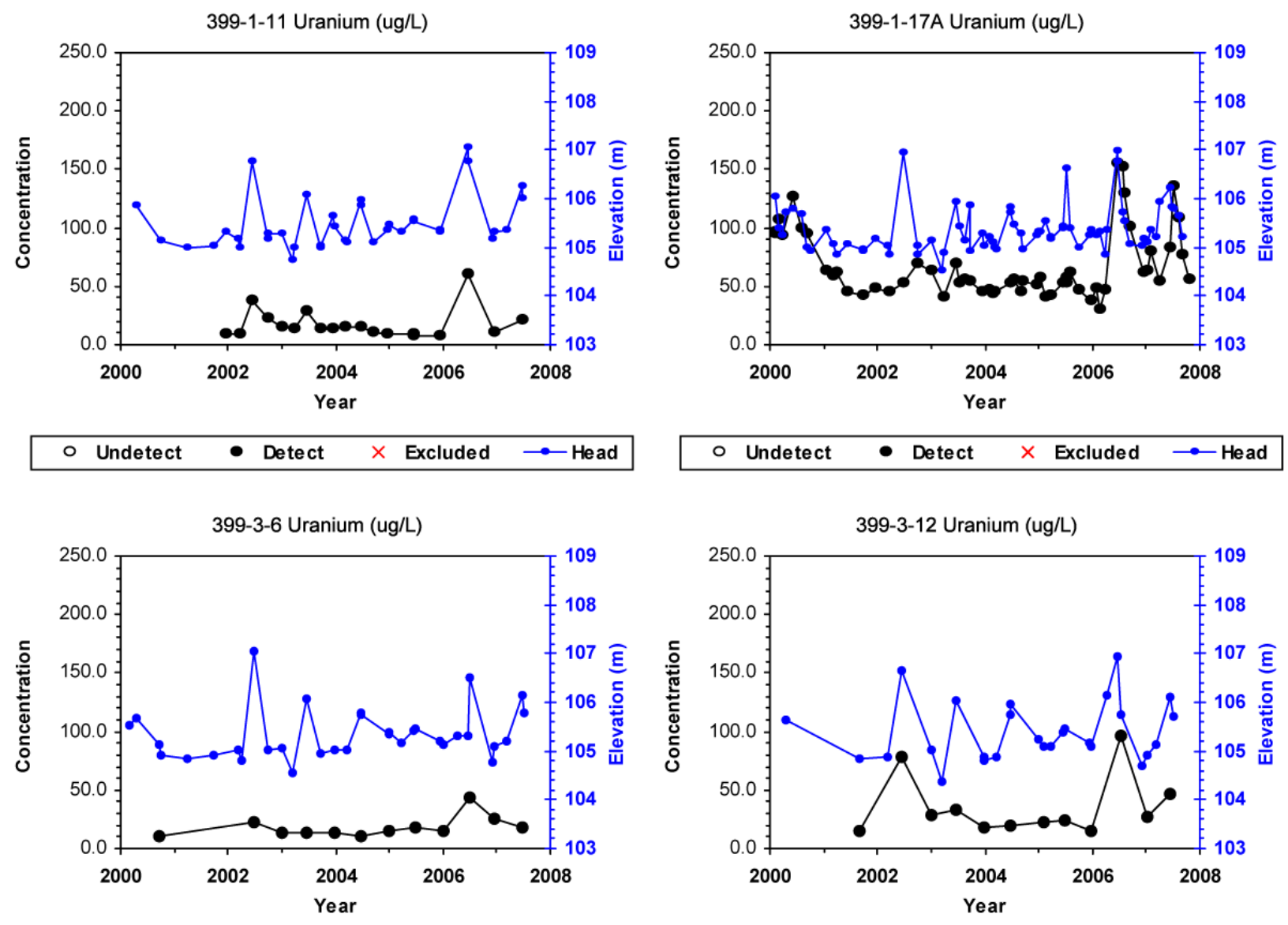

$\circ$ Undetect $\bullet$ Detect $\times$ Excluded $\longrightarrow$ Head

$\circ$ Undetect $\bullet$ Detect $\times$ Excluded $\multimap$ Head

Figure 3.11. Wells Showing Increased Uranium Concentrations When Water Level is Raised

of infiltrating river water is revealed by changing water quality characteristics, ${ }^{6}$ including the reduction of uranium concentrations by dilution. This causes a band of relatively low concentrations near the river to appear in the June maps, as compared to the December maps. The correlation between uranium concentrations and water levels in wells near the river is just the opposite of that observed in wells farther inland, as described above. This inverse correlation is illustrated by trends at several wells near the river (Figure 3.12). The relatively low specific conductance of the samples from these wells confirms the presence of river water at these wells during June. What is not yet clearly established is whether the reduction in concentrations is solely the result of dilution or if sorption onto sediment is also a contributor. The tendency for dissolved uranium to sorb onto sediment is increased in the geochemical environment involving river water, as compared to the groundwater environment (described in more detail in Section 6.0).

\footnotetext{
${ }^{6}$ The principal indicator is specific conductance. Mainstream river water has a relatively constant value of $\sim 130 \mu \mathrm{S} / \mathrm{cm}$. Nearshore river water at the 300 Area typically falls in the range from 150 190 $\mu \mathrm{S} / \mathrm{cm}$ while 300 Area groundwater falls in the range from 350 to $450 \mu \mathrm{S} / \mathrm{cm}$ and higher where certain contaminants are present. Other contrasts between river water and groundwater are revealed by alkalinity (lower in river water) and dissolved oxygen (higher in river water).
} 

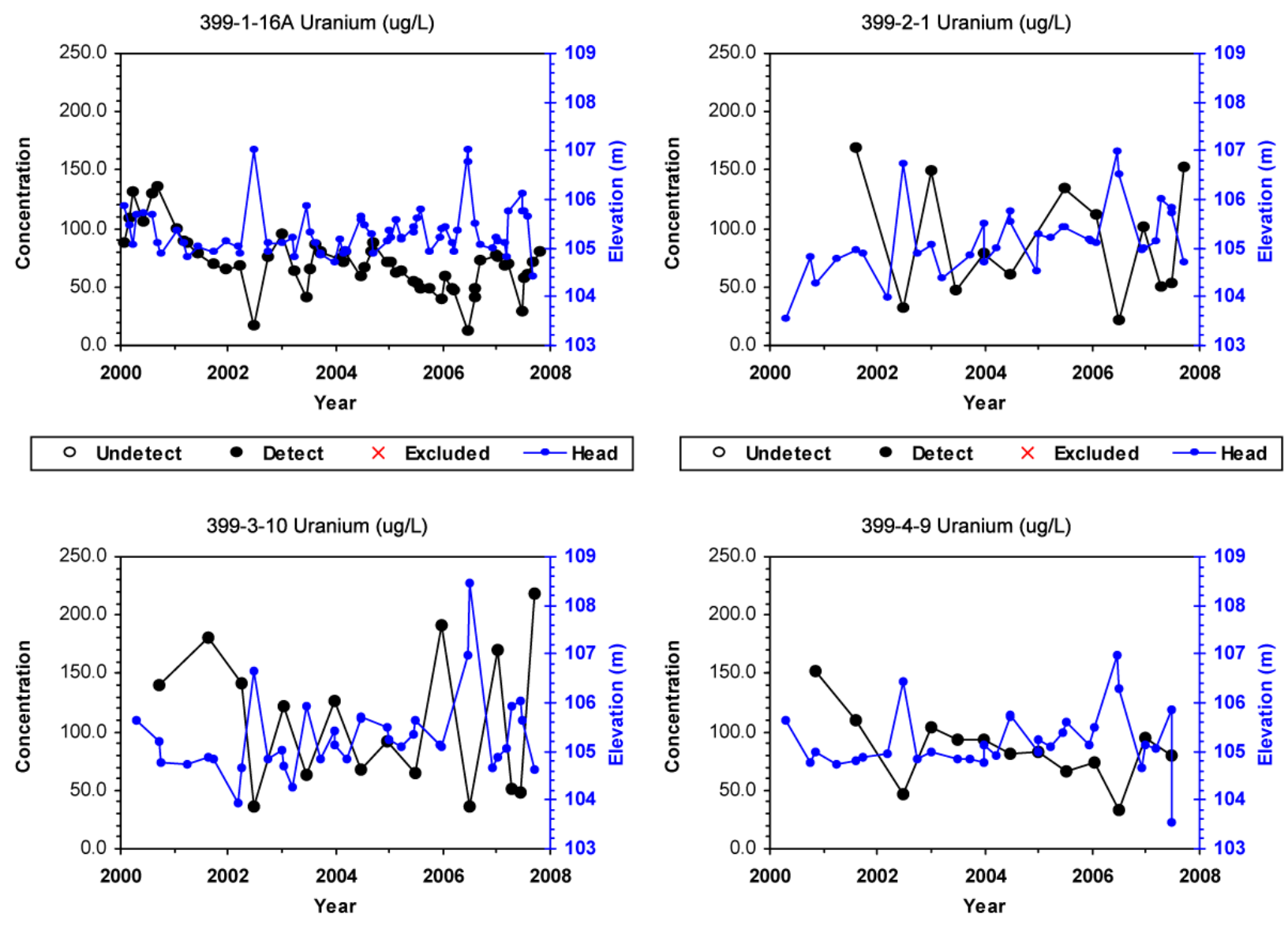

$\circ$ Undetect $\bullet$ Detect $\times$ Excluded $\multimap$ Head

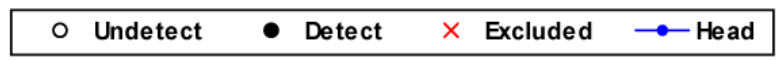

Figure 3.12. Wells Showing Decreased Uranium Concentrations When Water Level in Well is Raised

Efforts are underway to devise a means to "adjust” uranium concentrations in samples known to contain a mixture of groundwater and river water, thus providing an estimate for the uranium concentration in groundwater that is approaching the zone of groundwater/river mixing. This information is helpful for anticipating exposure conditions in the river environment when low stage conditions exist, i.e., very little dilution because of mixing. The information is also useful in developing criteria for remedial action objectives, as has been done for the chromium plumes at the $100-\mathrm{K}, 100-\mathrm{D}$, and $100-\mathrm{H}$ Areas where a presumed reduction in chromium concentrations because of dilution with river water is part of the record of decision for interim action (DOE-RL 1996b; EPA 1996b).

Adjustments for mixing have been attempted using the specific conductance of two water "types," i.e., groundwater and river water, as end members. Knowing the specific conductance of a sample that contains a mixture of the two water types allows a mixing fraction to be calculated in Equation (3.1):

$$
\mathrm{a}=\frac{\text { SCmix }- \text { SCrvr }}{\text { SCgw }- \text { SCrvr }}
$$


where

$$
\begin{aligned}
\mathrm{a} & =\text { proportion of groundwater in the sample } \\
\text { SCmix } & =\text { specific conductance of the sample } \\
\text { SCrvr } & =\text { specific conductance of river water } \\
\text { SCgw } & =\text { specific conductance of groundwater. }
\end{aligned}
$$

The values for specific conductance of the two end members must remain constant for this relationship to be completely valid. For the 300 Area aquifer, the specific conductance varies within a particular hydrogeologic unit (e.g., saturated Hanford gravels) and with time, so this attribute is not realized. River water shows a relatively constant value for specific conductance, although there are small seasonal variations.

In spite of the limitations, the relationship can be helpful in approximating the amount of mixing that occurs at shoreline monitoring sites. The proportion of groundwater in the samples was calculated using all results for specific conductance and uranium measurements made in samples collected from aquifer tubes and estimating a representative value for specific conductance of the groundwater that is approaching each tube site. Table 3.1 shows the average proportion of groundwater in samples from different depth categories for tube screens.

Table 3.1. Proportion of Groundwater in Samples from 300 Area Aquifer Tubes

\begin{tabular}{||c|c|c|c|c||}
\hline \hline $\begin{array}{c}\text { Depth } \\
\text { Category }\end{array}$ & $\begin{array}{c}\text { Depth Range } \\
\text { (feet below ground surface) }\end{array}$ & $\begin{array}{c}\text { Proportion of } \\
\text { Groundwater in Sample: } \\
\text { Average Value }\end{array}$ & $\begin{array}{c}\text { Proportion of } \\
\text { Groundwater in Sample: } \\
\text { Standard Deviation }\end{array}$ & $\begin{array}{c}\text { Number of } \\
\text { Samples }\end{array}$ \\
\hline \hline Shallow & $<10$ & 0.58 & 0.25 & 41 \\
\hline Medium & $10-20$ & 0.62 & 0.24 & 46 \\
\hline Deep & $>20<30$ & 0.67 & 0.25 & 29 \\
\hline
\end{tabular}

\subsubsection{Summary of Seasonal Variability of the Uranium Plume}

Although seasonal variability in uranium plume concentrations and concentration patterns have been acknowledged in numerous earlier reports, the maps constructed since the revised Operations and Maintenance Plan became effective in 2002 have provided an increased level of detail, primarily because of a greater number of wells being monitored. Figure 3.13 provides a summary of the two effects discussed above during June 2006 by illustrating locations where uranium concentrations typically increase when the water table is elevated and areas where concentrations are reduced when the water level in the well is raised. The map was prepared by examining long-term trends at wells and grouping them as to whether a positive or negative correlation between uranium concentrations and water levels was easily observable. The map reveals that concentrations may increase at inland locations that are not located immediately below a known waste site.

\subsection{Trends in Plume Parameters}

Trends in uranium contamination in 300 Area groundwater were described in an expanded groundwater report for fiscal year 2004 (Peterson et al. 2005). These trends included maximum observed concentrations by year in groundwater samples collected from monitoring wells and from aquifer tubes at the river shoreline from 1992 to 2004. Table 3.2 provides updated values for 2005, 2006, and 2007. 


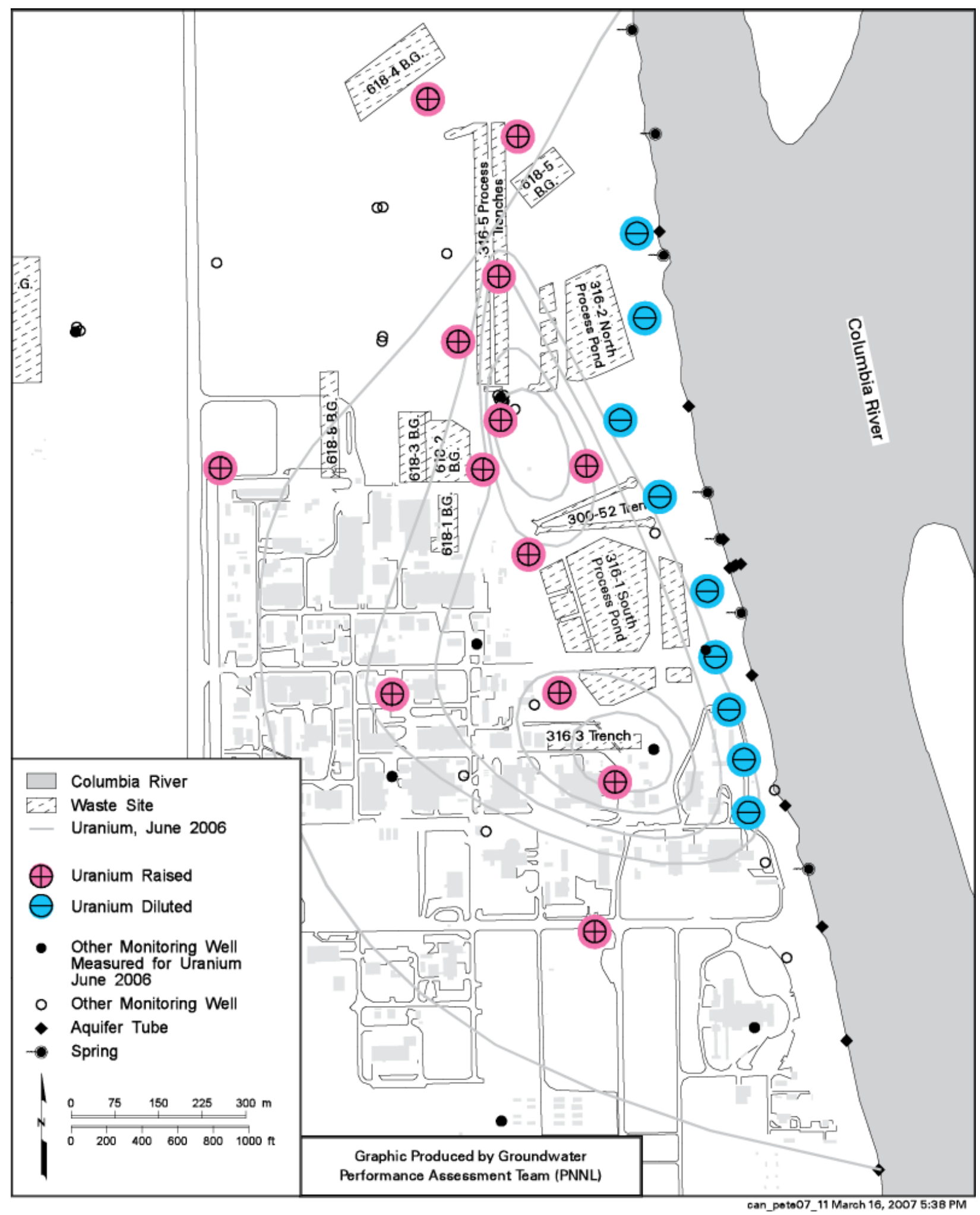

Figure 3.13. Map Illustrating Areas Where Uranium Concentrations Vary in Response to Raised Water Levels at the Well 
Table 3.2. Maximum Observed Uranium Concentrations ( $\mu \mathrm{g} / \mathrm{L})$ at 300 Area Wells and Aquifer Tubes

\begin{tabular}{|c|c|c|c|c|c|c|c|c|c|c|c|c|c|c|c|c|}
\hline Well/Tube Name & 1992 & 1993 & 1994 & 1995 & 1996 & 1997 & 1998 & 1999 & 2000 & 2001 & 2002 & 2003 & 2004 & 2005 & 2006 & $2007^{*}$ \\
\hline \multicolumn{17}{|c|}{ Wells that monitor the upper portion of the unconfined aquifer: } \\
\hline $399-1-1$ & & & & & & & & & & & 62 & 53 & 66 & 46 & 52 & 30 \\
\hline $399-1-2$ & & 21 & 28 & & 52 & 35 & 10 & 16 & 7 & 6 & 47 & 10 & 13 & 15 & 57 & 24 \\
\hline $399-1-3$ & & & & 53 & & & 134 & 153 & 100 & 65 & & & & & & \\
\hline $399-1-4$ & & 5 & & 14 & & & & & & & & & & & & \\
\hline $399-1-5$ & ND & 110 & 120 & & 105 & 80 & 51 & 48 & ******** & $* * * * * *$ & ******* & ******** & ******** & ******* & $* * * * * * *$ & ******** \\
\hline $399-1-6$ & 23 & 7 & 9 & 9 & 13 & 11 & 8 & 9 & & & & 9 & 7 & 7 & 8 & 8 \\
\hline $399-1-7$ & 160 & 110 & 131 & & 248 & 329 & 132 & 153 & 95 & 72 & 90 & 80 & 67 & 64 & 102 & 111 \\
\hline $399-1-10 \mathrm{~A}$ & 152 & 110 & 71 & 75 & 85 & 144 & 75 & 61 & 53 & 43 & 235 & 178 & 67 & 48 & 70 & 51 \\
\hline $399-1-11$ & 48 & 21 & 31 & 33 & 102 & 47 & & & & 9 & 37 & 28 & 16 & 10 & 60 & 21 \\
\hline $399-1-12$ & 83 & 44 & 50 & 60 & 83 & 53 & 22 & 23 & 16 & 17 & 40 & 22 & 21 & 16 & 37 & 23 \\
\hline $399-1-13 A$ & 6 & 6 & & 7 & 14 & & & & & & & & & & & \\
\hline $399-1-14 A$ & 6 & 6 & 7 & 8 & 20 & 13 & 6 & 8 & 6 & 6 & & & & & & \\
\hline $399-1-15$ & 5 & 6 & 4 & & 7 & & & & & & 7 & 7 & 6 & 7 & 9 & 7 \\
\hline $399-1-16 A$ & 156 & 145 & 87 & 165 & 123 & 137 & 124 & 115 & 136 & 100 & 94 & 86 & 88 & 71 & 77 & 81 \\
\hline $399-1-17 A$ & 111 & 43 & 71 & 247 & 300 & 313 & 248 & 166 & 126 & 64 & 70 & 70 & 56 & 62 & 155 & 135 \\
\hline $399-1-18 A$ & 5 & 5 & 6 & 5 & 6 & 7 & 6 & 6 & 6 & 6 & & 7 & 7 & 6 & 6 & 6 \\
\hline $399-1-19$ & & & ND & 198 & 271 & $* * * * * * *$ & ******* & ******** & ******* & $* * * * * * *$ & ******* & ******* & ******* & ******** & $* * * * * *$ & ******* \\
\hline $399-1-21 \mathrm{~A}$ & 82 & 46 & 23 & 24 & 63 & 101 & 36 & 32 & 18 & 12 & 47 & 22 & 49 & 97 & 86 & 72 \\
\hline $399-1-23$ & ********* & $* * * * * *$ & ******* & $* * * * * *$ & $* * * * * *$ & $* * * * * *$ & $* * * * * *$ & ******* & $* * * * * *$ & $* * * * * *$ & ******* & ******* & ******* & $* * * * * * *$ & 111 & 72 \\
\hline $399-2-1$ & 48 & 46 & 58 & 159 & 196 & 230 & 252 & 232 & & 169 & 149 & 79 & 61 & 134 & 111 & 152 \\
\hline $399-2-2$ & ND & 110 & 150 & 160 & 262 & 358 & 225 & 322 & 205 & 144 & 137 & 66 & 86 & 128 & 24 & 166 \\
\hline $399-2-3$ & 42 & ND & 118 & 147 & 68 & & & & & & & & & & & \\
\hline $399-2-5$ & ********* & $* * * * * *$ & ******* & $* * * * * *$ & $* * * * * *$ & $* * * * * * *$ & $* * * * * * *$ & $* * * * * * *$ & $* * * * * * *$ & $* * * * * * *$ & $* * * * * *$ & ******* & $* * * * * * *$ & $* * * * * *$ & $* * * * * *$ & \\
\hline $399-3-1$ & & & 53 & 81 & 56 & 189 & 219 & 285 & 234 & 198 & & & & 122 & 134 & 69 \\
\hline $399-3-2$ & 15 & 26 & 22 & 25 & & & & & & & & & & 12 & 11 & 9 \\
\hline $399-3-3$ & 10 & & 16 & & 18 & 27 & & 17 & 12 & & & & & & & \\
\hline
\end{tabular}


Table 3.2. (contd)

\begin{tabular}{|c|c|c|c|c|c|c|c|c|c|c|c|c|c|c|c|c|}
\hline Well/Tube Name & 1992 & 1993 & 1994 & 1995 & 1996 & 1997 & 1998 & 1999 & 2000 & 2001 & 2002 & 2003 & 2004 & 2005 & 2006 & $2007^{*}$ \\
\hline $399-3-6$ & & & 17 & 33 & 46 & 34 & 20 & 12 & 11 & & 22 & 14 & 14 & 18 & 43 & 19 \\
\hline $399-3-9$ & 27 & & 22 & & & & & & & & & & & 98 & 191 & 91 \\
\hline $399-3-10$ & 14 & 26 & 20 & 63 & 36 & 74 & 92 & 84 & 140 & 181 & 141 & 127 & 92 & 192 & 37 & 218 \\
\hline $399-3-11$ & 24 & 38 & 97 & 130 & & 66 & 35 & 48 & 28 & 23 & 85 & 42 & 107 & 76 & 121 & 97 \\
\hline $399-3-12$ & 32 & 37 & 39 & & 76 & 78 & 29 & 37 & & 15 & 78 & 33 & 20 & 24 & 97 & 47 \\
\hline $399-3-18$ & $* * * * * *$ & $* * * * * *$ & $* * * * * *$ & $* * * * * *$ & $* * * * * *$ & $* * * * * *$ & $* * * * * *$ & $* * * * * *$ & $* * * * * *$ & $* * * * * *$ & $* * * * * *$ & $* * * * * *$ & $* * * * * *$ & $* * * * * *$ & 109 & 145 \\
\hline 399-3-19 & $* * * * * *$ & $* * * * * *$ & $* * * * * *$ & $* * * * * *$ & $* * * * * *$ & $* * * * * *$ & $* * * * * *$ & $* * * * * *$ & $* * * * * *$ & $* * * * * *$ & $* * * * * *$ & $* * * * * *$ & $* * * * * *$ & $* * * * * *$ & 79 & 42 \\
\hline $399-3-20$ & $* * * * * *$ & $* * * * * *$ & $* * * * * *$ & $* * * * * *$ & $* * * * * *$ & $* * * * * *$ & $* * * * * *$ & $* * * * * *$ & $* * * * * *$ & $* * * * * *$ & $* * * * * *$ & $* * * * * *$ & $* * * * * *$ & $* * * * * *$ & 148 & 74 \\
\hline $399-4-1$ & 16 & 14 & 17 & 20 & 37 & 54 & 26 & 20 & 16 & 18 & 24 & 20 & 16 & 18 & 29 & 20 \\
\hline $399-4-7$ & 59 & 51 & 53 & 43 & 29 & 69 & 68 & 73 & 73 & 63 & & & & & 65 & 68 \\
\hline $399-4-9$ & 50 & ND & 39 & & 74 & 128 & 128 & 163 & 152 & 110 & 46 & 104 & 83 & 66 & 95 & 80 \\
\hline $399-4-10$ & 56 & 70 & 55 & 38 & & & & & & 94 & 94 & & 91 & 91 & 105 & 77 \\
\hline $399-4-11$ & 13 & 17 & & 24 & 40 & 51 & 23 & 20 & 16 & 17 & & & & & & \\
\hline $399-4-12$ & 25 & 25 & 23 & 21 & 40 & 43 & 32 & 37 & 22 & 21 & 24 & 22 & 22 & 23 & 26 & 30 \\
\hline $399-4-14$ & ******** & $* * * * * *$ & ******** & ******** & ********* & ******** & ******* & ******** & ******** & $* * * * * *$ & $* * * * * * *$ & ******* & ******* & ******* & ******** & \\
\hline $399-5-1$ & 7 & 6 & 5 & 5 & 12 & 10 & 7 & 9 & 7 & 7 & & & & & & \\
\hline $399-5-4 B$ & $* * * * * *$ & & & & & & & & & & & & & & & 7 \\
\hline $399-6-1$ & 10 & 9 & & & & & & & & & & & & & & \\
\hline $399-8-1$ & 5 & 5 & 5 & 5 & 12 & 17 & 8 & 5 & 5 & 5 & & & & & & \\
\hline $399-8-3$ & 5 & 5 & & & 14 & & & & & & & & & & & \\
\hline $399-8-4$ & 3 & & & & & & & & & & & & & & & \\
\hline $399-8-5 A$ & 11 & 11 & 7 & & 4 & 8 & 19 & 7 & 10 & 8 & 5 & 26 & 7 & 12 & 5 & 20 \\
\hline 699-S19-E13 & 4 & 5 & 5 & 5 & & & & & & & & & & & & \\
\hline 699-S19-E14 & 6 & 4 & & & & & & & & & & & & & & \\
\hline 699-S20-E10 & ******** & $* * * * * *$ & ******** & $* * * * * * *$ & ********* & $* * * * * *$ & $* * * * * *$ & $* * * * * * *$ & $* * * * * *$ & $* * * * * *$ & $* * * * * * *$ & ******** & $* * * * * * *$ & 2 & 2 & 2 \\
\hline 699-S27-E12A & & & & & & & 7 & 8 & 9 & & & & & 9 & & \\
\hline 699-S27-E14 & & & & & 7 & 8 & 8 & 7 & 7 & 8 & 9 & 7 & 8 & 7 & 9 & 9 \\
\hline
\end{tabular}


Table 3.2. (contd)

\begin{tabular}{|c|c|c|c|c|c|c|c|c|c|c|c|c|c|c|c|c|}
\hline Well/Tube Name & 1992 & 1993 & 1994 & 1995 & 1996 & 1997 & 1998 & 1999 & 2000 & 2001 & 2002 & 2003 & 2004 & 2005 & 2006 & $2007^{*}$ \\
\hline 699-S29-E12 & & & 4 & & & & & 6 & & & & & & 6 & & \\
\hline 699-S29-E16A & 2 & 1 & 3 & 2 & 3 & 5 & 4 & & 5 & 4 & 3 & 4 & 4 & 4 & 5 & 6 \\
\hline 699-S30-E15A & 2 & 3 & 2 & 2 & & & & 4 & 4 & 4 & 4 & 4 & 4 & 5 & & 5 \\
\hline \multicolumn{17}{|c|}{ Aquifer sampling tubes at the shoreline that monitor the upper portion of the unconfined aquifer: } \\
\hline AT-3-1-S & ******** & 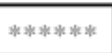 & *********1 & ******* & 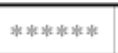 & 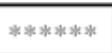 & ******* & 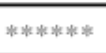 & ******** & ******** & ******** & 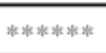 & 87 & 65 & 82 & 65 \\
\hline AT-3-1-M & $* * * * * *$ & ******** & ******* & $* * * * * *$ & ******* & $* * * * * *$ & $* * * * * *$ & $* * * * * *$ & ******* & $* * * * * *$ & $* * * * * *$ & $* * * * * *$ & 100 & 88 & 95 & 78 \\
\hline AT-3-1-D(1) & $* * * * * *$ & ******* & ******** & $* * * * * *$ & ******** & ******** & $* * * * * *$ & $* * * * * *$ & $* * * * * *$ & ******* & $* * * * * *$ & ******* & 93 & 82 & 65 & 68 \\
\hline AT-3-2-S & $* * * * * *$ & $* * * * * *$ & ******* & $* * * * * *$ & ******** & $* * * * * *$ & $* * * * * *$ & ******* & ******* & $* * * * * *$ & $* * * * * * *$ & $* * * * * *$ & & 58 & 84 & \\
\hline AT-3-2-M & $* * * * * *$ & ******* & ******* & $* * * * * *$ & ****** & $* * * * * *$ & $* * * * * *$ & $* * * * * *$ & ******* & $* * * * * *$ & $* * * * * *$ & $* * * * * *$ & 88 & 80 & 85 & \\
\hline 103mArray-US125 & ******* & ******** & 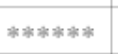 & ******** & ***k*k* & 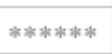 & ******* & ******* & ******** & 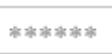 & ******** & ******** & ******** & 27 & 19 & \\
\hline 103mArray-US100 & $* * * * * *$ & ******** & ******** & ******* & ***k*k*k & ******** & $* * * * * * *$ & ******** & ********* & $* * * * * * *$ & $* * * * * * *$ & ******* & ******* & 34 & 27 & \\
\hline 103mArray-US75 & $* * * * * *$ & $* * * * * *$ & $* * * * * *$ & $* * * * * *$ & $* * * * * *$ & $* * * * * *$ & $* * * * * *$ & $* * * * * *$ & $* * * * * *$ & $* * * * * *$ & $* * * * * *$ & $* * * * * *$ & $* * * * * *$ & 99 & 69 & \\
\hline 300SPR9A-19cm & $* * * * * *$ & $* * * * * *$ & $* * * * * *$ & $* * * * * *$ & $* * * * * *$ & $* * * * * *$ & $* * * * * *$ & $* * * * * *$ & $* * * * * *$ & $* * * * * *$ & $* * * * * *$ & $* * * * * *$ & 107 & 152 & 33 & \\
\hline 300 SPR9A-86cm & $* * * * * *$ & ******* & $* * * * * *$ & $* * * * * *$ & $* * * * * *$ & $* * * * * *$ & $* * * * * *$ & $* * * * * *$ & $* * * * * *$ & $* * * * * *$ & $* * * * * *$ & $* * * * * *$ & 138 & 155 & 15 & \\
\hline 300SPR9A-142cm & $* * * * * *$ & $* * * * * *$ & $* * * * * *$ & $* * * * * *$ & $* * * * * *$ & $* * * * * *$ & $* * * * * *$ & $* * * * * *$ & $* * * * * *$ & $* * * * * *$ & $* * * * * *$ & $* * * * * *$ & 135 & 164 & 29 & \\
\hline 103mArray-US50 & $* * * * * *$ & $* * * * * *$ & $* * * * * *$ & $* * * * * *$ & $* * * * * *$ & $* * * * * *$ & $* * * * * *$ & $* * * * * *$ & $* * * * * *$ & $* * * * * *$ & $* * * * * *$ & $* * * * * *$ & $* * * * * *$ & 141 & 91 & \\
\hline 103mArray-US25 & $* * * * * *$ & $* * * * * *$ & $* * * * * *$ & $* * * * * *$ & $* * * * * *$ & $* * * * * *$ & $* * * * * *$ & $* * * * * *$ & $* * * * * *$ & $* * * * * *$ & $* * * * * *$ & $* * * * * *$ & $* * * * * *$ & 130 & 34 & \\
\hline 300-3-3B-376cm & $* * * * * *$ & $* * * * * *$ & $* * * * * *$ & $* * * * * *$ & $* * * * * *$ & $* * * * * *$ & $* * * * * *$ & $* * * * * *$ & $* * * * * *$ & $* * * * * *$ & $* * * * * *$ & $* * * * * *$ & 192 & 198 & 41 & \\
\hline $300-3-3 B-518 \mathrm{~cm}$ & $* * * * * *$ & ******* & $* * * * * *$ & $* * * * * *$ & $* * * * * * *$ & $* * * * * *$ & $* * * * * *$ & $* * * * * *$ & $* * * * * * *$ & $* * * * * *$ & $* * * * * *$ & $* * * * * *$ & & & 1 & \\
\hline $300-3-3 C-409 \mathrm{~cm}$ & $* * * * * *$ & $* * * * * *$ & $* * * * * * *$ & $* * * * * *$ & $* * * * * * *$ & $* * * * * *$ & $* * * * * *$ & ******* & $* * * * * *$ & $* * * * * *$ & $* * * * * *$ & $* * * * * *$ & & 188 & 117 & \\
\hline $300-3-3 C-589 \mathrm{~cm}$ & ****** & ******* & ******* & $* * * * * *$ & ******* & $* * * * * *$ & $* * * * * *$ & $* * * * * *$ & $* * * * * *$ & $* * * * * *$ & $* * * * * *$ & ******* & & 24 & & \\
\hline $300-3-3 A-124 \mathrm{~cm}$ & ******* & ******* & ******* & $* * * * * *$ & ****** & $* * * * * *$ & $* * * * * * *$ & ****** & ****** & ******* & ******* & $* * * * * *$ & 93 & 205 & 53 & \\
\hline $300-3-3 A-410 \mathrm{~cm}$ & ******* & ******** & 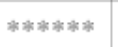 & $* * * * * *$ & ******* & ********* & ******* & ******* & 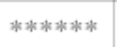 & ******** & ******* & ******** & 195 & 198 & & \\
\hline $300-3-3 A-579 \mathrm{~cm}$ & $* * * * * *$ & ******* & ******* & $* * * * * *$ & $* * * * * *$ & $* * * * * *$ & $* * * * * *$ & ******* & $* * * * * *$ & $* * * * * *$ & $* * * * * *$ & $* * * * * *$ & 14 & 49 & 49 & \\
\hline 103mArray-AT3A & ******* & ******** & ********* & $* * * * * *$ & $* * * * * *$ & ******* & $* * * * * *$ & $* * * * * *$ & $* * * * * *$ & ******* & ******* & ****** & ******* & 130 & 53 & \\
\hline AT-3-3-S & $* * * * * *$ & ******* & $* * * * * *$ & $* * * * * *$ & $* * * * * *$ & $* * * * * *$ & $* * * * * *$ & ****** & ******* & $* * * * * *$ & $* * * * * *$ & $* * * * * *$ & 195 & 195 & 394 & 137 \\
\hline
\end{tabular}


Table 3.2. (contd)

\begin{tabular}{|c|c|c|c|c|c|c|c|c|c|c|c|c|c|c|c|c|}
\hline Well/Tube Name & 1992 & 1993 & 1994 & 1995 & 1996 & 1997 & 1998 & 1999 & 2000 & 2001 & 2002 & 2003 & 2004 & 2005 & 2006 & $2007^{*}$ \\
\hline AT-3-3-M & $* * * * * *$ & $* * * * * *$ & $* * * * * *$ & $* * * * * *$ & $* * * * * *$ & $* * * * * *$ & $* * * * * *$ & $* * * * * *$ & $* * * * * *$ & $* * * * * *$ & $* * * * * *$ & $* * * * * *$ & 183 & 183 & 149 & 159 \\
\hline AT-3-3-D & $* * * * * *$ & $* * * * * *$ & $* * * * * *$ & $* * * * * *$ & $* * * * * *$ & $* * * * * *$ & $* * * * * *$ & $* * * * * *$ & $* * * * * *$ & $* * * * * *$ & $* * * * * *$ & $* * * * * *$ & 12 & 29 & 9 & 6 \\
\hline 103mArray-DS25 & $* * * * * *$ & $* * * * * *$ & $* * * * * *$ & $* * * * * *$ & $* * * * * *$ & $* * * * * *$ & $* * * * * *$ & $* * * * * *$ & $* * * * * *$ & $* * * * * *$ & $* * * * * *$ & $* * * * * *$ & $* * * * * *$ & 160 & 107 & \\
\hline 103mArray-DS50 & $* * * * * *$ & $* * * * * *$ & $* * * * * *$ & $* * * * * *$ & $* * * * * *$ & $* * * * * *$ & $* * * * * *$ & $* * * * * *$ & $* * * * * *$ & $* * * * * *$ & $* * * * * *$ & $* * * * * *$ & $* * * * * *$ & 160 & 41 & \\
\hline 103mArray-DS75 & $* * * * * *$ & $* * * * * * *$ & $* * * * * *$ & $* * * * * *$ & $* * * * * *$ & $* * * * * *$ & $* * * * * *$ & $* * * * * *$ & $* * * * * *$ & $* * * * * *$ & $* * * * * *$ & $* * * * * *$ & $* * * * * *$ & 66 & 25 & \\
\hline AT-3-4-S & ******** & $* * * * * * *$ & $* * * * * *$ & $* * * * * *$ & $* * * * * *$ & $* * * * * *$ & $* * * * * *$ & $* * * * * *$ & ******** & $* * * * * *$ & $* * * * * *$ & $* * * * * *$ & 241 & 161 & 195 & 124 \\
\hline AT-3-4-M & $* * * * * *$ & ********* $* *$ & $* * * * * *$ & ******** & ******** & ******* & $* * * * * *$ & ******** & ******** & $* * * * * *$ & $* * * * * * *$ & ********* & & 3 & 126 & 100 \\
\hline AT-3-4-D & ******* & 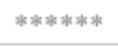 & ******* & ******** & ******* & ******* & $* * * * * *$ & ******** & 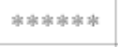 & $* * * * * *$ & ******* & ******** & & 130 & 157 & 94 \\
\hline AT-3-5-S & ******* & ******* & $* * * * * *$ & ******* & $* * * * * *$ & ******* & $* * * * * *$ & ******** & ******** & $* * * * * *$ & $* * * * * *$ & $* * * * * * *$ & 52 & & 62 & \\
\hline AT-3-6-S & ******* & ******* & $* * * * * *$ & $* * * * * *$ & $* * * * * *$ & ******* & $* * * * * *$ & $* * * * * *$ & $* * * * * *$ & $* * * * * *$ & $* * * * * *$ & ******** & 85 & 56 & 82 & \\
\hline AT-3-6-M & ******* & ******** & $* * * * * *$ & ******* & ******** & ******* & $* * * * * *$ & ******** & ******* & $* * * * * *$ & *k***** & ******** & & 80 & 111 & \\
\hline AT-3-6-D & $* * * * * *$ & $* * * * * *$ & $* * * * * *$ & $* * * * * *$ & $* * * * * *$ & $* * * * * *$ & $* * * * * *$ & $* * * * * *$ & $* * * * * *$ & $* * * * * *$ & $* * * * * *$ & $* * * * * *$ & & ND & 1 & \\
\hline AT-3-7-S & $* * * * * *$ & $* * * * * *$ & $* * * * * *$ & $* * * * * *$ & $* * * * * *$ & $* * * * * *$ & $* * * * * *$ & $* * * * * *$ & $* * * * * *$ & $* * * * * *$ & $* * * * * *$ & $* * * * * *$ & & 9 & 23 & \\
\hline AT-3-7-M & $* * * * * *$ & $* * * * * *$ & $* * * * * *$ & $* * * * * *$ & $* * * * * *$ & $* * * * * *$ & $* * * * * *$ & $* * * * * *$ & $* * * * * *$ & $* * * * * *$ & $* * * * * *$ & $* * * * * *$ & 18 & 20 & 21 & \\
\hline AT-3-7-D & $* * * * * *$ & $* * * * * *$ & $* * * * * *$ & $* * * * * *$ & $* * * * * *$ & $* * * * * *$ & $* * * * * *$ & $* * * * * *$ & $* * * * * *$ & $* * * * * *$ & $* * * * * *$ & $* * * * * *$ & & 5 & 6 & \\
\hline AT-3-8-S & $* * * * * *$ & $* * * * * *$ & $* * * * * *$ & $* * * * * *$ & $* * * * * *$ & $* * * * * *$ & $* * * * * *$ & $* * * * * *$ & $* * * * * *$ & $* * * * * *$ & $* * * * * *$ & $* * * * * *$ & 18 & 13 & 19 & \\
\hline AT-3-8-M & $* * * * * *$ & $* * * * * *$ & $* * * * * *$ & $* * * * * *$ & $* * * * * *$ & $* * * * * *$ & $* * * * * *$ & $* * * * * *$ & $* * * * * *$ & $* * * * * *$ & $* * * * * *$ & $* * * * * *$ & & & 71 & \\
\hline AT-3-8-D & 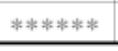 & 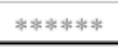 & $* * * * * *$ & ********* & 肃米米米* & $* * * * * *$ & ******** & $* * * * * * *$ & $* * * * * *$ & $* * * * * *$ & ******** & $* * * * * * *$ & & & & \\
\hline \multicolumn{17}{|c|}{ Wells that monitor the lower portion of the unconfined aquifer: } \\
\hline $399-1-8$ & 110 & 0 & 0 & & & & & & & 3 & 17 & 41 & 14 & 9 & 12 & 53 \\
\hline 399-1-10B & 0 & ND & 0 & 0 & & 0 & 0 & 0 & 0 & 0 & 0 & 3 & 0 & 0 & 0 & ND \\
\hline $399-1-13 B$ & 0 & 0 & 0 & ND & ND & & & & & & & & & & & \\
\hline 399-1-14B & 0 & 0 & ND & 1 & ND & 0 & & & & & & & & & & \\
\hline 399-1-16B & 5 & 5 & 6 & 9 & 3 & 14 & 15 & 14 & 14 & 15 & 14 & 14 & 14 & 15 & 14 & 12 \\
\hline 399-1-17B & 0 & ND & 0 & ND & 0 & 0 & 0 & ND & 1 & 1 & 1 & 3 & 0 & 0 & ND & 0 \\
\hline 399-1-18B & & & & & 0 & 0 & 0 & ND & 0 & 0 & & 0 & 0 & ND & 0 & 0 \\
\hline 399-1-21B & 0 & 0 & 0 & & 0 & & & & & 0 & 1 & 0 & 0 & ND & ND & ND \\
\hline $399-3-21$ & ******* & $* * * * * *$ & $* * * * * *$ & ******* & ******* & $* * * * * *$ & $* * * * * *$ & $* * * * * *$ & $* * * * * *$ & $* * * * * *$ & $* * * * * *$ & $* * * * * *$ & $* * * * * *$ & $* * * * * *$ & $* * * * * *$ & 0 \\
\hline
\end{tabular}


Table 3.2. (contd)

\begin{tabular}{|c|c|c|c|c|c|c|c|c|c|c|c|c|c|c|c|c|}
\hline Well/Tube Name & 1992 & 1993 & 1994 & 1995 & 1996 & 1997 & 1998 & 1999 & 2000 & 2001 & 2002 & 2003 & 2004 & 2005 & 2006 & $2007^{\star}$ \\
\hline $399-3-22$ & $* * * * * *$ & $* * * * * * *$ & ******** & $* * * * * *$ & $* * * * * *$ & $* * * * * *$ & $* * * * * *$ & $* * * * * *$ & $* * * * * *$ & $* * * * * *$ & $* * * * * *$ & $* * * * * * *$ & $* * * * * *$ & $* * * * * *$ & $* * * * * *$ & \\
\hline 699-S29-E16B & 0 & 0 & 0 & 0 & & & & & & & & & & & & \\
\hline \multicolumn{17}{|c|}{ Wells that monitor the uppermost confined aquifer: } \\
\hline $399-1-9$ & ND & 0 & 1 & & & & & & & & & & & & & ND \\
\hline $399-1-16 \mathrm{C}$ & ND & 6 & 0 & 0 & ND & & & & & & & & & & ND & \\
\hline $399-1-17 C$ & & & & & & & & & & & & & & & ND & \\
\hline $399-1-18 C$ & & & & & & & & & & & & & & & & ND \\
\hline $399-8-5 B$ & 0 & 0 & 0 & 0 & & & & & & & & & & & & \\
\hline $399-8-5 C$ & ND & 0 & 0 & ND & & & & & & & & & & & & \\
\hline 699-S29-E16C & ND & 0 & 0 & 0 & & & & & & & & & & & & \\
\hline
\end{tabular}


Estimates were also included in the fiscal year 2004 report for the areal extent, volume of contaminated groundwater, and mass of uranium within the 300 Area groundwater plume over time. These estimates used the contours developed each year for the annual groundwater monitoring reports (e.g., Peterson et al. 2007a) and assumed seasonal thicknesses for the contaminated unit. While the accuracy of the estimates is limited by that assumption and the subjective nature of drawing concentration contours, the precision of the estimates was believed to be sufficient to reveal long-term trends. Given the uncertainties in the estimates for each year, it appeared that the area of the plume remained relatively constant from 2002 to 2004, but the mass of uranium in the groundwater plume varied significantly from year to year. However, a distinct decreasing or increasing trend in mass was not apparent. The estimates suggested that the groundwater plume contained a greater mass of uranium during mid-year (December) than during the spring high-water-table condition (June).

Results from the recent LFI have made possible significant updates to the spatial framework for the uranium plume and for hydraulic properties associated with the contaminated sediment (Williams et al. 2007; see also Section 4.0 for a detailed description of the hydrogeologic framework for the 300 Area). The new information suggests that the assumed thickness values for the contaminated unit used for the fiscal year 2004 analysis of plume parameters, which were based on assumptions made during the initial remedial investigation (DOE-RL 1994b, p. 5-11), were too small. For example, in 2004, the average thicknesses for the contaminated layer during June and December for multiple years were assumed to be 3.3 and $3.0 \mathrm{~m}$, respectively. More recent stratigraphic analysis during the LFI for the extent of the saturated Hanford gravel unit, which contains the bulk of uranium contamination, suggests thicknesses for June and December 2006 of 9.8 and 8.0 m, respectively. These thickness values were calculated using EarthVision $^{\mathrm{TM}}$ software, which is the spatial data management system being used for 300 Area groundwater flow and transport simulations. A second update involves the total and effective porosity values assumed to be representative of the saturated Hanford gravel unit. A value for total porosity of $27 \%$ has been assumed in the past; results from the LFI and the computer simulation of groundwater flow suggest a somewhat lower value (see Section 5.0 discussion of flow modeling). A comprehensive analysis of porosity information for 300 Area sediment is presented in Williams et al. 2008, Appendix A).

Given the new information on the thickness of the contaminated unit and its porosity, the plume parameters originally presented in the 2004 report (Peterson et al. 2005) have been revised and updated to include values for 2005, 2006, and 2007. Table 3.3 lists the results. The net effect of the parameter changes has been to increase the contaminated volume and dissolved mass estimates compared to the 2004 estimates. Figure 3.14 shows the trends in these plume parameter estimates. The trend line for the area of the plume remains nearly constant while the trend lines for the volume of the plume and the mass of dissolved uranium suggest seasonal variability, with higher values often occurring during June. Also, since early 2004, the trends for mass, and possibly volume, appear to be gradually rising. This may be a short-term change following several years (2003, 2004, and 2005) during which the Columbia River discharge was relatively low, which also resulted in not having a particularly high seasonal water table elevation. Thus, the driver for re-supplying the plume from the vadose zone was lessened.

Using the updated spatial data and porosity information, the mass of dissolved uranium in the saturated Hanford gravel unit was also calculated using EarthVision ${ }^{\mathrm{TM}}$ software. The first step involved developing a concentration grid by fitting a surface to the observed uranium concentrations at wells and at control points that were added to represent the hand-drawn contours shown on the plume maps for June and December (see Figures 3.5 through 3.7). Grid cells outside the $10 \mu \mathrm{g} / \mathrm{L}$ contour (i.e., values less than $10 \mu \mathrm{g} / \mathrm{L}$ ) were set to zero. The second step involved creating a grid for thickness of the saturated Hanford 
gravel unit. This was done by subtracting the grid representing the contact between the Hanford gravel unit and the underlying Ringold Formation from the water-table elevation grid. Negative values, i.e., where the water table was below the top of the Ringold Formation, were set to zero. This thickness grid was then multiplied by the grid of uranium concentrations. The mass of dissolved uranium was then calculated by summing the values within the grid representing the product of saturated Hanford unit thickness and uranium concentration (meters times $\mu \mathrm{g} / \mathrm{L}$ ) and multiplying this by the width and length of each grid cell ( $25 \mathrm{~m}$ by $25 \mathrm{~m}$ ), and by the assumed Hanford formation porosity of 0.26 . The results indicate that the mass of uranium in the groundwater plume where mapped as greater than $30 \mu \mathrm{g} / \mathrm{L}$ for June 2006 is $71.8 \mathrm{~kg}$; for December 2006 it is $78.8 \mathrm{~kg}$; and for June 2007 it is $82.9 \mathrm{~kg}$ (the results are included in Table 3.3). These values compare reasonably well with those estimated using the less sophisticated analysis presented in fiscal year 2004.

Table 3.3. Attributes of 300 Area Uranium Plume in Groundwater

\begin{tabular}{|c|c|c|c|c|c|c|}
\hline \multirow[b]{2}{*}{$\begin{array}{l}\text { Time Period } \\
\text { Represented } \\
\end{array}$} & \multicolumn{3}{|c|}{$>30 \mu \mathrm{g} / \mathrm{L}$ Portion of Plume: } & \multicolumn{3}{|c|}{$>10 \mu \mathrm{g} / \mathrm{L}$ Portion of Plume: } \\
\hline & $\begin{array}{c}\text { Area of } \\
\text { Plume } \\
\left(\mathrm{km}^{2}\right)\end{array}$ & $\begin{array}{c}\text { Volume of } \\
\text { Water } \\
\left(\mathrm{m}^{3}\right)\end{array}$ & $\begin{array}{c}\text { Mass of } \\
\text { Uranium } \\
(\mathrm{kg})\end{array}$ & $\begin{array}{c}\text { Area of } \\
\text { Plume } \\
\left(\mathrm{km}^{2}\right)\end{array}$ & $\begin{array}{c}\text { Volume of } \\
\text { Water } \\
\left(\mathrm{m}^{3}\right)\end{array}$ & $\begin{array}{c}\text { Mass of } \\
\text { Uranium } \\
(\mathrm{kg})\end{array}$ \\
\hline June 2002 & 0.42 & $1,060,626$ & 54.4 & 1.01 & $2,580,241$ & 84.8 \\
\hline December 2002 & 0.43 & 901,216 & 78.0 & 0.86 & $1,794,192$ & 95.8 \\
\hline June 2003 & 0.42 & $1,067,334$ & 54.9 & 0.87 & $2,211,604$ & 77.8 \\
\hline December 2003 & 0.32 & 673,342 & 40.7 & 0.87 & $1,808,715$ & 63.4 \\
\hline June 2004 & 0.40 & $1,008,386$ & 60.8 & 0.85 & $2,170,544$ & 84.0 \\
\hline December 2004 & 0.40 & 836,520 & 52.3 & 0.95 & $1,979,449$ & 75.2 \\
\hline June 2005 & 0.42 & $1,061,158$ & 76.2 & 1.12 & $2,852,401$ & 112.0 \\
\hline December 2005 & 0.41 & 846,596 & 63.0 & 0.96 & $1,988,448$ & 85.9 \\
\hline $\begin{array}{l}\text { June } 2006 \\
\text { (EarthVision }^{\mathrm{TM}} \text { ) }\end{array}$ & $\begin{array}{c}0.40 \\
(0.41)\end{array}$ & $\begin{array}{l}1,025,135 \\
(994,158)\end{array}$ & $\begin{array}{c}76.9 \\
(71.8)\end{array}$ & $\begin{array}{c}1.12 \\
(1.11)\end{array}$ & $\begin{array}{c}2,850,525 \\
(2,835,993)\end{array}$ & $\begin{array}{c}113.4 \\
(105.2)\end{array}$ \\
\hline $\begin{array}{l}\text { December } 2006 \\
\text { (EarthVision }^{\mathrm{TM}} \text { ) }\end{array}$ & $\begin{array}{c}0.48 \\
(0.48)\end{array}$ & $\begin{array}{l}1,003,316 \\
(942,429)\end{array}$ & $\begin{array}{c}78.8 \\
(64.6)\end{array}$ & $\begin{array}{c}0.74 \\
(0.73)\end{array}$ & $\begin{array}{c}1,536,019 \\
(1,524,363)\end{array}$ & $\begin{array}{c}89.4 \\
(76.7)\end{array}$ \\
\hline $\begin{array}{l}\text { June } 2007 \\
\text { (EarthVision }^{\mathrm{TM}} \text { ) }\end{array}$ & $\begin{array}{c}0.50 \\
(0.50)\end{array}$ & $\begin{array}{r}1,263,458 \\
(1,280,611)\end{array}$ & $\begin{array}{c}82.9 \\
(77.9)\end{array}$ & $\begin{array}{c}0.83 \\
(0.84)\end{array}$ & $\begin{array}{c}2,119,758 \\
(2,206,019)\end{array}$ & $\begin{array}{l}100.1 \\
(95.6)\end{array}$ \\
\hline \multicolumn{7}{|c|}{$\begin{array}{l}\text { Assumptions: } \\
\text { 1. Contaminated thickness: } 9.8 \mathrm{~m} \text { (June) and } 8.0 \mathrm{~m} \text { (December) } \\
\text { 2. Total porosity of } 26 \% \text {. } \\
\text { 3. Mass is estimated using mid-point concentration between map contours. } \\
\text { Note: EarthVision }{ }^{\mathrm{TM}} \text { software will be used for future estimates of plume parameters. }\end{array}$} \\
\hline
\end{tabular}

\subsection{Discharge of Plume into the Columbia River}

Groundwater from the 300 Area unconfined aquifer discharges to the Columbia River via upwelling through the riverbed and to a lesser degree via riverbank springs that appear during periods of low river stage. The monitoring sites closest to the area of riverbed discharge are aquifer tube sites located near the low-stage shoreline at intervals of approximately $200 \mathrm{~m}$. Individual tubes monitor various depths in the aquifer at each tube site. These tubes were installed in early 2004 and have been sampled annually. To illustrate the uranium concentrations observed in the samples from the tubes, the highest value at each site has been plotted on the uranium plume map for December 2006 conditions (Figure 3.15). There is 


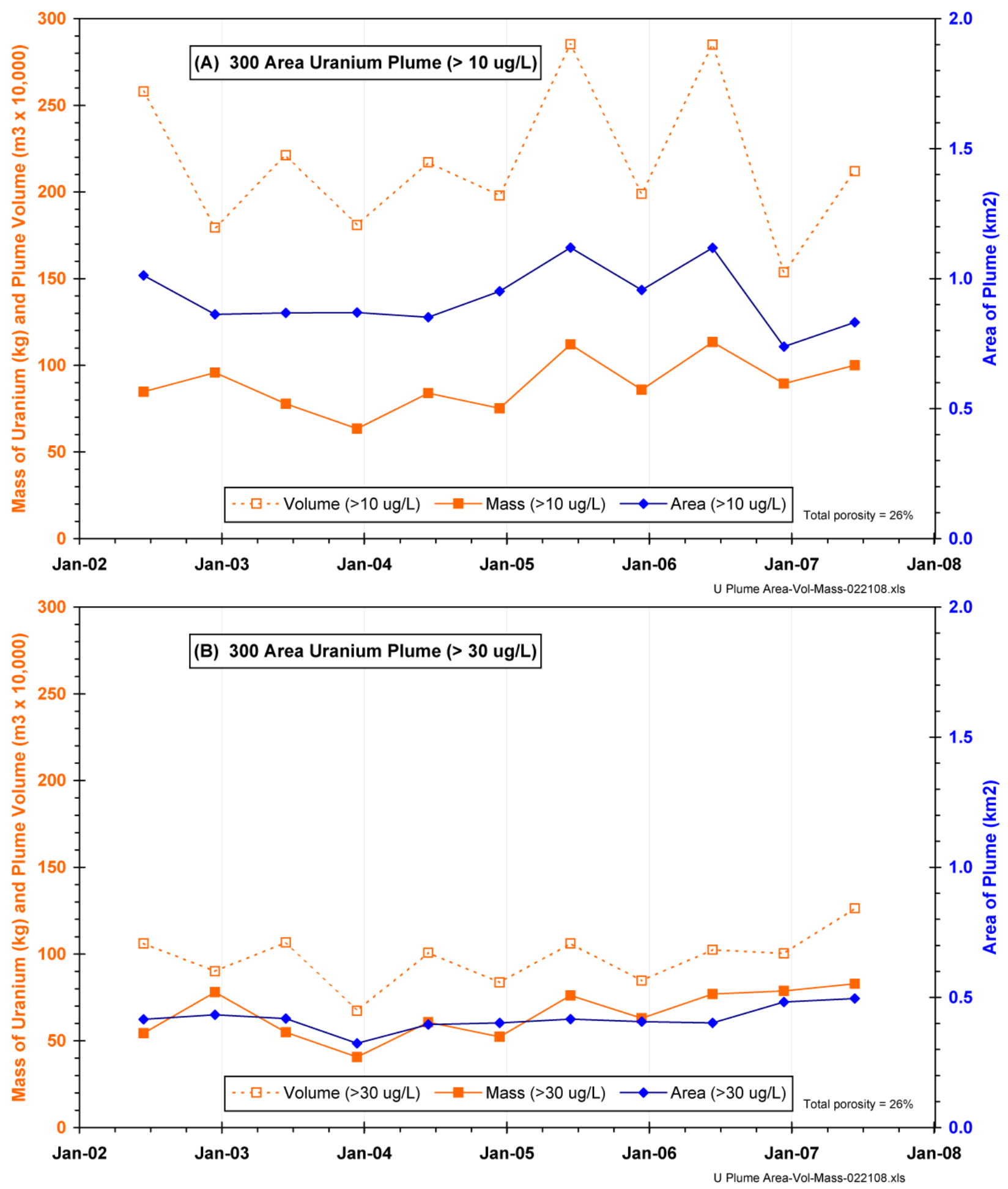

Figure 3.14. Trends in 300 Area Uranium Plume in Groundwater: Volume, Mass, and Area of Plume general consistency between data from wells near the river and from aquifer tubes regarding the extent of the plume and concentration pattern, even though the open intervals for sampling are quite different for the two types of sampling facilities (e.g., 15-ft well screen vs. 0.5-ft aquifer tube screen). 
Figure 3.16 is a vertical cross-section oriented parallel to the 300 Area shoreline. Aquifer-tube screens and screens for near-river wells are shown on this section, along with uranium concentrations for samples collected from December 2006 to January 2007. Concentrations observed in samples from monitoring wells do not necessarily represent the same aquifer characteristics as those observed in samples from aquifer tubes. A partial explanation for the differences in observed concentrations is that considerable spatial variability in concentrations is present (lateral and vertical variability) and also that concentrations at any particular location change rapidly with time, so unless sampling is conducted simultaneously at all locations, multiple explanations are possible for observed differences.

Information on where groundwater discharges from the aquifer into the riverbed is presented in Section 5.0. In very general terms, that discharge occurs within the lateral boundaries of the uranium plume as mapped (i.e., approximately $1500 \mathrm{~m}$ along the 300 Area shoreline) and on the Hanford Site side of the deepest part of the river channel. The "driver" for the discharge is the hydraulic gradient in the unconfined aquifer beneath the 300 Area, which is a product of higher water-table elevations to the west and the elevation of the Columbia River. Because the gradient changes with variations in river stage, the rate of groundwater discharge also varies.

Computer simulation of groundwater movement in the zone of interaction between the groundwater and river flow systems has revealed additional details regarding where groundwater is likely to discharge to the riverbed (100-H Area investigation described in Peterson and Connelly 2001, 2004). One finding is that upwelling of groundwater through the riverbed is more focused in the nearshore region than farther offshore, near the center of the channel. The area of the 300 Area riverbed likely to be impacted by discharge of the uranium plume has been estimated at $0.17 \mathrm{~km}^{2}$ for the portion of the plume that exceeds the $30-\mu \mathrm{g} / \mathrm{L}$ drinking water standard (Fritz et al. 2007). It is unlikely that uranium flux is evenly distributed throughout this area because of groundwater flow patterns and heterogeneity in permeability of aquifer sediment.

During the initial remedial investigation for the 300 Area, estimates for the current and future flux of uranium from the aquifer to the Columbia River were made (DOE-RL 1994b, pp. 5-18 and 5-19; their Tables 5-3 and 5-4). The estimate for "current” flux (i.e., 1992) was based on a model involving 1) groundwater movement across a vertical plane oriented parallel to the river; 2) uranium concentrations along various segments of that plane, based on the mapped plume; 3) an assumed contaminated thickness of $3 \mathrm{~m}$; and 4) an assumed flow velocity of $3 \mathrm{~m} / \mathrm{d}$. The result suggested a flux of $427 \mathrm{~kg} / \mathrm{yr}$ from the 300 Area aquifer to the Columbia River. A future flux (i.e., 2018) was estimated at $15 \mathrm{~kg} / \mathrm{yr}$, based on the change in groundwater concentrations during the period 1992 to 2018, as predicted by a groundwater flow model. A simple extrapolation of the rate of decrease suggests a flux during 2007 of $\sim 200 \mathrm{~kg} / \mathrm{yr}$.

More recent research involving the 300 Area's hyporheic zone has produced an estimate for water and uranium fluxes at a test site in the 300 Area nearshore region near spring S3-42-2 (Spring 9); see Figure 3.1 for location map. That work suggests an annual average uranium flux of $2.25 \mu \mathrm{g} / \mathrm{min} / \mathrm{m}^{2}$ for recent years (Fritz and Arntzen 2007). If this rate is applied to the $0.17 \mathrm{~km}^{2}$ of riverbed likely to be impacted by discharging groundwater, a total discharge of $\sim 200 \mathrm{~kg} / \mathrm{yr}$ results. This value is very similar to that produced during the initial remedial investigation, although this may be coincidence, given the numerous assumptions and uncertainties inherent in each method for estimating. 


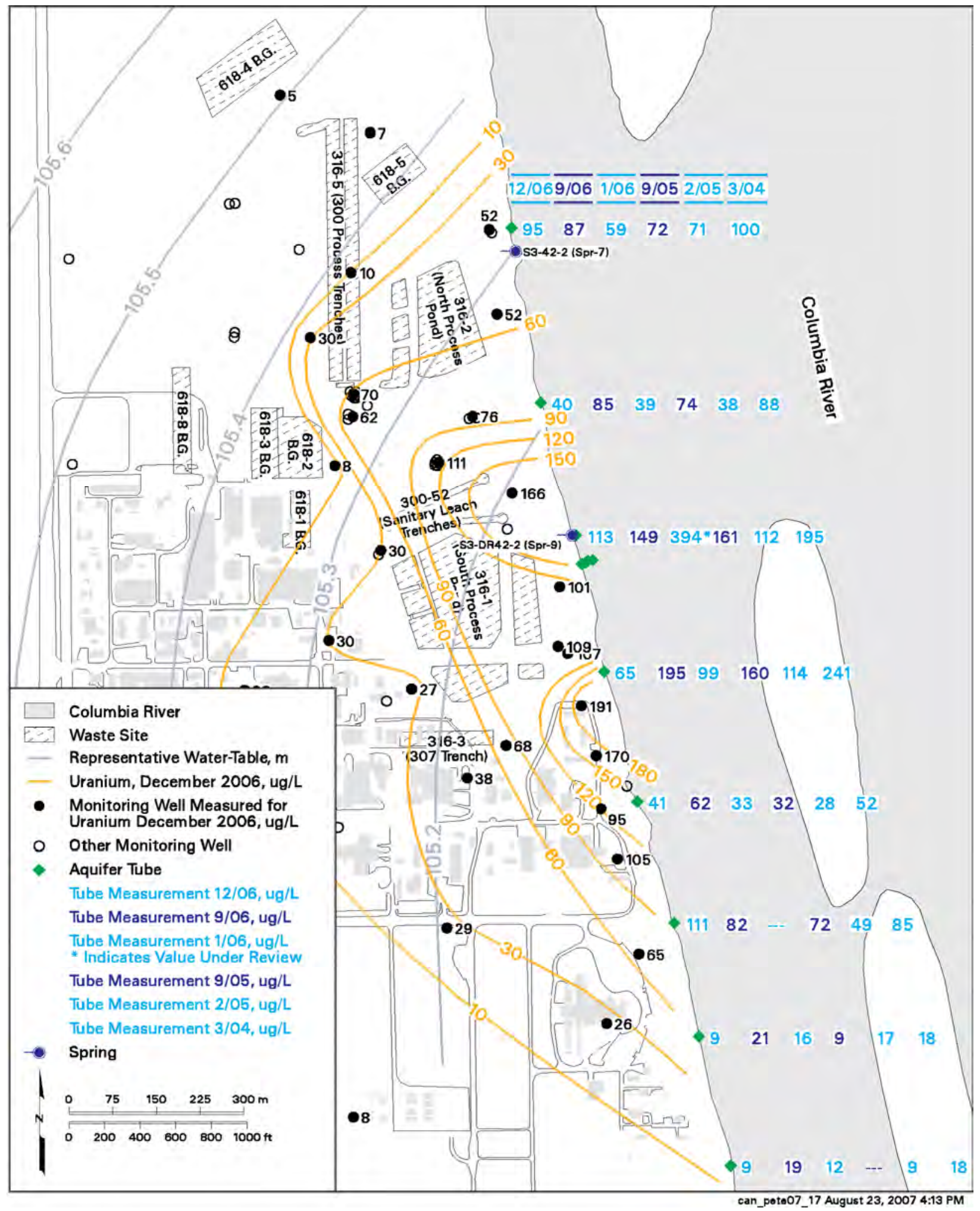

Figure 3.15. Map Showing Maximum Uranium Concentrations Observed at Aquifer Tube Sites 


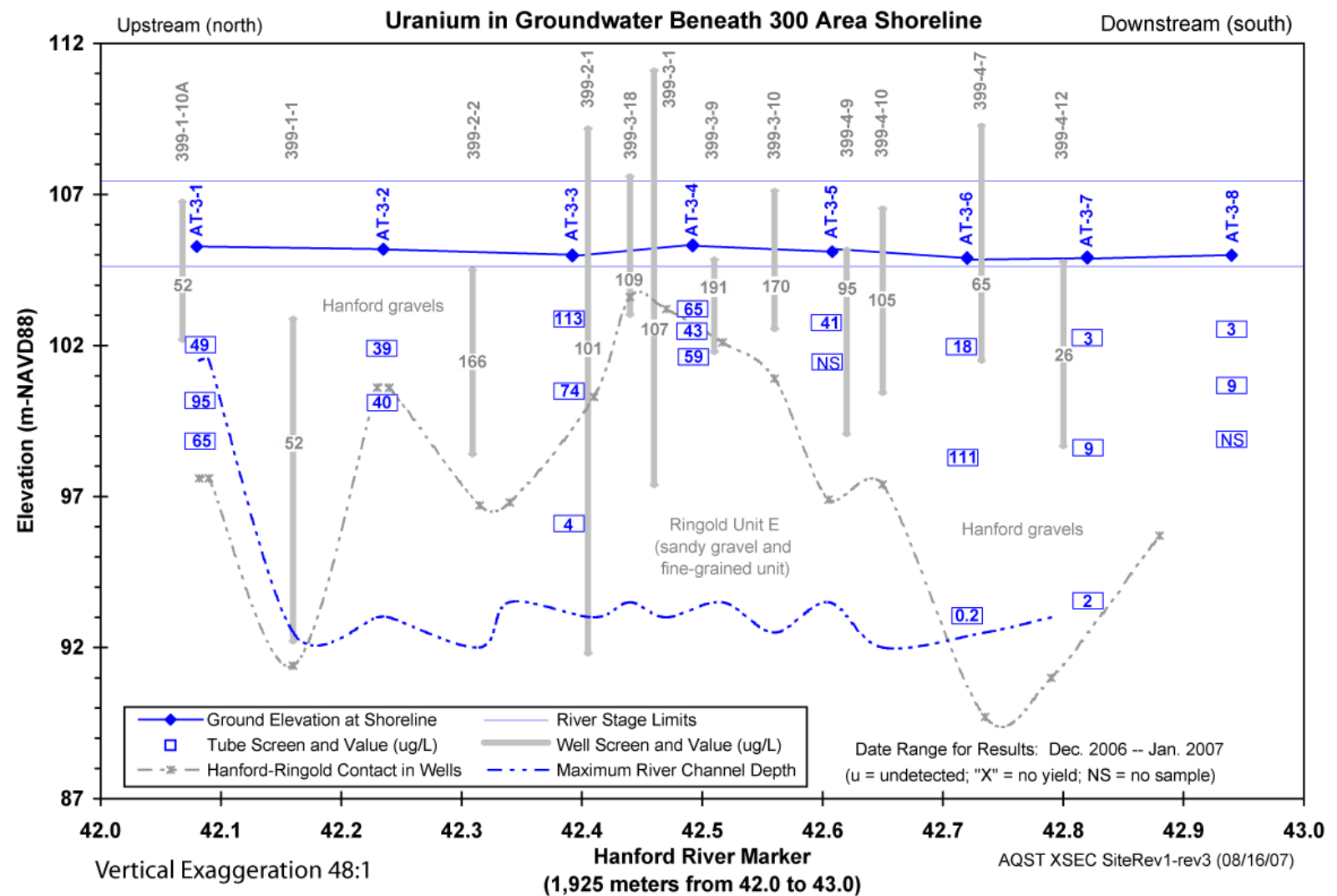

Figure 3.16. Uranium Concentrations for December 2006 Through January 2007 at 300 Area Aquifer Tubes and Wells near the River

\subsection{Uranium in Surface Water at the $\mathbf{3 0 0}$ Area Shoreline}

Riverbank springs and Columbia River water are monitored along the 300 Area shoreline as part of the Surface Environmental Surveillance Project, a component of the DOE's Public Safety and Resource Protection Program (DOE-RL 2000). One objective of this program is to monitor the migration of contaminants of Hanford Site origin to offsite receptors. Under this program, water samples are collected during the late summer/fall months from several riverbank spring locations along the 300 Area. These samples are analyzed for various radiological and chemical contamination indicators for 300 Area groundwater (e.g., uranium, volatile organic compounds). Nearshore river water samples are also obtained annually, with samples collected from water depths of less than $1 \mathrm{~m}$. The detailed schedule for program sampling is provided in an annual report (Bisping 2008).

Results for uranium (and gross alpha) in two prominent 300 Area riverbank springs for the period 2001 to the present are shown in Figure 3.17, which has been adapted from the 2006 Environmental Monitoring report for the Hanford Site (Poston et al. 2007, Section 10.5). Spring “42-2” is located east of the former 300 Area Process Trenches and North Process Pond, and spring "DR 42-2" is located east of the South Process Pond, and approximately 500 m downstream from spring "42-2” (see Figure 3.1 for spring locations). The range in uranium concentrations (i.e., up to $\sim 200 \mu \mathrm{g} / \mathrm{L}$ ) is consistent with values observed in near-river wells and aquifer tubes along the shoreline. Variability in riverbank springs 

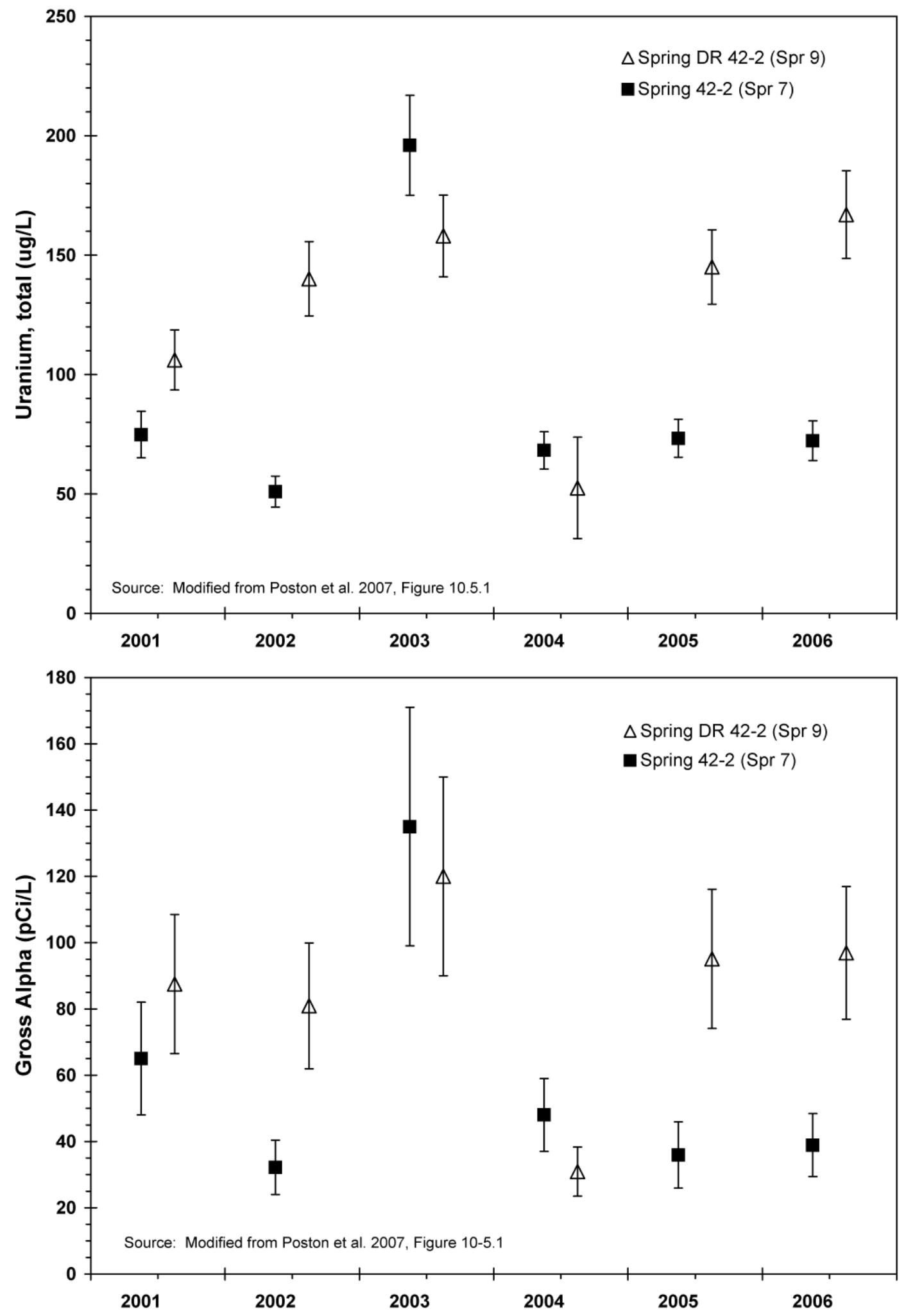

Figure 3.17. Uranium Concentrations in Water from Two Prominent Springs Along the 300 Area Shoreline 
uranium concentrations is caused by variability in the groundwater plume that approaches the shoreline, and by dilution that results from mixing with river water, which infiltrates the riverbank during periods of high river stage (see Section 3.3.2 for further discussion of mixing). The composition of riverbank springs also varies depending on how long a spring has been flowing before a sample is collected. Dilution by river water is greatest when a spring first appears during low river-stage conditions, and the composition becomes more like groundwater with time (Peterson and Johnson 1992).

Uranium concentrations in nearshore Columba River water along the 300 Area are very low relative to those observed in near-river wells, aquifer tubes, and in riverbank springs. The range in concentrations reported for 2006 is 0.37 to $0.49 \mathrm{pCi} / \mathrm{L}$ (approximately 0.52 to $0.69 \mu \mathrm{g} / \mathrm{L}$ ) (Poston et al. 2007, Table C.6), which is well below the EPA drinking water standard. Preliminary results for samples collected in 2007 indicate a similar range in concentrations, with a maximum observed value of $1.7 \mu \mathrm{g} / \mathrm{L}$ near spring "DR-42-2." Note this spring is in the zone where a seasonal high in the groundwater plume reaches the river. Similar low uranium concentrations are observed downstream of the 300 Area near the City of Richland water intake.

Uranium concentrations currently in surface water adjacent to the 300 Area are consistent with those observed during a comprehensive investigation of contamination along the shoreline in 2001 (Patton et al. 2002). That investigation was a joint effort between the Washington State Department of Health and Pacific Northwest National Laboratory, and had as its objective to "identify any contamination present and determine if it could present a risk to humans, and to plant and animal life.” Uranium, and the associated gross alpha, were the only contaminants that exceeded surface water quality criteria in samples of near-river groundwater, riverbank springs, and nearshore river water. Uranium in clam tissue was elevated relative to background levels, but no significant lesions were observed to suggest a detrimental impact. The radiological dose to humans from current-use exposure scenarios in the nearshore area (e.g., fishing and boating) was described as "not expected to be harmful," as was the chemical hazard to humans from uranium contamination. Dose rates estimated for aquatic organisms were "well below" guidelines for protection (DOE Order 5400.1).

\subsection{Uncertainties in Plume Characteristics}

Uncertainty in describing the extent of uranium contamination in the 300 Area unconfined aquifer is introduced by 1) gaps in monitoring well coverage, 2) limited information on the vertical distribution of contamination in the aquifer, and 3) frequency of sampling.

Referring back to Figure 3.1, it can be seen that gaps in monitoring well coverage are present in areas occupied by the two former liquid-waste disposal ponds. Before the remedial actions at these locations, it was not practical to install monitoring wells within these waste sites. With the completion of remedial actions at these sites, access is now possible. Well 399-2-5 was installed during summer 2007 within the footprint of the former South Process Pond as part of an ongoing investigation of volatile organic compounds (Kooiker et al. 2007), and additional wells are planned as part of the DOE's Integrated FieldScale Challenge project (PNNL 2007).

Although improvements in defining the vertical extent of the hydrologic unit containing the plume have been made in recent months as part of the LFI (Williams et al. 2007), the data available to describe the vertical concentration profile for uranium within that unit remain limited. The most direct observations are from aquifer tubes installed at multiple depths along the rivershore (see Figures 3.3 and 
3.16). In the absence of similar observations at inland locations, the assumption has been made that contamination is uniformly distributed vertically through the hydrologic unit and values from existing wells are representative of the concentration.

One outcome of the data quality objectives process that was employed to revise the Operations and Maintenance Plan for 300-FF-5 was the selection of a semi-annual frequency for monitoring the uranium plume (DOE-RL 2002a). The intent was to monitor the plume while the water table was at its seasonal high (usually June), to reveal what were believed to be the highest concentrations, and again in the middle of the seasonal cycle (December), to reveal concentrations representative of long-term average conditions. Subsequent monitoring results and groundwater flow simulations suggest that more frequent monitoring may be warranted in some areas to fully monitor the mechanisms causing changes in concentrations and to possibly identify sources that re-supply the uranium plume in groundwater. 


\subsection{Hydrogeologic Framework}

(P.D. Thorne)

This section describes the sedimentary hydrogeologic units that lie below the surface and above the basalt bedrock at the 300 Area. The hydrogeology of the 300 Area has been investigated and described in previous reports, including Lindberg and Bond (1979), Schalla et al. (1988), Gaylord and Poeter (1991), Swanson et al. (1992), and Peterson et al. (2005). The most recent new information was acquired from four characterization boreholes installed in 2006 as part of a LFI of uranium. These four boreholes were subsequently completed as monitoring wells (Williams et al. 2007).

Characterization activities associated with the boreholes provided new details on the subsurface stratigraphy that led to a revised interpretation of data from previously drilled boreholes and a substantial update of the 300 Area hydrogeologic framework in September 2006. A team of hydrogeologists evaluated, and in some cases, reinterpreted, the available borehole and surface geology data to create the hydrogeologic configuration described in this section. This is an update of the hydrogeologic framework described in Peterson et al. (2005). Nine new boreholes were also drilled in the 300 Area during 2006 to support the polyphosphate treatability test. Information from these boreholes, which are in a relatively small area, has not yet been used to further refine the hydrogeologic framework described in this section.

\subsection{Hydrogeologic Units}

Sedimentary units overlying the basalt bedrock at the 300 Area range in total thickness from 40 to $60 \mathrm{~m}$. The principal units consist of, from lower to upper, the fluvial and lacustrine sediments of the Ringold Formation, the glaciofluvial Hanford formation, and a relatively thin layer of eolian sand and silt at the surface. However, the surface eolian deposits have been removed by excavation over much of the 300 Area, and up to $10 \mathrm{~m}$ of backfill material is found at the surface in some places. The Cold Creek unit, which lies between the Hanford and Ringold formations in other parts of the Hanford Site, is apparently not present beneath the 300 Area. Figure 4.1 shows a schematic representation of the hydrogeologic column at the 300 Area.

In developing a groundwater flow model for the Hanford Site, Cole et al. (2001) delineated hydrogeologic units to reflect differences in hydraulic properties of sediments, such as effective porosity and hydraulic conductivity. These hydrogeologic units generally correspond to geologic units, but sometimes differ when geologic units with similar hydraulic properties are lumped together, or hydrogeologic subunits are delineated based on differences in texture or cementation within a geologic unit. At the 300 Area, the Hanford formation corresponds to model unit 1, and geologic subunits of the Ringold Formation correspond to model units 5, 8, and 9. Model units 2, 3, and 4 defined by Cole et al. (2001) are missing in the vicinity of the 300 Area. Unit 8 is the Lower Ringold Mud, which separates the Ringold sand and gravel of units 5 and 9. The Hanford formation (unit 1), composed predominantly of unconsolidated sand and gravel, is significantly more permeable than the underlying and older Ringold Formation, which includes more compacted and variably cemented fine-grained to gravelly sediment. The principal subunits of the Ringold Formation are described below. 


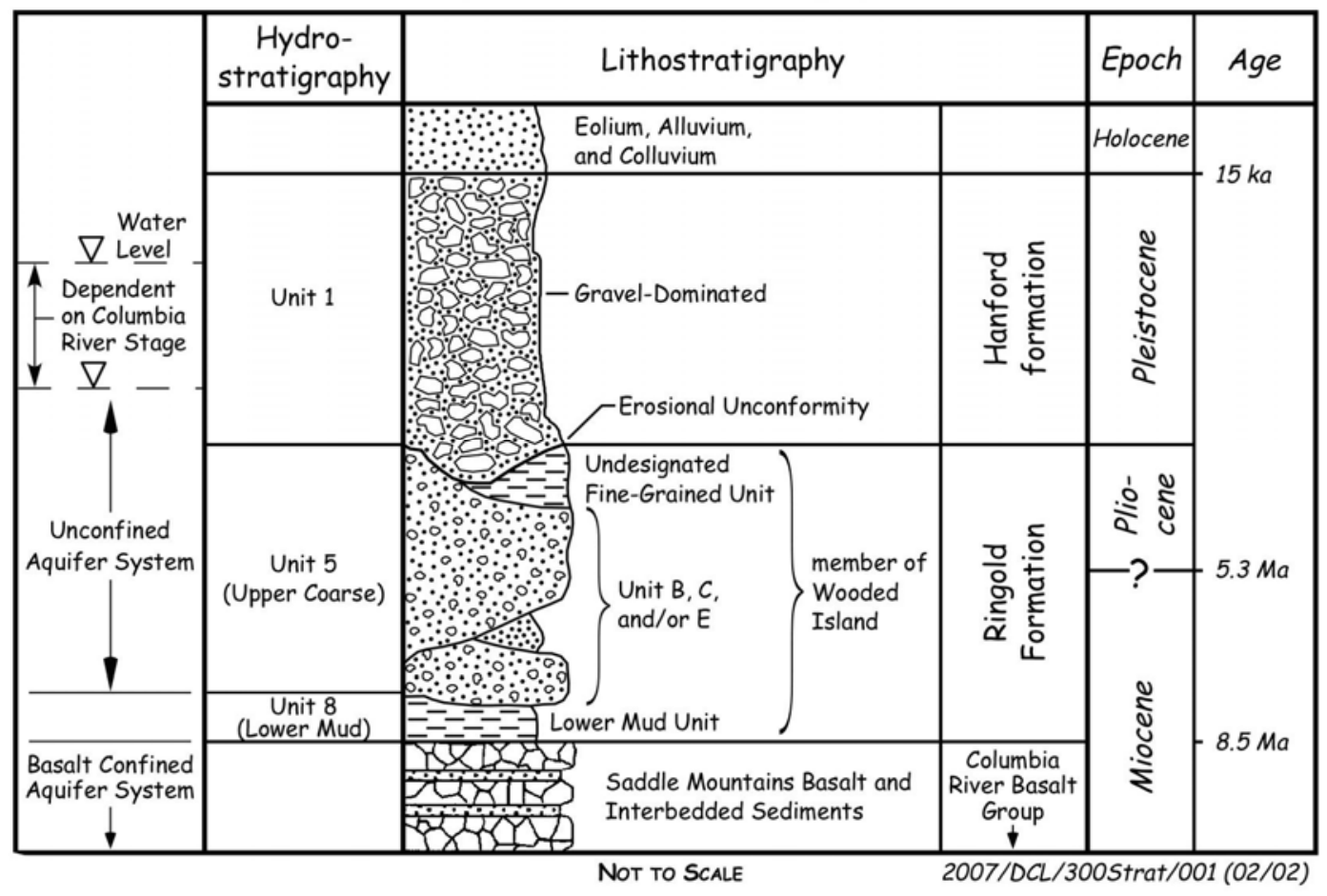

Figure 4.1. Hydrogeologic Stratigraphic Column for the 300 Area (modified from Reidel et al. [1992], Lindsey [1995], Williams et al. [2000], and DOE [2002b])

\subsubsection{Ringold Formation}

The Ringold Formation was deposited on top of the basalt by the ancestral Columbia River and its tributaries. The Columbia River eventually began to erode, rather than deposit, sediments in the Pasco Basin because the basalts and overlying sediments were uplifted. As a result, the upper portion of the Ringold Formation was eroded from the 300 Area.

Lindsey (1995) defined three informal members of the Ringold Formation based on dominant sediment facies types. Only the lowermost "member of Wooded Island" exists at the 300 Area. The overlying Ringold sediments were removed by erosion. The member of Wooded Island is divided into five gravel-dominated units (A, B, C, D, and E) separated by mud-dominated overbank and lacustrine deposits (Lindsey 1995).

The lowermost Ringold unit A sand and gravel (model unit 9) is discontinuous beneath the 300 Area. The Ringold lower mud unit (model unit 8), a relatively thick and continuous lacustrine mud comprised of silty clay to silty sand, forms a confining aquitard above the unit A gravel or lies directly on top of basalt where unit A is missing. Figure 4.2(a) shows a core sample of the Ringold lower mud from one of the recent characterization boreholes (399-3-18). Above the lower mud (model unit 8) are the combined Ringold units $\mathrm{B}$ and $\mathrm{C} / \mathrm{E}$ sand and gravel, which are indistinguishable except on the western side of the 300 Area, where they are separated by a discontinuous Ringold overbank deposit. Figure 4.2(b) shows a core sample of the Ringold C/E unit from borehole 399-3-18. For the current 300 Area groundwater model, the discontinuous overbank deposits have been combined with the gravel and sand Ringold sediments above the lower Ringold mud and designated as model unit 5. 


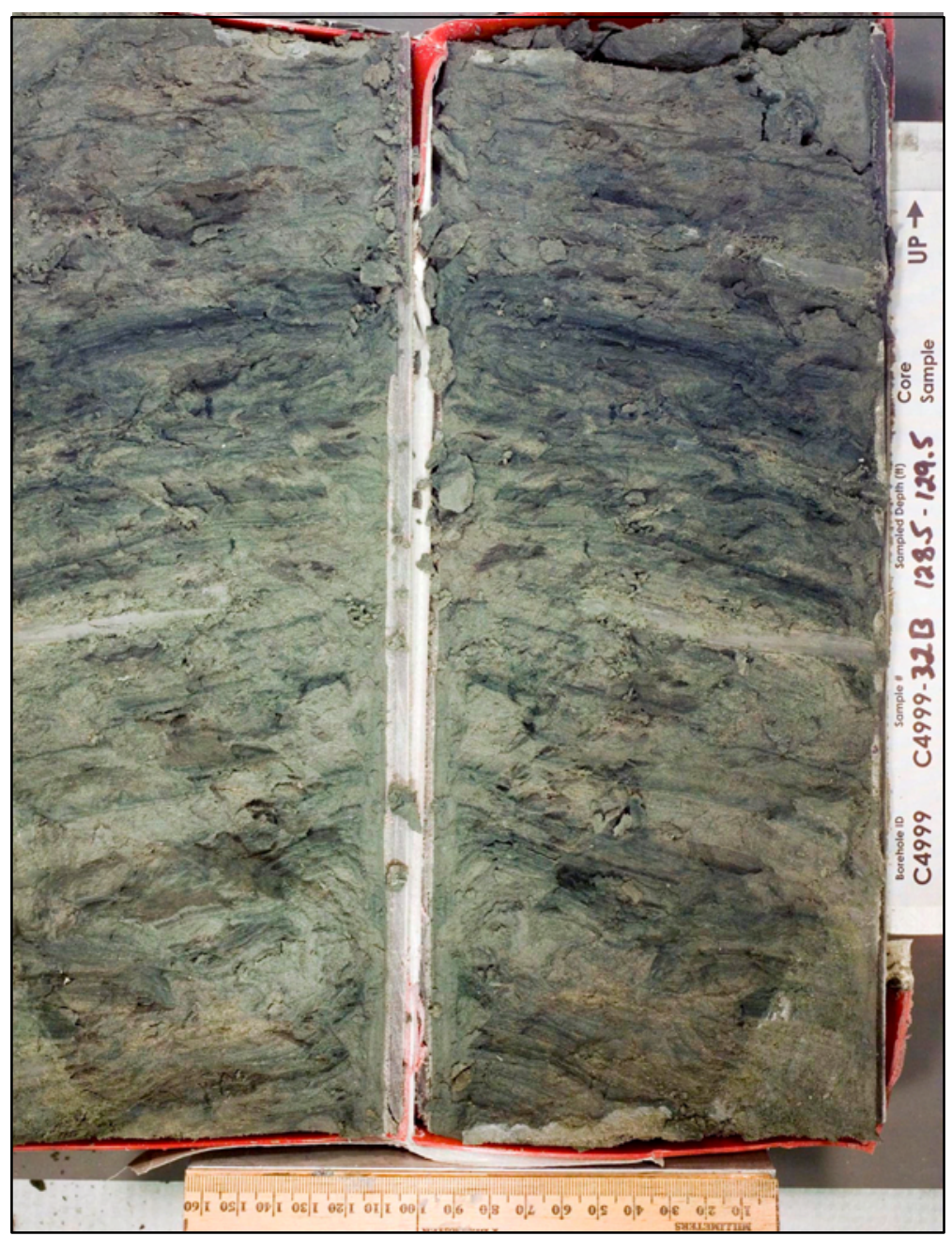

a) Ringold Lower Mud Unit

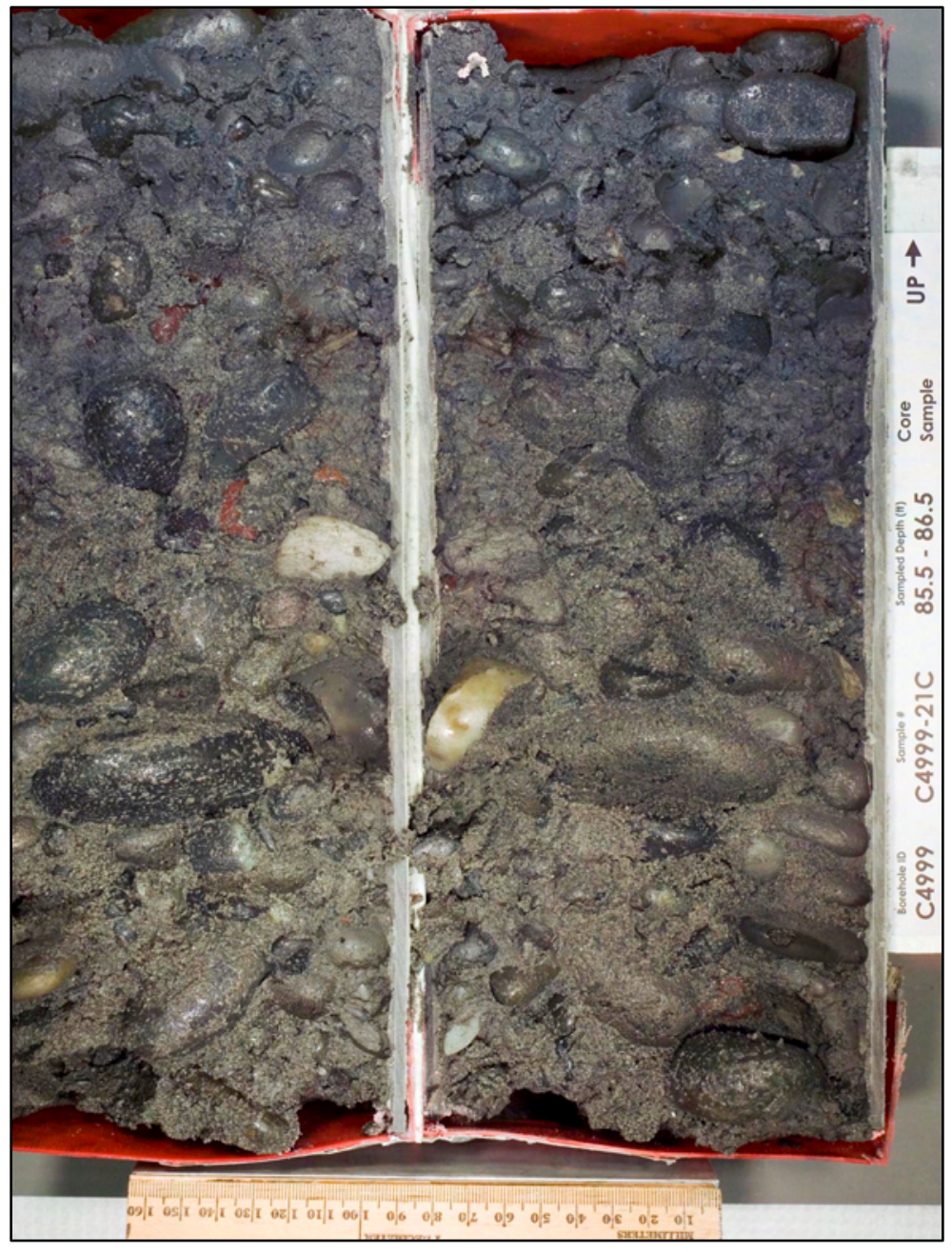

b) Ringold Unit E/C Sand and Gravel

Figure 4.2. Photos of Core Samples from the 2006 Characterization Borehole 399-3-18 


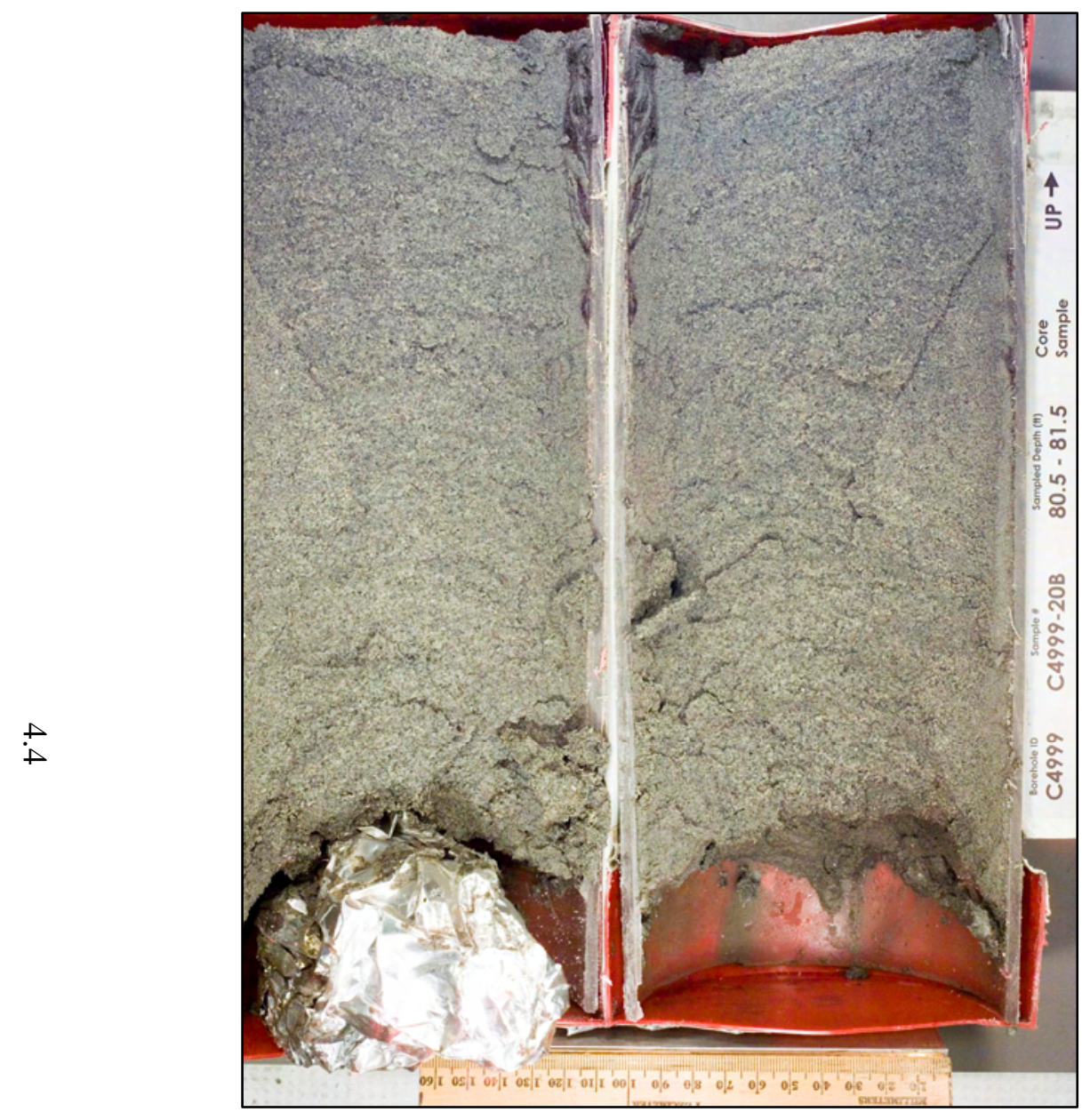

c) Fine-Grained Subunit of the Ringold E/C

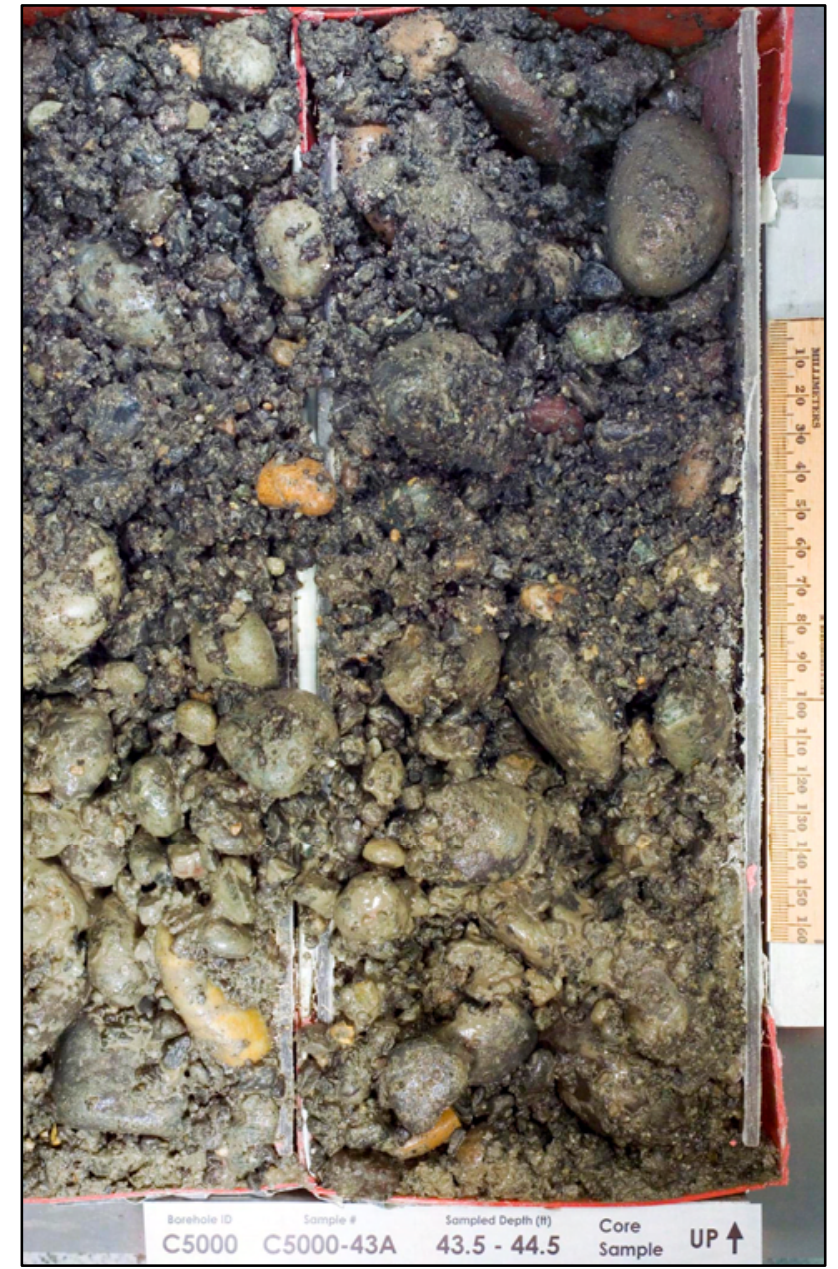

d) Hanford Formation Sand and Gravel

Figure 4.2. Photos of Core Samples from the 2006 Characterization Borehole 399-3-18 (contd) 
A previously undesignated fine-grained subunit has been identified in several boreholes at the top of the Ringold gravel and sand sequence. This subunit is composed of low permeability silty sand to sandy sediment. It was identified at three of the four new boreholes described in Williams et al. (2007), indicating that it is more continuous than previously thought. The silty-sand subunit is relatively consolidated and is characterized by alternating layers of oxidized and reduced fine-grained sediment. Figure 4.2(c) shows a core sample of the Ringold fine-grained subunit from borehole 399-3-18. Although it has primarily been found near the top of the Ringold sequence in the 300 Area, boreholes in other areas indicate that the subunit may sometimes be overlain by more typical Ringold sand and gravel. The distribution of the fine-grained Ringold subunit is discussed in more detail in Section 4.2.

\subsubsection{Hanford Formation}

The informally named Hanford formation was deposited by cataclysmic glacial floods that inundated the Pasco Basin a number of times during the Pleistocene, from about 1 million to about 13,000 years ago (DOE 2002b). The floods caused massive erosion of older sediments and the basalt bedrock and resulted in deposition of sediments in low-lying areas.

The Hanford formation has been divided into three major facies: 1) gravel-dominated, 2) sanddominated, and 3) silt-dominated. These facies generally correspond to coarse gravels, laminated sands, and graded rhythmites, respectively (DOE 2002b). Gravel-dominated strata consist of coarse-grained sand and granule-to-boulder sized, clast-supported gravel. The gravels can have an open matrix structure with large pore spaces and very high permeability. The sand-dominated facies consists of fine- to coarsegrained sand. Small pebbles and pebbly interbeds ( $<20 \mathrm{~cm}$ [8 in.] thick) may be encountered. The siltdominated facies consists of silt and fine- to coarse-grained sand forming normally graded rhythmites. Plane lamination and ripple cross-lamination is common in outcrops in these facies. Hanford formation sediments tend to have a large proportion of basaltic fragments because of the upstream erosion of basalt bedrock in the channeled scablands.

At the 300 Area, the Hanford formation is up to approximately $30 \mathrm{~m}$ thick and is composed primarily of the gravel-dominated and sand-dominated facies. The Hanford formation sediments are much more permeable than the Ringold sediments and tend to dominate groundwater flow in the vicinity of the 300 Area because of their coarse texture and lack of consolidation/cementation.

Williams et al. (2007) described Hanford formation sediments encountered at the four new LFI boreholes as unconsolidated boulder-to-pebble gravel with coarse-to-fine sand and minor amounts of silt. Figure 4.2(d) shows a Hanford formation core sample from borehole 399-3-18. Most often, Hanford formation sediments exhibit a clast-support structure with a matrix of poorly sorted sand and silt. Occasionally, the matrix is missing, which produces an open framework with large pores between the clasts. Reworked Ringold Formation sediment, which was eroded by the Pleistocene cataclysmic floods and redeposited, has been found within the Hanford formation during pit excavations at the 300 Area (Bjornstad 2004). These Ringold Formation sediments sometimes include reworked Ringold Formation mud either as rounded clasts up to $1 \mathrm{~m}$ in diameter or as a localized mud matrix deposited along with the Hanford formation cataclysmic flood gravel. Figure 4.3 is a photo of a Ringold mud clast dug from a pit in the Hanford gravel and sand formation. The mud clasts were eroded from upstream Ringold deposits that are similar to those exposed across the Columbia River from the 300 Area. These reworked Ringold Formation sediments, randomly deposited within the Hanford formation, may create localized zones of lower permeability that affect water movement through the vadose zone and the aquifer. 


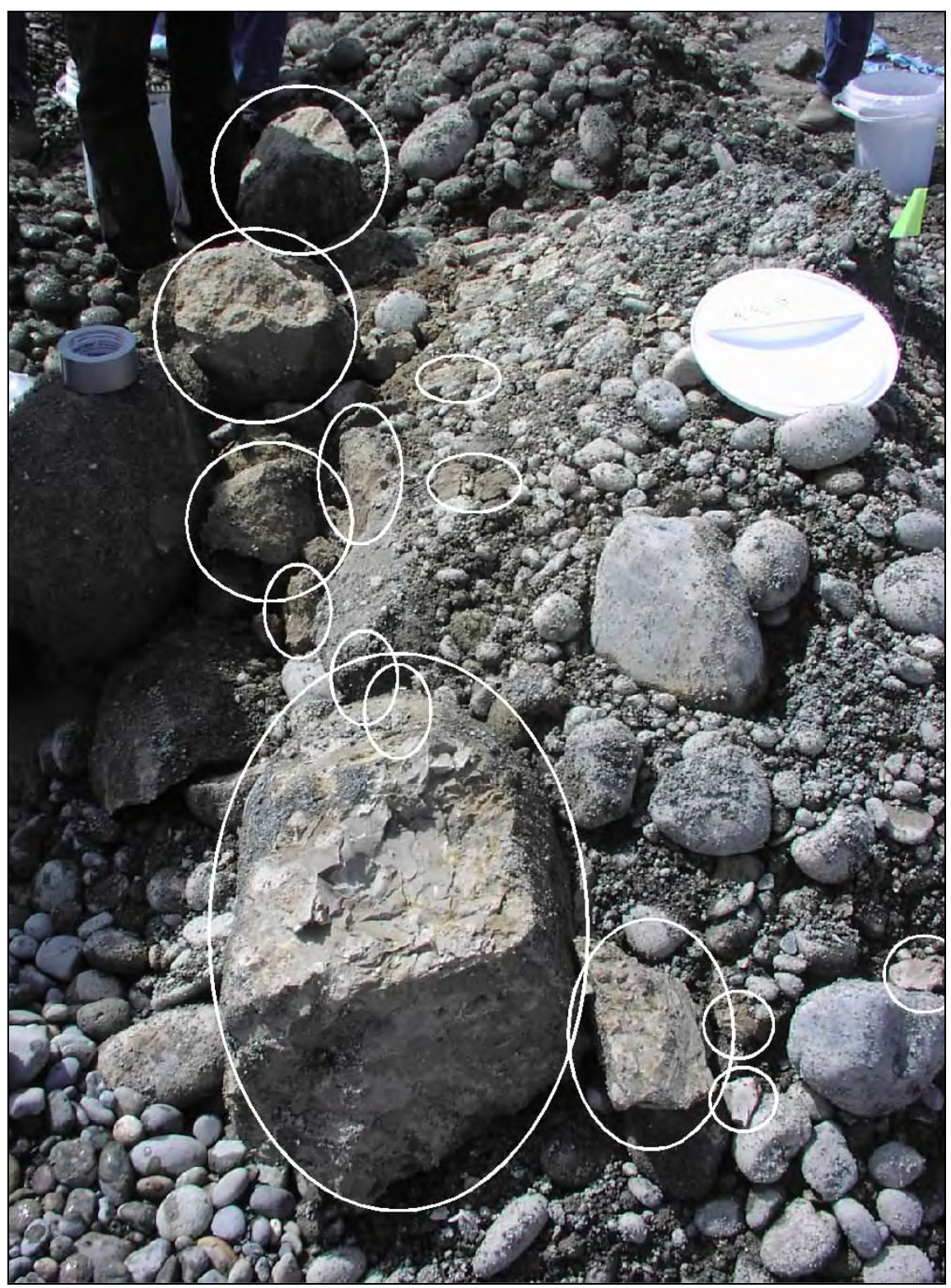

Figure 4.3. Ringold Mud Clasts Found Within the Hanford Formation Gravel and Sand at a Pit Excavated in the South Process Pond (Bjornstad 2004)

\subsubsection{Recent Eolian Deposits and Backfill}

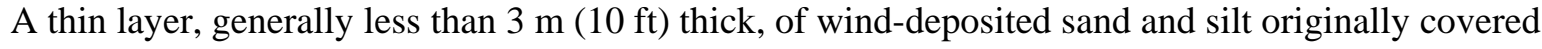
the Hanford formation in the vicinity of the 300 Area. However, much of this material has been removed by excavation. In some places, up to $6 \mathrm{~m}(20 \mathrm{ft})$ of backfill material is found at the surface. The backfill is composed of reworked sand and gravel from Hanford formation or eolian deposits, or of coal-plant ash in the area where power-plant waste was dumped. 


\subsection{Revision of Hanford/Ringold Contact Surface}

A revised interpretation of the geometry of the contact surface between the Hanford and Ringold formations was completed in September 2006. This reinterpretation was based on recent information acquired from four characterization boreholes drilled as part of a LFI of uranium in 2006 (Williams et al. 2007). Data from continuous core samples and characterization activities associated with the four new boreholes provided new details on the subsurface stratigraphy that led to a revised interpretation of data from previously drilled boreholes and a substantial update of the 300 Area hydrogeologic framework. The characterization information from the limited field-investigation boreholes included sediment sample analyses, spectral gamma logging, neutron moisture logging, and depth-discreet slug testing to estimate hydraulic conductivity. Comparing the correspondence between gamma logs and lithologic interpretations from the LFI boreholes with the gamma logs from older boreholes helped in reinterpreting the Hanford/Ringold contact at the older boreholes. In addition to revising the Hanford/Ringold contact surface, a discontinuous finer-grained subunit of the Ringold C/E gravel was delineated at the top of the Ringold Formation.

The process for developing the revised Hanford/Ringold contact consisted of the following steps:

- A hydrogeologist identified Hanford/Ringold contact elevations and the thickness of the fine-grained Ringold subunit in the four limited field-investigation boreholes.

- A team of hydrogeologists evaluated and, in some cases, re-interpreted the available information from other boreholes to determine the Ringold contact elevation and the thickness of the fine-grained Ringold subunit at each borehole location.

- A hand-drawn contour map of the Hanford/Ringold contact surface was created based on the selected borehole contact elevations and knowledge of the depositional and erosional history of the site.

- The borehole elevations and hand-drawn contours were used to create a digital grid of the contact surface in the EarthVision ${ }^{\mathrm{TM}}$ software.

- The thickness data from borehole interpretations for the fine-grained Ringold subunit were used with information on where the unit was missing to create a thickness grid for this subunit.

The revised hydrogeologic configuration described in this report is an update of the hydrogeologic framework described in Peterson et al. (2005). Table 4.1 lists the elevation picks for the Hanford/Ringold contact and the thickness and bottom elevation for the fine-grained Ringold subunit. There were additional boreholes where the fine-grained subunit was known to be missing. Figure 4.4 is a contour map of the top of the Ringold Formation elevation. The contours on this map match those in the handdrawn contour map for this surface. The borehole elevation picks used in defining this surface are also plotted on the map.

Five cross sections have been prepared to illustrate the relative positions and thicknesses of these principal hydrogeologic units (Figures 4.5 shows the locations of the cross sections, which follow as Figures 4.6, 4.7, 4.8, 4.9, and 4.10). Nearby monitoring wells are also shown on the cross sections. The total drilled depth of the wells is indicated by a vertical line and the position of screened or perforated open intervals is represented by a series of horizontal lines. 
Table 4.1. Elevation Picks for Top of Ringold and Fine-Grained Subunit

\begin{tabular}{|c|c|c|c|c|c|}
\hline Borehole & $\begin{array}{c}\text { Ground } \\
\text { Surface } \\
\text { Elevation (m) } \\
\end{array}$ & 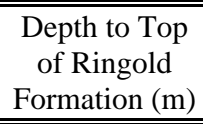 & $\begin{array}{c}\text { Elevation Top of } \\
\text { Ringold } \\
\text { Formation }(\mathrm{m}) \\
\end{array}$ & $\begin{array}{c}\text { Thickness of Fine- } \\
\text { Grained Subunit of } \\
\text { Ringold Formation (m) }\end{array}$ & $\begin{array}{c}\text { Elevation Top of } \\
\text { Ringold Formation } \\
\text { Sand and Gravel (m) }\end{array}$ \\
\hline 399-1-10B & 114.5 & 16.9 & 97.6 & 0 & 97.6 \\
\hline 399-1-11 & 115.7 & 13.1 & 102.6 & Unknown & -- \\
\hline 399-1-13A & 118.6 & 15.2 & 103.4 & Unknown & -- \\
\hline 399-1-14A & 117.0 & 13.8 & 103.2 & Unknown & -- \\
\hline 399-1-15 & 116.2 & 13.4 & 102.8 & $>1.2$ & $<101.6$ \\
\hline 399-1-17C & 115.5 & 15.2 & 100.3 & 0 & 100.3 \\
\hline 399-1-18C & 118.5 & 15.5 & 103 & 0 & 103 \\
\hline 399-1-2 & 118.2 & 19.2 & 99 & 0 & 99 \\
\hline 399-1-20 & 117.8 & 15.2 & 102.6 & Unknown & -- \\
\hline 399-1-21B & 117.0 & 20.9 & 96.1 & 6.1 & 90 \\
\hline $399-1-23$ & 115.47 & 15.1 & 100.4 & 0 & 100.4 \\
\hline 399-1-4 & 116.6 & 13.4 & 103.2 & 0 & 103.2 \\
\hline 399-1-6 & 114.2 & 12.8 & 101.4 & $>0.6$ & $<100.8$ \\
\hline $399-2-1$ & 114.7 & 14.4 & 100.3 & 1.5 & 98.8 \\
\hline $399-2-3$ & 115.1 & 18.3 & 96.8 & $>1.5$ & $<95.3$ \\
\hline 399-3-1 & 117.5 & 14.3 & 103.2 & 7 & 96.2 \\
\hline 399-3-10 & 117.7 & 16.8 & 100.9 & $>3.7$ & $<97.2$ \\
\hline 399-3-12 & 118.5 & 19.5 & 99 & $>0.3$ & $<98.7$ \\
\hline 399-3-18 & 117.68 & 14.1 & 103.6 & 10.7 & 92.9 \\
\hline 399-3-19 & 120.65 & 25.3 & 95.4 & $>0.6$ & $<94.8$ \\
\hline 399-3-20 & 120.45 & 24.7 & 95.8 & $>4$ & $<91.8$ \\
\hline 399-3-9 & 118.6 & 16.5 & 102.1 & $>4.6$ & $<97.5$ \\
\hline $399-4-1$ & 120.8 & 25.6 & 95.2 & 1.5 & 93.7 \\
\hline 399-4-11 & 123.8 & 26.5 & 97.3 & Unknown & -- \\
\hline 399-4-5 & 123.6 & 25.9 & 97.7 & 0.9 & 96.8 \\
\hline $399-4-7$ & 115.7 & 26.0 & 89.7 & 0 & 89.7 \\
\hline 399-5-1 & 121.0 & 18.9 & 102.1 & 3.7 & 98.4 \\
\hline $399-5-2$ & 119.7 & 14.6 & 105.1 & 0 & 105.1 \\
\hline $399-6-1$ & 118.8 & 17.1 & 101.7 & 0 & 101.7 \\
\hline 399-8-1 & 121.0 & 20.7 & 100.3 & 3 & 97.3 \\
\hline 399-8-2 & 121.6 & 21.4 & 100.2 & 8.8 & 91.4 \\
\hline $399-8-3$ & 120.6 & 18.0 & 102.6 & $<9.8$ & $<92.8$ \\
\hline 399-8-5C & 122.2 & 22.4 & 99.8 & 7 & 92.8 \\
\hline 699-S11-E12A & 111.7 & 18.3 & 93.4 & Unknown & -- \\
\hline 699-S11-E12B & 112.3 & 16.8 & 95.5 & Unknown & -- \\
\hline 699-S12-3 & 133.3 & 13.4 & 119.9 & 0 & 119.9 \\
\hline 699-S18-E2A & 133.0 & 22.8 & 110.2 & 0 & 110.2 \\
\hline 699-S19-E13 & 120.3 & 23.1 & 97.2 & 0 & 97.2 \\
\hline 699-S20-E10 & 119.7 & 14.4 & 105.3 & 0 & 105.3 \\
\hline 699-S22-E9C & 114.1 & 7.3 & 106.8 & Unknown & -- \\
\hline 699-S27-E14 & 122.7 & 21.4 & 101.3 & Unknown & 101.3 \\
\hline 699-S27-E9C & 119.3 & 8.9 & 110.4 & 0 & 110.4 \\
\hline 699-S29-E12 & 118.5 & 13.8 & 104.7 & Unknown & -- \\
\hline 699-S29-E16C & 115.9 & 16.4 & 99.5 & 0 & 99.5 \\
\hline 699-S30-E15A & 122.4 & 19.8 & 102.6 & Unknown & -- \\
\hline
\end{tabular}




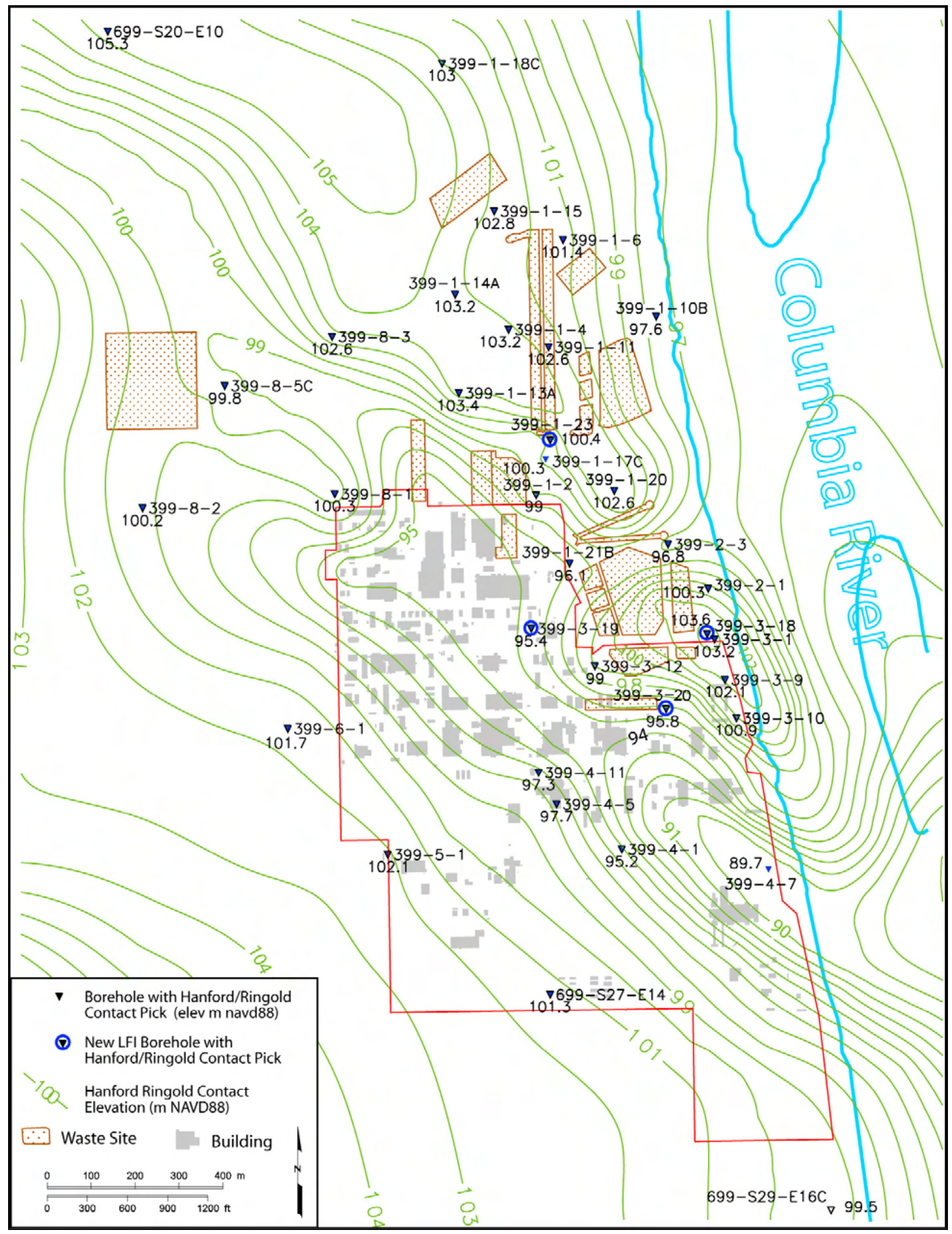

Figure 4.4. Contour Map of Contact Elevation Between the Ringold and Overlying Hanford Formations 


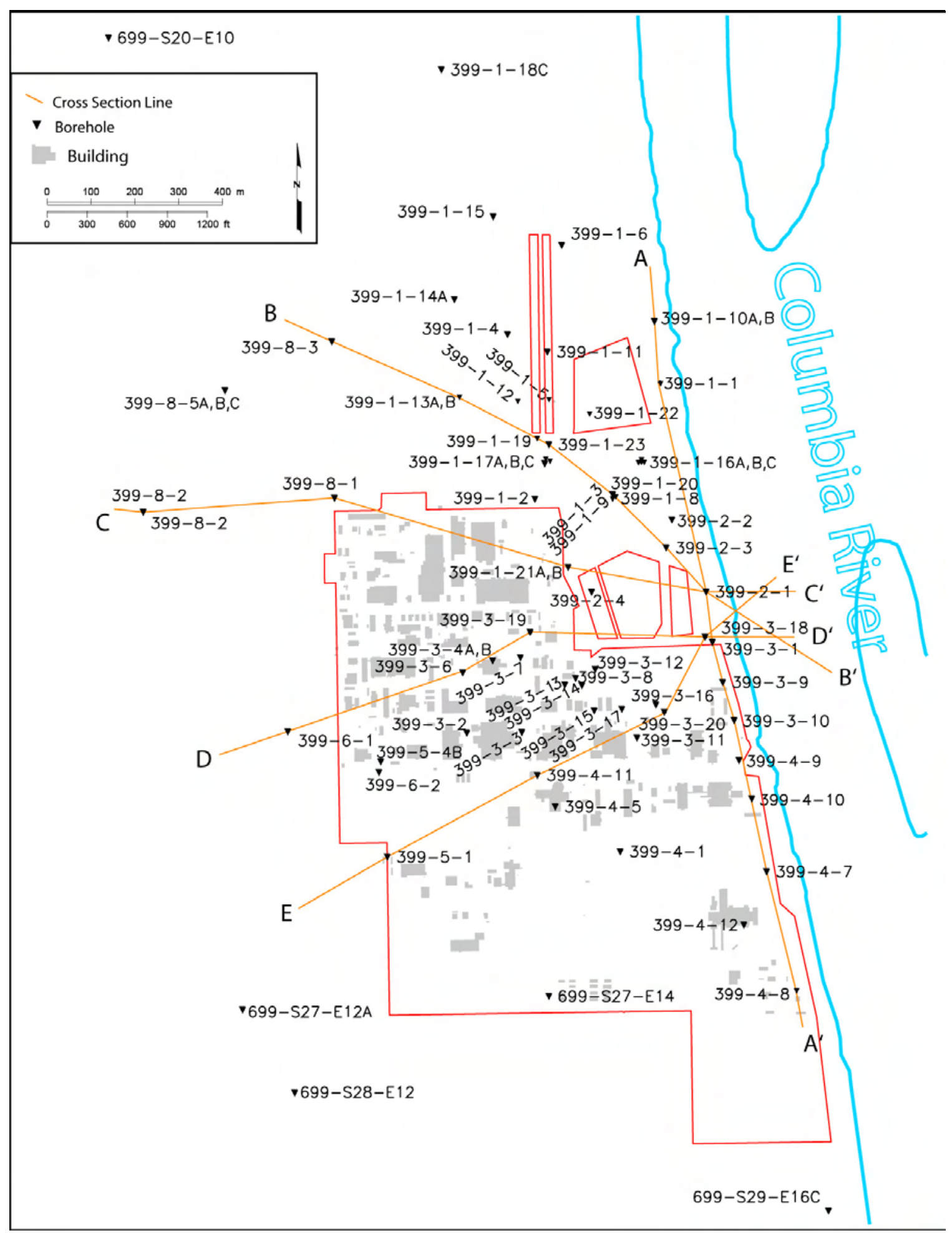

Figure 4.5. Map Showing Locations of Cross Sections 


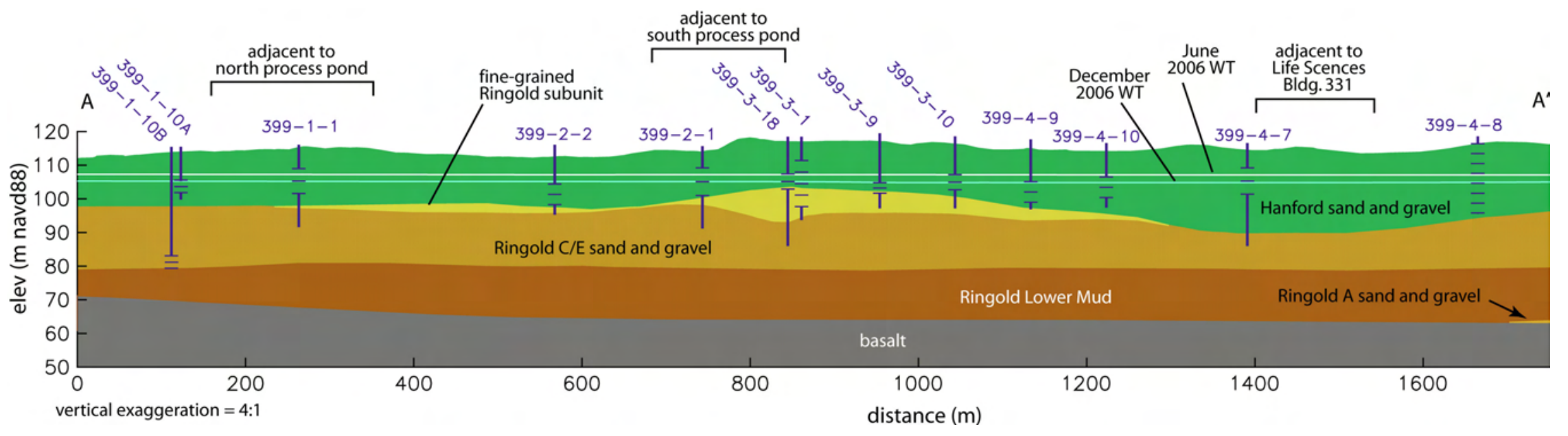

Figure 4.6. Cross Section A-A’ Showing Hydrogeologic Units and Seasonal Water Table Elevations at the 300 Area

$\stackrel{p}{\rightleftarrows}$

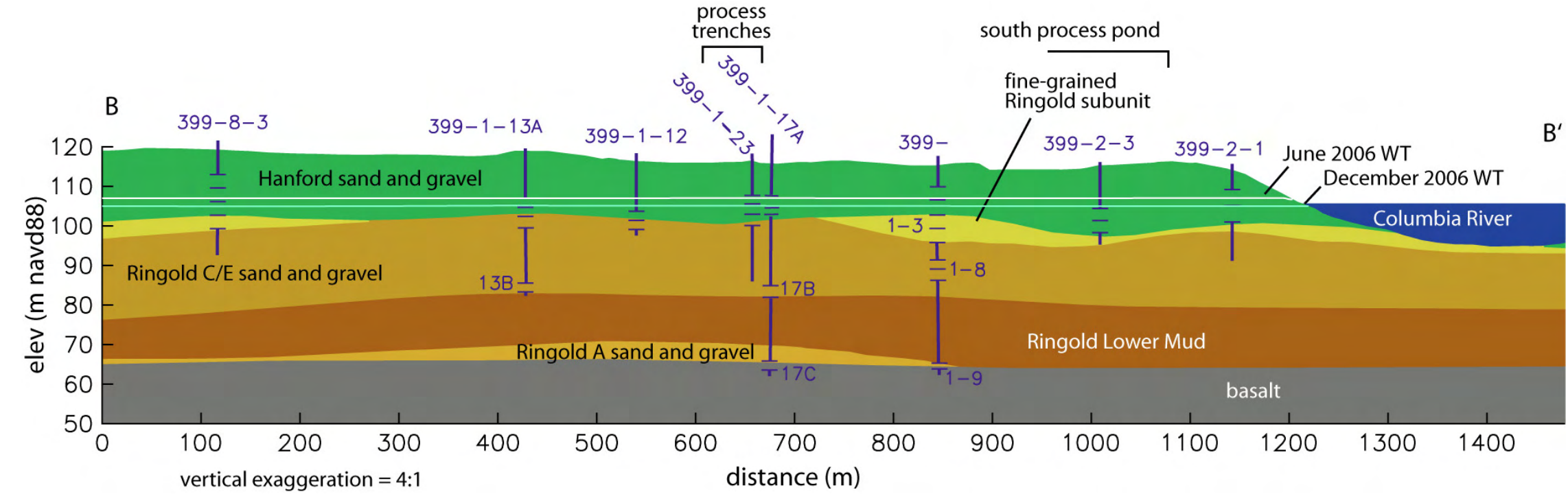

Figure 4.7. Cross Section B-B' Showing Hydrogeologic Units and Seasonal Water Table Elevations at the 300 Area 


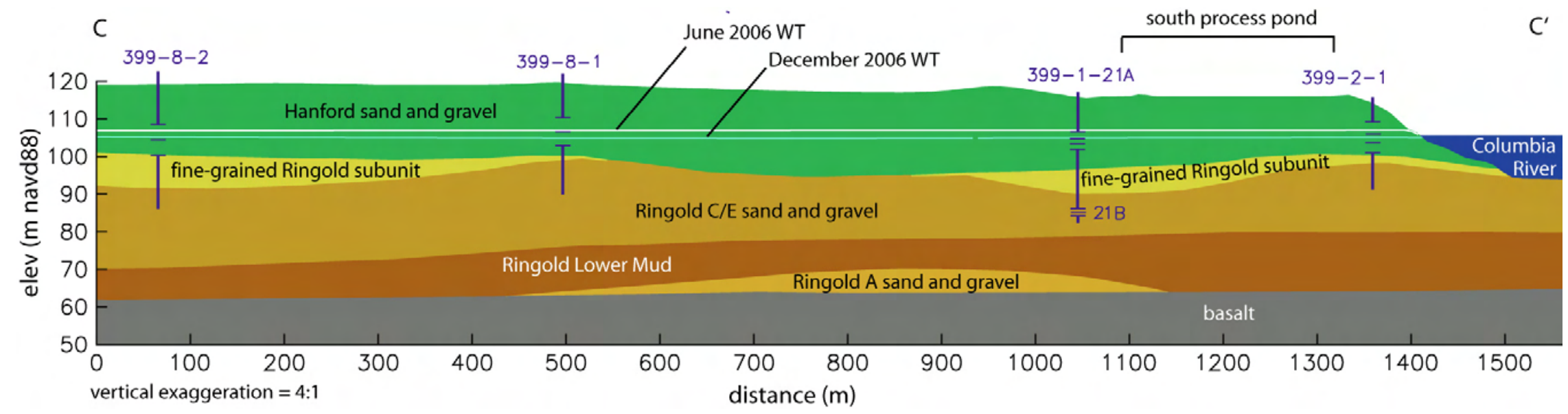

Figure 4.8. Cross Section C-C’ Showing Hydrogeologic Units and Seasonal Water Table Elevations at the 300 Area

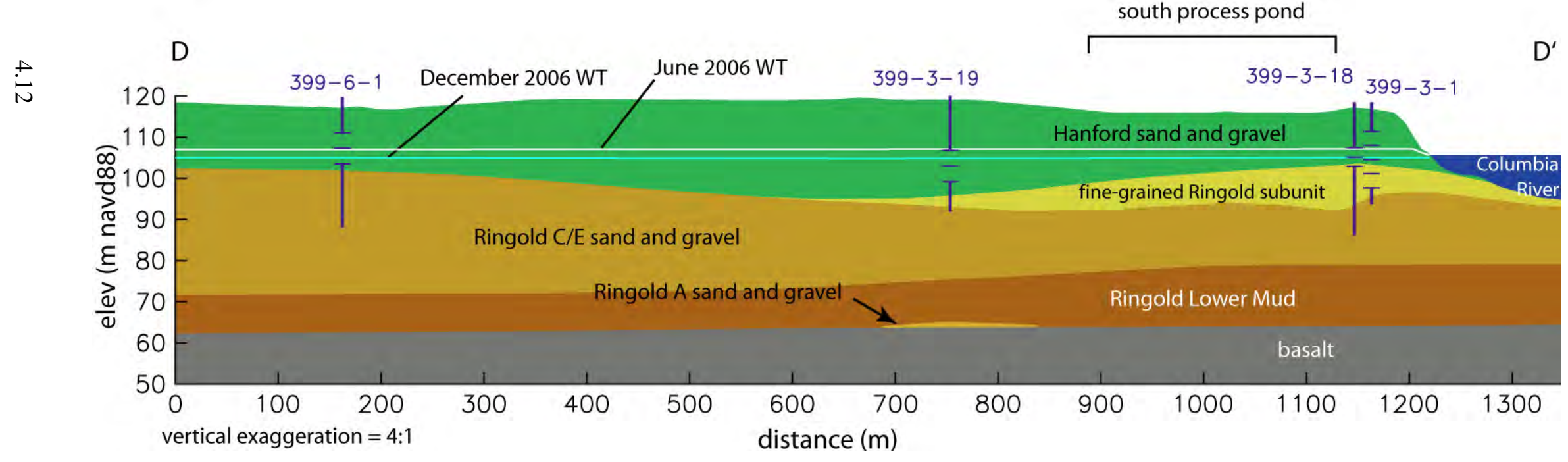

Figure 4.9. Cross Section D-D’ Showing Hydrogeologic Units and Seasonal Water Table Elevations at the 300 Area 


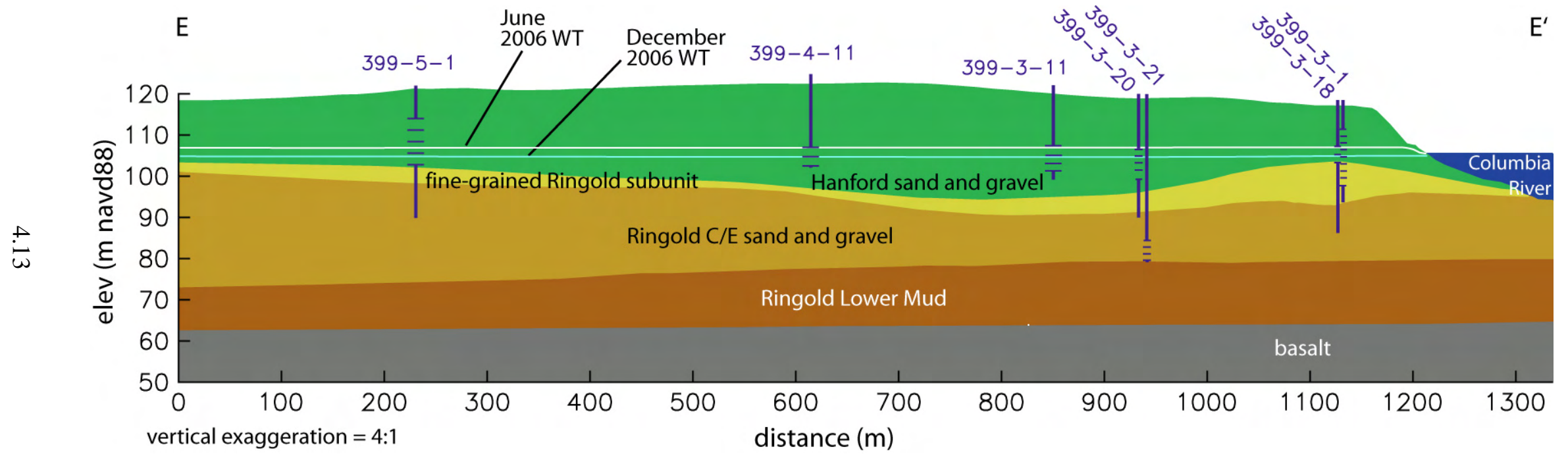

Figure 4.10. Cross Section E-E' Showing Hydrogeologic Units and Seasonal Water Table Elevations at the 300 Area 
Cross section A-A' (Figure 4.6) was drawn parallel to the Columbia River along the shoreline and is used to illustrate the variable saturated thickness of the Hanford formation near the river. The greatest exchange between river water and groundwater occurs in the thicker regions. Cross section B-B' (Figure 4.7) was oriented to show conditions along the presumed plume pathway from a known source for uranium contamination, i.e., the former 300 Area Process Trenches. The preponderance of contaminant uranium resides in groundwater associated with saturated Hanford formation sediment. Cross sections C-C', D-D', and E-E' (Figures 4.8, 4.9, and 4.10, respectively) all cross an erosional paleochannel feature that creates a low in the surface of the Ringold Formation before crossing a higher elevation remnant of Ringold sediment near the Columbia River. The paleochannel is filled with the more recent Hanford sediment and provides a preferential pathway for groundwater movement because of greater transmissivity.

The fine-grained subunit of the Ringold Formation lies at the top of the Ringold Unit C/E sand and gravel. Figure 4.11 shows a three-dimensional view of the top of the Ringold surface, with the finegrained subunit shown in a lighter color. Blue squares indicate the points where the top of the finegrained subunit was identified at a borehole. Boreholes where the fine-grained subunit appears to be missing are shown as a red vertical line. There is uncertainty in the extent of the fine-grained unit because information from many of the older boreholes is too limited to reveal its presence. At some boreholes, the subunit may have been missed because sediment samples were only collected every $1.5 \mathrm{~m}$ ( $5 \mathrm{ft}$ ). It also may be difficult to recognize the fine-grained unit in cuttings from boreholes drilled with cable tools.

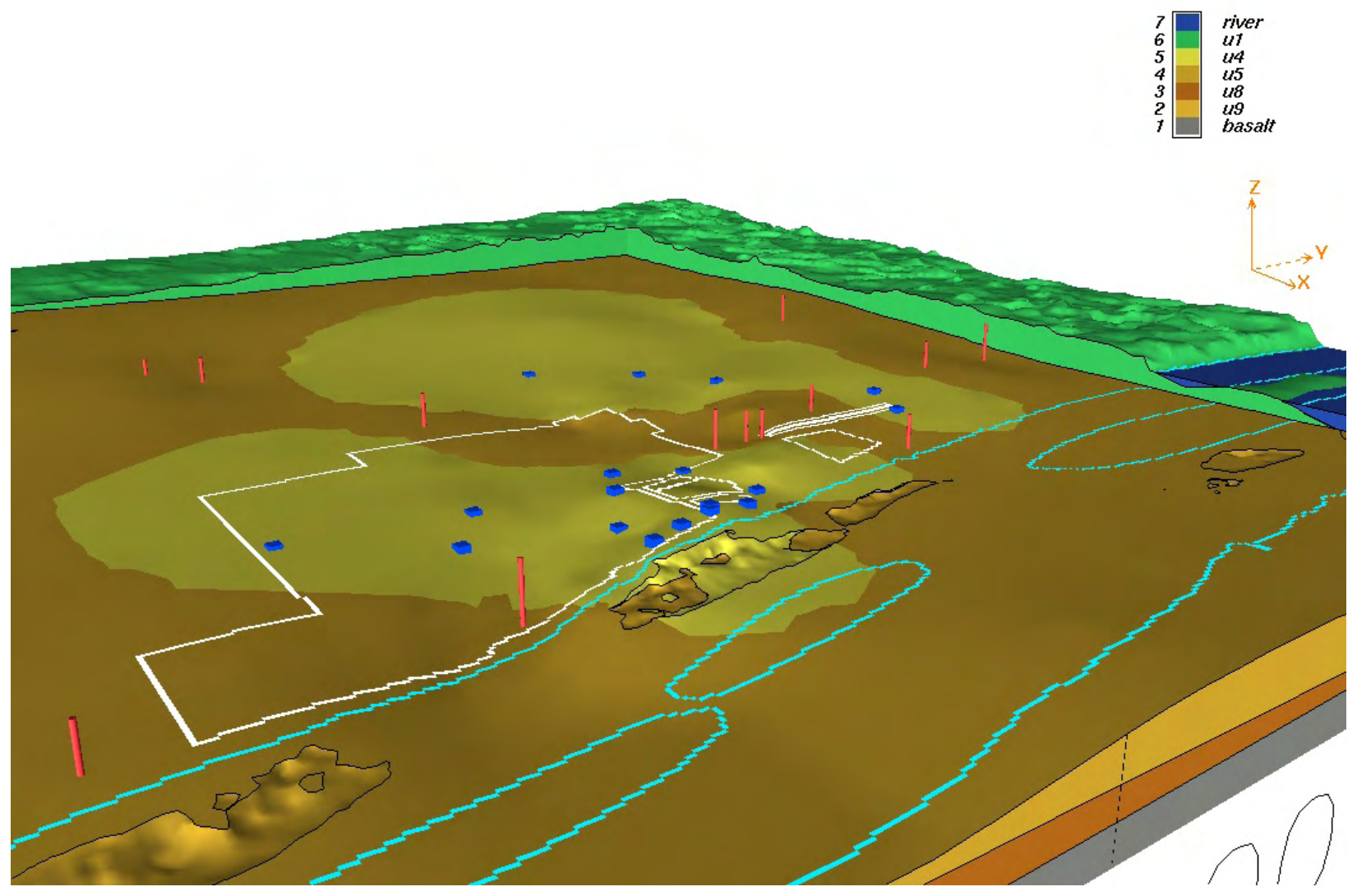

Figure 4.11. Three-Dimensional View of the Top of the Ringold Formation Showing Boreholes Defining the Fine-Grained Subunit 


\subsection{Vadose Zone}

The thickness of the vadose zone varies as the water table moves up and down in response to changes in the Columbia River stage. However, the water table is usually within the Hanford formation throughout most of the 300 Area. Therefore, the vadose zone is dominated by Hanford formation sand and gravel, recent eolian silt and sand, and, in some places, backfill. The backfill usually consists of reworked sand and gravel from the Hanford formation, or of coal-plant ash in the area where power plant waste was dumped.

\subsection{Aquifers}

Aquifers at the 300 Area include an unconfined aquifer, a locally confined sedimentary aquifer, and a series of basalt confined aquifers. The unconfined aquifer beneath the 300 Area is composed of Hanford and Ringold formation sediments between the water table and the top of the Ringold Lower Mud unit, which appears to be continuous in this area. The depth below ground surface to the top of the unconfined aquifer varies from a maximum of approximately $18 \mathrm{~m}$ to $0 \mathrm{~m}$ at the edge of the Columbia River. The uppermost confined aquifer exists in the discontinuous Ringold Unit A sand and gravel that lies between the Ringold Lower Mud and the top of the basalt. The top of this aquifer is approximately 30 to $40 \mathrm{~m}$ below ground surface where it exists in the 300 Area. The hydraulic head in this confined aquifer is approximately $10 \mathrm{~m}$ higher than the head in the overlying unconfined aquifer, i.e., the hydraulic gradient is directed upward.

A series of confined aquifers are found within the Columbia River Basalts that underlie the 300 Area sediments. These basalt confined aquifers are found in sedimentary interbeds (collectively called the Ellensburg Formation) and sometimes in permeable basalt-flow tops. The shallowest basalt confined aquifer beneath the 300 Area is in the Levey interbed and is approximately $80 \mathrm{~m}$ below ground surface. However, measured hydraulic head differences of more than $10 \mathrm{~m}$ indicate that communication between the basalt confined aquifers and the overlying sediments is limited by the low permeability of dense basalt flow interiors (Spane and Webber 1995; Thorne 1998).

Several pumping tests and slug tests have been conducted at 300 Area wells within the unconfined aquifer. Available pumping test results were evaluated to determine the reliability of values reported for the tests, and a few tests were reanalyzed. Figure 4.12 shows the location and hydraulic conductivity values for pumping tests that were determined to be reliable. Hydraulic conductivity values from slug tests conducted at the recently drilled LFI boreholes (Williams et al. 2007) are also shown. For some tests, it was not possible to determine an accurate hydraulic conductivity, but it was possible to determine that the conductivity must be greater than a particular value. Figure 4.12 shows that the mean hydraulic conductivity value for Hanford formation tests is 3,140 m/d (assuming the minimum value for those marked “>”). The average for Ringold sediments is $42 \mathrm{~m} / \mathrm{d}$. This large contrast in capability to transmit groundwater and contaminant plumes illustrates why the principal focus for the uranium plume is the saturated Hanford unit.

The water-table elevation in the 300 Area varies with changes in Columbia River stage. Even at low river stages, the water table is found within the Hanford formation over most of the 300 Area. However, the saturated thickness of Hanford sediments is reduced when the water table is low, particularly near the river. This affects the transmissivity distribution of the unconfined aquifer because Hanford formation sediments have higher conductivity than Ringold Formation sediments. Therefore, in some areas, the transmissivity may be much higher in the spring and early summer when the average river stage is higher 


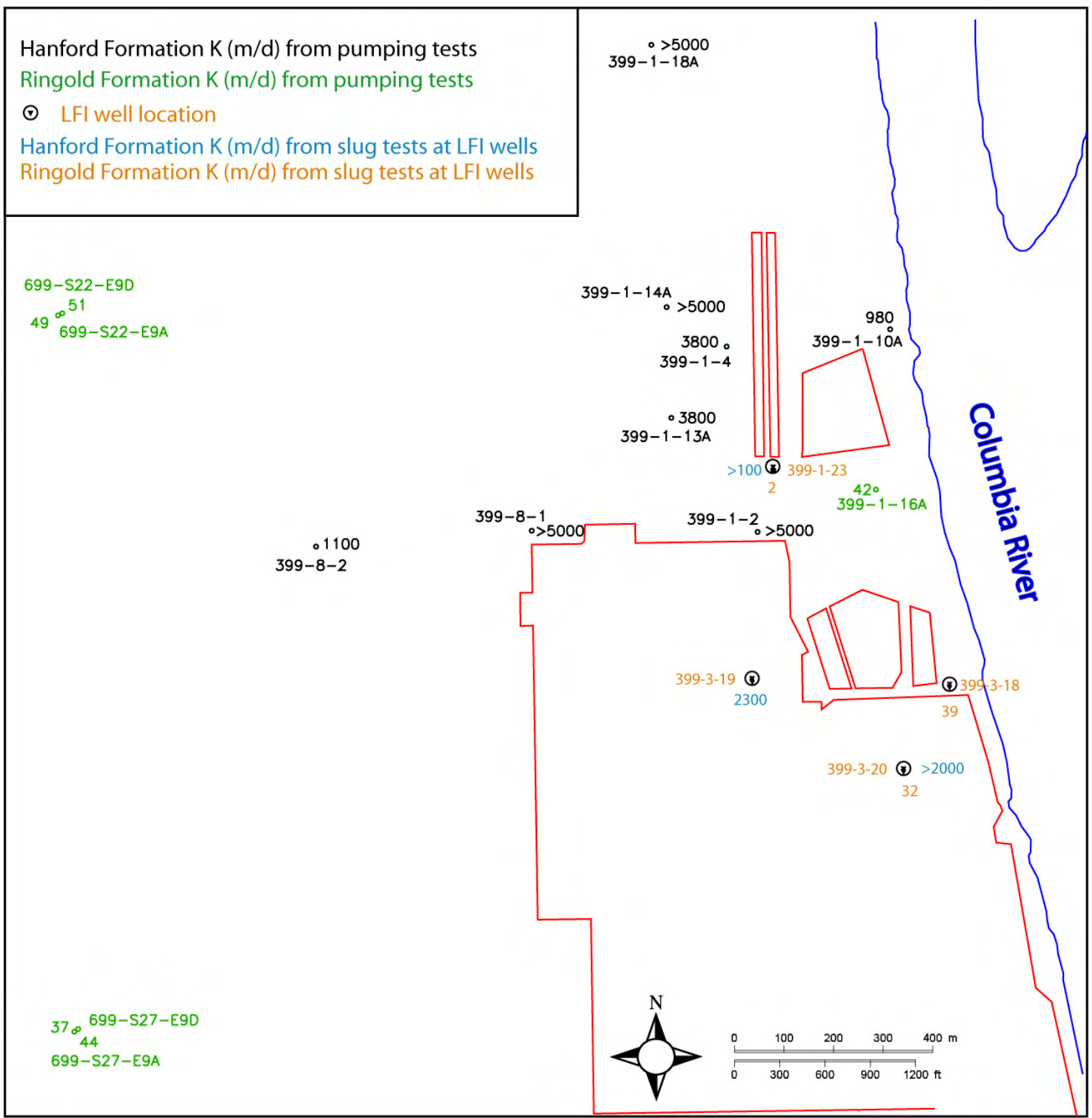

Figure 4.12. Locations for Pumping Tests and Hydraulic Conductivity Values for Results Considered Most Reliable

than in the fall and winter when the river stage is generally lower. Long-term average groundwater flow in the unconfined aquifer is toward the Columbia River. However, changes in the river stage combined with the configuration of the Hanford/Ringold contact result in changes in the direction of groundwater flow, particularly near the river (see Section 5.0). The groundwater flow direction is periodically reversed and river water infiltrates into the aquifer, resulting in "bank storage" at times of high river stage. Evidence of flow reversal near the river is revealed by measurements of hydraulic head and reduced specific conductance of water samples, which reflects a reduction in total dissolved solids and nitrate concentrations in groundwater near the river during a high river stage (see Section 3.0; Waichler and Yabusaki 2005). The dilution of contaminant concentrations is more prominent in the upper portion of the aquifer in the Hanford formation than in the saturated Ringold Formation. 
Groundwater in the basalt confined aquifers originates as recharge in upland areas on the western margin of the Columbia Plateau and in the Rattlesnake Hills west of the Hanford Site (DOE 1988). This groundwater also flows toward discharge areas along the Columbia River. However, these discharge areas are localized where the river cuts through the confining basalt flows or where structural features have caused increased vertical permeability. As noted by Spane and Webber (1995), groundwater within the basalt confined aquifers evolves from a calcium, magnesium, bicarbonate $\left(\mathrm{Ca}, \mathrm{Mg}-\mathrm{HCO}_{3}\right)$ chemical water type to a sodium (Na)-dominated water type with increasing residence time in the aquifer. At the 300 Area, water from the confined aquifers is sodium-dominated, indicating a relatively long residence time and in contrast to the relatively low sodium-content waters of the unconfined aquifer.

\subsection{Aquifer Interface with Columbia River Channel}

Groundwater in the 300 Area unconfined aquifer, except water extracted by wells, eventually discharges to the Columbia River. Some of this discharge is revealed as riverbank springs and seeps when the river stage is low. However, most of the discharge occurs in the bed of the river. Groundwater in the unconfined aquifer is unlikely to flow across to the eastern side of the Columbia River because the hydraulic head is higher in the unconfined aquifer on the eastern side of the river.

The subsurface zone where river flow influences the underlying aquifer (hyporheic zone) plays an important role in the movement of groundwater and in water quality, which may change because of mixing between river water and groundwater. The river channel is incised into Hanford and Ringold formation sediments, including the fine-grained Ringold unit, as revealed by work conducted under the Groundwater Remediation Project's science and technology investigations (Fritz et al. 2007; Mackley and Fritz 2007). Also, late-Holocene to recent deposition by the Columbia River has resulted in a layer of sediment along the river channel that forms a zone of lower permeability, which restricts the upwelling of groundwater from the aquifer to the river (Fritz and Arntzen 2007). The heterogeneous nature of sediments at the aquifer-river interface results in preferential flow paths for groundwater, and these flow paths may vary temporally depending on the river-stage elevation.

The aquifer/river interface in the current EarthVision ${ }^{\mathrm{TM}}$ hydrogeologic model framework is based on the September 2006 update of the Hanford/Ringold formation contact (see Figure 4.4) and a recently completed update to river bathymetry, which is based on data from the U.S. Fish and Wildlife Service (Anglin et al. 2006). The aquifer/river interface at the 300 Area has been the focus of recent work to better understand the nature of the connection between the aquifer and river, and also to test methods to quantify the rate of groundwater discharge to the river (Fritz et al. 2007; Mackley and Fritz 2007; Mendoza et al. 2007). Activities undertaken to characterize this interface are described below (see Fritz et al. 2007 for a comprehensive discussion on the methods and results of these recent investigations).

Drive-Point Penetration-1-inch-diameter steel rods with rounded points were driven into the riverbed at 14 locations until a "refusal" depth was reached. The refusal depth generally reflects the depth of the Hanford/Ringold contact because of the more consolidated nature of the Ringold sediments. This is especially likely if the fine-grained Ringold subunit exists at the top of the Ringold Formation. However, there is some uncertainty with this technique because a large boulder within the Hanford formation may also cause refusal. To help minimize this uncertainty or bias, multiple and repeat penetration tests were conducted. 
Figure 4.13 shows the locations of the drive-point penetrations and the depth of refusal results. Contact elevations from the drive-point penetration results generally agree with the interpretation by Williams et al. (2007) based on larger scale inland borehole geologic data. The elevation of the refusal layer trends upward in the downstream direction; however, the deepest penetration occurred near Spring 9. This indicates a structural low in the hydrogeologic confining layer (Ringold subunit), which suggests this as an area of preferential flow and increased discharge to the river.

Piezometer Head Measurements and Slug Tests-The vertical hydraulic gradient in riverbed sediment was measured using three piezometers that are installed adjacent to Spring 9, an historical environmental monitoring location (Fritz and Arntzen 2007; see Figure 4.13 for location). The tops of the piezometer screens were $19 \mathrm{~cm}, 86 \mathrm{~cm}$, and $142 \mathrm{~cm}$, respectively, and they were spaced about 1-m laterally. The hydraulic head and gradients measured in the piezometers varied as the river stage changed. The largest gradient was across the shallowest interval between the riverbed and 19-cm depth. Slug tests were also conducted in these piezometers and in six additional piezometers installed at distances up to $3 \mathrm{~m}$ away (Arntzen et al. 2006; Fritz and Arntzen 2007). The depth of the top of the screen for these piezometers ranged from 55 to $180 \mathrm{~cm}$ below the river bed. Slug test results also showed that sediment near the river bottom had the lowest permeability (Fritz and Arntzen 2007). Vertical water flux through the riverbed was calculated from the hydraulic conductivity determined by the slug test and measured gradients. The resulting estimated vertical water flux varied between 0.24 and $-0.37 \mathrm{~L} / \mathrm{min} / \mathrm{m}^{2}$ over the study period. A positive water flux indicates net water movement into the river, and negative flux indicates movement into the aquifer. The integrated flux over time showed net discharge to the river, but at a lower magnitude than estimated previously based on monitoring well measurements (Fritz and Arntzen 2007).

Underwater Video-The bottom of the river channel along the western shore was video recorded to map the textural characteristics of alluvial sediment and to identify outcrops of the Ringold Formation on the river bed. Although the majority of the riverbed along the 300 Area is composed of coarse-grained alluvium, exposures of the Ringold fine-grained unit were identified in the deeper portions of the river channel—likely exposed by erosion associated with strong river currents.

Bathymetry_-A revised interpretation of Columbia River bathymetry adjacent to the 300 Area was created from data collected by the U.S. Fish and Wildlife Service as part of their program to study Fall Chinook salmon in the Hanford Reach (Anglin et al. 2006). These data present a three-dimensional model of the river channel in high-resolution that make it possible to investigate the relation between the form of the river and the underlying geology. Fritz et al. (2007) identified features in the plan and profile of the Columbia River related to outcrops seen in underwater video and from direct grab samples.

Sub-Bottom Profiling-Acoustic profiling of the riverbed was done along multiple transects, some of which are shown in Figure 4.14. The objectives were to identify the depth of the river bottom, comparative densities of sediment on the river bottom, and image stratigraphic features (e.g., Ringold subunit) below the riverbed surface. The coarse-grained nature of alluvial sediments in the river channel made it difficult to achieve significant penetration below surface sediments, except in locations where alluvium was relatively finer grained or thinly bedded. In spite of this limitation, the acoustic profiles reveal reflection signatures, such as greater penetration and horizontally oriented features consistent with known exposures of the fine-grained Ringold subunit from an underwater video (Mackley and Fritz 2007). Figure 4.15 shows select acoustic profiles. 


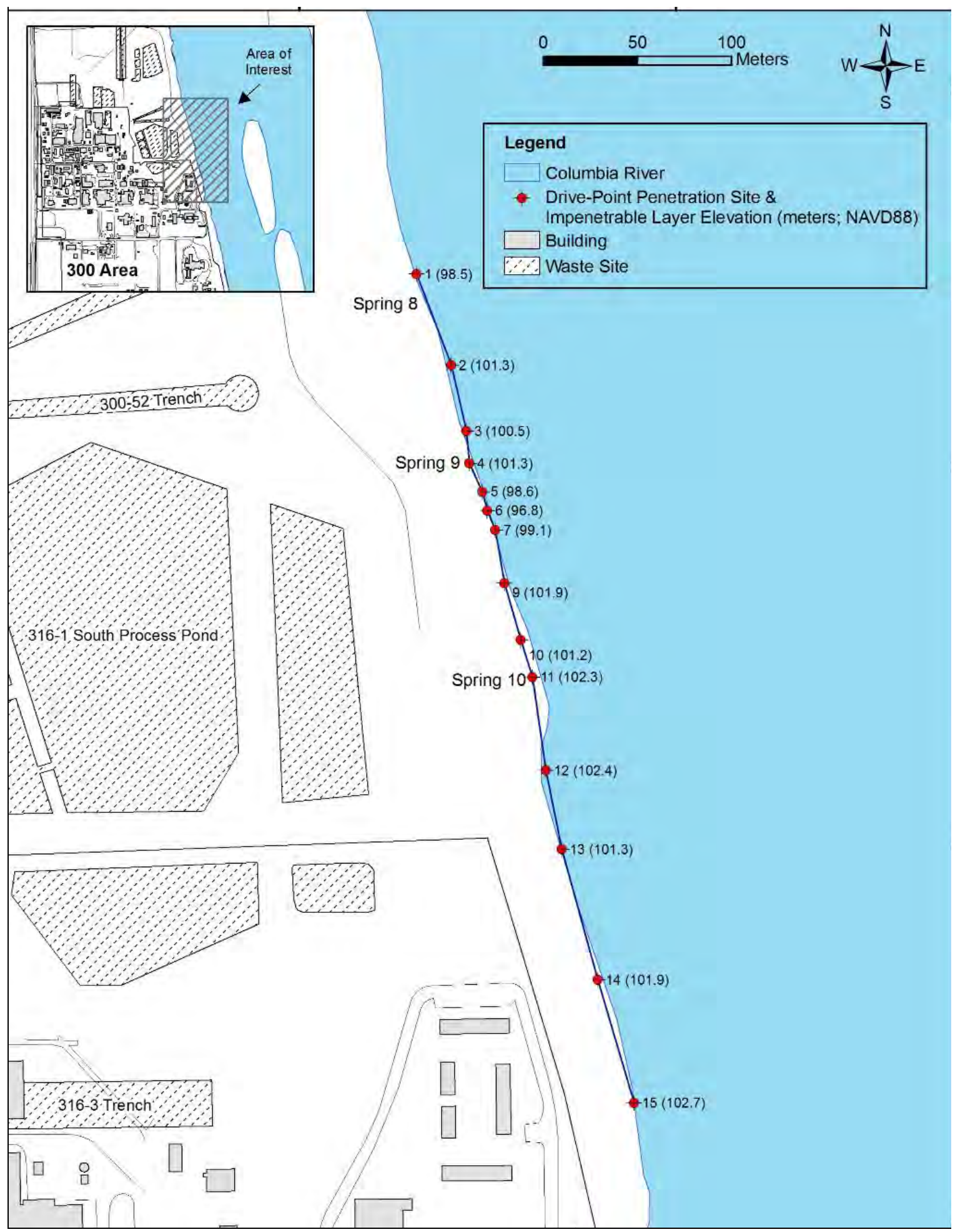

Figure 4.13. Locations of the Drive-Point Penetrations and the "Depth of Refusal” Results (Fritz et al. 2007) 


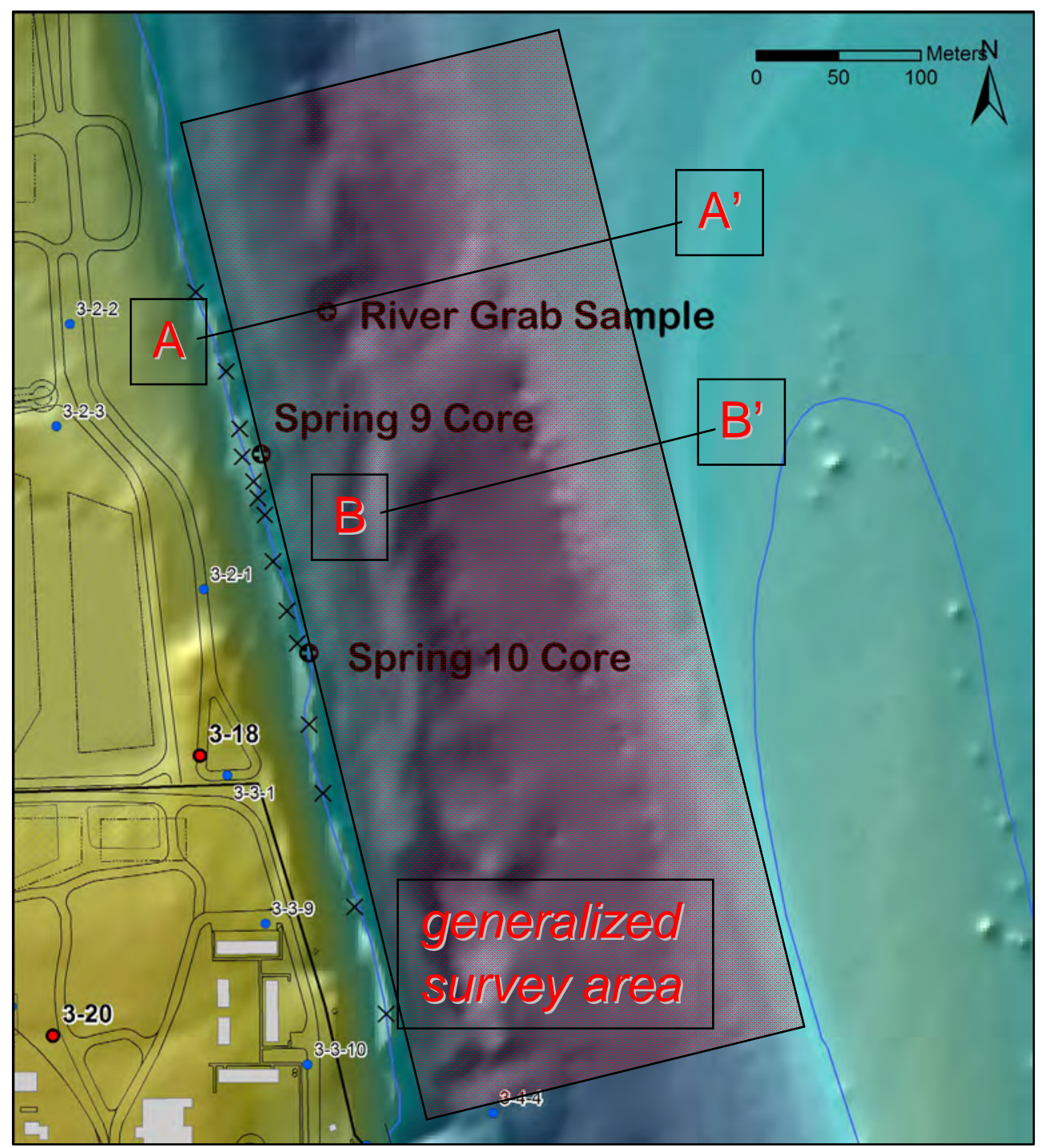

Figure 4.14. Transects for Example Acoustic Profiles of the Riverbed Shown in Figure 4.15 (Mackley and Fritz 2007) 

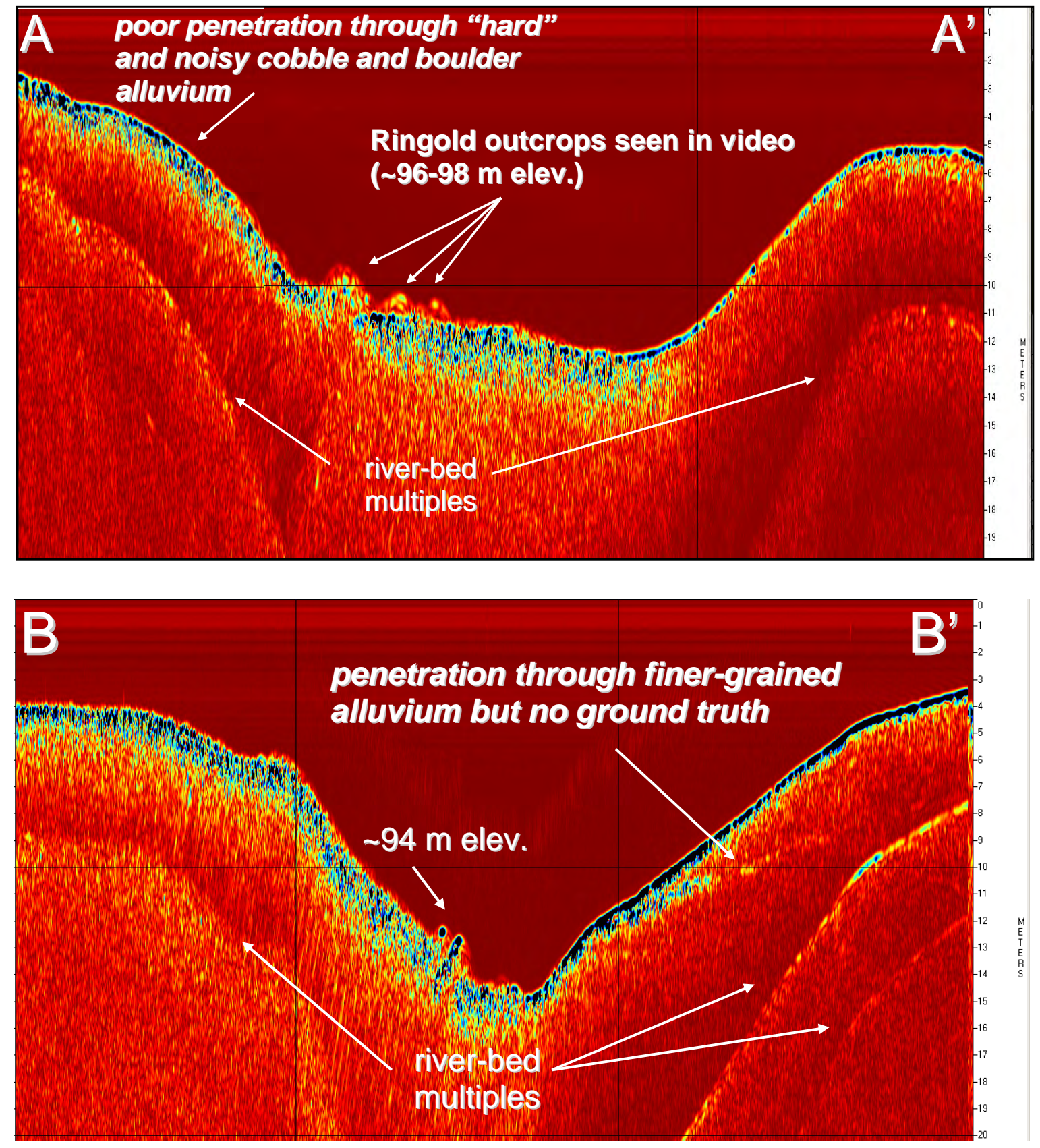

Figure 4.15. Example Acoustic Profiles of the Riverbed Along the Transects Shown in Figure 4.14 (Mackley and Fritz 2007)

Sediment Sampling-Sediment cores beneath the riverbed were obtained adjacent to Springs 9 and 10 using a Geoprobe ${ }^{\circledR}$ Macro-Core Sampler. In addition, a surface-sediment grab sample was obtained in locations where the fine-grained Ringold subunit could be seen outcropping in the riverbed in the underwater video surveys. Figure 4.16 shows the locations of these samples and photos of the sediments. Core samples of the fine-grained unit from three of the boreholes from LFIs are also shown for comparison. 
Because Hanford formation sediment is much more permeable than the underlying Ringold Formation, most of the groundwater discharging to the Columbia River through the riverbed comes from the Hanford formation. Figure 4.17 shows the area of riverbed adjacent to the 300 Area where the discharge of groundwater containing the uranium plume is estimated to occur. This representation is based on a projection of the Hanford and Ringold contact surface from land borehole data onto the channel bathymetry, using the EarthVision ${ }^{\mathrm{TM}}$ hydrogeologic model. The area shown in red on Figure 4.17 is approximately $0.17 \mathrm{~km}^{2}$, as reported in Fritz and Arntzen (2007). More recent work directly in the river channel indicates that the contact may actually occur at a somewhat higher elevation, which would result in a smaller contributing area. Additional work is planned to better define the Hanford/Ringold contact in the riverbed.

\subsection{Spatial Data Management (EarthVision ${ }^{\mathrm{TM}}$ database)}

The conceptual model of the hydrogeologic framework for the 300 Area is maintained using the geologic modeling software EarthVision ${ }^{\mathrm{TM}}$. Elevation data for the tops of hydrogeologic units from boreholes or outcrops are used to create grids representing the unit surface. Additional information, such as hand-drawn elevation contours and points where a unit is known to be missing, can also be used as input data for the gridding process. Control points are used to control extrapolation and interpolation in some areas based on knowledge of the geologic environment and depositional history. Surface topography in the model area was defined based on the U.S. Geological Survey's digital elevation model with a resolution of $10 \mathrm{~m}$. The Columbia River channel was defined as an erosional surface based on recently acquired data from the U.S. Fish and Wildlife Service (Anglin et al. 2006). The EarthVision ${ }^{\mathrm{TM}}$ software combined this information to create a three-dimensional representation of the hydrogeologic framework.

The EarthVision ${ }^{\mathrm{TM}}$ conceptual model grids are maintained under configuration control, as are numerical flow and transport models that are constructed based on the EarthVision ${ }^{\mathrm{TM}}$ conceptual model. Changes to the conceptual model are documented under PNNL quality assurance procedures.

The EarthVision ${ }^{\mathrm{TM}}$ software was determined to be "safety software" under the provisions of 10 CFR 830 and DOE Order 414.1C because the results may be used in decisions to provide protection from existing or future radiological hazards. The EarthVision ${ }^{\mathrm{TM}}$ (version 7.0.1) was determined to be

"acquired software" because it is commercial off-the-shelf software. In accordance with PNNL's quality assurance program, a grade of C (low potential impact) was assigned for this application because the results may be used in regulatory permitting or planning for potential radiological releases.

\subsection{Uncertainties in Defining the Hydrogeologic Framework}

Uncertainty in the hydrogeologic framework arises from the possibility of developing less than accurate interpretations because of incomplete observational data, and from actual spatial variability of the physical system. The stratigraphic characteristics for the subsurface at the 300 Area are heterogeneous. Misinterpretation of various stratigraphic relationships can arise from the incorrect identification of a unit at a borehole or from a unit being missed in the borehole interpretation. 


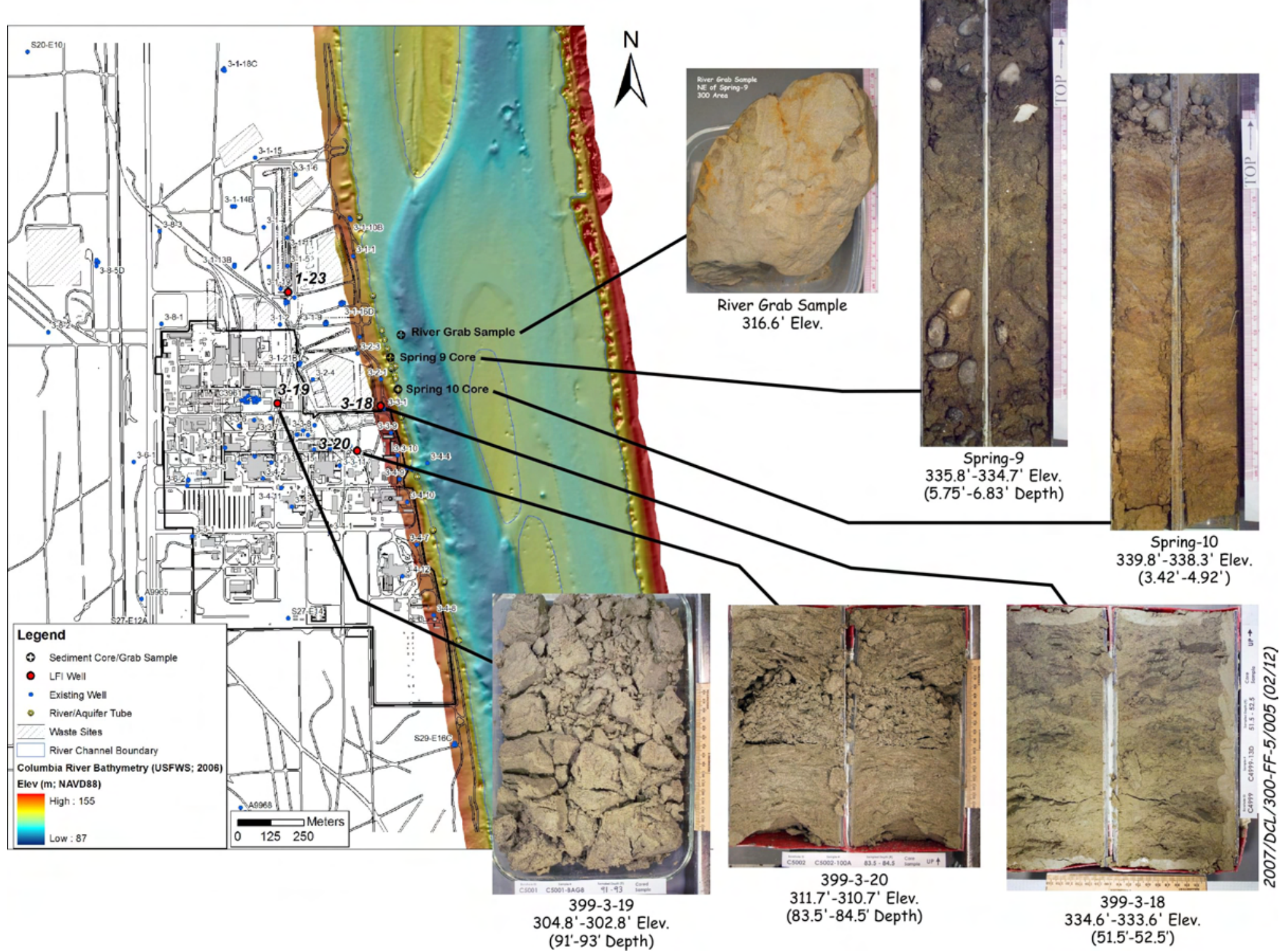

Figure 4.16. Locations of Sediment Samples Collected from the Riverbed and Photos of the Sediments (Mackley and Fritz 2007) 


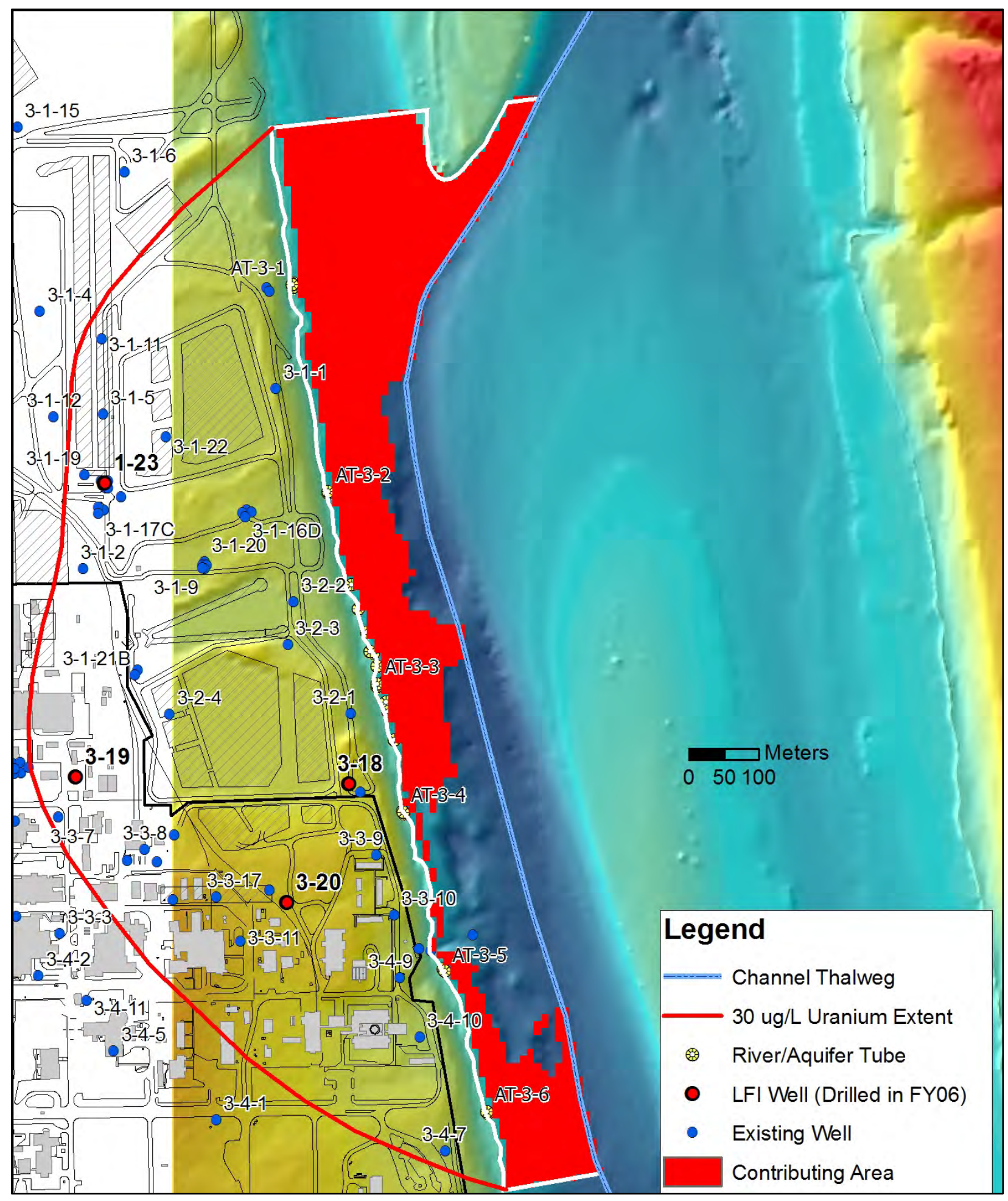

Figure 4.17. Area Where Saturated Hanford Formation Sediment is in Contact with the River Channel Based on the Current Hydrogeologic Model (Mackley and Fritz 2007) 
Samples are often logged only every 1.5 to $3 \mathrm{~m}$, which may not be sufficient to reveal a relatively thin unit. Incomplete descriptions or errors in descriptions and field interpretations can also lead to misinterpretation of units at a borehole location. However, even if the interpretation of units at boreholes was completely accurate, unit continuity and elevation between boreholes would continue to cause uncertainty because of the variability of the aquifer system between boreholes (i.e., the problem of interpolation and extrapolation under spatial variability). For example, erosional channels may exist within the Ringold formation surface and not be represented in the model because no boreholes are located in the channel area. Contrastingly, a unit may be present in an area where no boreholes exist and not be represented in the model. Specific uncertainties that may be particularly important in the 300 Area hydrogeologic model include:

- geometry of the Hanford/Ringold formation contact

- lateral extent of the Ringold Formation fine-grained subunit

- mixtures of Hanford formation and reworked Ringold formation sediment with elevated hydraulic conductivity being identified as native Ringold formation

- configuration of the Ringold/Hanford contact at the Columbia River interface

- presence and thickness of a recent (late Holocene) alluvial layer in the Columbia River bed. 



\subsection{Groundwater Flow and Transport}

(M.D. Williams and M.L. Rockhold)

This section describes the current understanding of groundwater flow directions and rates in the 300 Area. These studies include analysis of detailed water-level measurements, a summary of computer simulations of the 300 Area, including recent studies, and results of field tests in the 300 Area as they relate to groundwater flow direction and rates.

\subsection{General Flow Patterns and Velocities}

The water table at the 300 Area is very dynamic due to fluctuations in the stage of the Columbia River and the very high permeability of the Hanford formation sediments that comprise the uppermost part of the unconfined aquifer. Large daily, weekly, and seasonal fluctuations in the stages of the Columbia River (Figure 5.1) are caused by the operation of hydroelectric dams on the river and seasonal trends, such as the spring freshet. The dynamics of river-stage fluctuations and the water-table elevation cause a mixing zone of river and groundwater within the aquifer. River water enters the aquifer when the river stage is relatively high. Measurements of specific conductance and temperature at wells in the 300 Area, where the groundwater and river water have a large contrast in values, show that river water can encroach as far as $325 \mathrm{~m}$ inland in some areas when the river stage is unusually high, although a lesser distance is probably more representative of overall encroachment in the 300 Area (see Figure 3.13). When river stage is relatively low, groundwater discharges to the river, as revealed by specific conductance measurements (and other analytes) in aquifer tubes installed below the riverbed and in springs along the shoreline (Patton et al. 2002).

The configurations of the water table when the river stage is high (June) and when it is low (December) are shown on the uranium plume maps presented in Section 3.0 (Figures 3.5 and 3.6, respectively). The water table, along with the uranium concentrations, is distinctly different during these periods as shown in the figures. Additionally, the water table is relatively flat in the 300 Area (i.e., very small hydraulic gradients) because of the extremely high permeability of the Hanford formation comprising the uppermost portion of the unconfined aquifer.

Two separate high-resolution water-level monitoring networks have been set up in the 300 Area to investigate the water-table dynamics by collecting water-level data hourly and sub-hourly from these networks over a multi-year period. The first network was established in the early 1990s and operated until the mid-1990s (Campbell and Newcomer 1992; Campbell et al. 1993). This network covered the entire 300 Area. The current network was established in 2004 and consists of 13 wells. It covers a subregion within the 300 Area that focuses on the northeast portion of the 300 Area where the principal liquid-waste disposal facilities were located, i.e., where potential sources of uranium are presumed to remain in the vadose zone. Figure 5.2 shows the wells equipped with pressure transducers during each of these campaigns. These networks and the analysis of the data are discussed in the following two sections. Two cases of plume migration are also discussed below, for tetrachloroethene and uranium, in instances where concentration pulses can be tracked between multiple wells. Preliminary results of the field testing for the polyphosphate treatability study (Vermeul et al. 2007) are discussed below as they relate to groundwater flow directions and rates during two field injection tests conducted in fiscal year 2007. 


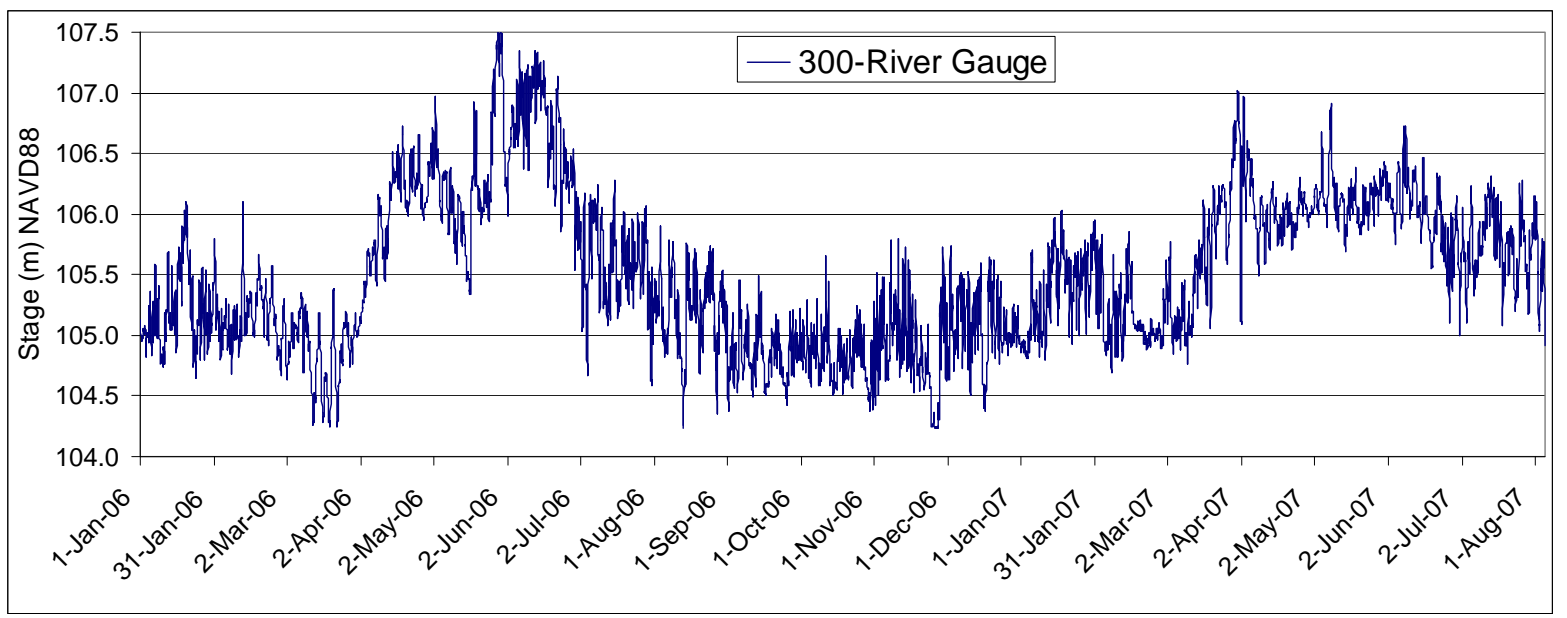

Figure 5.1. Columbia River Stage at the 300 Area SWS-1 Gauging Station, January 2006 to August 2007

\subsubsection{Early 1990s Water-Level Monitoring Network}

A water-level monitoring network was established in the 300 Area in the early to mid-1990s as part of the initial 300 Area remedial investigation and feasibility studies (DOE-RL 1990). The network included 32 wells and the Columbia River stage adjacent to the 300 Area; however, the monitoring periods for specific wells during this time were variable (Campbell and Newcomer 1992). Water levels were monitored in these wells at hourly intervals using pressure transducers and dataloggers. Pressuretransducer data were checked periodically with manual water-level measurements for these wells. These data are described in detail by Campbell and Newcomer (1992) and Campbell (1994), and are managed by Fluor Hanford, Inc. as part of their Virtual Library.

A time period from early 1992 to early 1993 was selected from this water-level monitoring network data set for analysis because it had the greatest number of wells (i.e., 20) with hourly water-level measurements monitoring the uppermost unconfined aquifer during this time (Figure 5.2; note that some wells are outside the boundaries of this map). Figure 5.3 shows the 300 Area river stage for this time period. Figure 5.4 shows the wells equipped with pressure transducers in screened intervals in the uppermost unconfined aquifer when the river stage is low. Figure 5.4 also shows contoured water-level data on triangular sets of wells with the hydraulic gradients calculated at the center of each triangular set.

Figure 5.4 shows spatial differences in the calculated hydraulic gradients that can provide information on relative hydraulic conductivities of the uppermost unconfined aquifer. The high hydraulic gradients (as indicated by the closely spaced contour lines and larger vector magnitudes) on the western portion of the area in Figure 5.4 are the results of the relatively lower hydraulic conductivity of the Ringold Formation at the water table in these wells (e.g. wells 699-S27-E9A and 699-S22-E9A) compared to the much higher hydraulic conductivity of the Hanford formation below the water table in the rest of the area (see Figure 4.4). Relative differences within the Hanford formation can also be seen in the steeper gradients in the northeastern portion of Figure 5.4, as compared to the flatter hydraulic gradient in central and southeastern portions. 
Water Table in 300 Area, March 2002

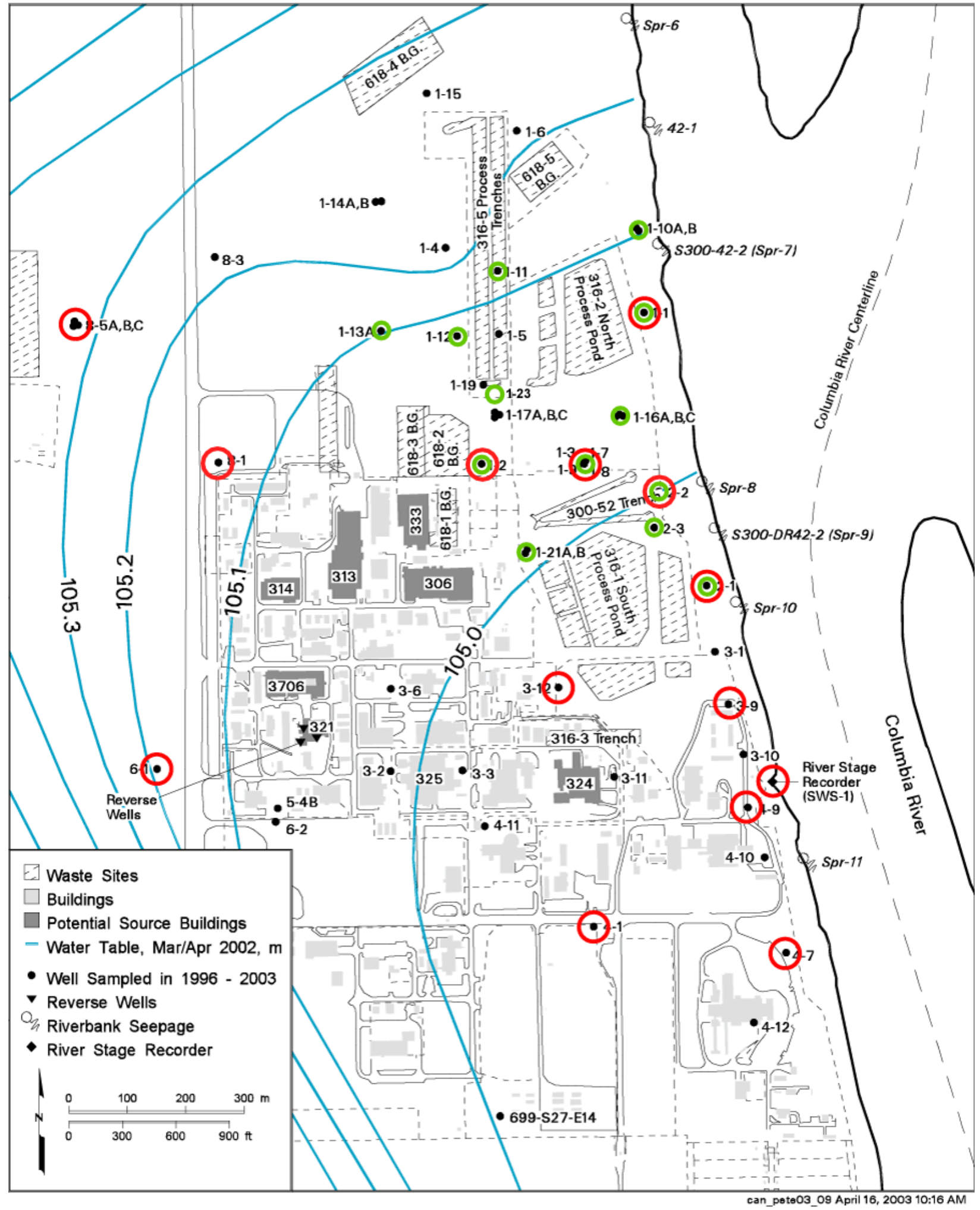

Figure 5.2. Wells Where Hourly Water-Level Data Have Been Obtained. Red circles indicate wells used during 1992 to 1993, while green circles indicate the 2004 + network wells. 


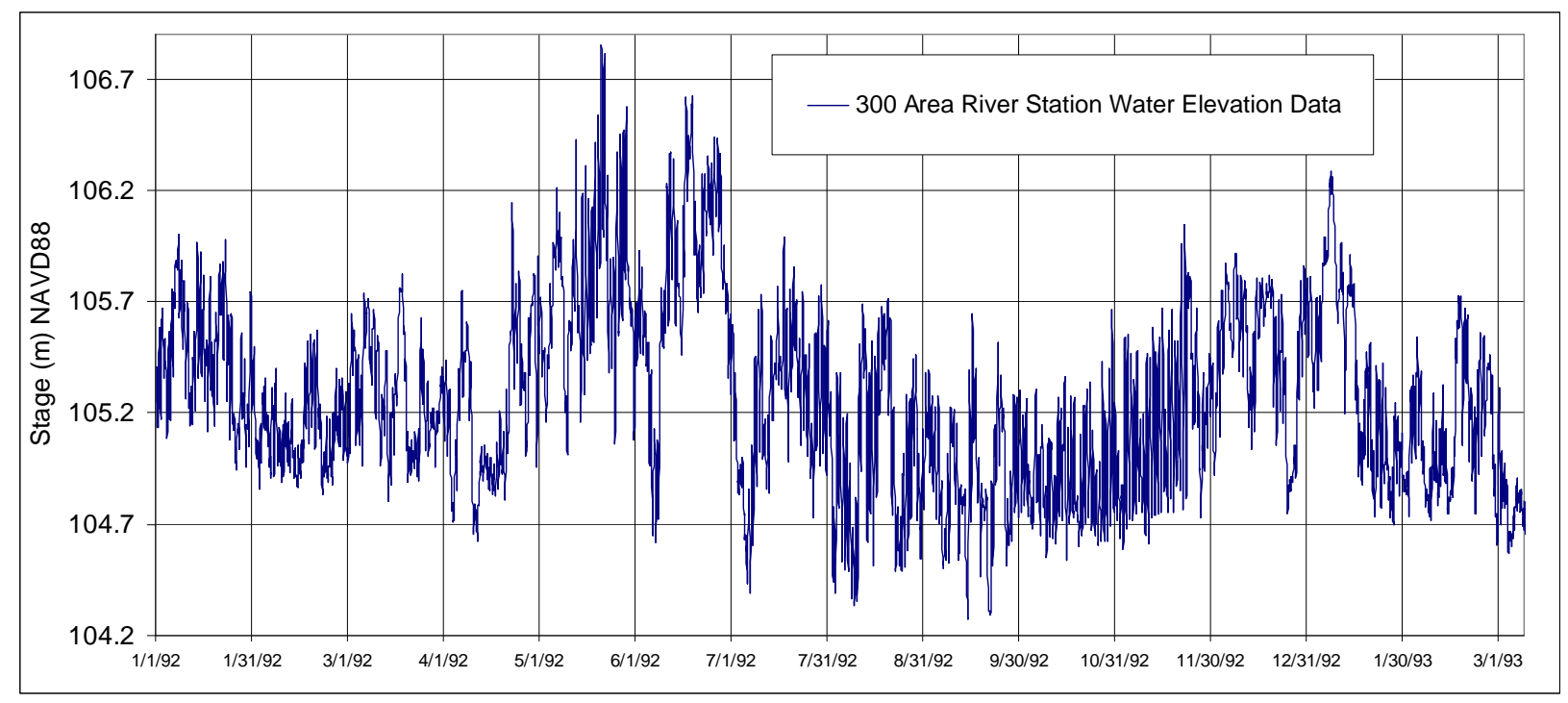

Figure 5.3. Columbia River Stage at the 300 Area SWS-1 Gauging Station, January 1992 to March 1993

\subsubsection{Current (2004 and Later) Water-Level Monitoring Network}

An automated water-level monitoring network was installed as part of the Remediation and Closure Science project (RACS) in the 300 Area in 2004 (Fritz et al. 2007). Nine wells were included initially in this network, which collected water levels on hourly and sub-hourly intervals in the area between the North and South Process Ponds, and extending westward past the southern portion of the 300 Area Process Trenches (see Figure 5.2). Six of these wells also monitored groundwater temperature and electrical conductivity. The 300 Area water-level monitoring network was supplemented in July 2006 with the addition of wells 399-1-23 and 399-1-16A, which expanded coverage compared to the original network. Wells 399-1-11 and 399-1-10A were also added in October 2006 to increase the northern extent of the coverage. The addition of wells 399-1-23 and 399-1-16A to this network showed significant variations in the gradient direction compared to the results computed from the coarser water-level network.

Figures 5.5 through 5.9 show contoured hydraulic head data and calculated hydraulic gradients for selected time periods in 2006 and 2007. The river stage during these periods is shown in Figure 5.1. The hydraulic gradient vectors in these figures were calculated at the center of triangular sets of wells. The specific times for these plots were selected to illustrate distinct periods during the yearly river stage cycle. Figure 5.5 shows a time with some of the highest inland-directed gradients during the initial high river stage of the year following sustained lower river stages during the winter. Figure 5.6 shows inland directed hydraulic gradients during the sustained period of the high river stage in June of 2007. Figure 5.7 shows high hydraulic gradients directed toward the river occur during the significant drop in the river stage (typically in late June or early July) following the period of sustained high river stage. Figures 5.8 and 5.9 show the two cases where the predominant gradient direction changed during a period when low river stage was sustained. 


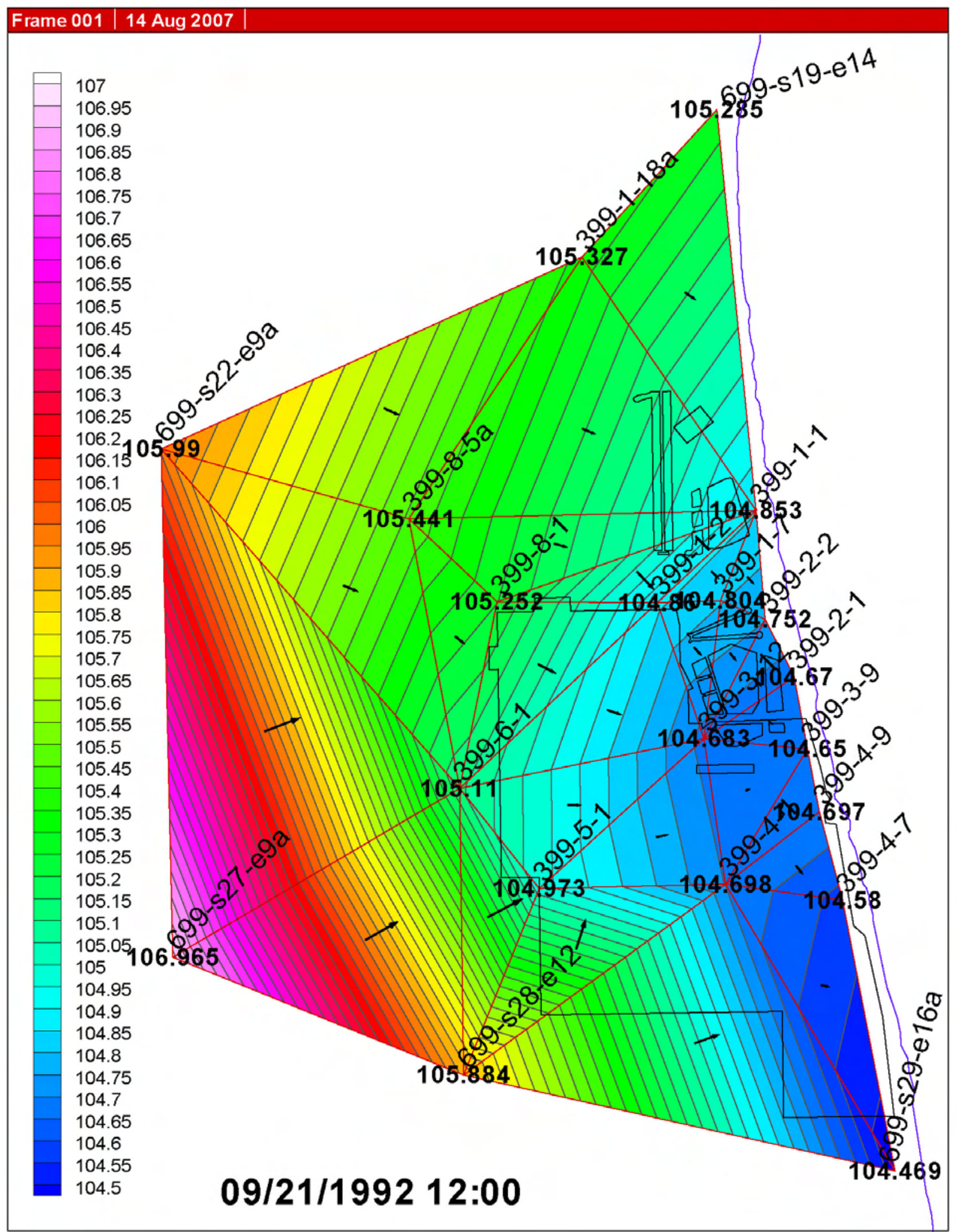

Figure 5.4. Wells in the Early 1990s Water-Level Monitoring Network with Low-River Stage Example 


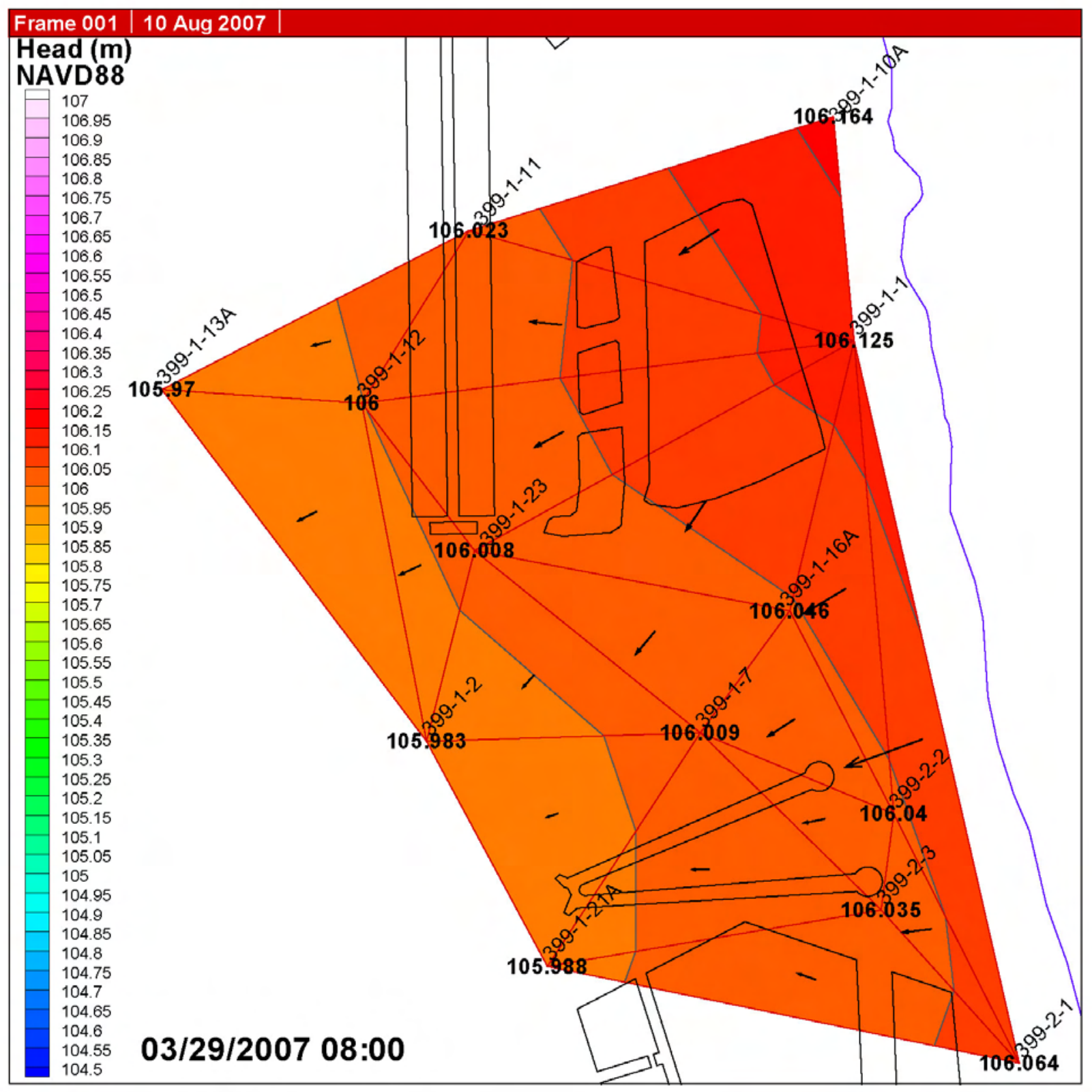

Figure 5.5. 300 Area Water-Level Monitoring Network-Initial High-River Stage Example 


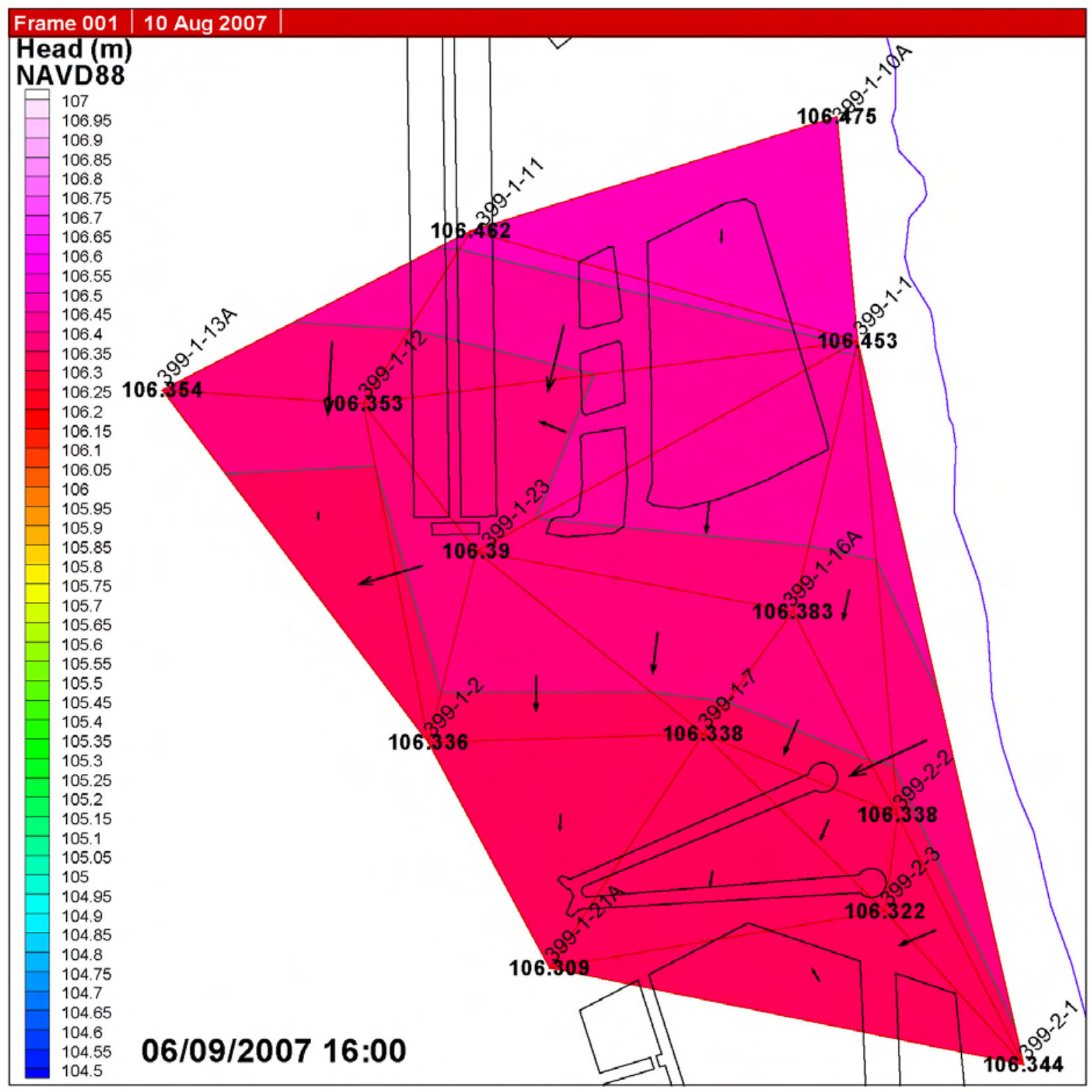

Figure 5.6. 300 Area Water-Level Monitoring Network—Sustained High-River Stage Example 


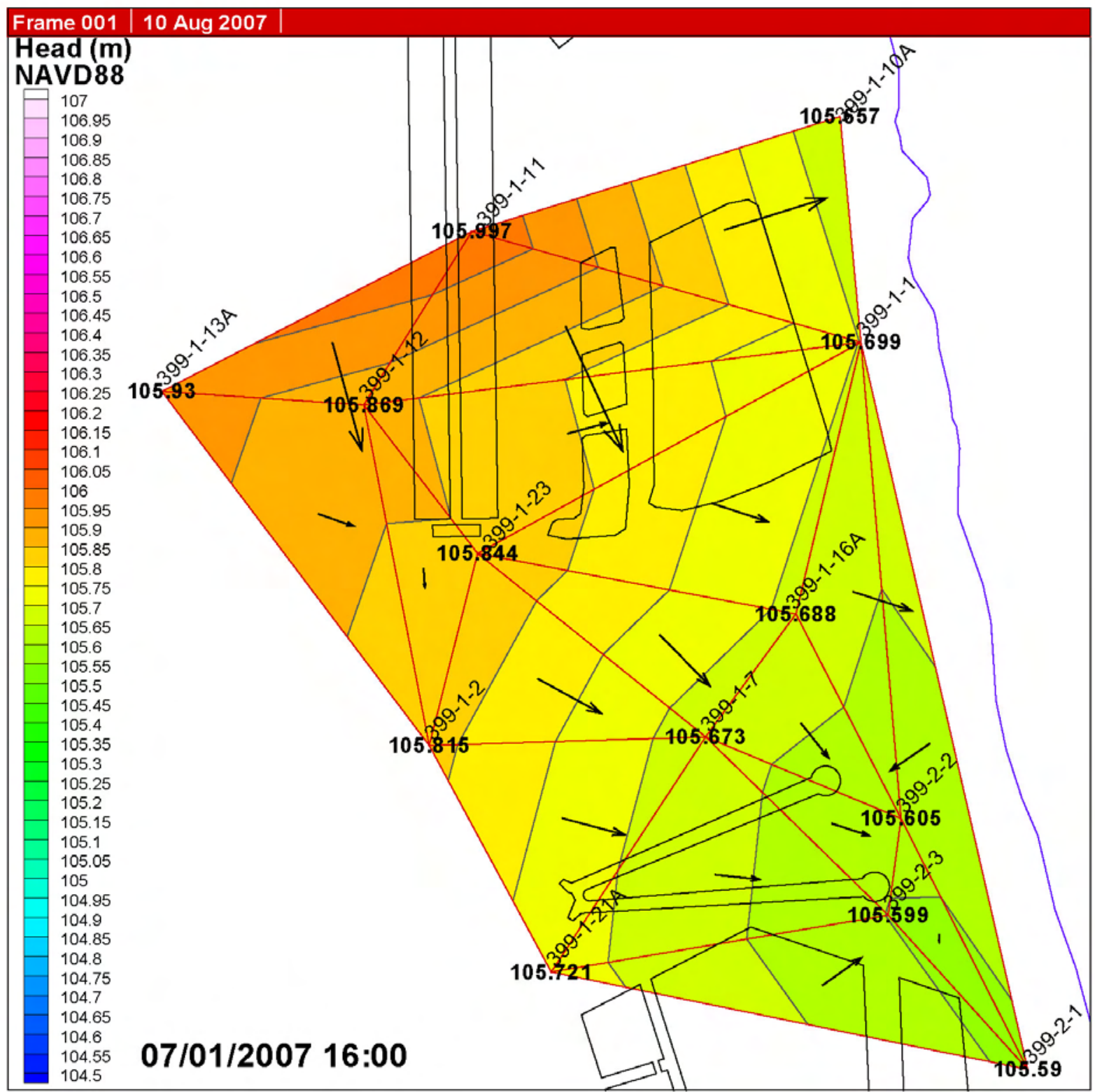

Figure 5.7. 300 Area Water-Level Monitoring Network—-Initial Lower River Stage Following High-River Stage Example 


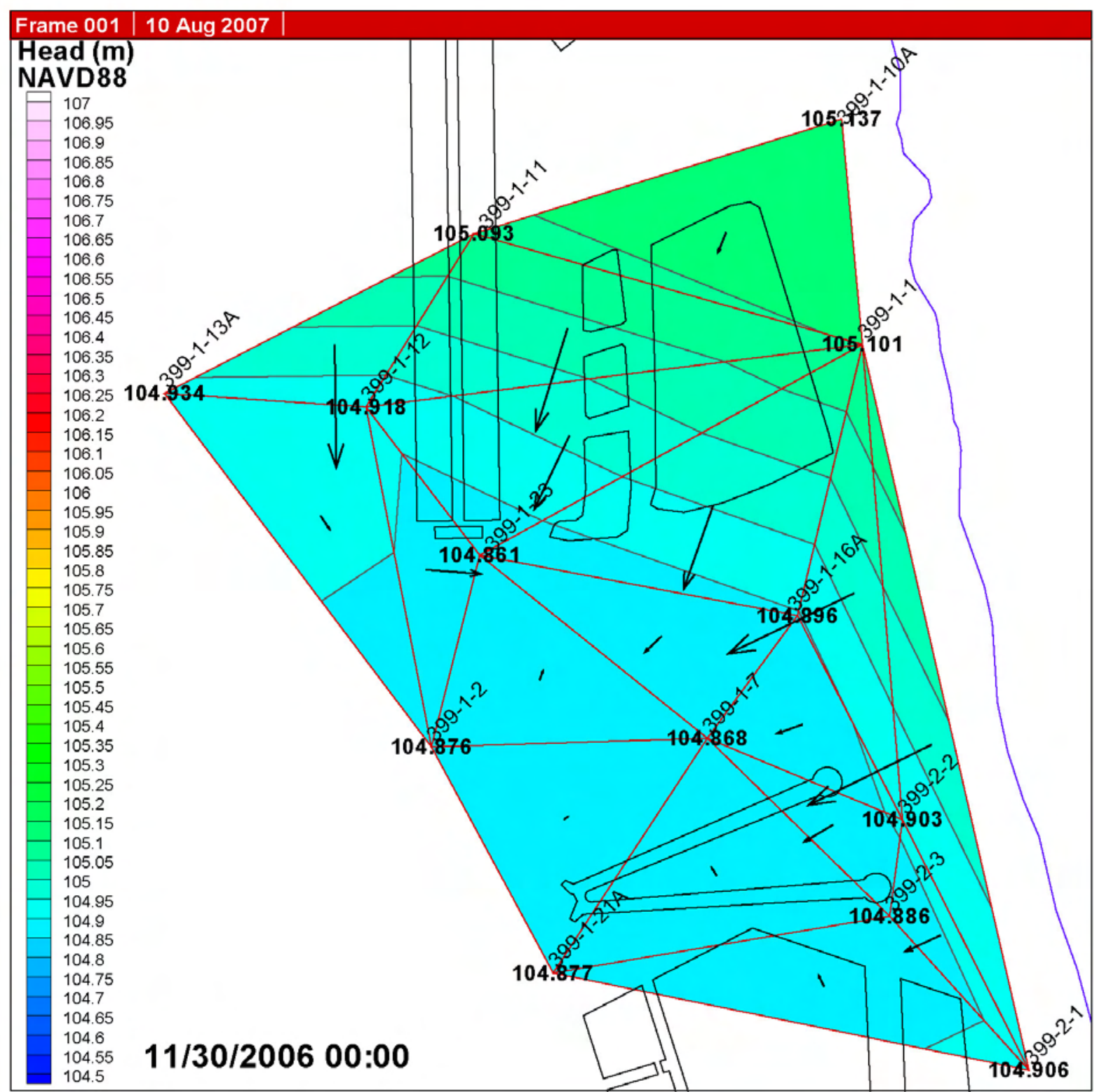

Figure 5.8. 300 Area Water-Level Monitoring Network—Sustained Low River Stage-Inflow Example 


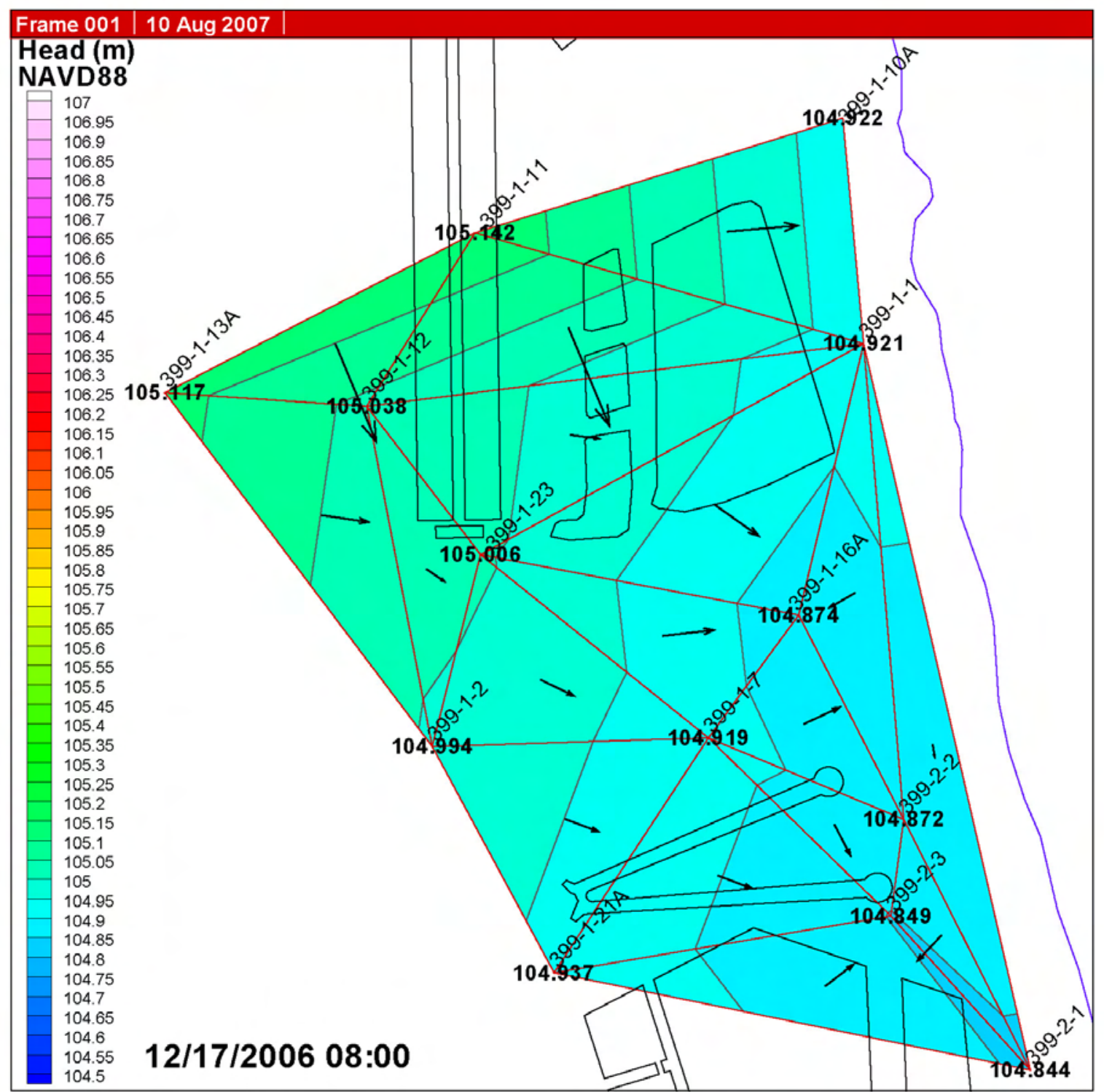

Figure 5.9. 300 Area Water-Level Monitoring Network—Sustained Low River Stage—Outflow Example

The contoured hydraulic head data in Figures 5.5 through 5.9 show generally higher gradients in the north and northeast portions of this monitoring well network, particularly during a low river stage in Figure 5.8. This indicates lower hydraulic conductivity for the Hanford formation unconfined aquifer compared to the southwest portion of the monitoring network.

Figures 5.10 through 5.14 are monthly rose diagrams showing the groundwater flow direction from this network using measurements every two hours for the period July 2006 to July 2007. These stacked rose diagrams are grouped monthly to show the seasonal variations in hydraulic gradients for each of these well clusters. These data are split out on separate monthly plots for one specific well cluster located toward the river of the water-level monitoring network in Figures 5.13 and 5.14. 

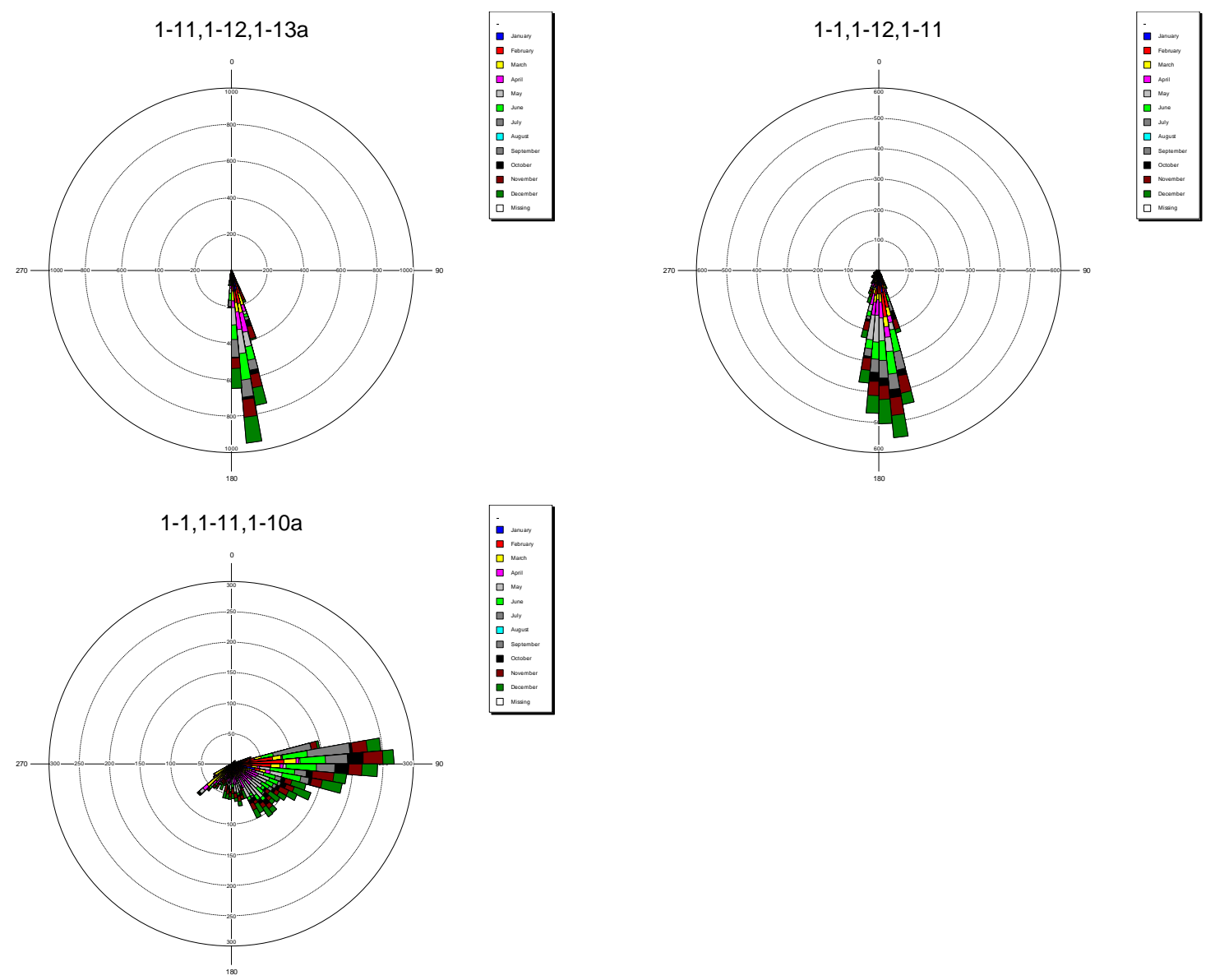

Figure 5.10. 300 Area Water-Level Monitoring Network-Hydraulic Gradient Rose Diagrams for MidOctober, 2006 Through July 26, 2007 (2-hour data intervals used-Note: partial year). Data for northern portion of monitoring network. Azimuth shows direction towards flow; 399- prefix removed from well names. (Note: data gaps for well 399-1-1.) 

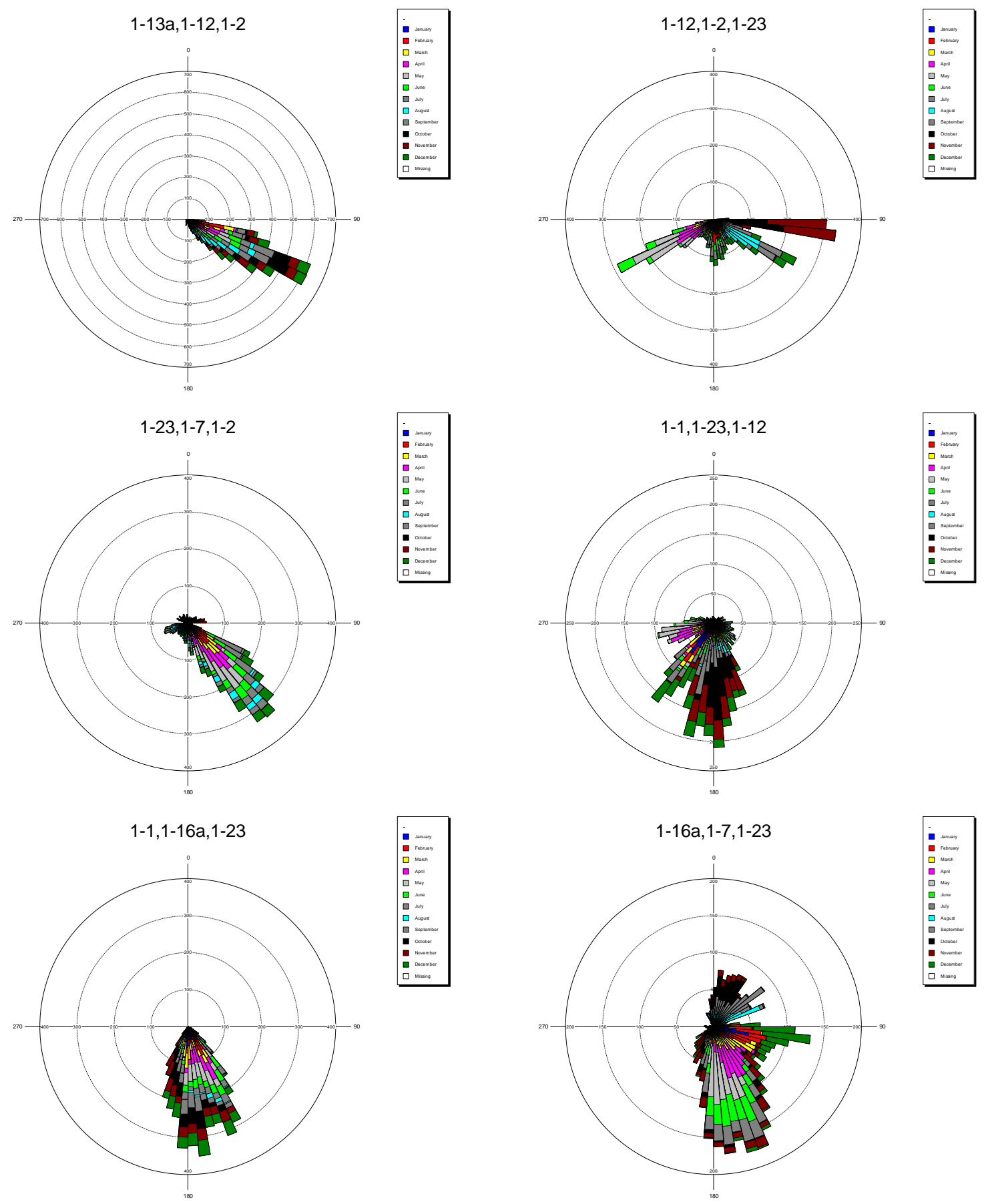

Figure 5.11. 300 Area Water-Level Monitoring Network-Hydraulic Gradient Rose Diagrams for July 26, 2006 Through July 26, 2007 (2-hour data intervals used). Data for central portion of monitoring network. Azimuth shows direction towards flow; 399- prefix removed from well names. (Note: data gaps for well 399-1-1). 

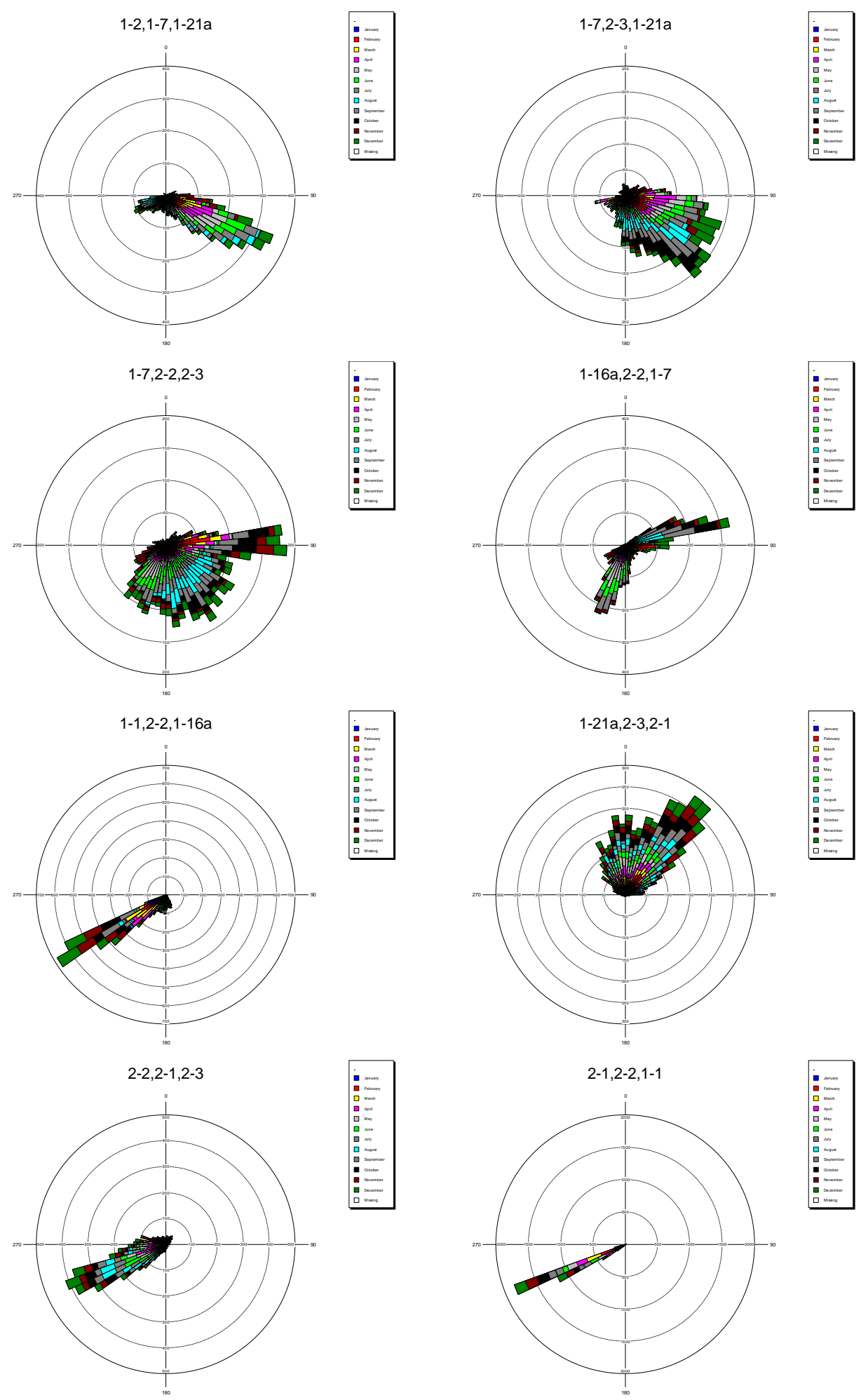

Figure 5.12. 300 Area Water-Level Monitoring Network-Hydraulic Gradient Rose Diagrams for July 26, 2006 Through July 26, 2007 (2-hour data intervals used). Data for southern portion of monitoring network. Azimuth shows direction towards flow; 399- prefix removed from well names. (Note: data gaps for well 399-1-1.) 


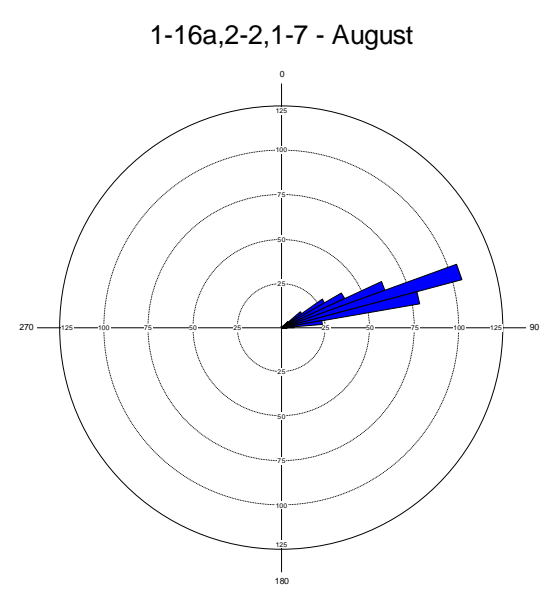

1-16a,2-2,1-7 - October

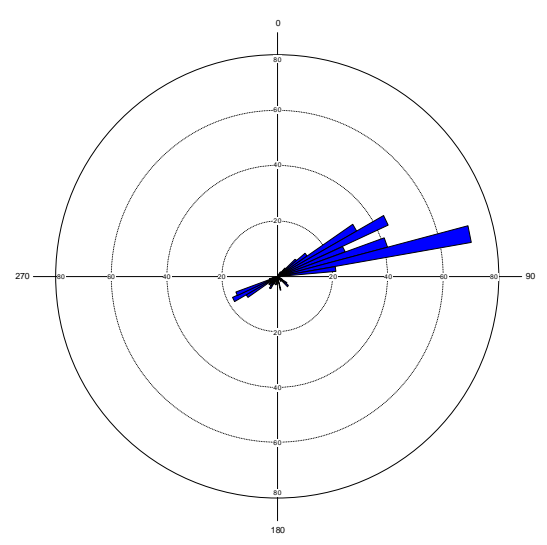

1-16a,2-2,1-7 - December

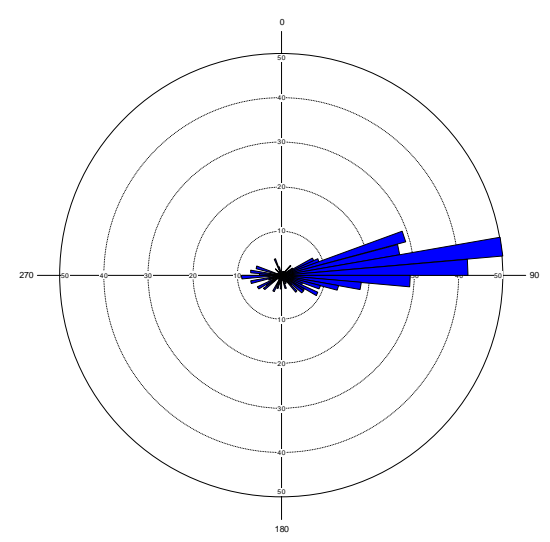

1-16a,2-2,1-7 - September

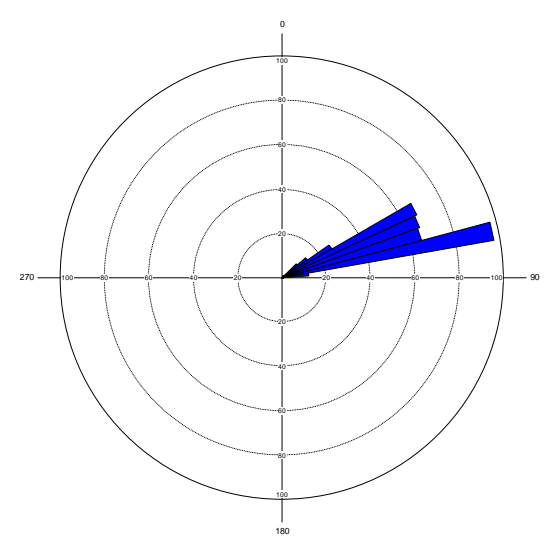

1-16a,2-2,1-7 - November

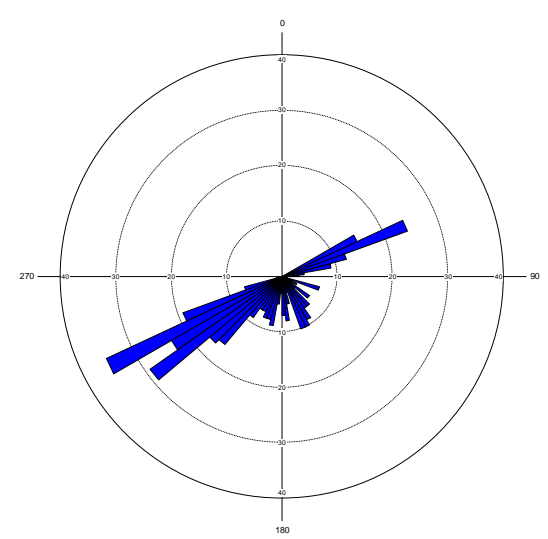

1-16a,2-2,1-7 - January

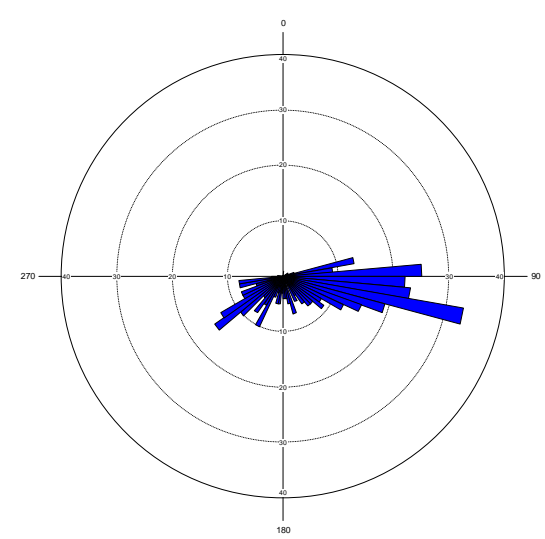

Figure 5.13. Hydraulic Gradient Directions for August 2006 Through January 2007 Calculated from 300 Area Automated Water-Level Network (2-hour data intervals used) for Well Cluster 399-1-16A, 399-2-2, and 399-1-7. Azimuth shows direction toward flow. 

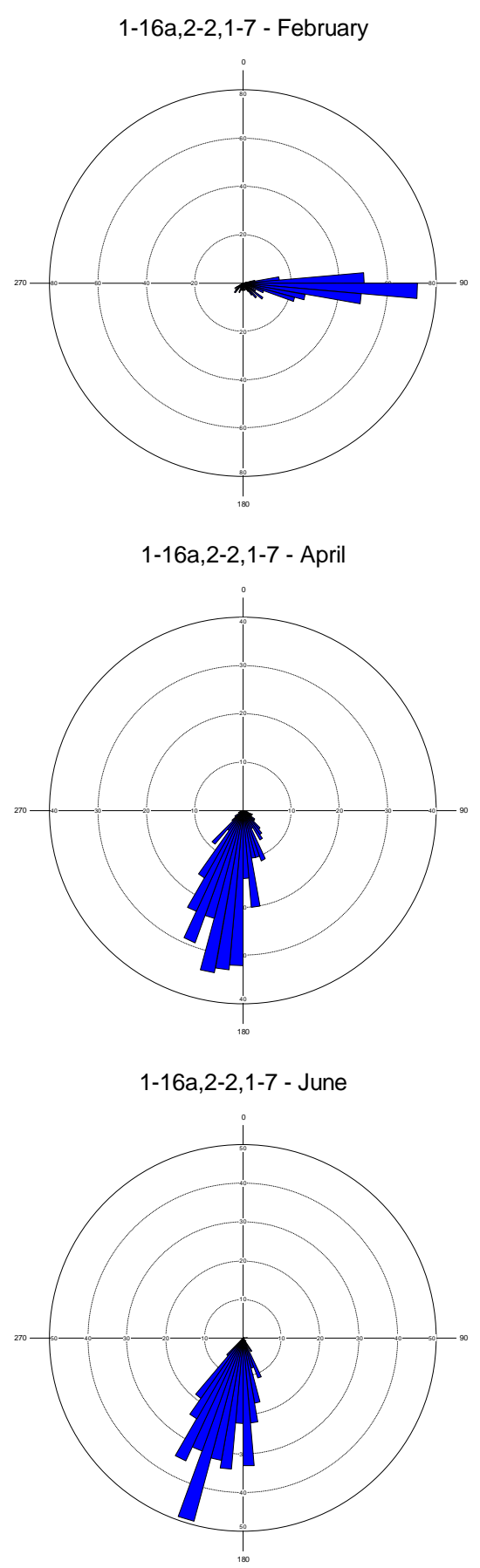
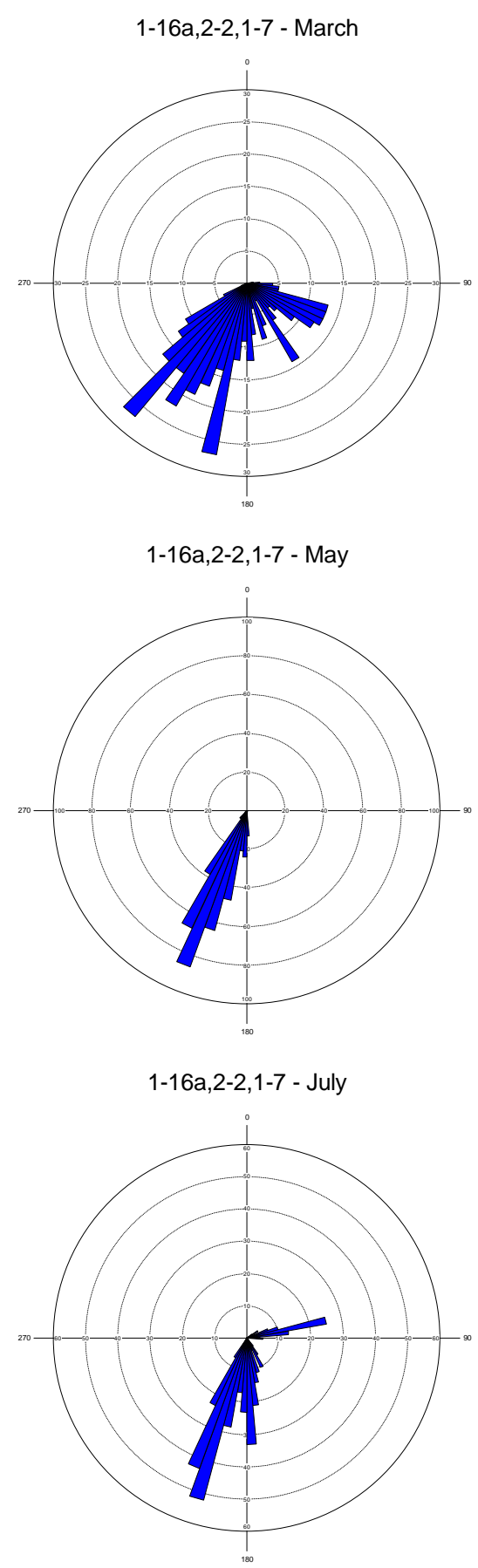

Figure 5.14. Hydraulic Gradient Directions for February 2007 Through July 2007 Calculated from 300 Area Automated Water-Level Network (2-hour data intervals used) for Well Cluster 399-1-16A, 399-2-2, and 399-1-7. Azimuth shows direction towards flow. (Note: some July data are for July 26, 2006 through July 31, 2006). 
Data from the automated water-level monitoring network were used to select the predominant downgradient direction for the location of the downgradient monitoring well for the December 2006 tracer test (predominantly southeast from the treatability test site). Results of the tracer test (discussed briefly in Section 5.1.4) coincided with this direction during that time based on the measured tracer breakthrough curves from the monitoring well network. An additional set of downgradient wells was installed at the polyphosphate treatability test site in May 2007, and the wells are oriented toward the south-southwest, south, and south-southeast of the injection well based on the predicted predominant downgradient directions when the river is at a high stage (April, May, and June). The higher resolution water-level monitoring network that includes the polyphosphate injection well was not operational during a period when the river stage was high, so the coarser dataset was used to guide downgradient directions during this period. Preliminary results of the polyphosphate treatability injection test conducted in early June 2007 showed that the predominant groundwater flow direction during the test was toward the south (flow was to the southeast during the December 2006 tracer test). There is good agreement between the predominant groundwater flow directions measured during these field tests and the predicted directions using these analyses with automated hourly water-level measurement data collected during prior years.

\section{Temperature and Electrical-Conductivity Measurements}

Temperature and electrical conductivity (specific conductance) have been measured hourly and subhourly, along with water-level measurements, in six of the wells in the RACS water-level monitoring network since 2004. These wells are shown in Table 5.1 along with the distance from the Columbia River (see Figure 5.2 for locations). Figure 5.15 shows temperature data for these wells in 2006, and Figure 5.16 shows electrical conductivity. During a relatively high river stage, the river water enters into the aquifer (i.e., bank storage) influencing the groundwater temperature and electrical conductivity. In addition to the differences in temperature between river water and the aquifer (river water is significantly colder that the aquifer), the electrical conductivity of these two waters is also distinctly different and can be used as an indicator for the groundwater/river water mixing zone (see Section 3.3.2 for a discussion of mixing between groundwater and river water). Ambient electrical conductivity values for groundwater (i.e., away from the river or during periods when the river stage is low) in the upper portion of the unconfined aquifer in the Hanford formation are typically 400 to $450 \mu \mathrm{S} / \mathrm{cm}(0.40$ to $0.45 \mathrm{mS} / \mathrm{cm})$ in the 300 Area. Values for Columbia River water near the 300 Area are approximately $130 \mu \mathrm{S} / \mathrm{cm}$ $(0.13 \mathrm{mS} / \mathrm{cm})$. The data in Figures 5.15 and 5.16 show that the extent of the groundwater/ river water mixing zone during the high river stage of 2006 (see Figure 5.1) was at least $188 \mathrm{~m}$ inland in this portion of the 300 Area, based on the responses at well 399-1-7. No impact was seen in the next farthest well inland, well 399-1-12, which is at a distance of $363 \mathrm{~m}$ from the Columbia River.

Table 5.1. Wells Where Hourly and Sub-Hourly Temperature and Electrical Conductivity Measurements are Available from the RACS (2004+) 300 Area Monitoring Network

\begin{tabular}{||c|rc||}
\hline Well Name & \multicolumn{2}{|c|}{ Distance to Columbia River } \\
\hline \hline $399-1-1$ & $50 \mathrm{~m}$ & $(163 \mathrm{ft})$ \\
\hline $399-1-7$ & $188 \mathrm{~m}$ & $(617 \mathrm{ft})$ \\
\hline $399-1-12$ & $363 \mathrm{~m}$ & $(1,190 \mathrm{ft})$ \\
\hline $399-2-1$ & $50 \mathrm{~m}$ & $(154 \mathrm{ft})$ \\
\hline $399-2-2$ & $78 \mathrm{~m}$ & $(256 \mathrm{ft})$ \\
\hline $399-2-3$ & $105 \mathrm{~m}$ & $(345 \mathrm{ft})$ \\
\hline
\end{tabular}




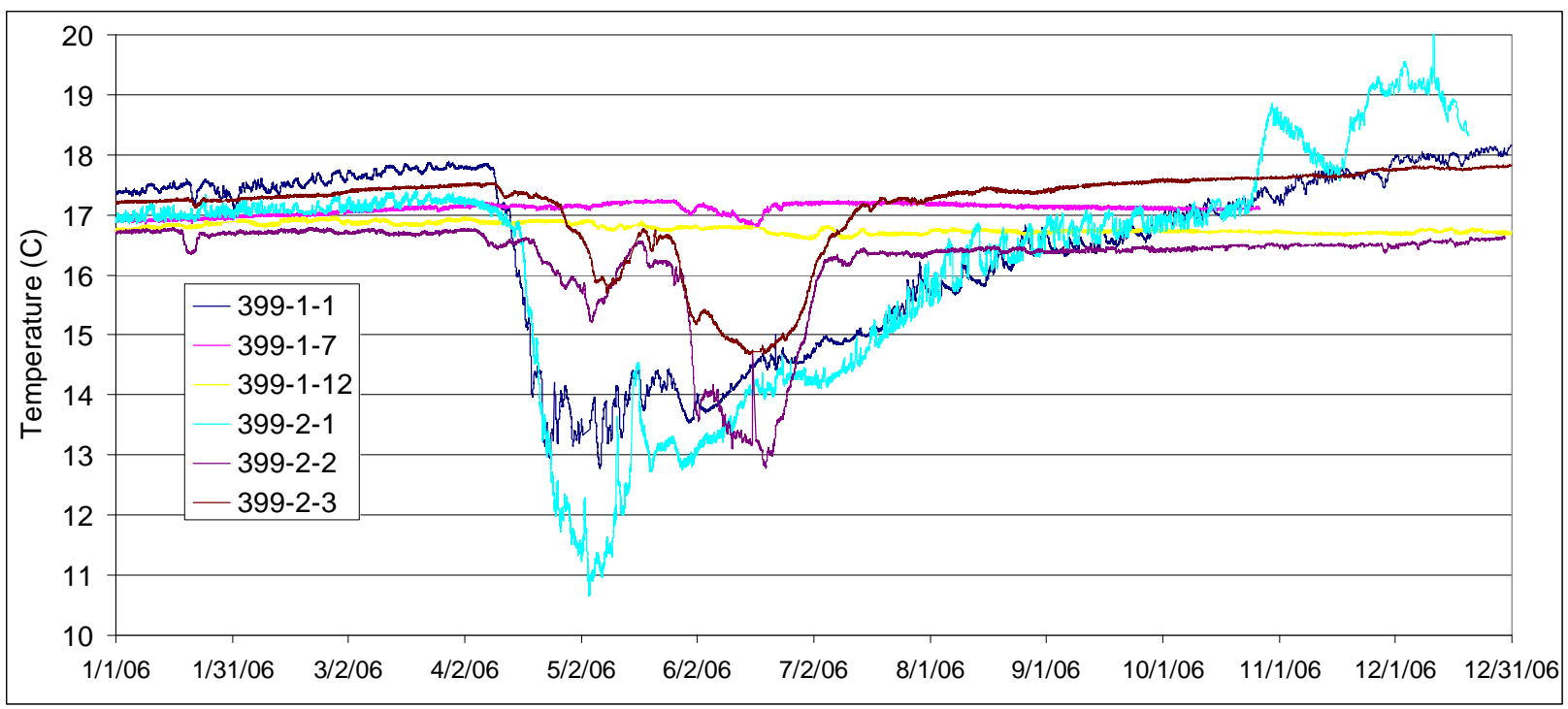

Figure 5.15. Temperature Measurements at Wells in the RACS 300 Area Monitoring Network for 2006

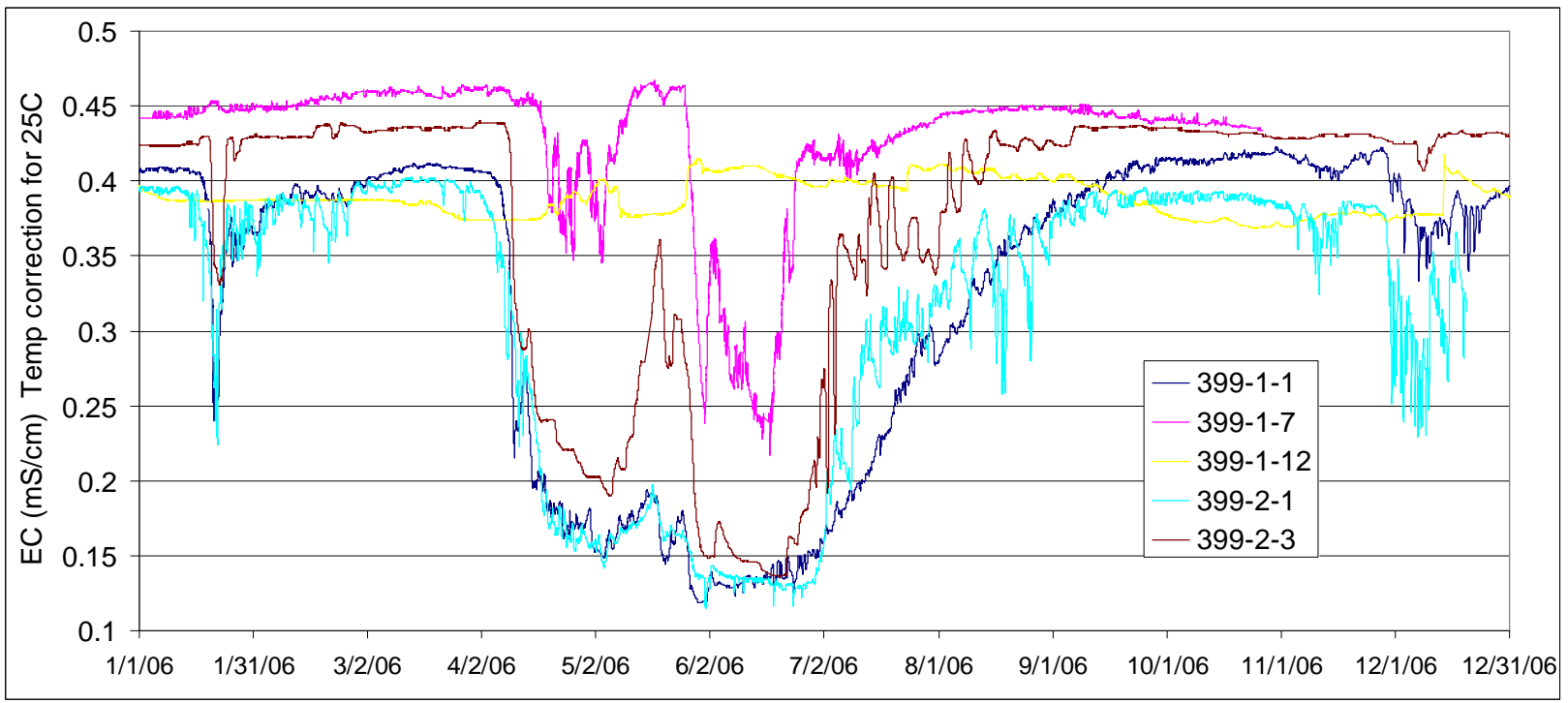

Figure 5.16. Electrical Conductivity Measurements at Wells in the RACS 300 Area Monitoring Network for 2006. (Note: Data for well 399-2-2 are not shown because of problems with this sensor in 2006.)

\subsubsection{Movement Rates Revealed by Historical Plume Events}

Several events have occurred in the past in the 300 Area that reveal information on the migration rates of contaminant plumes. Tetrachloroethene was inadvertently released to the former 300 Area Process Trenches on November 4, 1982 (120 gal) and again on July 6, 1984 (12 to 20 gal), as reported in Cline et al. (1985, pp. 45-52). The specific way in which tetrachloroethene was introduced into the trenches is not clearly described in the report, so it is assumed that the contaminant entered via the process sewer system, along with a considerable volume of other effluent (up to $\sim 2$ million gal/d in 1984). Groundwater monitoring for several days following the first release revealed concentrations of $\sim 1,800 \mu \mathrm{g} / \mathrm{L}$ at well 
399-1-5, which is within the footprint of the facility. Concentrations up to $\sim 700 \mu \mathrm{g} / \mathrm{L}$ were measured at the same well several days following the second release in 1986. Samples were also collected from the nearest riverbank spring (named "Spring 9" or "S3-DR42-2" in recent reports) during each release and permitted an estimate of $35 \mathrm{ft} / \mathrm{d}(10.7 \mathrm{~m} / \mathrm{d})$ for the movement of the contaminant plume.

Tetrachloroethene concentrations currently at wells along the migration path for this plume are very low, i.e., several $\mu \mathrm{g} / \mathrm{L}$ to nondetected (Peterson et al. 2005, p. 2.26).

During October 2002, source remedial actions were underway at the 618-5 burial ground, which is located adjacent to the northeast corner of the former 300 Area Process Trenches (DOE-RL 2005a). In December 2002, a sample collected at well 399-1-10A, located approximately $200 \mathrm{~m}$ southeast of the excavation site and along the downgradient flow path (see Figure 5.17 large-scale gradient map), revealed distinctly elevated uranium concentrations. The previous sample was collected on September 26 and showed a uranium concentration of $32 \mu \mathrm{g} / \mathrm{L}$, while the December 19 sample revealed a concentration of $235 \mu \mathrm{g} / \mathrm{L}$. This change in trend was interpreted as the arrival of a plume created at the burial ground during the excavation activities in October (Peterson et al. 2005, p. 2.2). Exact dates are not available for the excavation activities that might be related to a groundwater impact and for the arrival of the plume at the well. However, the general timing suggests uranium plume migration rates of several meters per day.

Uranium was widespread in the burial ground materials, although no evidence for bulk liquid waste disposal was found. As part of the closeout plan for this excavation, two test pits were excavated in February 2003 to provide a profile of uranium in sediment samples down to the water table. Water samples were also collected at the bottom of each profile and revealed uranium concentrations up to 1,190 $\mathrm{\mu g} / \mathrm{L}$ (Zachara et al. 2005, p. 2.8). So it appears that the burial ground excavation was a potential source area for the uranium plume that arrived at well 399-1-10A.

\subsubsection{Polyphosphate Treatability Test Flow Rates and Directions}

Work on a treatability test in the 300 Area for uranium stabilization in the aquifer using polyphosphate started in 2006 with field testing during 2007. Laboratory tests (Wellman et al. 2006) have shown that injection of polyphosphate solutions into uranium-bearing saturated porous media immobilized uranium by forming an insoluble mineral autinite. This technology also involves forming the mineral apatite (calcium phosphate) in the aquifer from the excess amounts of phosphate and calcium injected into the aquifer. Apatite can provide long-term sequestering capacity for dissolved uranium that migrates into the treatment areas.

The polyphosphate treatability test field site is centered around well 399-1-23, which is located near the south end of the former 300 Area Process Trenches (see index map in Figure 2.1; a well location map is shown in Figure 3.1). Figure 5.17 shows the current monitoring network for the test. Nine of these wells were installed in November 2006 for a tracer test, and six more wells were installed at the south portion of the site in May 2007 for the polyphosphate injection test. Three pairs of monitoring wells at the site are screened in the upper and lower portions of the Hanford unconfined aquifer. The rest of the wells at the site fully screen the Hanford formation aquifer, which is $\sim 5 \mathrm{~m}$ (15 ft) thick. 


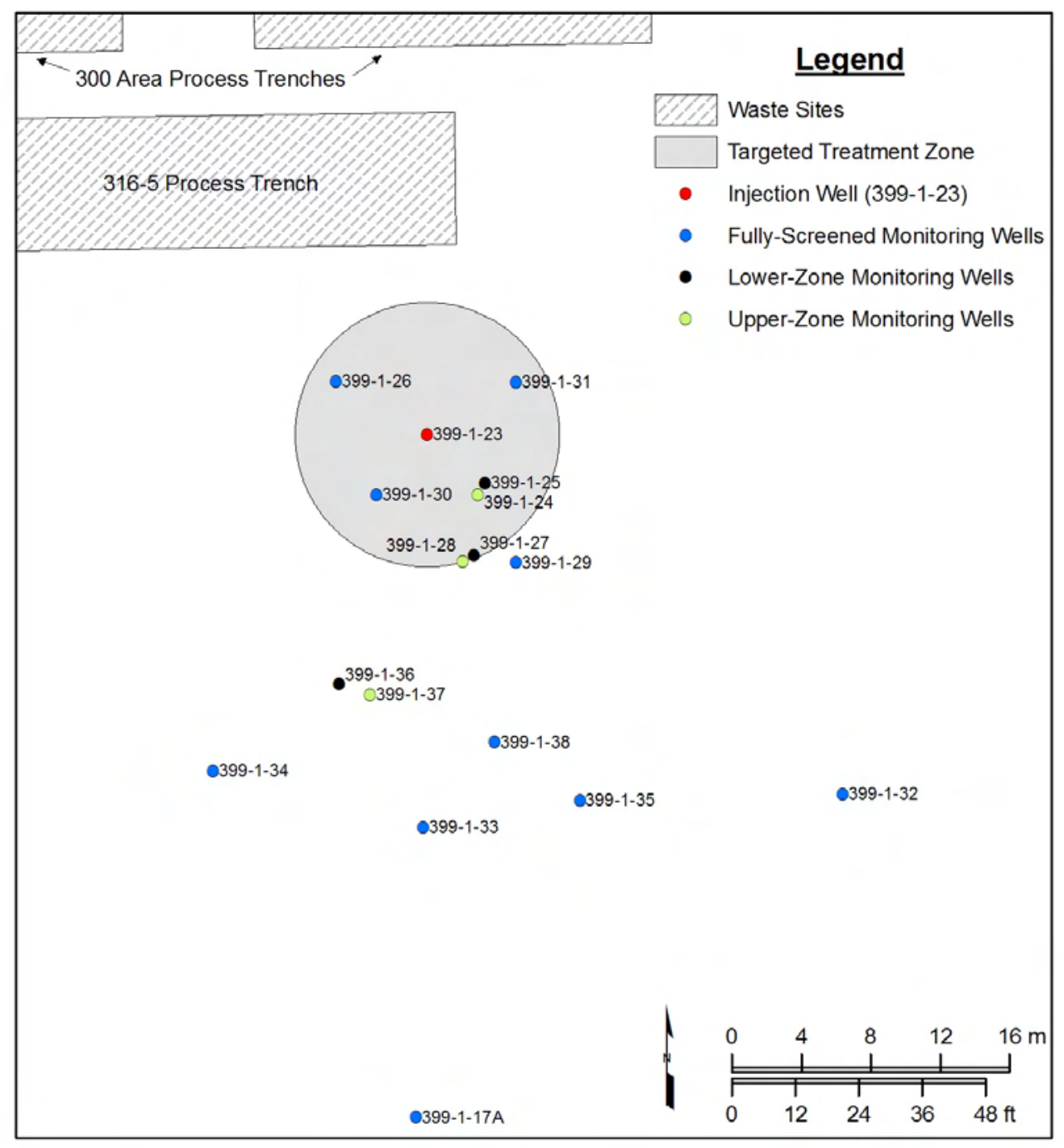

Figure 5.17. Monitoring Well Network for the Polyphosphate Treatability Test

A tracer test was conducted at the polyphosphate treatability test site located around well 399-1-23 on December 13, 2006. During the test, 539,800 L (142,600 gal) of sodium bromide tracer were injected into well 399-1-23 at a rate of $757 \mathrm{~L} / \mathrm{min}(200 \mathrm{gal} / \mathrm{min})$ for a total duration of 11.9 hours. The concentration of the injected tracer was $87 \mathrm{mg} / \mathrm{L}$. The water for the tracer test was supplied by pumping from well 399-1-7 during the test, which is located $190 \mathrm{~m}(620 \mathrm{ft})$ southeast of the injection well 399-1-23. Preliminary results of the tracer concentrations measured in the monitoring and downgradient wells after the injection estimated the tracer velocity at $15 \mathrm{~m} / \mathrm{d}(50 \mathrm{ft} / \mathrm{d})$ toward the southeast during the rest of December and into January of 2007. Relatively high concentrations of tracer (i.e., up to $70 \%$ of the injection concentration) were measured in well 399-1-32 approximately 2 days after the injection. This well is located $32 \mathrm{~m}$ (104 ft) southeast of the injection well. Low concentrations of tracer were also detected using in situ ion-selective electrodes in well 399-1-7 during the period 14 to 55 days after the injection. The effective porosity of the aquifer in the test area was estimated at $18 \%$, based on analysis of tracer arrivals downgradient wells near the injection site. 
Injection of polyphosphate occurred during the period June 11 to June 15, 2007, during which approximately 3,785,412 L (1,000,000 gal) of reagent were injected at well 399-1-23. The injection followed three steps, with an initial 946,352 L (250,000 gal) of sodium polyphosphate solution (a mixture of ortho-, pyro-, and tri-polyphosphate), followed by 1,892,706 L (500,000 gal) of a calcium chloride solution, and a final injection of another 946,352 L (250,000 gal) of sodium polyphosphate solution. Preliminary overall plume monitoring of the polyphosphate test, during and a few weeks following the injection, show that the plume drift is predominantly toward to the south during this time period (as compared to the southeast during the earlier tracer test). A report describing the test in detail and its results should become available by late summer 2008 .

\subsection{Computer Simulations of Groundwater Flow and Transport}

Field-scale groundwater flow and transport simulations of the vadose zone and aquifer are being developed to support the 300-FF-5 Operable Unit Phase III Feasibility Study (DOE-RL 2005b). The objectives of this effort are to a) develop numerical groundwater flow-and-transport models to help refine the site conceptual model, and b) assist in the assessment of proposed alternative remediation technologies that are focused on the 300 Area uranium plume.

The unconfined aquifer in the 300 Area is a very dynamic system because of the influence of fluctuations in the Columbia River stage (daily, weekly, and seasonal), the very high permeability of the Hanford formation (the unit at the water table), and the heterogeneous characteristics of aquifer sediment. To simulate the dynamics of this system, two groundwater flow-and-transport models were developed based on the availability of high resolution water-level data from networks of wells around the 300 Area. The aerial photograph in Figure 5.18 shows the lateral domains of the two model. These threedimensional models include the upper portion of the unconfined aquifer and the lower portion of the vadose zone. The first model has a larger domain and is based on the water-level monitoring network established in the early 1990s (Campbell and Newcomer 1992; Campbell 1994). The second model is based on the current water-level monitoring network that was established in 2004 by the RACS project and has been supplemented by other projects in the subsequent years (Fritz et al. 2007). This new water-level monitoring network covers the area between the former 300 Area Process Trenches (316-5 waste site) and the former South Process Pond (316-1 waste site). This water-level monitoring network is planned for a southern expansion in fiscal year 2008. These models use the STOMP code, a general-purpose tool for simulating subsurface flow and transport developed at PNNL (White and Oostrom 2000, 2004).

These groundwater flow models were built from a common three-dimensional hydrostratigraphic framework that was developed in EarthVision ${ }^{\mathrm{TM}}$ as described in Section 4.0. The models are focused on the upper portion of the unconfined aquifer where uranium contamination is present. The upper portion of the unconfined aquifer is composed of saturated sediment of the Hanford formation (the unit at the water table and the most permeable unit in the 300 Area), and a portion of the uppermost Ringold Formation that consists of gravels and a finer-grained subunit. The models also include the lower portion of the vadose zone just above the maximum elevation of the water table during the past few years. 


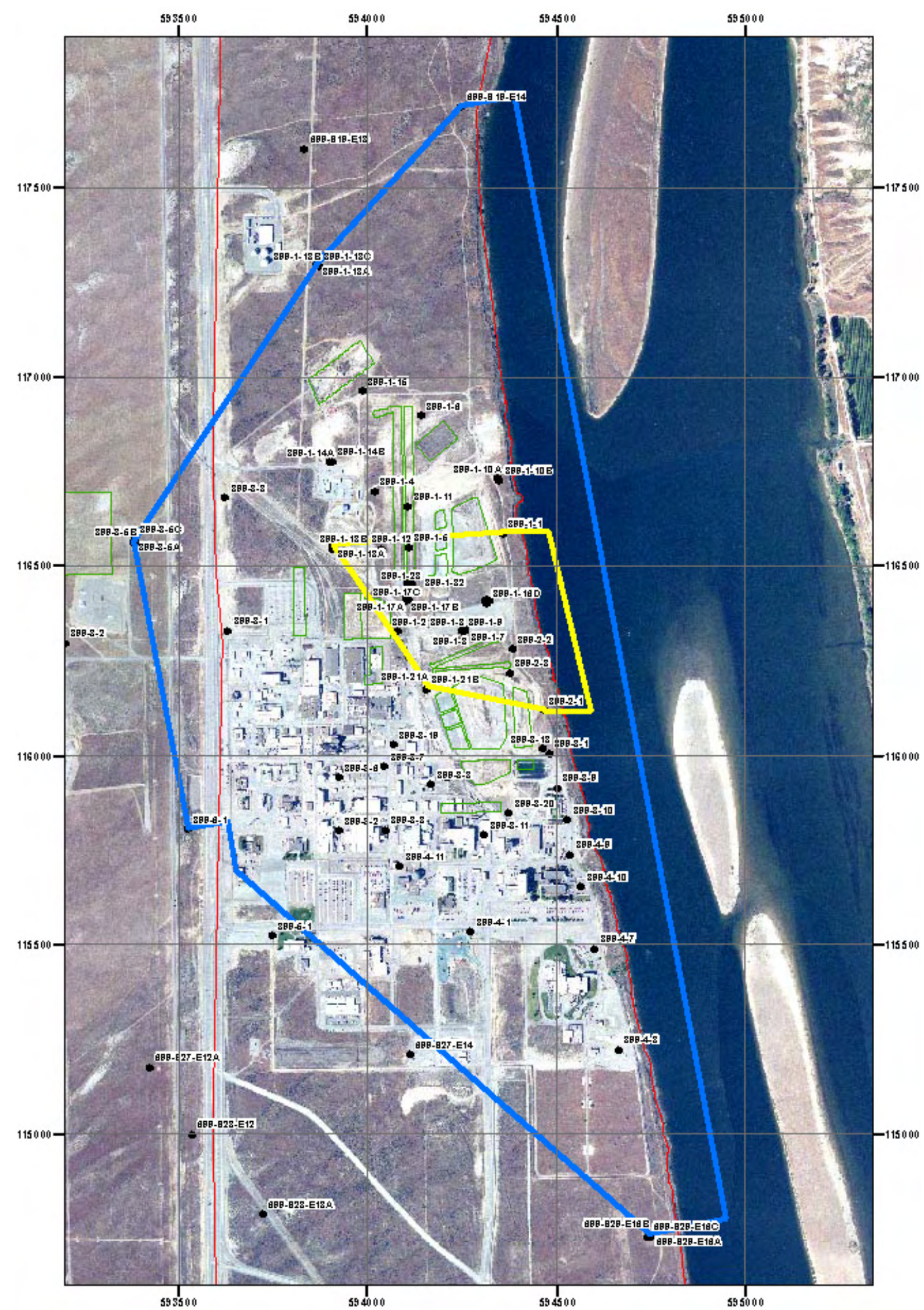

Figure 5.18. Boundaries for Three-Dimensional Models in the 300 Area. The blue line shows the domain of the larger scale model based on the early 1990s water-level monitoring network, and the yellow line shows the domain of the smaller scale model based on the $2004+$ network. 


\subsubsection{Previous Modeling Studies}

The earliest numerical groundwater modeling study of the 300 Area was by Lindberg and Bond (1979). They developed a submodel of the 300 Area with boundary conditions provided by the larger scale Hanford site model. These models were two-dimensional (x-y) transmissivity models that used the variable thickness transient groundwater flow finite difference code (Kipp et al. 1972). Lindberg and Bond (1979) developed a calibrated flow model by specifying transmissivity distributions to fit weekly water-level measurements collected from 29 wells in the 300 Area in 1977. Transmissivities for the final calibrated model ranged from 150,000 to $20,000,000 \mathrm{gal} / \mathrm{d} / \mathrm{ft}$, with the highest values in the central portion of the model. The transient flow model included water sources/sinks from the 300 Area operations. Average groundwater velocities from selected streamlines (using steady-state flow fields at selected times with an assumed porosity of $10 \%)$ were $5.5 \mathrm{~m} / \mathrm{d}(18 \mathrm{ft} / \mathrm{d})$ with ranges of the published streamlines from 0.3 to $43.3 \mathrm{~m} / \mathrm{d}$ ( 1 to $142 \mathrm{ft} / \mathrm{d}$ ). Pathlines were calculated using the transient flow field and were compared to a steady-state streamline at the same starting location and time that showed that the travel time to the river was longer in the transient pathline. Transport calculations for a number of radionuclides were run using the variable thickness transient velocity field with the multi-component mass transfer model for a test case based on spill from the 325 Building in 1979. Radionuclide transport was simulated using distribution coefficients $\left(\mathrm{K}_{\mathrm{d}}\right)$.

A three-dimensional numerical model was developed for the Phase I remedial investigation of the 300-FF-5 Operable Unit in 1993 (DOE-RL 1994b). This model used the PORFLO-3 code, a saturated/unsaturated finite difference flow-and-transport code. The model contained four hydrofacies zones, which had been developed for the 300 Area by Gaylord and Poeter (1991), and consisted of gravel, sandy gravel, sand, and mud/silt. These hydrofacies were applied to the grid to create 17 separate zones in the model. Flow calibration runs were made with limited monthly steel tape measurements along with a short period for which hourly water-level data were available. Final hydraulic conductivity for the model "ranged from $0.2 \mathrm{~m} / \mathrm{d}$ for mud/silt to $7500 \mathrm{~m} / \mathrm{d}$ for gravel” (DOE-RL 1994b, p. D-4). Flow-andtransport simulations were conducted with various $K_{d}$ values for uranium $(0,1,10$, and $25 \mathrm{~mL} / \mathrm{g})$ with initial uranium concentrations set for the aquifer from contoured measured concentrations from the first quarter of 1992. No additional input to groundwater from sources in the vadose zone were considered. Since there were no additional uranium sources for the model, simulated uranium concentrations decreased from the initial concentrations through time for all the cases. Results from the $\mathrm{K}_{\mathrm{d}}=1 \mathrm{~mL} / \mathrm{g}$ case starting with the 1992 uranium concentrations showed that simulated uranium concentrations decreased to less than $10 \mathrm{pCi} / \mathrm{L}$ by the year 2000 . For the $\mathrm{K}_{\mathrm{d}}=25 \mathrm{~mL} / \mathrm{g}$ case, maximum simulated concentrations were $23 \mathrm{pCi} / \mathrm{L}$ at the year 2018. This model was also used to investigate possible remediation scenarios (e.g. the impact of extraction wells). Simple one-dimensional analytic models were also developed based on the travel times from the three-dimensional model results. Results of these models were used for the RI/FS for the 300-FF-5 Operable Unit in 1995 (DOE-RL 1995b).

The Residual Radioactivity (RESRAD) model (ANL 1993) was used in the 300 Area to evaluate and help determine the uranium soil cleanup levels for the 300-FF-1 and 300-FF-2 source operable units (Callison and Clark 2002). The RESRAD simulations in this study were designed to represent future conditions at the site with a vegetated cover and natural recharge. Simulations were conducted to determine soil uranium concentrations in the upper $4 \mathrm{~m}$ of the soil zone that would not exceed the $30 \mu \mathrm{g} / \mathrm{L}$ maximum contaminant level for uranium in the aquifer immediately downgradient of the contaminated soil site. The simulations only considered the transport of uranium from initial residual contamination in the upper portion of the vadose zone $(4 \mathrm{~m})$. The lower vadose zone, i.e., below the 4-m depth, and aquifer 
were considered uncontaminated for the initial conditions used in this modeling effort. The aquifer was treated as a constant thickness with a hydraulic conductivity of $673,846 \mathrm{~m} / \mathrm{yr}(1,845 \mathrm{~m} / \mathrm{d})$ and hydraulic gradient of $5 \times 10^{-4}$. The study attempted to capture site-specific uranium leaching and sorption investigations using contaminated 300 Area sediment samples under various water chemistries in benchscale column and batch experiments (Callison and Clark 2002; Serne et al. 2002a). Based on the cited laboratory studies, a $\mathrm{K}_{\mathrm{d}}$ of $8.9 \mathrm{~mL} / \mathrm{g}$ was selected for the uppermost 4-m contaminated zone, and a $\mathrm{K}_{\mathrm{d}}$ of $0 \mathrm{~mL} / \mathrm{g}$ was used for the lower vadose zone and aquifer to provide a conservative estimate. The results from this study were used to revise the soil cleanup standard downward, from $350 \mathrm{pCi} / \mathrm{g}$ total uranium to $267 \mathrm{pCi} / \mathrm{g}$.

Waichler and Yabusaki (2005) developed a two-dimensional (x-z) model of the aquifer and vadose zone using the STOMP code along the transect between well 399-6-1 and the Columbia River. This model used hourly water-level data from the 300 Area and the hourly river stage measured at the 300 Area in the early 1990s (see Section 5.1.1) to provide boundary conditions for the two-dimensional model and for comparison with model predictions. Cases were run with the vertical domain extending down to the top of the basalt and a shallower domain down to the top of the Ringold mud unit. Simulated fluxes from the deeper model that extended to the basalt were small relative to fluxes in the uppermost part of the unconfined aquifer, so the shallower domain was used for the study. Cases were also run with different hydraulic conductivities (K) specified for the Hanford formation, which is the most permeable unit and is at the top of the unconfined aquifer in the 300 Area, ranging from 1,500 m/d day to 15,000 m per day. Solute transport simulations were conducted with these simulations to illustrate the mixing zone between the river and the aquifer. The mixing zone simulated by a river tracer extended up to $150 \mathrm{~m}$ inland for the base case (1,500 m/d Hanford formation $\mathrm{K}$ ) and extended further inland for the higher $\mathrm{K}$ case. The study showed large reductions in the extent of the simulated mixing zone using boundary conditions (i.e., river stage) averaged daily or monthly compared to simulated results using hourly forcing; however, the study stated that a 2-hour to 12-hour time step may be acceptable.

Meyer et al. (2007) described the development of a comprehensive methodology for a combined estimation of the hydrogeologic conceptual model, parameter, and scenario uncertainty as well as its application to uranium transport at the Hanford Site 300 Area. The methodology is based on an extension of a Maximum Likelihood implementation of Bayesian Model Averaging. For the 300 Area application, 8 alternative models representing uncertainty in hydrogeologic and geochemical properties as well as the temporal variability were considered. Two alternative scenarios representing the alternative future behavior of the Columbia River were also considered. The alternative models developed using MODFLOW and MT3DMS were calibrated using hydraulic head and uranium concentration observations over a 7-year period. Uranium concentrations under each scenario were then predicted over a 20-year period. This work represents the first successful attempt at joint calibration of groundwater flow and transport models for the 300 Area using hydraulic head and uranium concentration data. More importantly, this work demonstrates the feasibility of applying a comprehensive uncertainty assessment to large-scale, detailed groundwater flow-and-transport modeling. Note that Meyer et al. (2007) did not consider continuing the sources of uranium in the vadose zone, primarily because the uraniumconcentration distribution in the vadose zone is largely unknown. 


\subsubsection{Large Domain 300 Area Groundwater Flow and Transport Model}

Figure 5.19 is a plan view of the grid that is being used for large-domain STOMP flow-and-transport model simulations for the 300 Area. For model execution, the grid is oriented approximately 10 degrees counterclockwise from north, so in the plan view, it is approximately orthogonal to the Columbia River. This section briefly describes the model and example simulation results, which are described in detail in Williams et al. (2008).

Initial simulations are being conducted with these models to select hydraulic properties. Simulation results are being evaluated based on a best-fit with the water-level data for wells within the model domain. Hydraulic property distributions include uniform properties for the main Hanford and Ringold gravel units, limited hydraulic conductivity zonations within the Hanford formation, and a heterogeneous K distribution within the Hanford formation based on stochastic analysis of geophysical logs and sediment physical properties. Results of these models include water fluxes along the boundaries and river and conservative tracer pulses to help illustrate flow directions and plume velocities.

\section{Model Description}

The grid consists of 70 by 122 by 33 nodes in the $\mathrm{x}, \mathrm{y}$, and $\mathrm{z}$ directions, respectively, for a total of 281,820 model nodes. Some of these nodes along the southwest and northwest portions of the rectangular model finite-difference grid are inactive for alignment of the model boundaries between wells used for specifying boundary conditions. Nodes above the bottom of the Columbia River in the model domain are also inactive. The total number of active nodes is 242,290 (39,530 inactive). In the $\mathrm{x}$ (east-west) direction, grid-block sizes vary from a minimum of $10 \mathrm{~m}$ (32.8 ft) to a maximum of $100 \mathrm{~m}(328 \mathrm{ft})$. In the y direction (north-south), grid-block sizes vary from a minimum of $10 \mathrm{~m}$ (32.8 ft) to a maximum of $102 \mathrm{~m}$ (335 ft). The overall $\mathrm{x}-\mathrm{y}$ domain is defined to include groundwater flow below the waste sites of interest for the 300-FF-5 Phase III Feasibility Study and is based on the availability of hourly water-level data collected from wells in the early 1990s.

The 10-m x-y grid refinement area is for coarse transport simulations around the important waste sites and continuing to the river. Preliminary tracer pulse runs at different times of the year (i.e., different water table/river-stage regimes) were used to define the northern, western, and southern portions of the domain for 10-m refinement. The model domain extends vertically from an elevation of 90 to $109 \mathrm{~m}$ (295 to $358 \mathrm{ft}$ ) above mean sea level. (Note: the vertical datum for all elevations used in this model is NAVD88). This vertical range encompasses three hydrostratigraphic units (from top to bottom): undifferentiated Hanford formation gravels and sands, a fine-grained subunit of Ringold Unit E, and Ringold Unit E gravels. Although this model domain extends into the capillary fringe region, it does not include most of the vadose zone, which extends up to the ground surface. In the vertical direction, variable grid-block sizes are used, with 1-m spacing in the lower part of the domain to from the 90- to 95-m elevation followed by 0.5-m vertical grid spacing from 95 to $109 \mathrm{~m}$ for the upper part of the unconfined aquifer and the capillary fringe region. This was done to encompass the range of water-table fluctuations during the simulation period of the early 1990s in the lower vadose zone. Three 0.5-m vertical nodes (1.5-m total) of a riverbed alluvium are mapped on the river bottom below the bathymetry. 


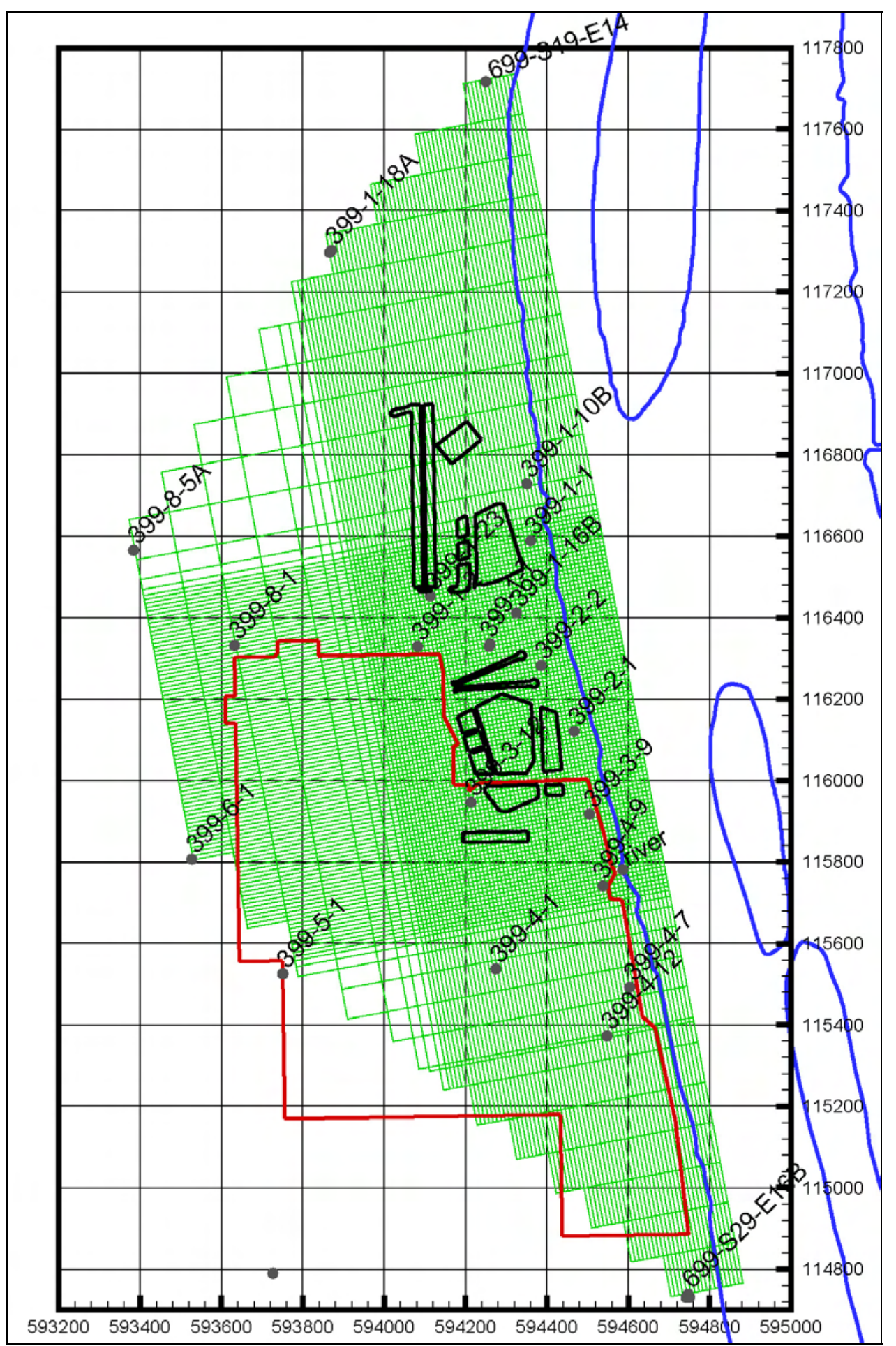

Figure 5.19. Plan View of STOMP Model Grid R5B with Selected Wells. Surfaces are shown by green lines and wells by solid gray circles. Also shown are outlines of the 300 Area (red lines), primary waste disposal areas (heavy black lines), the Columbia River shoreline and islands (blue lines). 
Boundary conditions for cell faces on the north, south, west, and east (river) sides of the model domain were specified as linked lists of seepage faces. For seepage face boundary conditions, Dirichlettype (specified head) boundary conditions are applied to the outer cell faces of grid blocks that have aqueous pressures greater than or equal to atmospheric pressure (101,325 Pa). No-flow boundary conditions are applied to the outer cells faces of grid blocks that have aqueous pressures less than atmospheric pressure (e.g. unsaturated conditions). This leads to flow into or out of the model domain, or no-flow conditions, depending on the pressures at the boundaries and the adjacent nodes. Boundary pressures are computed based on the aqueous pressure and coordinates for the first surface defined in the linked list. Changes in gravitational potential associated with differences between the elevation of the reference cell face and all other cell faces in the linked list are automatically accounted for. In addition, hydraulic gradients in $\mathrm{x}-\mathrm{y}$ directions can be specified to account for gradients in the river stage or between wells.

Model boundaries are driven by hourly water-level measurements from wells collected during the early 1990s (see Section 5.1.1) on the north, south, and west of the domain (see Figure 5.19). The largescale model domain was determined by the availability of data from the water-level monitoring network of the early 1990s. Measurements for wells in this network had differing periods of record. Wells for the boundary conditions were selected based on having data from approximately January 1992 to March 1993, a period that overlapped with the majority of wells in the network. Hourly water-level measurements from wells 399-6-1 and 699-S29-E16B were applied to the southern boundary with hydraulic heads linearly interpolated to model boundary surfaces between these wells. Note that well 699-S29-E16B has a deeper screen than the uppermost screen in well 699-S29-E16A, which is part of the same well cluster, but it had similar values; however, a portion of the data for well 699-S29-E16A (i.e., during the second half of 1992) were suspect (i.e., did not respond to river fluctuations). Hourly water-level measurements from wells 399-6-1 and 399-8-5A were applied on the western model boundary. The northern boundary was broken into two segments between three wells: 399-8-5A, 399-1-18A, and 699-S19-E14. The east boundary of the model, along the Columbia River, is set from hourly river-stage measurements from a river-stage recorder in the 300 Area (SWS-1). Transient Columbia River gradients are applied to the river stage on the eastern boundary of the model using values calculated from the MASS1 model (Waichler et al. 2005) from two points at different locations (north and south) along the 300 Area shoreline. The hourly water-level data for the model boundaries are sub-sampled every 2 hours to reduce simulation run times.

A flux of $55.4 \mathrm{~mm} / \mathrm{yr}(2.18 \mathrm{in} / \mathrm{yr})$ is applied for the upper boundary of the model on the west of the river shoreline to represent the long-term average natural groundwater recharge rate. This rate is based on the analysis by Fayer and Walters (1995), which uses data from the Buried Waste Test Facility (BWTF) in the 300 North Area (Rockhold et al. 1995, Table 3.1).

In addition to natural recharge, artificial recharge also occurred at the former 300 Area Process Trenches (316-5 waste site) during the simulation time period (1992 to 1993). This facility received discharge from the 300 Area process sewer. The estimates for volumes and dimensions that follow are from DOE (1997a). The estimated volumes for each year, in millions of liters, are: $1991(1,290), 1992$ (568), 1993 (416), and 1994 ( 378). The 300 Area Process Trenches consist of two parallel trenches

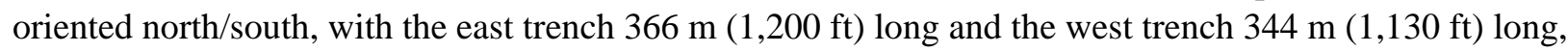
and located to the north of the 300 Area fence line boundary (see Figures 1.2 and 3.1). "Both trenches

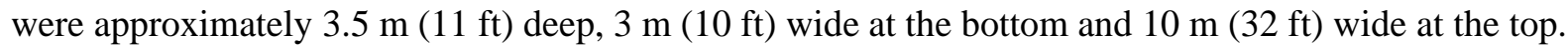
Trench bottoms slope gently to the north and are approximately $3.4 \mathrm{~m}(11 \mathrm{ft})$ above the water table” 
(DOE 1997a, p. 2-1). During operation, the east and west trenches were used alternately. "Effluent was delivered to one trench for 4 to 6 months or until it rose to an operationally determined level; it was then diverted to the other trench" (DOE 1997a, p. 3-1). Discharge to the west trench was ended in November 1992 (Lindberg and Chou 2001). All discharges to the trenches ended in 1994 when the effluent from the process sewer was routed to the newly constructed 300 Area Treated Effluent Disposal Facility.

In 1991, an Expedited Response Action was conducted on the 300 Area Process Trenches where contaminated soil was removed from the bottom and sides of the trenches (DOE 1992). While the total surface area of the waste site was large $\left(\sim 7,100 \mathrm{~m}^{2}\right.$ total), during the last 2 years of operation (1992

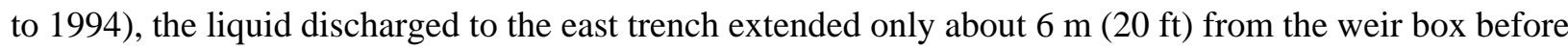
percolating into the soil (DOE 1997a). Based on this information, trench discharges were applied over four $10-\mathrm{m}$ by $10-\mathrm{m}$ grid blocks. This area is six times the reported area for one trench discharge during the early 1990s to provide for additional spreading of the water source since the top of the model domain is below the bottom of the trenches with the 10-m x,y grid spacing in this portion of the model domain. Since detailed records for operations of the separate east and west trenches have not been found, the simulated timing of the operation of the east and west trenches was estimated using a 6-month interval and back-calculating dates based on the reported November 1992 ending of the west trench operations as reported in Lindberg and Chou (2001).

Water withdrawal at water-supply well 399-4-12 for the aquariums in the 331 Building occurred during the simulation period. The average pumping rate for well 399-4-12 from June 9, 2003, through July 6, 2004, was 1,431 L/min (378 gal/min), based on records kept at the 331 Building (personal communication, T. M. Moon to R. E. Peterson, PNNL). This average pumping rate was assumed for the entire simulation period.

For unsaturated zone parameters in the STOMP code, a Brooks-Corey function is used along with a Burdine porosity distribution model for aqueous relative permeability. The air-entry pressure and lambda parameters for the Hanford formation are based on data from Rockhold et al. (1988, p. A.1), which represent the ("L-soil") sediment used in the BWTF lysimeters, located north of the 300 Area. The irreducible-saturation parameter, Sr, was estimated at 0.16 based on data from well 699-S20-E10 (see Figure 8 in Williams et al. 2006).

Hydraulic conductivity values and distributions, including a stochastic distribution based on sediment physical property measurements and geophysical logs, are being evaluated based on comparison of the simulated and measured water levels for wells within the model domain. An example of the properties and results from one example is given in the following section.

\section{Example Simulation Results}

Groundwater flow simulation results for an example case with uniform hydraulic properties for the Hanford formation (see Table 5.2 for hydraulic properties) are discussed below. Figure 5.20 shows the three-dimensional zonations for this model. 
Table 5.2. Hydraulic Properties Used in Case: coral:/files1/r5b-flow-lowrk

\begin{tabular}{||l|l||}
\hline \multicolumn{1}{|c|}{ Unit } & \multicolumn{1}{|c|}{ Hydraulic Conductivity } \\
\hline \hline Hanford gravels (Unit 1) & $\mathrm{Kxy}=6,000 \mathrm{~m} / \mathrm{d}, \mathrm{Kz} / \mathrm{Kxy}=0.1$ \\
\hline Fine-grained Ringold facies (Unit 4) & $\mathrm{Kxy}=1 \mathrm{~m} / \mathrm{d}, \mathrm{Kz} / \mathrm{Kxy}=0.1$ \\
\hline Ringold E gravels (Unit 5) & $\mathrm{Kxy}=40 \mathrm{~m} / \mathrm{d}, \mathrm{Kz} / \mathrm{Kxy}=0.1$ \\
\hline River alluvium & $\mathrm{Kxy}=1 \mathrm{~m} / \mathrm{d}, \mathrm{Kz} / \mathrm{Kxy}=1$ \\
\hline
\end{tabular}

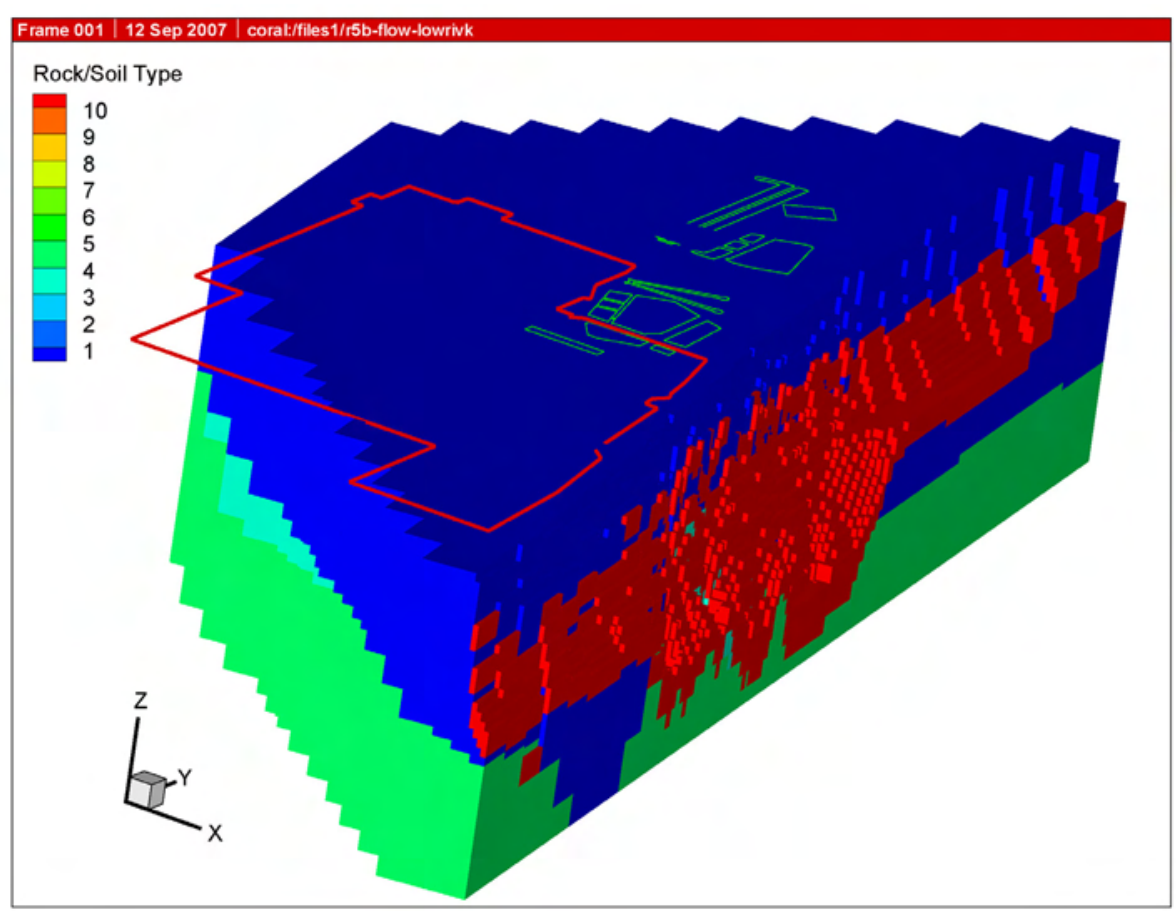

Figure 5.20. Three-Dimensional View of STOMP Model Grid R5B with the Top of the Model Domain in the Vadose Zone at an Elevation of $109 \mathrm{~m}$. The blue color is the Hanford formation (Unit 1), the blue-green color is the fine-grained Ringold unit (Unit 4), the green color is the Ringold E gravels, and the red color is the river alluvium. Also shown is the outline of the 300 Area (red line) and primary waste disposal sites (green lines).

Figure 5.21 shows water fluxes for the outer model boundaries over the simulation period for this case. Instantaneous fluxes for the river boundary are larger than for the other model boundaries and show rapid changes between inflow and outflow. Instantaneous fluxes are predominantly into the model domain on the northern and western boundaries (negative values) and out of the model domain on the southern boundary (positive values).

The shoreline length for the larger scale model is 3,019 $\mathrm{m}$ (distance between wells 699-S29-E16A and 699-S19-E14). The cumulative fluxes along the model boundaries are shown in Figure 5.22 for the simulation period. Figure 5.23 shows cumulative fluxes for a 1-year period from February 1992 to February 1993. This figure also shows the natural and artificial recharge and discharges for comparison with the boundary fluxes. 


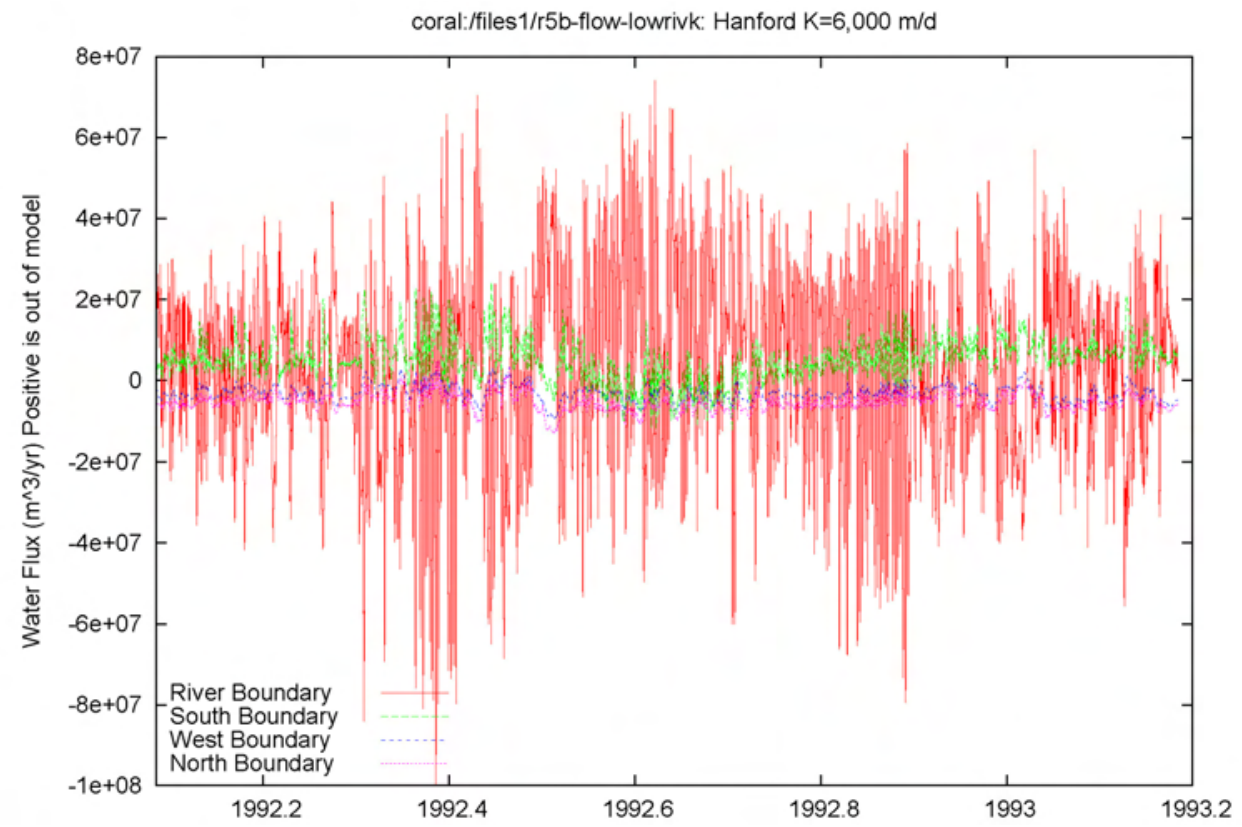

Figure 5.21. Simulated Instantaneous Water Fluxes Calculated for Model Boundaries (r5b-flow-lowrivk run)

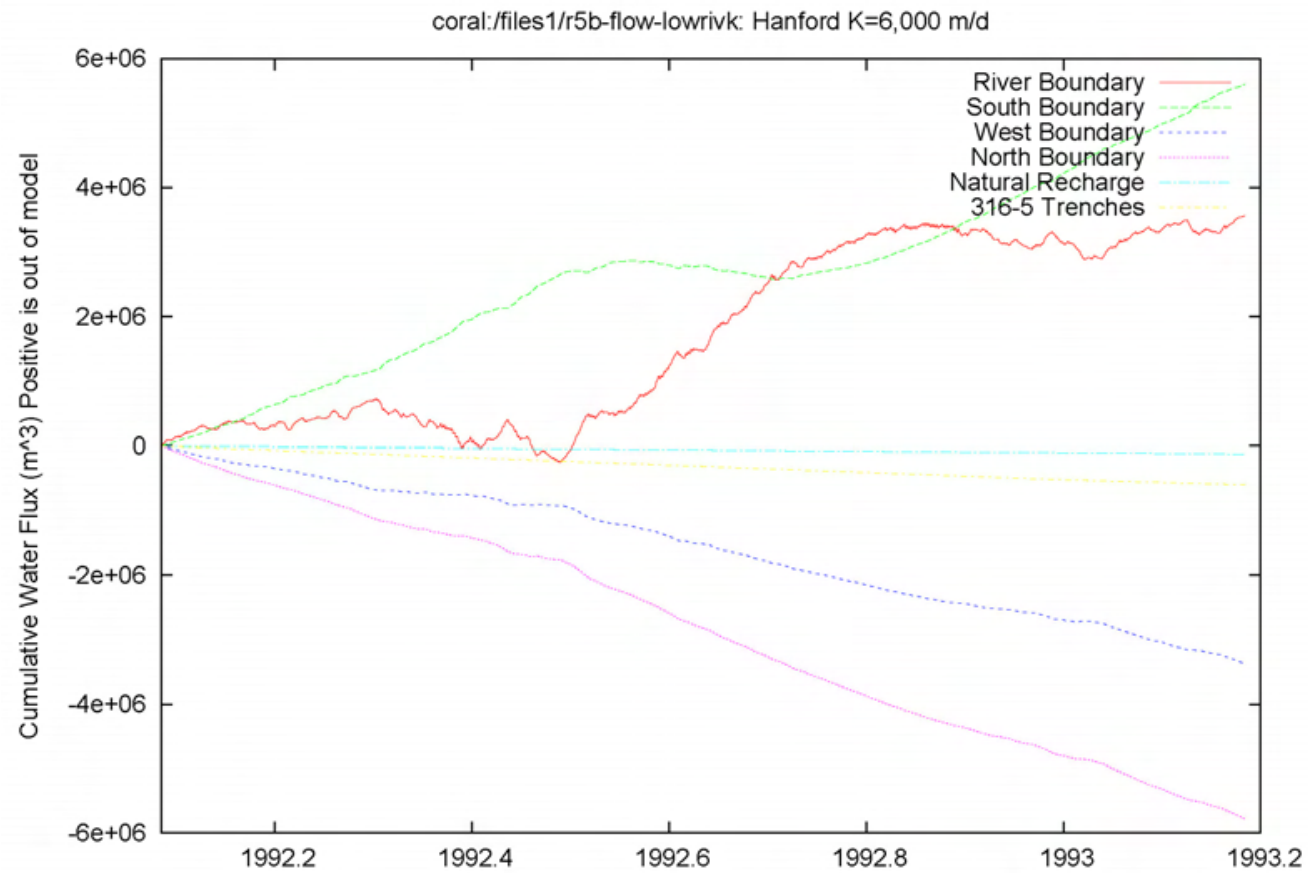

Figure 5.22. Simulated Cumulative Water Fluxes Calculated for Model Boundaries (r5b-flow-lowrivk run) 


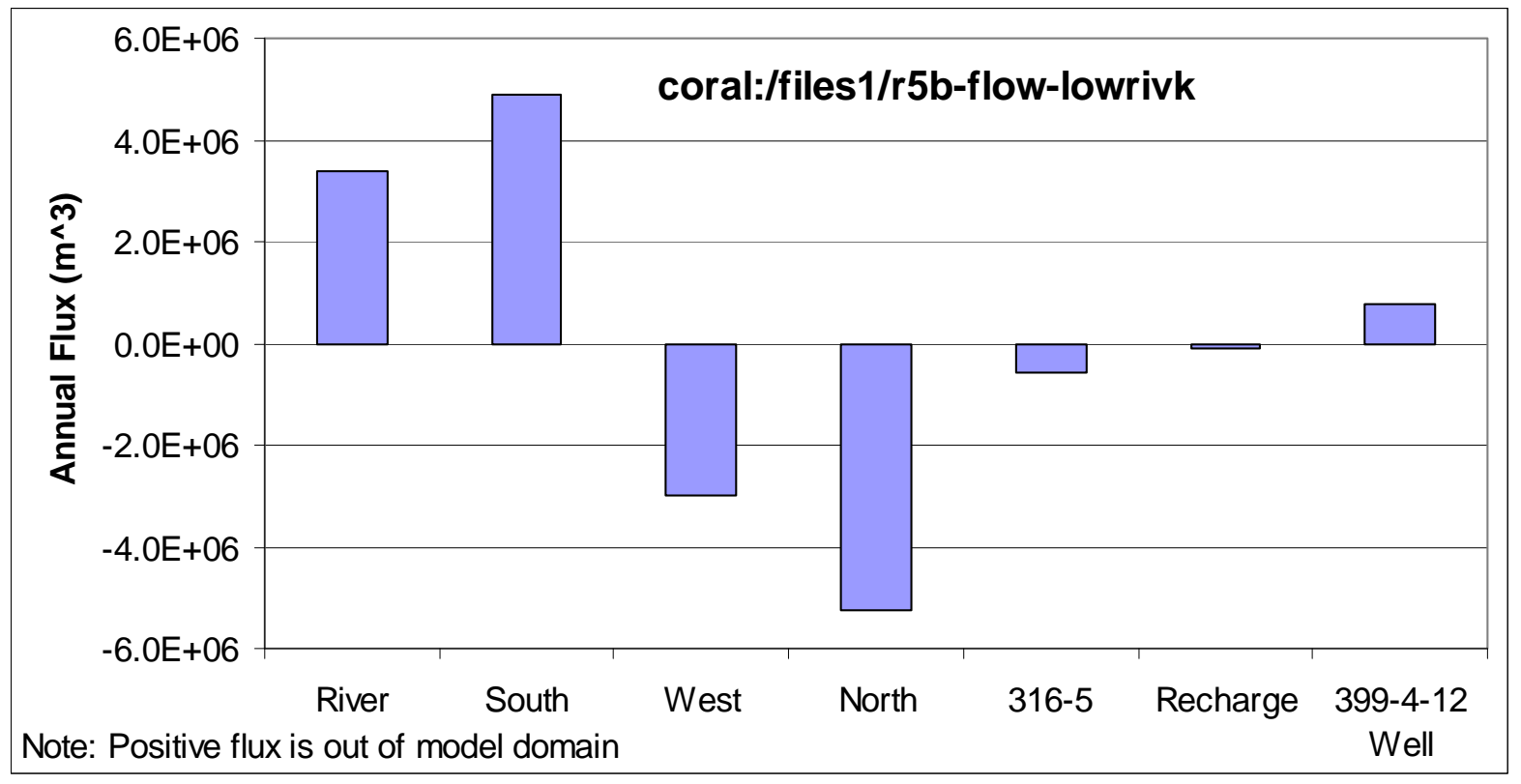

Figure 5.23. Simulated Annual Cumulative Water Flux for Period from February 1, 1992 to February 1, 1993, Along 3,019 m of 300 Area Shoreline

In addition to simulations with different hydraulic conductivities, tracer pulses are also being simulated with the larger scale model in the locations of three potential sources: North Process Pond, South Process Pond, and the 300 Area Process Trenches. The directions and rates of these simulated pulses are used to evaluate the simulations, based on plume velocities estimated from field tests, and to investigate potential migration directions from these source areas.

\subsubsection{Smaller-Domain 300 Area Flow and Transport Modeling}

Figure 5.24 is a plan view of the grid that is being used for smaller domain 300 Area STOMP flowand-transport model simulations based on the 2004 and more recent water-level monitoring network. This section briefly describes the model (see Williams et al. 2008 for details) and example simulation results. Initial simulations are being conducted with these models to select hydraulic property distributions and values. Simulation results are being evaluated based on 1) a best-fit with the water-level data for wells within the model domain, 2) the extent of the simulated groundwater/river water mixing zone compared to downhole probe electrical conductivity measurements (see discussion in Section 5.1.2 and Figure 5.16), and 3) a comparison of simulated groundwater flow directions and rates to results from field tests in the area. Results of these models include water fluxes along the boundaries and river and conservative tracer pulses to help illustrate flow directions and plume velocities.

\section{Model Description}

The STOMP grid consists of 93 by 48 by 31 nodes in the $\mathrm{x}, \mathrm{y}$, and $\mathrm{z}$ directions, respectively, for a total of 138,384 nodes. Some of these grid blocks along the north, south, and west sides of the model domain are inactive because of the alignment of the grid with wells used for boundary conditions. Nodes above the bottom of the Columbia River model domain are inactive. The total number of active nodes is 83,354 (55,030 inactive). Grid spacing in the $\mathrm{x}$ direction is variable with 10 -m grid spacing in the western portion of the domain and 5-m grid spacing in the river and extending inland (see Figure 5.24). 
The higher resolution around the river and shoreline is needed to better resolve transport in the groundwater/river water mixing zone. In the y direction, grid spacing is constant at $10 \mathrm{~m}$. The bottom of the model domain is at an elevation of $89.5 \mathrm{~m}$ (within the Ringold Formation), and the top of the model domain is at an elevation of $107.75 \mathrm{~m}$ in the lower vadose zone, which is above the highest river stage the past few years. Vertical node spacing is $1 \mathrm{~m}$ for the elevation range 89.5 to $92.5 \mathrm{~m}$, with 0.5 -m spacing above. Three 0.5 - $\mathrm{m}$ vertical nodes $(1.5 \mathrm{~m}$ total) of a river alluvium material are included on the river bottom below the bathymetry.

Boundary conditions for cell faces on the north, south, west, and east (river) sides of the model domain were specified as linked lists of seepage faces. Seepage face boundaries were described earlier for the large-scale model (Section 5.2.2). The outer boundary conditions of the model are calculated from hourly water level measurements from the more recent network of wells on the north, south, and west of the domain (see Section 5.1.2). For the north boundary, water-level measurements for wells 399-1-13A and 399-1-1 (see Figure 5.24) are applied to the closest grid blocks with hydraulic heads linearly interpolated for the grid blocks between these wells on the boundary. Hydraulic heads are specified in a similar manner for the south boundary using wells 399-1-21A and 399-2-1 and for the west boundary using wells 399-1-13A and 399-1-21A. Short sections of the model domain on the north and south are set to no-flow between the nearshore wells (399-1-1 and 399-2-1) and the river shoreline.

The eastern model boundary, along the Columbia River, uses data from the 300 Area hourly riverstage measurements (station SWS-1) from the Hanford Virtual Library, which contains data from automated water level recording equipment. The specified head values are applied to all the tops and exposed sides of the grid blocks identified within the river using the bathymetry data in EarthVision ${ }^{\mathrm{TM}}$ (see Section 4). Grid blocks above the bathymetry in the river are inactive. Values for the 300 Area Columbia River-stage recorder are translated north from the recorder to the southern boundary of the model using an estimated average Columbia River gradient for the 300 Area of $5.14 \times 10^{-5}$. This river gradient is also applied in a north/south orientation across the river boundary surfaces in the model. The average Columbia River gradient was estimated (no measurements in this area were found) based on the calculated mean river gradient of $5.14 \times 10^{-5}$ from the MASS1 simulations (Waichler et al. 2004) of model locations in the 300 Area during the period from December 1, 1991 to January 1, 1994. The hourly water-level data for the model boundaries are sub-sampled every two hours to reduce simulation run times.

Natural recharge is applied on the upper surface of the model domain inland from the shoreline. There is no artificial recharge or discharge in the model domain during this simulation period of 2006 and 2007. Natural surface recharge rates used in the model are based on the BWTF lysimeter, located in the northern portion of the 300 Area. Rockhold et al. (1995, Table 3.1) report an 8-year (1985-1993) record of drainage rates (equivalent to natural groundwater recharge) from a bare (i.e., unvegetated) lysimeter at the BWTF that range from 111 to $24 \mathrm{~mm} / \mathrm{yr}$, with an average of $55 \mathrm{~mm} / \mathrm{yr}$. Average annual precipitation rates at Hanford have increased slightly since the 1985-1993 time frame, so a higher recharge rate of $60 \mathrm{~mm} / \mathrm{yr}$ was assumed for the upper surface boundary condition in the model. 


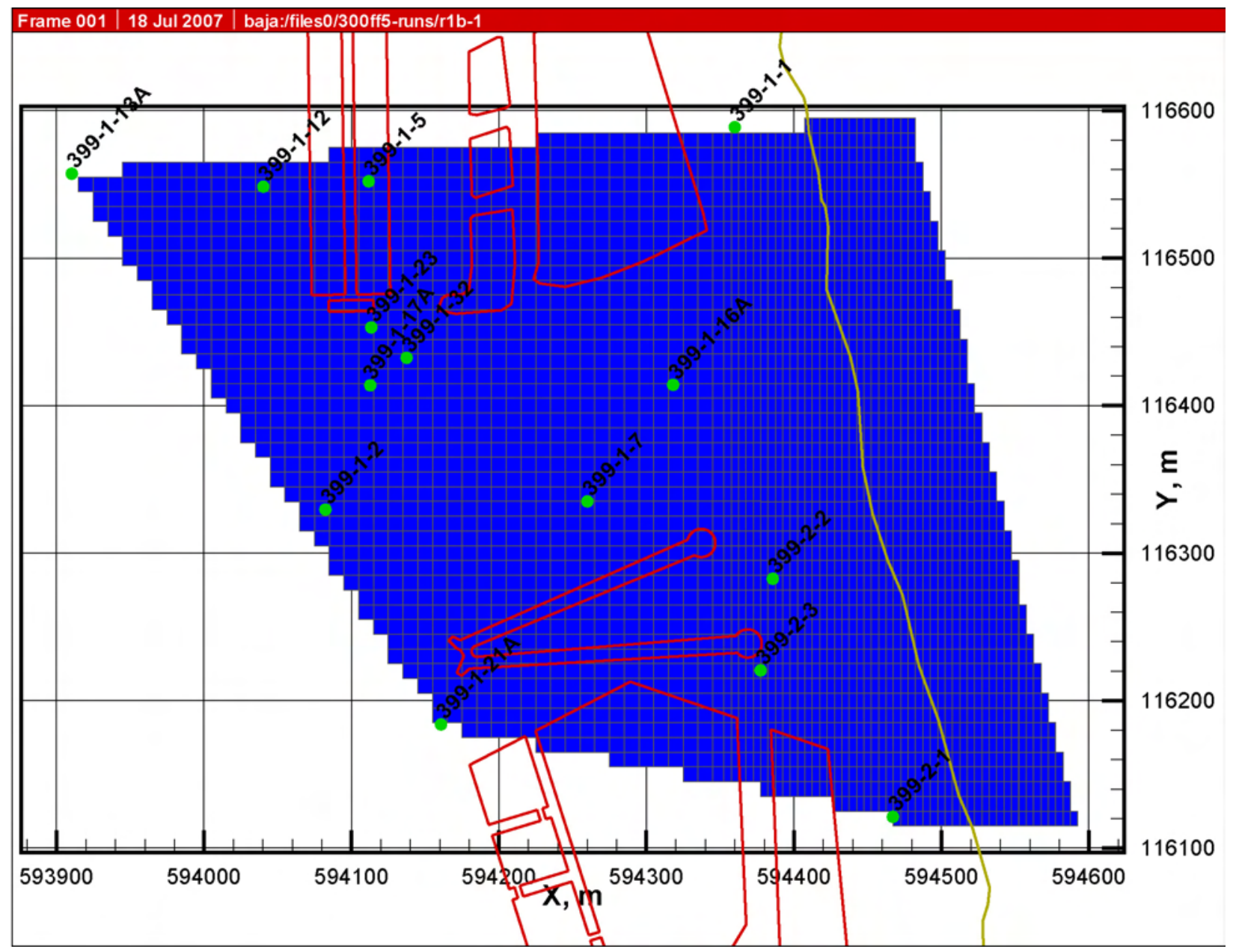

Figure 5.24. Plan View of STOMP Model Grid with Selected Wells. Surfaces shown by gray lines and wells with solid green circles. Also shown are outlines of the primary waste disposal areas (red lines) and the Columbia River shoreline.

Hydraulic conductivities for the Hanford formation are very high and variable in the 300 Area (see Section 4.4). Different values for hydraulic conductivity of the Hanford formation, along with different distributions, are being evaluated in the modeling effort, with the simulated results being compared to a) water-level data for wells within the model domain, b) the extent of the groundwater/river water mixing zone as measured from downhole probes in the well network (see Section 5.1.2), and c) characterization at the polyphosphate treatability test site that included tracer testing (see Section 5.1.4). Hydraulic conductivity values for the Ringold Unit E gravels and the fine-grained unit above these gravels are from aquifer testing that was done as part of the 300 Area LFI (Williams et al. 2007). Aquifer testing of the Hanford formation from that investigation was not sufficient for determining hydraulic conductivities because of the very high permeability of the formation.

Investigation of the hyporheic zone has shown the importance of the river alluvium in dampening aquifer response to the river-stage fluctuations (see Section 4.5). Hydraulic tests and pressure monitoring in a set of river tubes near Spring 9 showed relatively low hydraulic conductivities for depths up to $1.5 \mathrm{~m}$ below the river bottom, with hydraulic conductivities increasing with depth along with a large drop in the pressure response across the zone. A riverbed alluvium layer $1.5 \mathrm{~m}$ in thickness, composed of three 
0.5-meter vertical nodes, was added to the model to account for this layer. Prior simulation efforts without this lower hydraulic conductivity river alluvium zone resulted in over-predicting the riverinduced fluctuations in wells near the river, i.e., in wells within approximately $80 \mathrm{~m}$ of the river.

Unsaturated zone parameters used for this model are the same as previously described for the largescale model. Simulation results for an example hydraulic conductivity case are described in the following section. Results for a number of hydraulic conductivity cases and the best-fit case are described in Williams et al. (2008).

\section{Example Simulation Results}

In this example case, the Hanford formation was subdivided into two plan-view zones as shown in Figures 5.25 and 5.26 at two different depths. The Hanford formation was subdivided based on the steeper hydraulic gradients measured in the northern and eastern portion of the model domain from the hourly water-level monitoring network as described in Section 5.1.1. Figure 5.26 also shows the southeast-trending higher elevation Ringold structure below the water table in the model domain (see Hanford/Ringold structure contour map in Figure 4.4). Hydraulic properties for the zones in this example case are shown in Table 5.3.

Simulations for the smaller scale 300 Area model are run from January 2006 through July 2007. Figure 5.27 shows simulated water fluxes during this time period along the boundaries of the model, including the river boundary. Similar to the results from the larger scale model, the river-water fluxes have the largest range and show daily and seasonal changes in direction. The shoreline length of the river for this model is $480 \mathrm{~m}$ (distance from 399-1-1 to 399-2-1), compared to the 3,019-m shoreline for the larger scale model. Fluxes along the western boundary are predominantly into the model domain (negative values), and fluxes along the southern boundary are out of the model domain (positive values). Figure 5.28 shows cumulative fluxes along the model boundaries during the simulation period. The larger-scale model has a higher flux out of the model toward the river than the smaller scale model (compare to Figure 5.22). Possible explanations for this difference are 1) it is caused by the presence of a lower K zone for the Hanford formation in the smaller scale model, 2) the larger scale model includes the thickest portion of the saturated Hanford formation in the south of the domain, which is outside the domain of the smaller scale model and 3) the river stage was higher during the time period used for the small scale model compared to the larger scale model (compare Figures 5.1 and 5.3). Simulations with the Hanford formation subdivided into zones for the large-scale model as used for the small-scale model are planned. Cumulative fluxes along the western and southern boundaries are relatively constant over the simulated time period; however, there are significant seasonal changes in the direction and rates on the river and north boundaries. Figure 5.29 shows a summary of the cumulative fluxes along the model boundaries for a 1-year period. Natural recharge is also shown in this figure for comparison to the other boundary fluxes. For this example, the net water flux from the river boundary is into the aquifer for this time period. Given the variability along this river boundary, other time periods could show a net output to the river (e.g., summer and fall of 2006). The simulated river fluxes are strongly influenced by the hydraulic conductivities specified for the river alluvium and Hanford formation near the river. Additional simulations currently in progress have higher values specified for both of these units. 


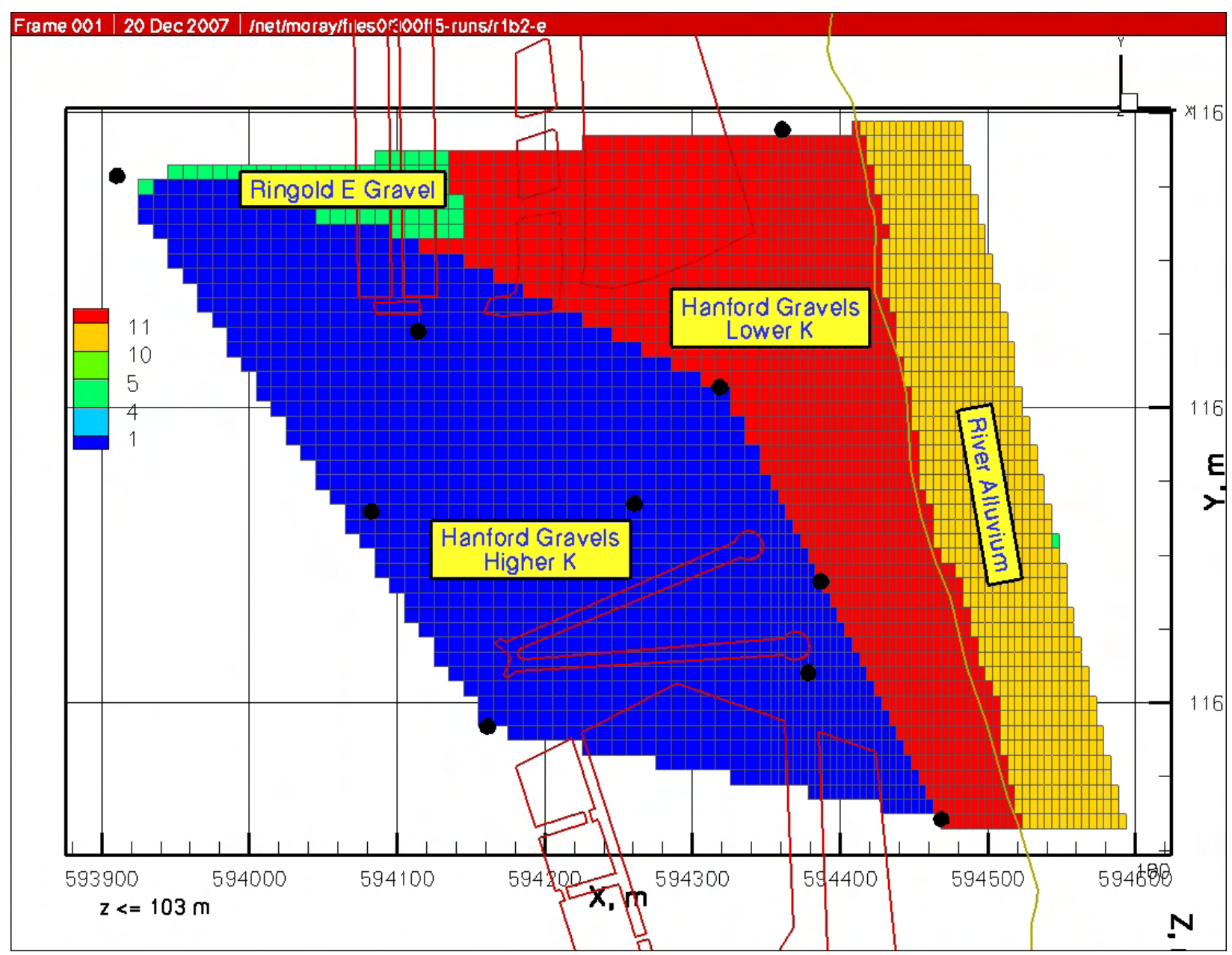

Figure 5.25. Hydraulic Property Zonation at $Z=103-m$ Elevation (NAVD88) for Small-Scale 300 Area Model 


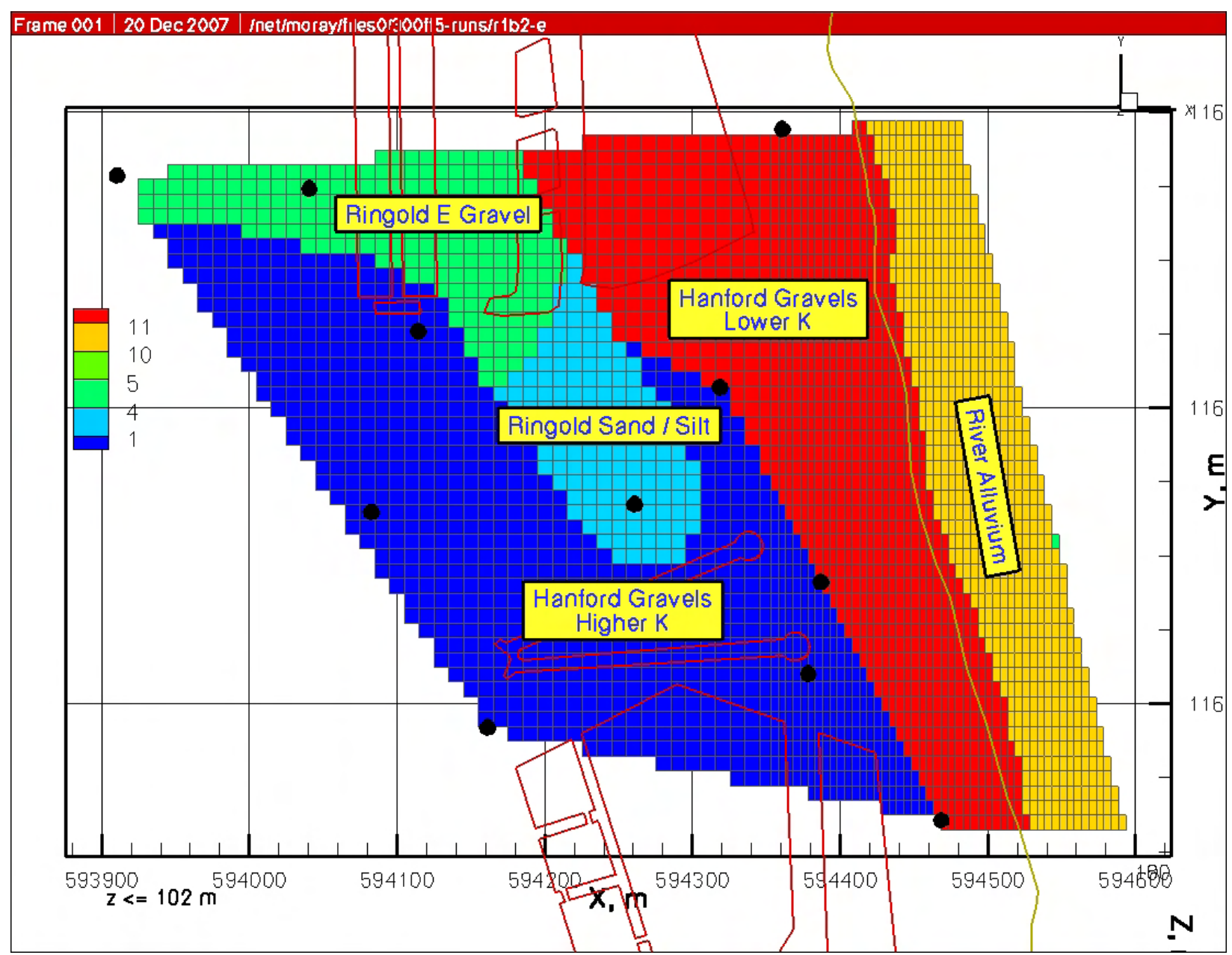

Figure 5.26. Hydraulic Property Zonation at $Z=102-m$ Elevation (NAVD88) for Small-Scale 300 Area Model 


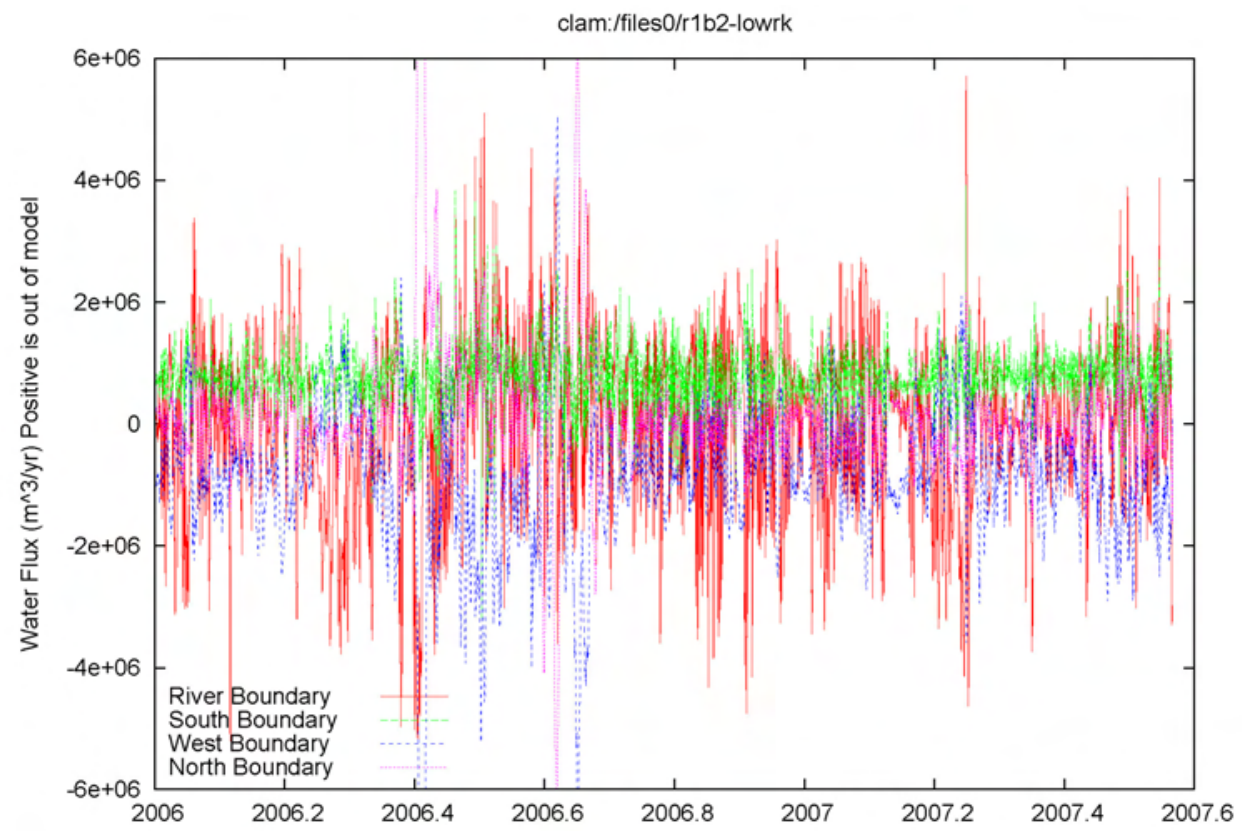

Figure 5.27. Simulated Instantaneous Water Fluxes Calculated for Model Boundaries (r1b2-lowrk)

Table 5.3. Hydraulic Properties Used in Case: clam:/files0/r1b2-lowrk

\begin{tabular}{||l|lc||}
\hline \multicolumn{1}{|c|}{ Unit } & \multicolumn{1}{|c||}{ Hydraulic Conductivity } \\
\hline \hline Higher K Hanford zone (Unit 1) & $\mathrm{Kxy}=6,000 \mathrm{~m} / \mathrm{d}, \mathrm{Kz} / \mathrm{Kxy}=0.1$ \\
\hline Lower K Hanford zone (Unit 1) & $\mathrm{Kxy}=2,000 \mathrm{~m} / \mathrm{d}, \mathrm{Kz} / \mathrm{Kxy}=0.1$ \\
\hline Fine-grained Ringold facies (Unit 4) & $\mathrm{Kxy}=$ & $1 \mathrm{~m} / \mathrm{d}, \mathrm{Kz} / \mathrm{Kxy}=0.1$ \\
\hline Ringold E gravels (Unit 5) & $\mathrm{Kxy}=$ & $40 \mathrm{~m} / \mathrm{d}, \mathrm{Kz} / \mathrm{Kxy}=0.1$ \\
\hline River alluvium & $\mathrm{Kxy}=\quad 1 \mathrm{~m} / \mathrm{d}, \mathrm{Kz} / \mathrm{Kxy}=1$ \\
\hline
\end{tabular}

Transport simulations for conservative tracer pulses were conducted for two different times, June 2006 and March 2007, to assess groundwater flow directions and rates during various river-stage regimes (see Figure 5.30). The simulated tracer pulses are for one day of injection for a volume of 1,152,000 gal (800 gal/min for 24 hours). Transport properties in the model were $18 \%$ total and effective porosity for the Hanford formation (based on preliminary analysis of the polyphosphate tracer test) with dispersivities of 0.5 and $0.1 \mathrm{~m}$ (longitudinal and transverse, respectively). Figures 5.31 and 5.32 show the results of the initial plumes and subsequent drift. Figure 5.33 shows plume-drift velocities calculated from the changes in the weekly position of the center of mass of the tracer plumes. For the March 2007 pulse (Figures 5.31 and 5.33), the initial plume drift is toward the southeast until the river stage increases significantly at the middle and end of March, causing the plume to move toward the southwest. The plume drifts towards the south in April during the sustained period of high-river stage. The second tracer pulse/drift case occurs during the end of a high-river stage in June of 2006 that is followed by a steep drop in stage in July (see Figures 5.30 and 5.32). The general direction of plume drift during this period is toward the south-southeast with a large increase in the plume velocity occurring during the large drop in river stage around the beginning of July (see Figure 5.33). Velocities calculated for the tracer plume drift during these time periods were less than the preliminary velocity for the polyphosphate tracer test conducted in December 2006 and January 2007 of 15 m/d. Simulations with higher hydraulic conductivity values for the Hanford formation are in progress and will be evaluated based on these and other criteria. 


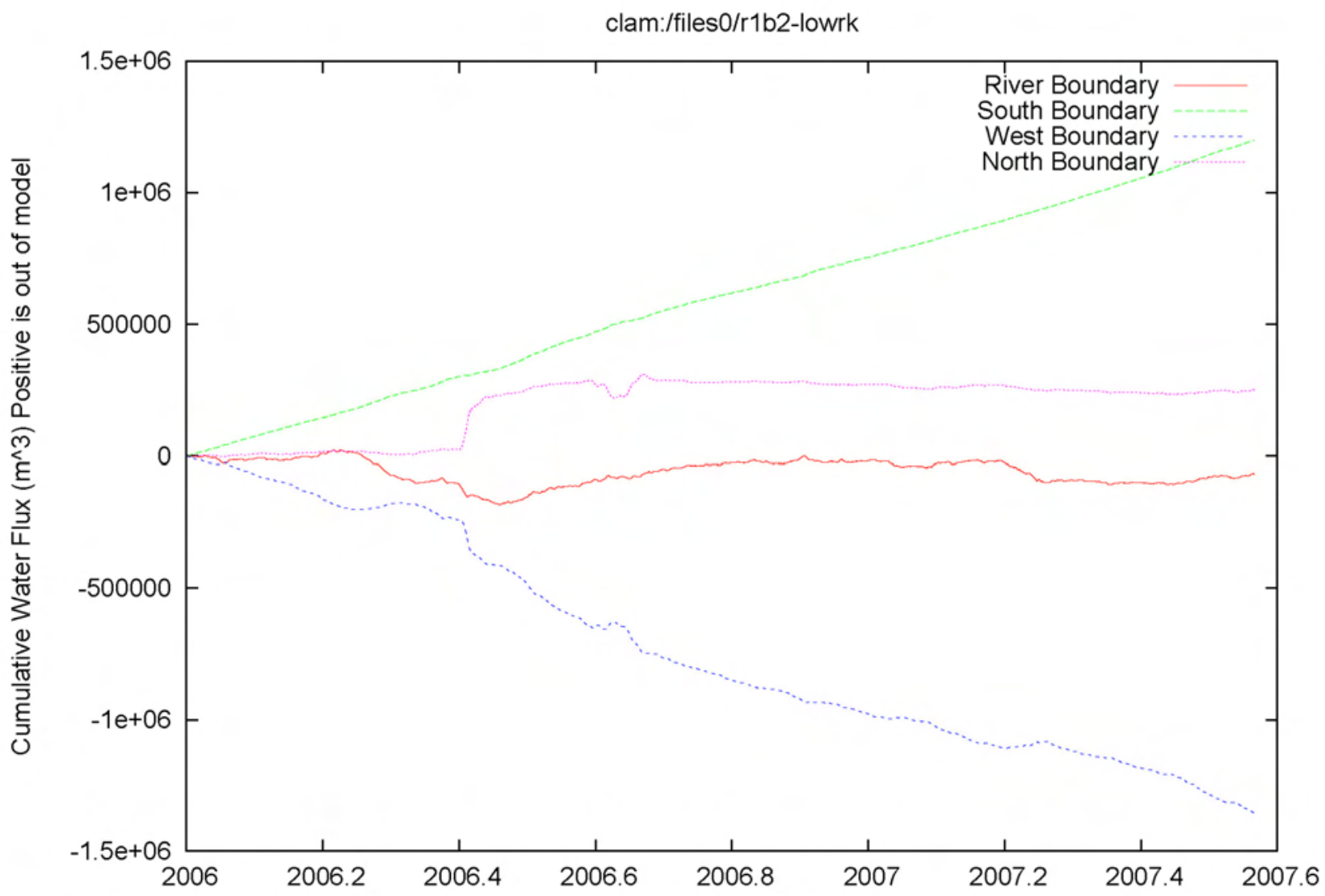

Figure 5.28. Simulated Cumulative Water Fluxes Calculated for Model Boundaries (r1b2-lowrk)

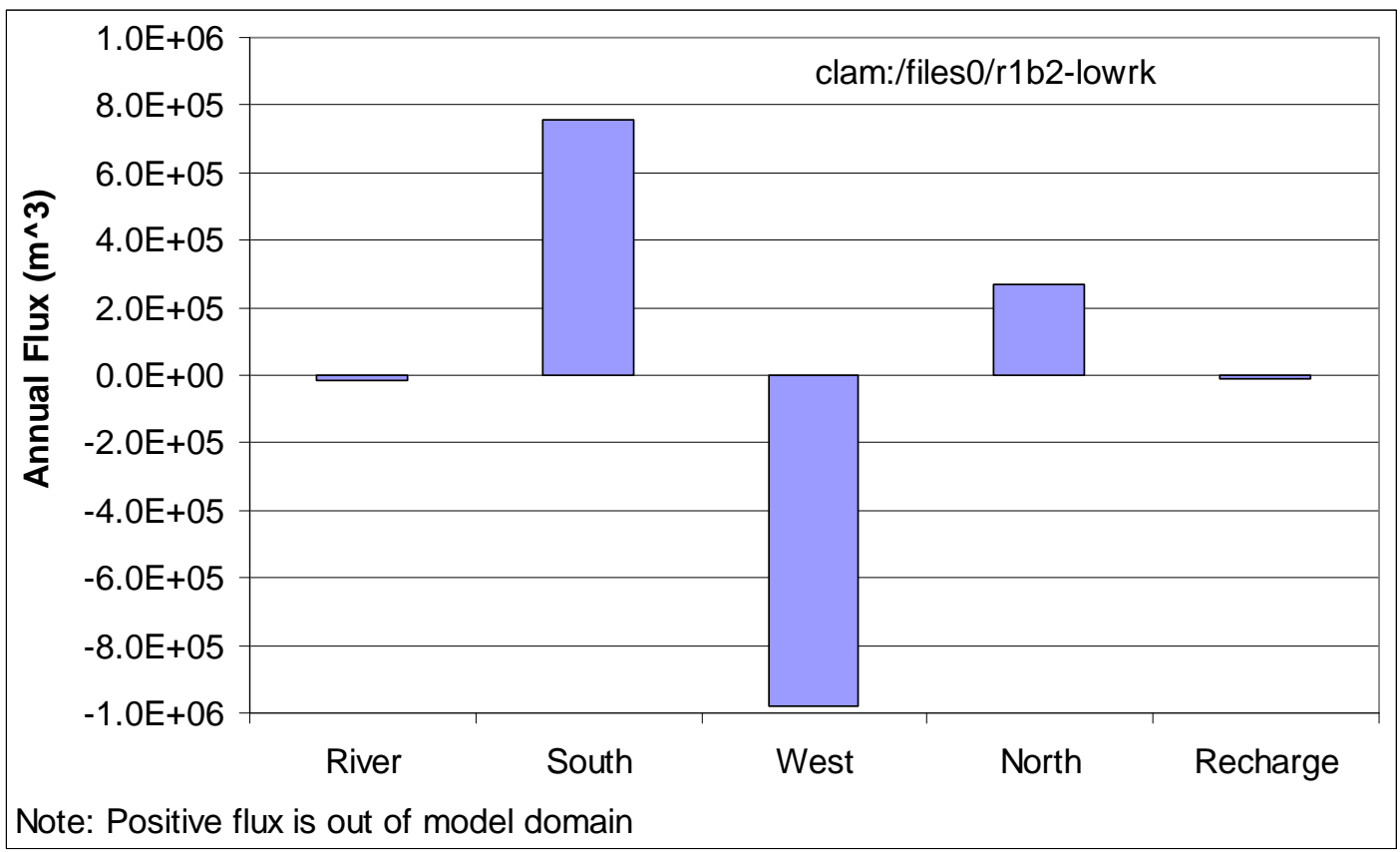

Figure 5.29. Simulated Annual Cumulative Water Flux for 2006. Shoreline Distance $=480 \mathrm{~m}$. 


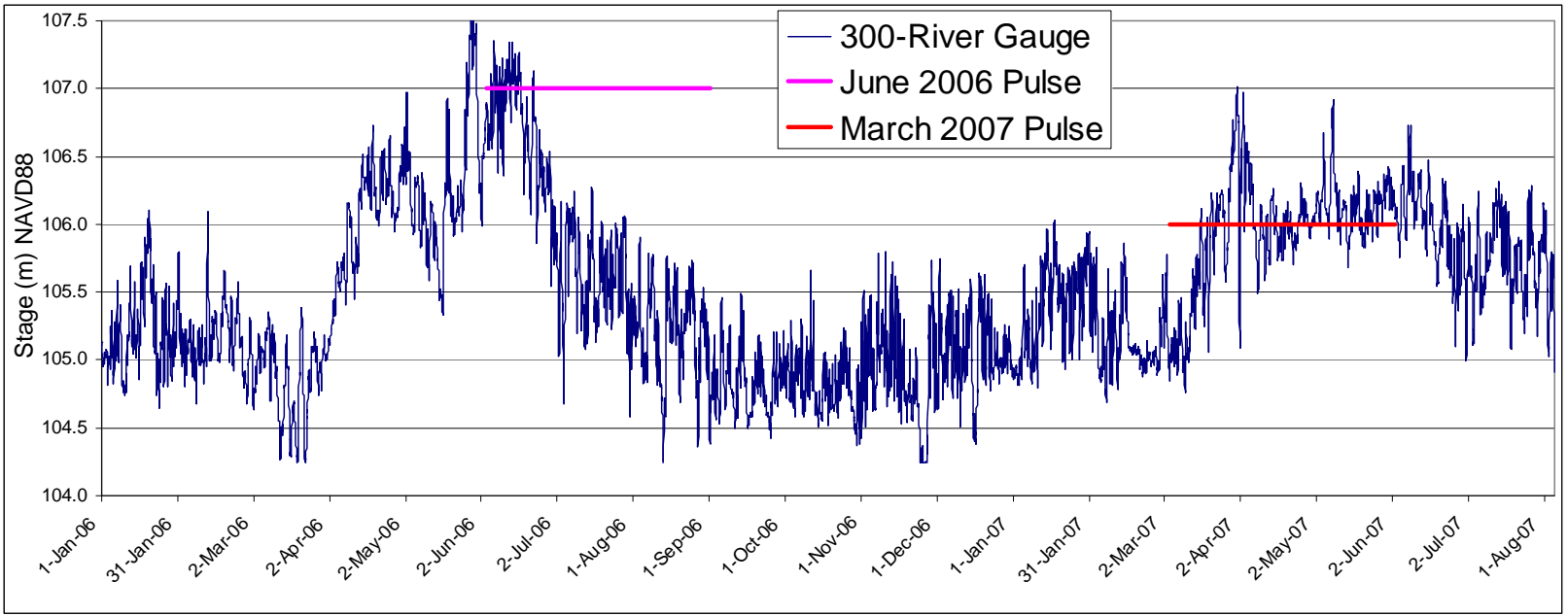

Figure 5.30. Timing for Tracer Pulses and Drift for Simulation Results Shown in Figures 5.31 to 5.33 

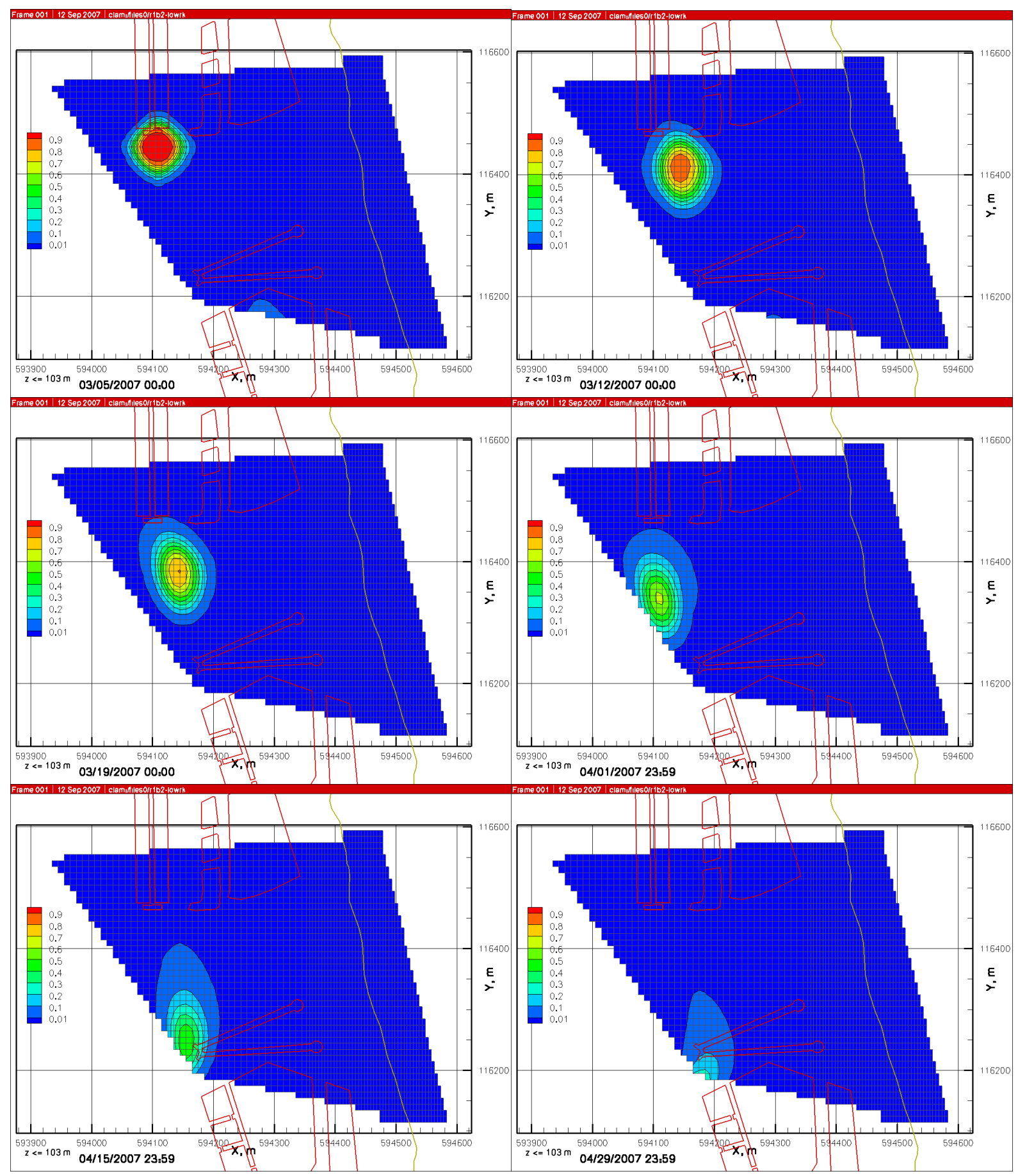

Figure 5.31. Simulated Conservative Tracer Pulse for Case r1b2-lowrk During Initial Seasonal River Stage Increase in 2007 (see Figure 5.30 for stage and timing). One million gallons of tracer injected in 1 day (800 gal/min), followed by drift period. Note: first two figures are 1 week apart with remaining figures 2 weeks apart. 

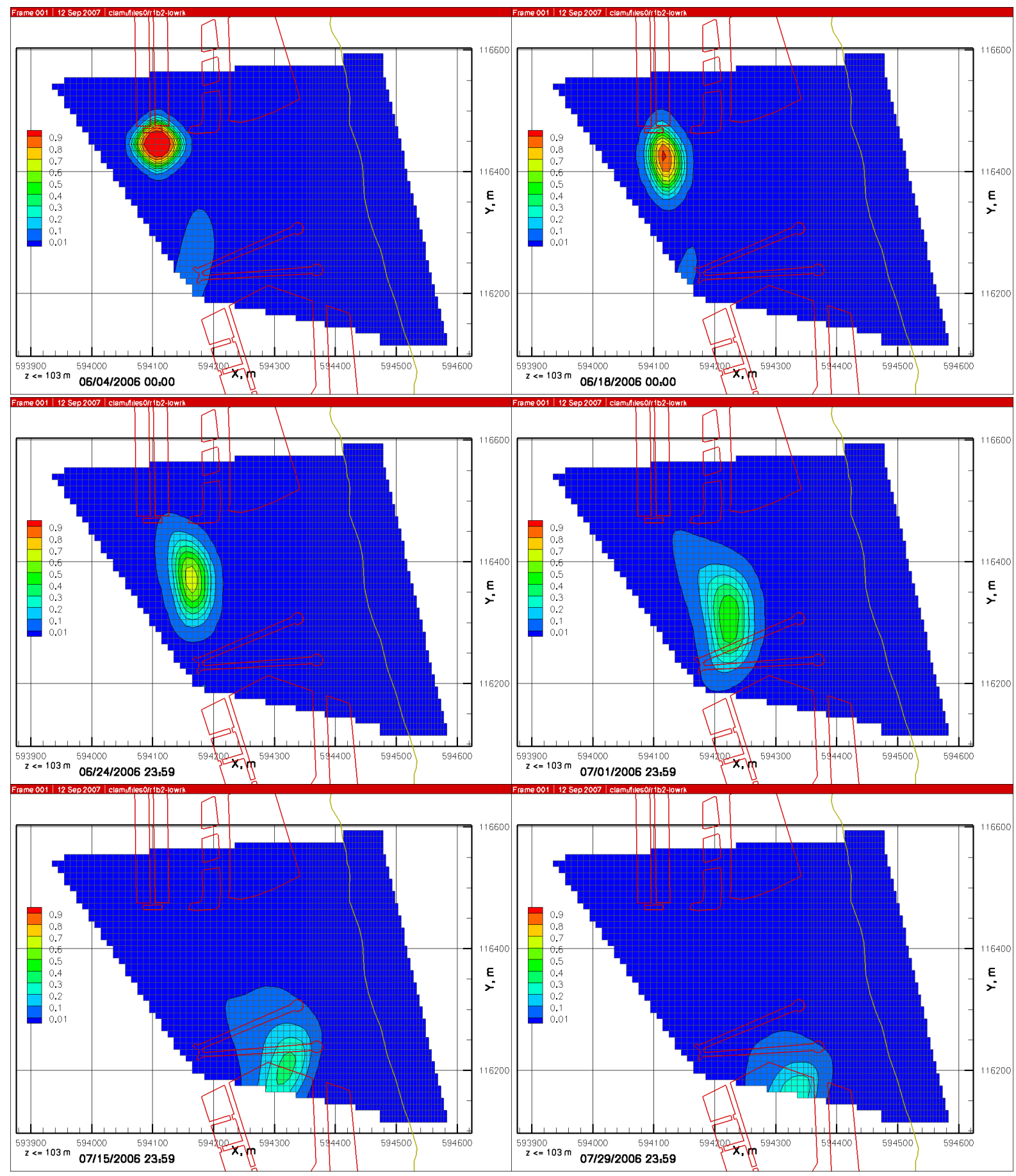

Figure 5.32. Simulated Conservative Tracer Pulse for Case r1b2-lowrk During High River Stage Period in June 2006 Followed by Lower Stage in July (see Figure 5.30 for stage and timing). One million gallons of tracer injected in 1 day ( $800 \mathrm{gal} / \mathrm{min}$ following by drift period. Note: second through fourth figures are 1 week apart with remaining figures 2 weeks apart. 


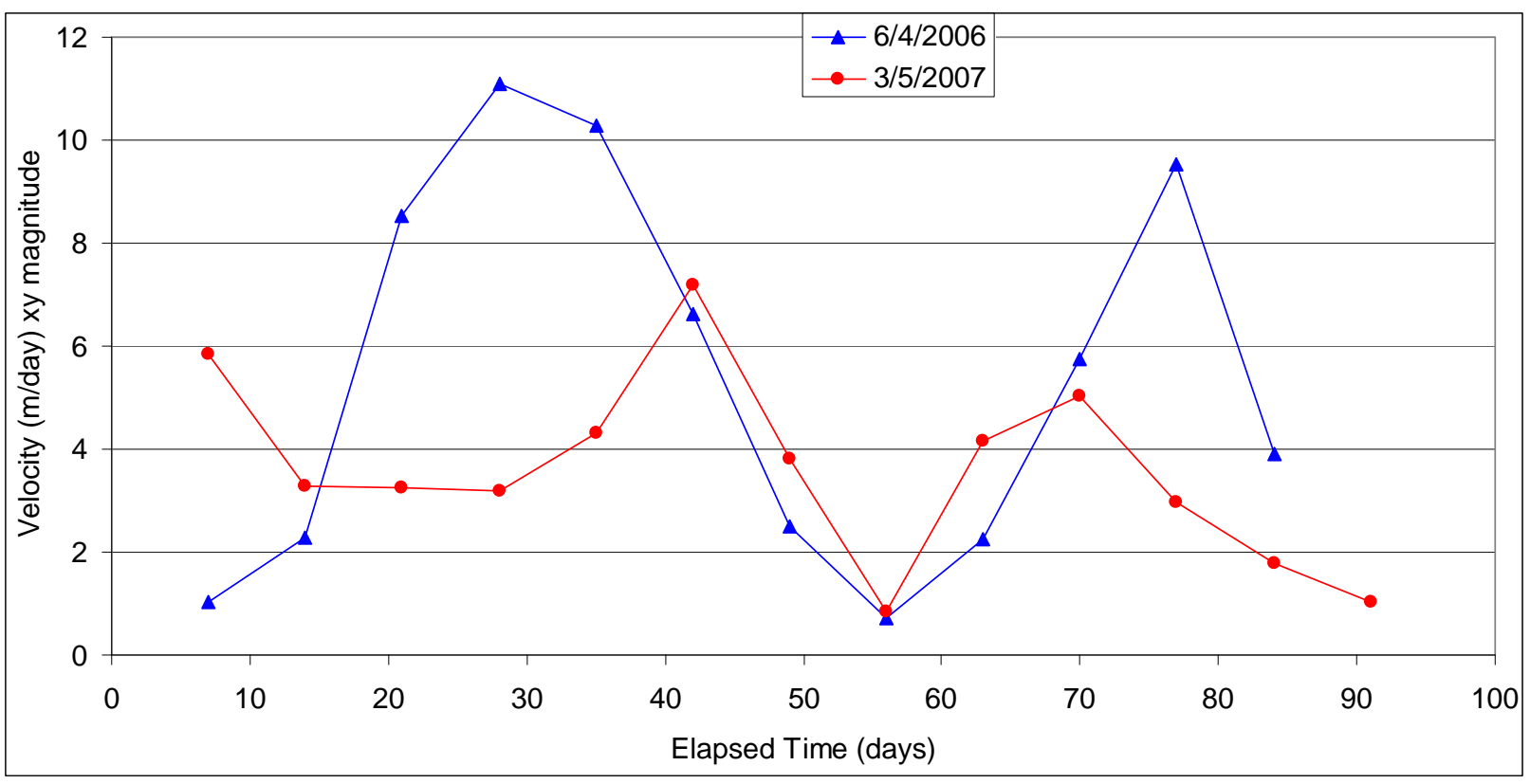

Figure 5.33. Simulated Velocities (xy magnitude) from Calculated Center of Mass Positions of Tracer Pulses for Case r1b2-lowrk (see Figures 5.31 and 5.32). Times are shown from the beginning of the tracer pulses.

\subsubsection{Summary}

Groundwater flow rates are very high in the upper unconfined aquifer in the 300 Area, within the Hanford formation, with velocities up to 10 to $15 \mathrm{~m} / \mathrm{d}$ (35 to $50 \mathrm{ft} / \mathrm{d}$ ) based on a tracer test and limited plume migration data. Groundwater flow rates and directions in the 300 Area are very dynamic because of the high hydraulic conductivities along with the large daily, weekly, and seasonal fluctuations in the stages of the Columbia River. The variability in the groundwater flow directions can be seen by analyzing automated water-level monitoring networks that have been established in the 300 Area that collect hourly and sub-hourly measurements from networks of wells. Generalized flow directions in the area between the North and South Process Ponds are toward the east to south with the directions changing toward the south and west during periods of increases in the river stage (daily and seasonal).

Recent studies of the hyporheic zone in the 300 Area have shown the importance of a lower hydraulic conductivity layer (relative to the Hanford formation) of river alluvium that is limiting the aquifer flux to the river and dampening the response of wells near the river to river-stage fluctuations. Downhole probe measurements of electrical conductivity and temperature of the aquifer in wells near the river have shown the extent of the groundwater/river water mixing zone. During 2006, for example, river water entered the aquifer to a distance of more than $188 \mathrm{~m}(617 \mathrm{ft})$ inland when the stage of the river was high.

Water fluxes in and out of the 300 Area aquifer have been calculated using the large domain groundwater model for the period of February 1, 1992 to February 1, 1993 (see Section 5.2.3). These include boundary fluxes on the north, west, and south of the model domain and at the river boundary (Figure 5.19). Results for the example case are shown in Figure 5.23 along with other natural and artificial sources and sinks considered by the model. River-stage conditions during this period were in general average and typical of the past 15 years, with stage elevation ranging between 104.3 to $106.8 \mathrm{~m}$. 
For this example case, the largest water fluxes into the model domain are along the north and west boundaries, and the largest fluxes out of the model are through the south and river boundaries.

As shown in Figure 5.23, the annual water flux out of the model was 4,900,000 $\mathrm{m}^{3}$ for the southern boundary and 3,400,000 $\mathrm{m}^{3}$ for the river boundary. To put this in perspective with other estimates for aquifer discharge to the river, the annual water flux to the river can be divided by shoreline length along the river boundary in this model $(3,019 \mathrm{~m})$, which yields a value of $1,100 \mathrm{~m}^{3}$ per meter of 300 Area shoreline. This value falls within the range of the historical assumptions for the annual aquifer discharge along the 64-km length of the Hanford Reach. Historical assumptions range from 560 to $1400 \mathrm{~m}^{3}$ per meter of shoreline, based on values of 36,000,000 to 90,000,000 $\mathrm{m}^{3} /$ year for the entire Hanford Site aquifer (summarized in Peterson et al. 2007b). However, the $1,100 \mathrm{~m}^{3}$ per meter of shoreline value is higher than results from recent sitewide groundwater modeling studies, which produced estimates of 480 and $700 \mathrm{~m}^{3}$ per meter of shoreline, based on estimates of 31,000,000 and 45,000,000 $\mathrm{m}^{3} / \mathrm{yr}$ for the entire Hanford Site (Vermeul et al. 2003 and Thorne et al. 2006, respectively). It is expected that the aquifer fluxes in the 300 Area would be higher than the sitewide average, given the relatively high hydraulic conductivities values in the 300 Area. Also, significant artificial water sources were included for the former 300 Area Process Trenches (316-5) in the example case simulation, but these should be more than offset by the withdrawals from water supply well 399-4-12 (see Figure 5.23). Water flux results for additional simulations using varying hydraulic properties were reported in Williams et al. (2008). Results from these simulations show the importance of the hydraulic properties on the flux estimates, particularly for the Hanford formation and the riverbed alluvium.

Contrasted with the larger-scale model, the simulated water fluxes for the smaller scale model showed a net influx from the river to the aquifer during the 2006 simulation period. However, the domain of the smaller-scale model is in the northern portion of the 300 Area, with thinner average thickness of the Hanford formation aquifer that doesn't include the thicker sequence of Hanford in the south and western portion of the larger-scale model domain. Additionally, the river stage during 2006 was relatively high compared to the average over the past 15 years. Both models did show that the largest net annual fluxes out of the model domain were along the southern boundary.

A large contributor to uncertainty associated with quantifying the groundwater flux in the aquifer beneath the 300 Area involves the values used for hydraulic conductivity in the Hanford formation and the distribution of those values. The very large values (i.e., greater than $1,000 \mathrm{~m} / \mathrm{d}$ ) for hydraulic conductivity of this formation make conducting and evaluating aquifer tests difficult. There also could be a large range in hydraulic conductivities in the 300 Area because of heterogeneities. Three-dimensional groundwater flow and transport simulations of the 300 Area aquifer are being developed using hourly water-level measurements from well networks in the area. These simulations are being used to test and estimate the hydraulic conductivities and alternative hydraulic conductivity distributions. The boundary conditions of these models are driven by the hourly water-level measurements, and simulation results are compared to measurements from wells inside the model domains for determining model fit. Results of these modeling studies are also being compared to tracer tests and the extent of the groundwater/river water mixing zone for additional evaluation of the simulation results. 


\title{
6.0 Geochemical Characteristics of Contaminant Uranium
}

\author{
(R.J. Serne)
}

This section presents the current geochemical characteristics for contaminant uranium in the subsurface at the Hanford Site's 300 Area. The vadose zone and upper portion of the unconfined aquifer are assessed, the latter containing the persistent groundwater uranium plume that is the focus for interim remedial action. A conceptual geochemical model is presented that could evolve into a detailed masstransfer model ${ }^{7}$ if the necessary parameters are quantified. Current knowledge of the geochemical features and processes involving 1) contaminant uranium remaining in the vadose zone following removal of the sediment within and immediately adjacent to the principal liquid-waste disposal facilities, ${ }^{8}$ and 2) contaminant uranium in the aquifer, including groundwater and aquifer solids, is actively growing.

Several recent and ongoing projects are focusing on determining the distribution of uranium and the geochemical interactions that are occurring in the 300 Area subsurface. The following sections summarize information that is relevant to remedial action decisions and offer a descriptive conceptual model for the interactions of uranium in the 300 Area subsurface. A considerable amount of detailed geochemical information is presented in, Serne et al. (2002a), Zachara et al. (2005), and numerous journal articles, as referenced below. Also, two comprehensive reports have been recently published that contain more details on 1) contaminant uranium distribution in the 300 Area subsurface, and 2) uranium sequestration processes, respectively (Williams et al. 2007; Zachara et al. 2007a). Many of the details that support the following summation of our understanding of uranium geochemistry in the 300 Area subsurface and the current distribution of uranium in the 300 Area vadose zone and aquifer are found in the four reports cited above.

The current understanding of geochemical interactions involving uranium in the 300 Area subsurface has advanced sufficiently to warrant a field demonstration of a remediation technology involving the injection of polyphosphate into the aquifer. This treatment will facilitate the transfer of soluble uranium into insoluble solids that are rich in uranium phosphate (Wellman et al. 2006; Vermeul et al. 2007). The treatability method has potential for use in the unsaturated vadose zone as well. As information on the distribution of contaminant uranium increases and the understanding of geochemical interactions between the dissolved and solid-phase uranium increases, additional support to building predictive simulations of uranium fate and selecting remedial-action alternatives will be forthcoming.

Current conditions regarding the uranium plume in groundwater were discussed in Section 3.0 of this report and references cited therein. The following subsections begin with an overview of uranium geochemistry and are followed by the uranium inventory "box" model, which includes detailed estimates of uranium mass currently present in various subregions within the vadose zone and uppermost aquifer beneath the 300 Area. The chapter ends with a summary of 1) the key variables that control the fate of uranium and its distribution between sediments and pore waters and 2) uncertainties in our current understanding of the 300 Area subsurface uranium plume.

\footnotetext{
${ }^{7}$ A mass-transfer model describes the interaction between a constituent in the aqueous phase (i.e., dissolved in pore water or groundwater) and the solid phase (i.e., sorption to sediment or precipitation of discrete solids). It is distinct from a mass-transport model in which a mass-transfer model is coupled to a hydrologic flow model in that the transport of a constituent through the aquifer can be simulated.

${ }^{8}$ South and North Process Ponds (316-1 and 316-2 waste sites, respectively) and the 300 Area Process Trenches (316-5 waste site).
} 


\subsection{Overview of Uranium Geochemistry}

Uranium is a naturally occurring element that is present as a trace constituent in the Earth's crust. Fabricating natural and slightly enriched uranium into fuel elements for nuclear reactors in Hanford's 300 Area and reprocessing irradiated fuel in Hanford's 200 Areas to obtain plutonium and other useful radioisotopes have led to significant uranium contamination in the vadose zone and groundwater at the Hanford Site. As a result of these activities, uranium is considered to be one of the primary risk drivers associated with long-term stewardship of the Site.

Uranium (U) is the central element of the nuclear fuel cycle, with ${ }^{235} \mathrm{U}$ being the source via fission processes of the neutrons used to interact with other isotopes such as ${ }^{238} \mathrm{U}$, the reactant for the formation of plutonium (Pu) and specifically, ${ }^{239} \mathrm{Pu}$. Uranium was handled in massive quantities during production years at the Hanford Site. Uranium fuels were assembled in the 300 Area, irradiated in eight nuclear reactors in the 100 Areas, and reprocessed to recover uranium and produce plutonium in the 200 Areas. During the course of these and associated waste disposal activities, an estimated 202,700 to 205,435 kg of uranium was discharged to the ground in the Hanford 200 and 300 areas (Corbin et al. 2005 and Simpson et al. 2006, respectively).

The large inventory of uranium released to the vadose zone, combined with its sometimes significant mobility under the oxidizing circum-neutral to mildly basic geochemical conditions found at Hanford has resulted in three identified groundwater plumes (Hartman et al. 2007). These have a combined area of $1.6 \mathrm{~km}^{2}$ with dissolved uranium concentrations above the EPA-established maximum contaminant level (MCL) of 30 parts per billion $\left(1.2 \times 10^{-7} \mathrm{~mol} / \mathrm{L} ; 30 \mu \mathrm{g} / \mathrm{L}\right)$. The migration of uranium to groundwater was facilitated by large volumetric releases of process waters, which magnified natural recharge. The groundwater uranium plume near WMA B-BX-BY continues to grow in size, and the uranium plume below the 300 Area is not dissipating as predicted (Peterson et al. 2005, 2007a), perhaps indicating sustained flux from the vadose zone or "recirculation" between the pore water and aquifer sediments. A larger number of vadose zone plumes of uranium exist beneath cribs, trenches, and retention basins located in the 200 Areas that have not yet migrated to groundwater. Concern exists over their future disposition, and knowledge is sought to predict the migration behavior of both vadose and saturated zone plumes of hexavalent uranium within acceptable levels of uncertainty in support of risk assessments and remedial-action decisions.

Generally, all Hanford nuclear fuels contained uranium in the metallic state, which was oxidized to the hexavalent state during fuel rod dissolution in the first step of reprocessing. It is also believed that the majority of uranium metal particulates and dissolved uranium deposited in ponds in the 300 Area quickly oxidized to the hexavalent form. The environmental chemistry of uranium is complex (Burns 1999) and is dominated by two stable valence states, hexavalent and tetravalent, depending on redox conditions. Under oxidizing conditions, such as where there is contact with the atmosphere or waters with $>1 \mathrm{ppm}$ dissolved oxygen $\left(\mathrm{O}_{2}\right)$, uranium exists in the hexavalent state as the uranyl cation $\left(\mathrm{UO}_{2}{ }^{2+}\right)$. Under reducing conditions (e.g., Eh $<\sim 0.25 \mathrm{~V}$ ), uranyl tranforms to the tetravalent state as the insoluble uranous cation $\left(\mathrm{U}^{4+}\right)$.

The tendency for the hexavalent/tetravalent redox reactions to convert back and forth is a strong function of the dissolved uranium concentration, the aqueous fluid composition that influences the aqueous speciation of the two uranium forms, and the concentration of oxidants [e.g., $\mathrm{O}_{2}, \mathrm{Mn}(\mathrm{III} / \mathrm{IV}$ )] or reductants [e.g., Fe(II)] that may function as electron acceptors or donors for the redox reaction 
(Langmuir 1997; Ginder-Vogel et al. 2006). The fuel rods were dissolved, and the irradiated nuclear fuels were reprocessed under oxidizing conditions that generally transformed and maintained uranium in the hexavalent state. Consequently, most environmental releases of dissolved uranium at Hanford were dominated by U(VI) (Corbin et al. 2005). Thus, and to large degree, the behavior of contaminant uranium at the Hanford Site as a reactive solute is dominated by the geochemistry of the uranyl ion. Note: For brevity in the following discussion, hexavalent uranium will be referred to as U(VI) and tetravalent uranium as $\mathrm{U}(\mathrm{IV})$.

\subsubsection{Chemical Species}

Dissolved uranyl cations $\left(\mathrm{UO}_{2}{ }^{2+}\right)$ react with other anions and cations in the aqueous phase to form aqueous species or complexes. The tendency for $\mathrm{UO}_{2}{ }^{2+}$ to engage in reactions of this sort is determined by 1) the total dissolved uranium concentration and $\mathrm{pH}, 2$ ) the concentrations of complexing anions and cations in the water, and 3) the equilibrium or stability constants for the product complexes. The term "aqueous speciation" refers to the distribution of specific and multiple aqueous complexes of uranyl that form under given conditions of $\mathrm{pH}$, solution composition, temperature, etc. The aqueous speciation of $\mathrm{U}(\mathrm{VI})$ is extremely complex and exerts a strong influence on the behavior of contaminant uranium.

The formation of aqueous complexes, and hence U(VI) speciation, is very important to uranium migration. The solubility of precipitated uranyl is determined by the activity of the free uranyl cation $\left(\mathrm{UO}_{2}{ }^{2+}\right)$, which, in turn, is directly related to its concentration. Aqueous complexation can dramatically increase the solubility of precipitated uranium by the formation of uranium species at concentrations that are many orders of magnitude above that of the free $\mathrm{UO}_{2}{ }^{2+}$ cation. Likewise, aqueous complexation leads to the formation of dissolved uranium species with very different charges, sizes, chemical bonding behavior, and aqueous diffusivities as compared to the free cation. These differences exert a profound influence on the extent to which U(VI) adsorbs to mineral surfaces by ion exchange or surface complexation and the rates of diffusive exchange between pore waters and reactive sediment particle interiors. Establishing and verifying an appropriate speciation or aqueous thermodynamic model is a critical first step in developing more involved reaction models for U(VI) adsorption/desorption and precipitation/dissolution in Hanford sediments (Liu et al. 2004; Dong et al. 2005; Ilton et al. 2006, 2007; Bond et al. 2007).

\subsubsection{Computerized Aqueous Speciation Calculations}

The computation of $\mathrm{U}(\mathrm{VI})$ aqueous speciation is fundamental to the interpretation of $\mathrm{U}(\mathrm{VI})$ geochemical and transport behavior in laboratory and field systems. Such computations are often performed with geochemical speciation models such as MINTEQA2 (Allison et al. 1998) or Geochemical Workbench-GWB (Bethke 2005). The basis for these calculations is well described in a variety of environmental chemistry text books (Sposito 1984; Langmuir 1997; Benjamin 2002). Aqueous complexation reactions proceed rapidly, and aqueous speciation is therefore generally assumed to quickly reach equilibrium conditions, which are readily calculated using the cited computer codes and/or similar codes. Table 6.1 summarizes uranium-reaction stoichiometries and stability constants that we favor, which represent the thermodynamic data needed for uranium speciation calculations. These are derived from experimental measurements of variable quality. Grenthe et al. $(1992,1995)$ and Guillaumont et al. (2003) have extensively reviewed the literature database on aqueous complexation reactions of U(VI) and, from these, suggest the most experimentally robust and statistically defensible values. We have accepted their extensive review. 
Table 6.1. U(VI) Aqueous Speciation Reactions

\begin{tabular}{|c|c|c|}
\hline Speciation Reaction & $\log K(I=0)$ & Source \\
\hline 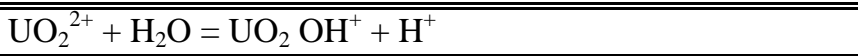 & 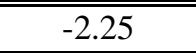 & 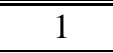 \\
\hline $\mathrm{UO}_{2}{ }^{2+}+2 \mathrm{H}_{2} \mathrm{O}=\mathrm{UO}_{2}(\mathrm{OH})_{2}(\mathrm{aq})+2 \mathrm{H}^{+}$ & -12.15 & 1 \\
\hline $\mathrm{UO}_{2}^{2+}+3 \mathrm{H}_{2} \mathrm{O}=\mathrm{UO}_{2}(\mathrm{OH})_{3}^{-}+3 \mathrm{H}^{+}$ & -20.25 & 1 \\
\hline $\mathrm{UO}_{2}{ }^{2+}+4 \mathrm{H}_{2} \mathrm{O}=\mathrm{UO}_{2}(\mathrm{OH})_{4}{ }^{2-}+4 \mathrm{H}^{+}$ & -32.40 & 1 \\
\hline $2 \mathrm{UO}_{2}^{2+}+\mathrm{H}_{2} \mathrm{O}=\left(\mathrm{UO}_{2}\right)_{2} \mathrm{OH}^{3+}+\mathrm{H}^{+}$ & -2.70 & 1 \\
\hline $2 \mathrm{UO}_{2}{ }^{2+}+2 \mathrm{H}_{2} \mathrm{O}=\left(\mathrm{UO}_{2}\right)_{2}(\mathrm{OH})_{2}{ }^{2+}+2 \mathrm{H}^{+}$ & -5.62 & 1 \\
\hline $3 \mathrm{UO}_{2}{ }^{2+}+4 \mathrm{H}_{2} \mathrm{O}=\left(\mathrm{UO}_{2}\right)_{3}(\mathrm{OH})_{4}{ }^{2+}+4 \mathrm{H}^{+}$ & -11.90 & 1 \\
\hline $3 \mathrm{UO}_{2}^{2+}+5 \mathrm{H}_{2} \mathrm{O}=\left(\mathrm{UO}_{2}\right)_{3}(\mathrm{OH})_{5}^{+}+5 \mathrm{H}^{+}$ & -15.55 & 1 \\
\hline $3 \mathrm{UO}_{2}^{2+}+7 \mathrm{H}_{2} \mathrm{O}=\left(\mathrm{UO}_{2}\right)_{3}(\mathrm{OH})_{7}^{-}+7 \mathrm{H}^{+}$ & -32.20 & 1 \\
\hline $4 \mathrm{UO}_{2}{ }^{2+}+7 \mathrm{H}_{2} \mathrm{O}=\left(\mathrm{UO}_{2}\right)_{4}(\mathrm{OH})_{7}^{+}+7 \mathrm{H}^{+}$ & -21.90 & 1 \\
\hline $\mathrm{UO}_{2}{ }^{2+}+\mathrm{CO}_{3}{ }^{2-}=\mathrm{UO}_{2} \mathrm{CO}_{3}(\mathrm{aq})$ & 9.94 & 1 \\
\hline $\mathrm{UO}_{2}{ }^{2+}+2 \mathrm{CO}_{3}{ }^{2-}=\mathrm{UO}_{2}\left(\mathrm{CO}_{3}\right)_{2}{ }^{2-}$ & 16.61 & 1 \\
\hline $\mathrm{UO}_{2}{ }^{2+}+3 \mathrm{CO}_{3}{ }^{2-}=\mathrm{UO}_{2}\left(\mathrm{CO}_{3}\right)_{3}{ }^{4-}$ & 21.84 & 1 \\
\hline $3 \mathrm{UO}_{2}{ }^{2+}+6 \mathrm{CO}_{3}{ }^{2-}=\left(\mathrm{UO}_{2}\right)_{3}\left(\mathrm{CO}_{3}\right)_{6}{ }^{6-}$ & 54.00 & 1 \\
\hline $2 \mathrm{UO}_{2}{ }^{2+}+\mathrm{CO}_{3}{ }^{2-}+3 \mathrm{H}_{2} \mathrm{O}=\left(\mathrm{UO}_{2}\right)_{2} \mathrm{CO}_{3}(\mathrm{OH})_{3}^{-}+3 \mathrm{H}^{+}$ & -0.86 & 1 \\
\hline $3 \mathrm{UO}_{2}{ }^{2+}+\mathrm{CO}_{3}{ }^{2-}+3 \mathrm{H}_{2} \mathrm{O}=\left(\mathrm{UO}_{2}\right)_{3} \mathrm{O}(\mathrm{OH}) 2(\mathrm{HCO} 3)^{+}+3 \mathrm{H}^{+}$ & 0.66 & 1 \\
\hline $11 \mathrm{UO}_{2}{ }^{2+}+6 \mathrm{CO}_{3}{ }^{2-}+12 \mathrm{H}_{2} \mathrm{O}=\left(\mathrm{UO}_{2}\right)_{11}\left(\mathrm{CO}_{3}\right)_{6}(\mathrm{OH})_{12}{ }^{-}+12 \mathrm{H}^{+}$ & 36.43 & 1 \\
\hline $2 \mathrm{Ca}^{2+}+\mathrm{UO}_{2}{ }^{2+}+3 \mathrm{CO}_{3}{ }^{2-}=\mathrm{Ca}_{2} \mathrm{UO}_{2}\left(\mathrm{CO}_{3}\right)_{3}(\mathrm{aq})$ & 30.70 & 1 \\
\hline $\mathrm{Ca}^{2+}+\mathrm{UO}_{2}{ }^{2+}+3 \mathrm{CO}_{3}{ }^{2-}=\mathrm{CaUO}_{2}\left(\mathrm{CO}_{3}\right)_{3}{ }^{2-}$ & 27.18 & 2 \\
\hline $\mathrm{Mg}^{2+}+\mathrm{UO}_{2}{ }^{2+}+3 \mathrm{CO}_{3}{ }^{2-}=\mathrm{MgUO}_{2}\left(\mathrm{CO}_{3}\right)_{3}{ }^{2-}$ & 26.11 & 2 \\
\hline $\mathrm{UO}_{2}^{2+}+\mathrm{PO}_{4}^{3-}=\mathrm{UO}_{2} \mathrm{PO}_{4}^{-}$ & 13.23 & 1 \\
\hline $\mathrm{UO}_{2}{ }^{2+}+\mathrm{H}^{+}+\mathrm{PO}_{4}{ }^{3-}=\mathrm{UO}_{2} \mathrm{HPO}_{4}(\mathrm{aq})$ & 19.59 & 1 \\
\hline $\mathrm{UO}_{2}{ }^{2+}+2 \mathrm{H}^{+}+\mathrm{PO}_{4}^{3-}=\mathrm{UO}_{2} \mathrm{H}_{2} \mathrm{PO}_{4}^{+}$ & 22.82 & 1 \\
\hline $\mathrm{UO}_{2}{ }^{2+}+3 \mathrm{H}^{+}+\mathrm{PO}_{4}{ }^{3-}=\mathrm{UO}_{2} \mathrm{H}_{3} \mathrm{PO}_{4}{ }^{2+}$ & 22.46 & 1 \\
\hline $\mathrm{UO}_{2}{ }^{2+}+4 \mathrm{H}^{+}+2 \mathrm{PO}_{4}^{3-}=\mathrm{UO}_{2}\left(\mathrm{H}_{2} \mathrm{PO}_{4}\right)_{2}(\mathrm{aq})$ & 44.04 & 1 \\
\hline $\mathrm{UO}_{2}{ }^{2+}+5 \mathrm{H}^{+}+2 \mathrm{PO}_{4}^{3-}=\mathrm{UO}_{2}\left(\mathrm{H}_{2} \mathrm{PO}_{4} \mathrm{H}_{3} \mathrm{PO}_{4}\right)^{+}$ & 44.05 & 1 \\
\hline
\end{tabular}

These thermodynamic data were used in a series of calculations to illustrate the U(VI) species that form in Hanford pore waters (Figures 6.1 and 6.2). Key parameters influencing U(VI) speciation in Hanford vadose zone and groundwater, i.e., $\mathrm{pH},\left[\mathrm{U}(\mathrm{VI})_{\mathrm{tot}}\right], \mathrm{CO}_{3}{ }^{2-}, \mathrm{Ca}^{2+}, \mathrm{Mg}^{2+}$, and $\mathrm{PO}_{4}{ }^{3-}$, were varied over relevant concentration ranges to ascertain their effects. The aqueous carbonate concentration was assumed to be in equilibrium with atmospheric $\mathrm{CO}_{2(\mathrm{~g})}$ partial pressure, with the consequent result that the total aqueous carbonate concentration increased with $\mathrm{pH}$ through carbonic acid dissociation. The calculations were made with an equilibrium speciation computer code, GWB. 

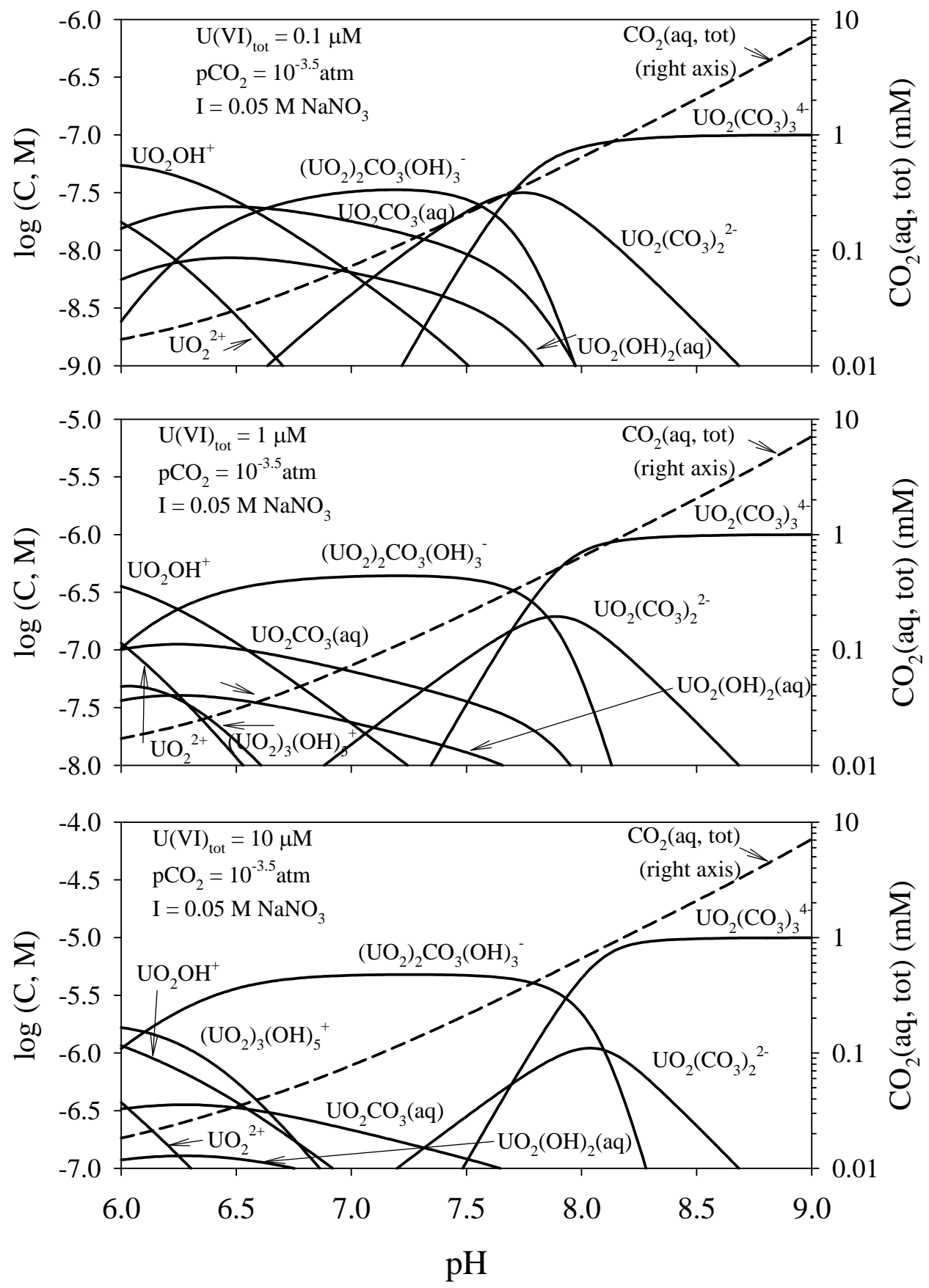

Figure 6.1. Aqueous U(VI) Speciation as a Function of $\mathrm{pH}$ and Total Aqueous U(VI) and Carbonate Concentrations in Hanford Sediment Pore Water. The carbonate concentration is in equilibrium with a $\mathrm{CO}_{2}(\mathrm{~g})$ pressure of $10^{-3.5}$ atmospheres. 

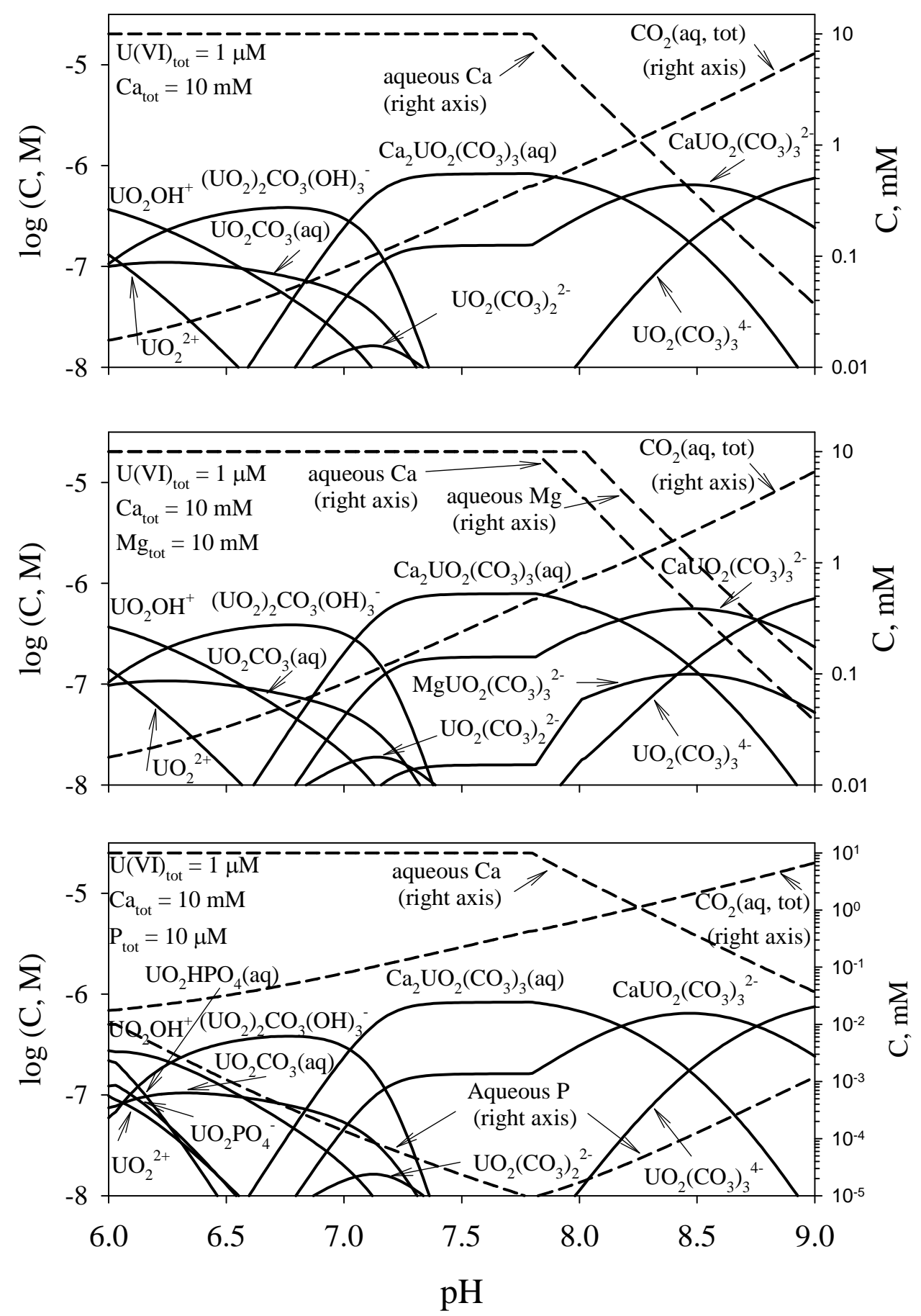

Figure 6.2. Aqueous U(VI) Speciation in the Presence of Ca (top panel), Ca and Mg (middle panel), and $\mathrm{Ca}$ and $\mathrm{PO}_{4}$ (bottom panel) in Hanford Sediment Pore Water. The total concentration of Ca was $10 \mathrm{mM}$, including both aqueous and solid phases in equilibrium. The solid calcium was represented by calcite. The total $\mathrm{Mg}$ concentration was $10 \mathrm{mM}$, including both aqueous and solid phase dolomite in equilibrium. The phosphate concentration was in equilibrium with the mineral hydroxyl apatite. 
The presence of calcium significantly changes uranyl aqueous speciation above $\mathrm{pH} 7$ (top plot in Figure 6.2). Below pH 6.5, calcium has no effect. U(VI) speciation is dominated by species $\mathrm{Ca}_{2} \mathrm{UO}_{2}\left(\mathrm{CO}_{3}\right)_{(\mathrm{aq})}$ from $\mathrm{pH} 7$ to 8 and by a combination of species $\mathrm{CaUO}_{2}\left(\mathrm{CO}_{3}\right)_{3}{ }^{2-}$ and $\mathrm{UO}_{2}\left(\mathrm{CO}_{3}\right)_{3}{ }^{4-}$ above $\mathrm{pH}$ 8. The total calcium concentration in the calculation was set to $10 \mathrm{mmol} / \mathrm{L}$, with Ca distributed between aqueous and solid phases, depending on $\mathrm{pH}$. The calcium solid phase was represented by the mineral calcite $\left(\mathrm{CaCO}_{3(\mathrm{~s})}\right)$, which is a minor but common component in the Hanford sediments. At this fixed total calcium concentration, the calcium all dissolves below $\mathrm{pH}$ 7.8, but it partially precipitates in equilibrium with calcite above $\mathrm{pH} 7.8$ as dissolved $\mathrm{CO}_{3}{ }^{2-}$ increases forcing precipitation. The decrease in aqueous calcium above $\mathrm{pH} 7.8$ causes a shift in $\mathrm{U}(\mathrm{VI})$ species dominance from $\mathrm{Ca}_{2} \mathrm{UO}_{2}\left(\mathrm{CO}_{3}\right)_{(\mathrm{aq})}$ to $\mathrm{CaUO}_{2}\left(\mathrm{CO}_{3}\right)_{3}{ }^{2-}$.

In the absence of calcium, magnesium, and phosphate, and with total U(VI) at a low concentration $(0.1 \mu \mathrm{mol} / \mathrm{L}$, a concentration approximately equal to the MCL), the $\mathrm{U}(\mathrm{VI})$ speciation is dominated by a mononuclear hydrolysis species $\left(\mathrm{UO}_{2} \mathrm{OH}^{+}\right)$below $\mathrm{pH}$ 6.5, a bi-nuclear species $\left[\left(\mathrm{UO}_{2}\right)_{2} \mathrm{CO}_{3}(\mathrm{OH})_{3}{ }^{-}\right]$from $\mathrm{pH} 6.5$ to 7.8, and mononuclear species $\left[\mathrm{UO}_{2}\left(\mathrm{CO}_{3}\right)_{2}{ }^{2-}\right.$ and $\left.\mathrm{UO}_{2}\left(\mathrm{CO}_{3}\right)_{3}{ }^{4-}\right]$ above $\mathrm{pH} 7.8$ (top panel in Figure 6.1). Increasing the total U(VI) concentration expands the region dominated by species $\left(\mathrm{UO}_{2}\right)_{2} \mathrm{CO}_{3}(\mathrm{OH})_{3}{ }^{-}$at the expense of mononuclear species in both lower and higher $\mathrm{pH}$ regions. When $\mathrm{U}(\mathrm{VI})_{\text {tot }}$ is increased above $10 \mu \mathrm{mol} / \mathrm{L}$ (i.e., > 100 times the MCL), multinuclear uranyl species, including $\left(\mathrm{UO}_{2}\right)_{3}(\mathrm{OH})_{5}{ }^{+}$(bottom panel in Figure 6.1), became important at lower $\mathrm{pH}$. The effect of U(VI) tot was minor above $\mathrm{pH} 7.0$ because $\mathrm{U}(\mathrm{VI})$ aqueous speciation was stabilized by high carbonate concentrations and very strong carbonate complexes [e.g., $\mathrm{UO}_{2}\left(\mathrm{CO}_{3}\right)_{2}{ }^{2-}$ and $\mathrm{UO}_{2}\left(\mathrm{CO}_{3}\right)_{3}{ }^{4-}$ ]. The calculated total dissolved carbonate concentration increased continuously from $0.02 \mathrm{mmol} / \mathrm{L}$ at pH 6 to $7 \mathrm{mmol} / \mathrm{L}$ at pH 9 (see dotted lines and right-hand legend on Figure 6.1).

The effect of $\mathrm{Mg}^{2+}$ is relatively minor compared with calcium (middle plot in Figure 6.2) because of the weaker stability constant of species $\mathrm{MgUO}_{2}\left(\mathrm{CO}_{3}\right)_{3}{ }^{2-}$ as compared to the corresponding Ca species. In our conceptual model, aqueous $\mathrm{Mg}^{2+}$ is projected to decrease above $\mathrm{pH} 8$ through dolomite precipitation, ${ }^{9}$ and this destabilizes the aqueous complex $\mathrm{MgUO}_{2}\left(\mathrm{CO}_{3}\right)_{3}{ }^{2-}$ at higher $\mathrm{pH}$. The effect of phosphate is also minor on U(VI) aqueous speciation (bottom panel in Figure 6.2) because its aqueous concentration is regulated to low levels by solubility equilibrium with various phosphate minerals. The calculated aqueous phosphate concentration in these calculations was fixed by equilibrium with hydroxyapatite, $\mathrm{Ca}_{5}\left(\mathrm{PO}_{4}\right)_{3}(\mathrm{OH})$, which has a low solubility in the calculated $\mathrm{pH}$ range. Phosphate influences U(VI) aqueous speciation below $\mathrm{pH} 6.5$ where species $\mathrm{UO}_{2} \mathrm{HPO}_{4}(\mathrm{aq})$ and $\mathrm{UO}_{2} \mathrm{PO}_{4}{ }^{-}$are contributing but not major aqueous species. The concentrations of uranyl phosphate aqueous complexes decrease dramatically with increasing $\mathrm{pH}$ as the solubility of hydroxyapatite decreases, and carbonate concentrations increase. Highly stable uranyl carbonate species outcompete those with phosphate at increasing $\mathrm{pH}$.

Most Hanford uncontaminated or slightly contaminated pore waters and groundwater exhibit a $\mathrm{pH}$ between 7.5 to $8.5, \mathrm{Ca}^{2+}$ concentrations between 0.5 to $10 \mathrm{mmol} / \mathrm{L}$, and equilibrium with $\mathrm{CO}_{2(\mathrm{~g})}$ that is slightly above atmospheric pressures (e.g., $>10^{-3.5} \mathrm{~atm}$ ). Higher $\mathrm{pH}$ and calcium concentrations in these ranges generally occur in sediments containing greater than a few weight-percent calcite. The speciation diagrams show that $\mathrm{U}(\mathrm{VI})$ under average Hanford geochemical conditions will be distributed between multiple species with $\left(\mathrm{UO}_{2}\right)_{2} \mathrm{CO}_{3}(\mathrm{OH})_{3}{ }^{-}$and $\mathrm{UO}_{2}\left(\mathrm{CO}_{3}\right)_{3}{ }^{4-}$ predominating at lower $\mathrm{Ca}^{2+}$ concentrations and

\footnotetext{
${ }^{9}$ In natural systems with low biotic activity, there is scientific debate on whether dolomite will readily form or whether there are kinetic hindrances to its formation. We assume that dolomite will precipitate in our conceptual U speciation calculations.
} 
$\mathrm{Ca}_{2} \mathrm{UO}_{2}\left(\mathrm{CO}_{3}\right)_{3(\mathrm{aq})}$ and $\mathrm{CaUO}_{2}\left(\mathrm{CO}_{3}\right)_{3}{ }^{2-}$ predominating at higher $\mathrm{Ca}^{2+}$ concentrations. These differences are significant in that calcium-uranium-carbonate complexes have been shown to be less susceptible to both adsorption and biologic reduction than those containing just uranium and carbonate (Brooks et al. 2003; Dong et al. 2005; Fox et al. 2006).

Notable aspects of $\mathrm{U}(\mathrm{VI})$ aqueous speciation in Hanford waters are 1) the presence of predominantly negative or neutral charges for the major species, 2) the near (effective) absence of the free cation (e.g., $\mathrm{UO}_{2}{ }^{2+}$ ) as a reactive species (its percent distribution in speciation calculations in Figures 6.1 and 6.2 is miniscule),${ }^{10} 3$ ) the importance of carbonate as a complexing ion, and 4) significant $\mathrm{pH}$ sensitivity to the $\mathrm{U}(\mathrm{VI})$ species distributions.

Typically, the computation of $\mathrm{U}(\mathrm{VI})$ aqueous speciation from a charge-balanced analysis of pore or groundwater or a laboratory aqueous sample that has contacted $\mathrm{U}(\mathrm{VI})$-containing sediment is a first step in data interpretation (see for example, Liu et al. 2004) and discussions/examples in Zachara et al. (2007a, Section 4.2). Given the importance of aqueous speciation to reactive transport, it is quite desirable to directly measure the dominant aqueous species to verify the overall thermodynamic model. Such verification is not easy and is performed by various spectroscopic techniques. It need only be performed occasionally when the system speciation is indicated, by calculation, to change dramatically. An example of such verification for Hanford pore water was performed by Wang et al. (2004) using Cryogenic Laser Induced Fluorescence Spectroscopy measurements on the pore waters removed from contaminated sediments from the BX-102 vadose zone plume. Details of the aqueous-species verification are found in Wang et al. (2004) and Zachara et al. (2007a).

\subsection{Contaminant Uranium in 300 Area}

The contribution from natural background uranium must be known and understood to monitor and evaluate contaminant uranium's environmental impacts at the Hanford Site. As part of 300 Area field campaigns in the 1980s and 1990s, sediments and groundwater samples were analyzed for background or "natural" uranium concentrations. A summary of these efforts and an overview of existing Hanford literature that is related to background uranium concentrations are presented in the following subsection.

\subsubsection{Background Uranium Concentrations in Hanford Media}

Table 6.2 contains the "total" concentration ${ }^{11}$ of uranium as measured in uncontaminated or background sediment samples. The data have been gathered either via recent field sampling and characterization campaigns or are based on historical analyses of site-wide samples (both near-surface soils/sediments/rocks and groundwater) in the early 1990s specifically to establish statistically based Hanford Site background data. Based on the information contained in references cited in the table, the background "total" uranium concentration in sediment collected throughout the Hanford Site ranges from a low of $0.392 \mathrm{mg} / \mathrm{kg}$ to a high of $5.10 \mathrm{mg} / \mathrm{kg}$. However, the two lowest concentrations in the cited

\footnotetext{
${ }^{10}$ The near absence of the free cation $\mathrm{UO}_{2}{ }^{2+}$ in the aqueous speciation distributions does not mean that the free cation is not an important specie adsorbed to solid phase sorption sites during adsorption-desorption reactions discussed later in this section and in Zachara et al. (2007a).

${ }^{11}$ In many instances the entire solid is not dissolved prior to making uranium measurements such that one cannot be certain that the total mass of uranium present has been captured. Some analytical techniques do measure total uranium (e.g., XRF, $\gamma$ spectroscopy) and the total fusion technique does dissolve the entire mass of solid. Other methods such as SW-846 and acid digests do not necessarily capture all the uranium in the solid.
} 
references were generated via strong acid digestion of the sediment, which does not solubilize all of the crystalline uranium in the sediment. Therefore, it would be most accurate to only include data from those analyses that quantitatively measure the entire uranium content of the sediment. Based on this restriction, the range of background uranium concentrations in Hanford Site sediment is 1.47 to $5.10 \mathrm{mg} / \mathrm{kg}$. In a field study specific to the 300-FF-1-Operable Unit, a statistically based concept called the upper tolerance limit was used to determine at what concentration a sediment from the 300 Area should be considered to contain so much uranium that it could not be a background or uncontaminated sample. DOE-RL (1994b) chose an upper tolerance limit value of $8.9 \mathrm{mg} / \mathrm{kg}$ for sediments from the 300-FF-1 Operable Unit.

Table 6.2. Background Uranium Concentrations in Hanford Site Sediment

\begin{tabular}{||l|c|l|l|l||}
\hline \multicolumn{1}{||}{ Location } & $\begin{array}{c}\text { Average Uranium } \\
\text { Concentration (mg/kg) }\end{array}$ & $\begin{array}{c}\text { Standard } \\
\text { Deviation }\end{array}$ & \multicolumn{1}{|c||}{ Method } & \multicolumn{1}{||}{ Reference } \\
\hline \hline WMA-B/BX/BY & $1.47 \mathrm{E}+00$ & $5.46 \mathrm{E}-01$ & Fusion & Lindenmeier et al. (2002) \\
\hline WMA-C & $3.92 \mathrm{E}-01$ & $6.20 \mathrm{E}-02$ & $\begin{array}{l}\text { SW-846, Methods 3050B } \\
\& 6020\end{array}$ & Brown et al. (2006) \\
\hline WMA-S-SX & $9.03 \mathrm{E}-01$ & $8.44 \mathrm{E}-01$ & $\begin{array}{l}\text { SW-846, Methods 3050B } \\
\& 6020\end{array}$ & Serne et al. (2002c) \\
\hline WMA-T & $2.59 \mathrm{E}+00$ & $9.48 \mathrm{E}-01$ & Fusion & Serne et al. (2004b) \\
\hline WMA-TX/TY & $2.31 \mathrm{E}+00$ & $5.66 \mathrm{E}-01$ & Fusion & Serne et al. (2004a) \\
\hline 300 Area & $5.10 \mathrm{E}+00$ & $1.37 \mathrm{E}+00$ & Gamma Energy Analysis & Serne et al. (2002a) \\
\hline Hanford Site & $2.27 \mathrm{E}+00$ & $6.42 \mathrm{E}-01$ & Alpha Spectroscopy & DOE-RL (1996a) \\
\hline
\end{tabular}

Table 6.3 contains the concentration of uranium as measured in uncontaminated or background groundwater samples gathered via historical analyses of site-wide groundwater samples. Based on the information contained in Table 6.3, the average background uranium groundwater concentration in samples collected from the unconfined aquifer throughout the Hanford Site was $2.57 \mu \mathrm{g} / \mathrm{L}$. These data are based on the analysis of 25 unconfined aquifer samples, which had an overall range of 0.5 to $12.8 \mu \mathrm{g} / \mathrm{L}$. Also contained in Table 6.3 are data from a recent review of the 300 Area uranium plume, which suggests a range of 5 to $8 \mu \mathrm{g} / \mathrm{L}$ for uncontaminated unconfined aquifer groundwater samples (Peterson et al. 2005). Based on these data, uncontaminated Hanford groundwater could contain as much as $12.8 \mu \mathrm{g} / \mathrm{L}$ uranium. DOE-RL (1994b) also used the upper tolerance limit concept to evaluate the concentration of uranium in groundwater below the 300-FF-1 operable unit that would be construed as being contaminated. The value chosen was $12.9 \mu \mathrm{g} / \mathrm{L}$, which agrees well with the highest value in the range shown in Table 6.3.

Table 6.3. Background Uranium Concentrations in Hanford Site Groundwater

\begin{tabular}{||l|l|l|l|l||}
\hline \multicolumn{1}{|c|}{ Location } & \multicolumn{1}{|c|}{$\begin{array}{c}\text { Average Uranium } \\
\text { Concentration }(\mu \mathrm{g} / \mathrm{L})\end{array}$} & $\begin{array}{c}\text { Standard } \\
\text { Deviation }\end{array}$ & \multicolumn{1}{|c||}{ Method } & \multicolumn{1}{c||}{ Reference } \\
\hline \hline Hanford Site (unconfined aquifer) & $2.57 \mathrm{E}+00$ & $2.85 \mathrm{E}+00$ & Unknown & DOE-RL (1997b) \\
\hline Hanford Site (confined aquifer) & $1 \mathrm{E}-02$ & $9 \mathrm{E}-03$ & ICP-MS & DOE-RL (1994b) \\
\hline 300 Area & $5 \mathrm{E}+00$ to 8E+00 & Not Available & ICP-MS & Peterson et al. (2005) \\
\hline
\end{tabular}

Conversely, the total uranium concentration measured in the confined aquifer underlying the Hanford Site is quite low. As seen in Table 6.3, the average uranium concentration in the confined aquifer was $0.01 \mu \mathrm{g} / \mathrm{L}$. These data indicate that uranium contamination presently residing in the unconfined aquifer 
has not migrated into the deeper confined aquifer (i.e., there is presently near complete isolation between the two hydrologic systems — at least at locations that have been measured for uranium).

\subsubsection{Mineral Form of Background Uranium}

Projecting how contaminant $\mathrm{U}(\mathrm{VI})$ may move in the future is contingent on understanding its molecular speciation, i.e., elements to which it is chemically bound and the resulting structure, and on identifying the mineral phases with which it associates. This information is fundamental to developing an appropriate conceptual geochemical model of contaminant reactivity. Furthermore, because uncontaminated Hanford sediments contain approximately 1.5 to $5 \mathrm{mg} / \mathrm{kg}$ of natural background uranium, and many contaminated sediments contain from 5 to $25 \mathrm{mg} / \mathrm{kg}$ of total uranium, distinguishing between the chemical forms of background and contaminant uranium becomes important as they may exhibit different molecular speciation and mineral residence.

Before recent studies presented in Zachara et al. 2007a, there was no information on the valence or mineral form of background uranium in Hanford sediments. Background uranium until recently has been analytically inaccessible to the most powerful of synchrotron techniques, which are typically used for these measurements, because of the low uranium concentrations. Collaborators at the Argonne National Laboratory in association with the Advanced Photon Source (a synchrotron light source) worked on this problem and devised a method employing unusually thick sediment thin sections that have allowed unequivocal identification of at least one background uranium mineral. Sediment samples ( $<2$-mm size fraction) from beneath the tank farms in the 200 Area Plateau and the 300 Area North Process Pond (sample NPP1-16 in Zachara et al. [2005]) were embedded in epoxy, microtomed, and polished into nonstandard thin sections approximately $300-\mu \mathrm{m}$ thick, each containing approximately $0.25 \mathrm{~g}$ of sediment. The average uranium in the sediments, as determined by bulk analysis, ranged from 8 to $17 \mathrm{mg} / \mathrm{kg}$. Microprobe X-ray fluorescence ( $\mu \mathrm{XRF}$ ) maps were made to determine the distribution of uranium, Fe, $\mathrm{Ca}$, and several other metals. Then the specific locations of the samples enriched in uranium were investigated further with microprobe X-ray absorption spectroscopy ( $\mu$ XAS) techniques, including X-ray absorption near-edge structure ( $\mu$ XANES) measurements to determine the average valence state of uranium and microprobe extended X-ray absorption fine structure ( $\mu$ EXAFS) measurements to determine the chemical speciation of uranium.

The $\mu$ XRF distributions for all the sediments probed showed a few intense nanometer ${ }^{2}$ locations of uranium and several other more diffuse locations of enriched uranium. The $\mu$ XAS spectra for the intense uranium $\mu$ XRF locations showed uranium spatial correlations with Fe and Ca. The $\mu$ XAS spectra from locations with diffuse uranium $\mu \mathrm{XRF}$ signals were consistent with contaminant $\mathrm{U}(\mathrm{VI})$ species because they displayed a resonance feature above the adsorption edge of a typical U(VI) uranyl moiety (Hudson et al. 1995). The $\mu$ XANES spectra from locations with intense uranium $\mu$ XRF signals did not contain the resonance feature above the absorption edge and were therefore more consistent with a U(IV) species that could be reduced contaminant uranium or a primary mineral associated with background uranium. The uranium chemical speciation of the areas with an intense uranium $\mu$ XRF signal was further investigated with $\mu \mathrm{EXAFS}$.

The $\mu$ EXAFS spectra for the locations with intense uranium $\mu$ XRF were all similar and had spectral properties indicative of the presence of crystalline mineral forms rather than an adsorbed species. The $\mu$ EXAFS spectra for the regions with intense $\mu$ XRF signals were compared to spectra for more than 20 known U(IV) minerals. The only mineral with a theoretical spectrum similar to the measured spectra was 
betafite $\mathrm{C}$ (Dickson et al. 1989), chemical formula $\mathrm{Ca}_{0.92} \mathrm{U}_{1.08}\left(\mathrm{Ti}_{2} \mathrm{O}_{7}\right)$. In the betafite $\mathrm{C}$ structure, Ca may substitute for uranium in approximately half of the uranium sites. Figure 6.3 shows the betafite $C$ structure. The $\mu$ EXAFS spectra for the intense uranium $\mu$ XRF locations were simultaneously refined using parameters based on the betafite $\mathrm{C}$ structure. The average distances from the uranium atoms to the neighboring atoms were compared to distances based on crystallography, and some distances were off by as much as $8 \%$. The difference between the refined $\mu$ EXAFS values and crystallographic values was caused by substituting Ca for uranium. More details on the synchrotron studies of these uranium-bearing Hanford sediments can be found in Zachara et al. (2007a).

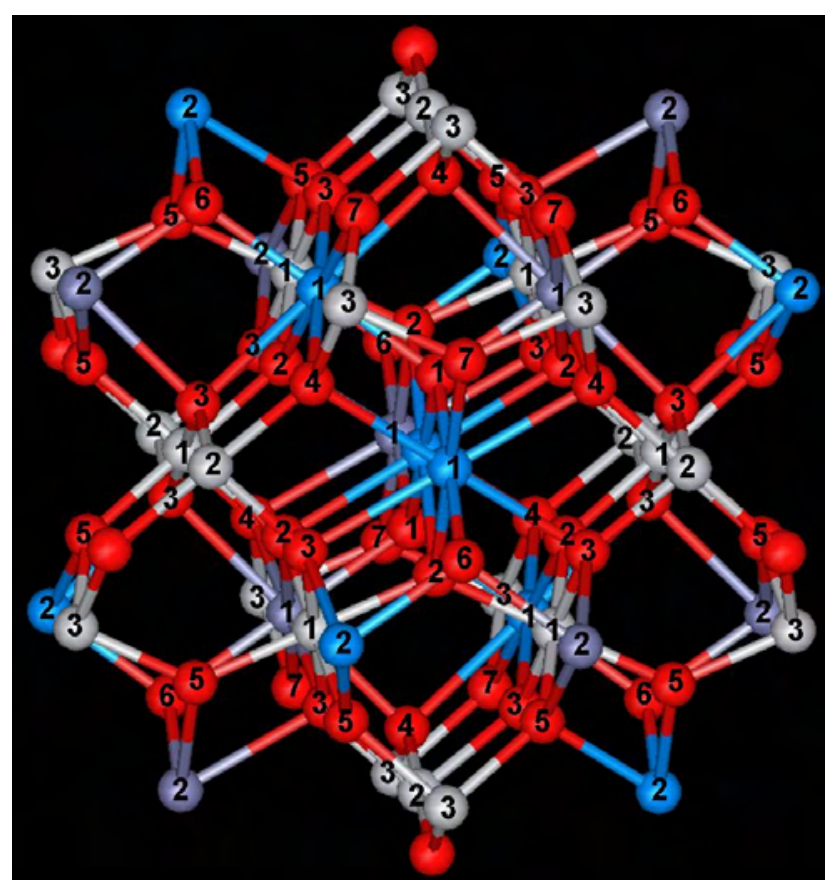

Figure 6.3. Crystal Structure of Betafite C, Based on Previous XRD Measurements. The blue, dark gray, light gray, and red spheres represent $\mathrm{U}, \mathrm{Ca}, \mathrm{Ti}$, and $\mathrm{O}$ atoms, respectively.

Betafite is structurally similar to a more common uranium mineral called brannerite, which is a frequently observed accessory uranium mineral in granites, granitic pegmatites, and uranite/coffinite uranium deposits (Finch 1996). Its origin in Hanford sediments apparently derives from the ubiquitous and substantial content of granitic lithic fragments (e.g., 15 to 35\%) that are common to all Hanford sediments. The provenance of some of these granitic fragments could be northwestern Washington, where a major uranium deposit containing both uranite and coffinite exists. The identification of this U(IV) phase in Hanford sediments, despite the overall low total uranium content, was allowed by its presence as discrete small mineral grains with a very high uranium concentration.

Betafite itself is highly resistant to weathering (Lumpkin and Ewing 1995, 1996), an observation which possibly explains its apparent long-term stability in Hanford sediments. Further research is needed to determine if betafite $\mathrm{C}$ is the dominant phase of $\mathrm{U}(\mathrm{IV})$ in natural Hanford sediments or if other U(IV) phases are also present, all of which could be a source to Hanford vadose zone and groundwater of U(VI) formed by natural oxidative weathering processes. The apparent frequent occurrence of betafite $\mathrm{C}$ in low concentration needs to be explicitly considered when attempting to interpret solid-phase speciation 
measurements of contaminant uranium in Hanford sediments. On the other hand, the amount of labile uranium [the portion of uranium that can readily dissolve in circum-neutral $\mathrm{pH}$ water and readily oxidize to $\mathrm{U}(\mathrm{VI})$ ] in betafite $\mathrm{C}$ should be miniscule over time periods of decades (i.e., time periods assumed to be of importance to dissipating the persistent groundwater plume in the 300 Area.

\subsubsection{Waste-Effluent Characteristics}

An estimated 202,700 to 205,435 kg of uranium was released to the ground surface at Hanford by depositing waste solutions to cribs, trenches, and process ponds and by inadvertently releasing tank waste (Corbin et al. 2005 and Simpson et al. 2006, respectively). The objectives of the Simpson et al. (2006) analysis were to 1) identify the specific disposal/waste sites containing the most uranium, 2) determine which high-inventory sites received uranium in acidic or basic waste streams (note: pH strongly controls uranium mobility), and 3) establish which sites received reactive organic complexants, such as citrate and EDTA/HEDTA, or inorganic ligands, such as carbonate and phosphate that might modify expected geochemical behavior.

Key results and implications of the Simpson et al. (2006) analysis pertaining to the top 17 uranium inventory sites at Hanford, which includes the three principal 300 Area sites-North and South Process Ponds and 300 Area Process Trenches_-are summarized here, especially in terms of identifying common elements and unique aspects. Readers seeking the comprehensive analysis of all Hanford disposal sites, including waste-stream loadings and waste-stream compositions, should consult Simpson et al. (2006), the Soil Inventory Model primary source document (Corbin et al. 2005) and citations therein, and Higley et al. (2004). The inventory analysis for 300 Area sites discussed here is constrained by the assumptions of the Soil Inventory (Corbin et al. 2005) and the Hanford Defined Waste (Higley et al. 2004) models as well as the process-related databases from which these two models were derived.

A key assumption in this modeling for uranium was that the nominal/average solubility limit for uranium in Hanford waste streams is approximately $860 \mathrm{mg}$ uranium per liter, which determined the distribution between dissolved and solid uranium forms in the waste streams sent to near-surface disposal facilities and to underground storage tanks. It is important to recognize that reconstructing the wastestream compositions and total mass loadings that went to the various waste facilities is challenging and uncertain. Unfortunately, there were very few direct and comprehensive analyses of Hanford waste streams during the early production years that can be used to verify the waste-stream character and composition used in these current model projections. Among other things, waste-stream $\mathrm{pH}$ and solids mass/composition were rarely measured. Corrosive or acidic waste streams were also commonly neutralized to undocumented end states as directed by empirically established processing or flow-chart considerations.

Close to $90 \%$ of the total uranium inventory disposed of at Hanford was projected to reside in 17 high-inventory sites (Table 6.4). Within these 17 sites, the total uranium inventory was observed to vary by about a factor of 50, from a high of $43,444 \mathrm{~kg}$ in 216-A-19 to 1,749 kg in the 300 Area Process Trenches. The three facilities in the 300 Area account for approximately $23 \%$ of the total uranium disposed of or leaked to the Hanford subsurface. Most of the residual uranium in the three 300 Area facilities was assumed to reside as precipitates in and sorbed species on the vadose zone sediments. Many thousands of tons of the vadose zone sediments in the footprint of the two process ponds and process trenches and surrounding region have been excavated and transported to the Environmental Restoration Disposal Facility (ERDF). 
Table 6.4. Uranium Disposed to Facilities at the Hanford Site

\begin{tabular}{|c|c|c|c|}
\hline $\begin{array}{c}\text { Site Ranking- } \\
\text { All Hanford } \\
\text { Uranium Sites } \\
\end{array}$ & Site & $\begin{array}{l}\text { U-Total Mean } \\
\text { Inventory }(\mathrm{kg}) \\
\end{array}$ & $\begin{array}{c}\text { Percent of Total } \\
\text { Uranium } \\
\text { Disposed } \\
\end{array}$ \\
\hline 1 & 216-A-19 & $43,444.5$ & $24 \%$ \\
\hline 2 & 316-1 (South Process Pond) & $26,166.0$ & $14 \%$ \\
\hline 3 & 216-U-8 & $25,511.6$ & $14 \%$ \\
\hline 4 & 316-2 (North Process Pond) & $19,391.4$ & $11 \%$ \\
\hline 5 & 216-B-12 & $15,112.3$ & $8 \%$ \\
\hline 6 & 216-A-25 & $12,192.6$ & $7 \%$ \\
\hline 7 & 241-BX-102 & $10,057.1$ & $5 \%$ \\
\hline 8 & 216-U-12 & $6,458.4$ & $3 \%$ \\
\hline 9 & 216-A-4 & $5,388.2$ & $3 \%$ \\
\hline 10 & 216-U-1\&2 & 3,955.5 & $2 \%$ \\
\hline 11 & 216-S-7 & $3,411.2$ & $2 \%$ \\
\hline 12 & 216-B-3 & $2,787.9$ & $2 \%$ \\
\hline 13 & 216-A-3 & $2,641.4$ & $1 \%$ \\
\hline 14 & 216-S-1\&2 & $2,219.8$ & $1 \%$ \\
\hline 15 & 216-U-10 & $2,158.5$ & $1 \%$ \\
\hline 16 & 216-A-9 & $1,886.7$ & $1 \%$ \\
\hline 17 & 316-5 (300 Area Process Trenches) & $1,749.2$ & $1 \%$ \\
\hline \multirow[t]{3}{*}{$18-148$} & Other Uranium Bearing Sites & 21,000 & -- \\
\hline & Total Uranium Disposed & 180,000 & $100 \%$ \\
\hline & Total Uranium Disposed at 300 Area & 47,306 & $26 \%$ \\
\hline
\end{tabular}

It is important to note that the uranium inventories shown in Table 6.4 are model projections. At locations such as the South and North Process Ponds as well as 300 Area Process Trenches, much of the contaminated sediments have been removed and sent to the ERDF waste disposal facility south of the 200 East Area. Verifying the mass of uranium still remaining in Hanford's subsurface is challenging because of difficulties in characterizing a three-dimensional subsurface plume with a complex structure with a limited number of boreholes or geophysical measurements primarily sensitive to total salt content. Field sampling campaigns within and near the South and North Process Ponds (Serne et al. 2002a; Zachara et al. 2005; Williams et al. 2007) have successfully intersected key zones of the uranium inventory in the 300 Area, but the overall areal extent of uranium in the 300 Area vadose zone is still lacking.

Some of the high-inventory waste sites exhibited a common origin for their uranium inventory, such as the concentrated uranyl nitrate hexahydrate waste stream from U-plant and PUREX [e.g., a PUREX waste stream called "Conc. Misc. UNH Streams" in Simpson et al. (2006)]. It is therefore possible that contaminant uranium in some Hanford waste sites may exhibit similar geochemical conditions and therefore transport behavior in subsurface sediments beneath the facilities. While this may be a reasonable hypothesis and is the basis for the "representative site approach" taken by the Fluor Hanford site remediation contractor, it was also found in the Simpson et al. (2006) inventory analysis that the concentration and timing of uranium release varied markedly between the different sites. The total volume of disposed water and the origins, nature, and composition of other co-disposed waste streams also varied markedly. These co-disposed waste streams, in addition to the primary uranium-containing 
waste stream, may have strongly modified the overall geochemical environment of the waste site and underlying sediments. The implications of waste mixing and variable water volumes on the behavior of the primary high-uranium-inventory waste stream requires due consideration.

Significant concentrations of organic complexants were projected for only a few of the lower uranium inventory sites (Simpson et al. 2006) that were not significant in the total uranium inventory analysis. Acidic uranium-bearing waste streams undoubtedly underwent waste-sediment reactions that moderated waste $\mathrm{pH}$ and lowered sediment $\mathrm{pH}$ by coupled dissolution and precipitation reactions but as yet remain unstudied at Hanford. ${ }^{12}$ It is speculated that acidic wastes would drive the dissolution of carbonates and fine-grained phyllosilicates in Hanford sediments and that poorly crystalline oxides would precipitate deeper in the sediment profile once the acidity had been neutralized. These reactions and their resulting aqueous and solid-phase byproducts, along with attendant changes to the original mineralogy and surface characteristics of the sediments, could strongly influence the post-disposal migration of contaminant uranium both in positive and negative directions. Relict phases and surface complexes resulting from these past $\mathrm{pH}$-neutralizing, sediment-waste reactions may be evident in the current chemical speciation of sorbed uranium in the 300 Area Process Ponds residual sediments.

Sites containing fuel-rod production wastes (e.g., South and North Process Ponds) were projected by the Soil Inventory Model analyses (Simpson et al. 2006) to have received large amounts of solid-phase uranium. This projection resulted from considering the total uranium inventories disposed of, the known volumes of waste fluids released, and an assumed value of U(VI) solubility in the waste stream (e.g., 860 parts per million). An increased value for the assumed solubility limit, as would occur under acidic conditions, would significantly lower the projected inventory of uranium solids within the waste streams disposed of to the 300 Area Process Ponds. It is plausible that most of the initially acidic, high $\mathrm{U}(\mathrm{VI})$ fuel-rod dissolution waste streams were neutralized before disposal, leading to the hydrolysis and precipitation of a variety of $\mathrm{U}(\mathrm{VI})$ oxyhydroxides. At this point, however, the presence of such wastestream uranium solids and their nature [e.g., metallic uranium, mixed U(IV) and U(VI), or U(VI)] remains undefined through the field sampling performed since the excavation and disposal of the vadose zone sediments from the process ponds and trenches at ERDF. Without a better understanding of the acidneutralization status on wastes disposed of to the South and North Process Ponds, it is difficult to ascertain how much of the uranium may have been in particulate form during active disposal. Wastestream solids containing uranium could significantly affect the long-term behavior of contaminant uranium present in most Hanford disposal sites. All the known liquid portions of the waste streams disposed of or released at Hanford are believed to be dominated by dissolved U(VI).

There are spatial correlations between waste sites of high uranium inventory and existing groundwater uranium plumes. This correlation is not expected to be exact because the waste sites exhibit markedly different hydrologic (e.g., process-water disposal and natural/enhanced recharge) and waste chemical histories, and the underlying vadose zones display significant differences in lithologic, geochemical, and hydrophysical properties that influence both physical and chemical retardation and migration vectors. The principal Hanford Site uranium plumes reside in three areas: 1 ) in the northnorthwest of the 200 East Area in the BP-5 groundwater operable unit, with a localized hot spot northeast of the BX tank farm (recall the large overfill event from 241-BX-102, 2) in the south portion of the 200 West Area (200-UP-1 Operable Unit) near the 216-U1\&U2 crib, and 3) along the Columbia River

\footnotetext{
${ }^{12}$ A converse reaction suite where high $\mathrm{pH}$ waste (such as leaked from single-shell tanks) reacts with Hanford sediment, in contrast, has been well studied and is complex (see literature summarized in Zachara et al. 2007b).
} 
shoreline in the 300 Area beneath and downgradient of the vertical projection (i.e., footprint) of the remediated South and North Process Ponds and 300 Area Process Trenches (Hartman et al. 2007).

In Section 6.3, we present details on our conceptual model of where and how much uranium remains in the 300 Area subsurface below the inactive liquid-waste disposal facilities and within the overall groundwater plume. Our mass-balance-box model suggests that approximately $9 \%$ of the disposed uranium estimated in Table 6.4 remains in the 300 Area subsurface. ${ }^{13}$ The next subsection begins a detailed discussion on the "box" model of where the residual uranium resides and conceptually introduces how uranium is released from the sediments and dissolved into the pore water or groundwater.

\subsection{Conceptual Geochemical Model (Based on Box Model Inventories)}

Three central questions were posed in Section 2.0 that must be answered to construct a robust conceptual model for the 300 Area uranium plume. The questions are:

- Where is the inventory of uranium that feeds the plume?

- What are the mechanisms by which the uranium is mobilized?

- How long can the inventory continue to supply uranium to the groundwater plume?

In the following four subsections (6.3.1 through 6.3.4), we will address the first question. In Sections 6.4 and 6.5, we will address the second question. The third question is best addressed using a computer model for contaminant transport, which relies on a three-dimensional water flow model coupled with detailed chemical reaction algorithms that describe solubility/precipitation and adsorption/desorption reactions. In addition, the transport code would need to be populated with realistic starting inventories of uranium and other key constituents and realistic boundary conditions for the key hydrologic and geologic parameters. One would then run the computer model and vary the most important parameters over a plausible range to obtain a suite of predicted times for the uranium groundwater plume to dissipate.

These activities are called a sensitivity analysis. A transport code based on three-dimensional numerical chemical reactions and the necessary database for initial and boundary conditions are being developed (at least portions of the chore) using a variety of projects and funding sources. We have summarized some very recent two-dimensional transport results in Section 6.5.3. The summary focuses on the time for the leading edge of a hypothetical uranium plume for uranium emplaced at two locations - one inland and one near the river - to reach the river if the regions outside the uranium emplacement do not contain any uranium. This summarization is for illustration only to show the complexity of the 300 Area uranium plume and to add some concrete examples of data needed to allow more realistic predictions.

To answer the first question, determining uranium inventory, PNNL researchers developed a "box" model that breaks the 300 Area subsurface into 10 compartments as follows:
A. Vadose Zone Sediments Above the High River Stage Within Footprint of Inactive Disposal Facilities
B. Vadose Zone Pore Water Above the High River Stage Within Facility Footprint
C. Vadose Zone Sediments Above High River Stage Outside Facility Footprints

\footnotetext{
${ }^{13}$ A summary of the mass of potentially contaminated sediment that has already been removed from the major liquid-waste disposal sites is presented in DOE-RL (2005a), with the following values (in U.S. tons): South Process Pond (256,888), North Process Ponds (154,825), and 300 Area Process Trenches $(37,961)$.
} 
D. Vadose Zone Pore Water Above High River Stage Outside Facility Footprints

E. Sediments in Intermittently Wetted "Smear" Zone Below Facility Footprints

F. Pore Water in the "Smear" Zone Below Facility Footprints

G. Sediments in Intermittently Wetted "Smear" Zone Outside Facility Footprints

H. Pore Water in the "Smear" Zone Outside Facility Footprints

I. Aquifer Sediments that are Always Below Water Table

J. Uranium Plume (Groundwater in the Aquifer Above $30 \mu \mathrm{g} / \mathrm{L}$ uranium concentration).

We have elected to assume, to simplify calculations, that any uranium bound to Columbia River bank and bed sediments and the pore waters retained therein have "escaped" from the groundwater plume despite the possibility that during high-river-stage conditions, uranium from these two neglected compartments may in fact be transported back into the latter six compartments (E-J). Our ability to determine the volumes of sediment and pore water/groundwater and the concentrations of uranium within these 10 compartments or "boxes" varies considerably. The following discussion leads to a first-order approximation of the total uranium inventory by compartment based on assumptions stated in the text. To help orient the reader to the discussion, Table 6.5 provides a summary of the results and Figure 6.4 provides a schematic of the uranium transfer between the compartments.

\subsubsection{Compartments A and B (Sediment and Pore Water Within Facility Footprints) and $E$ and F (Smear Zone Directly Below Facility Footprints)}

Various documents discuss the waste streams and inventories of chemicals disposed to the 300 Area facilities over the lifetime of the fuel fabrication and research activities performed in the 300 Area laboratory buildings. Section 2 (background) cites most of the available literature. However, we rely on the recent waste-stream analysis of Simpson et al. (2006) to guide our conceptual model development. Note however, that Simpson et al. (2006) did not tabulate records on waste disposal to the 307 Process Trenches (316-3 waste site) so that we do not have, at this time, any understanding on how much uranium might have been disposed therein. The South and North Process Ponds received significant masses of uranium and volumes of waste over their lifetimes (see Table 6.4). The South Process Pond received 26,166 kg of uranium in 51 billion L of liquid effluent, and the North Process Pond received 19,391 kg of uranium in 37 billion L of liquid effluent. The areal footprints of these two ponds during their active operation are estimated as 32,795 and 40,320 $\mathrm{m}^{2}$, respectively (Young and Fruchter 1991). However, during operation of the ponds, the bottoms were "dredged" several times to remove impermeable sludge (most likely sodium aluminate gels) to improve the percolation of fluids. Some of the dredged spoils were placed on dikes surrounding the perimeters of the ponds. Further, additional dredged sludge was spread out for several hundred feet directly south of the ponds. Thus, the effective footprint of the ponds is difficult to estimate accurately.

The ponds were used for liquid disposal through 1975, and then after many years with no further liquid disposal, most of the highly contaminated sediments were removed and trucked to the ERDF. DOE-RL (2005a) provides a good summary on the timing of remediation activities and the total mass of sediments removed and disposed of at ERDF. A summary table in this report shows 154,825 tons (U.S.) of sediment removed from the North Process Pond and 256,888 tons (U.S.) removed from the South Process Pond (see Section 2 for further discussion). After cleanup activities were completed, hand-held or mobile radiation meters were used to confirm that the ponds had been cleaned up to established acceptable levels of residual uranium contamination. 
Table 6.5. Uranium Inventory in Compartments of the Box Model for 300 Area

\begin{tabular}{|c|c|c|c|c|c|}
\hline Compartment & Description & $\begin{array}{l}\text { Process Ponds } \\
\text { Sub-Unit (kg) }\end{array}$ & $\begin{array}{l}300 \text { Area Process } \\
\text { Trenches } \\
\text { Sub-Unit }(\mathrm{kg}) \\
\end{array}$ & $\begin{array}{l}\text { Uranium } \\
\text { Inventory } \\
(\mathrm{kg}) \\
\end{array}$ & Comments \\
\hline $\bar{A}$ & $\begin{array}{l}\text { Vadose Zone Sediments Above } \\
\text { High River Stage Within } \\
\text { Footprint of Inactive Disposal } \\
\text { Facilities }\end{array}$ & $1,661.4$ & 439.2 & $2,100.6$ & $\begin{array}{l}\text { Total A+B for South Pond is } 524 \mathrm{~kg} \text { and for North } \\
\text { Pond is } 1,189 \mathrm{~kg} \text {. The total for } 300 \text { Area Process } \\
\text { Trenches is } 462.3 \mathrm{~kg} \text {. }\end{array}$ \\
\hline B & $\begin{array}{l}\text { Vadose Zone Pore Water Above } \\
\text { High River Stage Within } \\
\text { Footprint of Inactive Disposal } \\
\text { Facilities }\end{array}$ & $\begin{array}{l}33.3 \text { to } 70.0 \\
\text { (Average } \\
51.6 \text { ) }\end{array}$ & 23.1 & 74.7 & $\begin{array}{l}\text { B for South Pond varies } 10.2 \text { to } 12.2 \mathrm{~kg} \text { and for } \\
\text { North Pond } 23.1 \text { to } 57.7 \mathrm{~kg} \text { (low value based on } \\
\text { desorption } \mathrm{K}_{\mathrm{d}} \text { high value based on column leach } \\
\text { test). }\end{array}$ \\
\hline $\mathrm{C}$ & $\begin{array}{l}\text { Vadose Zone Sediments Above } \\
\text { High River Stage Outside } \\
\text { Footprint of Inactive Disposal } \\
\text { Facilities }\end{array}$ & 553.57 & 5.81 & 559.38 & $\begin{array}{l}\text { Total C+D for outside ponds is } 559 \mathrm{~kg} \text { and outside } \\
\text { trenches is } 6.3 \mathrm{~kg} \text {. }\end{array}$ \\
\hline $\mathrm{D}$ & $\begin{array}{l}\text { Vadose Zone Pore Water Above } \\
\text { High River Stage Outside } \\
\text { Footprint of Inactive Disposal } \\
\text { Facilities }\end{array}$ & 5.43 & 0.49 & 5.92 & $\begin{array}{l}\text { Assumes pore water concentrations of } 100 \mu \mathrm{g} / \mathrm{L} \text { near } \\
\text { ponds and } 800 \mu \mathrm{g} / \mathrm{L} \text { near trenches. Thickness } 9.3 \\
\text { and } 2 \mathrm{~m} \text { near ponds and trenches, respectively. }\end{array}$ \\
\hline $\mathrm{E}$ & $\begin{array}{l}\text { Sediments in Intermittent Wetted } \\
\text { River Stage Zone (Smear Zone) } \\
\text { Below Facilities Footprint }\end{array}$ & 906.35 & 156.3 & $1,062.65$ & $\begin{array}{l}\text { Assume 2-m-thick Smear Zone; then E+F for South } \\
\text { Pond is } 270 \mathrm{~kg} \text { and for North Pond is } 664 \mathrm{~kg} \text {. For } \\
316-5 \text {, trenches total is } 164.5 \mathrm{~kg} \text {. }\end{array}$ \\
\hline $\mathrm{F}$ & $\begin{array}{l}\text { Pore Water in Intermittent } \\
\text { Wetted River Stage Zone (Smear } \\
\text { Zone) Below Facilities Footprint }\end{array}$ & $\begin{array}{l}18.2 \text { to } 38.6 \\
\text { (Average } \\
28.35\end{array}$ & 8.2 & 36.55 & $\begin{array}{l}\text { F for South Pond varies } 5.2 \text { to } 6.3 \mathrm{~kg} \text { and for North } \\
\text { Pond } 12.9 \text { to } 32.3 \mathrm{~kg} \text { (low value based on desorption } \\
\mathrm{K}_{\mathrm{d}} \text { high value based on column leach test). }\end{array}$ \\
\hline G & $\begin{array}{l}\text { Sediments in Intermittent Wetted } \\
\text { River-stage Zone (Smear Zone) } \\
\text { Outside Facilities Footprint }\end{array}$ & 118.1 & 6.32 & 124.42 & $\begin{array}{l}\text { Assumption \#1 contaminated area outside equals } 2 \mathrm{X} \\
\text { facility footprint. Assumption \#2 sediments contain } \\
0.4 \mathrm{mg} / \mathrm{kg} \text { labile } \mathrm{U} \text {. Assumption } \# 3 \text { smear zone is } \\
2 \mathrm{~m} \text { thick. } \\
\text { Total } \mathrm{G}+\mathrm{H} \text { for outside ponds is } 120 \mathrm{~kg} \text { and outside } \\
\text { trenches is } 6.4 \mathrm{~kg} \text {. }\end{array}$ \\
\hline
\end{tabular}


Table 6.5. (contd)

\begin{tabular}{|c|c|c|c|c|c|}
\hline Compartment & Description & $\begin{array}{l}\text { Process Ponds } \\
\text { Sub-Unit (kg) }\end{array}$ & $\begin{array}{l}300 \text { Area Process } \\
\text { Trenches } \\
\text { Sub-Unit (kg) }\end{array}$ & $\begin{array}{l}\text { Uranium } \\
\text { Inventory } \\
(\mathrm{kg})\end{array}$ & Comments \\
\hline $\mathrm{H}$ & $\begin{array}{l}\text { Pore Water in Intermittent } \\
\text { Wetted River-stage Zone (Smear } \\
\text { Zone) Outside Facilities } \\
\text { Footprint }\end{array}$ & 1.9 & 0.08 & 1.98 & $\begin{array}{l}\text { Assumes pore water concentrations of } 100 \mu \mathrm{g} / \mathrm{L} \text { near } \\
\text { ponds and } 80 \mu \mathrm{g} / \mathrm{L} \text { near trenches. Smear Zone } \\
\text { thickness } 2 \mathrm{~m} \text { everywhere. }\end{array}$ \\
\hline I & $\begin{array}{l}\text { Aquifer Sediments (Always } \\
\text { Below Water Table) }\end{array}$ & NA & NA & 122 & $\begin{array}{l}\text { Gross averaging of } U \text { distribution in sediments. } \\
\text { Used field corrected } \mathrm{K}_{\mathrm{d}} \text { value of } 0.25 \mathrm{~mL} / \mathrm{g} \text {, bulk } \\
\text { density of } 2,060 \mathrm{~kg} / \mathrm{m}^{3} \text {, and average solution } \\
\text { concentration of } 72 \mu \mathrm{g} / \mathrm{L} \text { uranium for the volume of } \\
\text { aquifer within the } 30 \mu \mathrm{g} / \mathrm{L} \text { uranium isopleth. Used } \\
\mathrm{K}_{\mathrm{d}} \text { equation to calculate } \mathrm{S} \text { [ } \mathrm{S}=\mathrm{K}_{\mathrm{d}} \cdot \mathrm{C} \text { ]. }\end{array}$ \\
\hline $\mathrm{J}$ & $\begin{array}{l}\text { Groundwater Within the } 30 \mu \mathrm{g} / \mathrm{L} \\
\text { Uranium Isopleth }\end{array}$ & NA & NA & $62 \pm 15$ & $\begin{array}{l}\text { Assumes total porosity is } 26 \% \text {, aquifer thickness is } \\
8 \mathrm{~m} \text { and overall plume area is } 0.41 \mathrm{~km}^{2} \text { for } 30 \mu \mathrm{g} / \mathrm{L} \\
\text { isopleth. Smaller areas and higher uranium } \\
\text { concentration data are summed in the calculation } \\
\text { taking the mid point concentration between each of } \\
\text { the } 30-, 60-, 90-, 120-, 150-\text {, and } 180-\mu \mathrm{g} / \mathrm{L} \text { isopleths. } \\
\text { Data for } 2002 \text { through mid } 2007 \text { are averaged } \\
\text { (assumes plume area and uranium mass has remained } \\
\text { constant over past } 5 \text { years). }\end{array}$ \\
\hline
\end{tabular}




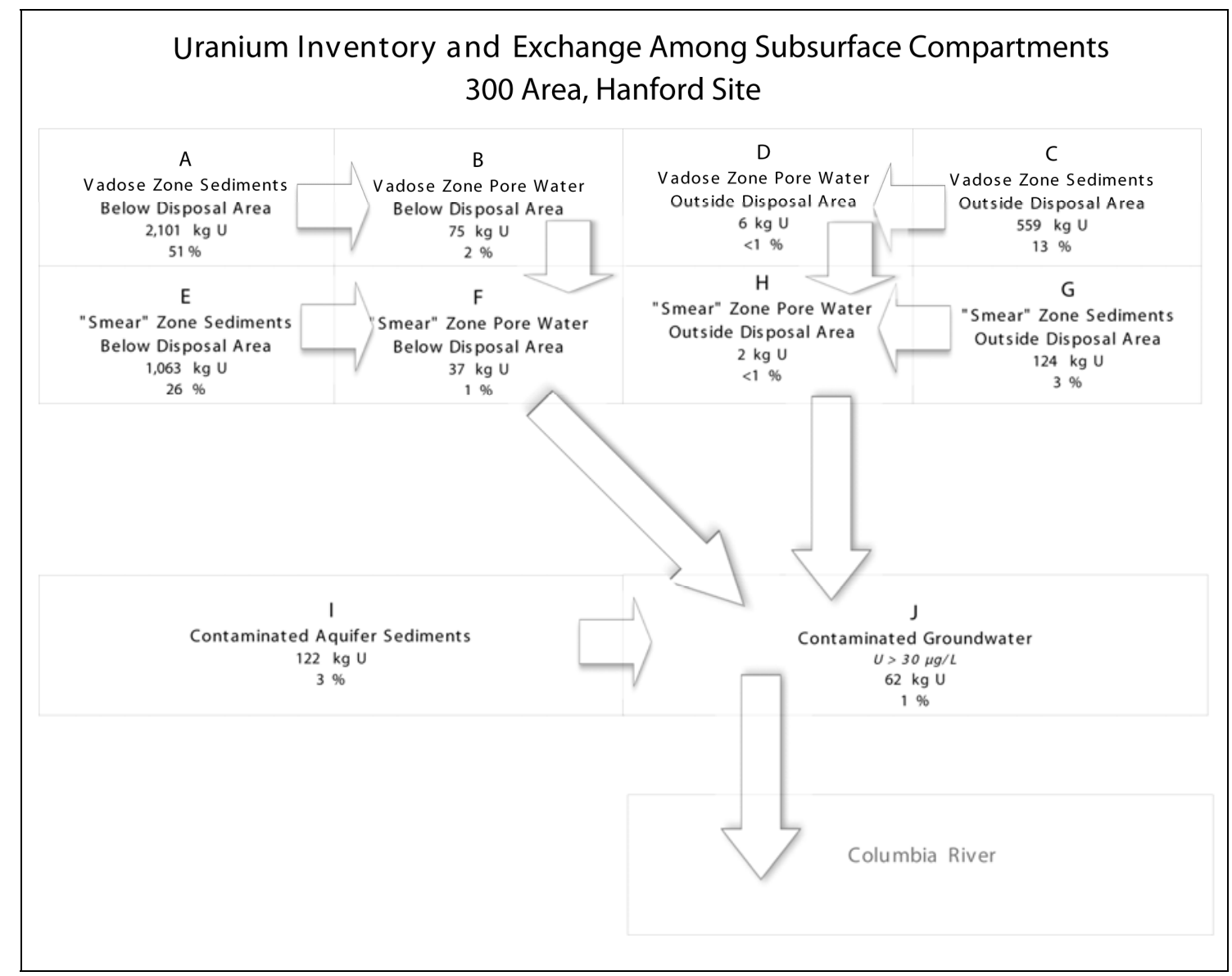

Figure 6.4. Schematic of Uranium Inventories in Compartments and Uranium Flow Between Compartments

In addition, cleanup verification sediment samples were collected from the bottom surface or exploratory trench bottoms of the large excavations in the North (26 samples) and South (37 samples) Process Ponds, respectively. The verification samples were sent to analytical laboratories, and subsamples were acid extracted and uranium isotopes determined by alpha energy spectroscopy. The ${ }^{238} \mathrm{U}$ isotopic activity data were converted to uranium mass concentrations using the specific activity of ${ }^{238} \mathrm{U}$ [pCi $=0.3363 \cdot \mu \mathrm{g} \mathrm{U}$ ]. The uranium-isotopic results are presented in Lerch (1999) and BHI (2003) for the North and South Process Ponds, respectively. Tables 6.6 and 6.7 show the results of these verification samples after we converted original activity data to mass. In addition, two other sampling campaigns described in Serne et al. (2002a) and Zachara et al. (2005) show that above-background concentrations of uranium still exist in the remaining sediments now covered with backfill ${ }^{14}$ at the two ponds. Pertinent uranium data for the sediments obtained by Serne and Zachara are shown in Tables 6.8 and 6.9, respectively. Older reports that give pre-excavation concentrations of uranium in pond sediments are also available in Section 2 to give some bounding information on what might be found in undiscovered "hot spots."

\footnotetext{
${ }^{14}$ A characterization borehole (C5708, completed as well 399-2-5) drilled through the South Process Pond in fall 2007 revealed that backfill material down to a depth of at least $7 \mathrm{ft}$ below ground surface contains weak-acid extractable uranium. A concentration of $3 \mathrm{mg} / \mathrm{kg}$ was measured in the $<2 \mathrm{~mm}$ size fraction, indicating the presence of residual Hanford process uranium.
} 
Table 6.6. Uranium in Residual Sediment at the South Process Pond After Excavation (BHI 2003)

\begin{tabular}{|c|c|c|c|c|c|}
\hline \multicolumn{6}{|c|}{ " South Process Pond (316-1) } \\
\hline \multirow{2}{*}{ Type } & \multirow{2}{*}{$\begin{array}{c}\text { Descriptive } \\
\text { Location }\end{array}$} & \multirow{2}{*}{$\begin{array}{l}\text { Uranium } \\
\text { (mg/kg) }\end{array}$} & \multirow{2}{*}{$\begin{array}{l}\text { Sample } \\
\text { Number }\end{array}$} & \multicolumn{2}{|c|}{ Washington State Plane Coordinates } \\
\hline & & & & Northing & Easting \\
\hline Trench 1 & "NW Corner & 6.4 & B0L884 & NA & NA \\
\hline Floor & NW Corner & 46.5 & B0YNN5 & 116,175 & 594,219 \\
\hline Floor & NW Corner & 87 & B0YNN6 & 116,152 & 594,190 \\
\hline Floor & NW Corner & 14.9 & B0YNN4 & 116,142 & 594,218 \\
\hline Floor & NW Corner & 35.9 & B0YNN2 & 116,132 & 594,203 \\
\hline Floor & NW Corner & 5.14 & B0YNN7 & 116,155 & 594,179 \\
\hline Floor & Mid W & 26.2 & B0YNP0 & 116,111 & 594,214 \\
\hline Floor & Mid W & 6.63 & B0YNN3 & 116,109 & 594,235 \\
\hline Floor & Mid W & 28.1 & B0YNN8 & 116,102 & 594,206 \\
\hline Floor & Mid W & 26.6 & B0YNN9 & 116,087 & 594,220 \\
\hline Floor & Mid W & 9.37 & B0YNN1 & 116,066 & 594,203 \\
\hline Floor & SW Corner & 146 & B0R3R1 & 116,057 & 594,243 \\
\hline Floor & SW Corner & 6.72 & B0YNM4 & 116,033 & 594,213 \\
\hline Floor & SW Corner & 48.5 & B0R3R4 & 116,031 & 594,243 \\
\hline Floor & SW Corner & 93.4 & B0R3R5 & 116,027 & 594,235 \\
\hline Floor & SW Corner & 69.5 & B0R3R6 & 116,021 & 594,264 \\
\hline Trench 6 & SW Scrapings & 121.7 & B0L888 & NA & NA \\
\hline Floor & N Corner & 93.8 & B0YNM2 & 116,186 & 594,288 \\
\hline Floor & N Corner & 36.3 & B0R3T1 & 116,173 & 594,290 \\
\hline Floor & N Corner & 66.9 & B0R3T0 & 116,162 & 594,315 \\
\hline Floor & N Corner & 60.6 & B0R3R9 & 116,156 & 594,299 \\
\hline Trench8 & N Corner & 50.84 & B0L885 & NA & NA \\
\hline Floor & Mid Center & 3.15 & B0YNM3 & 116,133 & 594,251 \\
\hline Floor & Mid Center & 48.9 & B0R3R8 & 116,133 & 594,286 \\
\hline Floor & Mid Center & 45.4 & B0R3R7 & 116,116 & 594,303 \\
\hline Floor & Mid Center & 65.5 & B0YNM1 & 116,077 & 594,266 \\
\hline Floor & Mid Center & 43.7 & B0YNM9 & 116,076 & 594,260 \\
\hline Floor & Mid Center & 47.0 & B0YNM6 & 116,081 & 594,326 \\
\hline Floor & Mid Center & 9.57 & B0YNM5 & 116,075 & 594,330 \\
\hline Trench 7 & Mid Center & 25.88 & B0L886 & NA & NA \\
\hline Floor & NE (Filter Backwash) & 19.5 & B0YNN0 & 116,145 & 594,416 \\
\hline Trench 3 & NE (Filter Backwash) & 35.37 & B0L887 & NA & NA \\
\hline Trench 4 & Center E (Filter Backwash) & 3.41 & B0L890 & NA & NA \\
\hline Floor & Center E (Filter Backwash) & 6.31 & B0YNM7 & 116,044 & 594,371 \\
\hline Floor & SE (Filter Backwash) & 7.72 & B0YNM8 & 116,025 & 594,424 \\
\hline Trench 5 & SE Scrapings & 3.20 & B0L889 & NA & NA \\
\hline
\end{tabular}


Table 6.7. Uranium in Residual Sediment at the North Process Pond After Excavation (Lerch 1999)

\begin{tabular}{|c|c|c|c|c|c|}
\hline \multicolumn{6}{|c|}{ North Process Pond (316-2) } \\
\hline \multirow{2}{*}{ Type } & \multirow{2}{*}{$\begin{array}{c}\text { Descriptive } \\
\text { Location }\end{array}$} & \multirow{2}{*}{$\begin{array}{l}\text { Uranium } \\
(\mathrm{mg} / \mathrm{kg})\end{array}$} & \multirow{2}{*}{$\begin{array}{l}\text { Sample } \\
\text { Number }\end{array}$} & \multicolumn{2}{|c|}{ Washington State Plane Coordinates } \\
\hline & & & & Northing & Easting \\
\hline Trench 2 & "NW Corner & 21.6 & B0L633 & Trench 2 & Cell 5F \\
\hline Floor & NW Corner & 36.3 & B0V029 & 116,629 & 594,185 \\
\hline Floor & NW Corner & 12.3 & B0V026 & 116,505 & 594,213 \\
\hline Floor & NW Corner & 8.93 & B0V028 & 116,119 & 594,142 \\
\hline Floor & NW Corner & 45.5 & B0V024 & 116,582 & 594,195 \\
\hline Floor & NW Corner & 54.2 & B0V025 & 116,575 & 594,180 \\
\hline Floor & SW Corner & 241 & B0V027 & 116,489 & 594,201 \\
\hline Floor & SW Scrapings & 11.2 & B0L656 & 116,436 & 594,161 \\
\hline Floor & SW Scrapings & 14.5 & B0L654 & 116,445 & 594,212 \\
\hline Floor & SW Scrapings & 5.51 & B0L655 & 116,412 & 594,205 \\
\hline Floor & SW Scrapings & 6.96 & B0L657 & 116,388 & 594,167 \\
\hline Trench 1 cell 5E & N Center & 71.2 & B0L633 & Trench 1 & Cell 5E \\
\hline Trench 1 cell 9E & N Center & 11.0 & B0L635 & Trench 1 & Cell 9E \\
\hline Floor & Mid Center & 305 & B0V030 & 116,587 & 594,233 \\
\hline Floor & Mid Center & 106 & B0V032 & 116,582 & 594,289 \\
\hline Floor & Mid Center & 133 & B0V031 & 116,561 & 594,258 \\
\hline Floor & Mid Center & 199 & B0V035 & 116,541 & 594,226 \\
\hline Floor & South Center & 361 & B0V034 & 116,511 & 594,250 \\
\hline Floor & S Center Scrapings & 52.4 & B0L659 & 116,478 & 594,284 \\
\hline Floor & S Center Scrapings & 32.4 & B0L653 & 116,450 & 594,249 \\
\hline Floor & S Center Scrapings & 25.7 & B0L651 & 116,436 & 594,291 \\
\hline Floor & S Center Scrapings & 24.1 & B0L658 & 116,406 & 594,261 \\
\hline Trench 5 & SE Scrapings & 4.57 & B0L648 & Trench 5 & Cell 6E \\
\hline Trench 3 & $\mathrm{NE}$ & 2.75 & B0L649 & Trench 3 & Cell 5D \\
\hline Trench 4 & Center E & 12.7 & B0L650 & Trench 4 & Cell 3E \\
\hline Floor & SE & 106 & B0V033 & 116,517 & 594,343 \\
\hline
\end{tabular}

Table 6.8. Locations and Uranium Concentrations in near-Surface Sediments Studied by Serne et al. (2002a)

\begin{tabular}{|c|c|c|c|c|c|c|}
\hline $\begin{array}{l}\text { Sample } \\
\text { Number }\end{array}$ & Location & $\begin{array}{c}\mathrm{XRF} \\
(\mathrm{pCi} / \mathrm{g})\end{array}$ & $\begin{array}{l}\text { XRF-2 } \\
\text { (pCi/g) }\end{array}$ & $\begin{array}{l}\text { GEA } \\
(\mathrm{pCi} / \mathrm{g})\end{array}$ & $\begin{array}{l}\text { Average } \\
\text { (pCi/g) }\end{array}$ & $\begin{array}{c}\text { Mass } \\
\text { Average } \\
\text { (mg/kg) }\end{array}$ \\
\hline B11494 & "North Process Pond (Southern Inlet) & 173 & 188 & 180 & 180 & $\overline{539.9}$ \\
\hline B11495 & North Process Pond (NE Wall) & 11.2 & $4.2^{(\mathrm{a})}$ & 15 & 13 & 39.2 \\
\hline B11BY4 & $\begin{array}{l}\text { 303K-Adjacent to North-Side } \\
\text { Concrete Pad }\end{array}$ & 175 & 186 & 220 & 188 & 562.9 \\
\hline B11BY5 & 303K-East Side of Building & 101 & 104 & 83 & 96 & 287.4 \\
\hline B11BY6 & $\begin{array}{l}\text { 303K-Adjacent to North-Side } \\
\text { Concrete Pad }\end{array}$ & 311 & 330 & 350 & 330 & 988.8 \\
\hline
\end{tabular}


Table 6.9. Locations and Uranium Concentrations in Process Ponds Sediment Samples Studied by Zachara et al. (2005)

\begin{tabular}{|c|c|c|c|c|c|c|c|c|c|}
\hline \multicolumn{10}{|c|}{$\begin{array}{l}\text { Solid Phase (U) in <2 mm Fraction or Groundwater Fines } \\
\end{array}$} \\
\hline \multicolumn{2}{|c|}{ South Process Pond Pit \#1 } & \multicolumn{2}{|c|}{ South Process Pond Pit \#2 } & \multicolumn{2}{|c|}{ North Process Pond Pit \#1 } & \multicolumn{2}{|c|}{ North Process Pond Pit \#2 } & \multicolumn{2}{|c|}{$\begin{array}{l}\text { North Process Pond } \\
\text { (Before Excavation) }\end{array}$} \\
\hline $\begin{array}{c}\text { Depth (From Top } \\
\text { of Excavation) } \\
\end{array}$ & $\begin{array}{c}\text { Solid Phase } \\
\text { (U) } \\
\end{array}$ & $\begin{array}{c}\text { Depth (From Top } \\
\text { of Excavation) }\end{array}$ & $\begin{array}{c}\text { Solid Phase } \\
(\mathrm{U})\end{array}$ & $\begin{array}{l}\text { Depth (From } \\
\text { Top of } \\
\text { Excavation) }\end{array}$ & $\begin{array}{c}\text { Solid Phase } \\
(\mathrm{U})\end{array}$ & $\begin{array}{c}\text { Depth (From Top } \\
\text { of Excavation) }\end{array}$ & $\begin{array}{c}\text { Solid Phase } \\
\text { (U) }\end{array}$ & \begin{tabular}{|c|} 
Depth (From \\
$\begin{array}{c}\text { Original Pond } \\
\text { Surface) }\end{array}$ \\
\end{tabular} & $\begin{array}{c}\text { Solid Phase } \\
\text { (U) }\end{array}$ \\
\hline (ft bex) & $(\mathrm{ppm})$ & (ft bex) & $(\mathrm{ppm})$ & (ft bex) & $(\mathrm{ppm})$ & (ft bex) & $(\mathrm{ppm})$ & (ft bgs) & $(\mathrm{ppm})$ \\
\hline 4 & 9.9 & 4 & $7.3 \pm 3.3$ & 4 & $14.4 \pm 2.8$ & 0.5 & $238 \pm 12$ & 1 & 3,310 \\
\hline 8 & $<6.5$ & 8 & $11.0 \pm 3.3$ & 8 & $12.9 \pm 2.7$ & 2 & $89.2 \pm 5.4$ & 2 & 2,390 \\
\hline 12 & $6.7 \pm 3.4$ & 12 & $12.2 \pm 2.7$ & 12 & $20.5 \pm 2.9$ & 4 & $138.9 \pm 7.5$ & 4.5 & 1,880 \\
\hline 16 & $13.6 \pm 3.3$ & 16 & $<5.3$ & 16 & $11.1 \pm 2.9$ & 8 & $44.7 \pm 3.5$ & 6 & 390 \\
\hline 18 & $12.5 \pm 3.2$ & 18 & $<5.4$ & 20 & $11.2 \pm 2.7$ & 12 & $15.2 \pm 2.7$ & & \\
\hline 22 & $6.2 \pm 2.7$ & 22 & $10.2 \pm 2.7$ & & & & & & \\
\hline GW Fines & $35.0 \pm 4.2$ & GW Fines & $12.7 \pm 3.4$ & GW Fines & $33.3 \pm 3.7$ & GW Fines & $200 \pm 11$ & & \\
\hline
\end{tabular}


Tables 6.6 through 6.9 show a wide range of uranium concentrations in residual pond sediments obtained after excavation but before backfilling with clean fill. Table 6.7 suggests that in the North Process Pond, the residual sediments at the excavation's floor in the southwest corner (where the waste stream inlet was originally located) and the south and middle of the original pond footprint contain the most elevated uranium concentrations, with concentrations ranging from 100 to $260 \mathrm{mg} / \mathrm{kg}$. Other portions of the pond footprint and the area south of the original pond where sludge scrapings were disposed of have lower uranium concentrations (range 5 to $50 \mathrm{mg} / \mathrm{kg}$ with one sample in the southeast corner of the footprint at $106 \mathrm{mg} / \mathrm{kg}$ ).

Two other sampling campaigns in the North Process Pond discussed in Serne et al. (2002a) and Zachara et al. (2005) found the following. The Serne et al. (2002a) study obtained two sediment samples (field sieved to $<6.35 \mathrm{~mm}$ ) in early 2001 using hand-held gamma detectors to survey for high readings on the walls and floor of the excavation. A sample taken in the northeast corner of the excavation contained $40 \mathrm{mg} / \mathrm{kg}$ of uranium, and a sample taken from a trench excavated down about $5 \mathrm{ft}$ below the large excavation floor in the southern edge of the pond, where the original inlet was located, contained $540 \mathrm{mg} / \mathrm{kg}$ uranium. In the other sampling campaign (Zachara et al. 2005), two backhoe excavations were performed in the excavated North Process Pond from February through May 2003. Sediment samples at both locations (one in the southwest corner of the pond and one in the southeast corner of the pond) were taken from the existing ground surface (still below natural grade as the backfilling activities had not been completed) down to the water table at intervals of every $2 \mathrm{ft}$. Table 6.9 shows the uranium concentrations in the $<2$-mm size fraction of the sediments. For the sediment profile near the original liquid-waste inlet (NPP-2), the sediment uranium concentrations ranged from 15 to $240 \mathrm{mg} / \mathrm{kg}$, and for the profile to the east, the sediment uranium concentrations ranged from 11 to $30 \mathrm{mg} / \mathrm{kg}$. In the sediment profile near the original waste inlet, there was a trend for sediment uranium concentrations to be higher in the upper $12 \mathrm{ft}$ than the lower $10 \mathrm{ft}$.

It would appear from these three sampling campaigns that residual "hot spots" likely exist in the upper vadose zone of the North Process Pond. Also shown in Zachara et al. (2005) is particle size data for a representative sample from the North Process Pond. The sediments are quite coarse with over $90 \%$ of the mass being larger than $2 \mathrm{~mm}$ in size and almost $75 \%$ being larger than $12.5 \mathrm{~mm}(>0.5$-inch sized stones).

Table 6.6 shows the South Process Pond verification samples (BHI 2003) after excavation was completed. The more elevated uranium concentrations at the floor of the South Process Pond excavation are also found in the southwest quadrant and southern portion of the center of the excavation. However, the absolute concentrations are smaller than found in the North Process Pond. Uranium concentrations in South Process Pond sediments from these areas range from 30 to $120 \mathrm{mg} / \mathrm{kg}$. The area to the southwest of the original pond where sludge scrapings were disposed of contained the highest measured uranium concentration (122 mg/kg). Zachara et al. (2005) also obtained two depth profiles of sediment, similar in technique to the profiles from North Process Pond, through the remediated South Process Pond (see data in Table 6.9) in 2003. In general, the sediments in the South Process Pond obtained by Zachara et al. (2005) contained lower concentrations of uranium, $<5$ to $15 \mathrm{mg} / \mathrm{kg}$ with little variation with depth, at the two profiles created using the backhoe.

If we assume that all these analyses on pond sediments, which had most or all of the gravel removed and thus represent between 10 and at most $30 \%$ of the whole sediment, contain the bulk of the uranium bound to the residual sediments, then some adjustment must be made to the concentrations reported in 
Tables 6.6 through 6.9. That is, if we assume that the larger gravel/cobbles do not contain any uranium, we can make a crude estimate of the remaining uranium inventory in the vadose zone sediments (compartments $\mathrm{A}+\mathrm{B}$ and $\mathrm{E}+\mathrm{F}$ ) in our box model. The extant pore water uranium remains in the sample during the uranium analysis such that we cannot separate the contributions between solid and liquid compartments from the available data.

We have elected the following assumptions to construct the uranium inventories for these (compartments A + B and E + F) compartments. Measured uranium concentrations on the samples with most gravel removed must be adjusted (reduced by a factor 10) to account for the coarse texture. By relying heavily on the uranium profiles in Zachara et al. (2005), we chose a value of $40 \mathrm{mg} / \mathrm{kg}$ to represent the current North Process Pond sediments ( $<2-\mathrm{mm}$ size fraction) to account for the higher concentrations in the southern portion but likely decreasing values with depth below the surface of the excavation. After adjustment for the high percentage gravel in the remediated North Process Pond sediment, a value of $4 \mathrm{mg} / \mathrm{kg}$ is obtained. For the South Process Pond, a value of $20 \mathrm{mg} / \mathrm{kg}$ is chosen for the overall profile of the $<2 \mathrm{~mm}$ fraction and after adjustment for the coarse nature a value of $2 \mathrm{mg} / \mathrm{kg}$ is obtained for the residual sediments.

We then assume that the bulk density of the sediment in the vadose below the ponds is $2.06 \mathrm{~g} / \mathrm{cm}^{3}$ $\left(2,060 \mathrm{~kg} / \mathrm{m}^{3}\right)$. This value was the average found by Swanson et al. (1992) during sediment investigations near and in the ponds before excavation [as referenced in Zachara et al. (2005) on page 2.75]. Using the areal extent of the original ponds, mentioned above, and depths to the top of the smear zone of $3.88 \mathrm{~m}$ for the South Process Pond and $3.58 \mathrm{~m}$ for the North Process Pond (obtained from Zachara et al. [2005] after subtracting $1 \mathrm{~m}$ to represent the upper half of a 2-m smear zone), the total uranium inventory in the sum of compartments A and B is 524 and 1,189 kg of uranium, respectively. ${ }^{15}$ Based on the time of year that these samples were obtained, we assumed that the river stage was near its mid-level and thus the depth to groundwater measured by Zachara et al. (2005) includes half of the smear zone ( 1 m of the $2 \mathrm{~m}$ maximum thickness). We also assumed that the river stage can cause a rise and subsequent fall of $2 \mathrm{~m}$ in the elevation of the water table, and the uranium concentrations in the smear zone sediments are the same as in the vadose zone sediments right above the smear zone. Thus the uranium inventories for the smear zone (compartments E + F) directly below the facilities' footprints can be simply calculated by using a thickness of $2 \mathrm{~m}$ with all other parameters remaining the same as used for compartments $\mathrm{A}+\mathrm{B}$. The smear zone uranium inventories, based on the same areas and residual sediment uranium concentrations used for compartments A + B and the 2 m thickness, are 270 and $664 \mathrm{~kg}$ for the South and North Process Ponds smear zones, respectively. The inventories of residual uranium in the vadose and smear zones below the footprints of the two process ponds represent 3\% $(794 / 26,166)$ for the South Pond and 9.6\% $(1,853 / 19,391)$ for the North Pond of the uranium disposed of to each of the facilities, respectively.

None of the sampling efforts in the process ponds attempted to directly extract vadose zone pore water such that pore water uranium concentration could be measured. There are two approaches that can be used to estimate the uranium concentration in the vadose zone pore water below the remediated ponds. One approach is to use columns, filled with the residual pond sediments, to perform leaching tests wherein aliquots of the leach test effluent are directly measured. To simulate the actual subsurface

\footnotetext{
15 These depths represent distances to the water table at a time when the ponds were not backfilled. A recent boring [C5708] through the South Process Pond in late September 2007 after the pond had been backfilled to grade was 9.75 m. Interestingly, the backfilled sediments showed higher than expected labile $U$ in the shallow depths suggesting that the ponds were backfilled with sediments containing Hanford process uranium. Thus the total inventory of labile uranium currently within the pond's footprints is not well established using all the data discussed herein.
} 
conditions would require that the vadose zone sediments be leached under unsaturated moisture conditions. Serne et al. (2002a) performed saturated column leach tests on the two sediment samples from the North Process Pond, which contained 540 and $40 \mathrm{mg} / \mathrm{kg}$ uranium. Using deionized water as a surrogate for rain water, the column leach tests generated leachates that contained 5,000 to 7,000 $\mu \mathrm{g} / \mathrm{L}$ dissolved uranium for the first pore volume, and between 1,200 and 6,500 $\mathrm{gg} / \mathrm{L}$ for several more pore volumes. If we assume that the vadose zone pore waters below the North Process Pond contain $5,000 \mu \mathrm{g} / \mathrm{L}$ and below the South Process Pond contain 1,200 $\mu \mathrm{g} / \mathrm{L}$, and use a steady state moisture content of 8 volumetric percent (based on a $60-\mathrm{mm} / \mathrm{yr}$ recharge rate taken from modeling discussions in Zachara et al. [2005] that rely on Gee et al. [2005]), the inventory of uranium in the pore water below the remediated process ponds would be 12.2 and $57.7 \mathrm{~kg}$ for the South and North Process ponds, respectively. These values represent $2 \%(12.2 / 524)$ and $5 \%(57.7 / 1,189)$ of the total uranium inventory in the sum of compartments A and B.

The second method of calculating the pore water concentrations is to use batch desorption test results on the sediments from the process ponds. Zachara et al. (2005) used several solutions representative of Hanford groundwater and groundwater mixed with Columbia River water in batch desorption tests. Batch desorption $\mathrm{K}_{\mathrm{d}}$ results for uranium associated with the $<2 \mathrm{~mm}$ size fraction sediments ranged from 0.5 to $28 \mathrm{~mL} / \mathrm{g}$. When corrected back to the field coarse-textured sediments (assume $90 \%$ non-sorbing gravel), the $\mathrm{K}_{\mathrm{d}}$ range would be 0.05 to $2.8 \mathrm{~mL} / \mathrm{g}$. Using a $\mathrm{K}_{\mathrm{d}}$ value of $2 \mathrm{~mL} / \mathrm{g}$ for the field-sized sediments and the relationship that the equilibrium solution concentration would be $C=S / K_{d}$ (where $C$ is the uranium solution concentration and $\mathrm{S}$ is the uranium solid concentration (2 mg/kg for South Process Pond and $4 \mathrm{mg} / \mathrm{kg}$ for North Process Pond sediments presented above), the vadose zone pore waters would contain 10.2 and $23.1 \mathrm{~kg}$ for South and North Process Ponds footprints. These inventory estimates are about a factor of 2.5 lower than those based on saturated leach tests for the North Process Pond sediments but fairly close for the South Process Pond. Despite some differences in the two calculations, it is safe to state that the bulk of the residual uranium inventory in the vadose zone footprint below the ponds is found bound to the sediments.

The only available results for sampling of sediments directly below the footprint of the 300 Area Process Trenches (316-5 waste site) after excavation and burial of contaminated sediments at ERDF are found in BHI (1998). The first remediation was an expedited response wherein $1 \mathrm{ft}$ of sediment off the walls and $4 \mathrm{ft}$ off the bottoms of the two process trenches was removed with backhoes. About 5,400 $\mathrm{m}^{3}$ of sediment from the interior of each trench was scraped out in August-September 1991 and placed in the depression northwest of the west trench and northernmost 90 to $100 \mathrm{~m}$ of both 457-m long trenches. Preexcavation sampling of the sediments showed the highest concentrations of uranium were present in the southern most $100 \mathrm{~m}$ (inlets were on the south end of trenches) and in the natural depression in the northwest corner of the facility. Pre-excavation sediment uranium concentrations reached 9,000 to 27,000 mg/kg uranium at the surface (Zimmerman and Kossik 1987). Uranium concentrations dropped off dramatically in the upper $1.5 \mathrm{~m}$ (limited sampling below $1.5 \mathrm{~m}$ showed pre-excavation sediment concentrations of $\sim 50 \mathrm{mg} / \mathrm{kg}$ uranium). After excavation and stockpiling the sediment at the north end of the trenches, a detailed radiation survey suggested the expedited response had removed most all the uranium. Very limited sampling of the new trench bottom surface showed no uranium values above $120 \mathrm{mg} / \mathrm{kg}$ based on acid digestion and uranium isotopic measurements (note: the reported ${ }^{238} \mathrm{U}$ values in pCi/g were divided by 0.33 to convert activity concentrations to mass concentrations).

Because the expedited response had found acceptable residual uranium concentrations in sediments in the excavated trench floors and sides, the final verification sampling (after the expedited response 
sediments had been trucked to ERDF) concentrated on the northern ends of the trenches and depression northwest of the west trench where all the expedited response sediments had been stockpiled. The final verification sampling, performed after the 37,961 tons of stock-piled sediments had been removed and sent to ERDF, consisted of taking 15 near-surface samples. In addition, two samples were taken below where the weir boxes had been at the inlets of each trench. Table 6.10 shows the final uranium concentrations in residual sediments. The method used to measure uranium was acid digestion of the fine-grained fraction (likely $<2 \mathrm{~mm}$ ) and alpha energy spectroscopy to quantify ${ }^{238} \mathrm{U}$. The ${ }^{238} \mathrm{U}$ activity (pCi/g) was converted to $\mathrm{mg} \mathrm{U} / \mathrm{kg}$ sediment by dividing by the specific activity of ${ }^{238} \mathrm{U}(0.33 \mathrm{pCi} / \mu \mathrm{g}$ uranium). The results show that the north end of the trenches and the residual sediments (unspecified fine grain fraction) in the natural depression contained between 150 to $400 \mathrm{mg} / \mathrm{kg}$ uranium and the residual sediment right below the original inlets to each trench contained between 120 and $160 \mathrm{mg} / \mathrm{kg}$ uranium. There was no depth profiling of residual sediments in the excavation before backfilling to finish the remediation. At the time of final verification sampling, the excavation was between 3.7 and $4.3 \mathrm{~m}$ below the natural ground surface. From some sampling performed before the expedited response, documented in Zimmerman and Kossik (1987), post-operational uranium concentrations near the trench bottom surfaces contained up to $27,000 \mathrm{mg} / \mathrm{kg}$ at the southern inlets and 7,000 to $9,000 \mathrm{mg} / \mathrm{kg}$ in the southern $100 \mathrm{~m}$ of the trenches. Concentrations appeared to drop off rapidly in the upper $0.5 \mathrm{~m}$ of sediment that was interrogated. Based on removal of $4 \mathrm{ft}$ of sediment off the bottom of the trenches during the expedited response, one might expect the final verification residual sediments to have contained less uranium than reported in BHI (1998).

Table 6.10. Uranium in Residual 300 Area Process Trenches Sediment After Excavation (BHI 1998)

\begin{tabular}{|c|c|c|c|c|c|}
\hline \multicolumn{6}{|c|}{300 Area Process Trenches (316-5) } \\
\hline \multirow[b]{2}{*}{ Type } & \multirow[b]{2}{*}{ Descriptive Location } & \multirow{2}{*}{$\begin{array}{c}\mathrm{U} \\
(\mathrm{mg} / \mathrm{kg})\end{array}$} & \multirow[b]{2}{*}{ HEIS \# } & \multicolumn{2}{|c|}{ Washington State Plane Coordinates } \\
\hline & & & & Northing & Easting \\
\hline Floor & East Apron (Inlet to Trench) & 164 & B0M4N1 & & \\
\hline Floor & West Apron (Inlet to Trench) & 115 & B0M4N4 & & \\
\hline Floor & $\begin{array}{l}\text { Extreme North East End Lobe } \\
\text { of West Trench }\end{array}$ & 18.4 & B0L950 & 116,930 & 594,076 \\
\hline Floor & $\begin{array}{l}\text { Extreme North East End Lobe } \\
\text { of West Trench }\end{array}$ & 21.9 & B0L951 & 116,930 & 594,076 \\
\hline Floor & NW Lobe of West Trench & 11.0 & B0L952 & 116,910 & 594,028 \\
\hline Floor & NW Lobe of West Trench & 2.18 & B0L953 & 116,879 & 594,028 \\
\hline Floor & SW End of Lobe West Trench & 438 & B0L954 & 116,879 & 594,012 \\
\hline Floor & SW End of Lobe West Trench & 371 & B0L955 & 116,874 & 594,025 \\
\hline Floor & SE Corner of Lobe West Trench & 144 & B0L956 & 116,880 & 594,070 \\
\hline Floor (13 ft bgs) & North End of West Trench & 203 & B0N1R4 & 116,857 & 594,068 \\
\hline Floor (13 ft bgs) & North End of West Trench & 257 & B0MD78 & 116,840 & 594,070 \\
\hline Floor (14 ft bgs) & North End of West Trench & 102 & B0L963 & 116,816 & 594,070 \\
\hline Floor (13 ft bgs) & Very North End of East Trench & 277 & B0MD75 & 116,918 & 594,088 \\
\hline Floor (12 ft bgs) & North End of East Trench & 80.5 & B0MDK3 & 116,882 & 594,088 \\
\hline Floor (12 ft bgs) & North End of East Trench & 125 & B0MDK0 & 116,836 & 594,088 \\
\hline
\end{tabular}

Boreholes drilled on the dike between the two process trenches from south to north, prior to remediation (prior to both the expedited response and final removal), showed no discernable elevated 
gross alpha activities above values measured in uncontaminated sediments from the 300 Area. Zimmerman and Kossik (1987) described the sediments, from the boreholes on the dike, down to the water table as being dominated by gravel. We thus will assume that the uranium concentrations measured during the post-remediation verification sampling in November 1997 as documented in BHI (1998) and shown in Table 6.10, need to be reduced by our factor of 10 to represent field conditions. Given the two ranges just mentioned (150 to $400 \mathrm{mg} / \mathrm{kg}$ for the north end of the trenches and 120 and $160 \mathrm{mg} / \mathrm{kg}$ uranium for the south end of the trenches), we will assume an overall average residual uranium concentration of $200 \mathrm{mg} / \mathrm{kg}$ for the measured samples, which becomes a "field corrected' concentration of $20 \mathrm{mg} / \mathrm{kg}$ for the sediments at the bottom of the excavation after remediation.

No depth profiling was performed on the excavated trench bottoms during the final verification sampling so it is not possible to objectively assign an averaged uranium concentration in the sediments between the excavated surface and the smear zone. We will assume that there is a decrease in sediment uranium concentration with depth such that the overall concentration of uranium in the coarse (gravel dominated) sediments is lower than values measured at the excavated trench bottom (value was $20 \mathrm{mg} / \mathrm{kg}$ at trench bottom). We will assume that the average uranium concentration in the sediments' depth profile between the excavation bottom and the water table is $4 \mathrm{mg} / \mathrm{kg}$ to account for decreasing uranium concentrations with depth. If we allow for a 2-m thick smear zone, the depth of contaminated vadose

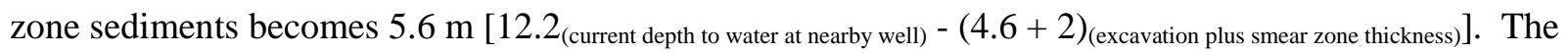
cross-sectional area of the original 300 Area Process Trenches and dike space between the trenches (15.4 m) was 9,982 $\mathrm{m}^{2}$ and with the estimated depth of residual contaminated vadose zone sediments of $5.6 \mathrm{~m}$, the inventory of uranium calculates to be $462 \mathrm{~kg}$ using the cited bulk density of $2,060 \mathrm{~kg} / \mathrm{m}^{3}$. The uranium in the 2-m smear zone below the trenches' footprint is estimated for these same sediment concentrations and areal footprint at $164.5 \mathrm{~kg}$. These values represent the total inventories for compartments A + B and E + F for the 300 Area Process Trenches, respectively.

Because there are no data for leach or desorption tests on residual sediments from the 300 Area Process Trenches, we will assume that $5 \%$ of these total inventories is in the pore water similar to the distribution percentage calculated for pore water in the pond sediments. Thus based on this assumption, the pore waters in the vadose and smear zones below the 300 Area Process Trenches are allocated 23.1 and $8.2 \mathrm{~kg}$ of uranium, respectively. The total inventory of uranium below the 300 Area Process Trenches footprint $\left(\frac{462+164.5}{1749.2}\right)$ represents $36 \%$ of the uranium deposited in the trenches. This is a much larger percentage than was estimated to currently remain in the footprints of the process ponds (i.e., 3 to 9.6\%). It is difficult to say whether this makes our estimates for the uranium currently remaining below the process trenches suspect, or whether the uranium deposited in the trenches might have been more prone to adsorption because the waste fluids were more dilute. Uranium adsorption to sediments is generally larger when the waste solutions are dilute in composition. However, without depth profiles of sediment uranium concentrations like those available for the ponds in Zachara et al. (2005) and the late September 2007 borehole C5708 through the remediated South Process Pond, we cannot objectively determine whether we have over-estimated the residual sediment uranium inventory for the 300 Area Process Trenches.

The final disposal facility to consider is the 307 Process Trenches (316-3 waste site). We have no estimate of the inventory disposed to this facility, but it is noted in Young et al. (1990) and Hulstrom (1994) that wastes from the research laboratories as well as fuel-fabrication facilities were disposed to the 
307 Process Trenches after being monitored in concrete retention basins to make sure that they were not too radioactive. However, both reports also mention that Haney (1960) stated that there were monitoring difficulties such that up to $40 \%$ of the waste disposed of to the 307 Process Trenches had in fact not been monitored. Young et al. (1990) also state that the 307 Process Trenches were filled with $76.5 \mathrm{~m}^{3}$ of contaminated sludge dredged from the South Process Pond in 1963 and additional fly ash after 1963. The 307 Process Trenches were used between 1953 and 1963 and were $183 \mathrm{~m}$ long by $3.05 \mathrm{~m}$ wide by $6.1 \mathrm{~m}$ deep. The $76.5 \mathrm{~m}^{3}$ of sludge from the South Process Pond reported by Young et al. (1990) would have filled the two trenches with only $7 \mathrm{~cm}$ of sludge.

Hulstrom (1994) presents data for three boreholes drilled through the inactive 307 Process Trenches between October 1991 and January 1992. Three boreholes were drilled within the trenches down to between 60 and $68 \mathrm{ft}$ bgs, and groundwater was contacted between 49.4 and $54.7 \mathrm{ft}$ bgs. Table 6.11 shows the uranium concentrations in the residual sediments after the alpha energy spectroscopy analysis of the ${ }^{238} U$ isotope was converted to mass concentrations. Hulstrom (1994) also tabulates data for gross alpha, gross beta, RCRA and common metals, and semi-volatile organic concentrations in the sediments from the three boreholes. Based on comparison of gross alpha and ${ }^{238} \mathrm{U}$ alpha spectroscopy data, we estimate that sediments from these three boreholes through the 307 Process Trenches footprint between the depths of 6 to $25 \mathrm{ft}$ bgs contain elevated concentrations of uranium, likely from Hanford process waste disposal. The average concentration of the uranium in these residual sediments throughout this depth zone is $\sim 32 \mathrm{mg} / \mathrm{kg}$. Assuming that the sediments in the 307 Process Trenches are as coarse as the other sediments in the 300 Area and that the analytical measurements were done solely on a fine-grained fraction of the sediment (very likely based on typical laboratory protocol for strong acid digestion followed by alpha energy analysis), we will use the same "gravel correction" factor of 10 that we have used for the other residual sediments. We thus estimate that the residual sediments in the ground below the footprint of the 307 Process Trenches contain on average $3.2 \mathrm{mg} / \mathrm{kg}$ uranium between 6 and $25 \mathrm{ft}$ bgs. Unlike the other facilities, the available data do not conclusively show, based on no elevated gross alpha results and low ${ }^{238} \mathrm{U}$ isotopic results between 25 and $55 \mathrm{ft}$ bgs under the 307 Process Trenches, definite evidence of Hanford process uranium in the deep vadose zone and smear zone near the water table.

The overall footprint of the 307 Process Trenches is between 1,116 and 1,858 $\mathrm{m}^{2}$, depending on whose measurements you choose (Young et al. 1990 vs. Hulstrom 1994). This footprint is about 2 to 3\% of the overall footprint of the process ponds. For now, we will assume that the 307 Process Trench sediments only contain residual Hanford process uranium in the upper vadose zone. These sediments are not deep enough to be impacting the smear zone and aquifer for the foreseeable future. The LFI borehole 399-3-20 was placed between the 307 Process Trenches and the Columbia River, and sediments from this borehole did not show any water-leachable uranium within the entire profile. Thus, we will not assign any residual uranium inventory to compartments A, B, E, and F in our box model for the 307 Process Trenches at this time. If it were not for the fact that much of the waste disposed of to the 307 Process Trenches was not monitored and the fact that there appears to be a groundwater seasonal uranium "hot spot” near the 307 Process Trenches during June (see Figure 3.5), we would dismiss considering this facility in future refinements of the box model. At this time, we assign no uranium inventory from the 307 Process Trenches residual footprint but suggest that another borehole be placed between boreholes 399-3-17 and 399-3-16 with coordinates listed in Table 6.11 and details shown in Hulstrom (1994). The recommended borehole should collect near-continuous core and sediment samples should be submitted for total uranium and water-leachable uranium testing similar to tests performed in the LFI (Williams et al. 2007). 
Table 6.11. Uranium in Residual 307 Process Trenches Sediment in 1992, Following Remediation in 1963 and Backfilling (Hulstrom 1994)

\begin{tabular}{|c|c|c|c|c|c|}
\hline \multicolumn{6}{|c|}{ 307 Process Trenches (316-3) } \\
\hline \multirow[b]{2}{*}{ Borehole } & \multirow[b]{2}{*}{ Depth (ft bgs) } & \multirow{2}{*}{$\begin{array}{l}\text { Uranium } \\
\text { (mg/kg) }\end{array}$} & \multirow[b]{2}{*}{ Sample Number } & \multicolumn{2}{|c|}{ Washington State Plane Coordinates } \\
\hline & & & & Northing & Easting \\
\hline \multirow[t]{13}{*}{ 399-3-17 } & 6.4 to 8.4 & 96 & B01RJ5 & $1115,857.72$ & $2594,274.58$ \\
\hline & 8.4 to 10.4 & 27.6 & B01RJ7 & & \\
\hline & 11.6 to 13.6 & 11.4 & B01RJ9 & & \\
\hline & 13.5 to 15.5 & 12.3 & B01RK0 & & \\
\hline & 15.7 to 17.7 & 63 & B01RK1 & & \\
\hline & 17.9 to 19.9 & 72 & B01RK2 & & \\
\hline & 20.0 to 22.0 & 8.7 & B01RK3 & & \\
\hline & 22.0 to 24.0 & 9.3 & B01RK4 & & \\
\hline & 25.3 to 27.3 & 4.5 & B01RK5 & & \\
\hline & 31.0 to 33.0 & 8.4 & B01RK6 & & \\
\hline & 36.0 to 38.0 & 7.2 & B01RK7 & & \\
\hline & 50.0 to $52.0^{\#}$ & 6 & B01RK9 & & \\
\hline & 63.0 to $65.0^{\#}$ & 1.8 & B01RK8 & & \\
\hline \multirow[t]{18}{*}{ 399-3-16 } & 0.0 to 3.0 & 3.9 & B01CC3 & $115,867.6$ & $594,350.32$ \\
\hline & 2.9 to 4.9 & 16.8 & B01CC5 & & \\
\hline & 4.9 to 6.0 & 51 & B01CC6 & & \\
\hline & 8.3 to 10.3 & 198 & B01CC7 & & \\
\hline & 10.4 to 12.4 & 24.6 & B01CD4 & & \\
\hline & 12.3 to 14.3 & 24.9 & B01CD5 & & \\
\hline & 14.3 to 16.3 & 66.3 & B01CD7 & & \\
\hline & 16.4 to18.4 & 14.4 & B01CD8 & & \\
\hline & 18.4 to 20.4 & 12.75 & B01CD9 & & \\
\hline & 20.4 to 22.4 & NR & B01CF0 & & \\
\hline & 22.0 to 24.0 & NR & B01CF1 & & \\
\hline & 24.0 to 26.0 & NR & B01CF2 & & \\
\hline & 28.7 to 30.7 & 1.8 & B01CF3 & & \\
\hline & 34.0 to 36.0 & 3 & B01CF4 & & \\
\hline & 39.0 to 41.0 & 11.1 & B01CF5 & & \\
\hline & 45.0 to 47.0 & 2.4 & B01CF6 & & \\
\hline & 56.0 to $58.0^{\#}$ & 1.5 & B01CF7 & & \\
\hline & 58.0 to $60.0^{\#}$ & 9.3 & B01CF8 & & \\
\hline \multirow[t]{17}{*}{ 399-3-15 } & 2.6 to 4.6 & 3.3 & B01CF9 & $115,853.8$ & $594,211.95$ \\
\hline & 5.0 to 7.0 & 2.4 & B01CG0 & & \\
\hline & 7.0 to 9.0 & 2.4 & B01CG2 & & \\
\hline & 9.4 to 11.4 & 4.2 & B01CG4 & & \\
\hline & 11.6 to 13.6 & 3.9 & B01CG5 & & \\
\hline & 13.0 to 15.0 & 12 & B01CG6 & & \\
\hline & 15.0 to 17.0 & 11.4 & B01CG7 & & \\
\hline & 18.0 to 20.0 & 5.1 & B01CG8 & & \\
\hline & 20.5 to 22.5 & 4.5 & B01CG9 & & \\
\hline & 22.5 to 24.5 & 23.7 & B01CH0 & & \\
\hline & 27.5 to 30.0 & 3.3 & B01CH1 & & \\
\hline & 35.0 to 37.0 & 4.8 & B01CH2 & & \\
\hline & 40.0 to 42.0 & 7.2 & B01RJ0 & & \\
\hline & 45.0 to 47.0 & 4.2 & B01RJ1 & & \\
\hline & 50.0 to 53.0 & 6.6 & B01RJ2 & & \\
\hline & 55.0 to $58.0^{\#}$ & 2.1 & B01RJ3 & & \\
\hline & 65.0 to $68.0^{\#}$ & 15.0 & B01RJ4 & & \\
\hline \multicolumn{6}{|c|}{$\begin{array}{l}\text { \# Sediments were saturated with water and were thus below the water table. Hanford coordinates are the same for all deeper } \\
\text { sediments in each borehole. } \\
\text { NR = not reported } \\
\text { Bold = Gross alpha and }{ }^{238} \mathrm{U} \text { isotopic results are elevated, thus confirming the presence of Hanford process waste. }\end{array}$} \\
\hline
\end{tabular}




\subsubsection{Uranium in Compartments $C$ and $D$ and $G$ and $H$ (Sediments and Pore Waters Outside Facility Footprints, Including the Smear Zone Compartments)}

The uranium concentrations in vadose zone sediments and vadose zone pore waters outside of the inactive facilities' footprints are not well defined. The only data available are from measuring total uranium concentrations in sediments from boreholes either drilled during disposal facility characterization or boreholes that were completed as groundwater monitoring wells. In the past, most groundwater monitoring wells were emplaced with no sediment sampling or chemical characterization of the sediments. The most recent characterization activity discussed in the LFI report (Williams et al. 2007) provides comprehensive data on four new boreholes. Some data have also been gleaned from DOE-RL (1994b), which contains data for gross-alpha and uranium-isotope measurements on sediments from four wells within or just west of the $10 \mu \mathrm{g} / \mathrm{L}$ groundwater isopleth and for four background wells west and south of the 300 Area uranium plume. The depths of the sediment samples, collected in the 1990s, vary from 28 to $176 \mathrm{ft}$ bgs. For simplicity, we have assumed that samples shallower than $\sim 50 \mathrm{ft}$ bgs represent the vadose and smear zones, and samples between 50 and $100 \mathrm{ft}$ bgs represent the Hanford formation portion of the aquifer where the uranium groundwater plume resides.

The sediment ${ }^{238} \mathrm{U}$ isotope concentration was measured by alpha-energy spectroscopy after strong acid extraction. We are fairly certain that the acid extract was performed on aliquots of sediment with most of the gravel removed, but there is no documentation in DOE-RL (1994b). We are also certain that the strong acid extract does not dissolve much of the native uranium, which is in the form of recalcitrant U(IV) minerals such as betafite C (see Section 6.2.2), but should dissolve most of the Hanford process uranium [i.e., adsorbed and precipitated U(VI)]. Thus, the alpha energy spectroscopy data in general capture the "contaminant" uranium but only partially measure background uranium. There are ${ }^{238} \mathrm{U}$ data for both the vadose and aquifer portion of the four background wells (699-S22-E9C, 699-S27-E9C, 699-S9-E16C, and 399-8-5C) and for sediments outside the footprints of inactive facilities but within or close to the $10 \mu \mathrm{g} / \mathrm{L}$ uranium groundwater isopleths (399-1-10B, 399-1-13B, 399-1-14B, and 399-1-21B). The range in acid-extractable uranium in the background wells for both the vadose zone and aquifer sediments is 0.2 to $1.2 \mathrm{mg} / \mathrm{kg}$. For the sediments considered outside inactive facility footprints but above and in the $10 \mu \mathrm{g} / \mathrm{L}$ uranium groundwater isopleths, the acid-extractable uranium ranges from 0.03 to $3.3 \mathrm{mg} / \mathrm{kg}$ for the vadose zone and 0.05 to $2.4 \mathrm{mg} / \mathrm{kg}$ for the aquifer sediments.

The LFI report (Williams et al. 2007) gives more detailed data on uranium content in the vadose zone and aquifer sediments at four new boreholes (Tables 6.12 and 6.13 list the results from the LFI). The uranium was measured on aliquots that include only small gravel and finer material (acid extracts) or material sieved through screens to remove all particles $>2 \mathrm{~mm}$ (microwave-assisted total digestion). The sediment aliquots with gravel removed were then either acid extracted, similar to the data in DOE-RL (1994b), or completely dissolved in mixed acids in a microwave. In LFI boreholes 399-3-19 and 399-3-20, it was determined that the uranium throughout the sediment profile was natural background uranium with concentrations averaging $0.96 \mathrm{mg} / \mathrm{kg}$ in the vadose zone and $1.27 \mathrm{mg} / \mathrm{kg}$ in the aquifer sediments. The sediment uranium data for these two boreholes ranged between 0.4 and $1.9 \mathrm{mg} / \mathrm{kg}$ with all of the values above $1.3 \mathrm{mg} / \mathrm{kg}$ associated with microwave digestion of $<2$-mm particles. Based on these data, we suggest that sediments with acid-extractable uranium concentrations less than $2 \mathrm{mg} / \mathrm{kg}$ likely represent sediments uncontaminated with Hanford process uranium and that such sediments do not react with water to leach significant quantities of uranium into the aquifer. 
Table 6.12. Total Uranium Concentration and Lithology of LFI Borehole Sediments with Hanford Process Uranium Present

\begin{tabular}{|c|c|c|c|c|c|c|c|}
\hline $\begin{array}{c}\text { C4999 } \\
(399-3-18)\end{array}$ & \begin{tabular}{|c|c}
$\begin{array}{c}\text { Depth } \\
\text { (feet below } \\
\text { ground surface) }\end{array}$ \\
\end{tabular} & $\begin{array}{c}\text { Total } \\
\text { Uranium } \\
(\mathrm{ppm}) \\
\end{array}$ & Lithology & $\begin{array}{c}\mathrm{C} 5000 \\
(399-1-23) \\
\end{array}$ & \begin{tabular}{|c|}
$\begin{array}{c}\text { Depth } \\
\text { (feet below } \\
\text { ground surface) }\end{array}$ \\
\end{tabular} & $\begin{array}{c}\text { Total } \\
\text { Uranium } \\
\text { (ppm) }\end{array}$ & Lithology \\
\hline C4999-3B MD & 9.0 & 2.84 & backfill & C5000-36AMD & 11.0 & 1.92 & Hanford gravel \\
\hline C4999-3B AE & 9.0 & 3.18 & backfill & C5000-36A WE & 11.0 & 0.76 & Hanford gravel \\
\hline C4999-5D & 18.0 & 1.60 & Hanford gravel & C5000-36EMD & 12.0 & 2.07 & Hanford gravel \\
\hline C4999-6A AE & 19.0 & 1.08 & Hanford gravel & C5000-36E WE & 12.0 & 0.67 & Hanford gravel \\
\hline C4999-6D & 22.0 & 2.11 & Hanford-93G4S3M & C5000-37AMD & 13.0 & 1.89 & Hanford gravel \\
\hline C4999-6D DUP & 22.0 & 2.06 & Hanford-93G4S3M & C5000-37A WE & 13.0 & 0.64 & Hanford gravel \\
\hline C4999-8E AE & 28.5 & 0.66 & Hanford gravel & C5000-38B MD & 13.0 & 3.35 & Hanford gravel \\
\hline C4999-9B & 30.5 & 2.51 & Hanford-87G10S3M & C5000-38B WE & 20.0 & 0.71 & Hanford gravel \\
\hline C4999-9C & 32.0 & 3.65 & Hanford gravel & C5000-38B DUP WE & 20.0 & 0.70 & Hanford gravel \\
\hline C4999-10C MD & 35.5 & 3.10 & Hanford-82G11S6M & C5000-38CMD & 21.0 & 6.67 & Hanford gravel \\
\hline C4999-10C AE & 35.5 & 1.17 & Hanford-82G11S6M & C5000-38C WE & 21.0 & 1.07 & Hanford gravel \\
\hline C4999-10D & 36.5 & 3.58 & Hanford gravel & C5000-39BMD & 23.0 & 14.96 & Hanford gravel \\
\hline C4999-11B & 39.5 & 2.45 & Hanford gravel & C5000-39B WE & 23.0 & 1.13 & Hanford gravel \\
\hline C4999-11B AE & 39.5 & 1.48 & Hanford gravel & C5000-39D MD & 25.0 & 4.40 & Hanford G72S21M7 \\
\hline C4999-11D & 41.5 & 10.53 & Hanford-93G4S3M & C5000-39D WE & 25.0 & 2.78 & Hanford G72S21M7 \\
\hline C4999-11D AE & 41.5 & 5.69 & Hanford-93G4S3M & C5000-40A & 30.0 & 6.86 & Hanford gravel \\
\hline C4999-12C & 46.0 & 6.50 & Hanford gravel & C5000-40B & 31.0 & 2.48 & Hanford gravel \\
\hline C4999-12D & 47.0 & 2.70 & Ringold sand, oxidized & C5000-40B & 31.0 & 2.54 & Hanford gravel \\
\hline C4999-12D AE & 47.0 & 2.04 & Ringold sand, oxidized & C5000-40C WE & 32.0 & 2.22 & Hanford G76S19M4 \\
\hline C4999-13E AE & 52.0 & 2.61 & Ringold sand, oxidized & C5000-40E MD & 34.0 & 1.13 & Hanford G71S22M7 \\
\hline C4999-13E DUP AE & 52.0 & 2.48 & Ringold sand, oxidized & C5000-40E WE & 34.0 & 0.77 & Hanford G71S22M7 \\
\hline C4999-14D AE & 56.0 & 2.13 & Ringold sand, reduced & C5000-40E DUP WE & 34.0 & 0.72 & Hanford gravel \\
\hline C4999-15A & 58.0 & 3.54 & Ringold sand, reduced & C5000-41BMD & 35.0 & 2.97 & Hanford gravel \\
\hline C4999-15B AE & 59.0 & 8.27 & Ringold sand, reduced & C5000-41B WE & 35.0 & 1.40 & Hanford gravel \\
\hline C4999-16 AE & 61.0 & 1.56 & Ringold sand, reduced & C5000-41C & 36.0 & 3.12 & Hanford G76S20M4 \\
\hline C4999-17A AE & 66.0 & 2.91 & Ringold sand, reduced & C5000-41E MD & 38.0 & 3.52 & Hanford gravel \\
\hline C4999-17B & 67.0 & 9.10 & Ringold sand, reduced & C5000-41E WE & 38.0 & 1.14 & Hanford gravel \\
\hline C4999-19B AE & 76.0 & 1.18 & Ringold sand, oxidized & C5000-43AMD & 44.0 & 2.65 & Hanford gravel \\
\hline C4999-21C & 86.0 & 2.02 & Ringold gravel, oxidized & C5000-43A WE & 44.0 & 1.03 & Hanford gravel \\
\hline C4999-21C AE & 86.0 & 1.24 & Ringold gravel, oxidized & C5000-43B & 45.0 & & Hanford gravel \\
\hline C4999-22E & 90.5 & 2.70 & Ringold gravel, oxidized & C5000-44B WE & 48.0 & 0.77 & Hanford gravel \\
\hline C4999-22E AE & 90.5 & 1.91 & Ringold gravel, oxidized & C5000-44C & 49.0 & & Hanford gravel \\
\hline C4999-25A AE & 98.5 & 0.75 & Ringold gravel, oxidized & C5000-44E-MD & 50.0 & 3.53 & Hanford gravel \\
\hline C4999-25B & 99.5 & 1.91 & Ringold gravel, oxidized & C5000-44E WE & 50.0 & 1.24 & Hanford gravel \\
\hline C4999-27B & 108.0 & 1.57 & Ringold sand, oxidized & C5000-45B & 53.0 & 3.42 & Hanford gravel \\
\hline C4999-27B AE & 108.0 & 0.39 & Ringold sand, oxidized & C5000-45C-MD & 54.0 & 4.39 & Ringold G83S13M4 \\
\hline
\end{tabular}


Table 6.12. (contd)

\begin{tabular}{|c|c|c|c|c|c|c|c|}
\hline 399-3-18 & \begin{tabular}{|c|c}
$\begin{array}{c}\text { Depth } \\
\text { (feet below } \\
\text { ground surface) }\end{array}$ \\
\end{tabular} & $\begin{array}{c}\text { Total } \\
\text { Uranium } \\
(\mathrm{ppm}) \\
\end{array}$ & Lithology & $\begin{array}{c}\mathrm{C} 5000 \\
399-1-23 \\
\end{array}$ & \begin{tabular}{|c|}
$\begin{array}{c}\text { Depth } \\
\text { (feet below } \\
\text { ground surface) }\end{array}$ \\
\end{tabular} & $\begin{array}{c}\text { Total } \\
\text { Uranium } \\
(\mathrm{ppm}) \\
\end{array}$ & Lithology \\
\hline C4999-29D AE & 117.0 & 0.60 & Ringold gravel & C5000-45C WE & 54.0 & 1.84 & Ringold G83S13M4 \\
\hline C4999-31C AE & 125.0 & 1.13 & Ringold gravel & C5000-45D & 55.0 & 3.66 & Ringold gravel \\
\hline \begin{tabular}{|l} 
C4999-31E \\
\end{tabular} & 127.0 & 3.52 & Ringold mud & C5000-46A WE & 56.0 & 1.73 & Ringold gravel \\
\hline C4999-32B AE & 128.0 & 1.93 & Ringold mud & C5000-46D & 59.0 & 1.38 & Ringold gravel \\
\hline \begin{tabular}{|l} 
C4999-32B DUP AE \\
\end{tabular} & 128.0 & 1.96 & Ringold mud & C5000-46D WE & 59.0 & 0.45 & Ringold gravel \\
\hline \multirow[t]{23}{*}{ 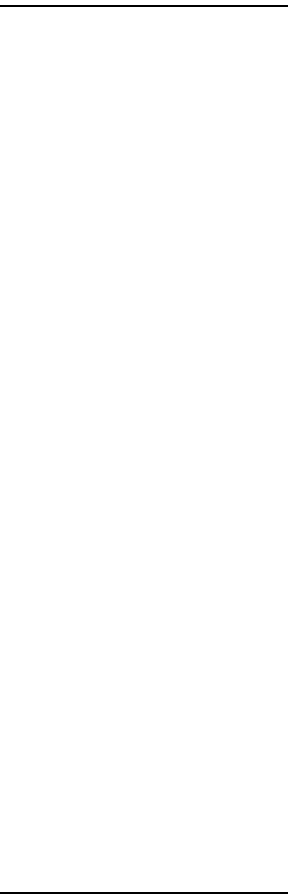 } & & & & C5000-47C MD & 61.5 & 1.76 & Ringold gravel \\
\hline & & & & C5000-48B & 63.0 & & Ringold gravel \\
\hline & & & & C5000-48D WE & 65.0 & 0.93 & Ringold sand \\
\hline & & & & C5000-48E MD & 66.0 & 2.09 & Ringold sand \\
\hline & & & & C5000-48E WE & 66.0 & 0.49 & Ringold sand \\
\hline & & & & C5000-49A & 67.0 & & Ringold gravel \\
\hline & & & & C5000-49D & 68.0 & & Ringold gravel \\
\hline & & & & C5000-49D WE & 68.0 & 0.89 & Ringold gravel \\
\hline & & & & C5000-50B MD & 71.0 & 2.63 & Ringold gravel \\
\hline & & & & C5000-50B WE & 71.0 & 0.80 & Ringold gravel \\
\hline & & & & C5000-51E MD & 77.0 & 1.50 & Ringold gravel, reduced \\
\hline & & & & C5000-51E WE & 77.0 & 0.69 & Ringold gravel, reduced \\
\hline & & & & C5000-52B & 79.0 & & Ringold gravel, reduced \\
\hline & & & & C5000-52B WE & 79.0 & 0.94 & Ringold gravel, reduced \\
\hline & & & & C5000-53E & 85.0 & & Ringold gravel, reduced \\
\hline & & & & C5000-53E WE & 85.0 & 0.92 & Ringold gravel, reduced \\
\hline & & & & C5000-54A & 86.0 & & Ringold gravel \\
\hline & & & & C5000-54E WE & 89.5 & 2.04 & Ringold gravel \\
\hline & & & & C5000-55D & 90.0 & & Ringold gravel \\
\hline & & & & C5000-57D WE & 100.0 & 0.60 & Ringold gravel, reduced \\
\hline & & & & C5000-58C & 103.0 & & Ringold gravel, reduced \\
\hline & & & & C5000-60C & 107.5 & & Ringold gravel, reduced \\
\hline & & & & C5000-60E WE & 109.5 & 0.48 & Ringold gravel, reduced \\
\hline \multicolumn{8}{|c|}{$\begin{array}{l}\text { Blue shading signifies aquifer sediments; green shading signifies that the water table was fluctuating over these elevations while the borehole was drilled. No shading on the dept } \\
\text { column signifies vadose zone sediments at time of drilling. Pink shading in the total uranium column signifies that the sediment sample was sieved to <2-mm fraction. No } \\
\text { shading in total uranium column signifies that the aliquot was not sieved but still was biased to material not including cobbles. "Reduced" signifies that the sediment’s redox state } \\
\text { was reduced (sulfide smell or coloration of reduced iron), "oxidized" = oxidized sediments (the norm at Hanford site); mud signifies dominated by silt and clay, numbers such as } \\
\text { G71S22M7 signify that the bulk sample was characterized by dry sieving and hydrometer to measure particle size G = gravel, S= sand, and M = mud. Thus, G71S22M7 is } \\
\text { 71 wt\% gravel, } 22 \mathrm{wt} \% \text { sand, and 7\% mud. }\end{array}$} \\
\hline
\end{tabular}


Table 6.13. Total Uranium Concentration and Lithology of LFI Borehole Sediments with No Signs of Hanford Process Uranium Present

\begin{tabular}{|c|c|c|c|c|c|c|c|}
\hline $\begin{array}{c}\text { C5001 } \\
(399-3-19) \\
\end{array}$ & $\begin{array}{c}\text { Depth } \\
\text { (feet below } \\
\text { ground surface) }\end{array}$ & $\begin{array}{c}\text { Total } \\
\text { Uranium } \\
(\mathrm{ppm}) \\
\end{array}$ & Lithology & $\begin{array}{c}\text { C5002 } \\
(399-3-20) \\
\end{array}$ & \begin{tabular}{|c|}
$\begin{array}{c}\text { Depth } \\
\text { (feet below } \\
\text { ground surface) }\end{array}$ \\
\end{tabular} & $\begin{array}{c}\text { Total } \\
\text { Uranium } \\
(\mathrm{ppm}) \\
\end{array}$ & Lithology \\
\hline C5001-63C & 8.0 & 0.57 & Backfill & C5002-83B rep 1 & 11.5 & 0.87 & eolian sand \\
\hline C5001-64E MD & 15.0 & 1.33 & Hanford gravel & C5002-83B rep 2 & 11.5 & 0.91 & eolian sand \\
\hline \begin{tabular}{|l} 
C5001-66A \\
\end{tabular} & 21.0 & 1.19 & Hanford G63S34M4 & C5002-83B & 11.5 & 0.41 & eolian sand \\
\hline C5001-66A & 21.0 & 0.40 & Hanford G63S34M4 & C5002-84C & 16 & 1.10 & eolian sand \\
\hline C5001-68A MD & 28.0 & 1.28 & Hanford gravel & C5002-86E & 21.5 & 1.63 & Hanford G80S16M4 \\
\hline C5001-68A DUP MD & 28.0 & 1.28 & Hanford gravel & C5002-86E & 21.5 & 0.67 & Hanford G80S16M4 \\
\hline C5001-68B & 29.0 & 1.28 & Hanford gravel & C5002-87D & 24.5 & 1.48 & Hanford gravel \\
\hline C5001-68B & 29.0 & 0.40 & Hanford gravel & C5002-87D DUP & 24.5 & 1.42 & Hanford gravel \\
\hline C5001-69C MD & 33.0 & 1.43 & Hanford gravel & C5002-90A & 32.5 & 1.75 & Hanford gravel \\
\hline \begin{tabular}{|l|} 
C5001-69D \\
\end{tabular} & 34.0 & 1.44 & Hanford G94S5M2 & C5002-90C & 34.5 & 1.72 & Hanford gravel \\
\hline C5001-69D & 34.0 & 0.42 & Hanford G94S5M2 & C5002-91C & 39.5 & 1.40 & Hanford G80S14M6 \\
\hline C5001-70D MD & 39.5 & 1.70 & Hanford gravel & C5002-91C & 39.5 & 0.46 & Hanford G80S14M6 \\
\hline C5001-70E & 40.5 & 1.32 & Hanford G83S14M3 & C5002-91D & 40.5 & 1.46 & Hanford gravel \\
\hline C5001-70E & 40.5 & 0.40 & Hanford G83S14M3 & C5002-92D & 48.5 & 1.39 & Hanford G86S12M2 \\
\hline C5001-71E MD & 41.5 & 1.50 & Hanford gravel & C5002-92D & 48.5 & 0.52 & Hanford G86S12M2 \\
\hline C5001-73B & 49.8 & 1.48 & Hanford G80S18M2 & C5002-93E & 54.5 & 1.93 & Hanford G87S13M1 \\
\hline C5001-73B & 49.8 & 0.59 & Hanford G80S18M2 & C5002-93E & 54.5 & 0.73 & Hanford G87S13M1 \\
\hline C5001-74B & 53.5 & 1.37 & Hanford G84S16M1 & C5002-94D & 65.5 & 1.68 & Hanford gravel \\
\hline C5001-74B & 53.5 & 0.58 & Hanford G84S16M1 & C5002-94D & 65.5 & 0.43 & Hanford gravel \\
\hline C5001-76C & 64.5 & 1.47 & Hanford gravel & C5002-98E & 81.0 & 1.20 & $\begin{array}{l}\text { Ringold gravel, oxidized } \\
\text { G81S17M2 }\end{array}$ \\
\hline C5001-76D & 65.5 & 1.60 & Hanford gravel & C5002-98E & 81.0 & 0.43 & $\begin{array}{l}\text { Ringold gravel, oxidized } \\
\text { G81S17M2 } \\
\end{array}$ \\
\hline C5001-76D & 65.5 & 0.52 & Hanford gravel & C5002-99D & 82.0 & 2.38 & Ringold sand, oxidized \\
\hline C5001-78A & 75.0 & 1.56 & Hanford gravel & C5002-99D & 82.0 & 1.08 & Ringold sand, oxidized \\
\hline C5001-79A & 81.5 & 2.56 & Hanford gravel & C5002-100A & 84.0 & 2.11 & Ringold sand, reduced \\
\hline C5001-79A & 81.5 & 1.06 & Hanford gravel & C5002-100A & 84.0 & 1.02 & Ringold sand, reduced \\
\hline C5001-80A & 85.5 & 2.72 & Ringold sand, oxidized & C5002-100A DUP & 84.0 & 0.85 & Ringold sand, reduced \\
\hline C5001-80A & 85.5 & 1.33 & Ringold sand, oxidized & \multirow{3}{*}{\multicolumn{4}{|c|}{$\begin{array}{l}\text { ading signifies aquifer sediments. Pink shading in total uranium column signifies tha } \\
\text { es aliquot was not sieved but still was biased to material not including cobbles. } \\
\text { eed iron), "mud” signifies dominated by silt and clay, "oxidized” = oxidized sedimen } \\
\text { cterized by dry sieving and hydrometer to measure particle size, where G = gravel, S }\end{array}$}} \\
\hline C5001-80A DUP & 85.5 & 1.19 & Ringold sand, oxidized & & & & \\
\hline $\begin{array}{l}\text { No shading on depth col } \\
\text { sediment sample was sie } \\
\text { "Reduced" signifies sedi } \\
\text { (the norm at Hanford Sit } \\
\text { sand, and M = mud. Thi }\end{array}$ & $\begin{array}{l}\text { S vadose } \mathrm{zc} \\
\mathrm{m} \text { fraction. } \\
\mathrm{x} \text { state was } \\
\text { such as } \mathrm{G} 7 \\
\text { I7 is } 71 \mathrm{wt}^{\circ}\end{array}$ & $\begin{array}{l}\text { limen } \\
\text { ading } \\
\text { d (sul } \\
17 \text { sig }\end{array}$ & $\begin{array}{l}\text { me of drilling and blue } \\
\text { al uranium column sig } \\
\text { mell or coloration of re } \\
\text { at bulk sample was ch } \\
\text { sand and } 7 \% \text { mud. }\end{array}$ & & & & \\
\hline
\end{tabular}


The other two LFI boreholes (399-3-18 and 399-1-23) are near but outside the footprint of inactive waste facilities and did show some water-leachable uranium in the lower vadose zone sediments. Vadose zone sediments, with most gravel removed, from these two boreholes that released significant waterleachable uranium (equivalent pore water concentrations $>200 \mu \mathrm{g}$ uranium/liter) contained on average $5 \mathrm{mg} / \mathrm{kg}$ uranium with a range of 1.1 to $15 \mathrm{mg} / \mathrm{kg}$. Aquifer sediments, with most gravel removed, from the two boreholes that released significant water-leachable uranium contained on average $3 \mathrm{mg} / \mathrm{kg}$ uranium with a range of 1.4 to $3.5 \mathrm{mg} / \mathrm{kg}$. The sediment uranium average concentration for these "contaminated" samples is only one to a few parts per million greater than sediments that do not appear to water leach significant amounts of uranium. Thus, there is very little difference between the uranium concentrations of vadose zone and aquifer sediments outside the footprint of inactive disposal facilities, which do water leach concentrations of uranium above drinking water standards, from sediments that do not water leach significant concentrations of uranium. It would thus appear difficult to designate sediments residing outside disposal facility footprints as contributing to the uranium plume in groundwater, based solely on their total uranium concentration, strong-acid extractable uranium, or total microwave-assisted digestion removable uranium. It would appear that the best way to designate sediments as contributing or not contributing to the existing groundwater plume is proximity to an inactive disposal facility and some type of mild extraction test using water or some solution less aggressive than strong acid.

Despite this problem of determining what sediments outside the inactive disposal facilities' footprints are contributing uranium to the aquifer (needed to complete our conceptual model), we will assume that the areal extent of vadose zone sediment outside facility footprints that may be contributing uranium to the existing groundwater plume is twice as large as the area under the facilities' footprints and that the gravel-corrected sediment labile uranium concentration is $0.4 \mathrm{mg} / \mathrm{kg}$ based on the two LFI boreholes that released significant concentrations of water-leachable uranium. These assumptions are based on very scant field data that will be augmented by two activities: 1) drilling of three additional characterization boreholes during the fall of 2007, and 2) drilling of numerous boreholes in the footprint of the South Process Pond for a basic science field experiment. The areal extent for sediments outside the facilities' footprints would be $\sim 154,000 \mathrm{~m}^{2}$ based on our assumption that it is twice as large as the sum of the footprints of the South and North Process Ponds, the 300 Area Process Trenches, and the 307 Process Trenches.

Determining the vertical extent of slightly contaminated sediments outside the facilities' footprints at this point can only be based on the two LFI boreholes, 399-1-23 and 399-3-18 ${ }^{16}$. Unfortunately, there was a large difference in the thickness of sediments in these two boreholes ( 4 and $11.3 \mathrm{~m}$ ), respectively, that water leached significant concentrations of uranium (see Figures 6.8 and 6.9, and Section 6.4.2 for more discussion). Borehole 399-1-23 is near the 300 Area Process Trenches, and borehole 399-3-18 is near (downgradient) from the South Process Pond. Based on the masses of uranium and the volume of waste disposed to these two facilities, finding a thicker zone of "contaminated" sediments near the pond is logical. We will thus separate the areal extent of contributing sediments into two bins, one for areas near but outside the ponds' footprints and one for areas around but outside the trenches' footprints. We also correct the thicknesses of the vadose zone sediments that contribute water-leachable uranium by assuming that the lower $2 \mathrm{~m}$ is the smear zone. This leads to thicknesses of vadose zone sediment outside the

\footnotetext{
${ }^{16}$ Data will be available in the near future from two boreholes drilled to investigate volatile organic compounds (C5706, completed as 399-3-22, and C5707, completed as 399-4-14). Preliminary results show water-leachable uranium concentrations in the upper vadose zone and smear zone at concentrations similar to those observed at the LFI borehoele 399-1-23 and 399-3-18.
} 
facility footprints that may contribute uranium to the groundwater plume to 9.3 and $2 \mathrm{~m}$ for sediments near but outside the footprint of ponds and trenches, respectively. Using these assumptions, a sediment bulk density of $2,060 \mathrm{~kg} / \mathrm{m}^{3}$ and the sediment contaminant uranium concentration of $0.4 \mathrm{mg} / \mathrm{kg}$, the total uranium in compartments C + D would be 559 and $6.3 \mathrm{~kg}$ for the sum of contaminated sediments and pore waters outside the footprints of the ponds and trenches, respectively. We will describe how to separate the pore water uranium inventories (compartment D) from these totals a few paragraphs below.

The smear zone (compartments $\mathrm{G}$ and $\mathrm{H}$ ) immediately below compartment $\mathrm{C}$ is assumed to have the same area, a thickness of $2 \mathrm{~m}$, and sediment uranium concentrations the same $(0.4 \mathrm{mg} / \mathrm{kg})$ as the vadose zone sediments outside of facility footprints. The total uranium in the smear zone (sum of compartments $\mathrm{G}$ and $\mathrm{H}$ ) would be 120 and $6.4 \mathrm{~kg}$ for outside the ponds and trenches, respectively.

None of the sediments in the vadose at the boreholes 399-3-18 or 399-1-23 were ultra-centrifuged in an attempt to directly obtain vadose zone pore water. However, most of the sediment samples were water leached (extracted) for 24 hours with enough deionized water such that the mass of total water (deionized and existing pore water) equaled the dry weight of the sediment sample. From these 1:1 sediment to water extracts and the known moisture content of each sediment sample, an estimate of the pore water concentrations can be calculated if one assumes that the deionized water acts solely as a diluent of the existing pore water. That is, one assumes that the deionized water does not dissolve or desorb constituents out of the sediment over the short contact time. This is certainly a simplification but has proven to be reasonable for significantly contaminated field moist sediments. However, it is less accurate for slightly contaminated sediments (see discussions in Serne et al. 2002b, 2002c, 2004a, 2004b).

For the vadose zone sediments from 399-3-18, the calculated pore water (from the 1:1 extracts) uranium concentrations varied from 50 to $350 \mu \mathrm{g} / \mathrm{L}$ with values in the deepest portion of the vadose zone ranging from 50 to $110 \mu \mathrm{g} / \mathrm{L}$. At borehole 399-1-23, the dilution-corrected water extracts (estimate of vadose zone pore water) contained 100 to 2,500 $\mu \mathrm{g} / \mathrm{L}$ of dissolved uranium. Based on these few data, we will assume that the average vadose zone pore water concentrations in deep vadose zone sediments above the smear zone contain $100 \mu \mathrm{g} / \mathrm{L}$ and $800 \mu \mathrm{g} / \mathrm{L}$ in the vadose sediments outside the footprints of the ponds and trenches, respectively.

Some of the sediment samples from the smear zone and aquifer from borehole 399-1-23 had the drainable liquids removed and the uranium directly measured. If we assume that these samples represent equilibrium conditions, then the pore water concentrations of uranium in the smear zone below compartment $\mathrm{C}$ sediments varies from 11 to $91 \mu \mathrm{g} / \mathrm{L}$ at 399-1-23. We will assume that the pore waters in the smear zone sediments outside the footprint of ponds contain $100 \mu \mathrm{g} / \mathrm{L}$ (based on the dilution corrected water extract information in previous paragraph) and in the smear zone sediments outside the footprint of trenches contain $80 \mu \mathrm{g} / \mathrm{L}$ (based on the actual pore water range just discussed). Other assumptions are that the smear zone thickness is everywhere $2 \mathrm{~m}$.

We assume that the thickness of vadose zone sediments above the smear zone outside the footprints of the ponds and trenches that are contaminated is 9.3 and $2 \mathrm{~m}$ (based on depth zones where elevated water leachable uranium was found in the two LFI boreholes), respectively, and that the smear zone is $2 \mathrm{~m}$ thick everywhere that there is elevated uranium in the sediments. We also assume that the vadose zone sediments contain $8 \%$ by volume moisture and that the smear zone contains on average $13 \%$ moisture ( $50 \%$ saturation based on total porosity of $26.3 \%$ volume). This allows us to calculate the uranium inventory in the water portions (compartments $\mathrm{D}$ and $\mathrm{H}$ ) associated with compartments $\mathrm{C}$ and $\mathrm{G}$ 
outside the footprint of inactive disposal facilities. The values are $5.43 \mathrm{~kg}$ uranium for the vadose zone pore water outside pond footprints and $0.49 \mathrm{~kg}$ uranium for the vadose zone pore water outside the trench footprints (sum of these two values is compartment D) and 1.9 and $0.08 \mathrm{~kg}$ uranium for the smear zone pore waters outside the footprints of ponds and trenches (sum of these two values is compartment $\mathrm{H}$ ). Again, the amount of uranium in the waters is small compared to the uranium bound to the sediments containing the water.

It should be noted that these estimates for compartments C, D, G, and $\mathrm{H}$ are based on the two LFI boreholes with water-leachable uranium and the many assumptions noted. The areas and volumes of the existing uranium groundwater plume are large compared to the regions for which we have data to make these estimates. Certainly more boreholes through regions of the vadose, smear, and aquifer zones containing water-leachable uranium above and within the existing groundwater plume strategically chosen to be near but down-gradient of the inactive facilities would be helpful to strengthen these inventory estimates.

\subsubsection{Uranium in Compartments $I$ and $J$ (Aquifer Sediments and Groundwater Within the $30 \mu \mathrm{g} / \mathrm{L}$ Uranium Isopleth)}

The areal extent of the existing groundwater plume is well established since the early 1990s based on years of monitoring the well network (see Section 3.0). However, the vertical profile of uranium in the groundwater is not as well established. There are only a few wells, including the four new LFI wells, for which any data on groundwater uranium concentrations as a function of depth are available. Thus, the volume of uranium-contaminated water at specific concentrations is difficult to estimate. It is known that the uranium in the upper unconfined aquifer is almost exclusively found in the gravel-dominated facies of the upper highly permeable Hanford formation. Below this highly permeable layer throughout much of the aquifer is a lens of either a gravelly Ringold or in some regions a lower permeability fine-grained Ringold Formation. Below the Ringold gravel is an aquitard called the Ringold lower mud unit (see Section 4.0 for more details). The depth of the highly permeable Hanford formation gravel layer in which most all the dissolved uranium resides varies from 1 meter near well 399-3-18 to $11 \mathrm{~m}$ at wells 399-3-19 and 399-3-20.

In Section 3.0, it was concluded that the best-estimate thickness for the uranium-bearing portion of the plume is $8 \mathrm{~m}$ in December (low river stage) and $9.8 \mathrm{~m}$ in June (high river stage). We will assume an average depth of the water table that is always saturated (i.e., below the smear zone or from the elevation when the river is low to the bottom of the highly permeable Hanford gravel facies) of $8 \mathrm{~m}$. If we assume that the groundwater uranium plume is not growing or receding, the average areal extent between January 2002 and January 2007 as delineated by the $30 \mu \mathrm{g} / \mathrm{L}$ isopleth is $0.41 \pm 0.04 \mathrm{~km}^{2}$ and as delineated by the $10 \mu \mathrm{g} / \mathrm{L}$ isopleth is $0.94 \pm 0.12 \mathrm{~km}^{2}$ (see Table 3.3). If we also assume that the mass of uranium in the plume is not significantly changing and that the aquifer porosity is 0.26 (based on a bulk density of sediment of $2,060 \mathrm{~kg} / \mathrm{m}^{3}$ and a particle density of $2,800 \mathrm{~kg} / \mathrm{m}^{3}$ ), the mass of uranium within the plume over the same time period (includes the smear zone contribution also) ranges from 62 to $65 \mathrm{~kg}$ with one standard deviation equal to $15 \mathrm{~kg}$ for the $30 \mu \mathrm{g} / \mathrm{L}$ isopleth area and 81 to $94 \mathrm{~kg}$ with a standard deviation equal to $\sim 17 \mathrm{~kg}$ for the $10 \mu \mathrm{g} / \mathrm{L}$ isopleth. The first value in the ranges reported is for the December plume, and the larger value in each range is for the June plume. In Table 6.5, we use the $30 \mu \mathrm{g} / \mathrm{L}$ isopleth uranium inventory for December to represent compartment J. Essentially the inventory differences between the June average and December average represent uranium in the smear zone porewater. 
The uranium concentration of the aquifer sediments is the last compartment (I) needed to complete our box model. The values of uranium content for saturated aquifer sediments are only available for the fine-grained aliquots used for acid- or microwave-assisted digestion of the four new LFI boreholes and a few data from old boreholes. The microwave digestion was performed on material sieved through 2-mm mesh. One has to then decide how to correct for the fact that $\sim 90 \%$ of the particles present in the sample were retained on the 2-mm sieve and not analyzed. If we assume that the larger particles that were discarded do not contain significant concentrations of uranium, then the measured values for the $<2 \mathrm{~mm}$ sediment can be reduced by a factor of 10 to estimate the in situ concentrations of uranium bound to the bulk aquifer sediments. The $<2$-mm aliquots of aquifer sediment uranium concentrations in the saturated zone of borehole 399-3-18 ranged from 2 to $5.7 \mathrm{mg} / \mathrm{kg}$ and for borehole 399-1-23 ranged from 0.7 to $4.4 \mathrm{mg} / \mathrm{kg}$. For the other two LFI boreholes, 399-3-19 and 399-3-20, the aquifer sediment aliquots contained from 0.4 to $2.7 \mathrm{mg} / \mathrm{kg}$ of uranium. The average uranium content for the samples from these four boreholes that were microwave digested was $2.5 \mathrm{mg} / \mathrm{kg}$. Given our assumption that the in situ sediments are much coarser than the aliquots used to estimate total uranium concentrations, the in situ sediments (and groundwater within) would contain $0.25 \mathrm{mg} / \mathrm{kg}$ uranium. For the areal extent of the $30 \mu \mathrm{g} / \mathrm{L}$ isopleths $\left(0.41 \mathrm{~km}^{2}\right)$, the assumed plume average thickness of $8 \mathrm{~m}$, and bulk density of $2,060 \mathrm{~kg} / \mathrm{m}^{3}$, the total uranium inventory on the aquifer sediments becomes $1,689 \mathrm{~kg}$ of uranium.

There is a problem herein because most of this uranium inventory is composed of natural uranium that acid leaches but is not water-leachable. Thus, a good portion of the $1,689 \mathrm{~kg}$ of uranium is in fact not reactive and capable of contributing to the groundwater plume and should thus be ignored in our box model. Therefore, we use the $\mathrm{K}_{\mathrm{d}}$ construct (described in Section 6.3.1) where we calculated the pore water uranium concentration using laboratory adsorption studies. If we assume that the "field corrected" $\mathrm{K}_{\mathrm{d}}$ for the aquifer sediments within the existing groundwater plume averages $0.25 \mathrm{~mL} / \mathrm{g}$ and that the average groundwater concentration over the entire volume of the plume (as defined by $30 \mu \mathrm{g} / \mathrm{L}$ isopleth) can be calculated as the mass of uranium within the $30 \mu \mathrm{g} / \mathrm{L}$ isopleth (estimated above at $62 \mathrm{~kg}$ for December [low river stage]) divided by the volume of water within the plume $\left(0.41 \mathrm{~km}^{2}\right.$ area times $8-\mathrm{m}$ thickness [at low river stage] times porosity [0.26]), an average value of $73 \mu \mathrm{g} / \mathrm{L}$ is calculated for the groundwater uranium concentration. Using the relationship that the concentration of uranium sorbed to the aquifer sediments is equal to $\mathrm{K}_{\mathrm{d}}$ times solution concentration, we can calculate the concentration of desorbable uranium on the aquifer sediments as $0.018 \mathrm{mg} / \mathrm{kg}$. Then using the volume of aquifer capturing the $30 \mu \mathrm{g} / \mathrm{L}$ isopleth $\left(0.41 \mathrm{~km}^{2} \cdot 8 \mathrm{~m}\right)$, and the bulk density of the sediments $\left(2,060 \mathrm{~kg} / \mathrm{m}^{3}\right)$, we obtain $122 \mathrm{~kg}$ of desorbable uranium currently bound on the aquifer sediments. More sophisticated calculations for smaller aquifer volumes could better bound this gross-averaging approach for determining the mass of desorbable uranium bound to aquifer sediments. These more sophisticated calculations would separate the more concentrated uranium-concentration isopleths and use different $K_{d}$ values for each selected region because of variation in water chemistry (especially total inorganic carbon content and calcium concentration) and sediment properties (especially amounts of fines [clay mineral types], hydrous ferric oxides contents, and calcite contents). At this time, we see do not have more detailed data for the $\mathrm{K}_{\mathrm{d}}$ values for sub-regions of the groundwater plume and thus can not make more sophisticated calculations.

\subsubsection{Observations on the Uranium Inventory in Box-Model Compartments}

The box-model uranium inventories (see Table 6.5 and Figure 6.4) suggest that the majority of the residual uranium resides in the vadose zone sediments and smear zone sediments below the footprints of the inactive facilities and most is within the footprints of the North and South Process Ponds. Our estimates show that $\sim 80 \%$ of the residual uranium estimate is under the inactive facilities' footprints, 
with $77 \%$ of the total box-model uranium inventory bound to the sediments and $3 \%$ in the pore waters within the facility footprints. Another $16 \%$ of the total residual uranium is spread out in the vadose zone and smear zone outside of the footprints of the inactive facilities. The current groundwater plume and aquifer sediments contain about $4 \%$ of the total residual uranium. Within the current aquifer plume (compartments I + J), two-thirds of the uranium inventory is bound to the sediments, and only one-third is dissolved in the groundwater. The overall estimate of residual "contaminant" uranium in the 300 Area from our box model is 4,150 kg. This mass represents about 9\% of the uranium that Simpson et al. (2006) estimate was disposed of in the 300 Area liquid waste disposal facilities.

\subsection{Controls on Uranium Mobility (Residual Uranium Still in the 300 Area)}

The following sections will give background on uranium geochemistry with the emphasis on environments specific to the 300 Area Site and then describe the processes that transfer the uranium between the 10 compartments of our box model and ultimately allow some uranium to flush into the Columbia River. Essentially, the information will elaborate on and hopefully answer the second key question introduced in Section 2.0 earlier, namely, "What are the mechanisms by which the uranium is mobilized?”

\subsubsection{Previous Uranium Mobility Investigations Using Residual 300 Area Sediments}

The objective of Serne et al. (2002a) was to perform controlled laboratory experiments to measure the leaching and adsorption characteristics of uranium in near-surface sediment samples collected from the 300 Area of the Hanford Site. The environmental restoration contractor used the results to model uranium mobility for the 300-FF-1 and 300-FF-2 Operable Unit waste sites. Eight near-surface (i.e., within a foot of the existing ground or excavation surface) sediment samples were collected by the environmental restoration contractor between December of 2000 and February 2001. The samples consisted of three 5-gallon buckets of uncontaminated background sediment, two 5-gallon buckets of uranium-contaminated sediment from the 300 Area North Process Pond (sample numbers B11494, near the excavated southern inlet, and B11495, from the wall in the northeast corner of the excavated pond), and three 5-gallon buckets of uranium-contaminated sediment collected in the vicinity of the 303-K building waste storage pads (sample numbers B11BY4, B11BY5, and B11BY6). All the sediments were screened in the field to remove gravel particles larger than $6.35 \mathrm{~mm}$ using a standard $1 / 4$-inch sieve.

Table 6.8 shows the total uranium concentration in the near-surface sediments taken from the open excavation at the North Process Pond and around the 303-K building. Two independent techniques (XRF and GEA) were used on separate aliquots of homogenized sediment from each location.

Additional studies, reported in Zachara et al. (2005), were performed on other sediment samples obtained February through May, 2003, from the North and South Process ponds using a backhoe excavator. Figure 6.5 shows the locations of the four excavations. The existing land surface in April 2003 in both ponds was below grade as "contaminated' materials had been excavated (see Figure 6.6) and hauled to the ERDF on the Central Plateau of the Hanford Site between May 1998 and June 1999. Subsurface sediments were collected in approximate 2-ft depth intervals from the excavated pond surface to the water table. Figure 6.7 is a photograph of the sampling location SPP\#2 in the South Process Pond. Groundwater and entrained silt/clay-sized fines within the disturbed groundwater were also sampled at each location. 


\section{Area Soil Sampling Locations}

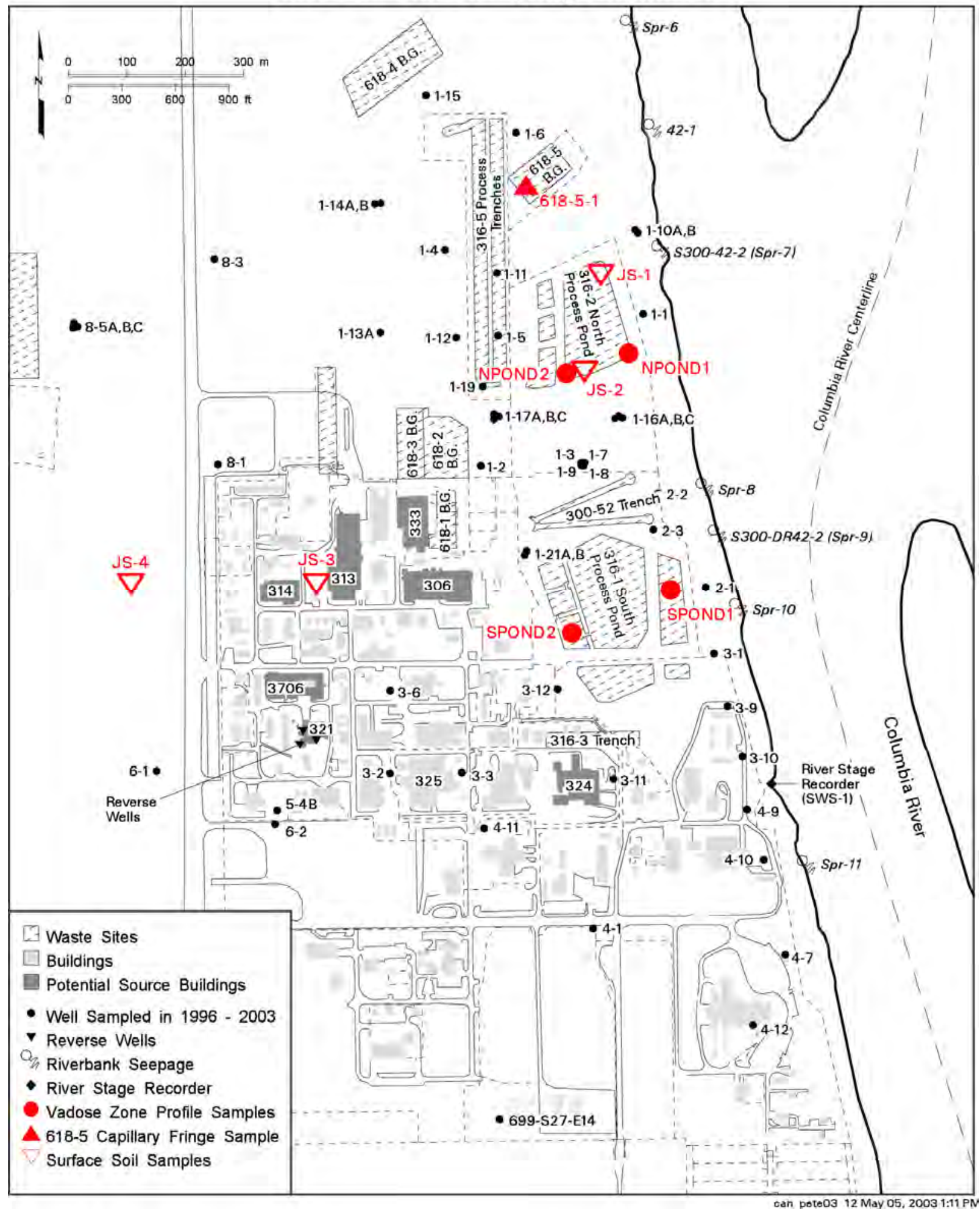

Figure 6.5. Sample Locations for Investigations by Serne et al. (2002a, open triangles) and Zachara et al. (2005, solid circles and triangle) 


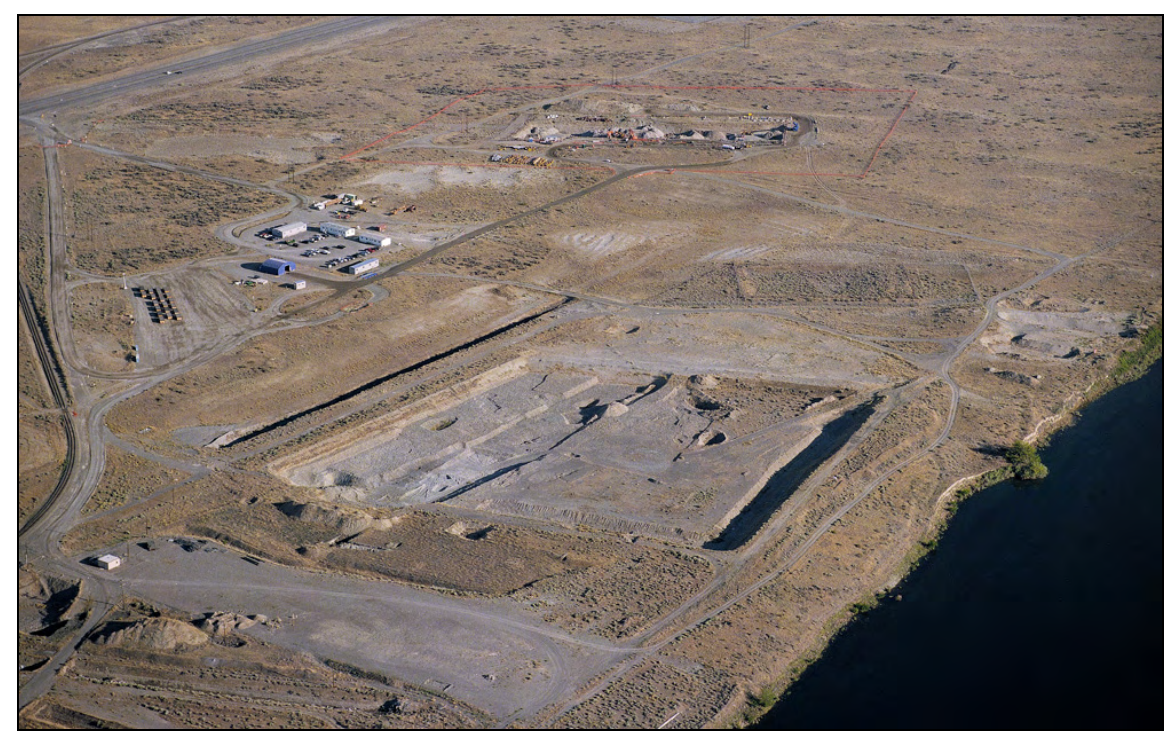

Figure 6.6. Aerial Photo of North Process Pond Open Excavation. Date of photo is prior to excavation of 618-5 burial ground, which started in October 2002.

Three sediment samples (NP4-1, NP4-2, and NP1-4.5) were also studied that had been collected in the early 1990s from the top $2 \mathrm{~m}$ of the North Process Pond before its excavation. These pre-excavation sediments had very high uranium and copper concentrations and represent the contaminated materials that were excavated during source-term removal.

The pond sediments collected in 2003 (after removing highly contaminated material) were quite coarse in texture, with 75\% larger than 12.5-mm cobbles. Aliquots of each pond sediment were sieved to less-than $2 \mathrm{~mm}$. All of the sieved samples, which constituted $~ 10 \%$ of the bulk sample, and groundwater fines were analyzed for their total uranium, copper, and trace-metal content by X-ray fluorescence. Labile, sorbed U(VI) was measured by a sodium bicarbonate-carbonate extraction (see Zachara et al. 2005 for details). Groundwater was analyzed comprehensively for anions, cations, $\mathrm{pH}$, and other relevant variables.

The total uranium concentrations in the $<2$-mm fraction of the sediments were highly variable, with generally greater concentrations found in the North Process Pond vadose zone sediments (see Table 6.9). All $<2$-mm fractions of the sediments contained uranium concentrations that were above background (1.5 to $3.0 \mathrm{mg} / \mathrm{kg}$ ). Sediments with the highest uranium (and copper) concentrations exhibited a palegreen hue from precipitated copper. Generally, sorbed uranium was highest in the finer textured mineral components of the sediment (e.g., silt and clay) because of its higher surface area and the presence of more reactive mineral components. Fine-grained mineral material isolated from the groundwater contained relatively high concentrations (12 to 200 parts per million) of uranium that showed a mild correlation with groundwater uranium concentrations. A variable fraction of sorbed uranium was found to be labile in the different sediments using the bicarbonate-carbonate extraction. The labile fraction is considered that portion of the total uranium pool that is available to desorb or dissolve into pore water or groundwater, and it should be used to estimate the inventory of uranium in sediments that can contribute to the aquifer plume. This is the reason for the recommendation in the previous section describing the box model to not use total sediment uranium concentrations because total uranium includes the unreactive natural background U(IV) solids. 


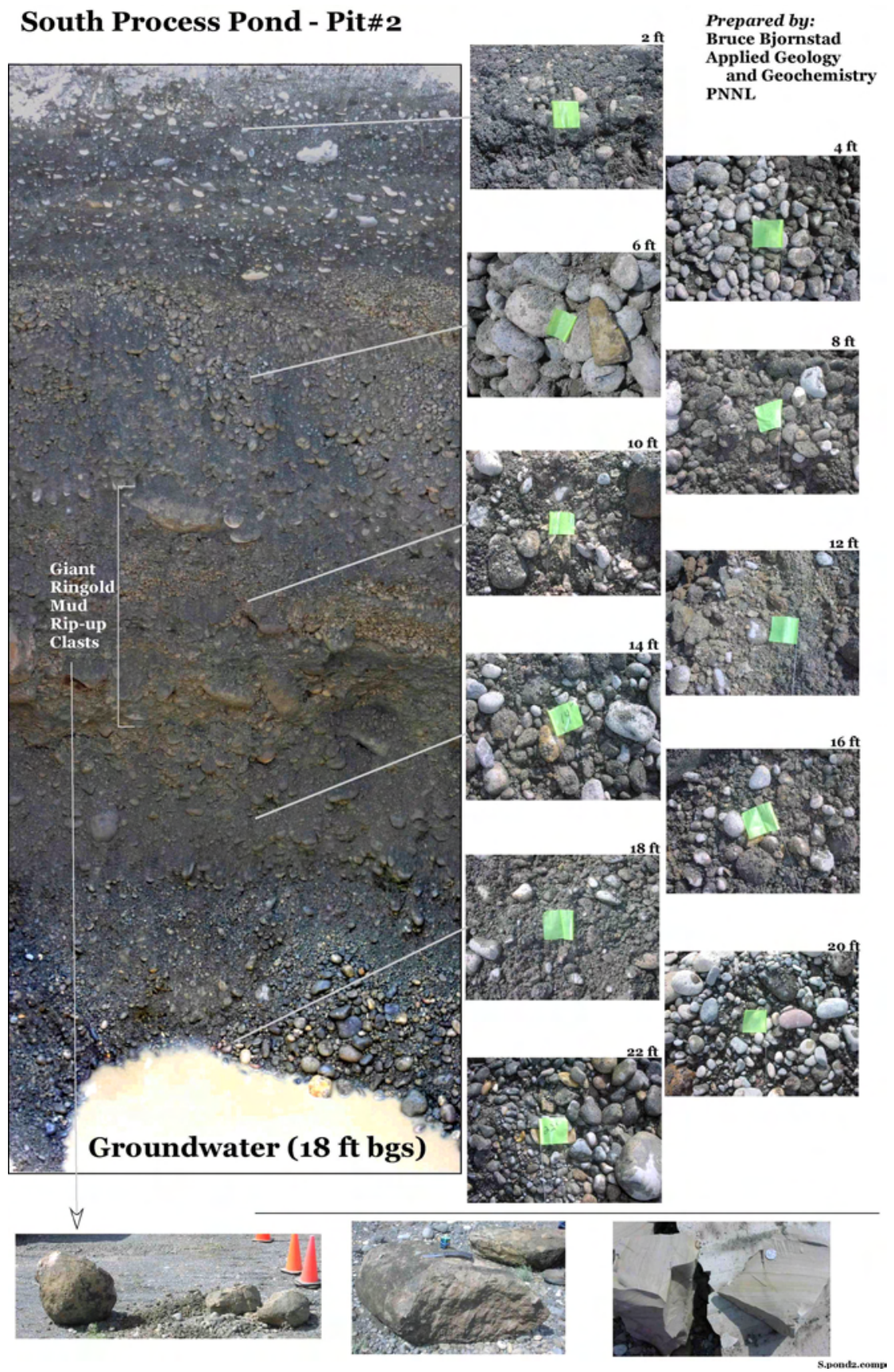

Figure 6.7. Photograph Montage of Samples from South Process Pond \#2 Site. Samples taken from $\sim 2$-ft intervals. Fine-grained materials were released to and suspended within groundwater during excavation. These were isolated by filtration and are labeled as "groundwater fines" throughout Zachara et al. (2005).

The laboratory findings from Serne et al. (2002a) and Zachara et al. (2005) are discussed further in Section 6.5 where solubility and adsorption processes are presented, and conclusions are drawn on their relative importance to determining the mass transfer of uranium between solid and solution. 


\subsubsection{LFI Results}

The most recent sampling of residual sediments in the 300 Area occurred during the LFI, and we summarize results from Williams et al. (2007) herein. The focus of the LFI was to determine the location and mobility characteristics of contaminant uranium that continues to re-supply the 300 Area groundwater plume. Presumed sources include uranium remaining in the vadose zone and/or sequestered in the aquifer sediments, which interact with the fluctuating groundwater-river water. The LFI information is fundamental for evaluating remedial-action alternatives to reduce the concentration of uranium in groundwater to meet regulatory standards. Four LFI borehole locations (see Figure 3.1 for locations of the four LFI boreholes) were chosen to investigate various combinations of proximity to former waste disposal sites, proximity to the Columbia River, and to cover sediments that exhibit a wide range in hydrogeologic features. Extensive analytical work was conducted on sediment samples collected from the continuous cores recovered from each borehole and on water samples collected from the saturated zone at depth-discrete intervals during drilling. Geophysical logging of the entire borehole was conducted to provide additional details on stratigraphic features and in an attempt to identify and quantify contaminant uranium concentrations. New information developed during the LFI pertains to stratigraphy and hydrologic units, the vertical distribution of uranium in the vadose zone and unconfined aquifer, and the potential usefulness of geophysical logging for mapping contaminant uranium in future boreholes. Principal findings relevant to uranium concentrations in sediments and mobility attributes follow.

Lower-than-expected levels of contaminant uranium were encountered in the sediment samples from the vadose zone at the four LFI boreholes. The uranium concentrations in the sediment profiles were too low to permit spectral gamma geophysical logging to be used in the field to define the vertical distribution of contaminant uranium in boreholes. Because of this, the planned Phase II drilling was modified as it depended solely on using spectral gamma logging to map the distribution of contaminant uranium over a broad area.

Relatively high concentrations of uranium were leached from the unsaturated sediment above the water table using 1:1 sediment to deionized water extracts in two of the four boreholes drilled (399-3-18 and 399-1-23). At 399-1-23, which is near the most recently active waste disposal site (300 Area Process Trenches), somewhat elevated levels of uranium are indicated in both the shallow and (deeper) lower portion of the vadose zone. Figures 6.8 and 6.9 show, using black bounding lines, the zone of vadose zone pore waters with elevated water-leachable uranium. Elevated levels of uranium contamination in the "smear zone" near the water table have been postulated as a source region that continues to supply uranium to the groundwater plume. Other leach tests are underway to better quantify the amount of uranium that could be re-supplied from these vadose zone sediments to the groundwater plume. At 399-3-18, the zone of sediments containing elevated water-leachable uranium is thicker than at 399-1-23. As mentioned in Section 6.3.2, having a thicker zone of elevated water-leachable uranium downgradient of the ponds seems logical given the larger mass of uranium deposited in the ponds in comparison to the process trenches (see Table 6.4).

Concentrations of total uranium in aquifer sediment samples from all four boreholes were present at relatively low levels and in most cases comparable to levels observed in background sediments (see Tables 6.12 and 6.13). However, as discussed in Section 6.3.3, the aquifer sediments can act as a storage medium, via sorption reactions, for uranium originally present in the water without showing significantly larger concentrations than uncontaminated sediments. That is, measuring total uranium in the sediments 


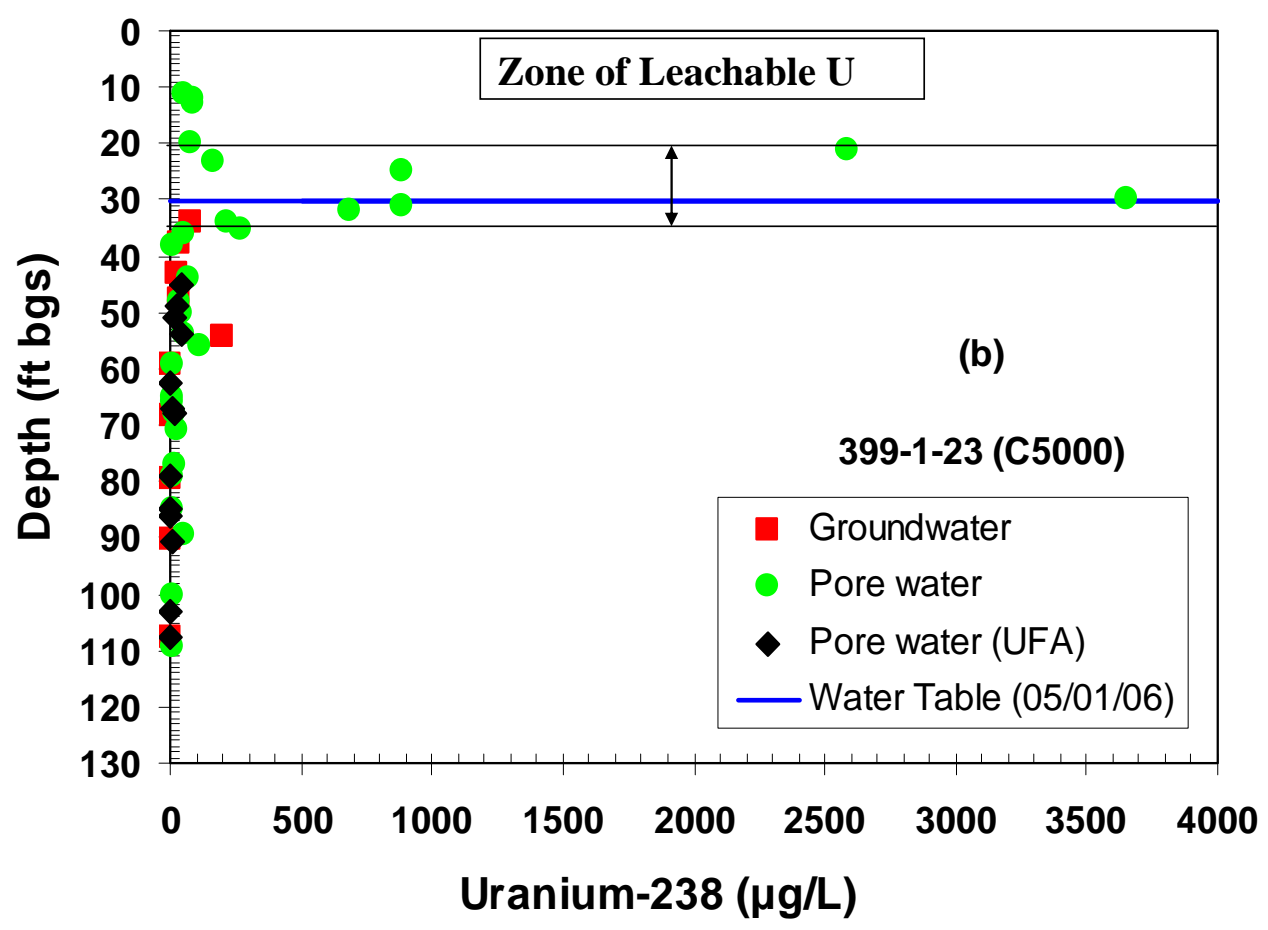

Figure 6.8. Estimated Vadose Zone Location (between arrows) with Elevated Water-Leachable Uranium at 399-1-23 (near 300 Area Process Trenches)

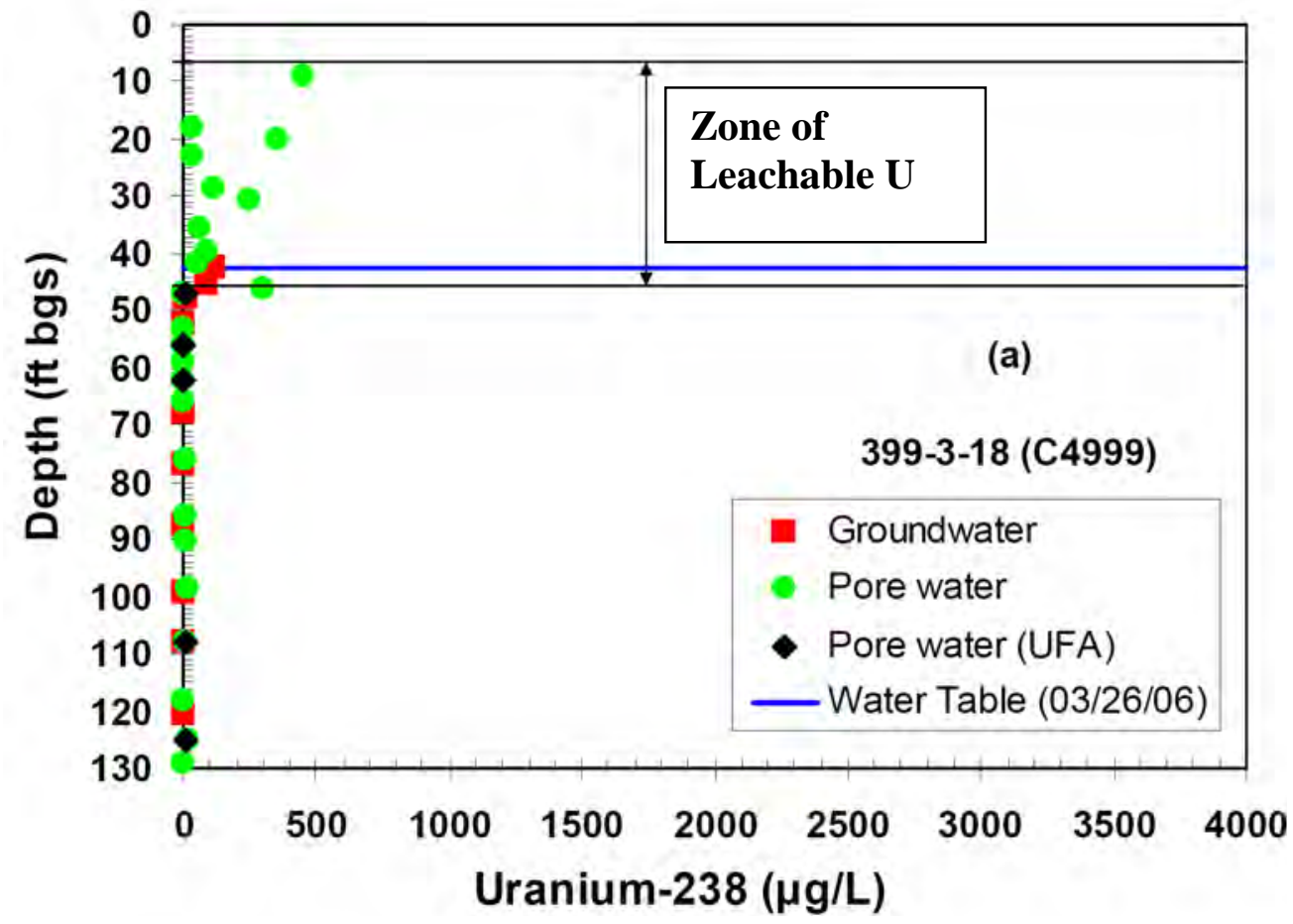

Figure 6.9. Estimated Vadose Zone Location (between arrows) with Elevated Water-Leachable Uranium at 399-3-18 (downgradient of South Process Pond) 
is not always a sensitive indicator as to whether contaminant uranium is present and sorbed to the solids. Again, this is caused by the background natural uranium concentration being 1 to 5 parts per million and the "contaminated" sediments having an overlapping range of uranium concentrations.

It is possible that isolated and small volumes of sediment with elevated uranium concentrations still exist as hot spots in and near the remediated process ponds. Tables 6.6 through 6.9 show some "hot spot" values ranging from 40 to 450 to nearly $1,000 \mathrm{mg} / \mathrm{kg}$ in sediments very near the surface $(<6.35-\mathrm{mm}$ size fraction) from the North Process Pond after preliminary excavation was completed and around the 303-K building after its removal, respectively. The concentrations in the North and South Process Ponds after excavation of the most contaminated sediments show that residual sediments contain between 5 and 200 parts per million total uranium in the $<2$-mm size fraction at the two locations sampled by Zachara et al. (2005). Because Hanford-process uranium associates much more strongly with the finer grained particles, especially silt and clay, it is difficult to compare results from one sampling campaign to the next and to account for the very coarse nature of the 300 Area sediments. For example, the pond sediments remaining after excavation and much of the strata sampled during the LFI continuous coring to the bottom of the upper unconfined aquifer showed $>70 \%$ of the mass of sediment to be gravel and especially cobbles larger than $12 \mathrm{~mm}$. It is difficult and very rare that a bulk sample of such coarse material is processed en masse to determine concentrations of contaminants. Given the commonly observed dependence of uranium concentration on particle size, determined by making total uranium measurements from samples sieved to different sizes, attempting to determine a total inventory of uranium in a particular "pool” such as the vadose zone sediments, or the intermittently wetted sediments in the "smear" zone, or the continually wetted sediments in the aquifer is problematic.

The total uranium concentrations in the size fractions of sediments studied from the four LFI boreholes show ranges of concentrations as follows. For the two boreholes with Hanford process uranium present, $<1$ to 15 parts per million uranium was found in vadose zone sediments and $<1$ to 11 parts per million uranium was found in the aquifer sediments. For the two boreholes that appear to be uncontaminated, the total uranium in sediment samples ranges from $<1$ to 1.7 parts per million in the vadose zone sediments and $<1$ to 2.7 parts per million in the aquifer sediments. It is clear that the four LFI boreholes did not intercept hot spots; however, as shown in Figures 6.8 and 6.9, two of the boreholes, 399-1-23 and 399-3-18, have vadose zone and smear zone sediments that can contribute to the persistent groundwater uranium plume.

The discrete interval groundwater sampling, laboratory geochemical extracts of the sediments, and hydraulic conductivity measurements conducted during the LFI confirmed that the groundwater uranium plume is constrained above the Hanford-Ringold contact boundary. These observations are consistent with groundwater uranium concentrations obtained from the current 300 Area monitoring well network.

The new information provided by the LFI has been used extensively in this refinement of the conceptual model for uranium contamination in the 300 Area subsurface environment. When combined with the results from treatability tests and on-going laboratory work on LFI sediments using funds from other research projects an updated conceptual model will be developed. The updated model and the Phase III Feasibility Study will lead to a future Proposed Plan for remedial action in the 300-FF-5 Operable Unit. 


\subsubsection{Dissolved vs. Particulate Uranium}

Concern has been raised that the Hanford process uranium disposed in the various ponds and trenches may have contained fine-grained uranium solids that remain suspended in solution and migrate as "colloids" with little interaction with the sediments. Hanford staff with years of experience on monitoring the groundwater and others who have performed numerous laboratory experiments focusing on uranium mobility were queried, and the informal consensus is that there is no evidence that uranium concentrations in 300 Area groundwater shows evidence of particulate uranium being present. The uranium values for filtered and unfiltered groundwater samples in general are similar. For some constituents associated with metal casing corrosion, such as iron, manganese, cobalt, and chromium, there are infrequently differences in measured concentrations that are dependent upon filtering or not filtering the water sample. These infrequent occurrences have generally been associated with observations of "rust" particles on the filters after filtering the groundwater. There is anecdotal evidence that mineralogical characterization of the "rust" solids has identified common ferric oxides as being present. Thus, casing corrosion products sloughing off the casing during water pumping may be the cause of differences in measured concentrations of select constituents pre- and post-filtration. In addition, there have not been significant differences in the uranium concentrations for unfiltered and filtered fluid samples measured in laboratory experiments wherein U-contaminated sediments are contacted with various leachants. Geochemical speciation calculations suggest that U(VI) species are relatively soluble and stable in the pH-Eh regime common for most Hanford subsurface environments. Thus, we opine that particulate or colloid transport concerns for uranium in the 300 Area subsurface are not supported.

\subsection{Controls on Uranium Mobility: Processes Contributing to Mass Transfer from Solid to Solution and Vice Versa}

In this section, we will discuss two key processes that can control the transfer of uranium from solid to solution or conversely from solution to the solid phase. The two processes, which are both considered to be reversible, are generally categorized as precipitation-dissolution and adsorption-desorption.

Precipitation-dissolution of solids is often quantified by a construct called the solubility product, which in its simplest form is expressed as requiring that the product of the concentration of the dissolved species that form a given solid is a constant at a fixed temperature and pressure. Stated differently, the solubility of a solid substance in a particular water at a fixed temperature and pressure is defined as the maximum amount of the solid that will dissolve in a fixed amount of the solvent to produce a stable system. As mentioned, the parameter that describes the maximum amount of each constituent that makes up the solid that will be in solution at equilibrium is called the solubility product, $\mathrm{K}_{\mathrm{sp}}$. For the uranium mineral tentatively identified (see Zachara et al. 2005, 2007a) in residual 300 pond sediments, metatorbernite, $\left[\mathrm{Cu}\left(\mathrm{UO}_{2} \mathrm{PO}_{4}\right)_{2} \cdot 8 \mathrm{H}_{2} \mathrm{O}\right]$, the $\mathrm{K}_{\mathrm{sp}}$ is

$$
K_{s p}=\frac{\{\mathrm{Cu}\}\left\{\mathrm{UO}_{2}\right\}^{2}\left\{\mathrm{PO}_{4}\right\}^{2}}{\text { activity of solid }}=\left\langle\{\mathrm{Cu}\}\left\{\mathrm{UO}_{2}\right\}^{2}\left\{\mathrm{PO}_{4}\right\}^{2}\right\rangle
$$

where $\{\quad\}=$ thermodynamic activity of specified aqueous species and activity $=\gamma \cdot$ concentration; further, the activity of water and any solid is set at 1 by convention.

Note that the aqueous species in the solubility equation represent only the free copper $\left[\mathrm{Cu}^{2+}\right.$, free uranyl $\left[\mathrm{UO}_{2}{ }^{2+}\right]$, and free phosphate $\left[\mathrm{PO}_{4}{ }^{3-}\right]$ and not the total of all aqueous species containing copper, uranyl, and phosphate. As mentioned in Section 6.1.2 and shown in Figures 6.1 and 6.2, U(VI) aqueous 
speciation distributions are dominated by complexes such that the concentration of free uranyl ion is quite low. At the $\mathrm{pH}$ of the pore waters in 300 Area sediments, the concentration of free copper is also low compared to the total concentration of all copper aqueous species. The correct calculation of the solubility of a solid such as metatorbenite requires a great deal of information.

If all the necessary thermodynamic data and water-composition data are available, the equilibrium concentration of the contaminant that is present in the system with excess solids can be calculated using a geochemical reaction computer code such as MINTEQA2 or GWB (both cited earlier in Section 6.1.2) with the known value of $\mathrm{K}_{\mathrm{sp}}$. Although the thermodynamic equilibrium approach is generally the most reliable method available for determining solubility, a number of factors can lead to results that are not consistent with measured solution concentrations. These can include the existence of non-equilibrium conditions, incorrect thermodynamic data, or lack of all necessary thermodynamic data for aqueous species that can form, and presence of mineral crystallinity deficiencies, such as the presence of trace constituent substitutions in the mineral's crystal lattices.

The second process, which is more likely controlling observed solution concentrations of uranium in the deeper portion of the vadose zone, the 300 Area smear zone, and aquifer, is adsorption. Adsorption processes are often quantified by using the $\mathrm{K}_{\mathrm{d}}$ construct, which in its simplest form is the ratio of the mass of uranium associated with surface sorption sites per mass of sediment divided by the mass of uranium dissolved in the contacting solution per volume of solution present. Much more thorough discussions of sorption constructs and how sorption reactions are parameterized for use in numerical transport codes can be found in Serne and Muller (1987), Morel et al. (1981), Sposito (1984), Krupka et al. (1999), and Davis et al. (2004a, 2005). The following subsections describe studies performed on 300 Area uraniumcontaminated sediments that allow us to evaluate the importance of these two processes, solubility and adsorption, in transferring uranium from sediments to pore waters or vice versa.

\subsubsection{Solid-Phase Characterization of 300 Area Process Pond Sediments}

Some of the most contaminated sediment samples obtained from the process ponds have been characterized in detail using state-of-the-art instrumentation and techniques to directly probe the solids for uranium speciation. Detailed discussions on the findings are found in Zachara et al. (2005, 2007a) and several journal articles referenced therein. Using highly sensitive micro spot X-ray microprobe and X-ray absorption spectroscopy methodologies in combination with scanning electron microscopes, scientists found that a uranium-rich mineral was present in a few of the 300 Area process ponds sediment samples. The best match to the various spectra and overall chemical composition of the enriched uranium particles was metatorbernite $\left[\mathrm{Cu}\left(\mathrm{UO}_{2} \mathrm{PO}_{4}\right)_{2} 8 \mathrm{H}_{2} \mathrm{O}\right]$ (Catalano et al. 2006; Arai et al. 2007), but the presence of uranophane $\left\{\mathrm{Ca}\left[\mathrm{UO}_{2}\right]_{2}\left[\mathrm{SiO}_{3}(\mathrm{OH})\right]_{2} \cdot 5 \mathrm{H}_{2} \mathrm{O}\right\}$ and rutherfordine $\left(\mathrm{UO}_{2} \mathrm{CO}_{3}\right)$ were also possibilities.

Both pre- and post-excavation vadose zone sediments from the North Process Pond also contained numerous particles with more widely distributed uranium. Two shallow vadose sediments collected after pond excavation, at 0.5 and $4 \mathrm{ft}$ below the post clean-up grade, were predominantly mineral and lithic clasts that were coated with aluminosilicate mineralization, similar to those found in the pre-pond cleanup samples. The coatings represent solids formed from interactions between the native sediments with the disposed liquid wastes. An overlay of the more sensitive X-ray microprobe results on EMP maps showed both uranium and copper within the aluminosilicate coatings, similar to the coatings found in pre-pond cleanup North Pond sediment samples. The uranium abundance map was consistent with the presence of much lower concentrations of uranium in post-cleanup aluminosilicate coatings than in the pre-cleanup 
sediments; however, low concentrations of uranium sequestered in coatings still remain in the post-pond cleanup sediments. Studies of post-pond cleanup sediments from $16 \mathrm{ft}$ below grade were inconclusive as to whether discrete highly enriched uranium particles or more distributed uranium in residual aluminosilicate coatings were present because of the low uranium concentrations present in these sediments from deeper below original ground surface.

To recapitulate, detailed analysis of pond residual vadose sediments indicated that uranium occurred in two or three modes: as $\mu$ m-scale precipitates of metatorbernite $\left[\mathrm{Cu}\left(\mathrm{UO}_{2}\right)_{2}\left(\mathrm{PO}_{4}\right)_{2} \cdot 8\left(\mathrm{H}_{2} \mathrm{O}\right)\right]$; as more diffuse uranium incorporated in aluminosilicate rinds, perhaps co-precipitated within $\mathrm{CaCO}_{3}$ cement; and perhaps as a significant sorbed component on aluminosilicate minerals. These three pools of solid-phase reactant could be supplying the 300 Area groundwater uranium plume through dissolution and diffusion through the coatings on native mineral surfaces and from desorption from surface adsorption sites.

The uranyl contamination entrained in the discrete and coated solid phases could represent a persistent source of uranium to the groundwater entering the Columbia River. The distribution of the uranium-enriched sediments has not been adequately determined in the overall 300 Area vadose zone because of the limited spatial coverage of the sampling performed to date. No sediments from beneath either of the two process trench facilities (300 Area Process Trenches and 307 Process Trenches) have been characterized. Further, of the limited number of process pond samples measured for total uranium content, only a few (emphasizing those with the highest uranium content) have been characterized in detail with the micro-solid phase tools required to determine the uranium's association with the particles (whether discrete uranium minerals, co-precipitated in coatings, or surface adsorbed).

However, a plausible conceptual model for some of the uranium in the vadose zone and smear zone sediments below the footprint of the process ponds can be constructed. The chemical form of secondary mineralization that controls uranium mobility was strongly determined by the original composition of the liquid-waste disposed of and its evolution during continued interaction with the native Hanford sediment and vadose zone pore water. A knowledge of particular waste compositions disposed could be used in combination with geochemical modeling codes to predict possible solid phases that may have precipitated during waste disposal and subsequent interaction with the native sediments. Such modeling has been used to interpret laboratory studies for uranium (see Zachara et al. [2007a, Section 10] for details) during construction of a uranium diffusion-precipitation model.

The evolution of uranyl-bearing wastes disposed to the ponds and process trenches could be expected to follow one of the paths described for natural solutions in Figure 6.10. Predicting specific solids within a group (silicate, phosphate, etc.) would be challenging because of uncertainty regarding the thermodynamic constants for some uranyl minerals (Finch and Murakami 1999) and the imprecision with which such changing parameters as $\mathrm{pH}$ can be estimated during waste interaction with the subsurface sediments. However, the composition of the solids and pore water can be measured, and the compositions of the waste streams for the 300 Area disposals may be available or estimated from archived records. Enough information is available to attempt some preliminary, mass-transfer, limited (kinetic) geochemical modeling of contaminant uranium in the 300 Area vadose zone and aquifer. Such geochemical mass-transfer models could then be coupled with multi-dimensional hydrologic flow codes such that uranium transport from the existing vadose zone through the upper unconfined aquifer to the Columbia River could be estimated. This is a future goal of the Hanford/OBER-ERSD Integrated FieldScale Challenge project (PNNL 2007), and some preliminary modeling activities by Yabusaki and colleagues are discussed below. 


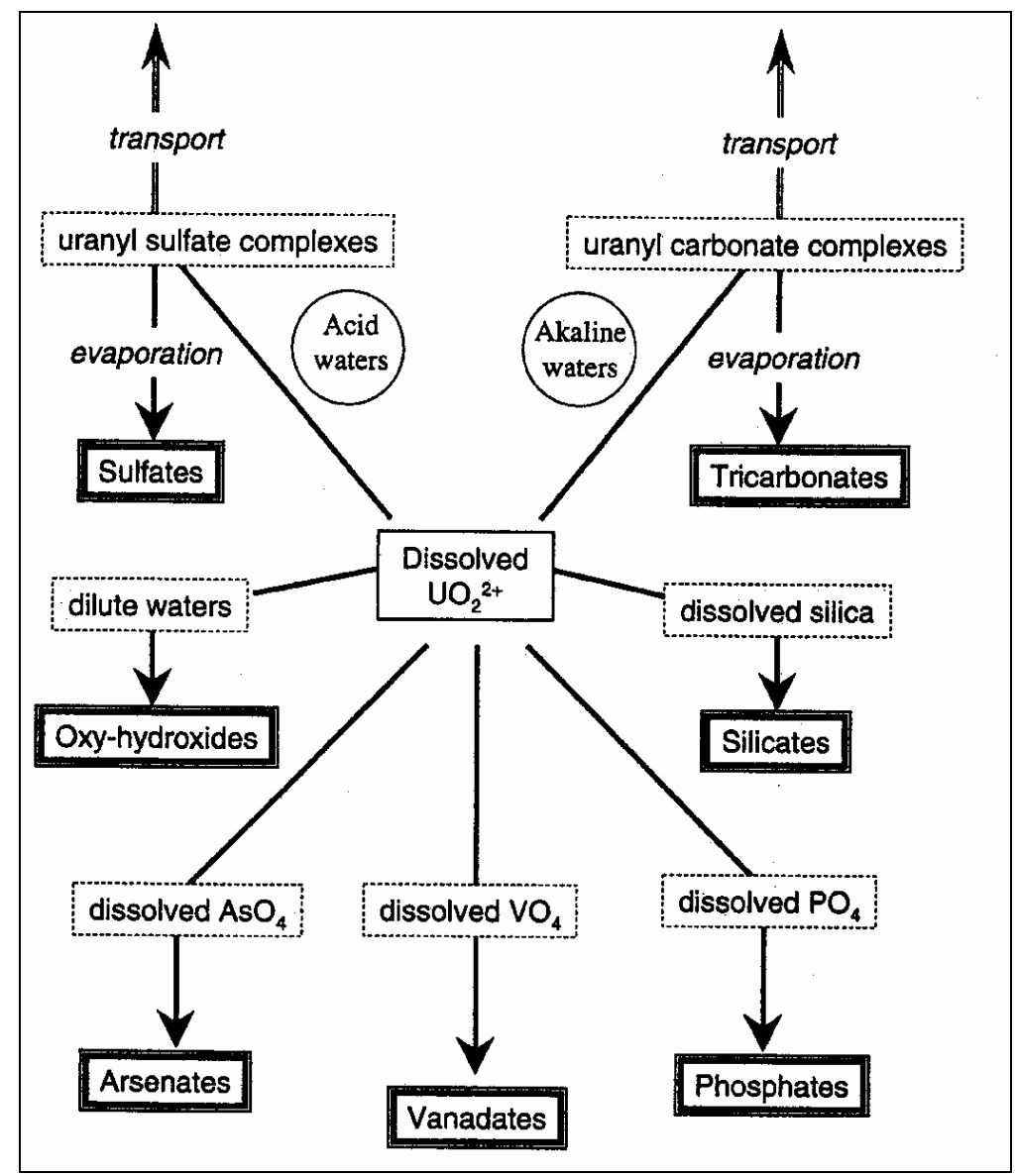

Figure 6.10. Schematic Representation of the Paragenesis of Important Uranyl Mineral Groups (Finch and Murakami 1999)

Other observations from the detailed microscopic characterization of the process pond sediments follow. The concentrations of copper $(\mathrm{Cu})$ and uranium correlated with one another in all pond sediments studied. The valence state of uranium was $\mathrm{U}(\mathrm{VI})$ and that of copper was $\mathrm{Cu}(\mathrm{II})$. These two elements were closely associated at spatial scales of 0.010 to $0.100 \mathrm{mms}$ but not at the molecular scale, i.e., they were generally not co-precipitated with one another. The pond sediments contained millimeter-sized domains of secondary, fine-grained aluminosilicate precipitates likely resulting from known high pH Naaluminate discharges to the ponds. Minute fine-grained $\mathrm{U}(\mathrm{VI})$ precipitates were observed within the aluminosilicate precipitates that also appeared to be cemented or indurated by $\mathrm{CaCO}_{3}$ precipitates. The zoning in $\mathrm{Cu}$ concentration within these precipitates indicated multiple precipitation events. Deeper vadose zone pond sediments contained thin (ca. 10 to $50 \mu \mathrm{m}$ ) precipitated rinds of secondary materials on mineral grains and lithic fragments resulting from waste discharge and fluid percolation below the ponds. The rinds appeared to be composed of $\mathrm{CaCO}_{3}$-indurated aluminosilicates and were readily imaged by their $\mathrm{Cu}$ content. Both $\mathrm{Cu}(\mathrm{II})$ and $\mathrm{U}(\mathrm{VI})$ were localized in these rinds as minute inclusions.

A key inference from these microscopic characterization efforts is that the widespread, multiphase distribution of $\mathrm{U}(\mathrm{VI})$ within fine-grained, $\mathrm{CaCO}_{3}$-cemented aluminosilicate precipitates and particle coatings resulting from multiple waste-reaction events will greatly retard the rate and extent of sorbed $\mathrm{U}(\mathrm{VI})$ release to pore or groundwater. 
Serne et al. (2002a) studied the leaching of uranium from North Process Pond residual sediments packed in columns. Results from column leach tests showed that uranium leaching did not follow a equilibrium solubility paradigm for common U(VI) minerals. The two North Process Pond sediments with 40 and $540 \mathrm{mg} / \mathrm{kg}$ total uranium showed a large near-instantaneous release of a few percent of the total uranium in the sediments in the first few pore volumes followed by a slower continual uranium release that continued for many more pore volumes (months). Steady-state uranium leachate concentrations were never attained. Uranium leaching kinetics were slow, and the measured leach curves most likely represent a slow, kinetically controlled diffusion- desorption or -dissolution paradigm. These descriptive leach results are consistent with the slow dissolution of the alumino-silicate rinds and subsequent slow release of uranium co-precipitated in or adsorbed to the rinds.

In summary, a few of the more contaminated sediments, which were generally from shallower depths in the excavated ponds, showed indications of some discrete crystalline uranium phases, most likely a copper (II)-uranyl [U(VI)]-phosphate, as well as much uranium associated with alumino-silicate coatings on native grains. In all cases, the uranium is present as oxidized uranium \{uranyl [U(VI)]\}. The significance of finding a discrete uranium solid phase and the uranium trapped in alumino-silicate coatings is that the uranium release to the water phase was found to be slower than uranium-desorption reactions from sediment surface adsorption sites. That is, the concentrations of uranium leaching from these phases are generally lower and the time to reach equilibrium or steady-state concentrations takes significantly longer (many months) in controlled laboratory testing than for uranium desorbing from surface adsorption sites under similar water-chemistry conditions. The vadose zone sediments beneath both the South Process Pond and the North Process Pond will remain as potential source terms to maintain groundwater U(VI) concentrations at or above the MCL. Their ultimate impact will be controlled by moisture flux rates through the vadose zone and the moisture's bicarbonate concentration. Increasing groundwater levels at high river stage will solubilize precipitated or sorbed U(VI) from the smear zone, and the small but ever-present natural recharge will move uranium from the slightly but contiguously contaminated sediments in the lower vadose zone sediments under the footprint of the inactive disposal facilities (at least the ponds for which depth profiling has shown slight but continuous contamination) to the smear zone.

However, as determined by Bond et al. (2007), the most dominant process that controls the movement of uranium between the aqueous phase and sediments in the deep vadose zone, smear zone, and upper unconfined aquifer in the 300 Area is adsorption-desorption processes. Thus, for the first mass-transfer and first mass-transport numerical modeling efforts (see Waichler and Yabusaki 2005; Sections 2.6 through 2.8 in Zachara et al. 2005; Yabusaki et al. 2008 for details), discrete uranium solubility reactions were not incorporated. As modeling efforts continue and more data on the masses and types of discrete uranium phases present in contaminated sediments become available, the conceptual model will consider the need to incorporate equilibrium or kinetically driven solubility reactions. The next subsection discusses three sorption-desorption-based numerical models that are incorporated into the current numerical mass transport code used to predict the movement of uranium between the various compartments of our box model.

\subsubsection{Adsorption-Based Models Used in the Current 300 Area Mass Transport Code}

Many laboratory adsorption-desorption tests have been performed on residual sediments from the process ponds after the bulk of the contaminated sediments had been excavated. Almost all of the tests were performed on fine-grained fractions of the sediment that represent only $~ 10$ to at most 30\% of the 
bulk material mass. Summaries of various adsorption-desorption testing documented to date are found in Serne et al. (2002a), Zachara et al. (2005), and Zachara et al. (2007a). The latter two reports also cite many journal articles that contain more details on most of the summarized studies. Laboratory adsorption-desorption studies continue on the residual pond sediments and sediments from the four recent LFI boreholes and sediments taken from the new borehole C5708 (completed as 399-2-5) through the South Process Pond. Therefore, sorption-desorption data used to refine the 300 Area uranium conceptual model and to parameterize numerical models are actively being refined and are increasing significantly.

A brief synopsis of findings from batch adsorption/desorption studies, $\mathrm{K}_{\mathrm{d}}$ measurement, and surface complexation modeling and their implications follow. Bicarbonate extraction and isotopic exchange was performed on 14 300-Area Process Pond vadose zone sediments and three samples of fines filtered out of turbid groundwater collected from the back hoe excavations within the footprint of the ponds to evaluate the fraction of the sorbed $\mathrm{U}(\mathrm{VI})$ pool that is exchangeable or reactive with pore water. The labile fraction in vadose zone sediments ranged from 21 to $76 \%$ with an average of $44 \%$, while the groundwater fines' labile fraction ranged from 24.1 to $47.8 \%$ with an average of $38.2 \%$. The non-labile fraction is effectively immobilized in the mineral fraction of the sediments. The labile fraction should be the only fraction explicitly considered in calculating $\mathrm{K}_{\mathrm{d}}$ values.

A series of batch sorption studies were performed with two smear zone sediments from the process ponds in contact with a series of artificial groundwater solutions. The magnitude of the adsorption/desorption $\mathrm{K}_{\mathrm{d}}$ values varied directly with solution bicarbonate concentration. Increasing bicarbonate concentration in the range of 0.05 to $10 \mathrm{mmol} / \mathrm{L}$ (the approximate range in bicarbonate present in 300 Area pore waters) caused major reductions in $\mathrm{K}_{\mathrm{d}}$. Across the range of bicarbonate concentrations studied, $\mathrm{K}_{\mathrm{d}}$ values for the $<2$-mm size fraction Hanford sediments ranged from 0.5 to $28 \mathrm{~mL} / \mathrm{g}$.

This significant variation in the $\mathrm{K}_{\mathrm{d}}$, caused by variations in solution composition, especially the bicarbonate concentration has been captured in a type of sorption model called surface complexation adsorption model (SCM). Besides capturing variations in $\mathrm{K}_{d}$ caused by solution composition, these SCM adsorption models account for differences in sediment particle size (surface area) and mineralogy. Surface complexation adsorption models can explicitly handle the variations in $\mathrm{K}_{\mathrm{d}}$ caused by particle size and mineralogy variations by adjusting the total number of adsorption sites and the stability constants for each specific adsorption reaction (each solution species that adsorbs to each type of surface site has its own stability constant). Therefore, for one specific type of SCM, the general composite SCM, has been incorporated into the current mass-transport code. Details on types of SCM models and the reason for choosing the general composite SCM for describing the adsorption of uranium in the 300 Area subsurface are found in Zachara et al. (2005, 2007a).

A two-reaction surface complexation model was formulated that accounts for the effects of solution bicarbonate concentration, sediment surface area, and aqueous $\mathrm{U}(\mathrm{VI})$ complexation speciation distribution on overall U(VI) sorption to 300 Area sediments. The model can predict the overall uranium $\mathrm{K}_{\mathrm{d}}$, at different solution $\mathrm{pH}$, total dissolved uranium, and alkalinity values, as well as other water composition parameters that influence sorption (e.g., calcium and sodium concentration and total ionic strength). Different sorption parameter data sets were required for the North Process Pond and South Process Pond sediments because of their different mineralogic characters (see Bond et al. 2007 for more details). 
Other flow-through column adsorption-desorption tests were performed on residual sediments from the process ponds to evaluate the time required to reach equilibrium in the adsorption-desorption reactions. The experiments were intended to evaluate the concentrations of U(VI) that might develop in pore waters as a result of 1 ) surface water recharge and infiltration and 2) groundwater height changes as a result of river-stage fluctuations. Additionally, the experiments evaluated the fraction of the total sorbed $\mathrm{U}(\mathrm{VI})$ that was labile to migrating fluids. U(VI) release from the pond sediments was found to be very slow and to require extensive water volumes for even partial removal of the sorbed U(VI) pool. $\mathrm{U}(\mathrm{VI})$ desorption was found to be a kinetic and not an equilibrium process. Long-term leaching experiments removed only 1 to $8 \%$ of the total uranium present in the sediments.

The extent of U(VI) leaching increased with increasing water saturation. Despite the slow leaching, all of pond sediments studied leached U(VI) at concentrations in excess of the MCL for extended pore volumes when realistic fluid residence times (water flow rates) were applied under water-saturated conditions. However, maximum effluent $\mathrm{U}(\mathrm{VI})$ concentrations did not exceed $0.4 \mu \mathrm{mol} / \mathrm{L}$ (95.2 parts per billion) in the studies of Zachara et al. (2005). When leaching was performed under unsaturated water conditions, the desorption extent decreased with decreasing water content. Equilibrium-based sorptiondesorption models were not as effective at predicting the observed unsaturated water content laboratory test results. Thus, a distributed rate model (DRM) — a kinetic driven model—was developed to predict the leaching behavior of U(VI) under both saturated and unsaturated conditions. Saturated-column DRM parameters, a $K_{d}$ and a rate parameter distribution (see Zachara et al. [2007a] Section 10 for explanation and details) were developed for the $<2$-mm fraction of North and South Process Pond sediments. For a fixed bicarbonate concentration of $1.05 \mathrm{mmol} / \mathrm{L}$, the long-term desorption $\mathrm{K}_{\mathrm{d}}$ values for the two pond sediments were found to be 50 and $14 \mathrm{~mL} / \mathrm{g}$, respectively, for saturated conditions. The desorption equilibrium $\mathrm{K}_{\mathrm{d}}$ values are larger than adsorption $\mathrm{K}_{\mathrm{d}}$ values for uncontaminated sediments contacting similar simulated pore waters spiked with uranium. DRM parameters developed under saturated conditions did not provide good descriptions of unsaturated uranium leaching regardless of hypothesis or assumption. The unsaturated leaching behavior of the labile fraction (desorbable fraction) of uranium is more complex than expected, and additional experiments are underway to better understand its behavior. Additional experiments are also being performed on smear zone sediments from two of the new LFI boreholes that contained measurable amounts of labile uranium. We expect to refine the uranium adsorption model(s) for 300 Area sediments after completion of these ongoing laboratory tests so that future mass-transfer and mass-transport numerical codes more accurately predict future uranium fate in the 300 Area subsurface.

\subsubsection{Variably Saturated Flow-and-Transport Predictive Modeling of $\mathbf{3 0 0}$ Area Vadose Zone and Groundwater Uranium Plumes}

Waichler and Yabusaki (2005) documented findings from variably saturated flow-and-transport predictive modeling exercises using three conceptual adsorption-desorption models derived from the laboratory experiments described in Zachara et al. (2005). Similar flow-and-transport predictions have been recently performed on a refined geohydrologic conceptual model that was created from the additional findings and insights gained from the LFI. Williams et al. (2007) documented the insights refined by the LFI for the geohydrologic conceptual model and new data on uranium distribution, including the labile fraction, in vadose zone, smear zone, and aquifer sediments. The LFI findings have been used heavily in this conceptual model report and recent predictive modeling activities. Yabusaki, Fang, and Waichler (PNNL) have also recently performed new transport calculations based on the LFI refinements to the 2005 flow-and-transport predictive model described in detail in Waichler and Yabusaki 
(2005). We mesh together herein a summary of their newest findings with the salient points found in Waichler and Yabusaki (2005) and a companion synopsis in Zachara et al. (2005). The updated transport model results are being prepared for journal publication (Yabusaki et al. 2008).

All the numerical modeling exercises used a two-dimensional flow-and-transport model with sediment and water properties for the 300 Area sediments, characteristics current at the time of each modeling exercise, and hourly water levels observed in the river and one inland aquifer monitoring well from March 1, 1992 to February 28, 1993. The two-dimensional transport model relied on using field data for water-table elevations and geologic strata thicknesses using one east-west transect perpendicular to the Columbia River near the middle of the current uranium plume. While the river stage in the 300 Area is always measured at an hourly interval, there are no commensurately comprehensive hourly datasets available for 300 Area monitoring wells, excepting the 1992-1993 dataset for well 399-6-1. Hourly water-table elevations in this well and Columbia River elevations were used for this 1-year period to calibrate the water-flow model. The hourly river-stage data were necessary to best match the water elevations in monitoring wells in the 300 Area that are measured a few times each year. Using longer time periods of daily or monthly averages for water levels yielded poor comparisons with measured data for the 1992-1993 time period. That is, accurate modeling of water flow (and by inference uranium transport) requires inclusion of the hourly changes in river stage in the predictive modeling activities.

The computer simulations suggest that the range of diurnal river-stage fluctuations averages $0.5 \mathrm{~m}$ and causes groundwater flow reversals twice a day that allow substantial exchange of river water and groundwater in the aquifer. The cumulative volume of flow back and forth across the aquifer/river interface over a year's time is estimated to be $\geq 18$ times larger than the annual net water flux to the river. The diurnal fluctuations are superimposed on seasonal variations linked to snowmelt fluctuations wherein spring runoff causes up to 3-m rises in the water table, larger than the $0.5 \mathrm{~m}$ average. Conversely, during fall, the low river stage can drop the water table a similar amount below the average. In other words, the "sloshing" back and forth of water in the aquifer is considerably larger in volume than the net water flux out of the aquifer into the river. Also, the elevation of the water table goes up and down with both a daily and a seasonal periodicity adding to the wetting and de-saturation cycles in the smear zone sediments. The bulk of the water movement occurs in the topmost portion of the upper unconfined aquifer, the transmissive Hanford gravels. The flow reversals occur twice a day and impact the regional flow field up to $400 \mathrm{~m}$ inland. Water-elevation changes (without flow reversal) can be observed up to $1 \mathrm{~km}$ inland from the river.

The intrusion of river water and the mixing with groundwater are controlled by the diurnal flow reversals, but the seasonal river-stage changes have a significant impact of the size and location of the mixing zone. Regardless, the groundwater-river-water mixing zone essentially remains in the Hanford gravels in the uppermost portion of the aquifer. The largest mixing zone coincides with the high river stage (high snow melt in May/June), and the smallest mixing zone is present in the low-flow (September/October) season. River water mixed with groundwater intrudes a maximum of $150 \mathrm{~m}$ inland, but as just mentioned, water-flow reversals reach $400 \mathrm{~m}$ inland. These estimates require using the hourly water-level measurements for monitoring wells and the Columbia River as boundary conditions to the hydrologic model. Simulations based on longer time-period averages (daily or monthly averaging of the hourly water levels at the river and inland in monitoring wells) significantly reduced the predicted flow reversals and river water intrusion into the aquifer, resulting in significant under-estimation of the volume of the mixing zone. Field-permeability data and hydrologic pump tests performed during the LFI corroborate that the water flow and uranium movement are restricted to the upper portion of the aquifer in 
the coarse-grained Hanford formation sediments. Predicted groundwater pore velocities in excess of 10 to $20 \mathrm{~m} / \mathrm{d}$ create opportunities for kinetics to be important in determining uranium transport.

Because the river water is distinctly more dilute than typical aquifer water, and uranium mobility is sensitive to changing solution chemistry, river water intrusion into the aquifer is thus a critical issue for uranium transport. Uranium fate was modeled using three different adsorption-desorption conceptual models and data. The first adsorption model was the constant $\mathrm{K}_{\mathrm{d}}$ construct that relied on a graveladjusted uranium $\mathrm{K}_{\mathrm{d}}$ of $1.12 \mathrm{~mL} / \mathrm{g}$ for the bulk sediments in the vadose zone and aquifer. The second model was a generalized surface complexation model that assumed that two uranium aqueous species $\left(\mathrm{UO}_{2} \mathrm{OH}^{+}\right.$and $\left.\mathrm{UO}_{2} \mathrm{CO}_{3}{ }^{0}\right)$ would adsorb to the generalized sediment surface sites. The density of the generalized sediment surface sites was set at 3.84 umoles $/ \mathrm{m}^{2}$ surface area, and the sediment-specific surface area and sorption stability constants were taken from Bond et al. (2007). The third adsorption model was a kinetically controlled numerical model, called DRM, that accounted for the slow attainment of sorption-equilibrium. The kinetic sorption model relies on first-order kinetics and a 2-parameter gamma distribution of an assemblage of sorption sites. All the sorption sites are assumed to have the same equilibrium $\mathrm{K}_{\mathrm{d}}$ set at 1.12 after gravel correction. Note that the currently available kinetic sorption model does not account for variable-water-chemistry effects. Details on the latter two adsorptiondesorption conceptual models are found in Zachara et al. (2005, 2007a) and journal publications presented therein. A refined DRM model that explicitly accounts for changing sorption with varying water chemistry is under development and will be available for future numerical predictive modeling activities.

Uranium mass-transport predictions were performed for the smear zone and aquifer zone based on the two-dimensional geo-hydrologic flow model briefly described above. Using each of the conceptual adsorption-desorption models just described, the movement of uranium between the sediment and pore water in the smear zone and upper unconfined aquifer was predicted for a $50-\mathrm{m}$ by $3.5-\mathrm{m}$ plane of sorbed uranium $(0.3 \mathrm{mg} / \mathrm{kg}$ ) placed along the two-dimensional transect and straddling the water table (half [1.75 $\mathrm{m}$ ] in the smear zone above the average water table and half below the water table) and at two distances from the river. The two distances were $280 \mathrm{~m}$ inland from the river and $30 \mathrm{~m}$ inland from the river. For these preliminary uranium transport calculations, we reiterate that the only uranium in the subsurface was that emplaced in the hypothetical 50-m by 3.5-m "emplacement" plane within the twodimensional model. Thus, the following description of uranium movement is illustrative of this uranium interacting with sediments outside the plane of emplacement that have all their sorption sites available for sorbing uranium that leaves the emplacement zone. Therefore, the following description and attached figures of uranium concentrations in the groundwater and adsorbed to the sediments do not reflect the actual field conditions, which has contaminant uranium distributed over a much greater volume, as yet not very well described. The described modeling results merely illustrate the degree of complexity required to accurately model the fate of uranium in the 300 Area subsurface.

The transport calculations predict that uranium sorbed to the sediments placed $280 \mathrm{~m}$ inland in the upper part of the smear zone, which is intermittently wetted, does not redistribute significantly, but the uranium sorbed to the continually wetted sediment in the aquifer does redistribute (see Figure 6.11). Within the plane of emplaced uranium contamination, the pore water uranium concentration reaches 300 parts per billion and stays at that concentration in the plane for over 10 years (see Figure 6.12). For the kinetic sorption model, the lateral extent of uranium movement away from the emplacement plane after 2 years is twice the distance as the movement for either the constant $\mathrm{K}_{\mathrm{d}}$ or surface complexation equilibrium sorption models. This prediction illustrates the importance of kinetics in determining the movement and mass transfer of uranium from solid to solution phases. The leading edge (defined by the 


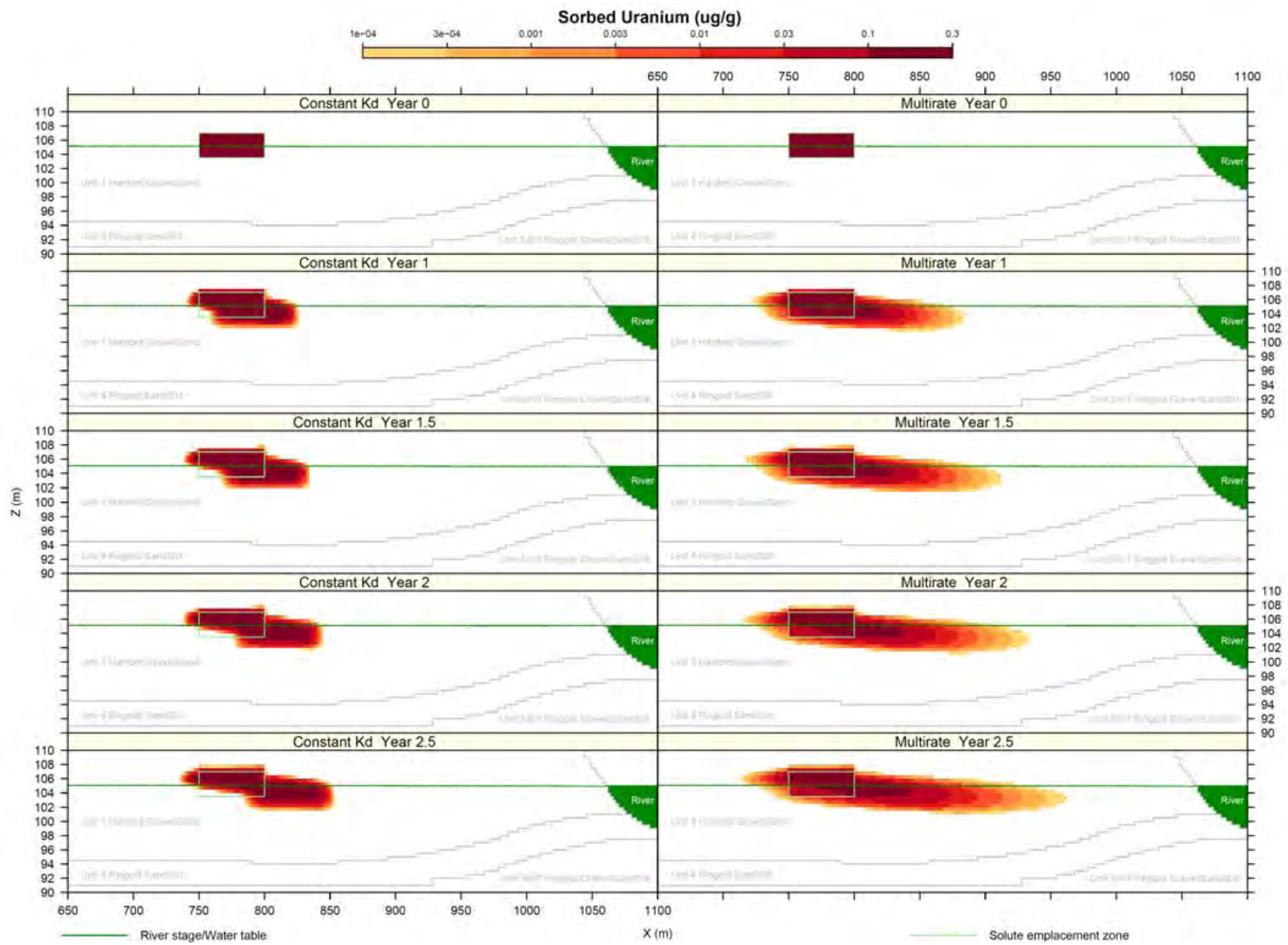

Figure 6.11. Simulated Sorbed Uranium Migration at 0, 1, 1.5, and 2.5 Years from the Emplacement Zone $280 \mathrm{~m}$ from the River for the Constant $\mathrm{K}_{\mathrm{d}}$ Model ((left panels) and Distributed Rate Mass-Transfer Adsorption Model (right panels) 


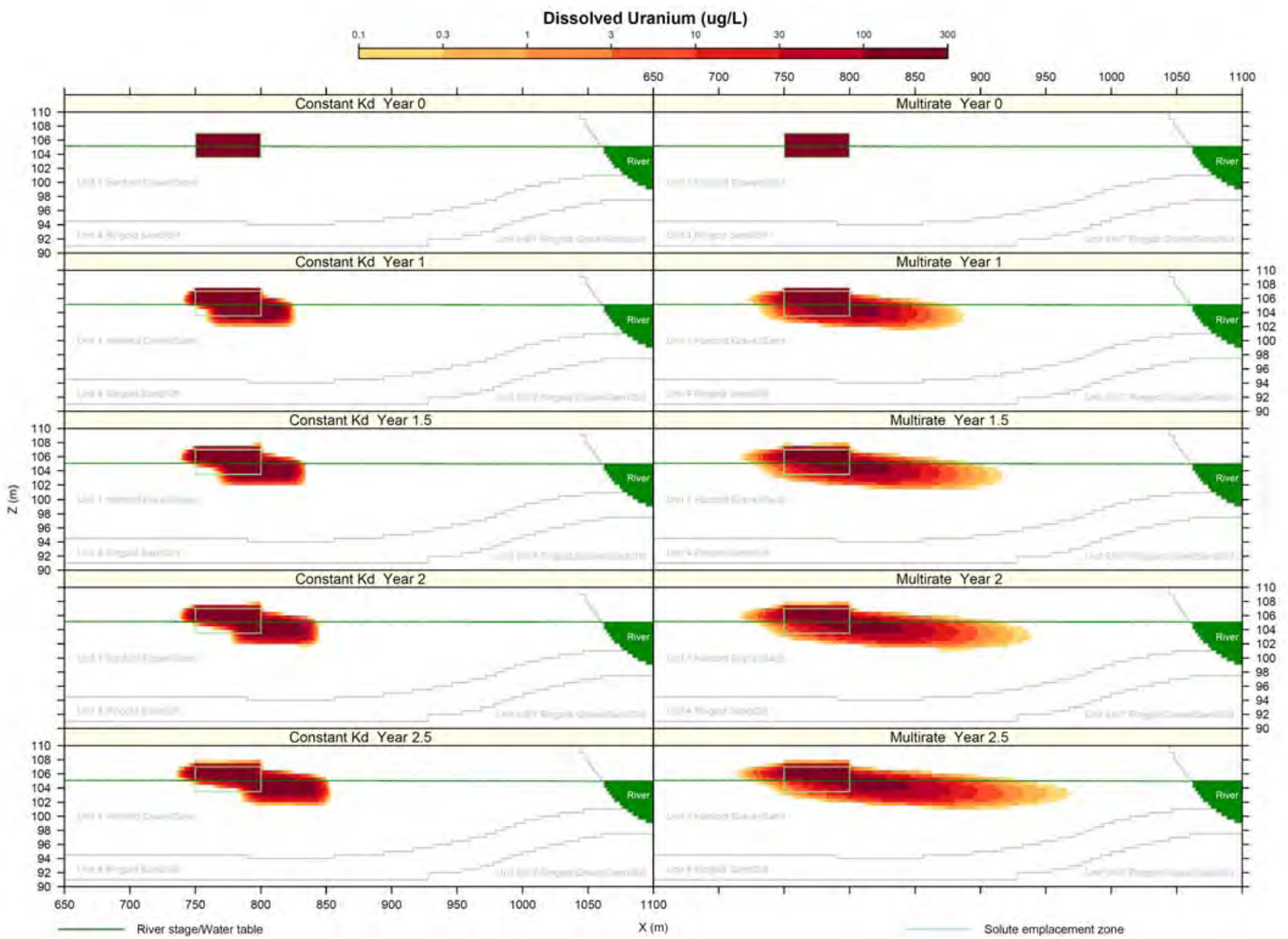

Figure 6.12. Simulated Aqueous Uranium Migration at 0, 1, 1.5, and 2.5 Years from the Emplacement Zone $280 \mathrm{~m}$ from the River for the Constant $\mathrm{K}_{\mathrm{d}}$ Model (left panels) and Distributed Rate Mass-Transfer Adsorption Model (right panels) 
3 parts per billion isopleths) of the predicted uranium plume emanating from the emplacement zone reaches the river after 5 years for the kinetic model, but for both the equilibrium sorption models (constant $\mathrm{K}_{\mathrm{d}}$ and SCM), uranium does not reach the river after 10 years (the length of time modeled). Most of the sorbed uranium in the upper smear zone (intermittently wetted) is still at the plane of emplacement. But in the lower smear zone (always saturated), the center of mass of the sorbed uranium has moved $100 \mathrm{~m}$ closer to the river after 10 years.

The predictions of uranium movement for the same plane of sorbed uranium contamination but placed $30 \mathrm{~m}$ from the river yield the following (see Figures 6.13 and 6.14 for the concentration of uranium sorbed and in the groundwater, respectively). For equilibrium sorption models, after 2 years, some of the uranium has been pushed inland to $150 \mathrm{~m}$ and up into the upper smear zone during high river stages. Then with time, the uranium center of mass heads back towards the river and gets released into the aquifer. After 10 years of transport, the uranium concentrations in the upper smear zone (above the average water table) become distributed similar to a conservative (non-sorbing) tracer distribution after 1 year, both distributions showing some net movement inland. Below the average water table, the net uranium movement is towards and into the river. For the kinetic sorption model, the lateral spread of uranium inland within the upper smear zone is larger, and for the lower smear zone (below the average water table), the net uranium transport is more towards the river than for predictions using equilibrium sorption models. Predicted uranium aqueous concentrations from the kinetic adsorption model are lower than the aqueous uranium concentrations for the equilibrium sorption models.

For the kinetic adsorption and constant $\mathrm{K}_{\mathrm{d}}$ models, sorbed uranium placed within $30 \mathrm{~m}$ of the river is predicted to show some net inland movement into the upper smear zone. In fact, some of the uranium is moved inland up to $200 \mathrm{~m}$ from the river (emplacement was $30 \mathrm{~m}$ from river). For uranium that is released into the water, there is a net inland flux of dissolved uranium in the upper smear zone and a net flux of dissolved uranium to the river for uranium in the lower smear zone. Predictions for the kinetic adsorption model show that the leading edge of the uranium plume, from the uranium emplaced $30 \mathrm{~m}$ away from the river, reaches the river in 35 days. For the constant $K_{d}$ model, the leading edge of the uranium plume reaches the river in $\sim 600$ days, and for the SCM adsorption model, the leading edge of the uranium plume reaches the river in $~ 1,700$ days. After 10 years the SCM adsorption model predictions show limited inland (25 $\mathrm{m}$ further inland) transport of the remaining uranium. The predictions from the SCM adsorption model have the highest concentrations of sorbed uranium in both the smear zone and aquifer sediments compared to the constant $\mathrm{K}_{\mathrm{d}}$ and kinetically controlled rate adsorption model. The reason for this is that only the SCM adsorption model accounts for the changing uranium adsorption with variations of water chemistry. Recall that the $\mathrm{K}_{\mathrm{d}}$ for uranium increases as solution $\mathrm{pH}$, bicarbonate, ionic strength, and uranium concentration decreases from the groundwater to the more dilute river-water composition. Thus, the sorption is dynamic and variable in the groundwater/river water mixing zone that can extend $150 \mathrm{~m}$ or more inland at a high river stage.

The overall picture that emanates from all the uranium transport modeling is that the 300 Area sediment/aquifer system is a large, distributed "two phase" plume, with the smear zone sediments acting as a long-term source of uranium that supplies the uppermost aquifer. The portion of the smear zone sediments that can be wetted during a high river stage is the key reservoir for the persistent uranium plume in groundwater. The SCM adsorption model results for uranium present near the river mutes the lateral spread and observed aqueous uranium concentrations because the influx of river water leads to a higher $\mathrm{K}_{\mathrm{d}}$ than for groundwater conditions. Thus, the water-borne uranium is effectively held up longer from escaping to the river. Predicted uranium aqueous concentrations for river water in contact with a 


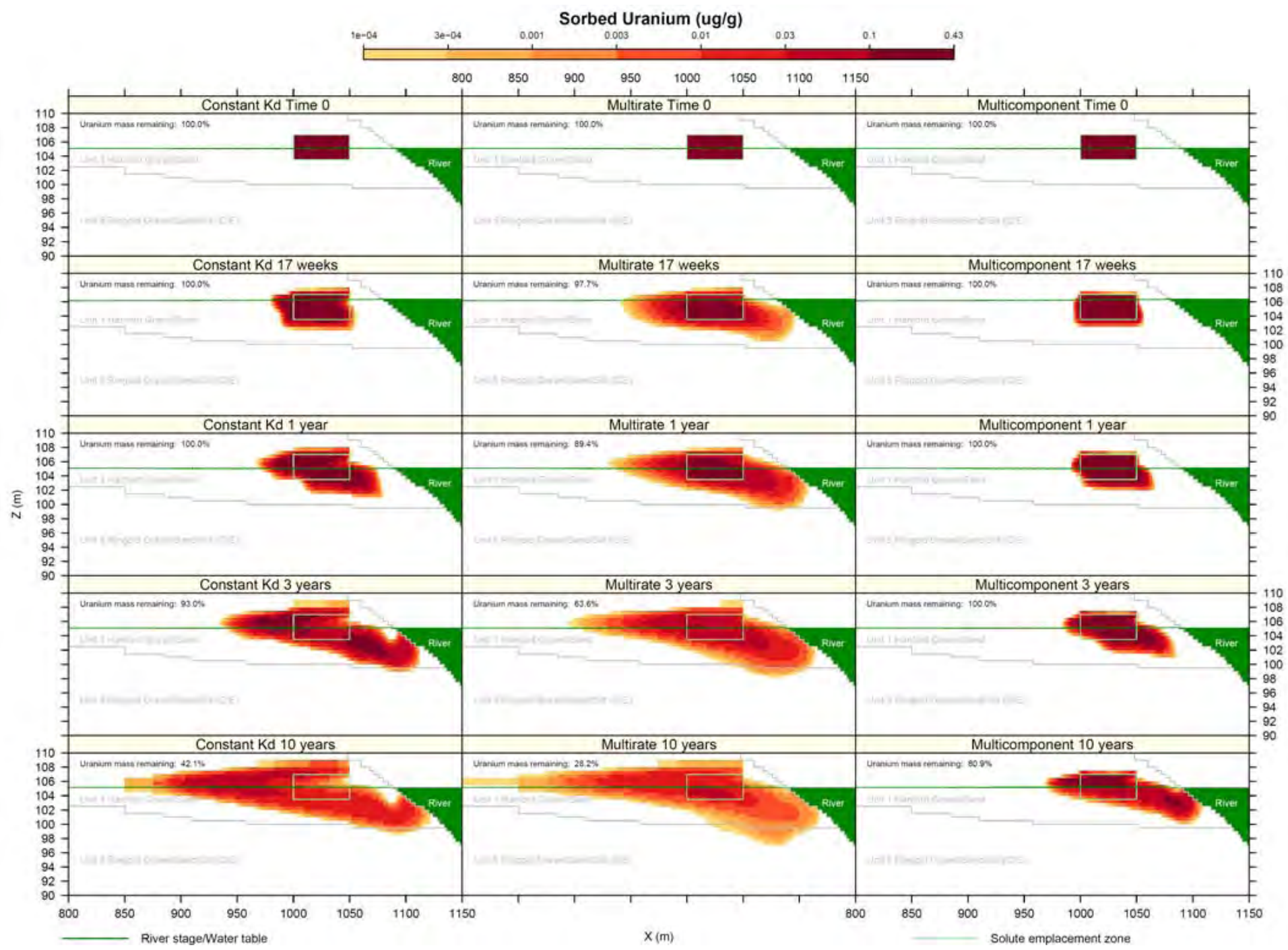

Figure 6.13. Simulated Migration of Sorbed Uranium at 0, 0.3, 1, 3, and 10 Years from the Emplacement Zone $30 \mathrm{~m}$ from the River for the Constant $\mathrm{K}_{\mathrm{d}}$ Model (left panels), Distributed Rate Mass-Transfer Model (middle panels), and Multi-Component Surface Complexation Adsorption Model (right panels) 


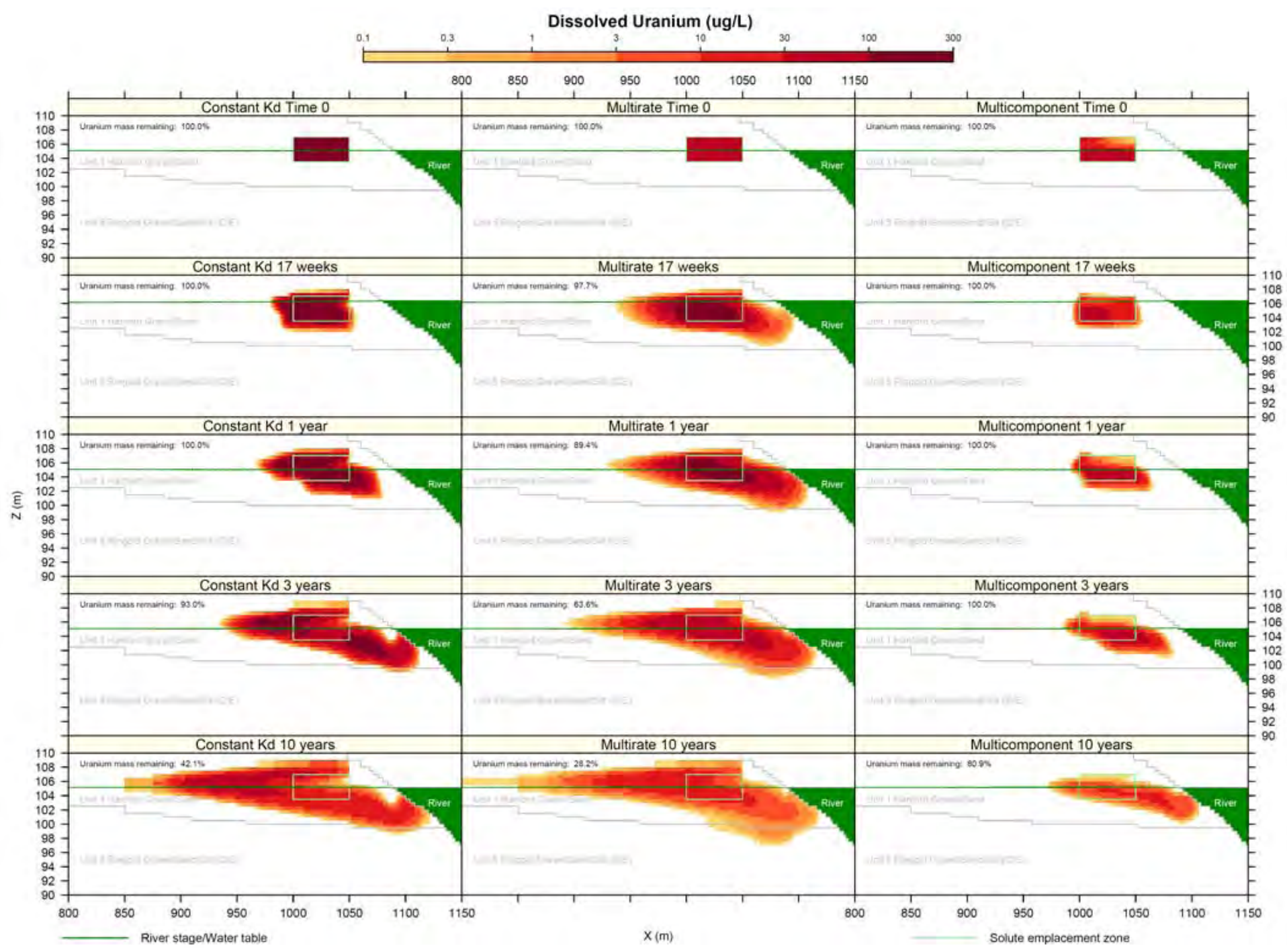

Figure 6.14. Simulated Migration of Aqueous Uranium at $0,0.3,1,3$, and 10 Years from the Emplacement Zone $30 \mathrm{~m}$ from the River for the Constant $\mathrm{K}_{\mathrm{d}}$ Model (left panels), Distributed Rate Mass-Transfer Model (middle panels), and Multi-Component Surface Complexation Adsorption Model (right panels) 
sediment with a set concentration of sorbed uranium can be two orders of magnitude lower than for groundwater in contact with the same contaminated sediment.

Related transport of uranium through the vadose zone into the smear zone driven by natural recharge was simulated with a one-dimensional unsaturated-flow numerical model using the same computer code and same three conceptual adsorption-desorption models. All three sorption models relied on laboratory experiments on $<2$-mm sediment obtained from the process ponds to parameterize the various sorption and kinetic rate constants needed for the sorption models. Details on the experiments are found in Qafoku et al. (2005), Zachara et al. (2005), and Bond et al. (2007). Vadose zone pore-water velocity driven by natural recharge, $60 \mathrm{~mm} / \mathrm{yr}$ and $8 \%$ volume water content, is $75 \mathrm{~cm} / \mathrm{yr}$. This flow rate is slow enough that the kinetic sorption model attains equilibrium, and thus for near-constant water composition, the uranium migration predictions are similar between the kinetic and the two equilibrium adsorption models. The leached/desorbed uranium vertical migration rate traveling through clean sediment is predicted to be $1 \mathrm{~m} / 30 \mathrm{yr}(0.033 \mathrm{~m} / \mathrm{yr}$ or $3.3 \mathrm{~cm} / \mathrm{yr})$. Based on the range of sediment residual uranium contamination levels that were observed in the South and North Process Ponds (and although not modeled as yet, residual 300 Area Process Trenches) and the three adsorption models, predicted peak aqueous uranium concentrations in the vadose zone pore water will exceed the MCL. That is, the computer simulations using the measured sediment uranium concentrations and available adsorption models predict resultant pore water uranium concentrations well above $30 \mu \mathrm{g} / \mathrm{L}$. This was corroborated in the water extracts performed on vadose zone and smear zone sediments from two of the LFI boreholes as discussed in Section 6.3.2. Further, if the vadose zone sediment profile has uniform uranium contamination present from the bottoms of the excavations all the way to the smear zone, then any leached/desorbed uranium in the slowly moving pore fluids can travel at the $75 \mathrm{~cm} / \mathrm{yr}$ rate (rate of water flux) to replenish uranium to the smear zone. This is caused by the fact that the deeper sediments adsorption sites may already be saturated with adsorbed uranium, and any newly leached uranium in the recharge water will not find unoccupied adsorption sites. The available vadose zone sediment data (see especially Zachara et al. [2005]) suggest that contamination may be present from the excavation depth to the smear zone and into the smear zone to the aquifer sediments permanently wetted even at low river stages below the process ponds footprints. The depth distribution of uranium in the residual sediments at the process trenches is not available; measurements of labile uranium in the vadose zone sediment below the trenches are especially needed. Knowledge of total uranium concentrations is not useful for sediments not shown to be "hot spots" because the concentration of native uranium in the sediments that does not leach/desorb is large enough to mask identifying low concentrations of labile (leachable/desorbable) Hanford process uranium that can lead to aqueous uranium concentrations above the MCL.

\subsubsection{Key Geochemical Variables Controlling the Transfer of Uranium Between Sediment and Solution}

In this section, we recap and emphasize the most sensitive parameters that control the movement of uranium between the compartments in our box model.

Given the expected range of parameter values in the 300 Area subsurface, the bicarbonate/carbonate concentration in solution has the largest effect on uranium leaching and desorption from contaminated sediments and sorption onto uncontaminated sediments of all the important parameters. This was discussed above in Sections 6.1.1 and 6.1.2 on uranium aqueous speciation and results of the laboratory adsorption-desorption tests found in Serne et al. (2002a) and Zachara et al. (2005). Figure 6.15 from Bond et al. (2007) provides one example of the strong sensitivity of uranium sorption to dissolved 
carbonate for 300 Area Process Pond residual sediments in contact with waters representative of vadose zone pore water and mixtures of groundwater with Columbia River water. These simulated waters cover the dissolved inorganic carbon range expected in the 300 Area subsurface. Note that the $\mathrm{Y}$-axis is $\log \mathrm{K}_{\mathrm{d}}$ and that it covers almost three orders of magnitude. The three lines shown in the figure represent SCM adsorption model predictions based on the laboratory experiments used to determine the stability constants for the same two adsorbing species noted in Sections 6.5.2 and 6.5.3. That is, this data set and SCM adsorption model was the one used in the mass-transport calculations (Yabusaki et al. 2008) just discussed. Figure 6.15 also shows that there is some difference between the adsorption properties of the North and South Process Pond residual sediments, despite the fact that the general composite SCM model attempts to account for differences in sediment surface area in an explicit fashion. The difference in the two predicted lines shows that the two pond sediments must have some different "mineralogical" attributes that are not captured by the specific general composite SCM adsorption model used, which assumes that all sorption sites are the same and that the specific adsorption site density is a fixed value and the same for both sediments. Thus, the number of adsorption sites in each sediment is controlled by the specific surface area of the two sediments, which is a readily measured parameter. The apparent "mineralogical" differences between the two pond sediments exhibit slightly more than a one-half log unit variability in adsorption values with the North Process Pond sediments being more sorptive than the South Process Pond sediments for a given solution of dissolved bicarbonate concentration. Again, the almost three-order-of-magnitude sorption sensitivity to the dissolved bicarbonate concentration over the expected range in the 300 Area subsurface is more significant than the unidentified "mineralogical" differences (only $\sim 0.5 \log$ units).

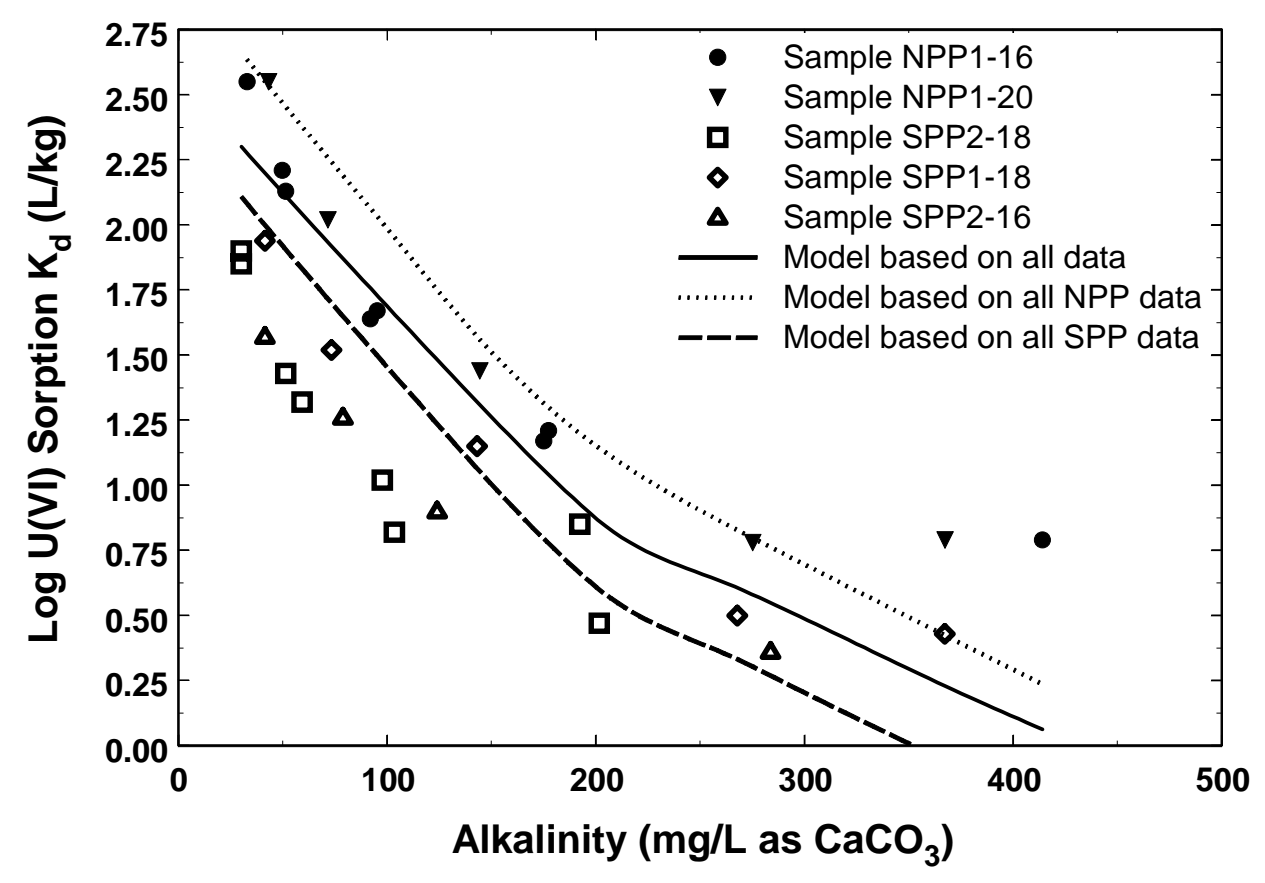

Figure 6.15. $\quad$ U(VI) Sorption (Log Kd) Dependence on the Alkalinity of Artificial Groundwater Solutions of Varying Composition. Solid curves show the fits to the data with a surface complexation adsorption model calibrated with all of the data, or separately with North Process or South Process Pond sediment data. 
The cause of the high sorption sensitivity to dissolved inorganic carbon (bicarbonate-carbonate) is the strong aqueous complex formed between the uranyl $\left[\mathrm{UO}_{2}{ }^{2+}\right]$ species and the carbonate-bicarbonate species. The complexes formed change the net charge of the uranium-bearing molecule from positive to negative or neutral. This change in net electrical charge profoundly alters sorption properties versus the free uranyl cation. In addition, the formation and dominance of carbonate complexes (see Figures 6.1 and 6.2) for geochemical environments of importance to the 300 Area subsurface allows the solubility of uranium to increase significantly over environments with low or no carbonate. In general, Hanford vadose zone pore waters contain more dissolved carbonate/bicarbonate than groundwater, and groundwater contains about three times as much carbonate as Columbia River water. Thus, unless other carbonate minerals start to precipitate and physically trap or substitute dissolved uranium into the forming secondary mineral (e.g., calcite), the order of uranium sorption tendencies for sediments in contact with different types of water follow the order Columbia River water $>$ Hanford groundwater $>$ vadose zone pore water. The discussion in Section 6.5.3 (especially regarding the right-hand panels of Figure 6.13 and 6.14) is one example of the impact of varying bicarbonate solution concentrations on the transfer of uranium between the sediments and groundwater and the transport of uranium from the hypothetical zone of emplacement to locations more inland or towards the river.

The reason that more uranium is observed in the groundwater at many monitoring wells away from the river during a high river stage (see Figure 3.12) is that the water rising into sediments, containing higher total uranium concentrations (sorbed and potentially relatively high pore water uranium concentrations), desorbs and flushes uranium into the water phase. Further, the diluting effect of river water, which lowers dissolved carbonate in the mixing zone, is moderated by several factors. Inland, the river water does not significantly mix with extant groundwater; it mostly "pushes” the groundwater to higher elevations and wets previously drier sediments. The formerly unsaturated sediments may also contain evaporated carbonate minerals that readily dissolve once rewetted, lowering any carbonatediluting tendencies caused by the river water. Because the kinetics of surface-adsorption reactions are relatively fast, the $K_{d}$ construct controls the net release of uranium from the higher uranium concentration bearing sediments into the rising groundwater. That is,

$$
\mathrm{K}_{\mathrm{d}}=\frac{U \text { sorbed sediment }}{U \text { in solution }}
$$

and if $U$ sorbed sediment is larger in the smear zone, then the $U$ in solution will increase as water rises into the smear zone to re-establish sorption equilibrium.

As mentioned in Section 6.5.1, the process ponds and potentially the process trench residual sediments may also contain coatings and rinds on native sediment grains and discrete secondary aluminosilicate precipitates generated from constituents in the liquid-waste streams. All of the coatings, rinds, and secondary precipitates can physically entrap uranium such that the timing of uranium release back into solution is hindered compared to uranium that is solely bound to particle-surface adsorption sites. This complication may be contributing to the persistence of the uranium groundwater plume along with the significant "sloshing back and forth" of the net water flow, which reaches toward the west at least $400 \mathrm{~m}$ inland from the Columbia River on the diurnal and seasonal time scales described in Section 6.5.3. Finally, the actual mixing of Columbia River water with the groundwater causes variations in bicarbonate (as well as other important variables such as calcium, total ionic strength) that causes the uranium to adsorb and desorb in a cyclical and varying fashion, thus keeping uranium from readily escaping to the river in a steady "monotonic" fashion. 


\subsection{Uncertainties Related to Uranium Geochemistry, Available Data for Uranium Distribution in the 300 Area Subsurface, and Future Mass Transport Simulations}

Although the geochemistry of uranium has been studied in great detail over the last hundred years, its aqueous speciation and number of solid minerals that can be formed is quite complicated and rather sensitive to other common geochemical constituents. Fortunately, in the 300 Area subsurface, the "contaminant" uranium is likely only found in the oxidized form $\mathrm{U}(\mathrm{VI})$. The tendency for $\mathrm{UO}_{2}{ }^{2+}$ to engage in aqueous complexation reactions is determined by 1) the total dissolved uranium concentration and $\mathrm{pH}, 2$ ) the concentrations of complexing anions and cations in the water, and 3) the equilibrium or stability constants for the product complex. Aqueous complexation can dramatically increase the solubility of precipitated uranium by the formation of uranium species at concentrations that are many orders of magnitude above that of the free $\mathrm{UO}_{2}{ }^{2+}$ cation. Likewise, aqueous complexation leads to the formation of dissolved uranium species with very different charges, sizes, chemical-bonding behavior, and aqueous diffusivities as compared to the free cation. These differences exert a profound influence on the extent to which $\mathrm{U}(\mathrm{VI})$ adsorbs to mineral surfaces by ion exchange or surface complexation, and the rates of diffusive exchange between pore waters and reactive sediment particle interiors.

Most Hanford uncontaminated or slightly contaminated pore waters and groundwaters exhibit a pH between 7.5 to $8.5, \mathrm{Ca}^{2+}$ concentrations between 0.5 to $10 \mathrm{mmol} / \mathrm{L}$, and are at equilibrium with $\mathrm{CO}_{2(\mathrm{~g})}$ that is at or slightly above atmospheric pressures. For these typical geochemical conditions, aqueous U(VI) will be distributed between multiple species with $\left(\mathrm{UO}_{2}\right)_{2} \mathrm{CO}_{3}(\mathrm{OH})_{3}{ }^{-}$and $\mathrm{UO}_{2}\left(\mathrm{CO}_{3}\right)_{3}{ }^{4-}$ predominating at lower $\mathrm{Ca}^{2+}$ concentrations, and $\mathrm{Ca}_{2} \mathrm{UO}_{2}\left(\mathrm{CO}_{3}\right)_{3(\mathrm{aq})}$ and $\mathrm{CaUO}_{2}\left(\mathrm{CO}_{3}\right)_{3}{ }^{2-}$ predominating at higher $\mathrm{Ca}^{2+}$ concentrations. These differences are significant in that calcium-uranium-carbonate complexes have been shown to be less susceptible to both adsorption and biologic reduction than those containing just uranium and carbonate. Notable aspects of U(VI) aqueous speciation in Hanford waters are 1) the presence of predominantly negative or neutral charges on the major species, 2) the near absence of the free cation (e.g., $\mathrm{UO}_{2}{ }^{2+}$ ) as a reactive species, 3 ) the importance of carbonate as a complexing ion, and 4) significant $\mathrm{pH}$ sensitivity to the species distributions.

Because uncontaminated Hanford sediments contain approximately 1.5 to $5 \mathrm{mg} / \mathrm{kg}$ of background uranium, and many contaminated 300 Area sediments contain from 5 to $25 \mathrm{mg} / \mathrm{kg}$ of total uranium, distinguishing between the chemical forms of background and contaminant uranium becomes important as they exhibit different molecular speciation and mineral residence. Recent characterization suggests that the native uranium in the sediments is from the betafite group, which is a U(IV) mineral that is highly resistant to weathering and leaching by water, in comparison to the Hanford process uranium, which is $\mathrm{U}(\mathrm{VI})$ and much more susceptible to long-term leaching from solids in circum-neutral $\mathrm{pH}$ waters. The small differences between total uranium and Hanford process uranium found in some 300 Area sediments makes differentiating the two forms based on total uranium measurements problematic. Natural variations in native uranium content can mask the designation of a sediment as containing "contaminant" uranium based solely on total uranium.

A further complication unique to the 300 Area sediments is their extremely large particle-size distribution showing mass percentages of gravel, cobbles, and small boulders summing from $>70$ up to $\sim 92 \%$ by mass. This results in most laboratory testing of sorption tendencies, typically performed on only the sand, silt and clay fraction, to ignore the bulk of the sediment. Further, it is a major challenge to 
determine the total uranium content of the sediments because most techniques rely on dissolving the solids (for ultimate measurement by ICP-MS or alpha energy spectroscopy) or pulverizing the solids to a powder (XRF). Gamma-energy analysis using measurement of the activity of uranium daughter products requires some assumptions regarding the status of the radioactivity equilibrium between uranium and the daughter products. The size of the solid particles that can be placed in gamma counting chambers and that can be effectively monitored by the small-sized detectors is limited. Therefore, all of the available measurements of total uranium in the sediments from the 300 Area are biased to a small percentage of the overall mass, the fine-grained fraction. No systematic correction factor has been established to convert data on the fine-grained fraction to the total mass of sediment residing in the 300 Area subsurface. Thus, there are large inherent uncertainties in scaling our data to the field scale to estimate total uranium inventories in our box model.

Verification of the mass of uranium still remaining in Hanford's subsurface is challenging because of difficulties in characterizing a three-dimensional subsurface plume with complex structure with a limited number of boreholes or geophysical measurements primarily sensitive to total salt content or gammaemitting radioisotopes. The latter radioactivity method proved to be not sensitive enough to detect and differentiate Hanford process uranium from natural background uranium at the four LFI boreholes (see further discussion in Williams et al. 2007).

The co-disposed waste streams, in addition to the primary uranium-containing waste stream, may have strongly modified the overall geochemical environment of the waste site and underlying sediments. The implications of waste mixing and variable water volumes on the behavior of the primary waste stream with a high uranium inventory requires due consideration. It is plausible that most of the initially acidic, high U(VI) fuel rod dissolution waste streams were neutralized before disposal, leading to the hydrolysis and precipitation of a variety of $\mathrm{U}(\mathrm{VI})$ oxyhydroxides. At this point, however, the presence of such waste-stream uranium solids, and their nature [e.g., metallic uranium, mixed U(IV) and U(VI), or $\mathrm{U}(\mathrm{VI})$ ] remains undefined through the field sampling performed since the process ponds and trenches were remediated. However, all the known liquid portions of the waste streams disposed of or released at Hanford are believed to be dominated by dissolved U(VI). Process records tabulated in Simpson et al. (2006) guided our conceptual model development. Note, however, that Simpson et al. (2006) did not tabulate records on disposal to the 307 Process Trenches so that we do not have, at this time, any understanding on how much uranium might have been disposed of therein or what the nature of the other co-disposed constituents were.

Regarding the post-excavation verification sampling of the residual sediments, we were surprised that residual concentrations in the bottom of the excavated 300 Area Process Trenches contain as much uranium as reported in Table 6.10 given the pre-excavation depth profiling results for the sediments, which showed a rapid drop off in uranium over the first $0.5 \mathrm{~m}$. Documents report that $1.2 \mathrm{~m}$ of sediment was excavated from the floor of the process trenches, and hand-held radiation monitoring was used to confirm adequate removal. There was no depth profiling of sediments after the 300 Area Process Trenches were excavated, and no post-excavation sediments were subjected to leach or desorption testing to determine the amounts and rates of uranium that may be entering the pore waters. Such testing has been done for process pond sediments so that we have more confidence in our uranium inventories for the box model for pond footprints. We therefore recommend some further sediment depth profiling through the 300 Area Process Trenches footprint with the same laboratory experiments performed as described in Serne et al. (2002a), Zachara et al. (2005), and Williams et al. (2007). 
If it were not for the fact that much of the waste disposed to the 307 Process Trenches was not monitored and the fact that there appears to be a groundwater seasonal uranium "hot spot" near the 307 Process Trenches during June (see Figure 3.5), we would dismiss considering this facility in future refinements of the box model. At this time, we assign no uranium inventory from the 307 Trench residual footprint but suggest that another borehole be placed between boreholes 399-3-17 and 399-3-16 shown in Hulstrom (1994) (see Table 6.11). The recommended borehole should collect near-continuous core samples, and the samples should be submitted for total uranium and water-leachable uranium testing similar to tests performed in the LFI (Williams et al. 2007).

The uranium concentrations in vadose zone sediments and vadose zone pore waters outside of the inactive facilities' footprints are not well defined. The only historical data available are from the measurement of total uranium concentrations in sediments from boreholes either drilled during 1990s characterization or boreholes that were completed as groundwater monitoring wells. In the past, most groundwater monitoring wells were emplaced with no sediment sampling or sediment chemical characterization. If there are new monitoring wells emplaced in the future, then sediment samples and budget should be provided to gather information on the sediment uranium contents and their leachsorption attributes.

Aquifer sediments from the LFI boreholes, with most gravel removed, that released significant waterleachable uranium contained on average $3 \mathrm{mg} / \mathrm{kg}$ "total” uranium with a range of 1.4 to $3.5 \mathrm{mg} / \mathrm{kg}$. The sediment "total" uranium average concentration for these "contaminated" samples is only one to a few parts per million greater than sediments that do not appear to water-leach significant amounts of uranium. Thus, there is very little difference between the "total" uranium concentrations of vadose zone and aquifer sediments outside the footprint of inactive disposal facilities that do water-leach concentrations of uranium above drinking water standards from sediments that do not water leach significant concentrations of uranium. It would thus appear difficult to designate sediments residing outside disposal facility footprints as contributing to the groundwater uranium plume based solely on their "total" uranium concentration. It would appear that the best way to designate sediments as contributing or not contributing to the existing groundwater plume is proximity to an inactive disposal facility and some type of mild extraction test using water or some solution less aggressive than strong acid.

Determining the vertical extent of slightly contaminated sediments outside the facilities' footprints at this point can only be based on the two LFI boreholes, 399-1-23 and 399-3-18 and the boreholes recently drilling as part of a volatile organics compounds investigation (C5706, completed as 399-3-22, and C5707, completed as 399-4-14). Unfortunately, there was a large difference in the thickness of sediments in the two LFI boreholes (4 and $11.3 \mathrm{~m}$, respectively), that water leached significant concentrations of uranium. Borehole 399-1-23 is near the 300 Area Process Trench and borehole 399-3-18 is near (downgradient) from the South Process Pond. Based on the masses of uranium and the volume of waste deposited in these two facilities, finding a thicker zone of "contaminated" sediments near the pond is logical.

The results of our box model with 10 compartments ( 5 sediment and 5 water) suggest that the amount of uranium in the waters is small compared to the amount of uranium bound to the sediments containing the water. It should be noted that the current estimates for compartments C, D, G, and H are based solely 
on the two LFI boreholes with water-leachable uranium and the many assumptions noted ${ }^{17}$. The areas and volumes of the existing uranium groundwater plume are large compared to the regions for which we have data to make these estimates. Certainly more boreholes would be helpful to strengthen our uranium inventory and fate-and-transport estimates. Future boreholes should be in regions of the vadose, smear, and aquifer zones containing water-leachable uranium above and within the existing groundwater plume, and they should be strategically chosen to be near but downgradient of the inactive facilities.

The areal extent of the existing groundwater plume is well established since the early 1990s based on years of monitoring the well network (see Section 3.0). However, the vertical profile of uranium in the groundwater is not as well established. There are only a few wells, including the four new LFI wells, for which any groundwater uranium concentration data as a function of depth are available. Thus, the volume of uranium-contaminated water at specific concentrations is difficult to estimate. It is known that the uranium in the upper unconfined aquifer is almost exclusively found in the upper highly permeable Hanford formation gravel-dominated facies. It was concluded that the best-estimate thickness for the uraniumbearing portion of the groundwater plume is $8 \mathrm{~m}$ in December (low river stage) and $9.8 \mathrm{~m}$ in June (high river stage).

The box model uranium inventories (see Table 6.5 and Figure 6.4) suggest that the majority of the residual uranium resides in the vadose zone sediments and smear zone sediments below the footprints of the inactive facilities, and most of the inventory is within the footprints of the North and South Process Ponds. Our estimates show that $\sim 80 \%$ of the total residual uranium is under the inactive facilities' footprints, distributed as $76 \%$ bound to the sediments and $3 \%$ in the pore waters. Another $17 \%$ of the total residual uranium is spread out in the vadose zone and smear zone outside of the footprints of the inactive facilities. The current groundwater plume and aquifer sediments below the average yearly water table contain about $4 \%$ of the residual uranium. Within the current aquifer plume, two-thirds of the inventory is bound to the sediments, and only one-third is dissolved in the groundwater. The overall estimate of residual "contaminant" uranium in the 300 Area from our box model is 4,150 kg. This mass represents about 9\% of the uranium that Simpson et al. (2006) estimate was disposed of in the 300 Area liquid-waste disposal facilities.

Example simulations of the complex flow reversals and varying sorption properties caused by the mixing of groundwater with Columbia River water were presented in Section 6.3.5. The reader is cautioned that the simulations are based on only one two-dimensional geologic/hydrologic (west to east) transect through the existing uranium plume. The 300 Area uranium plume is a three-dimensional phenomenon. Further, the simulation was based on only one year's water-level boundary conditions that were assumed to repeat year after year. The uranium mass-transport simulations were performed separately for a localized region of uranium emplaced at an inland location and at a near-river location. The uranium was assumed to be initially adsorbed to the sediments in the emplacement zone, and all other surrounding sediments were uncontaminated with uranium. Three differing uranium adsorption models, based on laboratory studies on the $<2 \mathrm{~mm}$ fraction of process pond residual sediments, were coupled to the hydrologic flow model to simulate uranium movement between the emplacement zones and other locations along the two-dimensional transect and transfer between the adsorbed and water phases. Simulations were run for 10 years.

\footnotetext{
${ }^{17}$ Useful data from boreholes C5706 and C5707 are now available to improve the sparse data set for uranium distribution outside disposal facility footprints.
} 
Key findings from these simplified simulations are that accurately predicting the migration of uranium in the 300 Area subsurface will require hourly time-step resolution to capture the variable water flow reversals that occur diurnally with additional seasonal influences. The adsorption model for uranium must also accommodate both kinetically controlled sorption reactions and variable sorption tendencies as a function of variations in water chemical composition, e.g., a combined distributed rate (kinetic) and surface complexation (SCM) adsorption model. The initial "labile" uranium distribution in the sediments and pore waters should also be input, perhaps based on our box model distributions, to more accurately set up the starting point for simulations. The transport computer code must also become a full threedimensional flow model or alternatively be run as a suite of two-dimensional models for several transects maintaining the hourly time-step requirement. 


\subsection{Conclusions}

(R.E. Peterson)

The persistence of uranium contamination in groundwater at concentrations that exceed the EPA drinking water standard of $30 \mu \mathrm{g} / \mathrm{L}$ has prompted additional investigation of the plume itself and of technologies that could potentially be used to reduce concentrations to meet the standard. The monitoring and plume characterization since the record of decision in 1996 for interim action have revealed a considerable amount of new information. A most important revelation is that the level of contamination in the plume is not falling at a rate that would cause concentrations to drop to below the drinking water standard in a reasonable length of time, which in the past has been defined as "by 2018," or the earliest date at which institutional controls on the use of the 300 Area may be relaxed.

A mass of contaminant uranium estimated to be somewhat comparable to estimates for the disposal inventory at the 300 Area has been removed during the excavation of sediment at former liquid-waste disposal facilities (Section 2.1). That uranium is now stored in the Environmental Restoration Disposal Facility. Groundwater discharge to the Columbia River and occasional surface runoff during containment failures at the former process ponds have also removed contaminant uranium from the 300 Area subsurface environment. Since 1982, uranium has been removed from the aquifer at a water-supply well that provides water for the aquariums in the 331 Life Sciences Building (note: uranium in aquarium water also ultimately ends up in the Columbia River). In spite of waste site remedial actions and other processes (natural and manmade) that remove uranium from the 300 Area subsurface, some contaminant uranium remains in various repositories. Release of that residual uranium is responsible for the persistence of the groundwater plume.

The conceptual model for this contamination identifies the following potential repositories (i.e., zones where contaminant uranium may be sequestered):

- Vadose zone sediment immediately adjacent to the former liquid-waste disposal sites

- Lower portion of vadose zone beneath the footprints of former disposal sites

- A vertical zone through which the water table rises and falls, which is subdivided laterally into regions immediately beneath waste sites and other more widespread regions defined by the extent of the groundwater plume

- Groundwater and solid materials in the upper portion of the unconfined aquifer

- Zone of interaction between the aquifer and river systems.

Recent efforts have been directed at evaluating the size of the inventory and mobility characteristics in each of these potential repositories. The following uncertainties are associated with the results: 1) the observational data available to prepare estimates for the quantities in various repositories are not equally distributed and 2) the numbers of samples from the various repositories are relatively few, and how representative those samples are of all potential regions where contamination may exist is not known. However, in the face of these uncertainties, some estimates can be made. 


\subsection{Uranium Plume Characteristics}

Calculations based on monitoring data reveal that the volume of contaminated water exceeding the drinking water standard in recent years falls in the range of 673,000 to $1,263,000 \mathrm{~m}^{3}$ and that the mass of uranium in that groundwater volume ranges between 41 and $83 \mathrm{~kg}$ (Section 3.4, Table 3.3).

Approximately $10 \%$ of the uranium in groundwater is from natural sources, i.e., not from waste-disposal operations. Various assumptions have been made in developing these estimates, including a total porosity of $26 \%$ for the contaminated portion of the aquifer, which is likely to be conservative, i.e., on the high side of the range. However, it appears reasonable to generalize that the plume includes roughly $650,000 \mathrm{~m}^{3}$ of groundwater and contains approximately 45 to $77 \mathrm{~kg}$ of uranium at any particular time of the year, based on observations during the past 5 years. Seasonal differences account for some of the variability in these estimates. Loss from the plume occurs via discharge to the Columbia River and withdrawal at well 399-4-12, which supplies water to the 331 Life Sciences Building. The rates of loss for each of these processes are not well-defined, but may be on the order of several hundred kilograms per year to the river, and several tens of kilograms per year via the well. Ongoing refinements to a threedimensional flow and transport model will enable more accurate and defensible estimates for these loss rates (Section 5).

The pathway occupied by this plume is the saturated portion of the Hanford gravels, i.e., the upper portion of the unconfined aquifer, which includes the water table (Section 4). This hydrologic unit is highly transmissive regarding groundwater flow and highly variable in thickness, with average values of $8 \mathrm{~m}$ for most of the annual cycle and $9.8 \mathrm{~m}$ during the seasonal high water table condition that occurs in May and June. Groundwater movement through this hydrologic unit can be quite rapid, with observational data suggesting up to $15 \mathrm{~m} / \mathrm{d}$ (Section 5.1.4). Because of highly variable hydraulic gradients, both in steepness and direction, movement patterns for contaminants are complex. The complexity in groundwater flow and contaminant transport is a consequence of the highly variable river stage, which may vary through a vertical range of up to $3 \mathrm{~m}$, causing a corresponding change in 300 Area water table through nearly as large a range.

In addition to the complexity introduced by river hydraulics, during high river-stage conditions, river water infiltrates the riverbanks and hyporheic zone ${ }^{18}$ and mixes with groundwater. This changes the geochemical environment and affects the mobility of uranium, i.e. the presence of river water in groundwater promotes adsorption of dissolved uranium onto aquifer solids. Monitoring data reveal the movement of river inland as much as $325 \mathrm{~m}$ at some locations within the 300 Area.

The contaminant plume pathway is incised by the Columbia River channel, creating an area of potential impact of approximately $0.17 \mathrm{~km}^{2}$ (Section 4.5). Ecological receptors that use the riverbed as habitat within this area are potentially exposed to uranium contamination carried by groundwater. The rate of groundwater (and contaminant) flux across the riverbed interface with the uranium plume is controlled by the hydraulic gradient in the aquifer and the stage of the river, in addition to other aquifer parameters. Discharge across the interface is also influenced by the nature of the riverbed substrate, with fine-grained alluvium resulting in a lower rate of flux to the free-flowing stream than where there is coarse, cobbly sediment or no sediment at all.

\footnotetext{
${ }^{18}$ River water that infiltrates the riverbank is referred to as "bank storage;" the term "hyporheic” is used to refer to the riverbed zone that is influenced by the free-flowing stream.
} 


\subsection{Potential Repositories for Contaminant Uranium}

In Section 2.0 of this report, three questions were posed with regard to information needed to support remedial action decisions associated with contaminant uranium in the subsurface beneath the 300 Area, along with current concepts regarding the answers:

- Where is the inventory of uranium that feeds the current groundwater plume?

- How is the inventory of uranium mobilized to re-supply the plume?

- How long can the inventory continue to supply uranium to the plume?

The subsequent sections described 1) current groundwater plume parameters, 2) the hydrogeologic framework within which the contamination is contained, 3) groundwater flow patterns as well as flowand-transport simulations, and 4) the geochemical aspects of uranium sequestered in the environment and moving with groundwater. All of these topics are relevant to helping find answers to these questions.

\section{Where is the inventory of uranium that feeds the current groundwater plume?}

Estimates have been prepared for the mass of contaminant uranium in each of 10 compartments that make up the various subsurface zones and media beneath the 300 Area (Section 6). The assumptions and uncertainties associated with each estimate are described in detail, and the results should be considered "first order approximations" of the inventory. Table 7.1 summarizes those estimates:

This inventory analysis suggests that the largest repositories of residual contaminant uranium are sediments in the vadose zone beneath the former liquid-waste disposal facilities. The residual uranium beneath the footprints of these facilities represents approximately $80 \%$ of the total amount of contaminant uranium remaining in the 300 Area subsurface environment, with $76 \%$ associated with sediment and $3 \%$ with sediment pore water. The current groundwater plume, including dissolved uranium and uranium bound to aquifer sediment, accounts for approximately $5 \%$ of the total. The total mass estimated for the various compartments in this model represent approximately $9 \%$ of the uranium estimated to have been disposed to 300 Area liquid effluent waste facilities.

\section{How is the inventory of uranium mobilized to re-supply the plume?}

Residual contaminant uranium remains in a variety of geochemical configurations in the vadose zone beneath former waste-disposal sites. These configurations include 1) discrete crystalline (i.e., mineral) phases, 2) as co-precipitates in coatings on natural sediment particles, and 3) as sorbed components on the surface of natural sediment particles. Some of these configurations, such as surface adsorption sites, are more susceptible than others to being mobilized if a transporting medium, such as infiltrating moisture, is available. The other forms are slow to release uranium to the aqueous state.

The primary controls on mobility associated with sorbed components in the vadose zone are moisture flux rates and the bicarbonate content of that moisture. Moisture flux under current conditions is low, with infiltration of natural precipitation during episodic events being the primary source in the absence of waste disposal to the ground. Application of water for dust suppression during remedial action of waste sites and facilities may also contribute to moisture in the vadose zone. For the lower portion of the vadose zone, the zone through which the water table rises and falls, and the aquifer, the dominant processes associated with the exchange of uranium between dissolved (i.e., mobile) and relatively fixed (sorbed to sediment) uranium are adsorption/desorption. 
Table 7.1. Summary of Uranium Inventory Estimates for Various Subsurface Repositories in the 300 Area

\begin{tabular}{|c|c|c|c|}
\hline $\begin{array}{c}\text { Compart- } \\
\text { ment } \\
\end{array}$ & Description & $\begin{array}{c}\text { Uranium } \\
\text { Inventory }(\mathrm{kg}) \\
\end{array}$ & $\begin{array}{l}\text { Percent } \\
\text { of Total }\end{array}$ \\
\hline 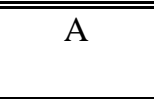 & $\begin{array}{l}\text { Vadose zone sediment above highest water-table elevation; beneath } \\
\text { footprint of former liquid-waste disposal facilities }\end{array}$ & $2,2,101$ & 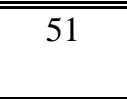 \\
\hline B & $\begin{array}{l}\text { Vadose zone pore water above highest water-table elevation; beneath } \\
\text { footprint of former liquid-waste disposal facilities }\end{array}$ & 75 & 2 \\
\hline $\mathrm{C}$ & $\begin{array}{l}\text { Vadose zone sediment above highest water-table elevation; outside } \\
\text { footprint of former liquid-waste disposal facilities }\end{array}$ & 559 & 13 \\
\hline \multirow[t]{2}{*}{$\mathrm{D}$} & $\begin{array}{l}\text { Vadose zone pore water above highest water-table elevation; outside } \\
\text { footprint of former liquid-waste disposal facilities }\end{array}$ & 6 & $<1$ \\
\hline & Vadose Zone Subtotal: & 2,741 & 66 \\
\hline $\mathrm{E}$ & $\begin{array}{l}\text { Sediment in intermittently wetted zone through which water table } \\
\text { rises and falls; beneath footprint of disposal facilities }\end{array}$ & 1,063 & 26 \\
\hline $\mathrm{F}$ & $\begin{array}{l}\text { Pore water in intermittently wetted zone through which water table } \\
\text { rises and falls; beneath footprint of disposal facilities }\end{array}$ & 37 & 1 \\
\hline G & $\begin{array}{l}\text { Sediment in intermittently wetted zone through which water table } \\
\text { rises and falls; outside footprint of disposal facilities }\end{array}$ & 124 & 3 \\
\hline \multirow[t]{2}{*}{$\mathrm{H}$} & $\begin{array}{l}\text { Pore water in intermittently wetted zone through which water table } \\
\text { rises and falls; outside footprint of disposal facilities }\end{array}$ & $<1$ & $<1$ \\
\hline & Water Table Zone Subtotal: & 1,224 & 30 \\
\hline $\mathrm{I}$ & $\begin{array}{l}\text { Aquifer sediment; within area of greater than } 30 \mu \mathrm{g} / \mathrm{L} \text { uranium } \\
\text { (average concentrations for } 2002 \text { to 2007) }\end{array}$ & 122 & 3 \\
\hline \multirow[t]{3}{*}{$\mathrm{J}$} & $\begin{array}{l}\text { Groundwater; within area of greater than } 30 \mu \mathrm{g} / \mathrm{L} \text { uranium (average } \\
\text { concentrations for } 2002 \text { to 2007; total porosity of } 26 \% \text { ) }\end{array}$ & 62 & 1 \\
\hline & Aquifer Subtotal: & 184 & 4 \\
\hline & Totals & 4,149 & 100 \\
\hline
\end{tabular}

Work to date in developing a computer simulation of uranium transport by groundwater has revealed clues suggesting a partial explanation for the persistence of the plume (Section 6.5.3). The explanation starts by assuming the current plume configuration, which has persisted under relatively constant environmental conditions for several decades since the last active disposal operations involving uranium ( 1985). During the seasonal high Columbia River conditions in May and June, the water table beneath the 300 Area is elevated by as much as several meters. Groundwater containing the uranium plume is moved upward into the normally unsaturated vadose zone. When the water table falls back to more typical elevations in late summer, some contaminated groundwater remains behind in the zone that is less than fully saturated because of forces other than gravity. How long this groundwater remains in the water-table zone is not yet clear, nor are the rates of adsorption/desorption easily defined for the exchange of uranium between the dissolved state and fixation onto sediment. It is an extremely complex and dynamic environment in which to model uranium movement. However, it does appear that this portion of the lower vadose zone may sequester uranium as a result of the rise and fall of the water table and therefore slow the flushing of contaminant uranium from the subsurface environment. 


\section{How long can the inventory continue to supply uranium to the plume?}

The predictions offered in the initial remedial investigation report (DOE-RL 1994b) and its subsequent revision (DOE-RL 1995b) suggested that advection of the plume and discharge to the river would result in maximum concentrations lower than the proposed drinking water standard by the year 2018. Approximately half the time since the predictions were made has passed, and concentrations in the plume remain relatively constant and above the current drinking water standard. A principal assumption for those estimates was no continuing re-supply of the groundwater plume, which at the time seemed reasonable in that extensive source cleanup actions which were just beginning.

Subsequent cleanup verification sampling, characterization drilling activities, and groundwater monitoring have revealed evidence that shows the assumption of no re-supply of uranium to the groundwater plume to be inaccurate. The plume is being re-supplied, and possibly by release from multiple subsurface repositories. The rates of release are currently determined by environmental conditions that have persisted for many years, and are likely to continue for many years. If the major processes controlling the persistence of the plume involves only the water table zone and aquifer, uranium might be cycled through this subsurface system for some time to come, based on the preliminary uranium transport simulations (Section 6.5.3).

The inventory and mobility characteristics of residual contaminant uranium in the 300 Area subsurface are not sufficiently well known to accurately predict the time during which the plume will continue to exceed the drinking water standard. The number of variables involved is large, and the uncertainties associated with location and amount of inventory, especially in the vadose zone, are also significant. Computer codes are available to process these variables, and to describe the uncertainties associated with the output. However, use of these codes for accurately predicting the number of years that the plume might persist requires more field observations. It is conservative to conclude, however, that the plume will persist at concentrations exceeding regulatory standards for the foreseeable future, i.e., to the time when institutional controls on the use of groundwater are likely to be relaxed, unless active intervention is attempted. The ongoing polyphosphate treatability test is a first step toward understanding the potential of in situ methods to reduce uranium concentrations in the plume.

\subsection{Ramifications for Remedial Action}

Most of what is known or inferred about contaminant uranium in the 300 Area subsurface environment suggests a strong link between 1) uranium in the lower portion of the vadose zone, and in particular, the water table zone beneath formerly active liquid-waste disposal sites, and 2) the persistence of the uranium plume in groundwater. Estimates for inventory in various subsurface vadose zone "compartments" indicate amounts that are much greater than the amount in the groundwater plume. Identifying the specific compartments from which uranium is supplied to groundwater is more problematic, in that to be transported, uranium must be in a form that can be mobilized by whatever transporting media or mechanism are available. Under current environmental conditions, moisture infiltrating from the ground surface and moving downward through the vadose zone sediment is one likely transporting medium, but the rate and amount of infiltration appears to be very low. However, the movement of groundwater upward and downward through the water table zone does provide a current transporting medium for uranium to be removed from that "compartment.” Also, estimates for uranium sequestered in the water table zone, either on sediment or in moisture, suggest an inventory many times larger than the inventory in groundwater. 
The interim action objective for groundwater contamination involves developing and implementing remedial actions that will cause a reduction in uranium concentrations to meet the EPA drinking water standard (currently $30 \mu \mathrm{g} / \mathrm{L}$ ). Residual uranium in the vadose zone beneath the former waste disposal ponds and trenches will strongly influence the remediation strategy that focuses on achieving this objective. Remediation of the uranium in the vadose zone sediments, particularly those under the waste disposal facilities and within the seasonal excursions of the groundwater table, will likely have the greatest effect in reducing persistent uranium concentrations in groundwater. 


\subsection{References}

Allison JD, DS Brown, and KJ Novo-Gradac. 1998. MINTEQA2/PRODEFA2, A Geochemical Assessment Model for Environmental Systems: User Manual Supplement for Version 4.0.

U.S. Environmental Protection Agency, Washington, DC.

Anglin DR, SL Haeseker, JJ Skalicky, and H Schaller. 2006. Effects of Hydropower Operations on Spawning Habitat, Rearing Habitat, and Stranding/Entrapment Mortality of Fall Chinook Salmon in the Hanford Reach of the Columbia River. Final Report, August 2006, U.S. Fish and Wildlife Service, Columbia River Fisheries Program Office, Vancouver, Washington.

ANL. 1993. Manual for Implementing Residual Radioactive Materials Guidelines Using RESRAD, Version 5.0. ANL/EAD/LD-2, Environmental Assessment Division, Argonne National Laboratory, Argonne, Illinois.

Arai Y, MA Marcus, N Tamura, JA Davis, and JM Zachara. 2007. "Spectroscopic Evidence for Uranium Bearing Precipitates in Vadose Zone Sediments at the Hanford 300-Area Site.” Environmental Science and Technology 41(13):4633-4639.

Arntzen EV, DR Geist, and PE Dresel. 2006. "Effects of fluctuating river flow on groundwater/surface water mixing in the hyporheic zone of a regulated, large cobble bed river.” River Research and Applications 22(8):937-946.

Benjamin MM. 2002. Water Chemistry. McGraw Hill, Columbus, Ohio.

Bethke CM. 2005. Geochemist Workbench Release 6.0. University of Illinois, Urbana-Champaign, Illinois.

BHI. 1998. 300 Area Process Trenches Verification Package. BHI-01164, Bechtel Hanford, Inc., Richland, Washington.

BHI. 2003. Cleanup Verification Package for the South Process Pond (WIDS Site 316-1), the Retired Filter Backwash Pond (WIDS Site 300 RFBP), 300-262 Contaminated Soil, and Unplanned Release Sites UPR-300-32, UPR-300-33, UPR-300-34, UPR-300-35, UPR-300-36, UPR-300-37, and UPR-300-FF-1. CVP-2003-00002, Rev. 0, Bechtel Hanford Inc., Richland, Washington.

Bisping LE. 2008. Hanford Site Environmental Surveillance Master Sampling Schedule for Calendar Year 2008. PNNL-17282, Pacific Northwest National Laboratory, Richland, Washington.

Bjornstad BN. 2004. Sampling and Hydrogeology of the Vadose Zone Beneath the 300 Area Process Ponds. PNNL-14834, Pacific Northwest National Laboratory, Richland, Washington.

Bond DL, JA Davis, and JM Zachara. 2007. "Uranium(VI) release from contaminated vadose zone sediments: estimation of potential contributions from dissolution and desorption.” In: Adsorption of Metals by Geomedia II (eds. MO Barnett and DB Kent), pp. 379-420. Academic Press, San Diego. 
Brooks SC, JK Fredrickson, SL Carroll, DW Kennedy, JM Zachara, AE Plymale, SD Kelly, KM Kemner, and S Fendorf. 2003. "Inhibition of bacterial U(VI) reduction by calcium." Environmental Science and Technology 37:1850-1858.

Brown CF, RJ Serne, BN Bjornstad, DG Horton, DC Lanigan, RE Clayton, MM Valenta, TS Vickerman, IV Kutnyakov, KN Geiszler, SR Baum, KE Parker, and MJ Lindberg. 2006. Characterization of Vadose Zone Sediments Below the C Tank Farm: Borehole C4297 and RCRA Borehole 299-E27-22. PNNL15503, Pacific Northwest National Laboratory, Richland, Washington.

Burns P. 1999. “The crystal chemistry of uranium.“ In: Uranium: Mineralogy, Geochemistry, and the Environment (eds. P.C. Burns and R. Finch). Reviews in Mineralogy V. 38. Mineralogical Society of America.

Callison SW, and SW Clark. 2002. Protection of 300 Area Groundwater from Uranium Contaminated Soils at Remediated Sites. BHI-01667, Rev. 0. Prepared by CH2M HILL Hanford, Inc. for Bechtel Hanford, Inc., Richland, Washington.

Campbell MD. 1994. Monitoring Groundwater and River Interaction Along the Hanford Reach of the Columbia River. PNL-9437, Pacific Northwest National Laboratory, Richland, Washington.

Campbell MD, and DR Newcomer. 1992. Automatic Measurement of Water Levels Within the 300-FF-5 Boundary. PNL-7874, Pacific Northwest Laboratory, Richland, Washington.

Campbell MD, WJ McMahon, and KR Simpson. 1993. Water Level Measurements for Modeling Hydraulic Properties in the 300-FF-5 and 100 Aggregate Area Operable Units. PNL 8580, Pacific Northwest Laboratory, Richland, Washington.

Catalano JG, JP McKinley, JM Zachara, SM Heald, SC Smith, and GE Brown. 2006. "Changes in Uranium Speciation through a Depth Sequence of Contaminated Hanford Sediments.” Environmental Science and Technology 40(8):2517-2524.

Cline CS, JT Rieger, JR Raymond, and PA Eddy. 1985. Ground-Water Monitoring at the Hanford Site, January-December 1984. PNL-5408, Pacific Northwest Laboratory, Richland, Washington.

Cole CR, MP Bergeron, CJ Murray, PD Thorne, SK Wurstner, and P Rogers. 2001. Uncertainty Analysis Framework Hanford Site-Wide Groundwater Flow and Transport Model. PNNL-13641, Pacific Northwest National Laboratory, Richland, Washington.

Corbin RA, BC Simpson, MJ Anderson, WF Danielson III, JG Field, TE Jones, and CT Kincaid. 2005. Hanford Soil Inventory Model Rev. 1. RPP-26744, Rev.0, CH2M HILL Hanford Group, Inc., Richland, WA.

Davis JA, DE Meece, M Kohler, and GP Curtis. 2004. “Approaches to Surface Complexation Modeling of Uranium (VI) Adsorption on Aquifer Sediments.” Geochimica et Cosmochemica Acta 68(18):36213641.

Davis JA, DL Bond, and P Fox. 2004. "Labile U(VI) and Progress Toward a Generalized Surface Complexation Model.” In: Workshop on Conceptual Model Development and Reactive Transport 
Modeling for the 300 Area Uranium Plume in 300-FF-5. May 10-11, 2004, Richland, Washington. Available at: http://www.hanford.gov/cp/gpp/public/workshops.cfm. Accessed October 1, 2007.

Davis JA, M Ochs, M Olin, TE Payne, and CJ Tweed. 2005. NEA Sorption Project Phase IIInterpretation and Prediction of Radionuclide Sorption onto Substrates Relevant for Radioactive Waste Disposal Using Thermodynamic Sorption Models. NEA No. 5992, Nuclear Energy Agency, OECD Publishing, Paris.

Deford DH, RW Carpenter, and MW Einan. 1994. 300-FF-2 Operable Unit Technical Baseline Report. BHI-00012, Rev. 00, Bechtel Hanford, Inc., Richland, Washington.

Dickson FJ, KD Hawkins, and TJ White. 1989. “Calcium uranium titanate - A new pyrochlore." Journal of Solid State Chemistry 82(1):146-150.

DOE. 1988. Site Characterization Plan. Consultation Draft, Reference Repository Location, Hanford Site, Washington. DOE/RW-0164, Vols. 1 and 2, U.S. Department of Energy, Washington, D.C.

DOE-RL. 1990. Remedial Investigation/Feasibility Study Work Plan for the 300-FF-5 Operable Unit, Hanford Site, Richland, Washington. DOE/RL 89-14, U.S. Department of Energy, Richland Operations Office, Richland, Washington.

DOE-RL. 1992. Expedited Response Action Assessment for the 316-5 Process Trenches. DOE/RL-9111, U.S. Department of Energy, Richland Operations Office, Richland, Washington.

DOE-RL. 1994a. Hanford Site Background: Part I, Soil Background for Nonradioactive Analytes. DOE/RL-92-24, Rev. 2, March 1994. U.S. Department of Energy, Richland Operations Office, Richland, Washington.

DOE-RL. 1994b. Phase I Remedial Investigation Report for the 300-FF-5 Operable Unit. DOE/RL-9321, Rev. 0, Vols. 1 (information) and 2 (data listings), U.S. Department of Energy, Richland Operations Office, Richland, Washington.

DOE-RL. 1995a. Proposed Plan for the 300-FF-1 and 300-FF-5 Operable Units. DOE/RL-95-88, Rev. 0, U.S. Department of Energy, Richland Operations Office, Richland, Washington.

DOE-RL. 1995b. Remedial Investigation/Feasibility Study Report for the 300-FF-5 Operable Unit. DOE/RL-94-85, Rev. 0, U.S. Department of Energy, Richland Operations Office, Richland, Washington.

DOE-RL. 1996a. Hanford Site Background: Part 2, Soil Background for Radionuclides. DOE/RL-9612, Rev. 0, U.S. Department of Energy, Richland Operations Office, Richland, Washington.

DOE-RL. 1996b. Remedial Design Report and Remedial Action Work Plan for the 100-HR-3 and 100KR-4 Groundwater Operable Units' Interim Action. DOE/RL-96-84, Rev. 0, U.S. Department of Energy, Richland Operations Office, Richland, Washington (updated by DOE/RL-96-84, Rev. 0-A, April 2003).

DOE-RL. 1997a. 300 Area Process Trenches Modified Closure/Postclosure Plan. DOE/RL-93-73, Rev. 2, U.S. Department of Energy, Richland Operations Office, Richland, Washington. 
DOE-RL. 1997b. Hanford Site Background: Part 3, Groundwater Background. DOE/RL-96-61, Rev. 0, U.S. Department of Energy, Richland Operations Office, Richland, Washington.

DOE-RL. 2000. Environmental Monitoring Plan, United States Department of Energy, Richland Operations Office. DOE/RL-91-50, Rev. 3. Prepared by Pacific Northwest National Laboratory for the U.S. Department of Energy, Richland Operations Office, Richland, Washington.

DOE-RL. 2002a. Operation and Maintenance Plan for the 300-FF-5 Operable Unit. DOE/RL 95-73, Rev. 1. Prepared by CH2M HILL Hanford, Inc. for U.S. Department of Energy, Richland Operations Office, Richland, Washington.

DOE-RL. 2002b. Standardized Stratigraphic Nomenclature for Post-Ringold-Formation Sediments Within the Central Pasco Basin. DOE/RL-2002-39, U.S. Department of Energy, Richland Operations Office, Richland, Washington.

DOE-RL. 2004. 2004 Annual Report on Waste Generation and Pollution Prevention Progress as Required by DOE Order 5400.1. Fluor Fernald, U.S. Department of Energy, Fernald Area Office, Cincinnati, Ohio.

DOE-RL. 2005a. 300-FF-1 Operable Unit Remedial Action Report. DOE/RL-2004-74, Rev. 0. Prepared by Washington Closure Hanford for the U.S. Department of Energy, Richland Operations Office, Richland, Washington.

DOE-RL. 2005b. Work Plan for Phase III Feasibility Study, 300-FF-5 Operable Unit. DOE/RL-200541, Rev. 0. Prepared by Pacific Northwest National Laboratory for the U.S. Department of Energy, Richland Operations Office, Richland, Washington.

DOE-RL. 2006a. 300-FF-5 Operable Unit Sampling and Analysis Plan. DOE/RL-2002-11, Rev. 1. Prepared by Pacific Northwest National Laboratory for the U.S. Department of Energy, Richland Operations Office, Richland, Washington. (author: RE Peterson).

DOE-RL. 2006b. CERCLA Five-Year Review Report for the Hanford Site. DOE/RL-2006-20, Rev. 1, November 10, 2006, U.S. Department of Energy, Richland, Washington.

Dong W, WP Ball, C Liu, Z Wang, AT Stone, J. Bai, and JM Zachara. 2005. "Influence of calcite and dissolved calcium on uranium(VI) sorption to a Hanford subsurface sediment.” Environmental Science and Technology 39:7949-7955.

Ecology. 2007. Dangerous Waste Portion of the Resource Conservation and Recovery Act Permit for the Treatment, Storage, and Disposal of Dangerous Waste. Permit No. WA7890008967, Rev. 8B, as amended, Washington State Department of Ecology, Olympia, Washington.

EPA. 1988. Guidance for Conducting Remedial Investigations and Feasibility Studies Under CERCLA, Interim Final. OSWER Directive 9355.3.3-01, U.S. Environmental Protection Agency, Washington, D.C. 
EPA. 1996a. Interim Record of Decision (ROD) for the 100-HR-3 and 100-KR-4 Operable Units, Hanford Site, Benton County, Washington. Agreement Between U.S. Department of Energy and U.S. Environmental Protection Agency, with Concurrence by Washington State Department of Ecology.

EPA. 1996b. Record of Decision for USDOE Hanford 300-FF-1 and 300-FF-5 Operable Units Remedial Actions. Agreement Between U.S. Department of Energy and U.S. Environmental Protection Agency, with Concurrence by the Washington State Department of Ecology.

EPA. 2001. US DOE Hanford Site: First Five Year Review Report. U.S. Environmental Protection Agency, Region 10, Hanford Project Office, Richland, Washington.

Fayer MJ, and TB Walters. 1995. Estimated Recharge Rates at the Hanford Site. PNL-10285, Pacific Northwest National Laboratory, Richland, Washington.

Finch WI. 1996. "Uranium provinces of North America - Their definition, distribution, and models." U.S. Geological Survey Bulletin 2141.

Finch R, and T Murakami. 1999. "Systematics and paragenesis of uranium minerals." In: Uranium: Mineralogy, Geochemistry, and the Environment. Mineralogical Society of America (PC Burns and R Finch, eds.) Washington, D.C., pp. 91-179.

Fox PA, JA Davis, and JM Zachara. 2006. “The effect of calcium on aqueous uranium(VI) speciation and adsorption to ferrihydrite and quartz.” Geochim. Cosmochim. Acta 70(6):1379-1387.

Fritz BG, and EV Arntzen. 2007. "Effect of rapidly changing river stage on uranium flux through the hyporheic zone.” Ground Water 45(6):753-760.

Fritz BG, RD Mackley, NP Kohn, GW Patton, TJ Gilmore, DP Mendoza, D McFarland, AL Bunn, and EV Arntzen. 2007. Investigation of the Hyporheic Zone at the 300 Area, Hanford Site. PNNL-16805, Northwest National Laboratory, Richland, Washington.

Gaylord DR, and EP Poeter. 1991. Geology and Hydrology of the 300 Area and Vicinity, Hanford Site, South-Central Washington. WHC-EP-0500, Westinghouse Hanford Company, Richland, Washington.

Gee GW, JM Keller, and AL Ward. 2005. "Measurement and Prediction of Deep Drainage from Bare Sediments at a Semiarid Site.” Vadose Zone Journal 4:32-40.

Gerber MS. 1992. Past Practices Technical Characterization Study - 300 Area -Hanford Site. WHCMR-0388, Westinghouse Hanford Company, Richland, Washington.

Ginder-Vogel M, CS Criddle, and S Fendorf. 2006. "Thermodynamic constraints on the oxidation of biogenic $\mathrm{UO}_{2}$ by Fe(III) (Hydr)oxides.” Environmental Science and Technology 40:3544-3550.

Grenthe I, J Fuger, RJM Konings, RJ Lemire, AB Muller, C Nguyen-Trung Cregu, and H Wanner. 1992. Chemical Thermodynamics of Uranium. Elsevier Science, Amsterdam, the Netherlands. 
Grenthe I, MCA Sandino, I Puidomenech, and MH Rand. 1995. "Corrections to the NEA-TDB review." In: Chemical Thermodynamics of Americium (RA Silva, G Bidoglio, M Rand, PB Robouch, H Wanner, and I Puigdomenech, eds.), pp. 347-374. Elsevier Science. Amsterdam, the Netherlands.

Guillaumont R, T Fanghanel, V Neck, J Fuger, DA Palmer, I Grenthe, and MH Rand. 2003. Update on the Chemical Thermodynamics of Uranium, Neptunium, Plutonium, Americium, and Technetium. Elsevier B.V., Amsterdam, the Netherlands.

Haney WA. 1960. Disposal of Radioactive Liquid Wastes from 300 Area Laboratory Facilities. HW64292, Hanford Atomic Products Operation, General Electric Company, Richland, Washington.

Hartman MJ, LF Morasch, and WD Webber. 2007. Hanford Site Groundwater Monitoring for Fiscal Year 2006. PNNL-16346, Pacific Northwest National Laboratory, Richland, Washington.

Higley BA, DE Place, RA Corbin, and BC Simpson. 2004. Hanford Defined Waste Model, Rev. 5. RPP19822, Rev. 0, CH2M HILL Hanford Group, Inc., Richland, Washington.

Hudson EA, JJ Rehr, and JJ Bucher. 1995. "Multiple-scattering calculations of the uranium $\mathrm{L}_{3}$-edge Xray-absorption near-edge structure.” Physical Review B 52(19):3815-3826.

Hulstrom LC. 1994. Summary of Remedial Investigations at the 307 Retention Basins and 307 Trenches (316-3), 300-FF-2 Operable Unit. WHC-SD-EN-TI-279, Rev. 0. Prepared by Golder Associates, Inc. for Westinghouse Hanford Company, Richland, Washington.

Ilton ES, C Liu, W Yantasee, Z Wang, D Moore, and JM Zachara. 2006. “The dissolution of synthetic Na-boltwoodite in sodium carbonate solutions.” Geochim. Cosmochim. Acta 70:4836-4849.

Ilton ES, NP Qafoku, C Liu, DA Moore, and JM Zachara. 2007. “Advective removal of intraparticle uranium from contaminated vadose zone sediments, Hanford USA.” Geochimica et Cosmochemica Acta (in press February 2008).

Kipp KL, AE Reisenauer, CR Cole, CR, and CA Bryan. 1972 (updated in 1976). Variable Thickness Transient Groundwater Flow Model-Theory and Numerical Implementation. BNWL-1703, Pacific Northwest National Laboratory, Richland, Washington.

Kooiker CA, RE Peterson, RM Smith, and BA Williams. 2007. Sampling and Analysis Instructions for TCE Characterization, 300-FF-5 Operable Unit, Fiscal Year 2007. SGW-32607, Rev. 0, addendum added August 2007. Fluor Hanford, Inc., Richland, Washington.

Krupka KM, DI Kaplan, G Whelan, RJ Serne, and SV Mattigod. 1999. Understanding Variation in Partition Coefficient, $K_{d}$, Values: Volume $I$. The $K_{d}$ Model, Methods of Measurement, and Application of Chemical Reaction Codes. EPA 402-R-99-004A, Washington, D.C. Prepared by Pacific Northwest National Laboratory for the U.S. Environmental Protection Agency, Richland, Washington.

Langmuir D. 1997. Aqueous Environmental Geochemistry. Prentice Hall, Upper Saddle River, New Jersey. 
Lerch JA. 1999. 300-FF-1 Operable Unit, North Process Pond/Scraping Disposal Area Verification Package. BHI-01298, Rev. 0, Bechtel Hanford, Inc., Richland, Washington.

Lindberg JW, and FW Bond. 1979. Geohydrology and Groundwater Quality Beneath the 300 Area, Hanford Site, Washington. PNL-2949, Pacific Northwest National Laboratory, Richland, Washington.

Lindberg JW, and CJ Chou. 2001. 300 Area Process Trenches Groundwater Monitoring Plan. PNNL13645, Pacific Northwest National Laboratory, Richland, Washington.

Lindberg JW, CJ Chou, and VG Johnson. 1995. Groundwater Monitoring Plan for the 300 Area Process Trenches. WHC-SD-EN-AP-185, Rev. 0A, Westinghouse Hanford Company, Richland, Washington.

Lindenmeier CW, RJ Serne, BN Bjornstad, GW Gee, HT Schaef, DC Lanigan, MJ Lindberg, RE Clayton, VL LeGore, IV Kutnyakov, SR Baum, KN Geiszler, K MM Valenta, and TS Vickerman. 2002. Characterization of Vadose Zone Sediment: RCRA Borehole 299-E33-338 Located Near the BBX-BY Waste Management Area. PNNL-14121, Pacific Northwest National Laboratory, Richland, Washington.

Lindsey KA. 1995. Miocene- to Pliocene-Aged Suprabasalt Sediments of the Hanford Site, SouthCentral Washington. BHI-00184, Rev. 00, Bechtel Hanford, Inc., Richland, Washington.

Liu C, J Zachara, and N Qafoku. 2004. "Modeling of Uranium Sorption/Desorption with Advection.” In: Workshop on Conceptual Model Development and Reactive Transport Modeling for the 300 Area Uranium Plume in 300-FF-5. May 10-11, 2004, Richland, Washington. Available at: http://www.hanford.gov/cp/gpp/public/workshops.cfm. Accessed October 1, 2007.

Lumpkin GR, and RC Ewing. 1995. “Geochemical alteration of pyrochlore group minerals: Pyrochlore subgroup.” American Mineralogist 80:732-743.

Lumpkin GR, and RC Ewing. 1996. "Geochemical alteration of pyrochlore group minerals: Betafite subgroup.” American Mineralogist 81:1237-1248.

Mackley RD, and BG Fritz. 2007. Characterizing the Hydrogeology of the Hyporheic Zone Along the 300 Area of the Hanford Site, Washington. PNNL-SA-56035. Oral presentation at the $6^{\text {th }}$ Washington Hydrogeology Symposium, May 1-3, 2007, Tacoma, Washington.

McKinley JP, JM Zachara, J Wan, DE McCready, and SM Heald. 2007. "Geochemical controls on contaminant uranium in vadose Hanford Formation sediments at the 200 Area and 300 Area, Hanford Site, Washington.” Vadose Zone Journal 6(4):1004-1017.

Mendoza F, BG Fritz, and GW Patton. 2007. Measurement of Contaminant Discharge into the Columbia River along the Hanford Reach using a Passive Flux Chamber. PNNL-SA-53838. Poster presentation at the $6^{\text {th }}$ Washington Hydrogeology Symposium, May 1-3, 2007, Tacoma, Washington.

Meyer PD, M Ye, ML Rockhold, SP Neuman, and KJ Cantrell. 2007. Combined Estimation of Hydrogeologic Conceptual Model, Parameter, and Scenario Uncertainty with Application to Uranium Transport at the Hanford Site 300 Area. NUREG/CR-6940 and PNNL-16396. Prepared by Pacific 
Northwest National Laboratory, Richland, Washington, for the U.S. Nuclear Regulatory Commission, Washington, D.C.

Moon HS, J Komlos, and PR Jaffee. 2007. "Uranium Reoxidation in Previously Bioreduced Sediment by Dissolved Oxygen and Nitrate.” Environmental Science and Technology 41(13):4587-4592.

Morel FMM, JG Yeasted, and JC Westall. 1981. "Adsorption Models: A Mathematical Analysis in the Framework of General Equilibrium Calculations.” In: Adsorption of Inorganics At Solid-Liquid Interfaces (eds. MA Anderson and AJ Rubin), pp. 263-294, Ann Arbor Science, Ann Arbor, Michigan.

Patton GW, SP Van Verst, BL Tiller, EJ Antonio, and TM Poston. 2002. Survey of Radiological and Chemical Contaminants in the Near-Shore Environment at the Hanford Site 300 Area. PNNL-13692. Pacific Northwest National Laboratory, Richland, Washington.

Peterson J, M MacDonell, L Haroun, and F Monette. 2007. Radiological and Chemical Fact Sheets to Support Health Risk Analyses for Contaminated Areas. Available at: http://www.riskcenter.doe.gov/techinfo/factsheets.cfm, November 2001; updated March 2007. Accessed October 1, 2007. Prepared by the Environmental Science Division, Argonne National Laboratory, Chicago, Illinois, for the U.S. Department of Energy, Richland, Washington, and Chicago, Illinois.

Peterson RE (editor). 2005. Contaminants of Potential Concern in the 300-FF-5 Operable Unit: Expanded Annual Groundwater Report for FY 2004. PNNL-15127, Pacific Northwest National Laboratory, Richland, Washington. (Contributors: E.J. Freeman, C.J. Murray, R.E. Peterson, P.D. Thorne, M.J. Truex, V.R. Vermeul, M.D. Williams, S.B. Yabusaki, J.M. Zachara, J.L. Lindberg, and J.P. McDonald.)

Peterson RE, and MP Connelly. 2001. Zone of Interaction Between Hanford Site Groundwater and Adjacent Columbia River Channel. PNNL-13674. Progress Report for the Groundwater/River Interface Task, Science and Technology, Groundwater/Vadose Zone Integration Project, Pacific Northwest National Laboratory, Richland, Washington.

Peterson RE, and MP Connelly. 2004. "Water Movement in the Zone of Interaction Between Groundwater and the Columbia River, Hanford Site, Washington.” Journal of Hydraulic Research 42(Extra Issue, 2004):53-58.

Peterson, RE and VG Johnson. 1992. Riverbank Seepage of Groundwater Along the Hanford Reach of the Columbia River, Washington. WHC-EP-0609, December 1992, Westinghouse Hanford Company, Richland, Washington, 44 pp. plus appendices.

Peterson, RE, JW Lindberg, and BA Williams. 2007a. "300-FF-5 Operable Unit." Chapter 2.12 in Hanford Site Groundwater Monitoring for Fiscal Year 2006, eds. MJ Hartman, LF Morasch, and WD Webber. PNNL-16346, March 2007. Pacific Northwest National Laboratory, Richland, Washington.

Peterson, RE, MD Williams, and GW Patton. 2007b. Hanford Site Groundwater and the Columbia River, South-Central Washington State. PNNL-SA-54634. Oral presentation at the $6^{\text {th }}$ Washington Hydrology Symposium, May 1-3, 2007, Tacoma, Washington. 
PNNL. 2007. 300 Area Integrated Field-Scale Subsurface Research Challenge (IFC) Field Site Management Plan. PNNL-17067, Rev. 0, July 2007. Pacific Northwest National Laboratory, Richland, Washington.

Poston TM, RW Hanf, RL Dirkes, and LF Morasch. 2007. Hanford Site Environmental Report for Calendar Year 2006. PNNL-16623, Pacific Northwest National Laboratory, Richland, Washington. Available at: http://hanford-site.pnl.gov/envreport. Accessed October 1, 2007.

Qafoku NP, JM Zachara, C Liu, PL Gassman, OS Qafoku, and SC Smith. 2005. “Kinetic Desorption and Sorption of U(VI) during Reactive Transport in a Contaminated Hanford Sediment.” Environmental Science and Technology 39(9):3157-3165.

Reidel SP, KA Lindsey, and KR Fecht. 1992. Field Trip Guide to the Hanford Site. WHC-MR-0391, Westinghouse Hanford Company, Richland, Washington.

Rockhold ML, MJ Fayer, and GW Gee. 1988. Characterization of Unsaturated Hydraulic Conductivity at the Hanford Site. PNL-6488, Pacific Northwest Laboratory, Richland, Washington.

Rockhold ML, MJ Fayer, CT Kincaid, and GW Gee. 1995. Estimation of Natural Recharge for the Performance Assessment of a Low Level Waste Disposal Facility at the Hanford Site. PNL-10508, Pacific Northwest National Laboratory, Richland, Washington.

Schalla R, RW Wallace, RL Aaberg, SP Airhart, DJ Bates, JVM Carlile, CS Cline, DI Dennison, MD Freshley, PR Heller, EJ Jensen, KB Olsen, RG Parkhurst, JT Rieger, and EJ Westergard. 1988. Interim Characterization Report for the 300 Areas Process Trenches. PNL-6716, Pacific Northwest Laboratory, Richland, Washington.

Serne RJ, and AB Muller. 1987. “A Perspective on Adsorption of Radionuclides onto Geologic Media.” In: The Geological Disposal of High Level Radioactive Waste, edited by DG Brookins. Theophrastus Publications, SA, Athens, Greece, pp. 407-443.

Serne RJ, CF Brown, HT Schaef, EM Pierce, JW Lindberg, Z Wang, PL Gassman, and JG Catalano. 2002a. The 300 Area Uranium Leach and Adsorption Project. PNNL-14022, Pacific Northwest National Laboratory, Richland, Washington.

Serne RJ, GV Last, GW Gee, HT Schaef, DC Lanigan, CW Lindenmeier, JW Lindberg, RE Clayton, VL LeGore, RD Orr, IV Kutnyakov, SR Baum, KN Geiszler, CF Brown, MM Valenta, and TS Vickerman. 2002b. Characterization of Vadose Zone Sediment: Borehole 299-E33-45 Near BX-102 in the B-BX-BY Waste Management. PNNL-14083, Pacific Northwest National Laboratory, Richland, Washington.

Serne RJ, HT Schaef, BN Bjornstad, BA Williams, DC Lanigan, DG Horton, RE Clayton, VL LeGore, MJ O’Hara, CF Brown, KE Parker, IV Kutnyakov, JN Serne, AV Mitroshkov, GV Last, SC Smith, CW Lindenmeier, JM Zachara, and DB Burke. 2002c. Characterization of Uncontaminated Vadose Zone Sediment from the Hanford Reservation - RCRA Borehole Core Samples and Composite Samples. PNNL-13757-1, Pacific Northwest National Laboratory, Richland, Washington

Serne RJ, BN Bjornstad, DG Horton, DC Lanigan, CW Lindenmeier, MJ Lindberg, RE Clayton, VL LeGore, RD Orr, IV Kutnyakov, SR Baum, KN Geiszler, MM Valenta, and TS Vickerman. 2004a. 
Characterization of Vadose Zone Sediments Below the TX Tank Farm: Boreholes C3830, C3831, C3832, and RCRA Borehole 299-W10-27. PNNL-14594, Pacific Northwest National Laboratory, Richland, Washington.

Serne RJ, BN Bjornstad, DG Horton, DC Lanigan, CW Lindenmeier, MJ Lindberg, RE Clayton, VL LeGore, KN Geiszler, SR Baum, MM Valenta, IV Kutnyakov, TS Vickerman, RD Orr, and CF Brown. 2004b. Characterization of Vadose Zone Sediments Below the T Tank Farm: Boreholes C4104, C4105, 299-W10-196 and RCRA Borehole 299-W11-39. PNNL-14849, Pacific Northwest National Laboratory, Richland, Washington.

Shaw T. 2006. “Conceptual Site Models-Don’t Start a Project Without One.” Oral presentation at Joint Services Environmental Management Conference and Exposition, March 2006, Denver, Colorado. (Travis Shaw, U.S. Army Corps of Engineers, Seattle District).

Simpson BC, RA Corbin, MJ Anderson, CT Kincaid, and JM Zachara. 2006. Identification and Classification of the Major Uranium Discharges and Unplanned Releases at the Hanford Site using the Soil Inventory Model (SIM) Rev. 1 Results. NUV-06-21106-ES-001-DOC, Rev.1, Nuvotec USA, Richland, Washington.

Spane FA, Jr, and WD Webber. 1995. Hydrochemistry and Hydrogeologic Conditions Within the Hanford Upper Basalt Confined Aquifer System. PNL-10817, Pacific Northwest National Laboratory, Richland, Washington.

Sposito G. 1984. The Surface Chemistry of Soils. Oxford University Press, New York, New York.

Swanson LC, GG Kelty, KA Lindsey, KR Simpson, RK Price, and SD Consort. 1992. Phase I Hydrogeologic Summary of the 300-FF-5 Operable Unit, 300 Area. WHC-SD-EN-TI-052, Rev. 0, Westinghouse Hanford Company, Richland, Washington.

Thorne PD. 1998. Upper Basalt-Confined Aquifer System in the Southern Hanford Site. PNL-12067, Pacific Northwest National Laboratory, Richland, Washington.

Thorne, PD, MD Bergeron, MD Williams, and VL Freedman. 2006. Groundwater Data Package for Hanford Assessments. PNNL-14753, Rev. 1, Pacific Northwest National Laboratory, Richland, Washington.

USACE. 2003. Conceptual Site Models for Ordnance and Explosives (OE) and Hazardous, Toxic, and Radioactive (HTRW) Projects. Engineering and Design Manual EM 1110-1 1200, February 2003, U.S. Army Corps of Engineers, Washington, D.C.

Vermeul, VR, MP Bergeron, CR Cole, CJ Murray, TD Scheibe, PD Thorne, SR Waichler, and Y Xie. 2003. Transient Inverse Calibration of the Site-Wide Groundwater Flow Model (ACM-2). PNNL-14398, Pacific Northwest National Laboratory, Richland, Washington.

Vermeul VR, MD Williams, BG Fritz, R Mackley, DP Mendoza, DR Newcomer, ML Rockhold, BA Williams, and DM Wellman. 2007. Treatability Test Plan for 300 Area Uranium Stabilization Through Polyphosphate Injection. PNNL-16571, Pacific Northwest National Laboratory, Richland, Washington. 
Waichler SR, and SB Yabusaki. 2005. Flow and Transport in the Hanford 300 Area Vadose ZoneAquifer-River System, PNNL-15125, Pacific Northwest National Laboratory, Richland, Washington.

Waichler SR, MS Wigmosta, and A Coleman. 2004. Natural Recharge to the Unconfined Aquifer System on the Hanford Site from the Greater Cold Creek Watershed: Progress Report 2004. PNNL14717, Pacific Northwest National Laboratory, Richland, Washington.

Waichler SR, WA Perkins, and MC Richmond. 2005. Hydrodynamic Simulation of the Columbia River, Hanford Reach, 1940-2004. PNNL-15226, Pacific Northwest National Laboratory, Richland, Washington.

Wang Z, JM Zachara, W Yantasee, PL Gassman, C Liu, and A Joly. 2004. "Cryogenic laser induced characterization of U(VI) in Hanford vadose zone porewater.” Environ. Sci. Technol. 38:5591-5597.

Wellman DM, JS Fruchter, and VR Vermeul. 2006. Experimental Plan: Uranium Stabilization through Polyphosphate Injection - 300 Area Uranium Plume Treatability Demonstration Project. PNNL-16101, Pacific Northwest National Laboratory, Richland, Washington.

White MD, and M Oostrom. 2000. STOMP, Subsurface Transport Over Multiple Phases. Version 2.0. Theory Guide. PNNL-12030, Pacific Northwest National Laboratory, Richland, Washington.

White MD, and M Oostrom. 2004. STOMP Subsurface Transport Over Multiple Phases, Version 3.1, User’s Guide. PNNL-14478, Pacific Northwest National Laboratory, Richland, Washington.

Williams BA. 2007. Borehole Data Package for Nine CY 2006 Polyphosphate Treatability Testing Wells, 300-FF-5 Operable Unit, Hanford Site, Washington. PNNL-16522, Pacific Northwest National Laboratory, Richland, Washington.

Williams BA, BN Bjornstad, R Schalla, and WD Webber. 2000. Revised Hydrogeology for the Suprabasalt Aquifer System, 200-East Area and Vicinity, Hanford Site, Washington. PNNL-12261, Pacific Northwest National Laboratory, Richland, Washington.

Williams BA, CF Brown, RE Peterson, EC Thornton, MJ Nimmons, SB Yabusaki, TG Naymik, JW Lindberg, ML Rockhold, and MD Williams. 2005. 300-FF-5 Operable Unit Limited Field Investigation Plan. DOE/RL-2005-47, Rev. 0. Prepared by Pacific Northwest National Laboratory for the U.S. Department of Energy, Richland Operations, Richland, Washington.

Williams BA, BN Bjornstad, DC Lanigan, JM Keller, and ML Rockhold. 2006. Borehole Data Package for One CY 2005 CERCLA Well 699-S20-E10, 300-FF-5 Operable Unit, Hanford Site, Washington. PNNL-15417, Pacific Northwest National Laboratory, Richland, Washington.

Williams BA, CF Brown, W Um, MJ Nimmons, RE Peterson, BN Bjornstad, DC Lanigan, RJ Serne, FA Spane, and ML Rockhold. 2007. Limited Field Investigation Report for Uranium Contamination in the 300 Area, 300-FF-5 Operable Unit, Hanford Site, Washington. PNNL-16435, Pacific Northwest National Laboratory, Richland, Washington. 
Williams MD, ML Rockhold, and PD Thorne. 2008. Three-Dimensional Groundwater Models of the 300 Area, Hanford Site, Washington. In preparation, February 2008, Pacific Northwest National Laboratory, Richland, Washington.

Yabusaki SB, Y Fang, and SR Waichler. 2008. "Building Conceptual Models of Field-Scale Uranium Reactive Transport in a Dynamic Vadose Zone-Aquifer-River System.” Water Resources Research (in press February 2008).

Young JS, and JS Fruchter. 1991. Addendum to Data Compilation Task Report for the Source Investigation of the 300-FF-1 Operable Unit Phase I Remedial Investigation. EMO-1026. Prepared by Environmental Management Operations for the U.S. Department of Energy, Richland, Washington.

Young JS, RM Fruland, and JS Fruchter. 1990. Data Compilation Task Report for the Source Investigation of the 300-FF-1 Operable Unit Phase I Remedial Investigation. PNL-7241, Pacific Northwest Laboratory, Richland, Washington.

Zachara JM (editor). 2005. Uranium Geochemistry in Vadose Zone and Aquifer Sediments from the 300 Area Uranium Plume. PNNL-15121, Pacific Northwest National Laboratory, Richland, Washington. (Collaborators: J.A. Davis, C. Liu, J.P. McKinley, N. Qafoku, D.M. Wellman, and S.B. Yabusaki.)

Zachara JM, CF Brown, J Christensen, PE Dresel, S Kelly, JP McKinley, RJ Serne, and W Um. 2007a. A Site-wide Perspective on Uranium Geochemistry at the Hanford Site. PNNL-17031, October 2007, Pacific Northwest National Laboratory, Richland, Washington.

Zachara JM, RJ Serne, MD Freshley, FM Mann, FJ Anderson, MI Wood, TE Jones, and DA Myers. 2007b. "Geochemical processes controlling migration of high level wastes in Hanford." Vadose Zone Journal (in press February 2008).

Zimmerman MG, and CD Kossik. 1987. 300 Area Process Trench Sediment Analysis Report. WHC-SP-0193, Westinghouse Hanford Company, Richland, Washington. ( 200 pages, microfiche only at Consolidated Information Center, Richland, Washington.) 


\section{Distribution}

No. of

Copies

\section{OFFSITE}

Mark Conrad

Lawrence Berkeley National Laboratory

1 Cyclotron Rd.

MS 70A-4418

Berkeley, CA 94720

John N. Christensen

Lawrence Berkeley National Laboratory

1 Cyclotron Rd.

MS 70A-4418

Berkeley, CA 94720

James A. Davis

U.S. Geological Survey

Bldg. 15, McKelvey Building

Menlo Park, CA 94025

Craig Arola

Vista Engineering

8203 W. Quinault Ave.

Kennewick, WA 99336

Tom Stoops, LPG

Oregon Office of Energy

Nuclear Safety Division

625 Marion Street NE

Salem, OR 97303

\section{ONSITE}

\section{DOE Richland Operations Office}

B.L. Charboneau

J.P. Hanson

R.D. Hildebrand

J.G. Morse

K.M. Thompson (6)

DOE Public Reading Room (2)
No. of

Copies

7 Fluor Hanford, Inc.

J.V. Borghese E6-44

D.B. Erb E6-44

B.H. Ford E6-44

J.W. Lindberg E6-44

D.S. Miller E6-44

S.W. Petersen E6-44

B.A. Williams E6-44

4 U.S. Environmental Protection Agency
A.L. Boyd (3)
B1-46
L.E. Gadbois
B1-46

3 Washington State Department of Ecology
J.A. Caggiano
H0-57
A.D. Huckaby
H0-57
J. Price
$\mathrm{H} 0-57$

2 Washington Closure Hanford, Inc.

J.W. Darby

L6-06

E.T. Feist

H4-22

30 Pacific Northwest National Laboratory

B.N. Bjornstad K6-81

C.F. Brown P7-22

P.E. Dresel K6-96

M.D. Freshley K9-33

B.G. Fritz K6-75

J.S. Fruchter K6-96

K.M. Krupka K6-81

G.V. Last K6-81

P.E. Long K9-33

J.P. McKinley K8-96

M.J. Nimmons K6-96

G.W. Patton K6-75 
No. of

Copies

R.E. Peterson (6) K6-75

M.L. Rockhold K9-36

R.J. Serne P7-22

R.M. Smith K6-96

P.D. Thorne K6-96

V.R. Vermeul K6-96

A.L. Ward K9-33

D.M. Wellman K3-62

M.D. Williams K6-96

S.B. Yabusaki K9-36

J.M. Zachara K8-96

Hanford Technical Library (2) P8-55

Distr. 2 